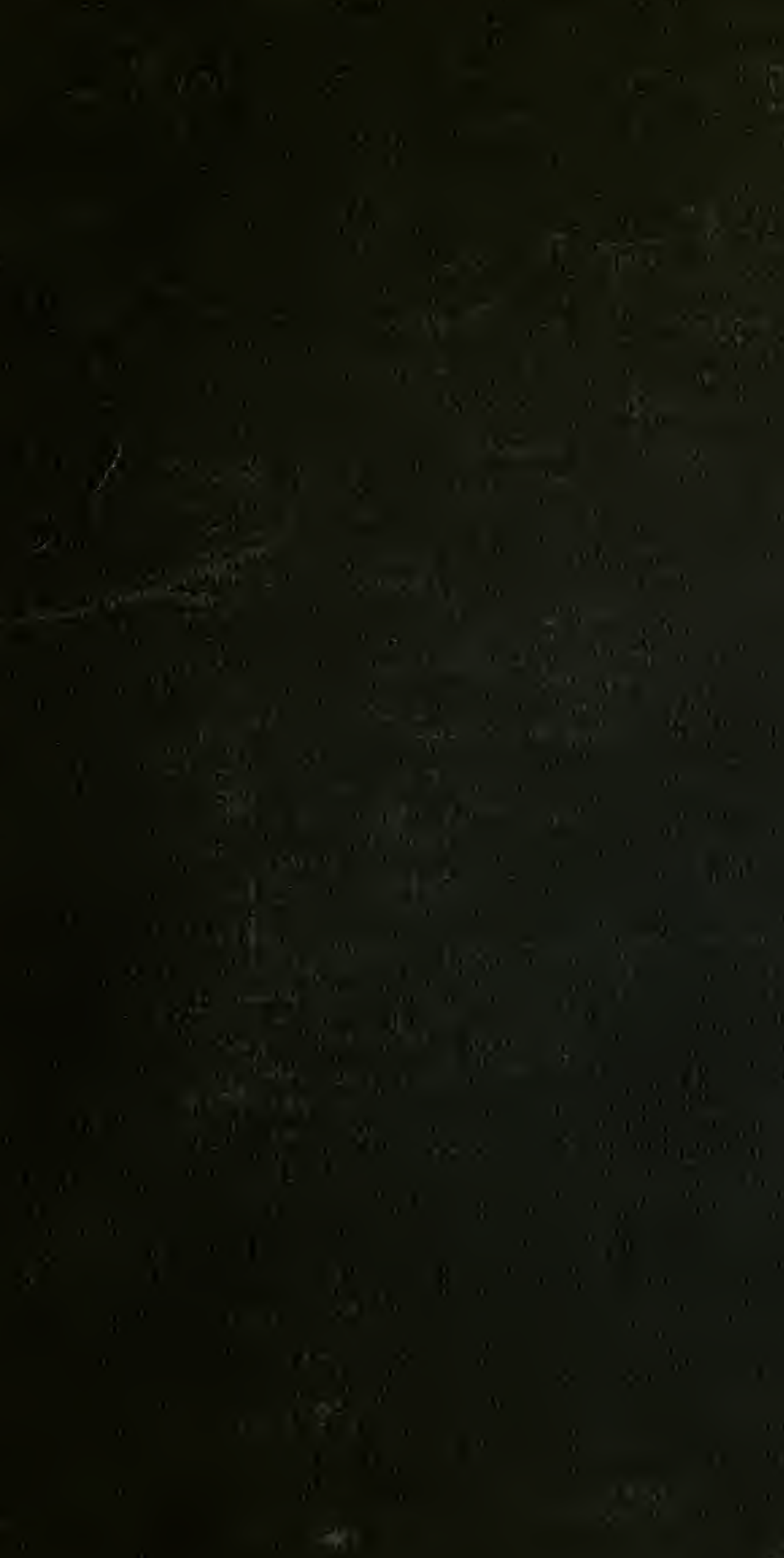


Hen, inargenest Atang
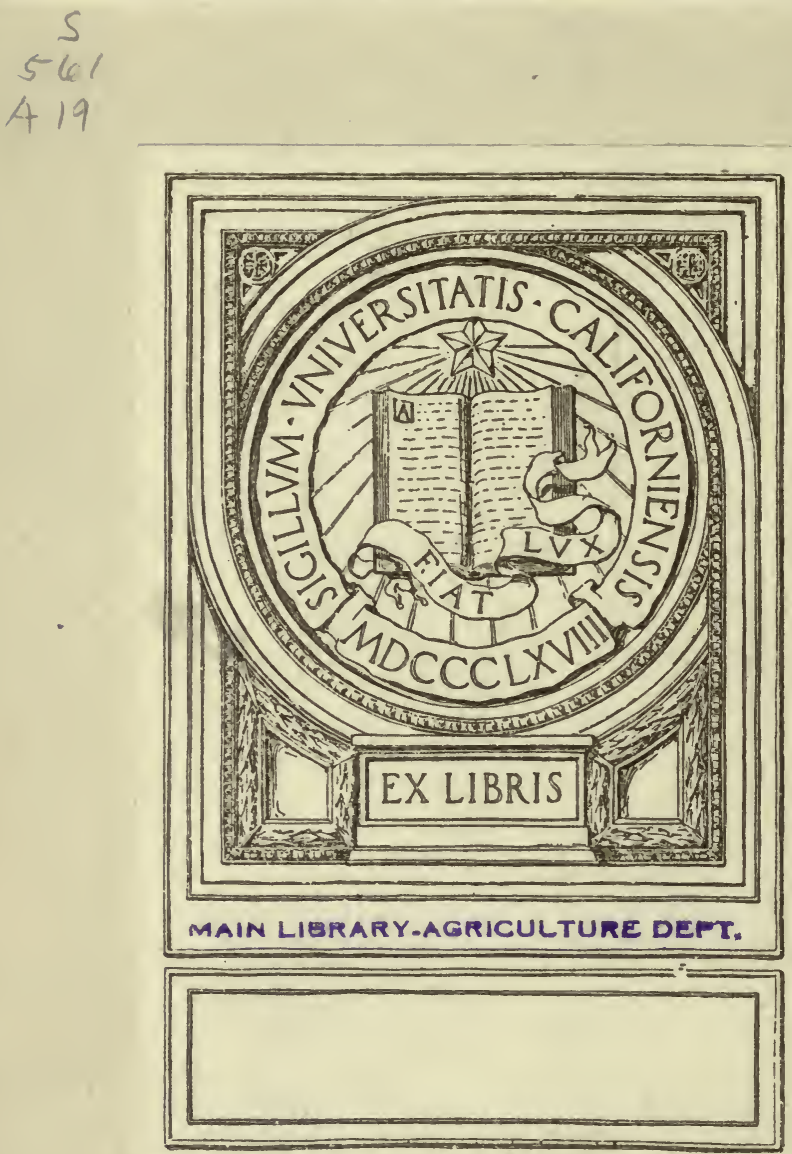


$$
\begin{array}{r}
+1101 \\
29 \\
26 \\
30
\end{array}
$$


Digitized by the Internet Archive in 2007 with funding from Microsoft Corporation 


\section{LIPPINCOTT'S COLLEGE TEXTS AGRICULTURE}

EDITED BY KARY C. DAVIS, Ph.D.

\section{AGRICULTURAL ECONOMICS}

JAMES E. BOYLE, Рн.D.

EXTENSION PROFESSOR OF RURAL "ECONOMY, COLLEGE OP AGRICULTURE, CORNELI, UNIVERSITY

90 ILLUSTRATIONS IN THE TEXT

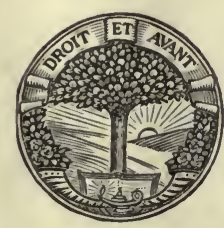

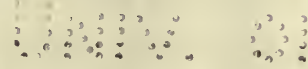

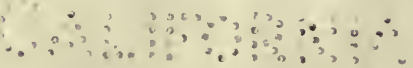

PHILADELPHIA, LONDON, CHICAGO

J. B. LIPPINCOTT COMPANY 


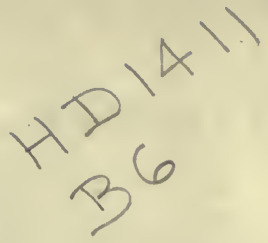

COPYRIGHT, I92I, BY J. B. LIPPINCOTT COMPANY

MAIN LIEFA $\rightarrow Y$ ? $\because$ I T:IRE DEPT

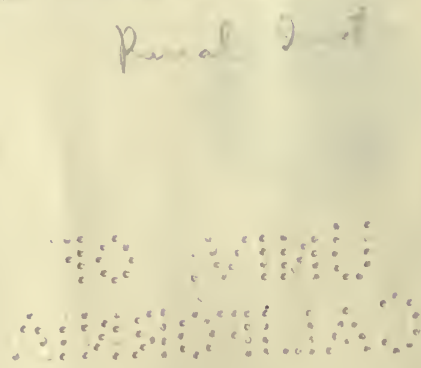

PRINTED BY J. B. LIPPINCOTT COMPANY AT THE WASHINGTON SQUARE PRESS PHILADELPHIA, U. S. A. 


\section{THE PLOUGH}

From Egypt behind my oxen with their stately step and slow,

Northward and east and west I went to the desert sand and the snow;

Down through the centuries one by one, turning the clod to the shower,

Till there's never a land beneath the sun but has blossomed behind my power.

I slid through the sodden rice fields with my grunting humpbacked steers,

I turned the turf of the Tiber plain in Rome's imperial years,

I was left in the half-drawn furrow when Coriolanus came

Giving his farm for the forum's stir to save his nation's name.

Over the seas to the north I went; white cliffs and a seaboard blue;

And my path was glad in the English grass as my stout red Devons drew;

My path was glad in the English grass, for behind me rippled and curled,

The corn that was life to the sailor men that sailed the ships of the world.

And later I went to the north again, and day by day drew down A little more of the purple hills to join to my kingdom brown;

And the whaups wheeled out to the moorland, but the gray gulls stayed with me,

Where the Clydesdales drummed a marching song with their feathered feet on the lea.

Then the new lands called me westward; I found on the prairies wide

A toll to my stoutest daring, and a foe to test my pride;

But I stooped my strength to the stiff black loam, and I found my labor sweet,

As I loosened the soil that was trampled firm by a million buffaloes' feet.

Then further away to the northward; outward and outward still

(But idle I crossed the Rockies for there no plough will till!),

Till I won to the plains unending, and there on the edge of the snow

I ribbed them the fenceless wheat fields, and taught them to reap and sow.

The sun of the southland called me; I turned her the rich brown lines,

Where her Parramatta peach trees grow and her green Mildura vines;

I drove her cattle before me, her dust and her dying sheep,

I painted her rich plains golden, and taught her to sow and reap.

From Egypt behind my oxen, with stately step and slow,

I have carried your weightiest burden, ye toilers that reap and sow!

I am the ruler, the King, and I hold the world in fee;

Sword upon sword may ring, but the triumph shall rest with me!

Will Ogilvie.

(Reprinted from "The Australian and Other Verses," through the courtesy of the publishers, Angus and Robertson, Sydney, N. S. W., Australia). 



\section{PREFACE}

Among the newer subjects which are claiming the attention of the thoughtful citizen are Agricultural Economics and Farm Management. Both are mere subdivisions of political economy. Farm management has to do with the farmer's relation to his individual farm, the central principle being the economic question of how he can secure the highest net returns. Agricultural Economics, however, is concerned with the social aspects of agriculture, and has for its first consideration the welfare of the Republic, and for its second consideration the welfare of agriculture as one component part of that Republic. Farm Management may be said to look on the farmer as practicing a trade: Agricultural Economics looks on the farmer as a citizen. The question of rural credit, for instance, is, to the teacher of Farm Management, the very concrete problem of where and how can farmer Jones borrow money at the lowest rate of interest: while this same question is, to the teacher of Agricultural Economics, the broad economic problem which recognizes the intimate and vital relation of sound credit to both the individual and community prosperity.

This book does not pretend to be a work of original research. It is a bringing together of some new and some old information which is scattered over a wide area of books, papers, reports, and other sources. The book is not written for the expert or specialist, but for the average student of agricultural problems.

My aim in writing this book is threefold: (1) to interest the reader in the subject of Agricultural Economics; (2) to point out by a few simple illustrations the most significant problems in this field; (3) and finally to stimulate thinking and discussion which may help towards the solution of these problems. Conversely, I have not tried to offer ready-made remedies for the problems discussed, or to formulate a set of "laws and principles," or, indeed, to present a large number of entirely new facts to the reader. The facts and illustrations given are believed to have real significance in interpreting the deeper movements in agriculture.

In peace or in war, the food supply of the nation is a question of fundamental importance. And the food supply is primarily a question of agriculture. In brief, agriculture is an industry which is fundamental in the political economy of our Republic. It is 
vital, therefore, that the problems in this field be discussed with sanity and with understanding. This book represents an earnest effort to select and organize such facts as will lead to this kind of a discussion of the subject. As cities increase in size, as the farm population proportionately decreases, we are destined to hear all sorts of proposals looking to a cheaper food supply for the benefit of the city dweller. Doubtless some of these proposals will have considerable merit; and doubtless others will be fraught with insidious danger, such as the proposal heard even now to place on our soil a race of Oriental laborers, with lower standards of living than our own.

The farmers of America are, up to the present moment, not so well mobilized as the persons in the other great industries and trades. But they are rapidly beginning to assume more conscious direction of the processes of production, and are asking for a wider influence in the economic and political life of the nation. For these reasons the study of Agricultural Economics is one of very great importance, both to the dweller in the open country and to his city cousin.

It has been said that when a problem is once clearly stated it is already partly solved. So the major effort of this book is to state problems clearly, in order that their final solution may be promoted. It is hoped that the casual reader will find these problems interesting. The serious student, I trust, will find their study both interesting and profitable.

ITHACA, New YoRK,

James ERnest Boyle. January, 1921. 


\section{CONTENTS}

Chapter

PAGE

I. Agriculture, Mandfacturing, Commerce............ 1

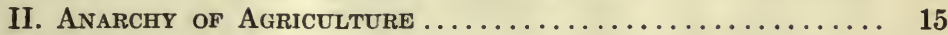

III. Farming versus Land Spectulation ................ 24

IV. The "Back to the Land" Movement............. 31

V. Land Tenure............................. 53

VI. Economic Condtion of the Farmer............. 83

VII. Agricultural Labor....................... 96

VIII. Agricultural Machinery and the Trust Question...... 115

IX. Marketing and the Middleman................. 130

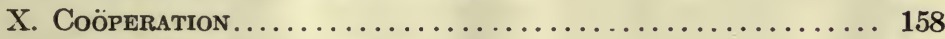

XI. Credit . . . . . . . . . . . . 174

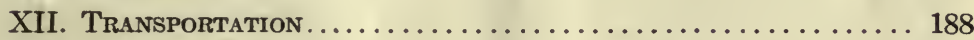

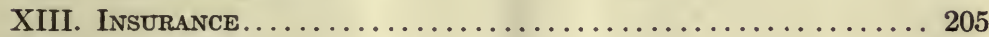

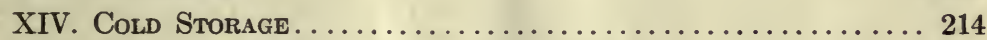

XV. Agricultural Prices and Valorization............. 225

XVI. Cost of Production and Farm Accounting............ 250

XVII. Speculation........................... 262

XVIII. The Agricultural Press..................... 279

XIX. Farmers' Organtzations.......................... 285

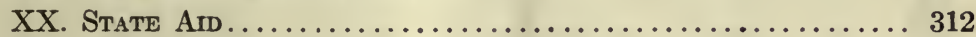

XXI. The County Agent........................... 329

XXII. The Grain Trade.......................... 337

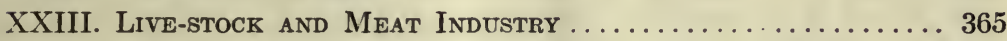

XXIV. Taxation Problems; Single Tax; Protective Tariff...... 393

XXV. Foreign Competition...................... 409

XXVI. Food SUpply Problem........................ 425

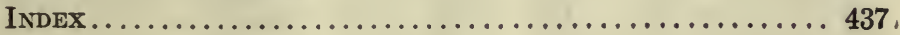





\section{AGRICULTURAL ECONOMICS}

\section{CHAPTER I}

\section{AGRICULTURE, MANUFACTURING, COMMERCE}

The Rank of Agriculture Among Our Industries.-For many years of our history agriculture was the leading industry. Agriculture came first as to the amount of capital invested, first as to the value of the output, and first as to the number of persons employed. This economic primacy gave agriculture an important place in the early political life of the nation, many congressmen and even several early presidents being actual farmers. George Washington for instance was born and reared on the farm, died on the farm, and lies buried on the farm. In Washington's day wealth, intelligence, dignity, influence, all went with farming. This primacy of agriculture has been lost due to the economic evolution of our country and the development of its vast and various resources. At the outset, then, let us examine some of the evidences of this change in the rank of agriculture. The United States Census Report for 1900 describes the situation in these words:

"Down to 1880 , or to some time between 1880 and 1890, agriculture was the principal source of wealth in the United States. At the last census (1890) the value of farm products was exceeded by that of manufactured products: At the census of 1900, the value of farm products is shown to have been $\$ 4,739,118,752$. In this total there occur certain duplications which the Report on Agriculture eliminates, leaving a residue of $\$ 3,764,177,706$ as the actual net value of all farm products in the census year. The net value of the products of manufactures, as computed in the census, is $\$ 8,370,595,176$, a sum more than double the value of the net products of the farm. If from this net value is eliminated everything in the way of crude materials contributed by the farm, the forest, the mine, and the sea, there is still left a value of $\$ 5,981,454,234$; and on this basis it appears that the contribution of manufactures and the mechanical arts to the wealth of the country exceeds the contribution of agriculture by more than a billion dollars.) The figures indicate that rapid as has been the development of agricultural interests, manufactures have advanced even more rapidly.

"This conclusion is strengthened by a consideration of the statistics of occupations as presented at the several censuses ... During the twenty years, 1880 to 1900 , the number engaged in agricultural pursuits increased 34.6 per cent, while the number engaged in manufacturing increased 87.2 per cent."

The 1910 census compares the two thirty-year periods, 1850 to 1880 and 1880 to 1910 . "During the first of these two periods," 
AGRICULTURE, MANUFACTURING, COMMERCE

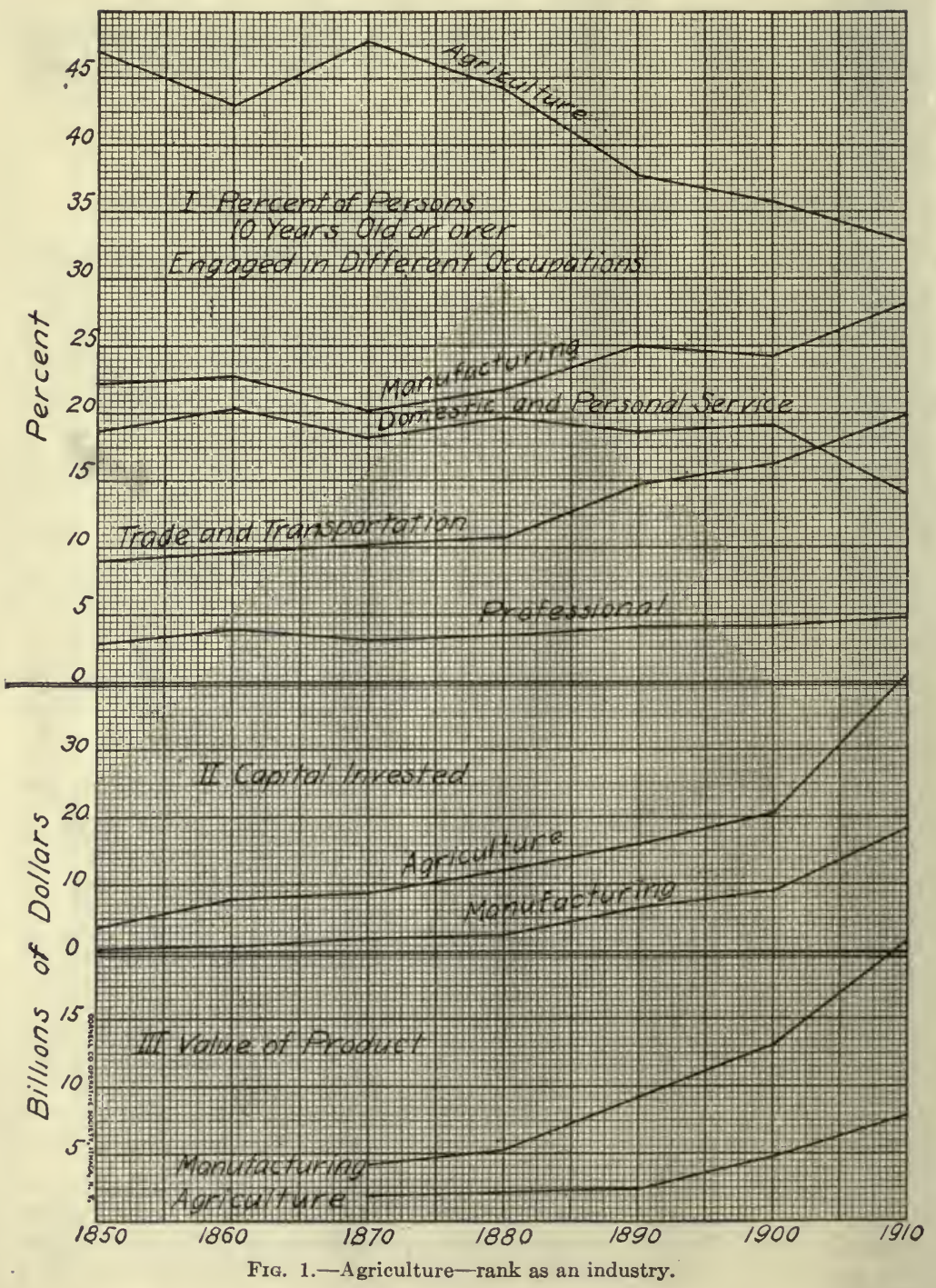


states the Census Report, "the agricultural industry, so far as can be measured by statistics as to the number of farms, farm land, and improved land, more than kept pace with the population." But it has failed to do so since. "The population increased 116.3 per cent between 1850 and 1880, while the number of farms increased 151.9 per cent; but from 1880 to 1910 the population increased 83.4 per cent, the number of farms only 58.7 per cent, and the improved farmi land only 68 per cent."

It is true that the value of farm property showed a gain of one hundred per cent in the ten-year period from 1900 to 1910 , increasing from some $\$ 20,000,000,000$ to $\$ 40,000,000,000$. Yet this gain of $\$ 20,000,000,000$ is rather an illusory gain, since $\$ 15,000,000,000$ of it represent merely an increase in land value and no added investment of capital whatever. This "unearned increase" in value therefore is a detriment rather than a benefit to the country at large, and is perhaps an evil to the farmers themselves. For it makes farms constantly higher in price to the would-be farmer and hence ownership more difficult to attain. It means more renters and more mortgages. For more and more it is becoming true that the farmers do not own the farms. The city investor or speculator or the "retired farmer" is becoming the farm owner, and is therefore getting the benefit of the $\$ 15,000,000,000$ increases in farm land value. And the farmer who is a tenant is helping pay the penalty. The report of the Thirteenth Census tells us, "It may be noted that at least since 1880 (and probably further back also) the farms operated by tenants have in each decade increased faster than those operated by owners" (Fig. 1).

Number of Persons Engaged.-There has been a gradual increase in the number of persons engaged in agriculture, manufacturing, professional service, domestic and personal service, and in transportation. But the proportion engaged in agriculture quite naturally shows a gradual decline. In 1870, 48 per cent of the workers were in agriculture; in 1910 , only 33 per cent. There are approximately six million farms in the United States, and allowing to each farm a family of five persons, we have thirty million of our population living in the open country. There remain therefore over seventy million who are living in cities and villages. The significance of these figures is important from the standpoint of an agrarian party or an agrarian policy in the United States. Any such a party with a policy of increasing agricultural profits at the expense of the consumer would be in a very hopeless minority. 


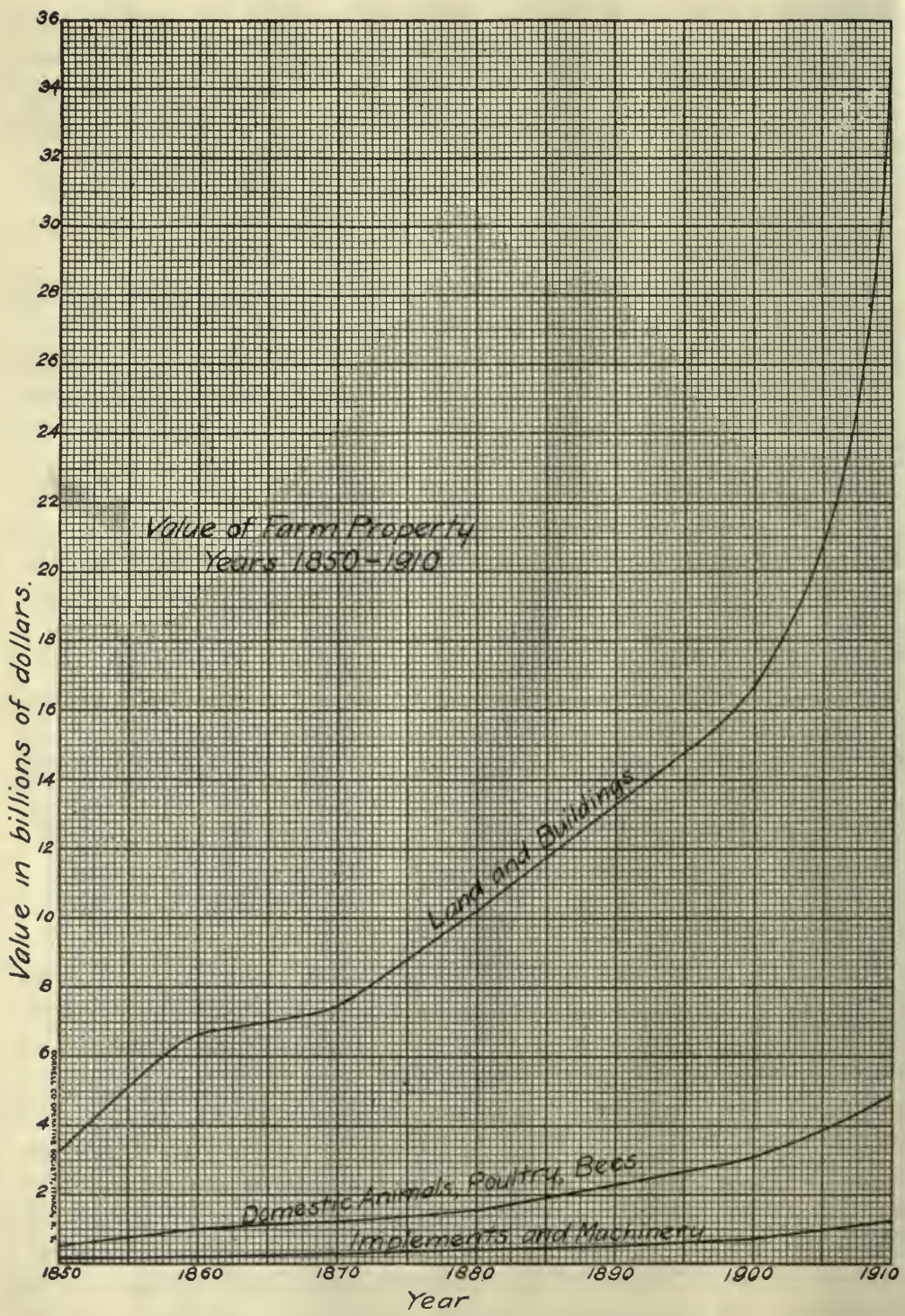

Fic. 2.-Value of farm property, years 1850-1910. 
However, any organization of farmers, along economic lines, with a policy of "savings, not profits," or "stabilizing of profits," would not collide with the self interests of the majority.

Capital Invested.-Mention has already been made of the capital invested in agriculture and manufacturing, but not of the difficulty of interpreting the word capital as applied to agriculture. The census figures for 1910 show total farm property, for instance, of forty billion dollars. But of this forty, twenty-eight is land value. And of this twenty-eight billions, fifteen billions is increase in land values since 1900, and represents no additional investment of capital. In 1910 some twelve billions of dollars represented the value of farm buildings, implements and machinery, and domestic animals, poultry, and bees. While land value increased in ten years 118 per cent, these buildings, implements, animals, etc., increased in value but 71 per cent (Fig. 2).

In manufacturing, however, in 1910, there was a capital investment of eighteen billion dollars-an increase over 1900 of 105 per cent. In banking in 1910 (in commercial banks only), there was invested capital to the amount of three billion dollars - a gain in ten years of 114 per cent. In transportation in 1910 (counting steam railroads alone) the capitalization was seventeen billión dollars, an increase in ten years of 42 per cent.

Value of Product.-We cannot of course compare the value of the products of all the great industries since these values are not a matter of record except in the cases of agriculture and manufacturing. Here, however, since 1870, the value of the product of manufacturing has been more than twice the value of the product of agriculture. According to the classification of the 1910 census, the values stood as follows: agriculture, eight billion dollars; manufacturing, twenty billions (Fig. 3). A study of the census figures shows that America, like some European countries, is now primarily a manufacturing country.

Value of Exports.-In time past our chief exports were foodstuffs. This has now changed. Thus in 1880 exports of foodstuffs were four times the amount of manufactures exported. In 1912, however, exports of manufactures were two and a half times as large as exports of foodstuffs. In other words, exports of foodstuffs remained at about four hundred million of dollars, while exports of manufactures grew from a hundred and twenty millions to over a billion dollars.

However, agriculture has many exportable products which are not foodstuffs, chiefly cotton (Fig. 4). Yet even counting 


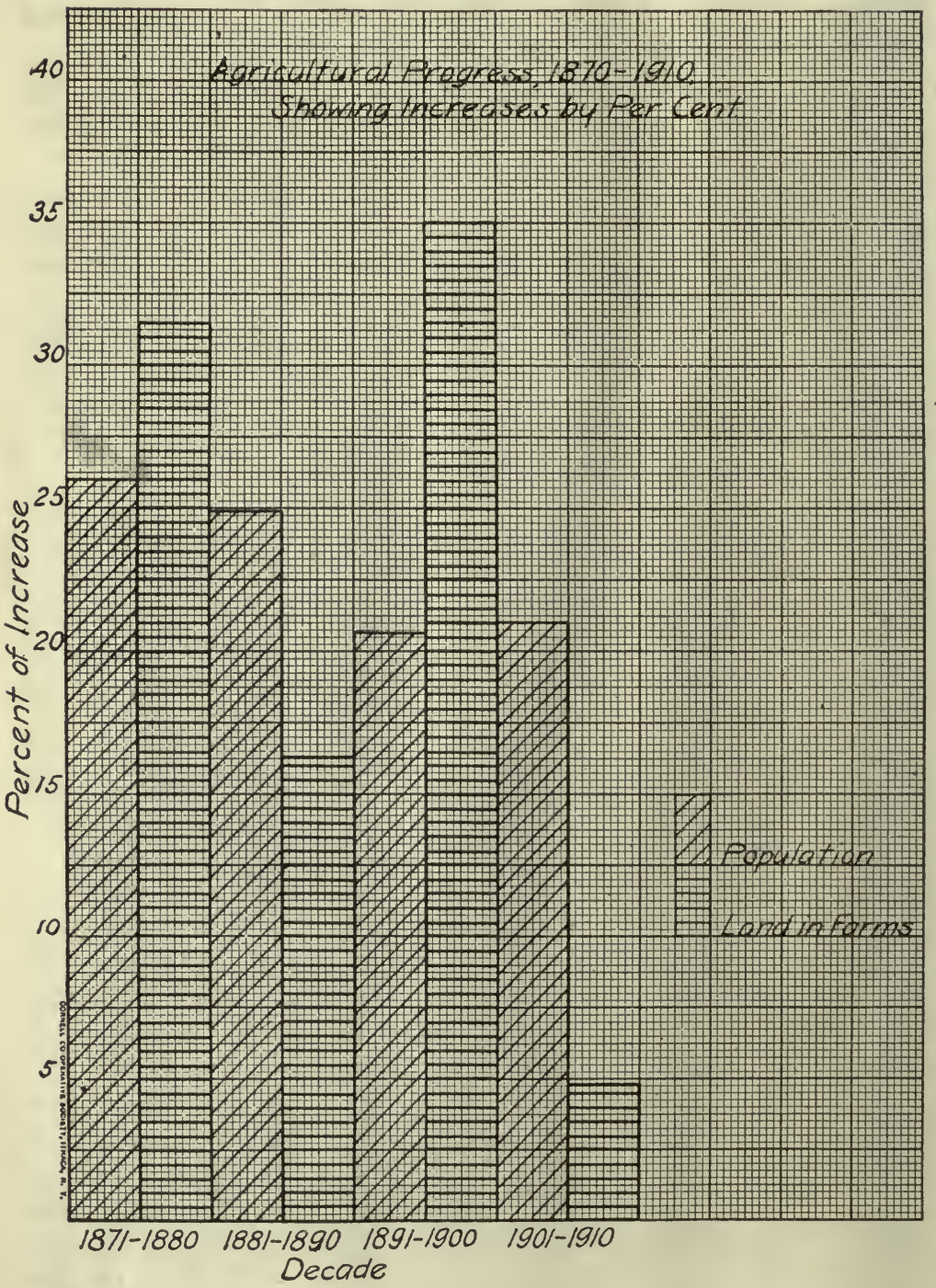

Frg. 3.-Agricultural progress, 1870-1910, showing increases by per cent. 
the total products of agriculture, over half of our exports are now of other products than those of agriculture. In 1913, for instance. our exports amounted to a total of $\$ 2,465,884,150$; of this amount

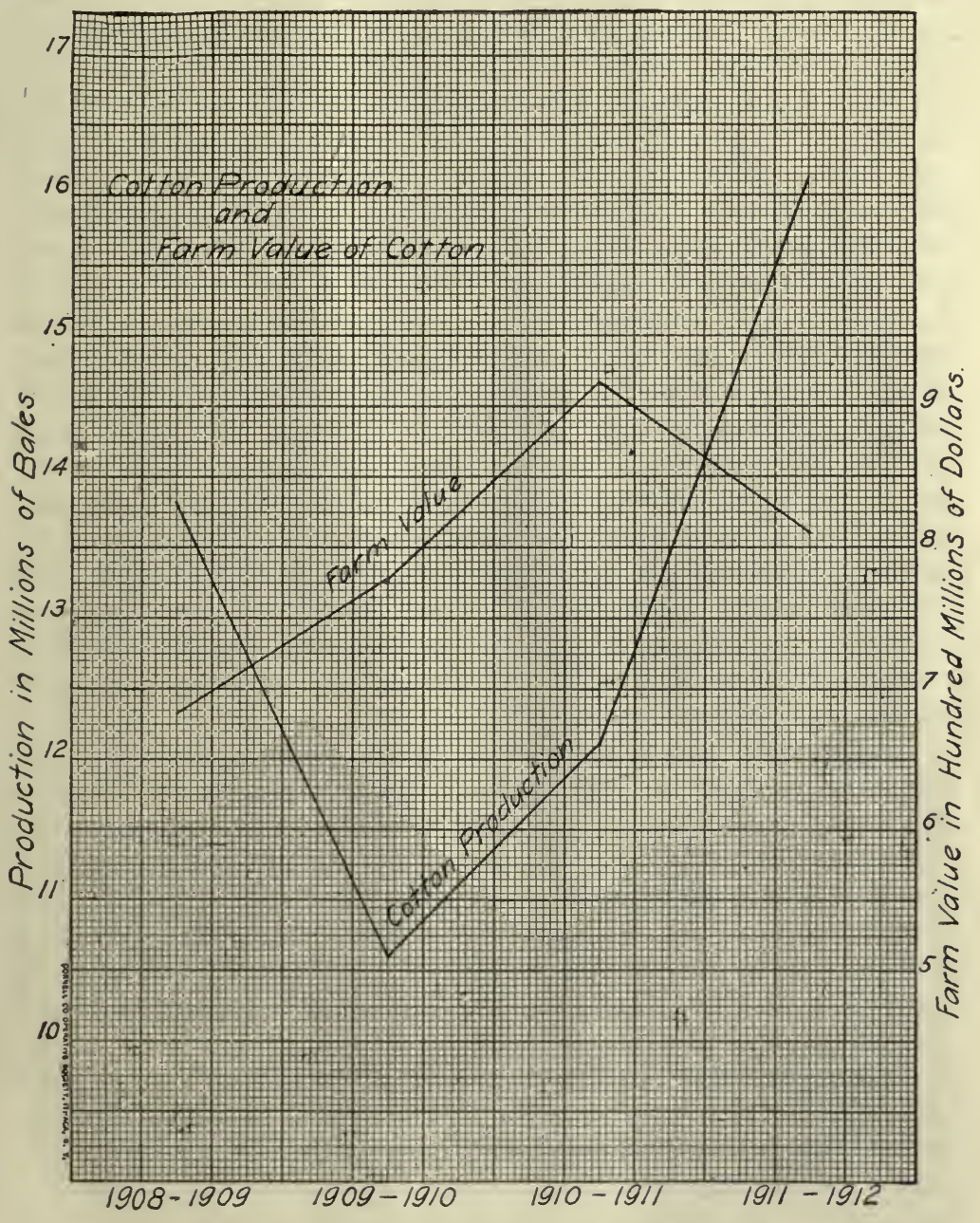

Fig. 4.-Cotton production and farm value of cotton.

the products of agriculture represent but $\$ 1,123,651,985$, or 45 per cent. Whereas agricultural exports remain about the same from year to year, or increase very slightly, the imports of agri- 
cultural products show a steady and rapid growth. Considering both our imports and exports of agricultural products we find that our net exports are only about $\$ 300,000,000$ a year. The big agricultural exports are, of course, cotton, packing-house products, grain (especially wheat and flour) and tobacco. The big agricultural imports are coffee, leather and hides, sugar, rubber, and silk.

Agricultural Land of the United States.-The United States has in its vast land area of two billion acres enough land to provide each man, woman and child of the population a twenty-acre tract. Of course, a large share of this land is not tillable. Much now is and must ever remain desert or mountain. At the 1910 census, only eight hundred million acres was "land in farms," and only half of this was "improved." By improved land is meant all land regularly tilled, or mowed, land pastured and cropped in rotation, land lying fallow, land in gardens, orchards, vineyards, and nurseries, and land occupied by farm buildings. The unimproved land in farms is, as indicated above, some four hundred million acres. In other words, our thirty million farming population on six million farms is actually utilizing but one-fourth of our land area. The average acreage of the "farm" in 1910 was one hundred and thirty-eight acres; of the "improved land" in the farm, seventy-five acres. In 1900 the average of improved land per farm was seventy-two acres, which indicates a slight tendency to increase the amount of land farmed by one farmer.

Exploitation and Conservation.-The economic history of the twentieth century in the United States begins with the birth of the doctrine of conservation-conservation of our soils, our waters, our rivers and our forests. This beginning marks a reaction against the nineteenth century of wanton and feverish exploitation of these same resources. The "soil-robbery" carried on by isolated and competing individuals, and known as farming during these hundred years, left a legacy of soil exhaustion problems for future generations to solve.

Better Business for Farmers.-Sir Horace Plunkett declared the rural life problems in the United States to be better farming, better business, better living. The report of the Roosevelt Country Life Commission found that from the commercial standpoint farming is not profitable enough, considering the labor, energy and risks involved, and the social and sanitary conditions of the open country.

The unattached man on the farm stands alone against the better mobilized interests of manufacturing and commerce. As a pro- 
ducer, he has been aided by the government. "Our attention has been concentrated almost exclusively," says the introduction of the report of the Country Life Commission, "on getting better farming. . . . Practically the whole of this effort has hitherto been directed towards increasing the production of crops. In the beginning this was unquestionably the right thing to do. The farmer must first of all grow good crops in order to support himself and his family. But when this has been secured, the effort for better farming should cease to stand alone, and should be accompanied by the effort for better business and better living on the farm." Thus the cotton growers of the South were taught how to increase the production of cotton, upon the theory that it is a blessing to make two blades of grass grow where only one grew before. But the report of the Secretary of the New Orleans Cotton Exchange states that while the cotton crop of 1911-12 increased by four million bales over the 1910-11 crop, the price received by the planter was over one hundred million dollars less. On the other hand, the crop of 1909-10 showed a falling off in production over 1908-09 by over three million bales, but an increase in value of a hundred million dollars. Thus in 1911 the energies of the Southern planters, devoted to cotton production, resulted in overproduction of this one crop and an under-production of other crops which the South needed, such as corn and hay, and also swine. In various important public meetings and congresses in the South, the farmers there have sought to stabilize their net returns by limiting the output of cotton to regular trade demands, while at the same time increasing their output of food crops and other crops needed by the South. This move for "limitation of output" has been misunderstood by the public since the practice itself has been associated with some of the methods of industrial warfare used by some radical labor unionists. In the case of the Southern planters, however, the agitation has been to produce a different output, not a smaller output - different crops, not smaller crops. It signifies a groping after a method of coördinating supply and demand. Lack of a balanced production is true for all the great staple crops, such as wheat and oats, for instance.

The wheat farmers produced a bumper crop in 1906, seven hundred and thirty-five million bushels. In 1907 they produced a hundred million bushels less, but got sixty million dollars more for it.

The farmers in 1910 produced the enormous quantity of $1,186,000,000$ bushels of oats with a farm value of $\$ 408,000,000$. Next year they produced a crop of two hundred million bushels less, 
but with a farm value of six million dollars more. In 1912 they increased the oats production by the unprecedented amount of five hundred million bushels, but the crop value only increased thirty-eight million dollars. Hence the problem of producing more is not the only problem of the farmer. It is no longer his greatest problem. He must produce more of the right thing. As Sir Horace says, the problem of better business must be solved if agriculture is longer to compare favorably with the other great industries.

Industrial Concentration.-The most striking economic difference between agriculture and the other great industries up to the present time is exhibited in the extent of organization and concentration in the general industries, on the one hand, as against the ! lack of organization and centralization in agriculture, on the other hand. Some evidence on this point will make the situation clear.

Lumber.-The Report of the Bureau of Corporations on the lumber industry (January 20, 1913), in speaking of our standing timber, says that these three facts are shown by the investigation: (1) the concentration of a dominating control of our standing timber in a comparatively few enormous holdings steadily tending toward a central control of the lumber industry; (2) vast speculative purchase and holding of timberland far in advance of any use thereof; (3) an enormous increase in the value of this diminishing natural resource, with great profits to its owners. This value, by the very nature of standing timber, the holder neither created nor substantially enhances. Forty years ago, continues the report, at least three-fourths of the timber now standing was (it is estimated) publicly owned. It passed from Government to private ownership. The three largest holders are now the Southern Pacific Company, the Weyerhaeuser Timber Company, and the Northern Pacific Railway Company. "The Southern Pacific Company holdings," continued the report, "is the greatest in the United States - one hundred and six billion feet. It is difficult to give an adequate idea of its immensity. It stretches practically six hundred and eighty miles along that railroad between Portland and Sacramento. The fastest train over this distance takes thirty-one hours. During all that time the traveler thereon is passing through lands a large proportion of which for thirty miles on each side belongs to the railroad, and in almost the entire strip this corporation is the dominating owner of both timber and land."

"These three holdings have enough standing timber to build an ordinary five- or six-room frame house for each of the sixteen million families in the United States in 1900." The holdings of 
the two railroad companies are government grants, and 80 per cent of the Weyerhaeuser Timber Company holding was bought from the Northern Pacific grant. By an interweaving of interest, corporate and personal, and by interlocking directorates, there is a further real concentration of control of a great many large holdings which on the surface appear to be separate holdings.

With the concentration in timber is also the concentration in the land which remains after the timber has been cut. In Florida 182 large timber holder's have over 16,990,000 acres, nearly one-half the land area of the state. In the area investigated by the Bureau of Corporations, the large timber holders had 89,744,000 acres-an area greater than the ten northeastern states, Maine, New Hampshire, Vermont, Massachusetts, Rhode Island, Connecticut, New York, New Jersey, Delaware, and Maryland.

To this concentration in timber and land must be added a closely connected railroad domination. "Still more impressive," continues the report, "are the possibilities for the future. In the last forty years concentration has so proceeded that one hundred and ninety-five holders, many interrelated, now have practically one-half of the privately owned timber in the investigation area (which contains 80 per cent of the whole). This formidable process of concentration, in timber and in land, certainly involves grave future possibilities of impregnable monopolistic conditions, whose far-reaching consequences to society it is now difficult to anticipate fully or to overestimate. Such are the past history, present status, and apparent future of our timber resources. The underlying cause is our public land policy, resulting in enormous loss of wealth to the public and its monopolization by a few interests. It lies before us now as a forcible object lesson for the future management of all the natural resources still remaining in the hands of the Government."

Other Industries.-Turning now to other industries, we find similar tendencies at work. The concentration of control of a large portion of our banking, railroad, and manufacturing industries in the hands of a few men-of one hundred and eighty men in fact-was shown by the Federal money trust investigation in 1912 and 1913. This small group of one hundred and eighty men, by a system of interlocking directorates, were shown to be represented in the directorships of corporations having total resources or capitalization of $\$ 25,325,000,000$. They held, to specify more in detail, three hundred and eighty-five directorships in forty-five banks and trust companies having total resources and deposits of 
$\$ 6,666,000,000$; fifty directorships in eleven insurance companies having total assets of $\$ 2,646,000,000$; one hundred and fifty-five directorships in thirty-one railroad systems having a total capitalization of $\$ 12,193,000,000$ and a total mileage of one hundred sixty-three thousand, two hundred; six directorships in two express companies and four directorships in one steamship company with a combined capital of $\$ 245,000,000$ and gross income of $\$ 97,000,000$; ninety-eight directorships in twenty-eight manufacturing, producing, and trading corporations having a total capitalization of $\$ 3,583,000,000$ and total gross annual earnings in excess of $\$ 1,145,000,000$; and forty-eight directorships in nineteen public utility corporations having a total capitalization of $\$ 2,826,000,000$ and total gross annual earnings in excess of $\$ 428,000,000$; in all seven hundred and forty-six directorships in one hundred and thirty-four corporations with total resources or capitalization of $\$ 25,325,000,000$. It is impossible to grasp the magnitude of this figure, but it may help to compare it with the value of all the farm land in the United States in 1900 , which was but $\$ 28,475,000,000$.

The interlocking nature of this concentrated control may be illustrated by the following examples. The firm of J. P. Morgan \& Co., of New York, had three directorships in the Northern Pacific Railway. This firm also had three directorates in the Astor Trust Co. and the Astor Trust Co. had two directorates in the Northern Pacific, as well as two in the Southern Pacific. In brief, the firm of J. P. Morgan \& Co. had twenty-three directorships in thirteen banks and trust companies, which companies in turn had fifteen directorships in the Northern Pacific Railroad and eight - in the Southern Pacific. To illustrate further the concentrating tendency in banking, railroading, and manufacturing, attention is called to the fact that the firm of J. P. Morgan \& Co., together with four neighboring banks in the city of New York, held three hundred and forty-one directorships in one hundred and twelve corporations having aggregate resources or capitalization of $\$ 22,245,000,000$. To carry the illustration of this tendency yet a step further, the fact may be cited that Mr. J. P. Morgan testified, ${ }^{1}$ that he named the entire board of directors of the United States Steel Corporation. This was a corporation capitalized at $\$ 1,400,000,000$, with some fifteen thousand stockholders, yet Mr. Morgan, owning but a small fraction of the stock, found the power of control of the corporation entrusted very largely to his judgment. Thus the

${ }^{1}$ Dec. 19, 1912. 
institutions above mentioned, especially the banks and railroads, control resources vastly in excess of what they own. They gain thereby an importance and a mobilized economic power which is impressive when compared with the unorganized agricultural industry. It is only fair to state that most of the great "captains of industry," so-called, have used their economic power in a constructive manner. And this is particularly true of the late J. P. Morgan, whose control and direction of big commercial investments was conspicuously successful and made more money for others than it did for himself. Hence the secret of his power.

A similar condition exists in Canadian agriculture, a country forming with the United States an economic and ethnic unit. A recent issue of the Grain Growers' Guide of Winnipeg ${ }^{2}$ discussed the question, "Who owns Canada?" The conclusion reached was that forty-two men controlled $\$ 4,000,000,000$ in resources, or more than 'nne-third of Canada's total wealth in railroads, banks, factories, mines, and lands. The railroads had been favored, says this report, with cash grants, $\$ 208,072,073$; with land grants, $56,052,055$ acres; and with bond guarantees, $\$ 245,070,045$. The forty-two men named in the article hold directorships in the following institutions; thirty directorships in financial institutions; forty-two directorships in transportation companies; fourteen directorships in insurance companies; and one hundred and eighteen directorships in industrial and other corporations.

Will Farmers Own the Farm Land?-The question suggests itself at this point, will not the ownership of our farm lands eventually pass largely into the hands of a small group of capitalists, just as we have had concentration of control of our other great industries? There are evidently many tendencies at work making for this very outcome; there are, however, opposing tendencies in operation which must also be taken into consideration. The question is a most serious one, as England and Ireland and other countries have already found out. But the discussion of this problem must be postponed to the chapter dealing with land tenure.

\section{QUESTIONS ON THE TEXT}

1. State and explain the rank of agriculture among our industries formerly and now.

2. Cite census figures as evidence of this change.

3 . Comment on the increase in value of farm lands.

4. Compare the great industries as to the number of persons engaged in each.

5. Compare the great industries as to the amount of capital invested. The same for the value of the product.

${ }^{2}$ June 25, 1913. 
6. Show the past and present rank of agricultural exports and imports.

7. What portion of the land area of the United States is "in farms" and what part is "improved"? Explain these terms.

8. Compare per cent of increase in population, for a series of decades, with increase in production of staple crops and live stock. Show significance of these figures (Fig. 5).

9. Show at what periods of our history we have followed the doctrines of "exploitation" and "conservation" respectively. Explain these terms.

10. According to Sir Horace Plunkett, what is the rural life problem in the United States?

11. State the conclusions of the Roosevelt Country Life Commission.

12. Show the fallacies and the true principles involved in the question of increased production of staple crops.

13. Show the significance of industrial concentration in various fields in recent years, such as lumber, banking, and railroads.

14. Compare Canadian industries as to a similar concentration.

15. What do present tendencies indicate as to the future ownership of farm lands in the United States?

\section{QUESTIONS SUGGESTED BY THE TEXT}

1. Is a large increase in land values a benefit to the farmers themselves?

2. What are some reasons for and against an agrarian party?

3. What portion of the land surface of the United States will likcly remain forever out of use for agricultural purposes? What are the limiting factors?

4. From the farmer's standpoint should there be an increase or a limitation of output of the staple crops? Reconcile the social and the agrarian viewpoint on the question of increased production.

5. What evidence is there, if any, of farm land ownership becoming centralized in the hands of big corporations? If corporation farming is more efficient than individual farming, should it not be promoted?

6. Give examples from your own village or city of the centralization of control over local enterprises in a few hands and explain the cause of this centralization.

\section{REFERENCES}

1. U. S. Census Reports. See especially 8th Census, volume on Agriculture $(1864)$; 10th Census, vol. iii; 12 th Census, vol. v, xvi-xxxvii.

2. Report of the Country Life Commission. Edited by L. H. Bailey.

3. Haworth, PaUl Leland: "George Washington, Farmer."

4. Report of the Industrial Commission, vol. x, i-lxiv (1901); vol. xix, 45-96 (1902).

5. Report of the Bureau of Corporations on the Lumber Industry (January 20,1913$)$.

6. BAKER, O. E.: "Arable Land in the United States, Yearbook," Department of Agriculture, 1918, 433-443.

7. Plunkett, Sir Horace: "Rural Life Problems of the United States."

8. Yearbooks, Department of Agriculture: 1903 - "Nation's Farm Surplus" 479-491. 1904- "Annual Loss Caused by Insects," 461-475. 1905 - "Diversified Farming in the Cotton Belt," 193-219. 1908 - "Causes of Social Rural Conditions: Remedy-Small Farms," 311-321. 1909-"Farming as an Occupation for City Bred Men," 239-249.

9. Wright, C. D.: "Industrial Evolution of the U. S.," Ch. 12.

10. Day, CuIve: "History of Commerce," chs. 51, 52, 53.

11. Nourse, E. G.: "Place of Agriculture in Modern Industrial Society." Journal of Political Economy, vol. xxvii, 466-497; 561-577.

12. Hall, A. D.: "A Pilgrimage of British Farming," 1910-1912, London, 1913. 


\section{CHAPTER II}

\section{ANARCHY OF AGRICULTURE}

Agriculture at present is an unorganized industry, carried on by millions of competing units. The man on the farm coöperates with nature, but not with his fellow-farmer. The so-called trusts and large combinations of capital have done much to integrate the other industries. Agriculture remains individualistic. Where industries have reached the monopoly stage or the stage of strong centralized control, we witness a coördination of production and consumption impossible elsewhere. Production is planned to fit the need; overproduction and underproduction are both to a certain degree avoided. This is illustrated in the case of refined petroleum. Many other large industries, without the monopoly element, yet involving the investment of considerable capital, show a reasonably close coördination of production and consumption. Take the mining of coal, for instance. Consumption needs increase as population increases, and as industrial expansion grows. Hence production of coal should increase in a constantly growing and unbroken ratio to meet this upward-moving demand. And such we find to be the case. A glance at the census figures reveals the situation:

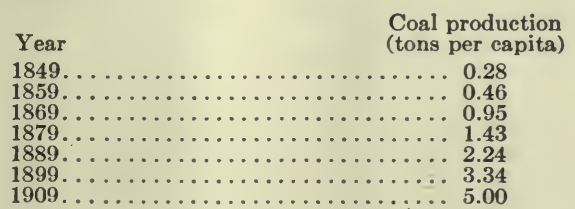

In manufacturing the same coördination is found, although not so perfect. The demand is estimated in advance, and this forecast is fairly accurate. However, competing manufacturers may overproduce or underproduce and in this manner cause supply to be out of line with demand. And, of course, in manufactured goods, we enter the field where there is more elasticity of demand, and hence more likelihood of failure of coördination of supply and demand.

When we come to the field of agriculture we find the greatest failure to coördinate supply and demand. Here we have an industry whose product is in universal demand. And this demand, 
as shown by the markets, is like the supply-not constant, but is dependent in part on fluctuating production in competing areas in foreign lands, in part on prices and uses of substitutes and alternates.

Compare the two great staples, for example, cotton and wheat. In 1886 the wheat crop was four hundred fifty-seven million bushels. Ten years later, with ten million more mouths to feed in the United States, the crop was thirty-seven million bushels less. And ten years later, with another ten million mouths to feed, the crop has increased by over three hundred million bushels. Eight years later, and the crop has increased by one hundred and fifty million bushels. Cotton production shows the same enormous variations. Taking the annual yield for five consecutive years, we have the following impressive figures:

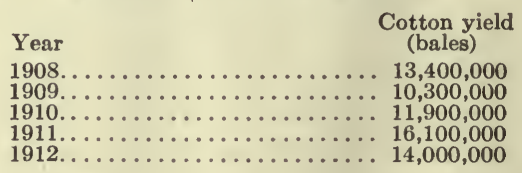

An increase of fifty per cent from one year to the next sometimes occurs in the production of cotton.

We may likewise compare two minor crops which are yet staples and for which the demand is never constant, namely, tobacco and potatoes.

Note the wide fluctuations in potato production from year to year in this brief table:

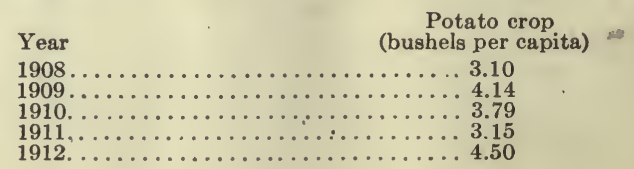

Statistics for tobacco production show similar fluctuations:

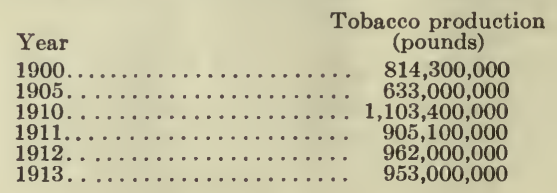

Animals follow the same erratic course, often decreasing rapidly as population increases, and again increasing far in advance of the slow and steady increase in population. This phenomenon makes the farm output differ from the factory output. 
Factors of Uncertainty.-Is it possible to coördinate production and consumption of farm crops? It is impossible to forecast demand, and it is clearly impossible to forecast or control the

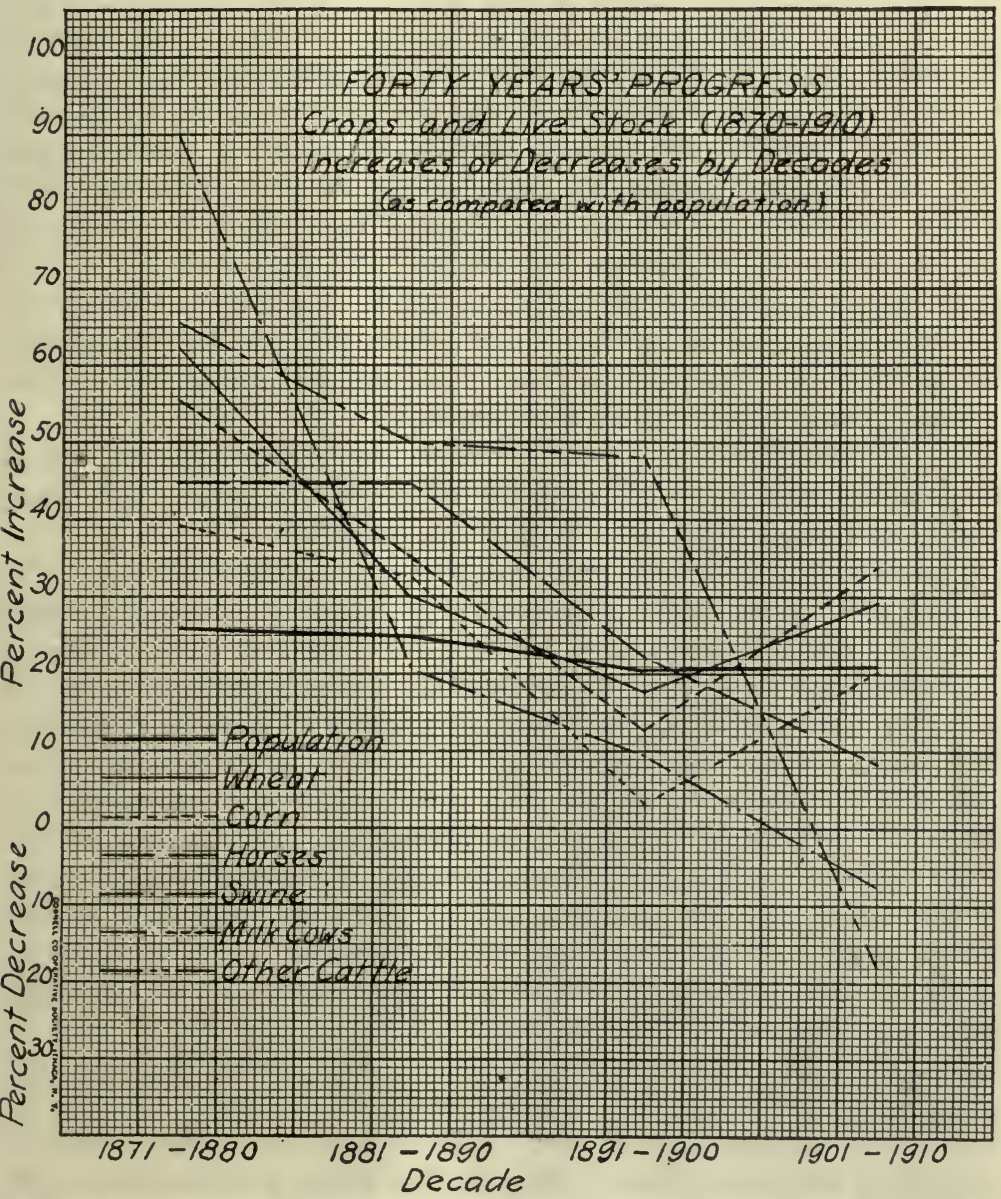

FIG. 5.-Forty years' progress, crops and livestock, 1870-1910. Increases or decreases by decades as compared with the population.

supply. There are too many factors of uncertainty. The chief of these factors, to name but three, are climatic conditions, plant diseases, and insect pests. A great loss to the American wheat crop, as well as to the European, is often caused by "winterkilling." The winter may be too mild, too severe with no snow 
blanket, or may alternately thaw and freeze till the wheat is killed. Late spring frosts may injure winter wheat or decrease acreage of spring wheat. Early frosts in the fall injure the wheat, as happened in 1907 and 1911 in the Northwest and in the Canadian West. Rain at harvest time, extreme heat, prolonged drouth, all may do serious damage to the wheat crop. In 1902 the Australian crop fell from $42,500,000$ bushels of the previous year to $19,800,000$ bushels. The 1903 crop rose to seventy-five million. This drouth had the effect of raising the price of wheat in the Pacific Coast States above the Liverpool price level. Bad weather conditions also lead to rust and smut which injure the crop seriously. Hail is an agent of destruction. Floods, as in Kansas in 1904, may destroy large areas of wheat. This same year, 1904, was known in America as Black Rust year, since the total loss due to this cause was seventy-five million bushels.

What has been said about climatic conditions and the wheat crop is believed to be typical for other farm crops. And these conditions can neither be foreseen nor removed.

Insects and Diseases.-Among the insect pests may be mentioned the "green bug" (Toxoptera graminum). The green bug made its appearance in 1890 and proved very disastrous to wheat and oats over a section of the country extending from Texas to Northern Missouri and eastward to Indiana. Again in 1900, and still again in 1907, this green bug appeared. In 1907 it attacked the wheat crop and almost totally destroyed the Texas crop, and seriously damaged the crops of Oklahoma and Kansas. The wheat grower also is in constant danger of serious loss from the Hessian fly, the chinch bug, the wheat midge, and the weevil. Other crops have an equal number of enemies.

Bulletins from our Agricultural Experiment Stations show the great variety and serious extent of plant and animal diseases in the United States. For livestock, as well as field crops, are in constant peril of disease. For instance, one bulletin of the Wisconsin Station alone treats of the following pathological conditions and insect enemies in that State: vaccine treatment of chicken-pox in fowls; contagious abortion (described as "the greatest menace to our dairy cattle"); root killing and body canker (in orchards and small fruits); potato rot and blight; potato scab; five cabbage diseases (black rot, soft rot, yellows, black leg, club root); rust and leaf blight of field crops; barley stripe disease; alfalfa leaf spot; cottony maple scale; cutworms; onion maggots (destroying from fifty to ninety-five per cent of the crop); codling moth (apple 
worm); plum curculio; San José scale; house fly; onion thrips and onion fly (Thrips tabaci and Pegomya cepetorum "now threaten this crop with destruction"); onion smut; pea blight; root rot of tobacco (Thielavia basicola, "As a conservative estimate it is thought that this single disease last year (1912) cost Wisconsin tobacco growers a loss of approximately $\$ 1,000,000 ")$; black rot of tobacco. This showing is significant, coming as it does from a state which is unusually free from plant and animal diseases. Mention may be made of the following animal diseases, prevalent in various parts of the United States, but now apparently in course of extinction: Glanders in horses, tuberculosis in cattle; cholera in hogs. In the year 1914 an outbreak of the foot-and-mouth disease among cattle occurred in the United States, entailing a loss of millions of dollairs.

Effects of These Factors.-The above list of pests and diseases contains only a few of the commoner and better known ones. It is evident, however, that climatic conditions, pests and diseases are factors of uncertainty in agriculture. These factors affect both the quantity and quality of the farmer's output, whether field crop or livestock. These factors therefore render coördination of supply and demand impossible. There must inevitably result from these great fluctuations in supply corresponding fluctuations in price. Price fluctuations in turn create a class of risk takers. The farmers themselves, where the markets are narrow, local, and unorganized, are of course the risk takers, and take both the gain and the losses of price fluctuations. In the great staple commodities sold on the world-market, however, where the organized market is the rule, a distinct class of risk takers, commonly known as speculators, has been slowly developed. It must be clearly apparent to every person giving the subject any thought that prices do not fluctuate because men speculate, but that men speculate because prices fluctuate. The service of the speculator to the farmer and the trade in general has often been pointed out by the Federal Government. For instance, the report of Cotton Exchanges ${ }^{1}$ makes this point very clear, in the following language:

"Dealings in cotton must always be accompanied by risk, either to the producer, the merchant middleman, the speculator, or the spinner. Natural conditions greatly affect the supply, and other conditions the demand, and both consequently affect the price. What is the equitable distribution of these risks? It is a general principle that much of the risk should properly be borne by the speculative class; that is, by those who neither produce nor

${ }^{1}$ Report of Bureau of Corporations on Cotton Exchanges; Part 1, 1908, pp. XVII-XVIII. 
spin cotton, but who are interested simply in making a profit out of the rise or fall of its price. Whatever justification there may be for the speculator lies in the fact that he stands ready to take a large share of the risk. His function is to (1) forecast future natural conditions affecting supply and demand, (2) to obtain as accurate information thereon as possible, (3) to make the price for future deliveries based on such information, and thus (4) to discount in advance as far as possible, for the benefit of the trade in general, the effect of such future conditions and thereby (5) keep prices free from violent fluctuations which otherwise would occur from unforeseen natural causes."

While this report of the government pertains to the cotton industry, it holds true in all essential respects for all commodities on the various exchanges. And it makes clear the very significant fact that this organized speculation lessens price fluctuations instead of increasing such fluctuations.

This same report quotes with approval the well-known treatise of Emery on the Stock and Produce Exchanges of the United States, especially that section of the treatise which makes the distinction between gambling and speculation. The objective economic distinction between the two, says Emery, is this: gambling consists in placing money on artificially created risks of some fortuitous event. Speculation consists in assuming inevitable economic risks of changes in value. ${ }^{2}$

Yields and Prices.-By means of insurance farmers are able to shift certain risks. Crops are frequently protected by hail insurance, livestock by livestock insurance. There still remain, however, inevitable economic risks which come from changes in supply, changes in demand, and changes in price. A farmer's prosperity has at least four variable factors in it as follows:

1. Good crops and good prices.

2. Poor crops and good prices.

3. Good crops and poor prices.

4. Poor crops and poor prices.

The relation between yields and prices has been too much neglected. The Experiment Station Record ${ }^{3}$ reviewing a work in this subject contains these words: "The author criticizes the views which he states are generally assumed by many writers and speakers, that large yields are always profitable and the best farmers are those who raise the largest crops; that large yields are a natural antidote for the high cost of living; that we should now copy the p. 102.

${ }^{2}$ Emery, Speculation on the Stock and Produce Exchanges of the U. S.,

${ }^{3}$ Experiment Station Record, Feb., 1915, p. 191. 
intensive methods of older countries; and that more capital is needed for the best results. He believes that it is relatively safe to invest capital freely upon the farm for the sake of correcting abnormal conditions and raising the yield to the normal, but that beyond that point, because of the law of diminishing returns, it will pay only when prices rise."

The anarchy of agriculture evidenced by frequent overproduction is made clear by an address of C. J. Brand, of the Bureau of Markets of the United States Department of Agriculture. ${ }^{4}$ The cantaloupe trade was cited by Mr. Brand to show an overdevelopment of the industry due to ignorance as to the development of competitive areas, which in 1914 resulted in disaster to the producers and to the large distributors. Yet the consumers failed to buy at any lower prices. "As usual," says the Record, "the slump in prices was not reflected in the retail trade, consumers paying practically as much as in a year of scarcity, while the surplus went to the aump." The conclusion is that "until we have a better adjustment of production to market requirements, this problem will continue to be with us." Carl Vrooman, Assistant Secretary of Agriculture, discussing farm problems before the 1914 Philadelphia meeting of the American Association for the Advancement of Science, corrected some of the false popular impressions as to the advantages of high acre yields. He showed by statistics that the largest crops do not necessarily mean the largest net income to the farmer, and that in years of relatively small production he often realizes quite as much from his crops as in years of maximum yield.

Seasonal Marketing.-Another point of great significance to the farmer must be noted, and that is the seasonal nature of his product. His chief crops are produced once a year. Yet the crop is consumed every day in the year. Since the crop is produced and harvested during a short period, and consumed during the whole year, there is thereby created the problem of storing, preserving, and financing the agricultural product. What, if anything, shall the farmers themselves do about it? That the situation to-day is one of anarchy was strikingly illustrated by one speaker at the 1915 Chicago meeting of the National Conference on Marketing and Farm Credits. R. W. Hockaday, of St. Louis, the General Industrial and Agricultural Agent of the M. K. and T. Ry. Co., in discussing the marketing of the Southern peach crop,

${ }^{4}$ Experiment Station Record, Feb., 1915, p. 106. 
stated that the St. Louis market could absorb twelve cars of peaches per day and no more. Yet, on one occasion a Georgia shipper, desiring to consign peaches to St. Louis, took the precaution to wire Mr. Hockaday for information concerning the peaches billed that day over the road to St. Louis. A brief examination disclosed the fact that seventy-five cars were on the way on this one road, to St. Louis! No wonder shippers find their commission men and other consignees sometimes paying prices less than original cost of production! Where does the blame lie? And where is the remedy? Both rest largely with the shippers.

The problem of marketing and the problem of the organized exchanges must be discussed in later chapters. But it is obvious that in some specialized, limited crop areas a part of the present anarchy in agriculture can be removed by organized production and by organized marketing. But the farmer cannot eliminate all risks. Much speculation in the products of the farm must ever remain.

\section{QUESTIONS ON THE TEXT}

1. Show the significance of lack of coördination of supply and demand in agriculture. Cite illustrations. Compare other industries.

2. Show why coördination of supply to demand is difficult, and in some respects, impossible. Show clearly the factors of uncertainty.

3. Show that with the existing "anarchy" in agriculture, speculation is rendered inevitable.

4. Quote the Government report on the Cotton Exchanges. What are the five functions of the speculator?

5. Quote Emery's definitions of speculation and gambling.

6. Quote Brand's statement about cantaloupe production and distribution.

7. Quote Vrooman's statement about the "fallacy of large yields."

8. Show the fundamental necessities back of storage and financing of farm crops.

9. Illustrate how market gluts arise. Who is to blame?

\section{QUESTIONS SUGGESTED BY THE TEXT}

1. Define anarchy. Can this term be applied to agricultural production and distribution?

2. Distinguish between speculation and gambling.

3. Do we ever have overproduction in agriculture? If so, who gains thereby? Who suffers?

4. Would the farmer gain by combining and producing smaller crops? Distinguish between individual and social welfare.

5. Have you any suggestions to make concerning the improvement of present methods of storing and financing farm crops from harvest time to consumption time?

6. To what extent ought farmers to enter the fields of storing, conditioning, and financing their crops, and to what extent ought specialists (middlemen) perform these functions? Ought a farmer to specialize exclusively in farming? 


\section{REFERENCES}

1. For statistics of agricultural production see Yearbook of the Department of Agriculture.

2. For statistics of the movement of grain crops to market see the annual reports of the Secretaries of the important exchanges, especially the following: Winnipeg, The Grain Exchange; Duluth, The Board of Trade; Minneapolis, The Chamber of Commerce; Chicago, The Board of Trade; Kansas City, The Board of Trade; St. Louis, The Merchants Exchange.

3. For abstracts from the reports issued by the Experiment Stations of the United States, and from other agricultural literature, consult the "Experiment Station Record," published by the Department of Agriculture, Washington.

4. WELD, L. D. H.: "The Marketing of Farm Crops."

Maladies Affecting Animals.

In the Secretary of Agriculture's Annual Report for 1915 he estimates the loss for the year as follows:

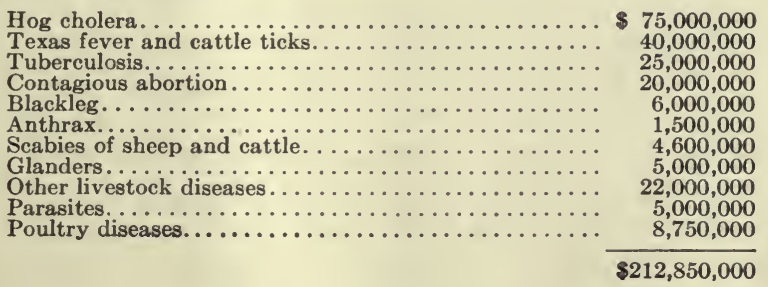




\section{CHAPTER III}

\section{FARMING VERSUS LAND SPECULATION}

As already mentioned in the preceding pages, only half the land in the United States is now in farms; only half the land in farms is "improved"; and this improved land, according to some critics, is not well farmed. It has also been shown in a preceding paragraph that farm land is passing out of the hands of the dwellers on the land, and, unless the tendency of the past forty years is broken, the time is not far distant when the land will practically all be farmed by tenant farmers or hired labor and not by the owner.

The criticism is also heard with increasing frequency that the farmer is one-third farmer and two-thirds speculator. This criticism is based on the fact that a part of the farmers aim to make their profits and do make their profits by selling their land, not by farming it. Many farmers frankly admit that were it not for this speculative gain their years of toil would show no balance to their credit. Indeed, the Assistant Secretary of Agriculture has stated that "the average farmer is only making wages; he is not making a profit over his wages and the interest on his investment." 1 As long as farmers own the land, the American people will doubtless be content to see the farmer receive as a reward for his years of toil this speculative gain coming from increase in land value. But when the land passes from the hands of the men who farm it, the question of "overcapitalized land" will doubtless become an insistent one, and one raised by the farmers themselves.

Overcapitalized Land.-The agitation among farmers which led to the "granger laws" for state regulation of railroads was based on harassing conditions: rates were unsatisfactory and discriminatory; railroads, especially of the western and Pacific States, were greatly overcapitalized. Perhaps overcapitalization, or "watered stock" as it was called, was the most loudly denounced of the evils. Briefly, the farmer considered it wrong that a road costing twenty-five thousand dollars a mile should be capitalized at forty or fifty thousand a mile. Applying this same logic to land now that was applied to railroads forty years ago, it may be an evil to capitalize land costing $\$ 25.00$ an acre at $\$ 50.00$ an acrean evil to the farmer and to the general public.

${ }^{1}$ Experiment Station Record. Feb. 1915, p. 105. 
The following case of C. L. Smith-a true story-is typical of many transactions in country real estate which are now being made every day throughout the entire United States. In the year 1907 C. L. Smith, a renter on an Illinois farm, decided to move westward and buy land in North Dakota. The Illinois land at this time, of good farming quality, was selling for $\$ 150$ an acre, whereas the Dakota land, of equal fertility, was selling at onethird or one-fourth, or even one-fifth that amount. It should be added also, that much Dakota land of an inferior grade was on the market at prices ranging from $\$ 10.00$ to $\$ 10.00$ an acre. $\mathrm{Mr}$. Smith, upon his arrival in North Dakota, was taken in charge by certain real estate agents. These agents had arranged for the conditional purchase of a farm of six hundred and forty acres at $\$ 20.00$ an acre. This farm the agents then sold to Mr. Smith at $\$ 31.50$ an acre, and Mr. Smith, thinking of the one-hundred-andfifty-dollar land, considered himself the discoverer of a bargain. He had been deceived, however, as later developments proved. This land, in common with other land in this community, was considered by the actual owners to be worth about $\$ 20.00$ an acre. Allowing the agent the commission of $\$ 1.50$ an acre (a $\$ 960$ commission), Mr. Smith should have paid $\$ 21.50$ an acre. Instead of that, he paid $\$ 31.50$, or $\$ 10.00$ an acre too much, a total excess of $\$ 6400$ on the section. The agents on an investment of $\$ 12,800$ made a profit of $\$ 7360$, or a net profit of 57 per cent. Mr. Smith paid $\$ 1000$ in cash when he bought the farm, and gave a mortgage on the farm for the balance. The farm had been grossly overcapitalized. It was consequently impossible to carry the load. This meant one of three possible courses: (1) submit to foreclosure proceedings, and lose the land and much of what had been invested in it. This frequently happens. (2) Renew the loan, thus shouldering the same burden for another period of years with no more hope of ultimate success. (3) Find a new buyer, ignorant of conditions (commonly spoken of as a "sucker") and sell the land to him at $\$ 50.00$ or $\$ 60.00$ an acre. This course would permit Mr. Smith to recoup his losses and retire with a profit. The mortgage was foreclosed before it was due, and Mr. Smith estimated his net loss on the deal as $\$ 5,000$. When asked to suggest some remedy for this system of merchandising land, Mr. Smith wrote, in language more forceful than grammatical, as follows:

"I had enough to pay for one hundred and sixty acres. That is what is hurting this county, because some of the agents are fleecing the men that come here with a little money. They overload them with land and when the 
pinch comes they lose all. I am not the only man that has lost all through them around here. If they would charge $\$ 1.50$ an acre for selling, we could stand that all right. And this county would boom if the ones that have come here could make a success of it, and we could if we were told the truth before we came here."

The process of "unloading" land onto the inadequately informed buyer is a practice which has assumed immense proportions in late years. The tiniest village now can boast of its "Real Estate Offices," with one or more men giving their whole time to this form of trading, whereas, a few years ago the marketing of agricultural lands was largely incidental to other businesses or was done by private agreements. Apparently the only check to this form of speculation and value-inflation (since there is ordinarily no organized Real Estate Exchange in the farm community) is the cycle of financial panics which visits the United States. In panic years, if the panic be a severe one, much liquidation in real estate takes place. This entails fearful losses on the land speculators, including farmer speculators. A good illustration of this was seen in Western Canada in 1913 and 1914, when the banks ceased to finance land trading. This was followed by a serious slump in land values, and a general depression involving the usual feature of heavy liquidations and business failures.

That real estate values are subject to wide fluctuations, and hence offer great opportunities for speculative gains, is strikingly illustrated by the Report of Senator Peffer, on "Agricultural Depression, Causes and Remedies," submitted to the Senate Committee on Agriculture and Forestry, February 15, 1894. This year was a time of low prices, but was both preceded and followed by a period of high prices. And this is true of every period of low prices. The following quotations from this report show the widespread depression in farm land values:

"In Illinois improved lands fell from $\$ 20.81$ in 1873 to $\$ 11.18$ in 1892."

"In Nebraska improved lands fell from $\$ 4.60$ to $\$ 3.72$, more than twenty per cent since 1885."

"In Kansas land was about fifteen per cent lower in 1892 than it was in 1874 or $1884 . "$

"In the New England states lands used for agricultural purposes are not valued as high as they were in 1875 by thirty per cent."

"There are many local influences which affect prices, and it is only by averages that we can approximate the general truth in regard to the matter. When men who own land are out of debt and do not want to sell, they hold their land as high as they ever did; while, on the other hand, when the owner is in debt or wants to sell, he does not strenuously hold up the price. From the best sources of information accessible, the committee are of the opinion that the prices at which farm lands in the older states could have been sold during the last five years is at least twenty-five per cent below the level of 
fifteen or twenty years ago. And if we are guided by the reports of land sales in foreclosure proceedings, the depreciation has been more than fifty per cent. In three hundred and eighty-three cases in six counties in one state the lands sold for but twenty-five per cent of the debt, and the debt was only one-third the estimated value of the land when the debt was incurred."

Investigating Agricultural Conditions.-Four years after this date-another cycle of prosperity having failed to develop-Congress passed an act (June 18, 1898) creating the Industrial Commission with powers to investigate and report on agricultural and other conditions. Volume X of the Industrial Commission's Report issued in 1901 contains these statements concerning farm land prices:

"The prices of agricultural land in the Eastern States have generally fallen, in some cases to about fifty per cent of the figures asked during the time of high prices. There is said to have been also a general decline in the price of land along the Mississippi river. Figures given for Pennsylvania show an increase in the average price of farm lands between 1859 and 1879 (the high prices preceding the latter year being explained by the inflated currency), but a drop by 1889 to a lower price than that of thirty years previous .... About 1890, California lands showed the effect of the high prices of fruit in an increase of values which could scarcely be expected to be permanent. Land can now be obtained at about one-third. or even less, of the prices prevailing at that time."

This decline in farm values may be the best thing, after all, considering the question from the standpoint of proper capitalization versus overcapitalization. For, as L. H. Bailey testifies, "valuation of farm properties have decreased. It is therefore apparent, if prices have not depreciated, that the income from investment in farm lands to-day is relatively greater than a generation ago. When farm values are low it is the time to purchase farms if one desires to make a living from the proceeds. In this view, therefore, the decline in farm values promises well for the earning power of farming."

Professor Bailey, however, is led into error in his conclusions concerning the permanence of low values. He says, "It has been a fault with farmers, perhaps, that they have considered the changes in farm values to be merely temporary, and they have therefore been free to contract debts hoping that the status would quickly regain itself. The fact seems to be, however, that the decline in farm values is general and relatively permanent."

A Rise in Selling Price.- Yet the value of farm land increased in the ten-year period, 1900-1910, by one hundred and eighteen per cent! Since the land in farms increased during this period by only four and eight-tenths per cent, it is evident that this enormous increase in land value is due almost wholly to a rise in the selling 
price of land. In short, the average value of land per acre rose from $\$ 15.57$ in 1900 to $\$ 32.40$ in 1910 , or one hundred and eight per cent. In one decade, therefore, the value of the farm land in the United States was more than doubled. Obviously the real estate market in its present unorganized condition offers opportunity for speculative gains rivalling and even exceeding those of the stock exchange or other organized exchanges. Is the farmer the beneficiary or the victim of high-priced land and of land speculation? The farmer who depends for a living on the proceeds of his farming is clearly the victim, since it is rapidly becoming more difficult to become a land owner. An increase in the number of mortgages accompanied by a decrease in tenancy would show a healthy movement of renters becoming owners. But such a movement is lacking. On the other hand, an increase in mortgages, accompanied by an increase of tenancy, shows an unmistakable movement of land ownership out of the hands of the farmers into the hands of absentee landlords. This movement is unhappily upon us.

Commercial Value vs. Market Value.-The selling price of the products of the land determine the commercial value of the land. When land sells for a price in excess of this value it has a market value out of line with its commercial value and may be said to be overcapitalized. This situation often exists, and may be due to various causes. But whatever the cause, the results are bad for the would-be land-owning farmer. Edwin A. Pratt in his book on "The Transition in Agriculture," gives us a striking statement of the case from his own observation in England. Says Pratt:

"Looking in the first place at the price which the would-be peasant proprietor must pay for his land independently of legal charges, it is certain that the English agriculturist who desires to purchase a small holding in the open market labors under special disadvantages. It is not alone that he has to compete with a number of others possessed of similar aspirations, but various causes have combined to give to much of the land in this country-more, perhaps than in any other country - a market value which is in excess of its commercial value - that is to say, its value when it is wanted for the production of commodities for sale. This is especially the case in regard to land which might be utilized for residential purposes for the sake of the social advantages afforded by the ownership of an estate or in the interests of sport. Not only do established country families seek to increase their properties, for one reason or another, by incorporating therein any bit of freehold they can secure in the immediate neighborhood, but the market value may be kept above the commercial value by reason of the fact that every Englishman, more or less, who has prospered, thinks it incumbent on him to set up his 'place' in the country, if he should not have one already. In either case a higher price would be forthcoming than could be afforded by a cultivator who desired the land as a means of obtaining a living thereon. Still more do these considera- 
tions apply in the neighborhood of a town or of a village not too far from a railway station-that is to say, in precisely those localities. which the small holder who wanted to start market gardening, or some other such business, would find the most desirable for his purpose. Here he might have to compete with the retired professional man, merchant, or tradesman, who, though unable to buy a large estate, wished for a 'bit of land,' which he could either build on or, at least, feel a pride in owning, and for which he is not disposed to look too closely at the price, assuming he finds what suits his fancy. So to begin with, the would-be small owner, standing as a solitary unit might agree to buy land at a higher price than he ought to pay-from a commercial standpoint - even if he had the money. But he has not got the money. He possesses a certain sum, and this the seller of the land agrees to accept, the remainder being left on mortgage."

This situation leads Pratt to the conclusion that tenancy at a fair rent is better than ownership at an overcapitalized valuation. His words are: "Looking at the matter from the point of view of first principles, I should say the purchase-provided tenancy on satisfactory lines can be secured instead-is the more undesirable because the small holder should be able to do better with his money. Farming as a business must be run on business lines, and there ought to be greater profit from capital placed in a business, with the possibilities of a more or less frequent turn-over, than from capital locked up in land that is wanted for cultivation, especially in land bought at, as I have said, more than its commercial valuation."

Overcapitalized land is a bad thing for the farmers themselves, as the foregoing discussion indicates. It is likewise a bad thing for the wage-earning class. The outstanding economic fact in our past history has been the abundance of cheap, fertile land. And this "free" land-as long as it lasted-was the one great force tending to maintain the high rate of American wages. Truly did Winthrop sense the situation when he wrote in 1645: "Our children's children will hardly see this great continent filled with people, so that our servants will still desire freedom to plant for themselves, and not stay but for verie great wages." In a similar vein wrote a royal official of New York in 1723: "North America containing a vast tract of land, everyone is able to procure a piece of land at an inconsiderable rate, and therefore is fond to set up for himself rather than work for hire. This makes labor continue very dear ..."

Earnings from "watered-stock" and earnings from the "unearned increment" in land value are in essence the same, and are indeed twin evils. Each man ought to reap where he sows and what he sows, and no more. How much profit, then, is the farmer entitled to? A fair answer to this question is contained in the 


\section{federal government's "Weekly News Letter to Crop Correspond-} ents," in these words: ${ }^{2}$

"The county agent is a part of a great agricultural movement. This movement has for its ultimate purpose the building up of a country life that shall be wholesome, attractive, cultured, efficient and profitable. There are many sections of our country to-day that have one or more of these conditions, but the sections where all are found in happy unison are comparatively few. The desire of those who are thinking on rural problems is that rural communities everywhere shall be wholesome, attractive, and cultured, and that each individual shall receive a fair reward for the labor done and the capital invested. In proportion as agriculture is made profitable will the community become attractive, cultured, and a place wholesome and desirable to live in.

"Just what is meant by a profitable agriculture? Simply this: There shall be a reasonable return on the capital invested in farming and a reasonable return for the farmer's labor and managerial ability. A farmer, like any other man in any other business, is entitled to just what he earns and no more; but what he earns should be sufficient to give him and his family some of the more essential conveniences of modern life, time for study, some recreation, and opportunity for education of his children. With some money in his pocket the farmer will support the church, place conveniences in his house, magazines and literature on the sitting-room table, and send his children to the best schools with very little outside prompting."

\section{QUESTIONS ON THE TEXT}

1. Distinguish between land farming and land speculation.

2. Distinguish between farmer and land owner.

3. Quote Vrooman on the farmer's average income.

4. Define and illustrate overcapitalized land.

5. Cite the case of Mr. C. L. Smith.

6. Give examples of fluctuations in land value.

7. Quote Bailey on land values.

8. Distinguish between commercial and market values.

9. State and explain Pratt's position as to ownership versus tenancy.

10. Show the interest of the wage earner in cheap land.

11. What profits, according to the Government Weekly News Letter, is a farmer entitled to?

\section{QUESTIONS SUGGESTED BY THE TEXT}

1. Ought the land owner to have the "unearned increment," so-called, on his land?

2. Is free trade in land the ideal method of land trading?

3. Is it for the public welfare to have cheap land or dear land? Reasons for your answer.

REFERENCES

1. Pratt, E. A.: "The Transition in Agriculture."

2. For a statement of the Single Tax view of the "unearned increment," see "Progress and Poverty," by Henry George; also, "The case for Land Nationalization," by JOSEPH HYDER.

3. Whittaker, Sir Thomas: "Ownership, Tenure, and Taxation of Land."

4. BoGART, E. L.: "Economic History of the United States," 229-235; 247-249; 286-299.

5. Coman, Katherine: "Industrial History of the United States," 285-307.

6. Marshall, Wright, Field: "Materials for the Study of Elementary Economics," 635-640.

${ }^{2}$ December 16, 1914, p. 4. 


\section{CHAPTER IV IV $_{\text {, } ~}$ o $n, s$. \\ THE "BACK TO THE LAND" MOVEMENT}

AN ideal held by a great many people in this Republic is a sturdy and substantial class of farmers, owning and tilling their own small farms. The farm is pictured in song and story as the true home of health and happiness as well as the very foundation of wealth and independence. Doubtless many of our forefathers shared the opinions of Jefferson when he fondly looked upon agrarian democracy as the goal of the new Republic; when he considered a large wage-earning class as well as a large commercial class (depending upon the "casualties and caprices of customers") as full of danger, corruption and subservience. To use Jefferson's own words: "Generally speaking, the proportion which the aggregate of other classes of citizens bears in any state to that of its husbandmen, is in the proportion of its unsound to its healthy parts and is a good enough barometer whereby to measure its degree of corruption." As to a wage-earning class: "Let our workshops remain in Europe ... The mobs of the great cities add just so much to the support of pure government as sores do to the human body... I consider the class of artificers as panderers of vice, and the instruments by which the liberties of a country are generally overturned." What would be Jefferson's opinion of his country to-day? Just after our Civil War the slogan, "Forty Acres and a Mule," was taken up by the people of the North and the carpet-bagger of the South, as the ideal solution of the negro problem in its economic aspects.

To-day from press and pulpit, from publicists and legislators, comes the cry, "Back to the Land." Now that seventy million of our people live in villages and cities, and only thirty million live in the open country, the problem of the "small farm," of the "closer settlement" is becoming a very interesting one. The cry is, "Back to the Land." The drift is away from the land. The situation is perplexing. What should be the attitude of the honest patriot towards this condition? What have other peoples in other lands found out about this question of the small farm?

The question of the big farm versus the small farm was a very hotly debated question in England three-fourths of a century ago. Good farming must perish with the breaking up of large 
farms, contended one side; not so, replied the other side. One British writer, a friend of the small farm owner, stated the matter concretely as follows: "Our agricultural writers tell us, indeed, that laborers in agriculture are much better off as farm servants than they would be as small proprietors. We have only the master's word for this. Ask the servant. The colonists told us the same thing of their slaves. If property is a good and desirable thing, I suspect the smallest quantity of it is good and desirable; and that state of society in which it is most widely diffused is the best constituted."

Norway is cited as an example where peasant proprietors are of oldest date and most numerous in proportion to population, and where as a consequence social and economic conditions are of the best. Concerning the effects of peasant proprietorship on the continent, the same writer goes on to say: ${ }^{1}$

"If we listen to the large farmer, the scientific agriculturist, the political economist, good farming must perish with large farms; the very idea that good farming can exist unless on large farms cultivated with great capital, they hold to be absurd. Draining, manuring, economical arrangement, cleaning the land, regular rotations, valuable stock and implements, all belong exclusively to large farms, worked by large capital, and by hired labor. This reads very well; but if we raise our eyes from their books to their fields, and coolly compare what we see in the best districts farmed in large farms with what we see in the best districts farmed in small farms, we see, and there is no blinking the fact, better crops on the ground in Flanders, East Friesland, Holstein, in short, on the whole line of the arable land of equal quality on the continent from the Sound to Calais, than we see on the line of the British coast opposite to this line, and in the same latitudes, from the Firth of Forth all round to Dover. Minute labor on small portions of arable ground gives evidently, in equal soils and climate, a superior productiveness, where these small portions belong in property, as in Flanders, Holland, Friesland, and Ditmarsch in Holstein, to the farmer. It is not pretended by our agricultural writers, that our large farmers, even in Berwickshire, Roxburghshire, or the Lothians approach to the garden-like cultivation, attention to manures, drainage, and clean state of the land, or in productiveness from a small space of soil not originally rich, which distinguish the small farmers of Flanders, or their system. In the best-farmed parish in Scotland or England, more land is wasted in the corners and borders of the fields of large farms, in the roads through them, unnecessarily wide because they are bad, and bad because they are wide, in neglected commons, waste spots, useless belts and clumps of sorry trees, and such unproductive areas, than would maintain the poor of the parish, if they were all laid together and cultivated. But large capital applied to farming is of course only applied to the very best soils of a country. It cannot touch the small unproductive spots which require more time and labor to fertilize them than is consistent with a quick return of capital. But although hired time and labor cannot be applied beneficially to such cultivation, the owner's time and labor may. He is working for no higher returns at first from his land than a bare living. But in the course of generations fertility and value are produced; a better living, and even very improved processes of husbandry,

${ }^{1}$ Laing, Notes of a Traveler, p. 299 et seq. 
are attained. Furrow draining, stall feeding all summer, liquid manures, are universal in the husbandry of the small farms of Flanders, Lombardy, Switzerland. Our most improving districts under large farms are but beginning to adopt them. Dairy husbandry, even, and the manufacture of the largest cheeses by the coöperation of many small farmers, the mutual assurance of property against fire and hail storms, by the coöperation of small farmersthe most scientific and expensive of all agricultural operations in modern times, the manufacture of beet sugar-the supply of the European markets with flax and hemp, by the husbandry of small farmers-the abundance of legumes, fruits, poultry, in the usual diet even of the lowest classes abroad, and the total want of such variety at the tables even of our middle classes, and this variety and abundance essentially connected with the husbandry of small farmers-all these are features in the occupation of a country by small proprietor-farmers, which must make the inquirer pause before he admits the dogma of our land doctors at home, that large farms worked by hired labor and great capital can alone bring out the greatest productiveness of the soil, and furnish the greatest supply of the necessaries and conveniences of life to the inhabitants of a country."

In France.-The British writer of over a century ago who was the warmest advocate of large farms, Arthur Young, traveled over nearly the whole of France. Even at that day France was known as the land of small farms, due to the repeated subdivisions of the land. Yet inveterate enemy of small farms as Young was, he found remarkable evidence of excellent cultivation in the little fields of France in the years 1787, 1788 and 1789. In his "Travels in France" we read, for instance, the following:

"Walk to Rossendal, where M. le Brun has an improvement on the Dunes, which he very obligingly showed me. Between the town and that place is a great number of neat little houses, built each with its garden, and one or two fields enclosed, of most wretched blowing dune sand, naturally as white as snow, but improved by industry. The magic of property turns sand to gold. ... From Gauge, to the mountain of rough ground which I crossed, the ride has been the most interesting which I have taken in France; the efforts of industry the most vigorous; the animation the most lively. An activity has been here, that has swept away all difficulties before it, and clothed the very rocks with verdure. It would be a disgrace to common sense to ask the cause; the enjoyment of property must have done it. Give a man the secure possession of a bleak rock, and he will turn it into a garden; give him a nine years' lease of a garden, and he will convert it into a desert ... Take the road to Moneng, and come presently to a scene which was so new to me in France; that I could hardly believe my own eyes. A succession of many well-built, tight, and comfortable farming cottages built of stone and covered with tiles; each having its little garden, inclosed by clipt thorn-hedges, with plenty of peach and other fruit trees, some fine oaks scattered in the hedges, and young trees nursed up with so much eare, that nothing but the fostering attention of the owner could effect anything like it. To every house belongs a farm, perfectly well enclosed, with grass borders mown and neatly kept around the corn fields, with gates to pass from one enclosure to another There are some parts of England (where small yeomen still remain) that resemble this country of Bearn; but we have very little that is equal to what I have seen in this ride of twelve miles from Pau to Moneng. It is all in the hands of little proprietors, without the farms being so small as to occasion a vicious and miserable population. An air of neatness, warmth and comfort breathes over the whole. 
It is visible in their new-built houses and stables; in their little gardens; in their hedges; in the courts before their doors, even in the crops for their poultry, and the sties for the hogs. A peasant does not think of rendering his pig comfortable if his own happiness hang by the thread of a nine years' lease. We are now in Bearn, within a few miles of the cradle of Henry IV. Do they inherit these blessings from that good prince? The benignant genius of that good monarch seems to reign still over the country; each peasant has the fowl in the pot."

Peasant Proprietors.-John Stuart Mill, in discussing "peasant proprietors" in 1848, after reviewing the evidence of many different writers, sums up his own conclusions in these sane words:

"The experience, therefore, of this celebrated agriculturist (Arthur Young) and apostle of la grande culture, may be said to be, that the effect of small properties, cultivated by peasant proprietors, is admirable, when they are not too small; so small, namely, as not fully to occupy the time and attention of the family; for he often complains, with great apparent reason, of the quantity of idle time which the peasantry had on their hands when the land was in small portions, notwithstanding the ardor with which they toiled to improve their little patrimony, in every way which their knowledge or ingenuity could suggest. He recommends accordingly, that a limit of subdivision should be fixed by law; and this is by no means an indefensible proposition in countries, if such there are, where the subdivision, having already gone farther than the state of capital and the nature of the staple articles of cultivation render advisable, still continues progressive. That each peasant should have a patch of land, even in full property, if it is not sufficient to support him in comfort, is a system with all the disadvantages, and scarcely any of the benefits of small properties; since he must either live in indigence on the product of his land or depend as habitually as if he had no landed possessions, on the wages of hired labor; which, besides, if all the lands surrounding him are held in a similar manner, he has little prospects of finding. The benefits of peasant properties are conditioned on their not being too much subdivided; that is, upon their not being required to maintain too many persons, in proportion to the produce that can be raised from them by those persons."

These words of Mill have an interesting confirmation in the so-called Wilson-Wallace Report of 1914, a report made by two qualified agricultural experts of Iowa. ${ }^{2}$

"We have also made a pretty thorough investigation," says this report, "of the methods used by the British government to furnish land to the landless. There are four or five counties in Ireland where the land is inferior, the rainfall very heavy, and the people very poor, living on very small farms, which can at best afford them only the food needed to support their families, whose male members spend the summers in England or Scotland, working for money to provide the winter necessaries for the family. The congested district board has bought up the lands in these counties, has divided them into economic areas or holdings large enough to support a family, twenty acres being the minimum, and is building houses on them. It is placing the congested population on these areas, charging them three and one-half per cent interest on the value of the land for sixty-eight and one-half years, at the end of which time they own the land in fee simple. They work under very strict limitations, however. They cannot sell or divide the land."

${ }^{2}$ Agricultural conditions in Great Britain and Ireland. By James Wilson and Henry Wallace. Published by the Iowa Department of Agriculture, Des Moines. 
Edwin A. Pratt, a British writer on present day problems in Agriculture, a friend of tenancy rather than ownership, has much to say concerning peasant proprietary at home and abroad. ${ }^{3} \mathrm{He}$ criticises the "excessive degree to which the subdivision of small properties has been carried"' in France. Generation after generation this subdivision has gone on. Says Pratt:

"Even again a property of 20 to 25 acres may be represented by 30,40 , or 50 small patches and parcels scattered over an entire commune . . . In the cultivation of these scattered fragments of land the practice followed by successive generations of peasant proprietors of France has been to produce a little of everything - vines, vegetables, corn, oats, barley, hemp, etc. - on the same soil irrespective of its suitability for such crops, the great idea of the cultivator being that he should avoid spending any money on the supply of his domestic wants ... But the work of cultivating, mainly by hand, so many separate morsels of land, for the production of so many different crops, represents a degree of toil that has often been only slavery under a different name."

Pratt quotes Lafarque, Lavergne, Michelet, Verney, Lecouteaux, and other French writers to bear out his contentions. Financially, says Pratt, the French peasants are in a bad way, since "few of the peasants hold their land free of mortgage, and many of them are heavily indebted besides." And in spite of the recent advance in agricultural unions and coöperative enterprises, says Pratt, "the fundamental disadvantages, both moral and material, inherent to the system of peasant proprietary still remain."

In Holland.- Speaking of Holland the same writer says: "In Holland the position brought about by peasant proprietary is, in some respects, still more acute than in France." Here most "farms" are under four acres in size, and very few contain over ten acres. The Dutch landowners are generally satisfied with a return of two and one-half to three per cent. The small holdings of a farm usually comprise, not one piece of land, but many different strips or parcels. The parceling of the land into these long strips is clearly illustrated in Pratt's book by a reproduction of the plan of the commune of Vledder (Drenthe), Holland. The average dimensions of a strip of land in one part of this commune is 380 yards by 14 yards. In one instance there is a length of 428 yards to a breadth of 4 yards. Another strip shows a length of 1275 yards and a width of 22 yards. Mention is made of one wealthy farmer whose holdings comprise 90 acres, consisting of 78 separate strips of land in different parts of his commune.

${ }^{3}$ Pratt, E. A. The Transition in Agriculture. London, 1909. John Murray, Publisher, one shilling. 
Concerning the Danish "peasant proprietors," whose thrift is much heralded in America, Pratt has this to say:

"Nominally, the peasant proprietors who constitute so important a section of the Danish people are freeholders; practically they are saddled with a mortgage debt estimated at about $\$ 300,000,000$, and representing 55 per cent of the value of their farms, with buildings, stock, and improvements. The debt is largely, though not entirely, due to certain credit associations which were formed in Germany in the 'fifties to enable the Danish agriculturists to purchase their farms or holdings, mortgages up to 50 or 60 per cent of the purchase price being granted, with repayment extending over periods of from 50 to 100 years ... Interest and repayment of principal still constitute a heavy burden, and many a Danish farmer is, with all his family, working for long hours, and looking to England for the profits he makes on his produce, not so much for his own gain as to satisfy the demands of his German creditors."

Effect of Coöperation.-With the coming in of successful coöperation in Denmark - perhaps the world's best example of coöperation - and with the anxiety of the farmers to buy the land there came a substantial increase in the price of the land. Thus it comes about, says Pratt, that "the Danish small holder who becomes a peasant proprietor starts by having to pay an altogether artificial price for the land he purchases; he sinks in the ownership of that land present capital which would otherwise be available for the purchase of stock and for other expenses; and he incurs, in place of rent, a rigid mortgage debt unduly swollen by the excessive price he has agreed to pay for his farm."

An Objection to Small Holdings.-And as a final objection to the very small holding, Pratt has this to say:

"And then there is that last problem of all for the solution of the small owner! What is to become of his few acres when he dies? If he leaves them to his widow and she sells, she will do so at a disadvantage. If he divides his holding equally among his children, and these in turn, divide their share among their children, it will not be long before a state of things is reached analogous to that found in certain parts of Italy, where twenty-five per cent of the peasants have properties of less than one-fourth acre each."

Passing now to the German farmer, we have a vivid picture of his customs, as given in a report by F. T. H. von Engelken of Florida: ${ }^{4}$

"German Customs.-It can well be believed that to an American farmer a walk through the country in Germany is full of interest. At first glance many of the customs and conditions are incomprehensible, and, to our large ideas, appear almost absurd. It is only in discussing with the German farmer his conditions and giving him an idea of those existing in our country that the

${ }^{4} 63$ Cong. 1 Sess. Sen. Doc. 201. The German Farmer and Coöperation. F. J. H. von Engelken, Washington, 1913. 
underlying principles and unyielding circumstances which control German agricultural operations are made clear, and that an idea is obtained of the reasons which make necessary their peculiar methods.

"It must be borne in mind from the first that Germany is a country, not of farms, or even small farms, but of patches of land. A German farmer may own as high as 100 acres of land, but instead of lying in a body, as with us, and being cultivated in large fields with modern tools, his entire holding will be broken up into innumerable small plots with, perhaps, no two adjoining, and these plots scattered over the country on all sides of the village in which he makes his home. The entire country is therefore divided into small tracts, generally oblong in shape, ranging from 15 to 20 feet wide and from 200 to 400 feet long. These tracts are never separated from each other by fences, for fences are an almost unknown quantity in agricultural Germany. The dividing line between two tracts is marked by a stone set in the ground, and so closely are they planted that if three adjoining tracts were planted in the same grain crop it would be impossible for a stranger to definitely locate any one of the three without hunting up the boundary stone. It is rarely the case, however, that adjoining tracts are planted in the same crops, for they belong to different owners who plant independently and what they wish. In walking through the country it is therefore quite a usual sight to see a plot of land 30 feet in width, and perhaps 300 feet in length, planted in rye, adjoining it one 12 feet in width and of the same length planted in stock beets, then one 20 feet wide of the same length in oats, then one 40 feet wide, same length, in potatoes, then one perhaps 25 feet wide in wheat, and so on through the entire list of the various crops grown in that particular section. These tracts may each belong to a different farmer in that community, and each farmer there will own from 20 to perhaps 100 such tracts scattered all over the 'Bezirk' or locality in which he lives. In the hay country, for instance, it is a common sight to see what appears to be a field of 40 acres or more of hay, which at first glance would appear to be a very respectable hay field, according to our ideas. A walk into it, however, will show that it is dotted all over with boundary stones showing that it is owned, not by one man, but perhaps by fifty, each of whom when the time comes will cut his little patch out of the field whenever he is ready, and moreover, will cut it with a scythe as his forefathers have done for generations. The value of such land ranges from $\$ 300$ to $\$ 1000$ per acre ...

"How Germans Live.-Having thus given a brief outline of the peculiar system under which the German farmer operates, let us follow one to see where and how he lives, for it is apparent that he does not live on the land among his crops.

"Germany is literally dotted with villages, and these villages are so unlike anything in our country that they must really be seen to be appreciated. Ranging in size from 10 to 200 homes and with a population of from 50 to 1000 , they are scattered all over the country as if sown there by some giant hand. Rarely as distant one from the other as two miles, there are often two or three clustered almost within a stone's throw of each other, and they are as peculiar and as striking in their difference from our country towns as are the methods under which their inhabitants work from ours.

"Throughout almost entire Germany the ground plan of the farmer's home is the same. The buildings are always of brick or stone (the very old houses being made of a framework of timbers with a rubble plaster filling), and the stables and storehouses are also built of the same lasting and noncombustible materials. Roofs are of tile, it now being against the law to use thatch. The house always fronts on the street or road. Built against one wall of this is the storehouse, a continuation of this is used for stables, and from this again continue the sheds for tools, etc. This group of buildings is built up on four sides of a square, forming in the center a large court. On one side of the house is the gate opening into the road, and when this is closed.the whole 
place is secure from trespass ... The outbuildings are also substantially built with the second floors supported either by heavy timbers or by iron beams. The storehouse is used for storing the crops from the fields, there being no buildings of any kind on the land. The stables are used for the milch cows and for the beef cattle being fattened, as well as, of course, for the necessary horses. It is one of the peculiar customs of Germany that wherever the soil is rich and is highly cultivated the cows and hogs and beef cattle are never taken out of the stables after once being put in. They are literally in for life. Green food is brought to them daily, and they are well taken care of. Cattle are chained to their stalls, each with its drinking trough, and they are daily cleaned off and bedded down knee deep in straw. Hogs are kept in the same way. Once in their pens they remain there till sold to the butcher; they eat and sleep and grow, nothing else. This system, while apparently very troublesome, is in vogue for two reasons; first, the land is too valuable for pasturage, as well as being in too small tracts, and secondly, by keeping livestock in this manner every bit of manure is saved, and manure, as one farmer aptly stated, is the life of German agriculture.

"Saving Fertilizer.-The method of saving this manure is an excellent one, and is one that could be used to great advantage by our farmers. In the center of the court around which stands the buildings is a large square pit about five feet in depth. On one corner is a runway by means of which a wagon can be run into the pit to facilitate loading. This large pit is for the dry manure, and into it is thrown everything with any fertilizing value.

"Between this and the stable is a deep concrete-lined well, much deeper than the dry manure pit, and this is used for collecting the liquid manure. This well is made water tight, and into it lead drains from all the stables and pens, as well as from the dry-manure pit. The liquid thus collected is pumped from this well into tanks and taken to the fields, where it is sprayed on the land. It can be stated here that this economical, thrifty, and intelligent use of natural fertilizers has made Germany a farming nation which, with a country smaller than the State of Texas, and with one-third of its area covered with forests, produces 95 per cent of its own food products, and its population is around $65,000,000$.

"Women do the Work.-In Germany, it must be understood, the greater portion of the farm work is done by the women. It is a common sight to see women hoeing or pitching hay or spreading manure, and they do it well and cheerfully. The girls of the poorer families go into service as maids, which means that they do not only a share of the housework, but also their full proportion of the work about the stables and in the fields. For this service a girl of, say, sixteen or seventeen years will receive wages of three dollars a month, with board and lodging. She becomes a member of the family and is considered and treated as such. It would be an interesting experience for some of our farm workers to try to keep up with one of these young girls in a day's work.

"The tendency in Germany is away from tenant farming and towards ownership. This movement is of course encouraged by the Government, which, in many cases, provides the medium for the conversion of large estates into small holdings, extending at the same time a helping hand to the small farmer in the purchase of the subdivisions. Other than this breaking up of large estates, real estate transfers in agricultural Germany are the exception rather than the rule. In fact, it is frequently impossible to buy from the small farmers their holdings. Instances are common where two or three times the value has been offered and refused."

In Australia.-Let us turn now to a country of large holdings, Australia. This country is generally recognized as one having too large parcels of land in its "farms." This feeling led the Legis- 
lative Assembly of Victoria, Australia, to pass a series of "Closer Settlement Acts" having for their aim the breaking up of the larger holdings and the placing of the smaller farms in the hands of actual owners.

These acts furnish land to the settler on what was intended to be liberal terms. The settler has thirty-one and one-half years to pay for his land, his annual payment (principal and interest) being 6 per cent. And when he makes improvements, the Government advances him a loan to the value of sixty per cent of his improvements; likewise he secures liberal advances for the purchase of stock. The Government, in carrying out these Closer Settlement Acts from 1904 to 1914, in the dry, irrigated area, bought some 87 large estates, containing a total of 468,188 acres. The original payment for these lands was about $\$ 30.00$ an acre, but the additional "loading" on this cost, due to various expenses, brings the cost price up to $\$ 35.00$ an acre. These lands were divided into some three thousand, three hundred and seventy-six allotments for sale to settlers at cost, on the liberal terms named above. To quote from the Government's Report on the administration of these acts: ${ }^{5}$

"The whole design of the Closer Settlement Legislation as may be gathered from its apparently liberal terms of repayment, is to enable men, experienced and able in farming pursuits, but possessed of limited capital, to get on to their own holdings, and stay there. The conditions imposed by such legislation, however, often defeat its own purpose."

The report exposes some very interesting conditions, the most important of which may be profitably reviewed here. Wheat growing is mainly relied upon by the settlers on these allotments. And, oddly enough, the farms have proved too small for profitable wheat growing. The average size of the wheat farm in certain quarters is 300 acres, and the least area on which a satisfactory living at wheat-growing can be made in this region is given as six hundred acres by the settlers. Again, in carrying out the acts, some unsuitable land was unloaded onto the State at a good price. This land is known as dry-farming land, and hence suited only to cereal growing and stock raising. During the investigation carried on by the committee making this report, the chairman of the Settlement Board was asked in effect, "Can a man live on three hundred acres of land suitable only for wheat-growing (that is, which does not permit of combined wheat growing and dairying

${ }^{5}$ Report from the Sub-Committee of the Cabinet on the Administration of the Closer Settlement Acts. Victoria, Melbourne, Aus., Feb. 3, 1914. 
or grazing) at $\$ 40.00$ per acre, which land will only carry one "wool' sheep to the acre?" His answer was disconcerting. He said, "I do not think so." Settlers in this region impressed on the committee that the least area on which a satisfactory living at wheat growing could be made was six hundred acres, or, twice the average size allotment held by settlers. Hence the result of many years of experimentation in "closer settlements" in the dry area of Australia proved that small holdings are not a success under certain conditions; that larger holdings must be encouraged under certain circumstances; and that in any event the size of the holding should be governed by such economic conditions as the nature of the soil and climate, the product of the soil, and the relation of this product to the wide question of supply and demand.

In New Zealand the farming industry is receiving the closest attention. At the 1916 meeting of the New Zealand Farmers Union, held at Wellington, among the important matters discussed was that of the adoption of more effective measures for preventing the increase of larger holdings of land, it being considered detrimental to the development of the country in general.

The Problem in the United States.-Two classes of our people are enthusiastically advocating the "Back to the Land" movement. Many of these accept the forty-acre farm unit as the ideal. These two classes are the editors of our city papers and the "High Cost of Living" sufferers, also city dwellers. To the city dweller, one cure for the high cost of living is cheap food. But while cheap food would be good for the city, it would be bad for the farm. Conversely, dear food is good for the farmer, since he has it to sell, but bad for the city man.

The problem is a complex one. The metropolitan editors usually say: "Be independent. Be good citizens. And by quitting the city for the farm, you will become both." Such a readjustment of our population, should there be any considerable drift to the land or development of small holdings, would demand a serious consideration of these economic problems: (1) Subtract labor from the city. This would decrease the output of what? If this shift would merely decrease the production of brass jewelry, artificial flowers and feathers, gewgaws and luxuries, a gain to society rather than a loss would occur. Such a change in consumption would doubtless be welcome-if it could be effected. (2) Add labor to the land. This would increase the output of what? More of the staple crops-corn, wheat, cotton, etc-are not wanted. Additional labor thrown into competition with the farmers now engaged 
in the production of these staples would simply lower the earnings of all thus employed to a meager subsistence level. In fact it frequently happens now that there is an overproduction of these crops, resulting in hardship to producers, and in little or no benefit to consumers.

The testimony of LeGrand Powers, before the United States Industrial Commission at Washington, in $1899,{ }^{6}$ is especially interesting in this connection.

Question: What have you to say in regard to the decline in the price of agricultural products in the last, say, thirty years?

Powers: There has been a very large decline at points where the price is affected by the cost of transportation; there has been a less decline in points from which that transportation has carried the produce. There has been a decline, but small, in articles that have not been overproduced; there has been an enormous decline in the articles whose production has increased faster than population ... .

Question: That holds good in all farm products, grains, cotton, etc.?

Powers: I believe that that principle in general applies to-day the same as it did two hundred years ago.

Question: The capacity to consume, by purchase or otherwise, has as much effect on prices of products as the question of overproduction or underproduction?

Powers: That comes in as a factor slowly modifying prices. With certain articles it has far greater influence than with others. The amount of bread which a man can eat, the number of pounds of breadstuffs, including wheat, corn, oats and all others that we use for human food varies but little. We may change the form of it, but the number of pounds a human being eats is substantially the same. He may substitute cornmeal or oatmeal for wheat, but the number of pounds consumed will be substantially the same. The general proposition is not true to so great an extent with articles of food that may be called luxuries. The rule governing the consumption of strawberries or California oranges or pears or fruit is quite different. Their consumption may be increased enormously, and such increase may exert but a little influence in decreasing the consumption of these other things. As showing something of the power to increase the consumption of food luxuries, I will mention the fact that Minneapolis, as a center of consumption and distribution of the Northwest, shows a doubling of fruit sales every three years for the last few years. Population has been doubling once every fifteen years, but the sales of fruit double every three years, or eight times as fast as population. A certain portion of the relief of agriculture must come from an increased consumption of these things, which represent relatively a large amount of labor. The increased demand of our people in the United States for these luxuries represents about as much for the farmer as our increased exports. Thus, note canning, which represents one phase of this business. It began about 1865 or 1870. Now the amount of fruits, vegetables, fish, and meat that is consumed in cans in this country is very great."

What are Luxuries?-The "luxuries" mentioned by Mr. Powers are now looked on as necessaries, rather than as luxuries, particularly the California oranges. The 1914 report of the general manager of the California Fruit Growers' Exchange,

${ }^{6}$ U. S. Industrial Commission Report, Vol. X, p. 186. 


\section{G. Harold Powell, has this to say on the consumption-overproduc- tion problem:}

"During the past few years the Exchange has increased the per capita consumption of citrus fruits by advertising. The population of the United States has increased 21 per cent during the past decade. The consumption of California oranges increased 74.6 per cent during the same period ... The citrus fruit crop of California increases 255 per cent from 1895 to 1900 ; 71.7 per cent from 1900 to 1905 ; 10.9 per cent from 1905 to 1910 ; and 48.5 per cent from 1910 to 1914 . The production will increase rapidly in the future, the acreage having increased 128.9 per cent in the last decade. The in-

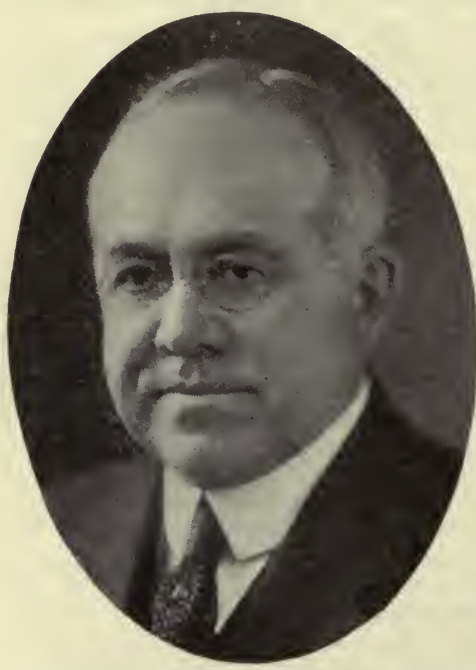

FIG. 6.-G. Harold Powell, Manager of the California Fruit Growers' Exchange, Los Angeles, Cal. crease in shipments of citrus fruits from Florida and California have more than doubled in the last decade. The exchange organizations have, therefore, an obligation, not only to sell their fruit wisely from year to year, but to develop a distributing and selling system and an advertising policy at the same time which will cause consumption to keep pace with the increase in production. Only through the stimulation of consumption in this way can the future financial stability of the two-hundredmillion dollars invested in the California citrus industry be assured. When production exceeds consumption, then the investment of the grower is jeopardized ... There are certain features of the California industry to which the exchange members must give serious consideration. They relate to the increase in production and to the future stability of many investments... The solution of the problems outlined will depend primarily on a large increase in the per capita consumption of citrus fruits and the ability of California to meet successfully the competition of

Florida oranges and grapefruit and of Italian lemons. There are a few leading fundamentals which the California industry must recognize if it meets these problems successfully. There must be an improvement in the average standard of the fruit that leaves the state, both in grade and in keeping quality. This makes it imperative to develop the manufacture of the lower grades into by-products . . There must be an improvement in the care of groves so that more fruit of higher quality may be produced per acre; and in the handling of the fruit so that decay and other preventable losses are eliminated ... Fruit of good eating quality only can be shipped in the future, if the industry is to maintain its integrity with the consumer ... The distribution of the oranges and lemons must be uniform throughout the year . ..." (Fig. 6).

This lengthy quotation from the manager's annual report has been given to illustrate the significant fact that a great industry can be conducted in such a way as to improve the product from year to year, and at the same time make this product cheaper to the consumer and bring more to the producer. And the whole 
process has been perfectly simple. Advertising has widened the market. The widened market has made possible certain largescale, coöperative processes in production and marketing and a standardization, whereby all possible wastes have been eliminated. This has left more income to the producer of the fruit, and a smaller cost for a better orange to the consumer. It has produced "savings," not "profits," as the coöperators term it.

Concerning the standardizing of the product and the advertising of it, the manager above quoted goes on to say:

"Primarily, the function of our advertising is to increase the consumption of citrus fruits. To do this it is necessary to have a brand around which we can build our advertising arguments. This brand is the consumer's protection. It is his guarantee as to the quality of the fruit. In other words, we want him to feel that all he needs to know about an orange or lemon is that it is "Sunkist." We must make the consumer realize that the name "Sunkist" on an orange or lemon means just what the Sterling mark means on silver. Our advertising will create in the minds of the consumers a public consciousness of the food value of oranges and lemons. This can only be done by maintaining the highest possible standard of quality, for unless an article has quality, it cannot be successfully advertised. The permanent prosperity of the citrus industry depends on getting a sufficient number of people to use oranges and lemons, and this can most thoroughly and economically be accomplished by giving the public the reasons why they should use them and suggesting to them the various ways in which they can be served. Advertising is not a mysterious thing. It is simply telling the people the truth about the thing we have to sell and telling them through those channels in which they have confidence and to which they are accustomed to look for information and guidance."

The foregoing discussion is given at some length to illustrate the truth that an increase in production is good for the farmer where an increase in demand keeps pace with such increase in production, but that an increase in the production of staple crops, where demand is stationary, is bad for the farmer.

Testimony of Prominent Witnesses.-The bonanza farm of the West and Northwest is a wheat farm. It stands for specialization. The small farm, on the other hand, is generally used for diversified farming. In industry the trend of modern times is towards specialization. In farming there are two discernible tendencies, the one towards specialization on the large farm, the other towards diversification on the small farm. The advantages of these two are open to debate. Doubtless local conditions must be the deciding factor in either case. Volume $\mathrm{X}$ of the Industrial Commission Report quoted above, contains the following digest of testimony, pro and con, on the advantages of the small farm, as given by practical farmers. ${ }^{7}$

${ }^{7}$ Report of Industrial Commission. CXCVI-CXCVII.

Vcl. X, Washington, 1901, pp. 
Robert Ransom Poole, Commissioner of Agriculture, Alabama.Mr. Poole says the farmers in the sandy counties of Alabama are more progressive than the large farmers. Mr. Poole thinks that if the farmers could be induced to sell off their lands in smaller tracts (than three hundred and twenty to two thousand) it would be much better for the country as a whole, but the person who owns property paying from ten to fifteen per cent on the investment is very loath to part with it.

Harry Hammond, Cotton Planter, Beech Island, South Carolina. - "I know of no record in history where a race of small proprietors has been prosperous. Everywhere they seem to form the wretched residuum of labor after all other occupations are supplied."

William Budge, Farmer and Real Estate Dealer, Grand Forks, North Dakota.-Mr. Budge says there are several big farms in North Dakota, and mentions one of above seven thousand acres. He adds that he would like to see them all out of the way. They take up so much space that they hurt the school districts. The owners ship in their supplies and ship their wheat out, and ship their men in and out. The plowing is done with gang plows ... One man can handle one hundred and sixty acres on a farm of that kind. The employees are generally single men. The farm owners hire a crew in the spring and let them go in the fall, except one or two to take care of the farm. Mr. Budge thinks some of the big farms are profitable and some are not, depending on how they are handled. The land has grown in value, and money is made in that way.

Brynjolf Prom, Banker and Farmer, Milton, North Dakota.Mr. Prom (who owns and farms 1120 acres) says the effect of bonanza farming is not good. The bonanza farmers do not patronize the villages, but ship in goods from the east, and act as wholesale grocery houses for themselves. They are also probably a drawback in the way of school privileges, which they do not need, and if there are small farms wedged in between bonanza farms the occupants of the small farms suffer. The bonanza farms are divided up into different parts with a foreman for each part. Each has a little village of its own. The hired help are usually single men; only the foreman is married. The bonanza farms are well conducted upon strictly business principles, the farming is done more scientifically and economically than on the small farms, and the percentage of profit is larger; but the general results to the people of the country are not good, and the people would generally favor the abolition of bonanza farming. 
M. F. Greeley, Stock Farmer; Editor of the "Dakota Farmer," Gary, South Dakota.-Mr. Greeley considers bonanza farming a curse to the country and to the man who tries it. If carried too far, after population gets more dense, it will keep thousands of men from having homes of their own. It employs men in squads, thus eliminating their individuality and independence. Those employed on these farms have to work with the worst kind of men. The soil is abused and then goes to other people in small holdings to be built up by careful rotation, stock farming and tillage. The bonanza farms are owned by men who spend their money in the cities or in other States. They rot the public schools, and detract much from the social life of the country. Mr. Greeley does not know of one very large farm that has been running for some time that is now paying, and says bonanza farming is on the decrease.

Franklin Dye, Farmer, Secretary of State Board of Agriculture of New Jersey.-Mr. Dye believes that the subdivision of bonanza farms into small tracts would be beneficial by increasing the population and giving employment to more people. The opportunity to use improved machinery on a very large scale on these farms tends to make their competition diastrous to Eastern farmers.

LeGrand Powers, Expert in Agriculture, U. S. Census Bureau, Washington, D. C.-Mr. Powers says all the big farms, including the Dalrymple farm in Dakota, are in the market for breaking up, just as the big farms in Southern Minnesota have been cut up.

Social Viewpoint or Individual Viewpoint?-Thus far in this chapter the question of the size of the farm has been considered from the social standpoint. The views once held by Thomas Jefferson on the subject of a rural versus an urban population have undergone much change in the last hundred years. ${ }^{8}$ But the question is still an important social problem, and one which may well engage the powers of the true statesman. The social aspect of this question takes on significance from the fact that the rural population of to-day determines very largely the character of the nation to-morrow. The country birth rate exceeds the city birth rate. Children on farms are an economic asset, in the city an economic liability. The children of the farm to-day recruit the city to-morrow. Hence if the country is to be occupied by an

${ }^{8}$ The popular usage of two words in our vocabulary throws an interesting side light on this question of town and country. From the Latin urbs (a city) comes our word "urbane"; from the Latin rus (the country) comes our word rustic. Webster's dictionary 'defines these two terms as follows: urbane; courteous in manners, polite, refined; rustic; rude, awkward, rough. 
inferior class to-day, the city and the nation of to-morrow will consist of an inferior class. In two important matters the city is now superior to the country, namely, public education and care of public health. The child wanting a high school and college education must go to the city. In matters of health, however, from Jefferson's day down almost to the World War, popular opinion seemed to hold that the open country with its fresh air was the home of good health, and the city was the home of the physically unfit. But the World War, with its military draft and consequent medical examinations of millions of young men from both country and city, showed that although country people have a better chance for long life, yet they also suffer from a greater number of preventable physical defects. The city consumer who would favor the bringing into our country and settling on the farms there the cheaper labor of the Orient or even those European peasants whose standards of living are low, has a sadly shortsighted view of his country's welfare. Any public policy which attempts to build up the city at the expense of the country, such as a protective tariff on manufactured goods, may easily cause a migration from the country to the city, or conversely, a migration to the country of immigrants and others with an un-American standard of living. The important thing, from the standpoint of a noble and powerful nation, is to have a country population with a high standard of living. And such a high standard of living is fundamentally a question of the individual farmer's economic welfare, although this standard includes wants of a so-called higher order. In short, the private welfare of the farmer is the public welfare of the state.

The question of the size of the farm may be briefly considered from the standpoint then of the individual farmer. The fundamental question is the same-What will produce the highest net returns? Under the law of survival of the fittest, those farmers will survive whose farms conform most nearly to this economic test.

Family Size Farm.-Numerous investigations and "surveys" have been made recently, looking into the size of the farm business, thanks to the newly discovered science of farm management. Only a few of these can be mentioned here. W. J. Spillman, while Chief of the Office of Farm Management, conducted such a survey in Chester County, Pennsylvania. This study emphasizes the "small-farm fallacy" (as some call it), and shows that less profits come from small farms than from large farms. Farms of from 30 to 40 acres required for each crop acre $\$ 15.00$ worth of machinery, 
as compared with $\$ 9.00$ worth on farms of 160 acres and over. Thus on small farms the expense of operation is much greater per unit of product than on large farms of similar type. The larger the farm the larger the total income, but the per cent of profits is independent of the magnitude of the business. A Nebraska farm management survey reached the conclusion that a "family size farm" pays best (Fig. 7). This is a farm which furnishes work for the younger members of the family and varies in size from two hundred to two hundred and fifty acres in eastern Nebraska. A farm management survey in Missouri, on the "Size of Farm Business," also finds that large farms yield more profits

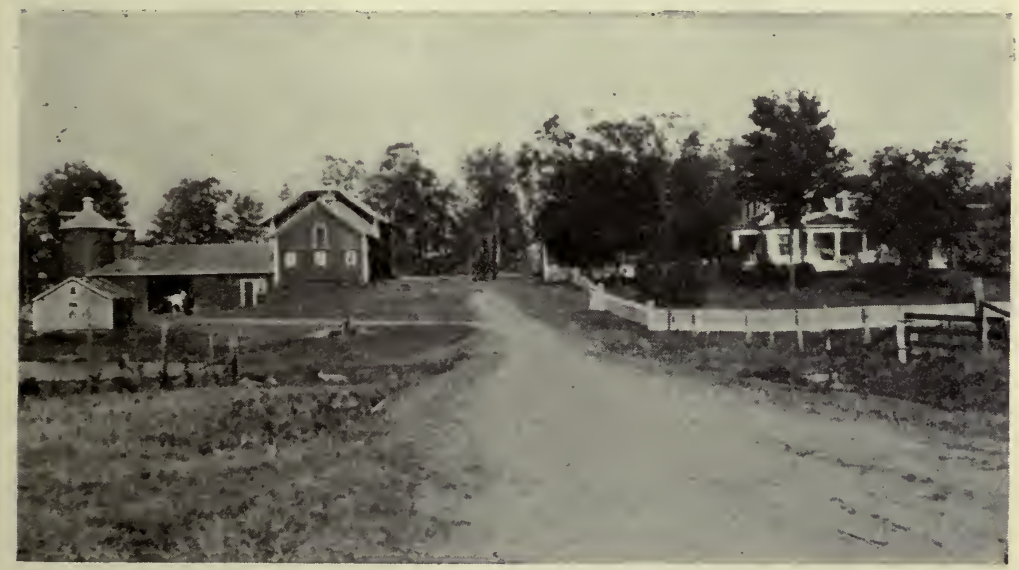

FIG. 7.-A family size farm, 200 acres.

than small farms (Figs. 8 and 9). On the large farm, 77.2 acres of crops per man are produced as compared with 15.9 on a small farm. The horse on a large farm cares for 21.2 crop acres, as compared with 7.3 acres on the small farm. Numerous other "surveys" in New York State and other states point to similar conclusions. In the Weekly News Letter of the Department of Agriculture for March 15, 1916, we find this statement, "Recent farm-management surveys indicate that the farmer with but little capital can, as a rule, make a better living by renting and operating a comparatively large farm than by putting his money into a small farm which he can büy outright."

Whether this statement be accepted for the whole truth or not (and it likely is not), it wisely stresses the factor of the purely commercial or economic aspect of a farm enterprise. 
In Australia the 300 -acre wheat farm has proved too small. In Dakota the 7,000-acre wheat farm has proved too large. Only actual experimentation can tell us what is the economical size of a wheat farm, or of any other kind of a farm. The experimenta-

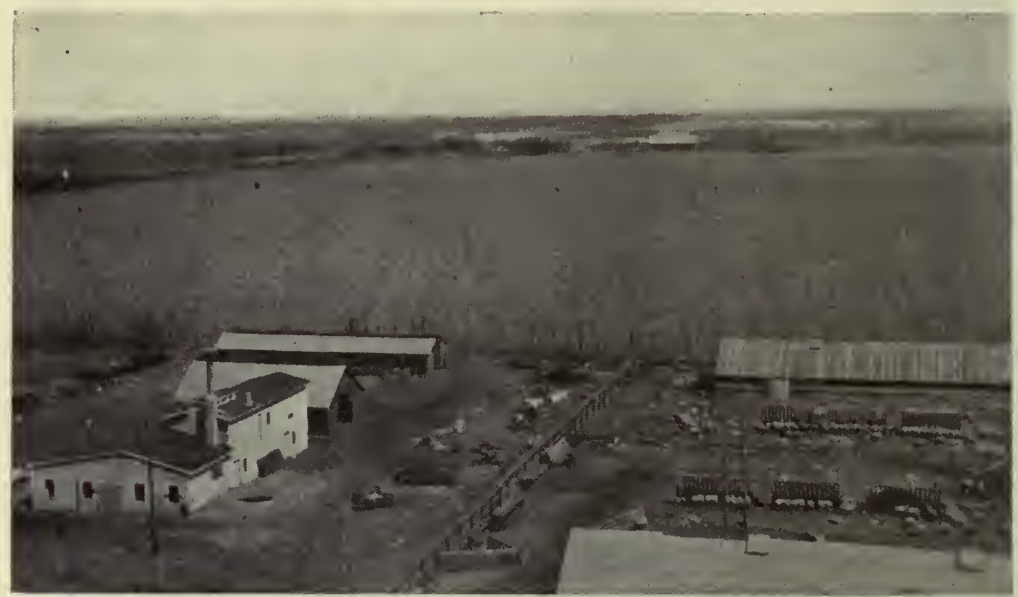

Fig. 8.-A large farm. View on the America Sharon Land Company's 40,000 acre farm in Red River Valley of North Dakota.

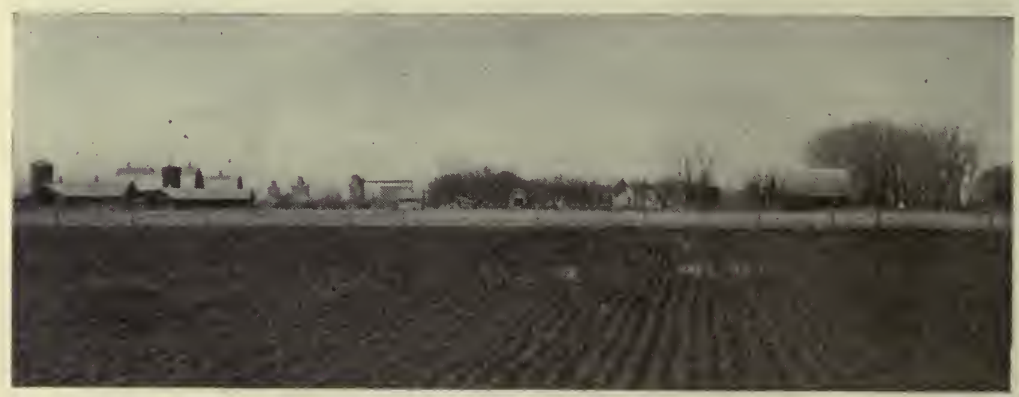

Frg. 9. - Some of the buildings and grain elevators on the America Sharon Land Company's big farm.

tion of the past, carried on in the various countries, as chronicled in the preceding pages, tends to prove that while big farms have bad features and good features, so also the small farms have good features and bad features. The socially desired solution of this problem coincides with the individually desired solution, namely, that sized farm which yields its owner the highest net returns. 
The Competition Question.-Following the World War there was a tremendous demand in the metropolitan press to settle returning soldiers on the land. The Secretary of the Interior sponsored a very large-scale plan to colonize soldiers on agricultural lands in frontier districts. Without entering here into any discussion of the merits or demerits of governmental colonization schemes - a very large question-we may well face one phase of the question of placing on the land suddenly a large number of additional farmers. These new farmers would compete with the present farmers. Any competition which increased the production of staple crops, or other crops, faster than demand increased for such crops, would tend to lower prices for such crops. In such cases we would have overproduction-or what the Single Tax school prefers to call "under consumption." The effect -on the producer is the same. An increase in demand would be necessary to offset the competition of the new farmer, assuming such new farmer actually to be placed on tillable, productive lands. The question of increasing the demand for food products, of increasing their consumption, is a question of more than academic interest. With two-thirds of the people now living in cities and towns, and with their potential buying power in the fields of food products, manufactured goods, amusements, etc., it becomes a matter of practical consideration as to how much they can and ought to spend for their food supply as compared with their other wants.

Increasing Consumption.- Under one condition could a system of "small proprietor" agriculture flourish at the present time in the United States, and that is, there must be an enormous increase in the consumption of agricultural products to offset the increase in production. With the staple crops there is an unknown margin of increase. Cotton, with its hundred by-products, is an example. Any one or more of these products may suddenly flare into worldwide demand. So also with the various uses and by-products of corn, wheat and oats. But clearly more is to be expected from the increase in the consumption of the minor products of the farm, such as milk, cheese, butter, poultry and poultry products, etc. The French peasant, however poor, is said to enjoy his "fowl in the pot." Yet to our city dweller a roast chicken is a luxury. The poultry crop now has about the same value as the wheat crop, but the room for increased consumption here is very vast. But increased consumption seems dependent on either improved quality or lowered price, and lowered price in turn depends on economies 
in production and marketing. In short, the poultry grower must learn the lesson from the orange grower of California.

Milk is of all foods the most ideal-the one perfect "balanced ration." Yet our daily consumption per person is only one-half a glass! When national prohibition arrived, we were spending $\$ 5.00$ a year for the milk we consumed, and $\$ 8.00$ a year for the beer we drank! The coming importance of our condensed milk trade is illustrated by the recent figures from our Commerce Reports. The condensed milk exports ran in value at about $\$ 1,000,000$ to $\$ 2,000,000$ a year for some years prior to 1915 , according to these Commerce Reports. For the year 1915, the value of condensed milk exports was $\$ 6,000,000$, most of these exports going to Europe. In the year 1918 the condensed milk exports to the one port of Hong-kong amounted to $\$ 3,611,500$, indicating the tremendous increase in the use of this food by the Chinese.

Cheese is a staple article of diet in foreign lands, being in all respects a wholesome and cheap food. Yet our daily consumption of cheese is only one one-hundredth of a pound per person. Condensed milk, fermented milk, and the various forms of milk byproducts suggest the possibility of developing an immense and profitable market here.

Tobacco.-In tobacco we are spending, according to Harvey W. Wiley, $\$ 1,200,000,000$ a year. ${ }^{9}$ This is twice as much as is spent for butter, condensed milk, and cheese. Some shifting of demand is possible here. In such case, however, the tobacco farmer, would need to shift his production to meet the change in demand.

Jam.-Pratt tells us that the English farmers when America and Canada ruined the wheat market for them, turned to more specialized foods. Jam is one. The acreage in fruit trees increased to three hundred thousand acres-an increase of sixty-three per cent in thirty years. In America many of the farmers' apples, peaches, pears, etc., rot on the ground. How much jam could, for instance, New York City alone consume? Doctor Howe tells us that New York is supporting commercialized leisure and amusements to the extent of eleven thousand, five hundred saloons, eight hundred dance halls, and six hundred motion picture shows, with an estimated expenditure on the people's part of $\$ 100,000,000$ a year. ${ }^{10}$ This merely illustrates the strength of market demand for those things which the people happen to want or are educated

${ }^{9}$ Good Housekeeping, Jan. 1916, p. 92.

${ }^{10}$ Howe, Modern City and its Problems, p. 307 (published in 1915). 
to want by successful advertising. Demand for food products is capable of almost unlimited expansion, provided the food article is low in price, and of standardized grade and quality and pack and the demand is carefully cultivated.

The city population is increasing three times as fast as the country population. This table from the census (where every place of fewer than twenty-five hundred inhabitants is considered rural) illustrates this tendency.

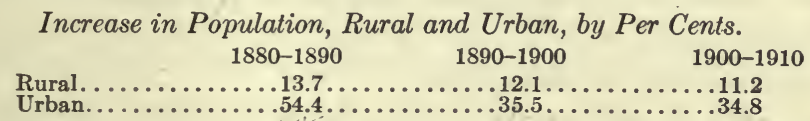

The average size of farms for the whole United States shows little if any tendency to decrease. Here are the figures:

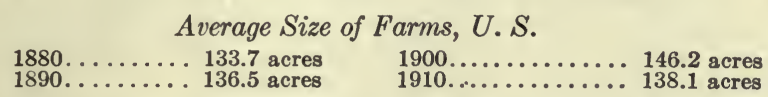

The size of farms in the old, well-established farming section (Ohio, Indiana, Illinois, Iowa, Missouri, Kansas) shows a gradual increase, as given in the following table:

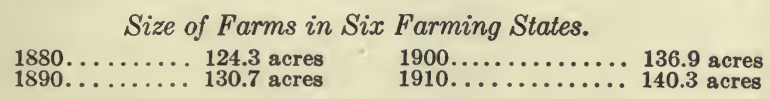

And in four of these six states the rural population showed a decrease in the decade 1900 to 1910 , while the urban population in all states in the union showed an increase. Hence we see that the problem of increasing the rural population and reducing the size of the farm is a problem that is not being solved.

\section{QUESTIONS ON THE TEXT}

1. What according to many, is this Republic's ideal landowning system?

2. State and explain Jefferson's ideal.

3 . Is the drift of population back to or away from the land?

4. State in full the arguments for small farms as given by Laing.

5. Give the views of Arthur Young; of John Stuart Mill.

6. State the findings of the Wilson-Wallace Report.

7. State in detail the position of Pratt, especially his comments on Denmark.

8. Give von Engelken's picture of German farming.

9. Describe the situation in Australia; in New Zealand.

10. State the problem confronting the United States.

11. Show relation of size of land holdings to overproduction, Quote Le Grande Powers. Discuss flexibility of demand. Illustrate.

12. Quote G. Harold Powell on the overproduction problem. Show the significance of "savings" rather than "profits." Show the place of advertising in this connection.

13. Cite evidence to show where specialized farming tends to prevail and where diversified farming tends to prevail. 
14. What are the usual arguments, from the social standpoint, against the big farm? Quote big farmers on this point.

15. Why is the nature of the rural population of such vast importance to the country as a whole?

16. Compare the sanitary conditions of city and country, as evidenced by the military draft.

17. What economic law will, in the end, determine the size of farms?

18. State the findings of the following "Surveys": Chester County; Nebraska survey.

19. Quote, with comment, the statement in the Weekly News Letter of the Department of Agriculture concerning renting versus buying a farm.

20. Show significance of competition question in agriculture.

21. Would a system of smaller holdings bring in harmful competition?

22. Show possibilities of increased consumption of farm products, particularly milk and milk products, fruit.

23. Cite statistics showing relative rates of increase of city and rural population; of changes in average size of farms. Is the rural population increasing? Is the size of farms getting smaller?

\section{QUESTIONS SUGGESTED BY THE TEXT}

1. Give an account of the strip system of land holdings in Europe.

2. Is Danish landholding a type of prosperity or lack of prosperity?

3. Should the farmer "specialize" or "diversify"?

4. Would "cheap food," supplied by a so-called peasant class of farmers, be a benefit or a curse to the Republic?

5. What is the fallacy, if any, in Jefferson's views of a rural versus an urban population?

6. What is a correct land policy for the United States? Do we have any land policy at the present time? If so, what is it?

\section{REFERENCES}

1. JoHnson, O. R.: "Big Farms or Little Farms-Which?" Farm Life, Nov., 1916.

2. Farming's Future. Editorial, Farm, Stock and Home, Sept. 1, 1916.

3. For conditions in Europe, Asia, Africa, Australia, South America, Mexico, see publications of International Institute of Agriculture, Rome, Italy, particularly International Review of Agricultural Economics.

4. For brief comment on current conditions and activities in all parts of the world, see the daily Commerce Reports, issued by the Department of Commerce, Washington, D. C.

5. Many books dealing with the problems of land settlement, closer settlement, size of holdings, etc., have appeared in recent years. Hence the following list deals chiefly with the older publications: Young, ARTHUR, "Travels in France"; "Land Tenure," Cobden Club Essays; KaY, JosePH, "Free Trade in Land"; SAgerson, George, "History of Land Tenures and Land Classes in Ireland"; PrATT, E. A., "The Transition in Agriculture."

\section{APPENDIX}

Migration from Denmark to the United States, Compared with Similar Migration from the Netherlands and Belgium, showing Relatively High Per Cent of Danish Migration.

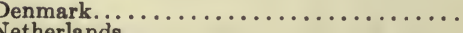

Netherlands. . . . . . . . . . . . . . . . .

Population

$2,775,076$

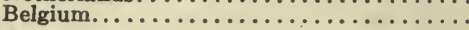

$6,114,302$

$7,571,387$
Foreign born

in U. S. 1910, born in-

181,621

120,053

49,397
Per cent of total population migrated to the United States 6.5

2.0 


\section{CHAPTER V}

\section{LAND TENURE}

Introductory.-Many changes are going on in the United States in respect to tenancy, mortgages, and size of farms. And yet there is very little agreement as to the significance of these changes.

This may be illustrated by a few quotations. For instance, at a recent meeting of the New York State Agricultural Society, one prominent gentleman spoke as follows:

"The heavy drain upon the country for its best blood to what seemed more attractive life in the city has left many fathers and mothers alone at an age when they were no longer fitted to carry the burden of the farm. Hard work in early life had made the day of retirement to the local town look bright. And the renter took his place. Now the so-called tenant system is in the minds of men a symbol of a degenerated agriculture, and I must confess that it has as a rule been true. The facts are that farm rental is no more degenerate in principle than the ownership of a building by one man and its occupancy by another; the tenant in some way having paid the owner of the building a fair value for its use. We have deplored tenantry and prayed for the day when prosperity would again come to the open country and the owner would become the occupant of the land. I venture a prophecy that the millennium will never come and furthermore that tenantry may increase. Tenantry leaves a bad taste, not because the thing is wrong, but because it has developed through unfortunate causes ... The system of tenantry is here because the farm as a business will not pay cash for the labor and leave a balance."

\section{The speaker is interrupted and interrogated as follows:}

"I want to ask Mr. Cook one question: Does he think that our descendants will stand for a thing that his ancestors and mine left Europe because oftenantry? Never, as long as we are Americans, will tenantry come into this great and glorious country."

Mr. Cook replies:

"The trouble is, it is here now. Come out into the country and see how many tenant farmers we have ... We have tenantry, and we are going to have it, and let us undertake to improve rather than destroy, as we cannot get rid of it." 1

Charles Stelzle, in reviewing the returns of the 1910 census, takes this somewhat cheerful view of the situation:

"While the population of the United States as a whole increased 21 per cent during the past ten years, the rural population increased only 11.2 per cent. The increase in the number of farms during the period was 10.9 per cent. The value of the farm property increased 100.5 per cent, but the greater part of this extraordinary increase was in the land itself, the value of which increased

${ }^{1}$ Bulletin 47. Proceedings of the Seventy-third Annual Meeting of the N. Y. State Agricultural Society. Albany, 1913, pp. 1265-1268. 
118.1 per cent. The average size of farms decreased from 146.2 acres to 138.1 acres. The tendency is slowly but surely towards the smaller farm." 2

These same figures are interpreted in quite a different manner by students with socialistic tendencies. Thus A. M. Simons writes of them as follows:

"If we disregard cotton, then nearly one-half of the agricultural staples of the United States are produced within 500 miles of Chicago.

"Census bulletins are now available for three typical states in this territory. These bulletins show the same tendencies in every state. It is therefore certain that what is true of these will hold good of this entire section, and probably of a much wider area. The three states are Indiana, Illinois, and Iowa. In all of these the average number of acres per farm is increasing. During the last ten years the average area of an Iowa farm has increased from 151 to 156 acres; of Indiana, from 97 to 98 ; and of Illinois, from 124 to 129 acres.

"This increase in size becomes still more evident when more closely examined. In all three of these states the largest increase in the number of farms has been in that of the little, intensively cultivated garden patch of less than ten acres. This would naturally tend to show a great decrease in the size of farms, were it not offset by the fact that the second group of farms to show a rapid increase in number is that of those containing between 175 and 500 acres.

"In all three of these states the area embraced in farms of between 20 and 100 acres shows a considerable decrease during the last ten years. In Illinois, which in all respects, shows a more advanced stage of development than any of the others, this decrease extends to farms of less than 175 acres. But it is the small farmer, owning between 40 and 160 acres, that has always been pointed out proudly as the backbone of American agriculture, the great conservative element in our society, the solid middle class farmer for whose salvation the politician loves to stand. Apparently, that 'backbone' is being broken ... .

"The other type, whose importance is rapidly increasing, is that on which it is possible to utilize the most efficient machinery. Hitherto this size has been limited by the system of using animal power. With the appearance of the mechanical tractor these farms will at first gain in importance, and then, in all probability, give way to a much larger size. The application of the power to farming will at once increase the size of the farm unit which can profitably be cultivated under a single management, and it is safe to say that the next census will show a great acceleration of all tendencies toward concentration.

"Another set of facts evident in all three of these states lends support and emphasis to the conclusion that we have entered upon a new era of concentration in farming throughout this territory. In spite of the rise in value of farm products, in spite of the multitude of garden patches near cities and all the general 'results of the 'back to the farm' movement, there has been a decided decrease in the total number of farms. In 1900 those three states contained 714,670 farms; by 1910 these had shrunk to 684,410 .

"But while the farms had grown larger in size and fewer in number, their value per acre had grown enormously. The farms of Indiana had increased in value from $\$ 32$ to $\$ 62$ per acre; those of Iowa from $\$ 36$ to $\$ 83$; and of Illinois from $\$ 55$ to $\$ 108$ per acre. The significance of these figures is seen when we apply them to the farm as a unit. We then see that the average value of a farm in Indiana has grown from $\$ 4,410$ to $\$ 8,396$; in Illinois from $\$ 7,588$ to $\$ 15,505$; and in Iowa from $\$ 8,023$ to $\$ 17,259$. Combining these facts multiplies their importance because they all tend in the same direction.

${ }^{2}$ United Mine Workers' Journal, October 10, 1912, p. 3. 
"A decreasing number of farms, an increasing size, requiring more expensive equipment, and this more than doubling of values, means that an impassable barrier has been erected between the landless farmer and the instruments essential to his existence.

"It is scarcely necessary to turn to the section of the census bulletin that deals with tenantry to be assured that such a condition would separate producer and possession. In each of these states there has been a steady increase in the number of farms operated by tenants for the last thirty years.

"The one big fact that stands out from an examination of the agricultural situation in the north and south, is that it is about time to quit talking about maintaining the small farmer in the ownership of his farm. Capitalism is abolishing that condition in agriculture as it already has in industry." ${ }^{3}$

Very clearly all is not well with agriculture in the United States. Thoughtful persons are pointing out changes in our land tenure situation which are fraught with very real and very imminent dangers. Let us examine in detail the Tenancy and the Mortgage questions, and then the two or three other matters involved in these two problems.

Tenancy.-Our theory of a sound agriculture has quite generally been that every man should dwell under his own vine and fig tree. And this happy situation actually existed for a short while at the beginning of our great Republic. But now, at a progressively increasing rate, we are departing from it. And the strange thing in the situation is that our powerful neighbor, Canada, forming with us an ethnological and economic unit, is moving in the opposite direction. Renters are few in Canada, and are becoming fewer. Renters are many in the United States, and are fast becoming the majority of occupiers of farms.

Putting side by side the census figures from each country, the situation is very vivid.

Farm Tenancy in Canada and the United States. Per Cent of Total Occupiers Canada Who are Tenants

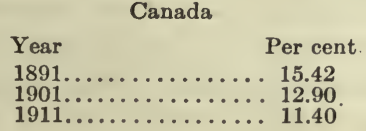

United States

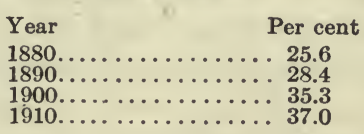

The fact is well established that tenant farming is increasing in the United States. In a few counties it exceeds 90 per cent of all the farms. The conclusion is also reached by our best students of the problem that farm tenancy will continue to increase in the United States in the future. The position of the Federal government investigators on this subject is very interesting. Thus we

${ }^{3}$ Brauerei Arbeiter Zeitung, May 18, 1912, p. 2, "Recent Tendencies in Agriculture," by A. M. Simons. 
find in the Report issued by Mr. Spillman, who was in charge of the office of farm management in 1912, this interesting statement: "The lack of future opportunity for taking up desirable public lands in our western states and the consequent general rise in the price of farm lands all over the country has resulted in an increase in tenant farming, especially in those sections where land values have risen to the point at which it is exceedingly difficult for the purchaser of a farm to meet both living expenses and interest on his indebtedness and also make payments on the principal. It is

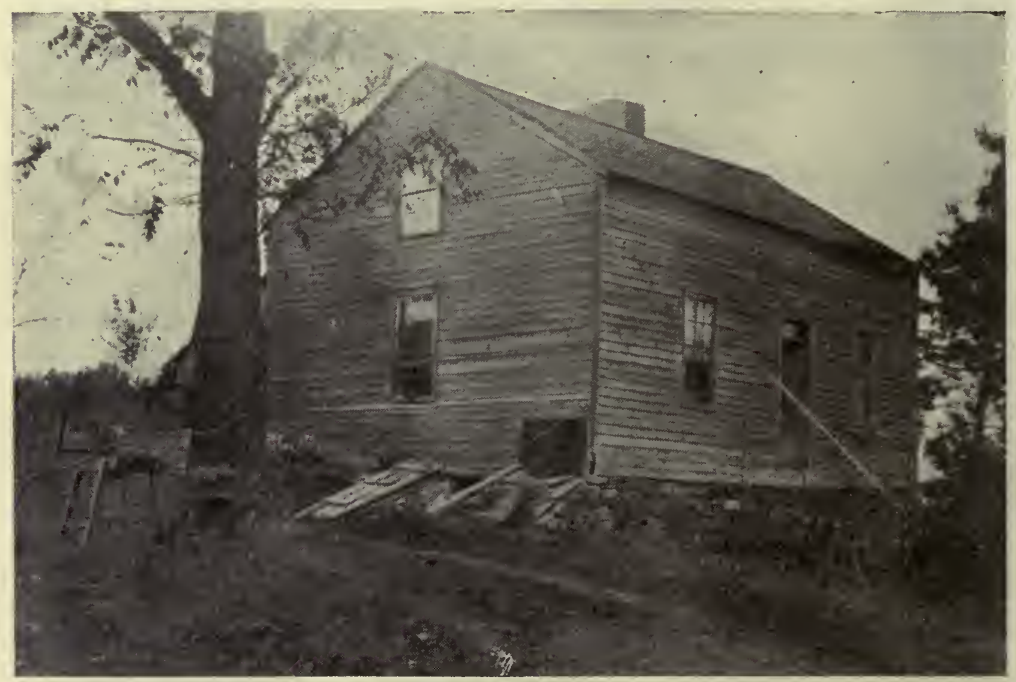

FIG. 10.-Farıning by a tenant.

hardly to be doubted that tenant farming will further increase in this country and that ultimately the land will be owned by the wealthier classes and be farmed by tenants with moderate capital." The question naturally presents itself. What will be the social or economic significance of an increase in farm tenancy? We have conclusions on this subject presented to us in a great number of rural life surveys made by various institutions such as the Department of Church and Country Life, Board of Home Missions of the Presbyterian Church of this country, by various State Universities, and by various other institutions and individuals. One such survey, speaking of northwestern Ohio, says: "Tenancy may not be a curse to agriculture and the country life, but under the system of land tenure prevalent throughout the most of the 
United States it usually is." In the section covered by this report the average length of time that a tenant stays upon the same farm is two and one-half years. This makes not only frequent removals but also the constant effort on the part of the tenants to take from the soil as much as possible while giving back to it as little as possible (Figs. 10 and 11). Such a process if continued must result in soil impoverishment and deterioration. Very few of the renters succeed in acquiring farms of their own. For the most part they remain a floating, discontented element in the population. They are the marginal members of the community, and their increasing numbers in northern Ohio constitutes not

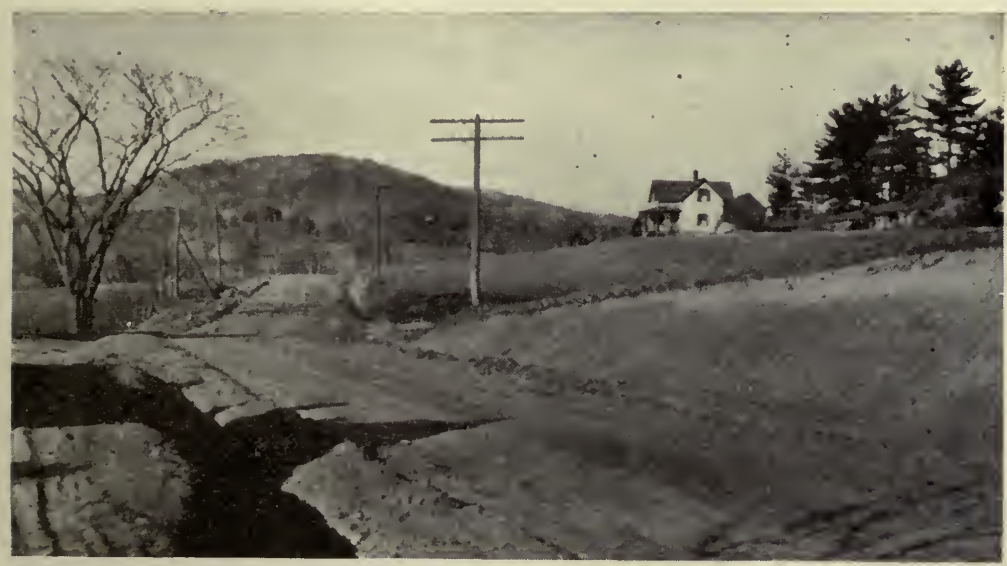

FIG. 11.-When the owner farms.

only a serious agricultural question, but a more serious social and religious problem. The United States Industrial Relations Commission probed the causes of unrest in the South and conducted hearings there. The Survey Magazine of New York speaks of these investigations in these words:

"About a thousand pages of testimony was taken in the five days of the hearings. A study of this testimony will reveal a remarkable coincidence of statement with regard to the actual conditions, and considerable difference of opinion as to what remedies should be adopted.

"It was generally admitted that a remarkable concentration in the ownership of land is taking place. With it are the attendant evils of a rising absentee landlord class and a descending tenant farmer class. It was shown that this concentration of ownership is aided by the farmers moving to town, by the credit system, by speculation and holding of land, etc.

"The growth of landlordism has been aided by the one-crop system, which in the South, makes it difficult for tenants to rise to the cash basis, and often impossible for them to become home owners. Excessive valuations of farm 
land have made the tenant's lot a harder one. Proprietors of large tracts have also used indirect methods of pressure to force smaller owners to sell their holdings. Seasonal depressions of crop prices throw thousands of mortgaged home owners back into the ranks of tenants. Depleted farm life accelerates the trend.

"The witnesses testified to considerable friction between landlords and tenants in this area. Oppressive tactics of landlords, in the form of unwarranted evictions, use of force to intimidate renters, arbitrary requirements in the matter of cropping contracts, threats to raise the rents where land taxes were involved if elections should carry in favor of the tax, and 'keeping the tenants on the move' when their political convictions might differ from the landlord's were among the injustices named. Some of these were considered general; others much less so.

"Tenants have been known to destroy the landlords' property and to foul the land by sowing Johnson grass, a noxious growth among cotton and grain crops. They have held mass-meetings of protest against rises in rent. They have held meetings for the purpose of declaring moratoriums. Threats of violence, and even the whipping of other tenants who had accepted increases in rents have been resorted to.

"It was a great day for the radical tenants when their representatives were permitted to take the stand and enter upon the records their side and their story of the renters' movement. From the mass of evidence introduced, some general truths were gleaned. Discontent of the producing classes has been growing in the Southwest for several years. It changed into a classconscious movement in 1911 when the Renters' Union of America was founded. This organization followed close upon a series of disturbances in Oklahoma and Texas. The cause of the disturbances appeared to lie in the movement on the part of the landlords to raise the rents above the traditional one-third of the grain and one-fourth of the cotton for the share of the landlord when he furnishes only land and house.

"Notwithstanding this effort at resistance the movement to increase the landlord's share of the crops has been steady, and several thousand tenants have been required to pay the landlords as high as one-third of the cotton instead of one-fourth, or to pay cash rent in addition to the share rent. A few landlords have been able to charge as high as 40 per cent of the crop for their share.

"It was the agitation of the land question by this organization that undoubtedly made it possible for James E. Ferguson to become the present governor of Texas. He swept aside all opposition and was elected by an overwhelming vote. One of the main planks in the governor's platform was to restrict the landlords' share of the rents by law. The governor testified that the rent plank was of great assistance in making him governor. On the stand he defended this plank, which has since become a law. He maintained that the cash system of renting land in the Southwest is unfair, because it places the burden of risk upon the tenant and often bankrupts him in the attempt to pay the landlord's share ...

"It was urged that the holdings of land for speculative purposes handicaps any effort to break the strangle hold of landlordism. It was interesting to note that some witnesses looked to the advent of corporation farming as the most efficient farming of the future. It was shown how the corporation or the large owner tends toward the factory idea of production. Should large farms be conducted on system methods by big capital, undoubtedly many tenant farmers of to-day would become wage hands.

"The Coleman-Fulton Pasture Company was pointed to as an example of the capital system. This company, which is controlled by the Charles $\mathrm{P}$. Taft interests, is a huge industrial enterprise of 80,000 acres on which lives a population of 4,000 souls. This company, through its associated corporations 
and partnerships, operates ranch land and farm land, cotton gins, stores, lumber yards, oil mill, packing-house plant, electric light plant, telephone, water works, and other enterprises. By means of experimentation and costcutting systems it has been able to reduce considerably the cost of operating farm land. It is able to command labor on its farms at eighty cents per day. And the laborers board themselves!" 4

\section{The final report of the Commission on Industrial Relations} summed up its findings on the Land Question in these words:

"It was obviously impossible for the commission to attempt a detailed investigation of Agricultural conditions, but because of the very immediate bearing of the land question on industrial unrest, it was felt necessary to make as thorough an investigation as possible of the phases which seemed to have the most direct bearing on our general problem. The phases selected for discussion were, first, the concentration of land ownership as shown by existing statistics; second, the problem of seasonal and casual agricultural labor; third, the increase and change in the character of farm tenancy; and, fourth, the introduction of industrial methods into agriculture through the development of corporations operating large tracts of land. The findings and recommendations with reference to the concentration of ownership and the problems of seasonal labor are set forth elsewhere. At this point it is desired to present the results of the investigations of tenancy and agricultural corporations.

"As a result of these investigations the following conclusions are fully justified:

"1. Tenancy in the Southwestern States is already the prevailing method of cultivation and is increasing at a very rapid rate. In 1880 Texas had 65,468 tenants' families, comprising 37.6 per cent of all farms in the State. In 1910 tenant farmers had increased to 219,571 and operated 53 per cent of all farms in the State. Reckoning on the same ratio of increase that was maintained between 1900 and 1910 there should be in Texas at the present year (1915) at least 236,000 tenant farmers. A more intensive study of the field, however, shows that in the 82 counties of the State where tenancy is highest the percentage of tenancy will approximate sixty.

"For Oklahoma we have not adequate census figures so far back, but at the present time the percentage of farm tenancy in the State is 54.8, and for the 47 counties where the tenancy is highest the percentage of tenancy is 68.13 .

"2. Tenancy, while inferior in every way to farm ownership from a social standpoint, is not necessarily an evil if conducted under a system which protects the tenants and assures cultivation of the soil under proper and economical methods, but where tenancy exists under such conditions as prevail in the Southwest, its increase can be regarded only as a menace to the Nation.

"3. The prevailing system of tenancy in the Southwest is share tenancy, under which the tenant furnishes his own seed, tools, and teams and pays the landlord one-third of the grain and one-fourth of the cotton. There is, however, a constant tendency to increase the landlord's share through the payment either of cash bonuses or of a higher percentage of the product. Under this system tenants as a class earn only a bare living through the work of themselves and their entire families. Few of the tenants ever succeed in laying by a surplus. On the contrary, their experiences are so discouraging that they seldom remain on the same farm for more than a year, and they move from one farm to the next, in the constant hope of lreing able to better their condition. Without the labor of the entire family the tenant farmer is helpless. As a result, not only is his wife prematurely broken down, but the children remain uneducated and without the hope of any condition better than that of their parents. The tenants having no interest in the results beyond the crops of a

${ }^{4}$ The Survey, April 17, 1915, pp. 63-64 (New York City). 
single year, the soil is being rapidly exhausted and the conditions, therefore, tend to become steadily worse. Even at present a very large proportion of the tenants' families are insufficiently clothed, badly housed, and underfed. Practically all of the white tenants are native born. As a result of these conditions, however, they are deteriorating rapidly, each generation being less efficient and more helpless than the preceding one.

"4. A very large proportion of the tenants are hopelessly in debt and are charged exorbitant rates of interest. Over 95 per cent of the tenants borrow from some source, and about 75 per cent borrow regularly year after year. The average interest rate on all farm loans is 10 per cent, while small tenants in Texas pay 15 per cent or more. In Oklahoma the conditions are even worse, in spite of the enactment of laws against usury. Furthermore, over 80 per cent of the tenants are regularly in debt to the stores from which they secure their supplies, and pay exorbitantly for this credit. The average rate of interest on store credit is conservatively put at 20 per cent and in many cases ranges as high as 60 per cent.

" 5 . The leases are largely in the form of oral contracts which run for only one year, and which make no provision for compensation to the tenant for any improvements which may be made upon the property. As a result, tenants are restrained from making improvements, and in many cases do not properly provide for the upkeep of the property.

"6. Furthermore, the tenants are in some instances the victims of oppression on the part of landlords. This oppression takes the form of dictation of character and amount of crops, eviction without due notice, and discrimination because of personal and political convictions. The existing law provides no recourse against such abuses.

"7. As a result both of the evils inherent in the tenant system and of the occasional oppression by landlords, a state of acute unrest is developing among the tenants and there is clear indications of the beginning of organized resistance which may result in civil disturbances of a serious character.

"8. The situation is being accentuated by the increasing tendency of the landlords to move to the towns and eities, relieving themselves not only from all productive labor, but from direct responsibility for the conditions which develop. Furthermore, as a result of the increasing expenses incident to urban life there is a marked tendency to demand from the tenant a greater share of the products of his labor.

"9. The responsibility for the existing conditions rests not upon the landlords, but upon the system itself. The principal causes are to be found in the system of short leases, the system of private credit at exorbitant rates, the lack of a proper system of marketing, the absence of educational facilities, and last but not least, the prevalence of land speculation.

"10. A new factor is being introduced into the agricultural situation through the development of huge estates owned by corporations and operated by salaried managers upon a purely industrial system. The labor conditions on such estates are subject to grave criticism. The wages are extremely low, 80 cents per day being the prevailing rate on one large estate which was thoroughly investigated; arbitrary deductions from wages are made for various purposes; and a considerable part of the wages themselves are paid in the form of coupons, which are in all essential particulars, the same as the "scrip" which has been the source of such great abuse. Furthermore, the communities existing on these large estates are subject to the complete control of the land-owning corporation, which may regulate the lives of citizens to almost any extent."

At the third national convention on Marketing and Farm Credits in Chicago, 1915, various speakers dwelt on the menace to our political and educational institutions which is even now 
beginning to be apparent in connection with the tenant class in certain sections of this country. For instance, items like the following in the daily press are becoming of greater frequency from month to month:

"Cape Girardeau, Mo., Nov. 23.-Five night riders and two private detectives were wounded in a pistol battle southwest of Clarkton, Mo., near here, early to-day. Seven of the night riders were captured later after an all day chase by bloodhounds and a posse.

"To-night virtually every citizen of Clarkton and every land owner in the vicinity is armed in expectation of another attack by the night riders. The latter are a secret band of tenants and farm laborers who have been waging a feud-like war for higher wages and lower food prices.

"Detectives on Secret Mission.-The struggle between tenants and laborers on one side and land owners and merchants on the other has been in progress here for several months and has spread throughout New Madrid county, in southeast Missouri. Six detectives have been camping secretly for two weeks in a shack on a swamp which is part of the farm of T. S. Heisserer, wealthy land owner and banker, against whom the night riders have centered their attacks...

"Though called riders, the men participating in night raids usually travel afoot, sometimes masked. The outrages attributed to them include arson, murder, blackmailing, tarring and feathering and horsewhipping of men and women. Nine of such several months ago were trapped at an organization meeting by officers of the postal department, and seven of these were convicted of sending threatening letters through the mails and were sent to the federal penitentiary at Leavenworth, Kan." ${ }_{5}$

The "I. W. W." (Industrial Workers of the World) disturbances which occur not only in the east, but flare up in our prairie sections, as in Minot, North Dakota, in 1914, may be considered as symptoms of agricultural unrest.

The amount of tenancy in different sections of the Union varies greatly. Tenancy is greatest in the South. It is also great and growing greater in the strictly agricultural states such as Indiana, Ohio, Illinois, Iowa, Missouri, Kansas, Oklahoma, and Nebraska. The table in the appendix to this chapter will indicate correctly the amount of tenancy in these sections. The actual condition of tenancy of each state in the Union as well as changes for better or worse are also shown in this appendix.

Rent Contract.-The rent contract in the United States is of two general types, the cash rent and the share rent type, and these two fall loosely into four systems of tenure, namely; the cash tenant, the share tenant, the share cropper, and the crop lien system, all of which are illustrated below. The significant feature however, of each form of rent contract is the short time of the tenure. In other words, we do not have a stability of farm operators. Unhappily this holds true also of farm owners. The one

${ }^{5}$ Des Moines Register, Nov. 24, 1915. 
redeeming feature of farm tenancy in England and Scotland, where it has apparently reached its perfection, is the long time tenure of the renter. The significance of our too short time tenures is brought out vividly in the various surveys alluded to above. Thus, to quote from a survey of Montgomery County, Maryland:

"Speaking broadly, it is common experience that under a system of tenantry the land is usually not so well farmed as when operated by its owners. The tenant usually has but a short lease on the land; inferior methods of farming are apt to be employed; the needs of the soil are not so carefully studied or attended to; there is generally a smaller working capital; the cost of operation is somewhat greater. In consequence, the property is not kept up; the fertility of the soil is seldom increased or even maintained; and in the long run, the net income is smaller. To have 45 per cent of the land operated under a tenant system and to have that system on the increase, would thus seem to present a problem worthy of consideration. The obvious solution would be along the line of aiding the present operators to obtain the ownership of the land. In Europe and to a lesser extent in some parts of the United States this need is met by an ably managed and extensive system of coöperative banking.

"Another interesting angle of this question has to do with the length of tenure. The average length of tenure for all farms is 12.4 years. But more than half of the farms and considerably more than half of the total acreage of farm lands, have changed hands at least once during the last ten years. This means an unstable element in the population large enough to cause concern. For all owned land, the average term of occupancy is 15 years, but for land operated by tenants, the average term of occupancy is only 4 years. Onefourth of the entire farming population, then is shifting, a fact which must necessarily hamper all efforts toward the betterment of rural life conditions along social, religious and educational lines."

A rural survey in one Tennessee community brings out this situation:

"Among the tenants 63 per cent rent land from neighboring farmers. This land is in many cases under the direct supervision of the owner, who designates what crops are to be raised, and sees to it that the soil does not become too much worn out. In many cases the renters although retaining their independence, are thus virtually hired men, who are paid in produce instead of in cash. This is particularly the case with the 'share cropper,' who owns neither land nor tools, but has tools, horses and seed furnished by the owner of the land. The cropper as a rule cultivates from 20 to 30 acres, and gives half the produce to the owner. Most of the croppers are negroes. The 'share tenant' or 'renter,' who furnishes his own tools and horses, pays to the owner one-third of the corn and one-fourth of the cotton. The cash tenant pays usually $\$ 4.00$ an acre. There are only ten hired men. Their wages are from seventy-five cents to $\$ 1.00$ a day and keep."

There is of course another side to this picture. The Federal government has been quoted as accepting tenancy as a permanent institution. In line with this belief the Federal government has issued a bulletin entitled, "A System of Tenant Farming and Its Results." This bulletin shows a successful example of tenant farming where the landlord has secured stability of farm operators. An extended quotation is worth while in this connection. Accord- 
ingly we print the following extract from this report, which was issued in the year 1911.

"In the older sections of the eastern United States the necessity for considering permanent types of farming has long been felt and much effort has been made to meet the need. A very good example of success in solving this problem along general farming lines is that of a large estate in eastern Maryland. This estate is the more interesting because it represents a system embracing 56 tenant farms under one ownership that has been in successful operation for more than 30 years. During this period yields of wheat and corn, which are the principal crops grown, have been maintained and in some cases increased. A large number of tenants have been on the estate for more than 20 years; several have been there for more than 30 years, and their sons have succeeded them.

"These facts show clearly that the relationship between owner and tenant has been satisfactory. This is further brought out from the standpoint of the tenant by the fact that many tenants have made enough money by farming on the estate to buy farms of their own. In several instances, however, they are so well satisfied that they continue as tenants and rent their own farms to some one else.

"On the other hand, the estate itself is fairly well satisfied. It has been able to keep up the productiveness of the different farms until many of them yield better than when bought. Attractive dwellings and substantial barns have been maintained on every farm, and all the fields are well fenced with board, hedge, or wire. Many fields have been enlarged by clearing waste places and, made more productive by underdraining with tile. Every farm is clean, neat and attractive in appearance.

"The returns from the farm have paid for all these improvements, have paid all taxes, and are now bringing in to the estate more than 5 per cent interest on the total investment. . Some of the farms have nearly trebled in value in the last 30 years. These returns to both tenant and owner are unusual. It is seldom that so large an estate is handled so satisfactorily, and a closer study of the system followed may prove profitable.

"In detail, the estate consists of 15,630 acres, or about 24 square miles of land, subdivided into 56 farms varying in size from 98 to more than 1,000 acres, an average of about 279 acres per farm. These farms are scattered over a radius of about 12 miles from the central office. Considerable areas of waste land are found on some of them, so that on the average only about 72 per cent of the land is in actual cultivation. The price of cultivated land away from the influence of towns varies from $\$ 40$ to $\$ 65$ per acre, and these farms will probably show a like variation in value. The soil of most of the farms varies from a sandy loam to a clay loam, is comparatively free from stones, and is generally well adapted to wheat culture. The land is sufficiently level for the operation of labor-saving machinery.

"One of the interesting facts relative to these farms and their organization into a profitable system of farming is that they were accumulated one at a time and organized by a merchant who had no special knowledge of agriculture, yet he formulated and put into practice over 30 years ago a system which has maintained yields and given satisfactory profits to both owner and tenants up to the present time. The latter is regarded as the most important fact in this bulletin.

"At the time of the owner's death, 13 years ago, the system of farming which he put in operation had become so well established that with practically no change since then the yields of the farms have been maintained, a considerable indebtedness has been paid, the buildings and fences have been kept in a good state of repair, and a net income from the farms averaging a little more than 5 per cent has been paid to the estate." 
This quotation raises the ever-occurring question of capitalistic farming versus the small-scale farmer. Evidence is given on both sides of this much mooted question so that the reader may draw his own conclusion. In the past it has been customary for a tenant to purchase a farm, pay part cash and give a mortgage for the balance. A study of statistics when such a condition existed revealed the true situation. However, at the present time a careful study of the census returns of owners free, owners mortgaged, and tenants shows that the tenants are not increasingly becoming buyers with mortgage encumbrances, but, on the other hand, the owners are mortgaging their farms. In brief, those who have occupied a farm from two to four years should show a large per cent of owners with mortgages. Then in the course of time these owners with mortgages would become owners free. Those who have been on the farm ten years and over would in such an event show a marked decrease in the number of mortgages. However, statistics show that this happy condition of affairs does not exist.

According to a bulletin issued by the Iowa Experiment Station:

"To obtain greater economic independence requires more years of saving before ownership now than formerly. Hence, the age of ownership to-day is about six years later in life than it was 25 years ago. Farmers make their first payment on land now at the age of 34 , while 25 years ago ownership was obtained at 28 years of age." ${ }^{\circ}$

A bulletin of the Texas Station (No. 21) asks: "What chance has the farm tenant in Texas to become a home owner? Some of them have the same chance or opportunity to become home owners that the average merchant in the town has to become a merchant prince. The chances are slight."

A study of the tenant systems of farming in the cotton belt along the Mississippi River between Memphis and Vicksburg, made in 1913, and covering many hundred records, found the following situation:

Share Croppers, Share Renters, Cash Renters.-The study makes a comparison among share croppers, who supply nothing but their labor and receive one-half the crop; share renters who supply their own implements and livestock and receive two-thirds or three-fourths of the crop; and cash renters, who supply the same items as share renters but pay a fixed rent in cash or lint cotton. In this area the tenants form 92.0 per cent of all farmers. The average labor income of share croppers was $\$ 333$; for share renters

${ }^{6}$ Lloyd, O. G., Farm Leases in Iowa. Iowa Exp. Sta. Bul. 159. 
$\$ 398$; and for cash renters $\$ 178$. The average rate of interest received by the landlord from share croppers was 13.6 per cent; from share renters 11.8 per cent; and from cash renters 6.6 per cent.

A survey in Johnson County, Missouri, speaks of farm tenancy there in these terms:

"A rural community where 80 per cent of the population is changing every five years cannot have desirable social conditions."

"A study of the foregoing results (advantages and disadvantages of tenancy) leads to the conclusion that the present system of land tenure is undesirable, first because it encourages tenants to become shiftless, second, because it depletes the soil, third, because it is very detrimental to the improving of rural social conditions."

The Wisconsin State Board of Public Affairs, in 1912, sought a remedy for increasing tenancy. They first canvassed the actual situation in Wisconsin, and found that in the new lands of the north there is little tenancy, but in the older higher priced lands, tenancy is large and growing larger. To quote, and condense freely, from the Board's report:

"This suggests that in Wisconsin as in other parts of the Middle West the proportion of farm tenancy increases as the cost of a farm becomes greater... There is no convincing evidence of an increase in farm ownership. On the contrary, the evidence seems to indicate that there will be a continuous increase in tenancy generally throughout Wisconsin, unless steps are taken to prevent it. It is the duty of the state to encourage the proper settlement of its undeveloped farm lands. It is just as much the duty of the state - and this is a duty of self-protection-to encourage farm ownership by taking measures to check the growth of farm tenancy. These measures should be taken in time while the proportion of tenant farmers in the state is still relatively low and the problem of dealing with them, therefore, more simple than it will be if left unattacked until a solution is absolutely forced on the people of the state.

"Wisconsin should be taking warning from the experience of other states in the Middle West. The 1910 census shows that already in Illinois more than 41 in every 100 farms are operated by tenant farmers and that in some counties in that state more than 60 in every 100 farms are so operated ... .

"The best that can be said for any system of farm tenancy involving any large proportion of the agricultural population, is that it is better than something worse. It may be argued, for example, that it is better for the negro in the southern states to be a tenant farmer than to be a slave or a casual laborer. In comparison with farm ownership, there can be no argument for farm tenancy as a system of land tenure. Statesmen and political thinkers the world over have for centuries recognized the truth in this statement and have urged and enacted into law plans for governmental activity to check landlordism and promote farm ownership by the actual farmers. To-day some of the most important questions engaging the attention of the parliaments of Europe, Australia and New Zealand are questions of land policy. The people of Great Britain are at the present time engaged in a tremendous struggle to free the land in England from the grasp of the landlord so that the man who will farm it can have it to farm advantageously. In Ireland the 
land is already being turned back to the ownership of the men who cultivate the soil-but at the expense of a state subsidy costing the treasury of the United Kingdom millions of pounds. New Zealand and Australia have been legislating for many years to break up large land holdings and prevent the growth of landlordism.

"The State of Wisconsin cannot afford to permit the growth of a landed aristocracy or the creating of a permanent class of tenant-farmers. Worldwide experience warns against the social and economic dangers in allowing such conditions. The question is what preventative measure shall the state adopt? . . . It is a serious question, as urged by Dr. Richard T. Ely, whether or not a state could maintain a system of state landlordism in the face of the united opposition of the majority of its tenants.

"There are four ways of attacking the farm tenant problem," said the Board: "(1) Assume farm tenancy to be inevitable. Make provisions to improve the conditions of tenancy, such as long-time leases, legal regulation of rights and duties of landlord and tenant. (2) Assume farm tenancy to be inevitable. Make the state itself the landlord. (3) Assume tenancy to be undesirable and unnecessary. The State may adopt a taxing system to break up landlordism and land speculation. (4) Assume tenancy to be undesirable and unnecessary. The State may use state-aided land purchase, on long time farm mortgage loans at low rates of interest, thus enabling tenants to become land owners. The fourth method is recommended by the Wisconsin Board as the "only adequate method of attacking the problem which is capable of immediate adaption to conditions in Wisconsin."

Corporation Farming.-Corporation farming has long been known in all parts of the United States. No records are available showing what per cent of such corporations fail and what per cent succeed. An increasing number of railroad and industrial corporations are now operating large farms largely for experimental purposes. The International Harvester Company is conspicuous for its work in this line. The Portland Cement Company owns large tracts of land all over the United States, not originally purchased for agricultural purposes, but now being used for crop production. A general manager supervises these farms, using up-to-date business methods in developing farm properties, including cost account keeping. A New York financial editor in speaking of this situation expresses himself thus hopefully:

"If one company can operate farms all over the country under a central office, using the most modern business methods of development and marketing, the example is likely to be followed. Just why a big company could not buy extensive land and work it in the same way is hard to understand. It might be a relief to many struggling farmers whose incomes often become less and less each year, to join the payroll of a Farm Corporation and be sure of a salary every two weeks ... The economic advantages are obvious, but the social advantages would be equally great. An intelligently conducted farming corporation would out of self interest find a way to make rural lifemore attractive for its employees, and by both example and practice would be able to reverse the city-ward tendency of our population, which is one of the great evils of the present day in America. The picture of a great farm scientifically and sympathetically conducted by a wise and progressive corporation is in fact 
so attractive to both the financier and the sociologist that we shall be surprised if it does not soon take shape in the prospectus of such an enterprise and the issuance of its securities under responsible auspices." 7

This roseate picture of a good and wise corporation, with the farmer on its payroll, will not be likely to meet with the hearty approval of the farmers themselves. But if "efficiency" is on that side, the corporation may in the end prevail.

Size of Farms.-What change is taking place in the size of farms? Omitting the bonanza farms of the northwest, the plantations of the south and the great ranches of the west, we find that the size of the farm has apparently begun to grow bigger. This is a further indication of our trend toward capitalistic agriculture. For the complete statistics on this point the student is referred to the table in the appendix to this chapter. The size of farms in the strictly agricultural states is given in the brief table below:

Size of Farms in Six Typical Farming States.-Acres

\begin{tabular}{|c|c|c|c|c|c|c|}
\hline & Ohio & Indiana & Illinois & Iowa & Missouri & Kansas \\
\hline $\begin{array}{l}1910 \ldots \ldots \\
1900 \ldots \ldots \\
1890 \ldots \ldots \\
1880 \ldots \ldots \\
1870 \ldots \ldots \\
1860 \ldots \ldots \\
1850 \ldots \ldots\end{array}$ & $\begin{array}{r}88.6 \\
88.5 \\
92.9 \\
99.2 \\
110.8 \\
113.8 \\
125.0\end{array}$ & $\begin{array}{r}98.8 \\
97.4 \\
102.8 \\
105.3 \\
112.3 \\
124.3 \\
136.2\end{array}$ & $\begin{array}{l}129.1 \\
124.2 \\
126.7 \\
123.8 \\
127.6 \\
145.9 \\
158.0\end{array}$ & $\begin{array}{l}156.3 \\
151.2 \\
151.0 \\
133.5 \\
133.6 \\
164.6 \\
184.8\end{array}$ & $\begin{array}{l}124.8 \\
119.3 \\
129.3 \\
129.3 \\
146.3 \\
215.4 \\
178.7\end{array}$ & $\begin{array}{l}244.0 \\
240.7 \\
181.3 \\
154.6 \\
148.0 \\
171.0 \\
\cdots \cdots\end{array}$ \\
\hline
\end{tabular}

Average of Six States Above for Seven Decades:

$\begin{array}{ll}1850-156.5 \text { acres } & 1880-124.3 \text { acres } \\ 1860-155.8 & 1890-130.7 \\ 1870-129.8 & 1900-136.9 \\ & 1910-140.3\end{array}$

We may illustrate the tendency of the large farmers to absorb the small farmer by the following concrete illustration: Shortly after the close of the Civil War an ex-soldier by the name of John McNiel moved from Ohio to the eastern part of Kansas and settled on a farm. He located in a community settled almost entirely by people from his section of Ohio. Here John McNiel with his wife built a home on a 160 acre farm. He was a man of unusual industry and of sterling honesty. They reared a family of two children, one boy and one girl. They faced the privations of pioneer life with courage. They lived through many months of discouragements, but managed to save a little from year to year. By the

7 Theodore Price in Commerce and Finance, Aug. 23, 1916, Dec. 13, 1916. For a statement of the case for corporation farming, by Pres. G. A. Vincent, of the University of Minnesota, and a spirited reply thereto, see the Dakota Farmer, Sept. 15, 1916, p. 972. 
happy combination of hard work and good management this man made a success of farming. He built a home far above the average farm home both in beauty and convenience. His yard was decorated with beautiful shade trees and pine trees. His out-buildings were painted. Now the neighbors of John McNiel likewise built themselves homes and also planted trees on the prairie. After the lapse of twenty-five or thirty years these trees became groves of immense shade trees. But these neighbors were not prosperous. First John McNiel buys out the neighbor on one side. This house is demolished; every tree is cut down; the place where once a human habitation stood was reduced to cultivation and became the site of green cornfields. And then the neighbor on the other side was bought out. "The well was filled up; the trees were cut down; the houses removed; this home was obliterated from the face of the earth. Likewise with a third farm. Now, this process may be viewed as a process of growth or as a process of decay. From the standpoint of John McNiel, farming is a success and the large holding is better than the small holding; from the standpoint of the three neighbors, however, farming is a failure. The writer on a recent visit to this section was impressed with the process of decay which is overtaking these homesteads, especially those houses built from thirty to fifty years ago. He carries in mind the vivid impression of one house in particular where the outbuildings had fallen into decay and the house itself was converted into a sheep fold. About the house and even passing in and out of the doors were hundreds of sheep, suggesting the days of Queen Elizabeth, when enclosures had converted tillable lands into sheep pastures to such an extent that laws were enacted against the "decay of villages." In this same neighborhood is another farm which was given, "ready made," new house, buildings, equipment, and all, to a young farmer and his wife by the mother of the farmer. This place has changed hands, the present owner having greatly improved it and enlarged it by adding two small farms to it. The farmer to whom it was given could not make a living on it, and is now working as a day laborer. This case simply illustrates the human side of the problem of land tenure and of any scheme of legislation intended to benefit small landholders. Some men are tenants and ought to remain tenants, because they are not qualified to be owners. Some are day laborers because of their personal qualifications. There can never be a perfect system of land tenure until there is a perfect race of men to occupy the land. 
Mortgages.-The number of mortgages, like the amount of tenancy, is increasing in the United States. Do mortgagors become owners? This point has already been mentioned. Our conclusion is that a smaller and smaller per cent of mortgagors become owners. On the other hand, a great many present owners will in time become mortgagors. Mortgages again like tenancy differ with different sections of the United States. The chief class of tenancy was given as the short-term tenure. The chief mortgage system to-day (before the Federal Farm Loan system has had time to change it) is the short-term mortgage, namely, five years. Custom has apparently established the term of mortgage as about five years. The rate of interest of course varies with different sections of the country. When we consider manufacture, transportation, or any of the other capitalistic forms of industry, we at once think of their bonds as having a fairly long time to run. The ordinary corporation bond, whether it be municipal, public utility, industrial, mining, or other form, commonly runs twenty to forty years. Agricultural bonds, in other words, mortgages on farms, have the same reasons exactly for running long periods as the various classes of bonds mentioned above. A five-year mortgage means that the mortgagor very commonly must renew his mortgage at the end of the five years or submit to foreclosure proceedings. We have developed an institution in the United States sometimes known as the "padded" mortgage and sometimes known as the "fake" mortgage. For instance, a farmer desiring to participate in land speculation arranges to buy a farm for $\$ 8,000$. He pays cash $\$ 4,000$. He then gives a mortgage for $\$ 12,000$ making the apparent cost $\$ 16,000$ instead of $\$ 8,000$. The seller of the farm gives his promissory note for $\$ 8,000$ as an offset to the fictitious part of the mortgage. When the newcomer appears on the scene to buy the farm he is of course impressed with the fact that the farm is mortgaged for $\$ 12,000$, which is represented to him to be three-fourths of its actual value. He becomes the buyer then at $\$ 16,000$. This form of real estate speculation is in vogue in certain sections of our country. The mortgage situation under the Federal Farm Loan Act is discussed in a later chapter dealing with Credit.

Free Trade in Land.-The English theory that no one can secure absolute title in fee simple to the land has never obtained in the United States. Neither has this country hedged the buying and selling of land with restrictions or obstacles as in some of the older countries, the government claiming original title to the land, 
and giving the individual absolute ownership of the soil. The owner of the soil may transfer the ownership at will and with very little formality and with very little expense. This has produced in the United States an unorganized market for real estate. In every city, in every village, in every hamlet, we have now dealers in real estate. Some are stable dealers occupying permanent quarters, guaranteeing the titles to the lands they handle and rendering other services incidental to real property. Some dealers are merely scalpers in the market looking for a few chance bargainis here and there, having no standard prices or commissions and rendering no services of any kind to the community. It is this class of dealers that charges a commission on land sales ranging from $\$ 1.00$ to $\$ 50$ an acre. It may be truthfully asserted that nowhere is speculation more rife or more injurious than in the unorganized market. Oddly enough the farmers manifest a tremendous and ardent interest in the activities of Wall Street, the produce exchanges, and the grain exchanges of the country, which have very little effect upon the farmer and at the same time they remain largely unconcerned about the unorganized speculative land market which lies at their door. In this unorganized market, as intimated above, we have the reliable dealers, the scalpers, and the out-and-out frauds. For instance, the Federal government has but recently succeeded in convicting a group of prominent men of frauds in connection with the sale of Florida lands. Misuse of the mail brought the case into the Federal Court. This case is typical of hundreds of others which are known to every reader of our daily and weekly press.

Free trade in land has been undoubtedly the best thing for the country in spite of the many abuses which have crept in. The question now is how to remedy some of the obvious defects in our methods of land trading. Some hopeful signs are now in evidence. Two things are now being done. In some localities farmers' organizations are now listing all farm lands which are for sale. The list is prepared by the farmers and contains a correct and honest description of the land and, what is more important, a fair price. This list is brought to the attention of would-be settlers, thereby precluding the chance for the middleman to take an unduly large commission. Another step which has been taken may be called state oversight of land sales. For example, in connection with the state departments of agriculture in the states of Connecticut, Pennsylvania, New Jersey, New York, Alabama, and others, a booklet is issued from year to year giving a descriptive and accu- 
rate list of farm lands for sale in these respective states. This tendency to take charge of the marketing of land in such a way as to eliminate the huge wastes of the middleman, the overcapitalization of land, the robbery and ruin of the immigrant, is one of the most hopeful tendencies now discernible in connection with this subject. Indeed, some attention is now being given to the advisability of land certification.

The Torrens System.-The weak point in our land title system at present is the cumbersome method of recording land titles. The title is registered with some governmental functionary commonly known as the County Register of Deeds. The purchaser, to be sure of the soundness of his title, usually is put to the expense of securing what is familiarly known as an abstract of title. The records are searched from the original grant of the land down to the present moment of sale to see if there are any outstanding claims which would cast a shadow on the title. Where titles have changed hands many times as is the case in the older sections the expenses of this investigation are considerable. Even then a flaw may be discovered later in the title. A new system is coming into use in the United States known as the Torrens System. It is now in use in about half of our states. This system originated in South Australia in 1858 and has spread widely throughout the British Colonies. The most important features of this system are simple enough, namely: Land owners record their titles to real property with a Registrar. This official, after due examination, grants a Certificate of Ownership which is an absolute and indisputable title against all the world. From that moment on transfers of real property can be made by the transfer of the certificate and proper registration of this fact. The title is given to owners in actual possession. If, however, another person should later establish his legal right to the property he can claim indemnity only for his loss but cannot recover the property itself. Funds for such emergency payments are usually furnished by the state and come largely from the registration fees. The adoption of this system in this country would offset all necessity for securing the so-called abstract of title, and would eliminate the very expensive work now performed by the title guarantee companies.

Land Certification.-Progressive traders in the real estate market are proposing that the purchaser of farm land be protected by receiving a certificate with his land title, correctly setting forth the topography and the soil conditions (based on the federal soil survey), climatic conditions, based on official statistics as to tem- 
perature, rainfall, etc., and possibly economic statistics as to assessed valuation, crop yields for a period of years, etc. Since this is the age of "blue sky laws," "pure food laws," and certified products of various kinds, it is logical to expect a development of some form of land certification.

As Vermont Sees the Problem of Land Trading.-The Agricultural Commissioner of Vermont, in a recent report, ${ }^{8}$ discussed the problem of the sale of farms in that State. Both his experience and his conclusions are typical, and are worth quoting in full:

"Land values in Vermont are so low in comparison with those in other parts of the country that proper advertising of our opportunities as carried on by the publicity bureau of the Secretary of State's Office, coupled with assistance in the way of giving specific information to prospective farm buyers residing at a distance would undoubtedly enable Vermont to attract a large number of people who would become good farmers and good citizens. It has seemed to the commissioner of agriculture that as a preliminary to a satisfactory program of this kind an example should be made of real estate agents who are carrying on a campaign of farm sales which result all too often in injustice to the purchaser.

"We have in many sections of the State farms containing much rough land which may be bought at low prices. This affords opportunity for a certain type of real estate agent to purchase or secure options upon these properties at small cost and then, by advertising them for what they are not, sell them to unsuspecting persons at prices which will net the agent a large profit. While the purchasers of these properties might succeed if the farms were secured at their real value, they are unable to make a living and pay interest upon the excessive capitalization. Therefore, after a period of discouragement they abandon the property in disgust. The State thereby losing the possibility of securing a desirable citizen.

"One such case was brought to our attention in the spring of 1913 by the late Bishop William F. Weeks. An investigation showed that the real estate firm of M. Susskind \& Co. secured by option or otherwise the contract of certain farms in Sandgate which were subsequently sold to some German families. One of the farms, known as the Hamilton farm, was sold to one Paul Gobel, who, after occupying it for a short time, was obliged to abandon it after foreclosure of a mortgage on the personal property. The records of this case seem to indicate that Gobel had been induced to buy this farm through misrepresentation and fraud. A report was made to Gov. Allen M. Fletcher, with a request that the matter be investigated by the legal department of the State. An investigation by Attorney General Brown led to the indictment of M. Susskind and Otto Trieb, members of the firm of M. Susskind \& Co., at Manchester, June 1914. For various reasons the case was not brought to a final issue until Aug. 15, 1916. On this date the respondents entered a plea of nolo contendere, paid a fine of $\$ 200$ each and paid Paul Gobel a sum of money which partially reimbursed him for his loss. It is hoped that this example will put an end to real estate operations of this nature in the State of Vermont, because such sales profit only the real estate operator and are a detriment to all others."

${ }^{8}$ Eighth Annual Report of the Commissioner of Agriculture, State of Vermont, 1916, E. S. Brigham, Commissioner, pp. 13-14. 
The buying and selling of land is more important than the buying and selling of the products of the land. It is high time that earnest citizens gave it serious thought.

Real Estate Exchanges. - In the grain trade, as in the stock and bond market, the responsible traders have found it wise, as a protection to themselves and a protection to the public, to organize and adopt strict trading rules. These associations or "Exchanges" operate under rules and commission charges open and public and known to all parties interested. In the real estate market there is now apparent a beginning, here and there, of a Real Estate Exchange, operating under definite and ethical rules, as a protection to the honest real estate dealer and to the public. The honest dealers realize the scriptural truth that their enemies are they of their own household, and so, by organizing exchanges with severe membership requirements, are taking steps to weed out the unscrupulous traders.

\section{QUESTIONS ON THE TEXT}

1. Illustrate the different interpretations of the increase of farm tenancy, citing for this purpose the speakers before the meeting of the New York State Agricultural Society.

2. Compare the views of Stelzle and Simons on the changes in the size of farms.

3. What does Simons mean by "capitalism" in agriculture?

4. What has been our theory of a sound agriculture so far as land-ownership is concerned?

5. Compare Canada and the United States as to changes in farm tenancy.

6. Is tenancy likely to increase or decrease with us? Quote Spillman in 1912.

7. On the social and economic significance of farm tenancy, cite the findings of the Ohio "Survey"; of the United States Industrial Relations Commission; the Cape Girardeau, Missouri, affair.

8. Name, define, and illustrate the different forms of rent contracts.

9. Show the economic and social significance of short time tenures (particularly in Maryland, Tennessee, Iowa, Texas, Mississippi, Missouri, Wisconsin).

10. Illustrate successful farm tenancy in eastern Maryland, as described by the Federal government.

11. What changes are taking place in the size of farms? Cite the case of John McNeil, and state its significance.

12. Give examples of corporation farming. What is its success? State the views of Theodore Price on corporation farming.

13. What changes are taking place as to the number of mortgages on farms?

14. Contrast the agricultural mortgages with the mortgages in other industries as to the usual term of years each runs; as to rate of interest.

15. Explain the padded mortgage.

16. What is meant by free trade in land? In this respect compare the United States and England.

17. Show how the real estate market is usually conducted in the United States.

18. Explain and justify the Torrens System.

19. Show how some defects in our land trading may be remedied.

20. Cite the Vermont case of merchandising. 
21. State the need of organized exchanges to deal in real estate.

22. Give the views of Henry Wallace on tenancy.

23. Give the main points in the "Declaration on Farm Tenancy" issued by the Agricultural Commission of the American Bankers Association.

24. Cite statistics from 9 states illustrating the rule that cheap land means few tenants, dear land many tenants.

\section{QUESTIONS SUGGESTED BY THE TEXT}

1. State your approval or disapproval of Simons's theory of capitalism in agriculture, and give reasons for your position.

2. Formulate a land policy for the United States which will recognize and preserve the good features of tenancy and eliminate the bad features.

3. Formulate a workable Land Certification program.

4. State the case for organized Real Estate Exchanges built up on principles akin to those of the Grain Exchanges. Give the working of some such Real Estate Exchange.

5. Complete the tables in Appendices by adding statistics from the 1920 census.

6. Prepare tables of statistics from the Census Reports, showing per cent of farms mortgaged by decades, 1890-1920 (a) by Grand Divisions, and (b) for each State separately.

\section{REFERENCES}

1. Benton, A. H.: "Farm Tenancy and Leases." Bulletin 178, University of Minnesota Agricultural Experiment Station, St. Paul, Dec., 1918. Statistics are given showing that "Farm tenancy has been rapidly increasing in Minnesota, particularly in the southwestern part of the State where the average land values are highest."

2. Ely, Richard T.: "Private Colonization of Land." American Economic Review, Sept. 1918, pp. 522-548.

3. Ely, Richard T., and Galpin, Charles J.: "Tenancy in an Ideal System of Land Ownership." American Economic Review, Vol. 9, pp. 180-212 (March 1919). Also reprinted in bulletin form by the American Association for Agricultural Legislation, Madison, Wisconsin, 1919.

4. Galpin, C. J., and Hoag, Emily F.: "Farm Tenancy: an Analysis of the Occupancy of 500 Farms." Research Bulletin 44, Agricultural Experiment Station, University of Wisconsin, Feb., 1919.

5. Haggard, H. Rider: "The Poor and the Land." London, 1905.

6. Pratt, E. A.: "Small Holders. What They Must Do to Succeed." London, 1909.

7. Wendt, Dr. C. L.: "A Partnership, Not a Tenancy." The Dakota Farmer, July 1, 1918.

8. Report of the Land Settlement Board of the State of California. Sacramento, June 30, 1918, and later annual reports. Farm allotments and farm laborers' allotments in the Durham State Land Settlement. State Land Settlement Board, Sacramento, May, 1918.

9. International Institute of Agriculture, Rome. "Monthly Bulletin of Economic and Social Intelligence" (changed to "International Review of Agricultural Economies" January, 1916).

Finland.-“"Results of Interior Colonization." Nov., 1916, 106-114; Jan., 1917, 90-114.

Russia.- "Results of the New Agrarian Reform," Dec., 1916; Feb., 1917, 89-107. "Activity of the Peasants' Land Bank," Oct., 1917, 34-51. "Abolition of Landed Property," May, 1918, 437-438. 
Bosnia, Herzegovina.-- "Agrarian Question," Oct., 1916, 69-83. Ferfalk, Dr. F.: "A New Way to Solve the Agrarian Question in Bosnia." June, $1917,80-86$.

Portugal.- "Consolidation of Scattered Slips," Aug., Sept., Oct., 1919, 568-570.

Italy.-- "Colonization in Somaliland," March, 1917, 94-116. "Italian Colony of Erythrea," Feb., 1917, 67-89. "Collective Farms" of Italy, May, 1918, 366-383.

South Africa.--"Land Settlement in," Aug., 1918, 682-697.

Australia.-Peterson, J. W.: "Land Settlement and the Provision of Credit in Western Australia," Dec., 1916, 93-104. "Land Settlement, South Australia," May, 1918, 434-435. "Land Settlement in New South Wales," Aug., Sept., Oct., 1919, 525-535. " "Closer Settlement in New Zealand," June, 1916, 109-113. "New Zealand, Land Tenure," etc., Sept., 1918, 743-764. JENKINs, J. E.: "Land Settlement in Victoria," July, 1916, 87-95. "Land Settlement, Queensland," April, 1916, 77-87. "New Zealand, Torrens Title," April, 1916, 92-113. "Land Settlement, Victoria," January, 1916, 85-97. "Land Settlement," April, 1917, 100-101. "Agricultural Conditions and Land Tenure, Victoria," Nov., Dec., 1918, 911-921.

New Zealand.-“"Credit for Land Settlement," Oct., 1918, 817-823.

Argentina.- "Land Problems," Aug., 1918, 645-663. "Rural Property and the "Problems of Colonization," April, 1918, 329-337. "Subdivision of Lands," etc., Nov., Dec., 1917, 677-678. "Present Agricultural Conditions Affecting Land Settlement," Nov., Dec., 1919, 641-648.

Japan.- "Results and Progress of the Redivision of Lands Admitting of Cultivation," May, 1918, 409-432.

Scotland.- "Land Tenure, Land Court and Its Work," June, 1917; May, 1919, 301-311. "Workings of Small Holdings Act of 1908 in Scotland, England, Ireland," July, 1916, 107-116.

Ireland. " "Recent Statistics of Land Purchase Credit," Dec., 1919, 627-

636. "Land Purchase Credit in the Years 1912-1917," May, 1919, 280-301. Switzerland.- "Land Settlement in," May, 1919, 311-319.

Korea.- "State Tenants Association," June, July, 1919, 351.

France.- "Consolidation of Strips," May, 1916, 116-129. "Law of 1918. Redivision of Lands," Nov., Dec., 1918, 933-938.

Germany.- "Colonization," March, 1916, 124. "Prussian Legislation as to the Rentengüter and Its Results," etc., July, 1917, 41-46. "The Subdivision of Land in Old Bavaria," April, 1917, 77-84.

Hungary.- "Interior Colonization and the Future of Small Property," Oct., 1917, 72-77.

Spain.- "Distribution of Rural Property and Land Settlement in Their Relation to the Agrarian Problem," May, 1916, 99-116.

Paraguay.- "Private Agricultural Colonization," Feb., 1916, 135-137.

India.-Doure, J. M.: "Land Tenures in the Punjab in 'Their Original Form and as Affected by British Rule," July, 1917, 51-61.

Serbia.- "Distribution of Landed Property," Aug., 1916, 110-118.

Canada.- "Colonization by Pacific Railway," Dec., 1916, 133. "Coloni- . zation of Discharged Soldiers," April, 1919, 232.

Palestine.- "Jewish Agricultural Colonization," April, 1919, 206-223.

United States.-HibBard B. H.: “The Settlement of Public Lands in the United States," January, 1916, 97-118. Also "Farm Tenancy in the United States," April, 1917, 90-100. "Reclamation of Uncultivated Land for Settlement of Returned Soldiers," Nov., Dec., 1919, 648-660. "Large Holdings of Southern California," Aug., Sept., Oct., 1919, 574-578. "Land Tenure and the Organization of Agriculture on Indian Reservations," May, 1917, 63-77.

"Russian Land Reforms," 4 (1914) No. 2, 119-134, Nov.; 5 (1914) No. 1, 132-160; 5 (1914) No. 2, 137-147, July. 
"Russian Colonization in the Caucasus," 1908-1912, 1914, 125-140, Oct. "Russian Agricultural Reforms," 1915, July, 97-118.

"Siberian Colonias," 1915, May, 96-115; 1915, March, 111-126.

"Home Colonization in Finland," 1913, Feb., 142-160.

"New Land Reforms" (Russian), Nov., 1913, 119-134.

Finland.- "Distribution of Farms," July, 1914, 137-147.

"Subdivisions of Land in Various European Countries," March, 1912, 217-225.

Spain.-"Home Colonization," Dec., 1912, 175-195.

Switzerland.-"Restriping of Holdings, Its Present State and Practical Results," March, 1913, 128-152.

Holland.- "Bill to Enable Laborers to Become Proprietors of Land," July, 1912, 199-203.

Belgium.- "Agricultural Economy, Including Organization of Small Rural Holdings,” Dec., 1913, 94-100.

Columbia.--"Colonization," Aug., 1915, $118 \mathrm{ff}$.

Peru.- "Land Question and Colonization," July, 1913, 140-154.

Norway.- "Agricultural Organization, Large and Small Holdings," Aug., 1914, 145-154. "Home Colonization," July, 1913, 129-140.

Prussia. - "Results of Legislation on Division of I tands Held in Common, Uniting Scattered Strips," etc., June, 1911, 228-242; July, 223-228. " Home Colonization in Northern Germany," May, 1913, 99-112; Sept., 95-119; Oct., 93-103. "Purchase and Allotment of Landed Estates in West Prussia and Posen," Dec., 1912, 133-174. "A New Law Against Subdivision of Land," Oct., 1912, 203-204.

Austria.- "Restriping of Lands in Austria," April, 1912, 205-214. "New Agricultural Legislation," Feb., 1913, 85-100; May, 115-129. "Farm Tenancy," May, 1915, 75-81; June, 95-103; Aug., 111-118; Sept., 77-85. "Contemporary Agricultural Policy," March, 1915, 73-92.

England.-"Compensation to Tenants," July, 1914, 89-103. "Rural Depopulation," May, 1912, 163-186, also July, 161-179.

Scolland.- "Proposal for Land Reform," Sept., 1915, 85-100.

Wales.- "Proposals for Land Reforms," Nov., 1915, 97-106.

Ireland.- "Congested Districts Board," Feb., 1915, 103-128.

South Africa.- "Land Settlement Act of 1912," April, 1915, 105-113. "Provisions for Small Holdings," July, 1914, 103-109.

India.- "Tenure, Settlement," etc., Nov., 1914, 125-141, also Dec., 85-99. "Holdings, Partition," etc., Jan., 1915, 102-121, also Oct., 87-96.

Australia.- "Various Forms of Land Settlement," March, 1913, 105-113, also Aug., 137-151. "Land Settlement in Victoria," Jan., 1916, 85-97.

France.- "Enquiry in Reference to Metayage," etc., Sept., 1913, 120-140. "Position of Small Holdings," July, 1912, 143-160.

Mexico.- "Land Tax, Distribution of Rural Landed Property," Nov., 1914, 141-148.

- Denmark.- "Colonization," April, 1915, 89-95.

10. Carver: "Selected Readings in Rural Economics." Land Ownership: Broderick, "Law and Custom of Primogeniture," 352; Leslie, "Land System of France," 410; DE LAVELEYE, "Land Systems of Belgium and Holland," 433; HagGard, "State Small Holdings of Denmark," 478.

Tenancy: Holmes, "Tenancy in the United States," 487; Hibbard, "Tenancy in (1) North Atlantic States," 498; (2) "Central States," 508; (3) "Southern States," 523; (4) "Western States, 536. Same in Quarterly Journal of Economies, X, 34; XXV, 710: XXVI, 105, 363; XXVII, 482; BASTABLE, "Irish Land Purchase Act of 1903," 898-913. Same Quarterly Journal of Economics, XVIII, 1. 
11. Holman, C. W.: "Revolution in the Rural South-Story of the Militant Renters' Union and.Its Remarkable Influence in Solidifying the Tenants to Resist the Aggressions of the Landlords," Twentieth Century Magazine, May, June, 1912.

12. Yearbook Department of Agriculture. Spillman, W. J., ANd GoldDenWeiser, E. A., "Farm Tenantry in the United States," 1916, 321-347; Hol.mes, GEo. K.: "Movement from City and Town to Farms," 1914, 257-275.

13. Mead, Elwood: "Government Aid and Direction in Land Settlement." Discussion by R. T. Ely, G. F. Warren, C. F. Marbut. American Economic Review, March, 1918, 72-113 (Vol. 8, No. 1).

14. Lease Contracts - Crop and Livestock-in Minnesota. Grain Growers Guide, March 19, 1919.

15. Putnam, George E.: "Agricultural Credit Legislation and the Tenancy Problem."-American Economic Review, Dec., 1915, 805-816 (Vol. 5, No. 4).

16. Lloyd, O. G.: "Farm Leases in Iowa." Bulletin 159, September, 1915, Iowa Ag. Exp. Sta.

17. Wilcox, E. V.: "Lease Contracts Used in Renting Farms on Shares." Bulletin 650, United States Department of Agriculture.

18. Grimes, W. E.: "Farm Leases in Kansas," Bulletin 221, June, 1919, Ag. Exp. Sta. Kansas.

19. Hudson, Manley O.: "Land Tenures and Conveyances in Missouri," Uni. of Missouri Bulletin, Vol. 16, No. 16, June, 1915.

20. Johnson, O. R., AND Foard, W. E.: "Land Tenure" (Survey of 4 Missouri Townships). Bulletin 121, Dec., 1914, Ag. Exp. Sta., Missouri.

21. Wilson, James, and Wallace, Henry: "Agricultural Conditions in Great Britain and Ireland." (No date). Published by the Iowa Dept. of Agriculture, Des Moines (1913?).

22. Stewart, Chas. L.: "Land Tenure in the United States with Special Reference to Illinois." University of Illinois Studies in the Social Sciences. Vol. 5, No. 3, 1916.

23. Froley, J. W., and Smith, C. Beaman: "A System of Tenant Farming and Its Results." Farmers' Bulletin, Department of Agriculture, Washington, 1911.

24. "Industrial Commission." Vol. X, cvi-cx; Vol. XIX, 96-105.

25. "Survey" (magazine), April 17, 1915, 63-64.

26. "United States Commission on Industrial Relations, Final Report," 1916.

27. Sigerson, G.: "Land Tenures of Ireland," 1871.

28. KaY, Jos.: "Free Trade in Land," 1880.

29. "Corporation Farming." Commerce and Finance, Aug. 23, 1916; Dec.

13, 1916. "Dakota Farmer," Sept. 15, 1916.

30. "Annual Report, Secretary of the Interior," Washington, 1918.

31. Torrens Title. Niblac, W. C.: "Torrens System," 1903; Cameron, A. G.: "The Torrens System," 1915; "Laws Relating to Rural Credit and Land Registration," 64 Cong. 1 Sess. Sen. Doc. 351.

32. "The Lease Contract"-Hoard's Dairyman, Feb. 6, 1920. Black, J. D.: "Landlord's and Tenant's Share." BLACK, J. D.: "Share Leases for Dairy Farms." "Iowa Stock Share Leases." "Dairy Farm Lease."

33. JAckson, T. C. (3d. ed.): "Agricultural Holdings and Tenant Right Valuations," Preface; 1-6; 181-344, 1917.

34. "Farm Lease for Grain Farming"-Suggestion from University of Illinois. Banker-Farmer, Jan., 1920, p. 10.

35. "Where Does Tenancy Lead?" Banker-Farmer, Jan., 1920, p. 12.

36. "Anti-rent War in New York," 1844. Niles Register, Vol. 67, pp. $256,272$. 
37. "Scully Lands in Kansas." Commercial West, Feb. 15, 1919, p. 40. Compare large holdings in Argentina, Daily Consular and Trade Report, No. 165. July $16,1919,334-335$.

38. "Small Farms for Uruguay"- the beginning of the subdivision of the large estates. Monthly Consular and Trade Reports. June, 1909, 86.

39. Mead, Elwood: "Summary of Soldier Settlements in English Speaking Countries, Department of the Interior," Washington, 1918.

40. "Land Settlement in the Mother Country." Issued by the English and Scottish Boards of Agriculture with the approval of the Admiralty and War Office, 1919.

41. "Renting Land in Missouri, etc., with Model Forms of Lease." Bulletin 167, Agricultural Experiment Station, Columbia, Mo., February, 1920.

\section{APPENDIX}

Corporation Farming.-Corporation farming is now being conducted in many specialized crops in the United States. As an instance of this, mention may be made of the American Fruit Growers, Inc., with headquarters at Pittsburgh, Penn.

The fruit and vegetable industry in the United States ranks next to grain and meat in the volume and value of the food produced. The annual volume of fruits and vegetables marketed aggregates more than 750,000 car loads, and the annual value of this volume is some three billion dollars. Tremendous wastes have been common in this trade, due to poor packing, poor distribution, and other marketing defects.

The corporation above named owns and operates apple orchards and apple packing houses and is also in the distribution business, to the end that certain savings and economies may be introduced in standardizing and stabilizing various departments of this great industry.

Henry Wallace on Farm Tenancy.- "Productive value cannot be maintained under our present system of leasing.

"It is useless to attempt to develop a social value when half our lands are farmed by an unstable population.

"Country schools are declining in efficiency . . . and will so long as our present system of leasing continues.

"Many leases are simply conspiracies against the voiceless land to rob it . . . The land is silent now, but bides its time and takes its sure revenge."Henry Wallace, Address before Banker Farmer Conference, Chicago, 1915. 
Farm Mortgages.-Per Cent of Farms Mortgaged, Arranged in Order of Per Cent Mortgaged, Showing Changes, if Any, in Twenty Years

\begin{tabular}{|c|c|c|c|c|c|c|}
\hline & \multicolumn{2}{|l|}{1910} & \multicolumn{2}{|l|}{1900} & \multicolumn{2}{|c|}{1890} \\
\hline 50 per cent -59 per cent & $\begin{array}{l}\text { Iowa } \\
\text { Wis. } \\
\text { N. D. }\end{array}$ & $\begin{array}{l}51.8 \\
51.4 \\
50.9\end{array}$ & $\begin{array}{l}\text { Iowa } \\
\text { N. J. }\end{array}$ & $\begin{array}{l}53.0 \\
51.9\end{array}$ & $\begin{array}{l}\text { Kans. } \\
\text { Iowa } \\
\text { S. D. } \\
\text { Neb. }\end{array}$ & $\begin{array}{l}55.5 \\
53.3 \\
52.4 \\
52.0\end{array}$ \\
\hline 40 per cent -49 per cent & $\begin{array}{l}\text { N. J. } \\
\text { Mich. } \\
\text { Vt. } \\
\text { Minn. } \\
\text { Mo. } \\
\text { Kans. } \\
\text { N.Y. } \\
\text { Okla. } \\
\text { Conn. } \\
\text { Mass. } \\
\text { Cal. } \\
\end{array}$ & $\begin{array}{l}49.6 \\
48.2 \\
46.9 \\
46.3 \\
46.3 \\
44.8 \\
43.7 \\
43.5 \\
43.2 \\
40.9 \\
40.5 \\
\end{array}$ & $\begin{array}{l}\text { Mich. } \\
\text { Vt. } \\
\text { N. Y. } \\
\text { Wis. } \\
\text { Neb. } \\
\text { Minn. } \\
\text { Mo. } \\
\text { Kans. } \\
\text { Conn. }\end{array}$ & $\begin{array}{l}48.3 \\
46.9 \\
46.3 \\
45.8 \\
45.4 \\
44.8 \\
42.4 \\
41.8 \\
40.7\end{array}$ & $\begin{array}{l}\text { Mich. } \\
\text { N. J. } \\
\text { N. D. } \\
\text { Minn. } \\
\text { Vt. } \\
\text { N. Y. } \\
\text { Wis. }\end{array}$ & $\begin{array}{l}49.4 \\
48.9 \\
48.7 \\
46.4 \\
44.3 \\
44.2 \\
42.9\end{array}$ \\
\hline 30 per cent-39 per cent & $\begin{array}{l}\text { Neb. } \\
\text { Ill. } \\
\text { Ind. } \\
\text { S. D. } \\
\text { Del. } \\
\text { Md. } \\
\text { Wash. } \\
\text { Ore. } \\
\text { U. S. } \\
\text { Tex. } \\
\text { Idaho } \\
\text { Miss. } \\
\text { Pa. } \\
\end{array}$ & $\begin{array}{l}39.4 \\
39.2 \\
38.8 \\
38.2 \\
37.2 \\
36.4 \\
34.1 \\
33.7 \\
33.6 \\
33.3 \\
33.4 \\
32.9 \\
31.1 \\
\end{array}$ & $\begin{array}{l}\text { Ill. } \\
\text { Mass. } \\
\text { Md. } \\
\text { S. D. } \\
\text { Del. } \\
\text { Ind. } \\
\text { Pa. } \\
\text { Cal. } \\
\text { N. D. } \\
\text { U. S. }\end{array}$ & $\begin{array}{l}39.3 \\
38.6 \\
36.8 \\
36.7 \\
36.5 \\
36.5 \\
32.3 \\
32.2 \\
31.4 \\
31.0\end{array}$ & $\begin{array}{l}\text { Inl. } \\
\text { Mo. } \\
\text { Ind. } \\
\text { Cal. } \\
\text { Conn. } \\
\text { Mass. } \\
\text { Md. }\end{array}$ & $\begin{array}{l}36.7 \\
36.4 \\
33.1 \\
32.5 \\
31.1 \\
30.5 \\
30.0\end{array}$ \\
\hline 20 per cent -29 per cent & $\begin{array}{l}\text { R. I. } \\
\text { Ohio } \\
\text { Ala. } \\
\text { Me. } \\
\text { Colo. } \\
\text { N. H. } \\
\text { S. C. } \\
\text { Utah } \\
\text { Ark. } \\
\text { Mont. } \\
\end{array}$ & $\begin{array}{l}29.6 \\
28.9 \\
26.9 \\
26.6 \\
26.4 \\
25.6 \\
24.0 \\
22.9 \\
21.4 \\
21.1 \\
\end{array}$ & $\begin{array}{l}\text { Ohio } \\
\text { R. I. } \\
\text { Miss. } \\
\text { Colo. } \\
\text { Me. } \\
\text { N. H. } \\
\text { Ore. } \\
\text { Tex. } \\
\text { Wash. } \\
\text { S. C. } \\
\end{array}$ & $\begin{array}{l}29.8 \\
27.1 \\
27.1 \\
27.0 \\
26.7 \\
25.5 \\
25.2 \\
23.4 \\
21.7 \\
20.6 \\
\end{array}$ & $\begin{array}{l}\text { Del. } \\
\text { Ohio } \\
\text { U. S. } \\
\text { Penn. } \\
\text { Wash. } \\
\text { Colo. } \\
\text { Ore. } \\
\text { Me. } \\
\text { N. H. }\end{array}$ & $\begin{array}{l}29.4 \\
28.9 \\
28.2 \\
27.4 \\
26.8 \\
25.5 \\
23.4 \\
22.1 \\
21.8\end{array}$ \\
\hline 10 per cent-19 per cent & $\begin{array}{l}\text { Wyo. } \\
\text { Ky. } \\
\text { Ga. } \\
\text { La. } \\
\text { N. C. } \\
\text { Tenn. } \\
\text { Nev. } \\
\text { Va. } \\
\text { Fla. } \\
\text { Ariz. } \\
\text { W. Va. }\end{array}$ & $\begin{array}{l}19.7 \\
19.6 \\
19.0 \\
19.0 \\
18.5 \\
16.9 \\
16.7 \\
16.0 \\
14.8 \\
12.9 \\
12.6\end{array}$ & $\begin{array}{l}\text { Nev. } \\
\text { Ala. } \\
\text { La. } \\
\text { Idaho } \\
\text { N. C. } \\
\text { Ky. } \\
\text { Va. } \\
\text { Ga. } \\
\text { Ark. } \\
\text { W. Va. } \\
\text { Mont. } \\
\text { Wyo. } \\
\text { Tenn. } \\
\text { Utah } \\
\text { Fla. } \\
\end{array}$ & $\begin{array}{l}19.3 \\
19.2 \\
17.7 \\
16.4 \\
15.8 \\
15.2 \\
14.7 \\
14.7 \\
14.3 \\
14.1 \\
14.0 \\
12.2 \\
11.5 \\
11.1 \\
10.3 \\
\end{array}$ & $\begin{array}{l}\text { R. I. } \\
\text { Nev. } \\
\text { Idaho } \\
\text { Mont. } \\
\text { W. Va. } \\
\text { Wyo. }\end{array}$ & $\begin{array}{l}19.1 \\
17.2 \\
16.3 \\
15.6 \\
13.0 \\
13.0\end{array}$ \\
\hline 1 per cent -9 per cent & N. M. & 5.4 & $\begin{array}{l}\text { Okla. } \\
\text { Ariz. } \\
\text { N. M. }\end{array}$ & $\begin{array}{l}9.2 \\
6.9 \\
2.3\end{array}$ & $\begin{array}{l}\text { S. C. } \\
\text { Miss. } \\
\text { Ariz. } \\
\text { Tex. } \\
\text { Utah } \\
\text { N. C. } \\
\text { Ala. } \\
\text { Ark. } \\
\text { Ky. } \\
\text { La. } \\
\text { Ga. } \\
\text { Va. } \\
\text { Tenn. } \\
\text { N. M. } \\
\text { Fla. }\end{array}$ & $\begin{array}{l}.0 \\
7.7 \\
6.8 \\
5.7 \\
5.5 \\
4.9 \\
4.4 \\
4.2 \\
4.1 \\
4.0 \\
3.4 \\
3.2 \\
3.2 \\
3.0 \\
2.9\end{array}$ \\
\hline
\end{tabular}


Farm Tenancy.-Per Cent of Farms Operated by Tenants, Arranged in Order of Per Cents, Showing Changes, if Any, in Thirty Years

\begin{tabular}{|c|c|c|c|c|c|c|c|c|}
\hline \multirow[b]{2}{*}{60 per cent- 69 per cent } & \multicolumn{2}{|c|}{1910} & \multicolumn{2}{|c|}{1900} & \multicolumn{2}{|c|}{1890} & \multicolumn{2}{|l|}{1880} \\
\hline & $\begin{array}{l}\text { Miss. } \\
\text { Ga. } \\
\text { S. C. } \\
\text { Ala. }\end{array}$ & $\begin{array}{l}66.1 \\
65.6 \\
63.0 \\
60.2\end{array}$ & $\begin{array}{l}\text { Miss. } \\
\text { S. C. }\end{array}$ & $\begin{array}{l}62.4 \\
61.1\end{array}$ & & & & \\
\hline 50 per cent -59 per cent & $\begin{array}{l}\text { La. } \\
\text { Okla. } \\
\text { Tex. } \\
\text { Ark. }\end{array}$ & $\begin{array}{l}55.3 \\
54.8 \\
52.6 \\
50.0\end{array}$ & $\begin{array}{l}\text { Ga. } \\
\text { La. } \\
\text { Ala. } \\
\text { Del. }\end{array}$ & $\begin{array}{l}59.9 \\
58.0 \\
57.7 \\
50.3\end{array}$ & $\begin{array}{l}\text { S. C. } \\
\text { Ga. } \\
\text { Miss. }\end{array}$ & $\begin{array}{l}55.3 \\
53.5 \\
52.8\end{array}$ & S. C. & 50.3 \\
\hline 40 per cent -49 per cent & $\begin{array}{l}\text { N. C. } \\
\text { Del. } \\
\text { Ill. } \\
\text { Tenn. } \\
\end{array}$ & $\begin{array}{l}42.3 \\
41.9 \\
41.4 \\
41.1\end{array}$ & $\begin{array}{l}\text { Tex. } \\
\text { Ark. } \\
\text { Okla. } \\
\text { N. C. } \\
\text { Tenn. }\end{array}$ & $\begin{array}{l}49.7 \\
45.4 \\
43.8 \\
41.4 \\
40.6\end{array}$ & $\begin{array}{l}\text { Ala. } \\
\text { Del. } \\
\text { La. } \\
\text { Tex. }\end{array}$ & $\begin{array}{l}48.6 \\
46.9 \\
44.4 \\
41.9\end{array}$ & $\begin{array}{l}\text { Ala. } \\
\text { Ga. } \\
\text { Miss. } \\
\text { Del. }\end{array}$ & $\begin{array}{l}46.8 \\
44.9 \\
43.8 \\
42.4\end{array}$ \\
\hline 30 per cent -39 per cent & $\begin{array}{ll}\text { Neb. } & 3 \\
\text { Ia. } & 3 \\
\text { Kans. } & 3 \\
\text { Ky. } & 3 \\
\text { Ind. } & 3\end{array}$ & $\begin{array}{l}38.1 \\
37.8 \\
36.8 \\
33.9 \\
30.0\end{array}$ & $\begin{array}{l}\text { Ill. } \\
\text { Neb. } \\
\text { Kans. } \\
\text { Ia. } \\
\text { Md. } \\
\text { Ky. } \\
\text { Va. } \\
\text { Mo. }\end{array}$ & $\begin{array}{l}39.3 \\
36.9 \\
35.2 \\
34.9 \\
33.6 \\
32.8 \\
30.7 \\
30.5\end{array}$ & $\begin{array}{l}\text { N. C. } \\
\text { Ill. } \\
\text { Ark. } \\
\text { Md. } \\
\text { Tenn. }\end{array}$ & $\begin{array}{l}34.1 \\
34.0 \\
32.1 \\
31.0 \\
30.8\end{array}$ & $\begin{array}{l}\text { Tex. } \\
\text { La. } \\
\text { Tenn. } \\
\text { N. C. } \\
\text { Iii. } \\
\text { Ark. } \\
\text { Fla. } \\
\text { Md. }\end{array}$ & $\begin{array}{l}37.6 \\
35.2 \\
34.5 \\
33.5 \\
31.4 \\
30.9 \\
30.9 \\
30.9\end{array}$ \\
\hline 20 per cent -29 per cent & $\begin{array}{l}\text { Mo. } \\
\text { Md. } \\
\text { Ohio } \\
\text { Fla. } \\
\text { Va. } \\
\text { N. J. } \\
\text { S. D. } \\
\text { Pa. } \\
\text { Minn. } \\
\text { N. Y. } \\
\text { Cal. } \\
\text { W. Va. }\end{array}$ & $\begin{array}{l}29.9 \\
29.5 \\
28.4 \\
26.7 \\
26.5 \\
24.8 \\
24.8 \\
23.3 \\
21.0 \\
20.8 \\
20.6 \\
20.5\end{array}$ & $\begin{array}{l}\text { N. J. } \\
\text { Ind. } \\
\text { Ohio } \\
\text { Fla. } \\
\text { Pa. } \\
\text { N. Y. } \\
\text { Cal. } \\
\text { Colo. } \\
\text { W. Va. } \\
\text { S. D. } \\
\text { R. I. }\end{array}$ & $\begin{array}{l}29.9 \\
28.6 \\
27.4 \\
26.5 \\
26.0 \\
23.0 \\
23.1 \\
22.6 \\
21.8 \\
21.8 \\
20.2\end{array}$ & $\begin{array}{l}\text { Kans. } \\
\text { Ia. } \\
\text { N. J. } \\
\text { Va. } \\
\text { Mo. } \\
\text { Ind. } \\
\text { Ky } \\
\text { Neb. } \\
\text { Fla. } \\
\text { Pa. } \\
\text { Ohio } \\
\text { N. Y. }\end{array}$ & $\begin{array}{l}28.2 \\
28.1 \\
27.2 \\
26.9 \\
26.8 \\
25.4 \\
25.0 \\
24.7 \\
23.6 \\
23.3 \\
22.9 \\
20.2\end{array}$ & $\begin{array}{l}\text { Va. } \\
\text { Mo. } \\
\text { Ky. } \\
\text { N. J. } \\
\text { Ia. } \\
\text { Ind. } \\
\text { Pa. }\end{array}$ & $\begin{array}{l}29.5 \\
27.3 \\
26.5 \\
24.6 \\
23.8 \\
23.7 \\
21.2\end{array}$ \\
\hline 10 per cent-19 per cent & $\begin{array}{ll}\text { Colo. } & \\
\text { R. I. } \\
\text { Mich. } \\
\text { Ore. } \\
\text { N.D. } \\
\text { Wis. } \\
\text { Wash. } \\
\text { Nev. } \\
\text { Vt. } \\
\text { Idaho } & 1\end{array}$ & $\begin{array}{l}18.2 \\
18.0 \\
15.8 \\
15.1 \\
14.3 \\
13.9 \\
13.7 \\
12.4 \\
12.3 \\
10.3\end{array}$ & $\begin{array}{l}\text { Ore. } \\
\text { Minn. } \\
\text { Mich. } \\
\text { Vt. } \\
\text { Wash. } \\
\text { Wis. } \\
\text { Conn. } \\
\text { Nev. }\end{array}$ & $\begin{array}{l}17.8 \\
17.3 \\
15.8 \\
14.6 \\
14.4 \\
13.5 \\
12.9 \\
11.4\end{array}$ & $\begin{array}{l}\text { R. I. } \\
\text { Cal. } \\
\text { W. Va. } \\
\text { Vt. } \\
\text { Mich. } \\
\text { S. D. } \\
\text { Minn. } \\
\text { Ore. } \\
\text { Conn. } \\
\text { Wis. } \\
\text { Colo. }\end{array}$ & $\begin{array}{l}18.7 \\
17.8 \\
17.7 \\
14.6 \\
14.0 \\
13.2 \\
12.9 \\
12.6 \\
11.5 \\
11.4 \\
11.2\end{array}$ & $\begin{array}{l}\text { R. I. } \\
\text { Cal. } \\
\text { Ohio } \\
\text { W. Va. } \\
\text { Neb. } \\
\text { N. Y. } \\
\text { Kans. } \\
\text { Ore. } \\
\text { Vt. } \\
\text { Ariz. } \\
\text { Colo. } \\
\text { Conn. } \\
\text { Mich. }\end{array}$ & $\begin{array}{l}19.9 \\
19.8 \\
19.3 \\
19.1 \\
18.0 \\
16.5 \\
16.3 \\
14.1 \\
13.4 \\
13.2 \\
13.0 \\
10.2 \\
10.0\end{array}$ \\
\hline 1 per cent-9 per cent & $\begin{array}{l}\text { Conn. } \\
\text { Ariz. } \\
\text { Mont. } \\
\text { Wyo. } \\
\text { Mass. } \\
\text { Utah } \\
\text { N. H. } \\
\text { N. M. } \\
\text { Me. }\end{array}$ & $\begin{array}{l}9.8 \\
9.3 \\
8.9 \\
8.2 \\
8.1 \\
7.9 \\
6.9 \\
5.5 \\
4.3\end{array}$ & $\begin{array}{l}\text { Mass. } \\
\text { N. M. } \\
\text { Mont. } \\
\text { Utah } \\
\text { Idaho } \\
\text { N. D. } \\
\text { Ariz. } \\
\text { Wyo. } \\
\text { N. H. } \\
\text { Me. }\end{array}$ & $\begin{array}{l}9.6 \\
9.4 \\
9.2 \\
8.8 \\
8.8 \\
8.5 \\
8.4 \\
7.6 \\
7.5 \\
4.7\end{array}$ & $\begin{array}{l}\text { Mass. } \\
\text { Wash. } \\
\text { N. H. } \\
\text { Ariz. } \\
\text { Nev. } \\
\text { N. D. } \\
\text { Me. } \\
\text { Utah } \\
\text { Mont. } \\
\text { Idaho } \\
\text { N. M. } \\
\text { Wyo. } \\
\text { Okla. }\end{array}$ & $\begin{array}{l}9.3 \\
8.5 \\
8.0 \\
7.9 \\
7.5 \\
6.9 \\
5.4 \\
5.2 \\
4.8 \\
4.6 \\
4.5 \\
4.2 \\
0.7\end{array}$ & $\begin{array}{l}\text { Nev. } \\
\text { Minn. } \\
\text { Wis. } \\
\text { Mass. } \\
\text { N. H. } \\
\text { N. M. } \\
\text { Wash. } \\
\text { Mont. } \\
\text { Idaho } \\
\text { Utah } \\
\text { Me. } \\
\text { S. D. } \\
\text { N. D. } \\
\text { Wyo. }\end{array}$ & $\begin{array}{l}9.7 \\
9.1 \\
9.1 \\
8.3 \\
8.1 \\
8.1 \\
7.2 \\
5.3 \\
4.7 \\
4.6 \\
4.3 \\
3.9 \\
3.9 \\
2.8\end{array}$ \\
\hline
\end{tabular}


Farm Tenancy in Canada.-Per cent of Total Occupiers Who are Tenants

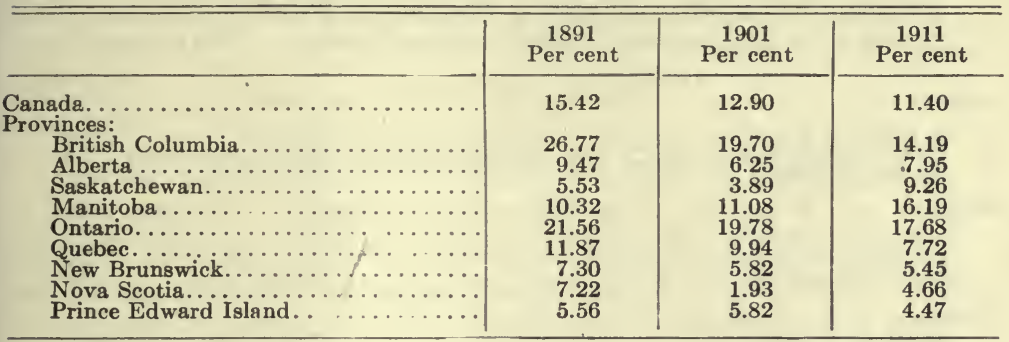

Shifting of Farmers, or Term Farmer Spends on One Farm. Term of Occupancy of Farm (Owners and Renters)

\begin{tabular}{|c|c|c|}
\hline & 5 Years and over & Less than 4 years \\
\hline 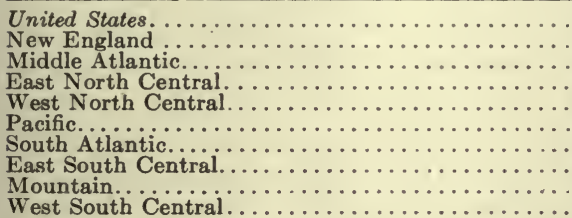 & $\begin{array}{l}48.24 \text { per cent } \\
70.08 \text { “ } \\
63.34 \text { “ } \\
59.00 \text { “ } \\
49.59 \text { “ } \\
46.92 \text { “ } \\
46.67 \\
40.79 \text { “ } \\
39.93 \text { “ } \\
33.48 \text { “ }\end{array}$ & 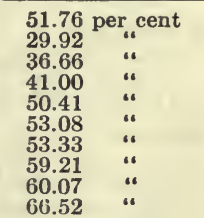 \\
\hline
\end{tabular}

Conference of the Agricultural Commission of the American Bankers Association, Washington, February 26-27, 1919

Declaration on "Farm Tenancy."- "Farm tenancy is a constantly increasing menace to a permanent, prosperous, and safe agriculture, and a contented country life. It has resulted in a loss of the priceless fertility of the soil-the creation of an unsettled farm population-illiteracy-an inefficient country school system-a drift from farm to city - and unprofitable methods of agriculture.

"Means must be found by which the industrious young farmer of character and skill in agriculture, even though of limited financial resources, can look forward to becoming a farm owner.

"This conference recommends that committees on agriculture of the bankers' State associations give serious attention to methods of correcting this dangerous condition.

"To the committees is suggested the advisability of selecting a banker leader in each county to bring together farm owners and tenants to devise means for the purchase of farms, utilizing governmental and private agencies.

"The committees should also inspire better systems of leasing that will provide protection for the fertility of the soil, longer tenures, and provisions for the maintenance of livestock." - Banker Farmer, A pril, 1919, p. 2. 
Relation of Tenancy to Land Value. Dear Land Means More Tenants. Examples of Largest and Smallest Amount of Tenancy, by Rural Counties, in Certain States; Also Average Land Values in Same Counties. 1910 Census.

Alabama: Tenancy

Average for State.

Per cent

Land value

$\ldots 10.46$

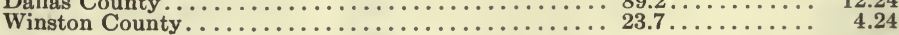

Georgia:

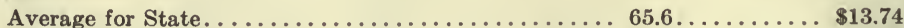

Dougherty County .....................

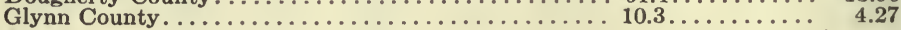

Illinois:

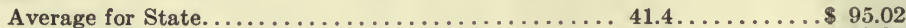

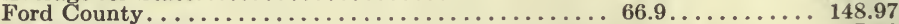

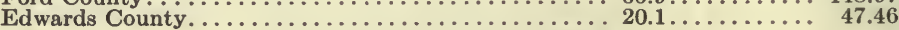

Iowa:

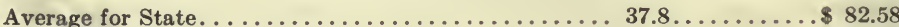

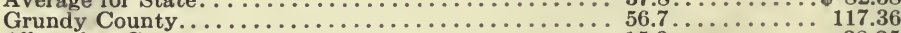

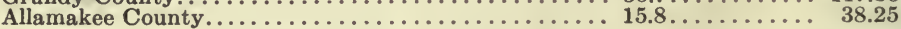

Mississippi:

Average for State $\ldots \ldots \ldots 6.1 \ldots \ldots \ldots \ldots \$ \$ 13.69$

Leflore County............................ $95.4 \ldots \ldots \ldots \ldots \ldots 43.64$

George County. ....................... $\ldots .5 \ldots \ldots \ldots \ldots .8 .19$

Oklahoma:

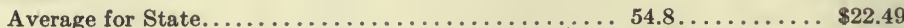

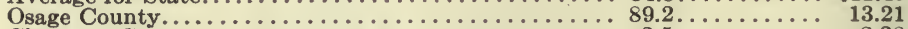

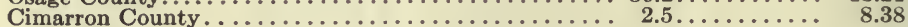

South Carolina:

Average for State. . . . . . . . . . . . . . . $63.0 \ldots \ldots \ldots \ldots . . \$ 199$

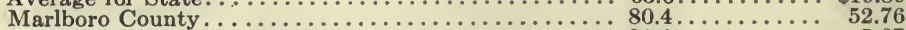

Georgetown County................... 21.1....... 5.67

Texas:

Average for State. . . . . . . . . . . . . . . . $52.6 \ldots \ldots \ldots \ldots 14.53$

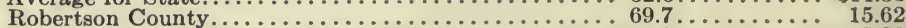

Winkler County...................... $0.8 \ldots \ldots \ldots \ldots, 5,22$

Wisconsin:

Average for State. . . . . . . . . . . . . . . . 13.9. . . . . \$43.30

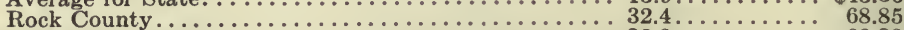

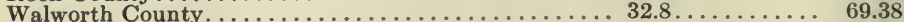

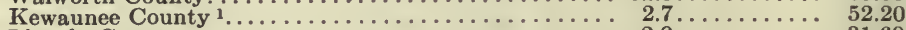

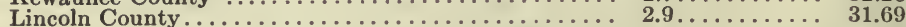

1 Kewaunee County, Wisconsin, furnishes an interesting exception to the rule. Here German and Bohemian farmers, owning small farms of high-priced land, are in the majority. 


\section{CHAP'TER VI}

\section{ECONOMIC CONDITION OF THE FARMER}

Introductory.-Whatever schemes may be tried to induce people to go back to the land, the outstanding fact is and must ever be that when the farm pays people will flock to the farm without other inducements. The industries of the city offer greater economic inducements than the farm does, either in the size of income or in the certainty or continuity of income.

Does Farming Pay?-It is difficult to measure all the returns of farming. These returns include among other things such nonmeasurable things as independence, since the farmer has no employer to please; joy in labor, since the farmer labors for himself; peace of mind, since panics in the business world will have no influence on the farm's fertility. But the tangible return, the one which can be measured, is the economic income. This economic income goes far to determine the farmer's social status in his community, the amount of leisure at his disposal, and to a large degree his importance and opportunity in a political way. It is the basic underlying factor in the farmer's life. Therefore the importance of this question, "Does Farming Pay?"

Income of $\$ 408$ a Year.-A great many attempts have been made to estimate the farmer's income; many investigations and "surveys" have been made. The Federal government carried on a careful investigation in the heart of our great farming section, for instance. The following quotation from this investigation illustrates very adequately all phases of this very complex question:

"The economic condition of the farming population is a matter of great concern to everybody. According to the last census (1910), thirty-two per cent of our population actually live on the farms, and the efficiency and prosperity of these directly affect the condition of all the rest. Farming has never been regarded as a very remunerative business, and there have been obvious reasons throughout most of our history why the direct and immediate returns could not be large. With fertile prairie land practically free, it was not to be expected that the common crops would bring much more than the labor cost of producing them by the ordinary methods, for while there is a great opportunity in agriculture for the use of intelligence and scientific skill, it is also true that routine farming can be learned and carried on by anyone. During the period when good lands could be had by homestead entry, the opportunity to obtain a farm free was in itself a great inducement to the settlement of vacant lands, and a factor in making low prices on farm products.

"With the passing of the period of free lands, and as population gained upon farm area, the prices of farm products began to advance. A pronounced 
change has taken place since the decade 1890-1899, with the result that there has been a general outcry from consumers over the rise in the cost of living. During the calendar year 1913 the twenty principal farm staples included in the price tables of the Bureau of Labor averaged 165.8 per cent of the average level of the same commodities in the period 1890-1899. It would be naturally supposed that with this advance in the prices of his products, the position of the farmer must have improved; but it is seriously argued that this is not so. Statisticians and experts are contending that farming is still a business of very poor returns."

Bulletin 41 of the United States Department of Agriculture consists of a report of a survey of 520 typical farms in Indiana, Illinois and Iowa made by representatives of the Department. Of these farms 273 were operated by the owners, and it is reported that after allowing five per cent interest on the capital investment, these owners only received an average of $\$ 408$ per year, plus house rent and food supplied by the farm, for their labor and management. The 247 renters did better, for they received an average of $\$ 661$, but this was because the landlords received only 3.5 per cent interest on the value of their investment. This showing leads the investigators to the conclusion that the assertion that farmers are making large profits is erroneous. "They are living on the earnings of their investment and not on the real profits of the farm." The report says:

"As farming is a business, investing both capital and labor, the farmer should receive a fair income on his investment as well as wages for his labor."

The problem for the man on a farm is no different from that of the man in a railroad office or a bank; it is to get himself into the class that is above the average in efficiency. By so doing he will not only benefit himself but help to raise the level of production and consumption for the whole community."

\section{An Example of Successful Farming.-One of the well-known} bankers of the State of Iowa, Mr. Charles Shade, President of the First National Bank of Rock Rapids, having referred incidentally to the success of a young farmer of his acquaintance, as an example of what was being accomplished by industry and good management in the business of farming Iowa soil, was asked to give the account in writing and did so, adding another instance, and his statement is quoted below. It was written without reference to the above discussion, but is given as explaining why farming lands have been advancing in value.

"The young man referred to is a German by descent-was born and reared in our own country. His people are hard working, frugal farmers so that he has had the proper training in his profession and has been taught to make the most of his opportunities in cultivating the soil. His name is John Busch. The story runs as follows:

"After reaching his majority he began farming on his own account in the Spring of 1908 by renting 80 acres of land from a neighbor, giving one-third 
of the small grain and paying cash rent of $\$ 4.00$ an acre for all the land put into corn. His father gave him two horses and he used his father's machinery to put in the crop. We loaned him $\$ 600$ to be used in buying hogs and cattle.

"In 1909 he rented a half section of land and out of the proceeds of his crop of 1908 he purchased farm machinery of his own and more horses. The seasons of 1909 and 1910 were good crop years, and during these two years he added more stock to his farm and more fully equipped himself for the handling of 320 acres of land by the purchase of more horses and more machinery. During all of this time we continued to carry him on the first loan of $\$ 600$ by renewing the note each year, he paying the interest.

"In 1911 we loaned him an additional \$500 making his total indebtedness to us $\$ 1,100$. The season's crop of 1911 was very large and the price was good. Out of this crop he sold sufficient amount of grain to pay up all the money borrowed from us and to liquidate other small debts he had made in buying machinery, cattle, horses and hogs, so that in the Spring of 1912 he had all of his debts paid, with a good herd of cattle, a large stock of hogs, horses and machinery sufficient to carry on the 320 acre farm. The erop of 1912 was not an average one, so that the profits of that season were very light. He continued farming this same land during 1913 and 1914, putting the larger part of it into corn. The market price for corn was large, and as he had practically all of the work done without outside help other than one additional farm hand, his expenses were light.

"Out of the crop of 1913, after paying current expenses and without selling the cattle and hogs, he had about $\$ 2,000$ in money which he left with us on deposit.

"During the crop season of 1914 he planted 200 acres of corn. This crop averaged about 60 bushels per acre, making 12,000 bushel yield. This corn was worth better than 50 cents per bushel. The accumulation of cattle and hogs had been very rapid, so that by the first day of December, 1914, out of the proceeds of this crop and the sale of cattle and hogs, after paying current expenses he left with us $\$ 5,000$ additional money, making in all $\$ 7,000$.

"He purchased a 160 acre farm in November, 1914, and promised to pay for it $\$ 28,000$, eight thousand cash down and long time on the balance at 5 per cent. The land was deeded to him and he gave a mortgage back for $\$ 20,000$. We loaned him $\$ 1,000$ for sixty days, assisting him to make up the $\$ 8,000$. In January he disposed of hogs sufficient to pay back to us the $\$ 1,000$. So that this young man now has $\$ 8,000$ paid in on a splendid quarter section of land which is well improved and has ten years to pay the balance of it at 5 per cent. He also owns eight head of horses, 25 head of cattle, 20 head of brood sows and more than $\$ 2,000$ worth of farm machinery with seed and feed ample to carry him through this season.

"I make an estimate of the value of his personal property as follows:

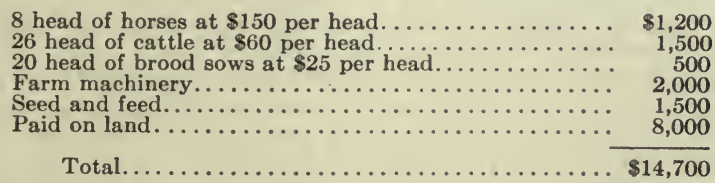

"Now that is the net profit from his farming operations in six seasons. When you take into account that this young man started empty handed, it seems to me that it is a remarkable case. This man has also been handicapped by not being married and has done his own housekeeping.

"I also have another case which I might cite you of great thrift in our territory. It is that of Fred Schimmel, a German whose ancestors as far back as I know were farmers. This man started farming in 1900 by his father 
giving him a team and his renting 80 acres of land. In 1901 he was married. He continued to rent land, giving to the landlord one-third of the crop raised on the land until 1905 when he purchased 160 acres of land at $\$ 60$ per acre, making a payment of $\$ 3,000$ at the time of the purchase with a promise to pay $\$ 500$ per year and interest. He moved onto this farm and erected good buildings during the next 3 years besides making payment of his $\$ 500$ each year and interest. In 1908 he traded this land for a half section of land, turning this farm in at $\$ 125$ per acre and taking the other land at $\$ 120$ per acre. Last January he refused $\$ 48,000$ for this land. He has an encumbrance of $\$ 16,000$ against it. He also has a short horn cattle herd of 65 head, 16 horses, 50 or 60 head of hogs, full equipment of farm machinery, with seed grain and feed to carry him more than one year, in the grainery. Mr. Schimmel has the equivalent of at least $\$ 40,000$, and all of this has been the outgrowth of his farming operations in 14 years, some of which have been lean years."

Best Practices Popularized. $\rightarrow$ A somewhat similar situation was described by Bradford Knapp while with the Department of Agriculture. Speaking before the First Annual Conference of the Bankers Committees on Agricultural Development and Education at Minneapolis in 1911, he said:

"The great problem of to-day is the dissemination of existing knowledge. That is true not only of agriculture but of almost every other human endeavor. If the existing knowledge with regard to human health were known and commonly practiced by the people generally, the ills of the human body would be much decreased. If the knowledge that is in existence in every state in the Union with regard to the best and most successful methods of conduct of farms were to become the common practice of the average farmer, the agriculture of this country would be revolutionized. In every community, in every county, in every state, you will find farmers who are making a distinct success of the business of farming. Also in every community you will find men who are merely scratching the surface of Mother Earth for a very poor existence. It is a lamentable fact that the best practices of a few are not the common practices of many. In every community we find farmers of poorer grade who are pulling down the average production per acre, and therefore whose return for their labor is very low indeed. It would astonish you if you were to look into figures and find out what the average earning capacity of the average farm worker of this country in the various states is or was. We found the figures for the year 1900, I cannot give you the exact statistics for 1910 yet, because the Census Bureau has not published the total number of farm workers, but I can give you a few figures for the year 1900; for example in the state of South Carolina the average earning capacity of the average farm worker was but $\$ 146$ per annum. In the state of Iowa in that year, not including the livestock industry of that state, it was a trifle over $\$ 600$ per annum, and in North Dakota for that year it was a little over $\$ 700$ per annum.

"It is a well known fact and appreciated by all thinking men, that the population of the country has practically stood still, or advanced very little, while the population of our cities and towns of over two thousand population have increased enormously simply because men have been going from the farms to the cities. The great cities and centers of population have paid tribute to the best blood that has been upon the farm. Without going into the figures to show these things, and without commenting upon the statistics which could be produced, it is a lamentable fact that this tendency exists to-day, and has existed in this country for the past twenty years.

"If you were to ask me why this thing has been I would say it was for three reasons. 
1. Because the average earning of the average farmer has netted too small a return for his labor.

2. Because he lacks education and social advantages.

3. And by no means, least, in many parts of the country what he did earn was earned at too great a personal sacrifice-labor for long hours and no recreation."

The Farmer's Income-Other Estimates.-In recent years many studies have been made of the farmer's income. Farmers' Bulletin No. 746, by Goldenweiser, ${ }^{1}$ is one of the best estimates we have, because it is based on several different investigations carried on by various bureaus of the federal government. An exact statement in money of the farmer's income is not possible, since the farmer has such earnings as house rent, value of foods and fuel supplied by the farm, and other earnings not on the money basis. The average earnings of the farmer, says this Bulletin, are about $\$ 600$, made up of cash, $\$ 200$, and about $\$ 400$ supplied by the farm. This $\$ 600$ may be compared with the $\$ 460$, earned by the factory hand, and with the $\$ 663$ earned by the average clergyman. About two-thirds of the farmers are landowners. "In view of the lower cost of living on the farm," says Goldenweiser, "and the fact that two-thirds of the farmers have interest in addition to wages it appears that farmers, as a class, are better off than the majority of persons engaged in other pursuits." Paul L. Vogt, formerly of Ohio State University, one of our trustworthy investigators, discussed the farmer's income in an economic magazine. $^{2}$ He shows the difficulty of comparing a farmer's income who combines in himself three factors of production (ownership of the business, management of the business and the labor) with the incomes of breadwinners in cities where these factors are more sharply differentiated. Vogt cites average farm incomes of $\$ 439$, $\$ 423$, and other amounts. There is a tendency, he says, for changes in gross income to manifest themselves in rises in land values rather than in labor income. He also sees a tendency toward equalization of labor incomes in all parts of the country. His conclusions are that the farmer now is better off than the great majority of breadwinners in the cities, and is also better off than such salaried professional men as clergymen and school teachers.

The " survey" method of determining the farmer's income has come into vogue very much in recent years, particularly since the publication of that very able piece of farm management pioneering

' Farmers' Bulletin No. 746. United States Department of Agriculture, July 6, 1916 .

2 The Farmers' Labor Income. Paul L. Vogt; American Economic Review, Dec., 1916. 
in this field by Professors G. F. Warren and K. C. Livermore of Cornell University, namely, "An Agriculturai Survey, Townships of Ithaca, Dryden, Danby, and Lansing, Tompkins County, New York," and published in March, 1911, as Bulletin 295. Since this survey covers a partially deforested area, very much the worse for the wear and waste of a century, and competing but badly with the fresh lands of the newer states, this study may be said to represent about the average conditions of New York State. The principal topics covered in this survey are as follows: profits, capital, receipts, expenses, size of farms, value per acre, soils, distance from market, labor, crops, woodlot, livestock, dairy herds, poultry, bees, systems of farming, forms of tenure, women as farmers, education of farmers, size of farm families, abandoned farms, farm buildings, roads, rural free delivery of mail, telephones, farm as a home for persons otherwise employed, summary of recommendations. While the survey is primarily an economic study, yet it does deal to a small extent with other social problems, such as education, transportation and communication. However, the chief point of interest to be emphasized here is the "labor income" of the farmer. On the 615 farms operated by owners, the average labor income was found to be $\$ 423$; on the 134 farms operated by tenants the labor income was $\$ 379$.

The various terms used in this study, such as "labor income," "capital," etc., are all clearly defined. The more important definitions are the following:

"Capital includes the value of all farm property, land, houses, buildings, stock, feed, seed, tools and cash necessary to keep the farm running. It does not include house furnishings that are not used in farming. The average of the amount at the beginning and at the end of the year is considered to be the capital invested in the business."

"Receipts include all money received from the sale of any farm products, also receipts from outside work, rent of farm buildings, etc. If the value of the buildings, stock, produce, or equipment is greater at the end of the year than at the beginning, the difference is considered a receipt."

"Expenses include all farm expenses. If the value of the buildings, stock, produce, or equipment at the end of the year is less than at the beginning, this loss is included with expenses. Household or personal expenses are not included, but the value of board furnished to hired help is counted. Expenses, therefore, include all business expenses. Taxes are not included in expenses. 
"Farm income is the difference between receipts and expenses. This is the net return as a result of the use of the capital and unpaid labor. It does not represent what the farmer earned, because both the farmer and his money were working. ' In order to see what was produced by the unpaid labor, we must subtract the amount that the capital would have earned if placed at interest."

"Income from unpaid labor is the farm income less 5 per cent interest on the capital."

"Labor income.-Often the farmer is helped in the farm work by members of his family. If such help has been given, the amount that it would have cost to hire it is deducted from the income from unpaid labor in order to get the amount that the farmer earned by his own labor. If a farmer's labor income is $\$ 500$, it means that as a result of his year's work he has made 5 per cent interest on his capital and has cleared $\$ 500$ above all farm expenses, besides having the use of a house and such farm produce as the farm furnished for consumption in the house. T'his figure can, therefore, be compared with wages paid to a hired man who is given a house, garden, etc."

These definitions are stated in simple, direst terms, familiar to farmers who are not learned in the mysteries of accounting principles and practices. Modern farm accounting, it may be added, is as yet neither a science nor an art. Hence these definitions quite naturally run counter to certain usages observed by some accountants in other lines of business. However, the accountants do not agree among themselves.

Calculating Labor Income.-The following case from the survey above described illustrates concretely the method of determining the farmer's "labor income":

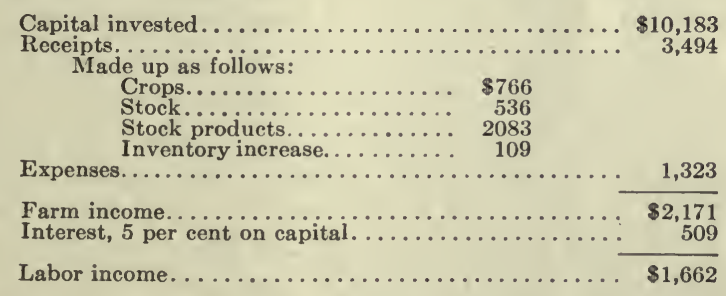

It will be observed that interest on "capital invested" is deducted in arriving at the farmer's labor income. This is correct. Accounting practice in other lines of business which refuses to allow interest on investment as one of the legitimate items of expense seems to be an error. Obviously the farmer could invest his capital in bonds 
and secure a job (or a "position") yielding him wages (or "salary"). The above statement of income makes no aliowance for the rent of the house which the farmer occupies or for the garden truck and general farm produce which he consumes at his table. This fact must be borne in mind when comparing "labor income" on the farm and labor income in the city. The value of the house and garden is very difficult to determine with any approach to accuracy. In Farmers' Bulletin, 635, the Federal Department of Agriculture has attempted to find the value of the farm-grown foods consumed.

What the Farm Contributes.-The Farmers' Bulletin, 635, considered the interesting subject of what the farm contributes directly to the farmer's living. If it were not for those products, says this bulletin, contributed by the farm without any actual cash expenditure, a great many farmers would not have a comfortable living. Extensive investigations relative to the profits in farming indicate that the average labor income of the farmer probably differs little from ordinary farm wages, but in addition to this he has the "products" contributed by the farm. Statistics were secured by means of a house-to-house canvass among 483 families living in ten states. An earnest effort was made to get a faithful estimate of the amount which the farm itself contributed. The conclusion was reached that the average annual price of food, fowl, oil and shelter actually consumed by our farmers was $\$ 595.08$, of which $\$ 421.17$ was furnished by the farm and the balance purchased. The "family ration" varies not only with the season of the year, but also from state to state. The consumption of cereals varies with the fancies of the individual families. Approximately one head of poultry per month for each person is the average for all sections. Each person consumes annually 3.1 bushels of apples. In the southern states more sweet potatoes than Irish potatoes are used. The average consumption per person for all sections is 5.7 bushels of Irish and one bushel of sweet potatoes. For those sections not using sweet potatoes, the average consumption of Irish potatoes is 7.3 bushels per person. The house labor is performed chiefly by members of the family, only 4 per cent being hired. The average annual value of this labor is $\$ 203$ per family.

Comparison With City Incomes. - The farmer's "labor income" has been found in many different States, under many varying conditions, by means of the "survey" method. These surveys omit certain very definite and tangible parts of the farmer's income, such as his garden produce, and also omit, as imponderable, what may be termed his psychic income. It must be borne in mind in 
this connection, that all similar statements of the city man's income omit certain factors of his income which are very real and very important, and yet cannot be stated in terms of dollars and cents. To turn first to the commoner "public utilities" of the city, which the city man enjoys, and for which he says he pays in the form of taxes or otherwise.

City versus Country.- The city man has the use of city water, sewers and electric lights. For these he pays a certain amount of money, to be sure. But would not any farmer gladly pay, not merely what the city man pays for these services, but at least three times what the city man pays, if these services could be had in his farm house? Few farm homes can afford modern conveniences. A recent rural survey in Iowa ${ }^{3}$ listed the following modern conveniences sometimes found in farm homes: running water; bath tubs; indoor toilets; electric lights; power washing machines; electric irons; furnace heat; refrigerators. While these are very rare in farm houses, they are fairly common in city homes. In favor of the city home may be named the delivery of groceries, of ice, milk, etc., the use of sidewalks, and pavements, street car service, etc. Other attractions furnish the city man a "psychic income," but which can be enjoyed by the country man only at the sacrifice of time and money necessary to bring him to the city. These attractions include the theater, opera, concerts, amusements, moving picture shows, lectures, clubs, libraries, art galleries, museums, etc.

Education and Health.-But far more important than any of these factors are two others, namely, medical aid and education. The country child cannot secure an education in the country. The few country children who do go on with their schooling beyond the pathetic "education" they secure in the "little red school house," usually do so only through some sacrifice on the part of their parents, such as renting a temporary home in the city (thus maintaining two homes at a financial sacrifice), or such as paying for the board and room of the child in the city (thus seeing with anguish of heart a child of tender years go from the protecting shelter of the home, that he may enjoy the education that is free to the city child). The factor also of medical attention must not be forgotten in this connection. It is certainly well known that hospitals are not found in the country; that medical aid when sum-

${ }^{3}$ Bulletin No. 184, Iowa State College of Agriculture, "A Rural Social Survey of Orange Township, Blackhawk County, Iowa." December, 1918, by George H. von Tungeln. 
moned, particularly in the night, is slow to arrive, or may not come at all. Indeed many country homes do not use the services of a doctor at all, but depend in part on neighbors (particularly in obstetric cases) and partly on the liberal use of "patent medicines." True, these patent "pain killers," rheumatism "cures," cancer "cures," rupture "cures," blood "purifiers" are so adroitly advertised in most rural papers (and in some "respectable" (?) periodicals) that the readers are converted to the belief that their symptoms, under their own diagnosis, show them to have these dire diseases. Hence not only is money wasted for useless nostrums, but physical and mental harm is done by consuming various chemical mixtures for imaginary diseases. The city man is near a doctor, and usually near one or more good doctors. Likewise, in cities of any size, hospital facilities are available, and trained nurses. It is only natural, therefore, that the city born and bred youth to-day is more fit physically, than the country born and bred youth.

Other Attractions.-Given enough income, the farmer can have a "modern" house with most of the city conveniences. But this means an income considerably in excess of that now received by the average farmer. Other attractions of the city, however, he can have only by going to the city, just as the city man can enjoy certain pleasures of life only by going to the country.

Conclusions.-Considering the risks involved and the amount of labor and capital expended, the farmer's economic income is too low. Economic income, it is necessary to emphasize, is used here in a strict sense. What other income has the farm family? The sociological economists have worked out a trinity of happiness which comprises these three factors: Health, home, security of income. Health is considered the chief requisite to the human being's happiness. Without this he would be unhappy under any conditions. The home is considered essential to a fully developed human personality. Security of income but not a big income is considered essential to a certain degree of peace of mind which contributes to his happiness. To these three factors we must add a fourth, namely, hope. The individual must see an opportunity for himself or at any rate for his offspring to rise to a higher level than that which he at the moment occupies (Fig. 12). This ambition need not be economic but may be social, educational, political or of any other kind which will bring some recognition to the individual. Does the farm promise to satisfy these four fundamental needs as completely as the city promises to satisfy them? 
The judgment of those competent to speak seems to differ on this point. An authority in American education, reared as a boy on the farm, educated in a common country school and in the State University, a traveler, a sojourner in many great cities and finally Dean of the School of Education in a State University, has given us his conclusions in the book entitled "Rural Life and the Rural School." In this book he points out all the shortcomings of country life. Then, turning to the other side of the picture, he shows that there are fewer hours of labor than formerly on the farm, that the

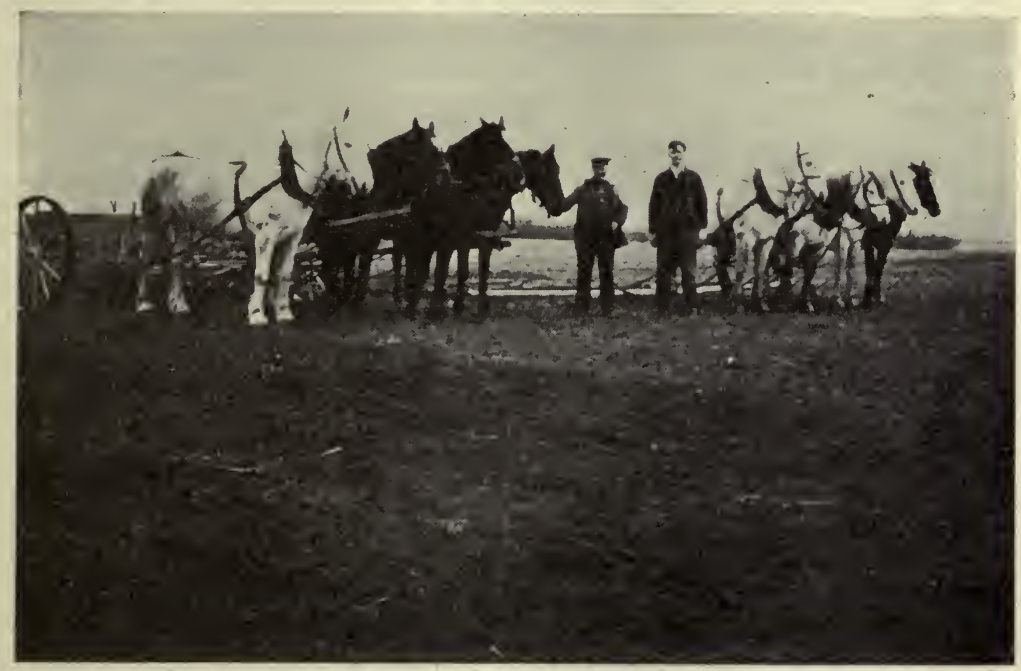

FIG. 12.-A prosperous Icelandic farmer and son in North Dakota.

mental factor is growing, that, so far as the boy is concerned, the farm boys enjoy time to go fishing, hunting, skating, coasting, trapping; that he learns the ways and habits of beasts, birds and fishes; that the lessons now taught to the Boy Scouts with so much effort and learned easily and early by the farm boy, that even his daily and regular work under most strenuous conditions is of a large and varied kind-not like the making of one-tenth of a pin, which has a tendency to reduce the worker to one-tenth of a man. "On the farm" says this writer, "the worker begins and finishes a piece of work. He sees it through. The whole of it receives expression in him. It is his piece of work, and it faces him as he has to face it. The tendency is for both to be honest." In view of the circumstances and opportunities just mentioned, life in the 
country is the best and most complete life possible to a human being. "Country life" continues this writer, "is the best cradle of the race. To have a good home and rear a family in the heart of a great city is well-nigh impossible for the average laboring man. The struggle for existence is too fierce, and the opportunity in childhood and youth for self-expression and initiative is too meager. The environment is too vast, complex and overwhelming, with nothing worth while for the child to do. Individuals may stand, but generations will slip on such an inclined plane of life." 4 While the surface attractions of the city are more alluring, yet country life is "the finest life on earth" is the Dean's conclusion.

We have already mentioned in this book that George Washington was a successful farmer. He enjoyed not only the economic but all the other returns of agriculture. In the closing years of his life he wrote as follows to the great English student of farming, Arthur Young: "The more I am acquainted with agricultural affairs the better I am pleased with them, insomuch that I can nowhere find so great satisfaction as in those innocent and useful pursuits. In indulging these feelings, I am led to reflect how much more delightful to an undebauched mind is the task of making improvements on the earth than all the vain glory which can be acquired from ravaging it by the most uninterrupted career of conquest."

\section{QUESTIONS ON THE TEXT}

1. What is the significance of the economic factor in drawing people to or away from the farm?

2. Does farming pay? What factors are to be considered in answering this question?

3. Cite the findings of a federal "survey" giving the farmer's annual income. Does this study include the value of house rent and the use of a garden?

4. Cite the examples of successful farming given by Mr. Shade.

5. According to Bradford Knapp what is the great problem of to-day? Give the facts on which he bases his statement. State his three reasons for the city drift of population.

6. Cite Goldenweiser's conclusions as to the relative prosperity of the farmer.

7. Cite the conclusions of Vogt on the same subject.

8. - Explain the "survey" method, as exemplified by Warren and Livermore. Define these terms: capital; receipts; expenses; farm income; labor income.

9. What has been the estimated money value of those products contributed by the farm to the farmer's living?

10. Show difficulty of comparing farm and city incomes. Illustrate. What are the chief advantages of city life, not represented by money cost?

11. Is the farmer's income too low? Indicate the kind of "income" you are discussing.

12. Cite the conclusions of Dean Kennedy.

13. Quote from letter of Washington to Arthur Young.

${ }^{4}$ Kennedy, Joseph. Rural Life and the Rural School, Ch. 15. 


\section{QUESTIONS SUGGESTED BY THE TEXT}

1. In calculating the farmer's income give reasons for and against allowing interest on his investment; for and against allowing income for house rent and garden produce.

2. As used in agriculture what is included in the term "capital"?

3 . What conclusions are we justified in reaching concerning the relative income of farmers and city dwellers?

\section{REFERENCES}

1. Funk, W. C.: "What the Farm Contributes Directly to the Farmer's Living." Farmers' Bulletin 635, United States Department of Agriculture.

2. GoLDENWEISER, E. A.: "The Farmer's Income." Farmers' Bulletin 746, United States Department of Agriculture.

3. VoGT, PAUL L.: "The Farmer's Labor Income." American Economic Review, Dec., 1916.

4. Warren, G. F., and Livermore, K. C.: "An Agricultural Survey, Township of Ithaca, Dryden, Danby, and Lansing, Tompkins County, New York." Bulletin 295, College of Agriculture, Cornell University, March, 1911.

5. Von Tungeln, George H.: "A Rural Social Survey of Orange Township, Blackhawk County, Iowa." Bulletin 184, Iowa Agricultural Experiment Station, Dec., 1918.

6. KENNEDy, Joseph: "Rural Life and the Rural School." 


\section{CHAPTER VII}

\section{AGRICULTURAL LABOR}

Several Aspects of the Farm Labor Question.--Reference is frequently made to the problem, so called, of farm labor. Is there such a problem, and if so what is it? A very brief investigation convinces anyone that there is such a problem. It is illustrated by the report made in 1913 by our Consul at Leeds, England, on the "English Farm Labor Problem." In this report our Consul speaks as follows:

"The northern counties of England are experiencing an inconvenient condition caused by a dearth of farm labor. General opinion voiced by members of chambers of agriculture indicates that it is realized that farm servants do not get sufficient relaxation; cottage accommodation is often poor, and there is little incentive generally for a man to settle to a life's work of labor on the farm. Some say that most farmers would be quite agreeable to granting, at convenient seasons, sufficient relaxation to their servants to make up for any compulsory half holiday such as most other industries enjoy. Others think that the possibility of one pound $(\$ 4.87)$ a week as wages and cottage would keep men from moving into the town.

"Big batches of farm laborers are emigrating; often 20 to 30 together. In many cases Canada or Australia is the destination.

"Agitation is afoot to form a Farm Workers' Union. Meetings of farm laborers have been addressed by officials of the Workers' Union for enrolling sufficient men and women to warrant forming branches. A press statement says:

"'The aim of the Workers' Union, or the agricultural section of it, as set out in the literature disseminated is to secure a working week of not more than 60 hours, payment for overtime work, and extra pay for all Sunday labor; limitation of hours for all women workers; fixing of a minimum wage rate, both for piecework and day-work, all employees to know at the time of hiring the rates they will have to work at; and to secure the freedom of laborers' cottages.'

"Comparisons have been drawn between the earnings of the women of agricultural sections of the county, making 30 to 37 cents per day at some classes of work, and the earnings of the women weavers of Lancashire, who can make $\$ 6.70$ per week. From the news reports it appears that the farm laborer is slow to respond to the agitation. All his characteristics prepare one for that attitude, but every fresh hiring timo is showing him his position of vantage for making terms.

"At the recent Whitsuntide hirings higher prices had to be paid all around for farm hands, who then hire out for a six-months' term. The next term commences Martinmas, November 11. The following are some of the hiring wages paid at the chief centers; board and lodging in addition:

Place and Wages for Six Months ${ }^{1}$

\begin{tabular}{|c|c|c|c|c|}
\hline & $\begin{array}{l}\text { Best } \\
\text { men }\end{array}$ & $\begin{array}{l}\text { Second } \\
\text { men }\end{array}$ & $\begin{array}{l}\text { Boys and } \\
\text { youths }\end{array}$ & $\begin{array}{l}\text { Girls and } \\
\text { women }\end{array}$ \\
\hline $\begin{array}{l}\text { Appleby, Westmoreland................... } \\
\text { Cockermouth, Cumberland (wages highest }\end{array}$ & $\$ 83-\$ 102$ & $\$ 68-\$ 80$ & $\$ 46-\$ 68$ & $\$ 36-\$ 66$ \\
\hline 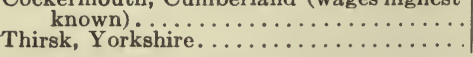 & $\begin{array}{l}78-117 \\
80-107\end{array}$ & $\begin{array}{l}68-83 \\
63-78\end{array}$ & $\begin{array}{l}24-68 \\
29-54\end{array}$ & $\begin{array}{l}24-58 \\
41-92\end{array}$ \\
\hline
\end{tabular}

${ }_{1}^{1}$ Daily Consular and Trade Reports, July 12, 1913, p. 238. 
This report indicates the several aspects of the farm labor question. There was published at London in 1913 for official use by the Board of Agriculture and Fisheries a Report on Migration from Rural Districts in England and Wales. This report, like the consular report above quoted, indicates the situation confronting England. This London report says that there certainly appears to be a fairly general deficiency of skilled farm hands. The manual arts of agriculture are being neglected even by those who still seek employment on the land. To quote the words of the report, we have the following:

"The low wages in the rural districts are mentioned as a cause of discontent, but it may be doubted whether this in itself is so powerful a factor as the lack of opportunity, and, in fact, there appears no evidence that emigration is greatest in districts where wages are lowest. More than once in these reports it is observed that many who emigrate would prefer to stay at home if they could see a reasonable prospect of advancement in life. Better education, and, as is remarked by some, a kind of education which gives a distaste for country life, is referred to; while the desire for shorter hours of work, for free Sundays and for more holidays is also mentioned; but these are causes for leaving the country which are more likely to lead to migration to the town than emigration to the colonies. The lack of housing accommodation is frequently mentioned as influencing men to leave the villages. It appears paradoxical that complaint should be made at the same time of dwindling population and insufficient cottages, but there can be no doubt that the question of rural housing is acute." 2

Similar Conditions in the United States.--These reports bring before our mind conditions in England. Similar conditions exist in the United States. The chief difference is that with us the difficulties are more sharply accentuated. A great many reports and a great many books have been printed dealing with agricultural labor in the United States. It seems to me, however, that the two following letters, written with no thought of publication, throw considerable light on the question. The first letter is from a young man who had been working on a North Dakota farm in the summer time. The second letter is from a social worker in Chicago and goes into the problem of taking the unemployed man from the city and placing him on the farm. The letters are printed exactly as they were written.

"Doubtless it will surprise you to hear from me in this town, but I came up here last night. I couldn't stand the pressure of the farm any longer. The man I worked for was a fine fellow, but like all North Dakota farmers he had no respect for the Sabbath. We worked the last three Sundays and had good prospects for working four more, and I did not like that, so I left.

"Yesterday was the first time I had a bath in over three weeks. Last Sunday morning after breakfast I shaved myself before I went to work. I

${ }^{2}$ Board of Agriculture and Fisheries. Report on Migration from Rural Districts in England and Wales, 1913, p. 3. 
expected him (the farmer) to say something, but he did not. If he had I certainly would have told him what was on my mind. And then another thing that made me sore was that they served beer at the table.

When we started harvesting we got up at four bells and worked in the field until eight. Then I had ten horses to care for so I never got to bed before ten P.M. I was about all in.

"I am undecided just what to do, but think I will come to Minneapolis and get work.

Sincerely," etc.

The second letter, from the Chicago social worker, follows:

"Your letter indicates that you do not fully understand the situation with unemployed men. How are these men to reach Minnesota? Will you send the railroad fare for ten men and take your chances as to whether the ten are good men, and as to whether they will stay after they reach you? Do you realize that more than two-thirds of these men have never worked on the farm, and that if you and your friends found them to be incompetent you would dismiss them? Usually when they are dismissed they are without money for railroad fare to return to the city. These men are laboring men, mechanies and their helpers, in so far as they work. Hundreds of them are only temporarily out of work, and, for a variety of causes, have no money. Not many of them are too lazy to work. A large number of them are incapacitated by drink and other bad habits.

"If you will send me the money for the railroad fare and take your chances on these men, I will send you twenty men, or more. We will buy the tickets ourselves and take the men to the train.

"I know you will treat your men kindly, but I know, also, from personal knowledge, that some farmers compel them to sleep in the attic, or in the barn, give them poor food, and work them, without any privilege of going to the town, or seeing anything but the farm. These men are human and they want to see other men have some amusements, and be treated with some respect. Hundreds of farmers show them positively no consideration and give them the same care that they do their mules. If the farmer does not like them, he discharges them at once, but he grumbles if they leave him because they do not like him.

"I can pick out a number of men that I think will work, but I have often been mistaken, and may be again. Yours very cordially," etc.

Seasonal Nature of Work.-Let us now direct our attention to some of the details of the problem of agricultural labor. The first and one of the most important aspects of the problem is the seasonal nature of farm work. Farm crops are planted, cultivated, and harvested, as a rule, in the summer-time. The winter is the dull season on the farm. Therefore, a very large part of the labor which is necessary in the summer-time cannot find employment on the farm in the winter-time. That gives us the pathology of a floating population. This evil is greatly aggravated in sections devoted largely to one crop such as the wheat sections of the Northwest and of the Middle West. Take for example the State of North Dakota. In the winter season men find employment in the woods as lumber-jacks. With the approach of spring logging operations in the woods largely cease. These men drift into the harvest fields 
in the summer-time. When the harvest and threshing season is over these men drift back along the main routes of travel into the woods and into the cities to the east of them. This makes an army of laborers numbering many thousands of men. They congregate in the villages and small cities. With this army of laborers goes a smaller army of criminals preying on the larger group. In the northwest in October and November police officials always expect and prepare for a wave of crime. Desperadoes who follow the army of workers returning with wages on their person do not stop at violence and even murder.

Records of Crime.-The daily press of this section at this season is full of accounts of the misdeeds which are a by-product of this floating labor population. As a sample let us take one issue of a northwestern paper published at a point on one of the main routes of travel between the farms and the woods where the wagon roads and railroads cross the Red River of the North. Taking the issue of the Grand Forks Herald for October 12, 1915, which may be considered typical, we find accounts like the following. The first news item on the first page is dated Carrington, North Dakota, a railroad junction:

"With armed posses still scouring the country-side for the two bandits who escaped after one of their comrades had been killed in a desperate gun fight, and another captured, the fugitives were still at large at a late hour tonight. The condition of Carl Nelson, chief of police, who was shot in the stomach during the battle, which took place in the Gilby rooming house shortly after 2 o'clock Sunday morning, was reported no worse to-night at the St. Paul hospital, where he was rushed on a special train following the shooting, and it is believed that he has a chance for recovery. The battle was the culmination of a bold holdup Saturday night when the four outlaws lined up seven men in the J. Hopkins pool hall here and relieved them of approximately $\$ 250 . "$

Another headline reads as follows:

"Man is held up at the point of a gun."

This dispatch is sent from the village of Hamilton, N. D.

Another dispatch bears the headline:

"Wanted to earve up a threshing crew. On rainy days men receive a shipment of booze with bad results."

This dispatch is dated Velva, N. D.

Another dispatch from Velva reads as follows:

"County jail is filled to limit. Officers have been very busy in Towner."

Another dispatch illustrates how the transportation difficulties are sometimes involved. The headline reads as follows:

"Conductor and men have a long fight with hoboes. Shoot at brakeman." 
In this connection it may be stated that it sometimes happens that the returning harvest hands capture a freight train and force the train crew to carry them without compensation. Indeed it seems to be a common practice with the returning laborers not to pay carfare. They prefer to steal a ride in empty freight cars. This in turn gives the robbers a better chance to ply their nefarious trade. This illustrates the situation as it is in the fall of the year. A situation very much similar to this exists in the spring when the men are drifting westward to the farms. It seems fair, therefore, to consider the seasonal nature of farm work as one of the most serious problems which those concerned in agriculture are called on to solve.

I. W. W's.-The Industrial Workers of the World, first organized as an industrial union, began to have significance for farmers shortly after the year 1910. This group remains, as these lines are written, as one of the unsolved problems in the farmer's labor situation. The States of the Northwest find their peaceful workers and often their civil authorities in collision with wandering bands or members of this organization. Repressive measures fail to repress them. They must be viewed as symptoms of some underlying unrest. Yet legislative and administrative measures dealing with them aim at their "suppression," but do not touch any of the causes which produce them.

The spirit of the farmer towards the I. W. W. is expressed in the following resolutions adopted at the tenth annual convention of the Farmers' Coöperative Association of South Dakota, held at Sioux Falls in December, 1916:

"Whereas, there is in existence an organization known as the I. W. W., consisting in many instances of a lot of worthless men who go about the country intimidating its citizens and preventing honest labor from coming into our State, and

"Whereas, the farmers of South Dakota are depending at different times of the year upon what is known as transient labor, therefore, we recommend the passage of some law that will rid the State of this band of lawless and ruthless fellows."

The I. W. W. members, on their part, demand larger pay and shorter hours, as a general rule. Refusal to meet their demands leads to strikes, sabotage, and various forms of destruction to property and life.

Wages of Farm Labor.-It is a matter of common observation that wages of farm hands have been increasing for many years past. By referring to statistical publications we find this increase has been fairly constant for at least 150 years. For instance, in Massa- 
chusetts, a farm laborer was paid for a day's work without board in 1752, thirty-three cents; by the time of the Revolutionary War, he was receiving forty cents. The Federal government has made nineteen investigations of wages of farm labor. In the year 1912 the report of the Federal government on this subject makes this statement concerning day wages:

"For day labor other than harvest work, with board, the rate in 1866 was sixty-four cents in the United States. It reached sixty-eight cents in 1874 or 1875 , and declined during the industrial depression of the 'seventies, so that the subsequent increase reached seventy cents in 1881 or 1882 . From that year to 1898 the rate of day wages for labor other than harvest work with board remained about stationary except for the depression of the 'nineties. In 1898 the rate was seventy-one cents; in 1899, seventy-five cents; in 1902, eighty-three cents; in 1906, one dollar and three cents; and in 1909, the same amount, one dollar and three cents."

This shows a very substantial increase in wages in recent years. This increase has been accompanied with an increase in the cost of living. However, wages had risen faster than the cost of living up to the time of the World War. To quote further from the same report:

"These comparisons establish the conclusion that the money wage rates of farm labor have increased during the 18 years covered in a considerably greater degree than the wages of working-men in non-agricultural operations. In the purchasing power of wages in terms of retail prices of food the working men barely gained from the first period to the second, the mean index number for the second period being 101.4. For the farm laborer the gain was from about 10 to 15 per cent, so that, notwithstanding the great rate of increase of retail prices of food, the rates of wages of farm labor increased in degrees sufficient to make as a net result a substantial rate of increase."

The Federal government published the following table comparing the years 1909 and 1915:

Farm Wages Per Year Without Board

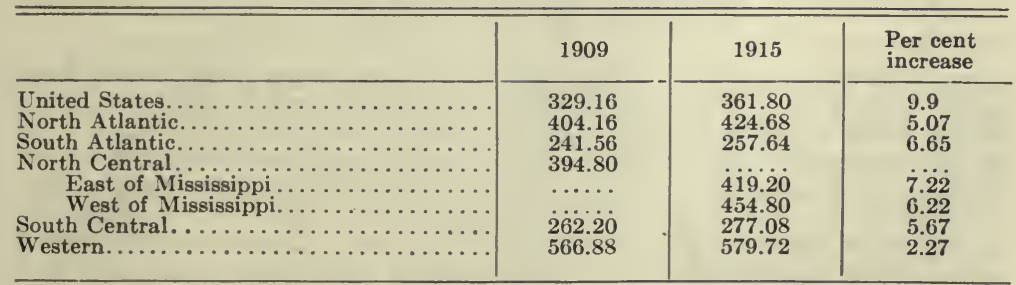

The Decline of Women's Work Since I871. - The Federal government has reported on the subject of Supply of Farm Labor.

"The outdoor labor of women on farms has undergone an immense reduction within a generation or two. In 1871, the department of agriculture investigated the subject in all parts of the country and these results were published in the report for that year. At that time reports from the following 
sections are typical, indicating clearly the reports from all the states. In New England very little regular labor in the fields is performed by women. Canadian women, and occasionally Irish, hire out or work on shares in different parts of New England, though the number employed is not large, and they will undertake nearly all kinds of farm work. Similar customs prevail in New York, comparatively little outdoor service being rendered by Americanborn women. In many districts in Pennsylvania very little outdoor employment is undertaken by women, while in others, especially in those less improved, or with a large foreign element in the population, much and various farm work is done by women. Among the poorer classes of whites in some

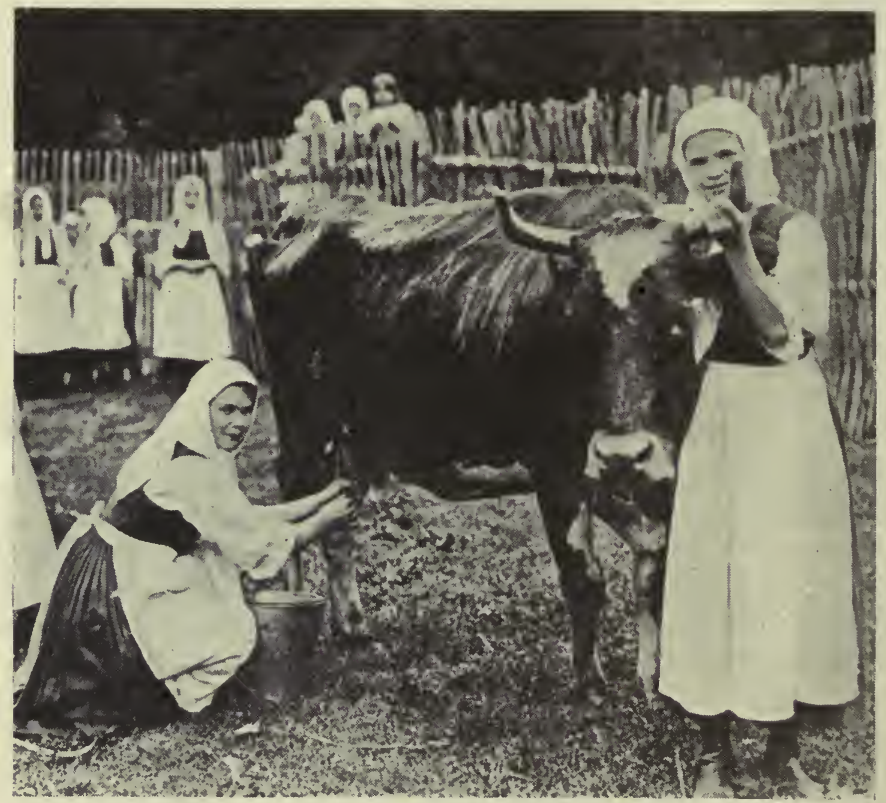

FIG. 13.-Women of foreign birth doing farm work.

counties in Maryland, the Germans especially, the women assist in such labor as planting, hoeing corn, weeding tobacco and raking grain. Sometimes they obtain men's wages, but usually about three-fourths as much. In such work they are often quite as efficient as men. Negro women have been accustomed to all kinds of farm labor, though generally employed in the lighter branches. Throughout the Southern States a large portion of the females among the negroes were accustomed to general farm labor, most of whom now decline it, appearing to regard it as a relic of slavery and not 'suited to ladies.' It is stated of some States that not more than a fourth part as many do outdoor work as formerly. Very little farm work is done by native Americans in all the States of the Ohio Valley and the Lakes, that little being casual assistance in emergencies, as a matter of convenience and sometimes of necessity, as is reported of all other sections of the country. Gardening and fruit picking are preferred, and hop picking, where hops are grown. Immigrants do more outdoor work, 'expecially for a few years after coming here. As they become Americanized they work less on the farm"" (Fig. 13). 
At the present time about one agricultural laborer in seven is a woman. Her work has been reduced largely to domestic affairs, and even in domestic affairs there seems to be a reduction of work in the manufacture of food, clothing, and supplies. Continuing the same report to which we have alluded, we have the following interesting situation:

"With regard to very recent years census statistics of female agricultural labor afford no satisfactory conclusions. A general knowledge of farming conditions throughout the country, past and present, is more definite. The outdoor work of white women on the farms of medium and better sort has very greatly declined from early days, and the decline was more especially marked after the Civil War. Farmers' wives and daughters no longer milk the cows and work in the field and care for the livestock. They do not work in the garden as much as before, nor assist so much in fruit and berry harvest; they are making less butter, and cheese making on the farm has become a lost art. They may care for the poultry and the bees, do housework and gather vegetables for the table, and cook and keep the dwelling in order. Their domestic work is substantially the limit of their work on the farm.

"Decline of Household Labor.-In farm household matters the situation is acute with regard to the supply of hired labor. Country girls as well as city girls, no matter how humble their lot in life, regard household labor for hire as unrespectable. Joined with this fact is the other one that the women of the farmer's family are neither able nor willing to repeat the manual labor performance of their grandmothers on the farm. Besides this, the farmer's standard of living has risen, certainly on the medium and better sort of farms in the North and West; and in a perceptible degree the women of the farmer's family have engaged in social functions which are beginning to be incompatible with the performance of household labor without the aid of a servant. The social obligations undertaken by them are for the Grange, the woman's clubs, the Maccabees, the Women's Christian Temperance Union, the local church, the farmers' clubs, a list that might be much extended.

"Domestic Industries. - The old-time domestic industries are all but forgotten. The women of the farm make no more soap, candles, or lye, and so on with a long list of the domestic products of former days; it is rare that one of the younger of the women knows how to knit. Throughout large areas the pride of the housewife in great stores of preserved, dried, and pickled fruits, berries, and vegetables exists chiefly in history, and dependence is placed mostly upon the local store for the products of the cannery and the evaporator.

Women and War Work.-The World War brought tremendous social readjustments in all fields, one phase being the employment of women for outdoor work on farms. The Woman's Land Army, so called, rendered a very distinct service. But how permanent this participation of women in farm work will be it is impossible to forecast.

The social and labor needs of farm women have been studied by the Federal Department of Agriculture. "Where the farm woman is the mother of three children or more," writes a Massachusetts farm woman, "she should have an aid, and thus be allowed to give a large part of her attention to her work as mother, at least until the children are of age to help. A 'hired woman' is as essential as a 
'hired man,' where there are several small children. This does not seem to have occurred to either the farmers or their organizations."

Number and Supply.--In 1910 we had six million, four hundred thousand farmers (including 2,350,000 tenants). These farmers employed 3,000,000 transient laborers during the year. Adding this number to the number of tenants and owners who move every year, we have a total of 5,000,000 persons who are more or less transient. Laborers who seek employment for the entire season are generally sons of farmers. For the seasonal demand of the harvest, however, the country must call on the city for labor as it does for money to move the crops. But the shipment of currency from the city bank to the country banks is now reduced to a system simple and adequate. But the labor question is still far from solution. Only a few of the more important proposed or attempted solutions can be discussed here.

Private Employment Agencies. - These agencies operate in the larger cities, and undertake to supply unskilled labor for any and all kinds of jobs. To a small extent they furnish agricultural laborers. The farmer applying here for help must take his chances-a big risk - of getting what he wants or needs. Thus a Bohemian farmer, living in a Bohemian colony in North Dakota, applied at a Chicago agency for two "hands," stipulating that they must be Bohemians. Two Austrians were sent. They were released after one week's work. Often the men sent quit the job at once and seek for other employment, or for transportation to new fields. Indeed, some of them seem endowed with a tourist-instinct.

The Unorganized Movement.-The harvest season brings a so-called "army" of laborers, each worker following his own lead. This "mob," arriving thus in hit-or-miss fashion, may greatly oversupply or undersupply the farmers' demands. When the supply is large, farmers of course select the best and get them at a "fair" wage. On the other hand if the supply is a little scarce, and the crops are ripening fast, the laborers become very severe and lofty in their demands. They congregate in the railroad village and wait for the farmer-bidders to come in, with rigs to haul them to the fields. They may even assume an arrogant tone, and ask the farmer "to bring in his farm" and let them have a look at it before accepting employment. During the pressure of the harvest and threshing seasons, these casual laborers may sometimes demand an increase from the ordinary two-dollar-a-day wage (prevailing before the World War) to a wage of five or even ten dollars a day. 
National Farm Labor Exchange.-The National Farm Labor Exchange was organized at Omaha in 1915. Its second annual convention was held at Kansas City in 1916. It is the plan of this National Exchange to ascertain through the means of sub-agencies the needs of the harvest fields of the several States, from Oklahoma to North Dakota, in their order as grain ripens. Next, it plans to direct the laborers to the place where they are needed, and to inform them as to the conditions and nature of their employment. It is believed that through this method it will serve the unemployed advantageously.

Federal Government and Farm Labor.- The United States has adopted the policy of directing laborer to employer, and employer to laborer. This is done by means of Employment Bureaus established in cities and towns throughout the country. Such a vast administrative scheme will need careful attention to save it from the usual bureaucratic extravagance. There is danger of a maximum of outlay and a minimum of results.

The County Farm Bureau.- The counties that are enjoying the services of a county Farm Bureau and a county agricultural agent are conducting employment bureaus for farm laborers. Since these county bureaus are in direct contact with the farm labor problem, their services bring the maximum of result with the minimum of outlay.

Mr. H. J. Hughes, former editor of the Farm, Stock and Home, diagnosed the need of the State as comprising a state-wide clearing house of labor, functioning and coöperating with the farmers' clubs, the commercial club of the village or city, and the railroads. And five conditions, says Hughes, are essential to the satisfaction of the hired man, namely: (1) good food and regular meals; (2) good sleeping quarters; (3) not over nine or ten hours of work per day; (4) fair wages; (5) steady time from day of hiring till job is done. Yet usually not more than two of these conditions are met.

Irregular Employment.-As long as any community depends chiefly on one or two or three staple crops, a situation is created whereby irregularity of employment of labor is inevitable. "Long hours, small pay, and irregular employment are what the immigrant can expect on the farm," says Hourwich. ${ }^{3}$ Hence the laborer's preference for work in the city. In consequence of limited demand for it, says the Industrial Commission Report, " agricultural labor is the least paid of all great groups of occupations, even

${ }^{3}$ Hourwich. Immigration and Labor, p. 112.

${ }^{4}$ Report of Industrial Commission, vol. X, p. xx. 
allowing for the laborer's garden and other privileges." Hourwich thinks a market for agricultural labor may grow up in the future with the eventual spread of intensive agriculture. But now even many American farmers are migrating to Western Canada. In 1910 there were 103,984 emigrants from the United States to Canada. Since the American farmer cannot keep his own sons on the farm, there is certainly not demand enough there to attract laborers from the city, except during the high demand and high wages of harvest seasons.

Transportation and Distribution Problem.-One of the most sensible remedial measures for dealing with the labor supply problem has been proposed by W. R. Porter, Superintendent of the Demonstration Farms of the North Dakota Agricultural College. In his opinion the United States should find the same solution that Canada has found in securing transient labor for her great western harvests. The laborers live in eastern Canadamore than a thousand miles from the grain fields. The Canadian laws strictly forbid the "stealing of rides" on trains, the custom so universal in the United States. The Canadian railroads run "excursion trains" from the East to Winnipeg and the West, charging ten dollars to go and twenty-eight dollars to return at the end of the summer. This practice, now twenty years old, has resulted in the farmers of western Canada securing an abundant supply of labor of the best quality. Many thousands of these industrious young men, who went west to see the country, remained as permanent settlers. In the United States this class of young men will not pay the regular first class fare to go to the western fields, neither will they "beat their way" on the railroad trains. Consequently they do not go at all. A solution of this transportation problem, in conjunction with the subsequent distribution of the worker, would go a long way towards solving the farmer's labor problem. For factory work, like farm work, is in many cases seasonal.

Drift to the City. - It has long been recognized that persons of ability and capacity for leadership, born on farms, usually move to the city. Thus during the hearings before the Industrial Commission in 1899, the question was asked of Le Grand Powers:

"Is it not true that the bankers, lawyers, doctors, the leading men in all pursuits, in every city in the United States, were originally farmers?"

Mr. Powers answered, "Yes, very largely so." It is now a matter of common observation that if we call the roll of the mer- 
chant princes, the captains of industry, the railroad magnates, the coal and oil barons and the notables in the various lines of human endeavor, a large percentage of them were once country boys. It should be more generally recognized that many and various forms of farm labor have now been transferred to the city. What is now the division of labor between farm and factory and what was it formerly? The American farm of the first half of the nineteenth century was really a diversified business in itself, comprising not merely the production of the raw materials of food and clothing and tillage tools, but the actual manufacture and preparation of foods, shoes and clothing, and the ruder implements of tillage.

Wakefield, in 1833, describes the American farmer for us in these words:

"Free Americans, who cultivate the soil, follow many other occupations. Some portion of the furniture and tools which they use is commonly made by themselves. They frequently build their own houses and carry to market, at whatever distance, the produce of their own industry. They are spinners and weavers; they make soap and candles, as well as, in many cases, shoes and clothes for their own use."

But now where are their shoes and clothes made? In the city. So also with their soap, their candles, their lumber, their furniture. And transportation by steam and electricity has likewise centered in the cities. In short, farm activities have largely been transferred to the city. There are now 800,000 persons in cities engaged in manufacturing automobiles and tractors-most of which machines are for farmers. It is no wonder then that the industrial growth of the United States has taken leaders and laborers from the farms to the cities. The manufacturing States of the East were the first to show a decrease-in rural population. Thus in the decade ending in 1890, New England and New York showed a loss in rural population. In 1900 New Jersey, Delaware, Ohio and Kansas showed losses. Out of the ninety-nine counties in Iowa, the 22 urban counties showed gains, while the 77 rural counties showed a loss. The great farming country of the Middle West now shows a loss in rural population. Thus in 1910 the following losses were registered:

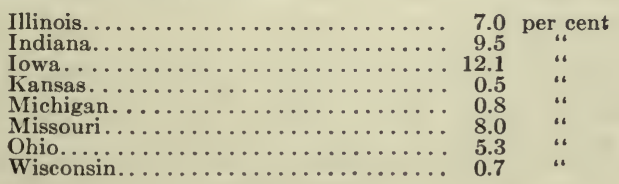


More remarkable still is the loss shown in the newer agricultural States, such as Oklahoma and North Dakota. Four counties in North Dakota showed losses in rural population, ranging from 4 to 17 per cent. In Oklahoma eight counties showed a falling-off in their population, ranging from 2.9 per cent to 23.2 per cent. Four of these counties lost over 10 per cent apiece. Seven counties gained less than five per cent each. Yet all the cities of the State, with the exception of one increased over 200 per cent in population during the decade. The contrast in the growth of rural and urban population is seen in this table:

\section{Increase in Population, Oklahoma, 1900-1910}

Cities of 25,000 inhabitants or more in $1910 \ldots \ldots \ldots \ldots 526.1$ per cent

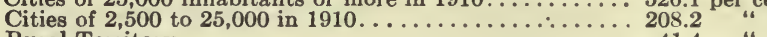

Rural Territory............................ 41.4

The better market for labor in the city causes, in large part, this emigration from the country to the city. And it is a loss to the country of native Americans of American stock.

Labor-saving Machinery.-Le Grand Powers, testifying before the Industrial Commission, expressed his belief that machinery is displacing labor on the farm. But, he continued, the effect is to elevate labor. "Speaking of the effect of improved machinery on labor," said Powers, "I would say that the introduction of improved machinery, in my opinion, has been an important factor in the elevation of labor. It has called, first, for greater intelligence on the part of the workingmen on the farm; it has stimulated that, and it has otherwise improved the intellectual status of the American farmer."

H. W. Quaintance has undertaken to estimate how much farm labor has been displaced by the modern "labor-saving" farm machinery. He tells us that it formerly required 11 hours of man labor to cut and cure a ton of hay; it now requires $1 \frac{1}{2}$ hours. The quantity of labor saved by machinery in producing the farm crops of the last decade of the nineteenth century, as compared with hand methods in use fifty years earlier, is estimated at $450,000,000$ days. This saving would represent the labor of one and a half million men the three hundred working days of the year.

The writer, as a boy on the farm, assisted in "butchering" the winter's meat. What a slow, heavy and laborious process butchering on the farm was! Now in the great packing houses of Chicago or Kansas City a gang of 150 men butcher 105 cattle per hour. Since this and other branches of farm work have 
gone to the city, the hired man has gone to the city too, in ever increasing numbers.

H. E. Hoagland has described the movement of rural population in Illinois. ${ }^{5}$ According to this author the poverty of rural social life has not been the cause of rural depopulation, since the regions with a decrease in population are not found to be the ones where the farmer's life is duller or more monotonous than those in which the rural population has increased. The exodus from rural communities has been fully as active since the introduction of rural free delivery, the telephone, and better roads as before. The increased use of machinery, increase in the relative number of horses, and in saving of time by use of the telephone and by improving the roads have done much towards increasing the efficiency of the farmers, so that it takes fewer of them to produce a given quantity.

City Labor for Farms.- The question was put to Le Grand Powers concerning placing the city man on the farm. He saw little hope of success here, since it takes time to learn the business of farming.

Immigration and Farm Labor.-The "old" immigration from the British Isles and Northwest Europe settled very largely on the land. The "new" immigration does not do so. "After their arrival in the United States," says the Federal government, "these immigrants (Italians, Slavs, Hungarians) do not seek employment in agriculture, partly because of the difficulties in the way of securing it, but mainly because of the higher rates of wages in other industries. In transportation, manufacturing, mining, and in building, the demand for common labor has been very great." 6

Colonies of the older immigrants are so common in all parts of the United States as to excite no comment whatever. The English speaking immigrants-Irish, Scotch, English, Canadian, are soon Americanized and absorbed. Bohemians, Germans, and Scandinavians in rural colonies slowly but surely become Americanized. According to Le Grand Powers, the Germans seek to maintain their language, especially when they are settled under semi-religious auspices. This is doubtless true of the others, yet the foreign language rarely survives a second generation.

Professor Cance of the Massachusetts Agricultural College has made a very extensive investigation of immigrant rural communities, particularly of the Americanization and assimilation

5 Journal of Political Economy. Vol. 20, pp. 913-927.

${ }^{6}$ Labor Bulletin, No. 72, p. 406, September, 1907. 
problem. "In general," says Cance, "all foreign rural communities in the East, particularly Hebrew farm colonies, where not very large nor closely segregated, manifest a lively desire to speak and read English, to adopt American dress, customs and methods of farm practice, and where encouraged, to seek naturalization as quickly as possible. There is no question that Americanization and assimilation take place more rapidly among the less segregated rural immigrants than in congested industrial groups in urban localities. Land ownership confers dignity, imposes financial and social responsibility, stimulates activity in civic affairs, and awakens community interest and personal pride. In short, so far as the immigrant is concerned, rural life in most instances has had a most salutary effect. It has frequently taken an ignorant, abject, unskilled dependent foreign laborer and made of him a shrewd, self-respecting, independent farmer and citizen. His returns in material welfare are not great, but he lives happily, comfortably and peaceably, and in time, accumulates a small property. The second generation of these south European immigrants are frequently not less progressive than Americans." But, says Cance, leadership and encouragement are needed, and some opportunity for land ownership - an opportunity, however, now fast disappearing. "Between the Italian cotton tenants of the Mississippi Delta region," concludes Cance, "among whom are few citizens, numerous illiterates, few children in school, very meager community institutions and no political interest and their kinsmen in upland Arkansas, with a majority of naturalized citizens, a most lively participation in public matters, exceptionally fine educational and religious institutions, little illiteracy, and a rapidly rising standard of comfort, the contrast is most striking. The social superiority of the upland Arkansas colony is due largely to efficient leadership and individual ownership of land. Other instances might be cited to demonstrate the very significant truth that progress is much more rapid and satisfactory where there is some one to lend a friendly hand from the beginning." 7

Life of Farm Laborer.- "How are farm laborers cared for generally? What privileges or helps do they get besides their wages?" This question was put to Mr. Powers by the United States Industrial Commission. "In our section," said Mr. Powers, "the average farm hand lives with the family of the employer, in the same house, boards at the same table, and is one of them."

${ }^{7}$ A. C. Cance, "Immigrant Rural Communities." Annals, March, 1912, pp. 79,80 . 
The conclusions reached by John Lee Coulter on this subject are substantially the same. "It is impracticable," says Coulter, "to furnish a separate house or building for these hired laborers, and, therefore, the common thing is for the hired laborers to be assigned rooms in the family residence or sleeping quarters in some of the stables or hay barns. At the same time it is very customary for the hired laborers to sit at the table for meals with members of the family unless the number is large enough to warrant setting the table twice. Where only one or two laborers are employed, it is almost a universal practice for these one or two laborers to live in the homes with the resident farmers." 8

\section{QUESTIONS ON THE TEXT}

1. Is it correct to speak of an "agricultural labor problem"?

2. What concrete aspects of the farm labor problem were mentioned by the American Consul at Leeds?

3. Cite the conclusions of Board of Agriculture and Fisheries in its Report on Migration from Rural Districts. What factors, other than low wages, are mentioned?

4. What general conditions of farm labor are set forth in the two American letters quoted?

5. Show the meaning and significance of the seasonal nature of farm work. Show the social pathology of such a condition.

6. Show the relation of the I. W. W. movement to agriculture.

7. Discuss wages of farm labor as to increases, and purchasing power.

8. Discuss in detail the decline of women's work on farms since 1871 .

9. Discuss the number and supply of farm laborers.

10. Name and describe the various employment agencies in the field: private agencies; national farm labor exchange; federal agencies; farm bureaus.

11. Show the evils of an unorganized movement of seasonal farm labor in "mobs."

12. Describe and comment on the solution offered by Mr. Hugh J. Hughes, particularly his five points making for the satisfaction of the hired man.

13. What fundamental conditions lie back of irregular employment on farms, and what effects do these conditions have on immigrants?

14. Show the place of transportation and distribution in solving the labor problem.

15. State some of the fundamental factors underlying the drift to the cities, commenting in particular on leadership in eities, and the division of labor between city and farm now and formerly.

16. Cite statistics showing decreases in rural population and increases in urban population.

17. Show economic and social significance of labor saving machinery in agriculture. Cite findings of $\mathrm{H}$. W. Quaintance.

18. What is the outlook for using city labor on farms, according to Le Grand Powers?

19. Compare the "old" and the "new" immigration as to farmers and farm laborers.

${ }^{8}$ John Lee Coulter, Agricultural Laborers in the United States, Annals, March, 1912. 
20. What records have been made by our immigrant farm colonies? Show the economic, social, and civic significance of the different nationalities.

21. The life of the farm laborer has what social advantages and disadvantages?

22. What six States show no loss in rural population in the decade 1900-1910?

\section{QUESTIONS SUGGESTED BY THE TEXT}

1. Formulate a plan for meeting the seasonal requirements of agriculture for labor. Is it possible to coördinate this demand with the city's seasonal demand?

2. To what extent should we endeavor to abolish the problem of seasonal demand for labor by diversification of crops and smaller sized farms?

3. Is the I. W. W. movement in agriculture a cause or an effect of pathological conditions in agriculture? Discuss this movement carefully, both as a symptom and as a cause. Suggest remedies, both suppressive and constructive. Criticise the position taken by the South Dakota farmers on this subject.

4. Show to what extent farm labor (in the old sense) is now being done in cities, and the social significance of this condition. (E.g., manufacture of the farmer's food, clothes, implements, supplies, etc.)

5. Why should three New England States show no loss in rural population, 1900-1910, while all the neighboring States showed such a loss?

6. "The farm labor problem is a problem of transportation and distribution." Debate.

7. Complete the table in the Appendix of this chapter.

\section{REFERENCES}

1. Coulter, John LeE: "Agricultural Laborers in the United States," Annals, March, 1912.

2. CANCE, A. C.: "Immigrant Rural Communities," Annals, March, 1912. 927.

3. Hoagland, H. E.: "Journal of Political Economy," Vol. 20, pp. 913-

4. Hourwich, IsaAc A.: "Immigration and Labor."

5. Labor Bulletin 72, United States Bureau of Labor Statistics, Sept., 1907.

6. Report of the United States Industrial Commission, Washington, 1898-1902, Vol. X.

7. Board of Agriculture and Fisheries, Report on Migration from Rural Districts in England and Wales. London, 1913.

8. Daily Consular and Trade Reports, Washington, July 12, 1913, p. 238.

9. New York State Boys' Working Reserve Circular No. 1. New York State Food Commission, Albany, March, 1918.

10. Wilcox, E. V.: "Plan of the Department of Agriculture for Handling the Farm Labor Problem." Am. Ec. Review, March, 1918, 158-171.

11. Barnes, C. B.: "Employment and the Labor Market." Am. Ec. Review, March, 1918, 171-177.

12. Seager, H. R.: "Coördinating Federal, State and Municipal Employment Bureaus." Am. Ec. Review, March, 1918, 141-147.

13. Discussions of above three papers by App, Willard, Barnett, Billings, Wileman, Lescohier. Am. Ec. Review, March, 1918, 177-194.

14. Osborn, Chas F.: "Methods of Meeting the Demand for Labor." Monthly Review, U. S. Bureau of Labor Statistics, Sept., 1917.

15. Leiserson, W. M.: "Mobilizing and Destributing Farm Labor in Ohio." Monthly Review, U. S. Búreau Labor Statisties, April, 1918. 
16. Agricultural Wages Board. Report of the Committee Appointed by the Agricultural Wages Board to Enquire into the Financial Results of the Occupation of Agricultural Land and the Cost of Living of Rural Workers; London, 1919.

17. Wages and Conditions of Employment in Agriculture. 2 vols. Vol. I, General Report; Vol. II, Reports of Investigators, London, 1919.

18. Stoddard, C. T.: "How the United States Employment Service is Mobilizing Workers." Monthly Review, U. S. Bureau Labor Statistics, May, 1918.

19. Abstract of the Report on Recent Immigrants in Agriculture, 1-75. The Immigration Commission, 1911.

20. Hasbach, W.: "A History of the English Agricultural Laborer," London, 1908.

21. Savage, W.: "Rural Housing." London, 1915.

22. Hеath, F. G.: "British Rural Life and Labor." London, 1911.

23. KеввеL, T. E.: "The Agricultural Laborer." London, 1893.

24. Farm Wages in North Dakota in 1919. Commercial West, January 3,1920 , p. 49 .

25. New Agricultural Laborer's Code in Germany. Labor Gazette (Canada), November 1919, p. 1313.

26. Yearbook Department of Agriculture, 1911. Seasonal Distribution of Labor on Farms, 247-256.

27. Yearbook Department of Agriculture, 1910. Supply and Wages of Farm Labor, 189-201.

28. Yearbook Department of Agriculture, 1918. McCormick, E. B.: "Housing the Workers on the Farm," 347-357.

29. Industrial Commission, Vol. X, xxiï-xxiv, cxlvi-cliv, xciii-xcvii; Vol. XI, 73-144; Vol. XIX, 115-123.

30. Jenks AND LAuck: "Immigration Problems." See chapter on Immigrants in agriculture.

31. Bailey, L. H. (editor): "Cyclopedia of American Agriculture."

32. Putnam, Bertha H.: "The Enforcement of the Statute of Laborers During the First Decade After the Black Death" (Columbia University Studies, 1908, Vol. 32).

33. Hammond: "The Village Laborer, 1760-1832." A study in the government of England before the Reform Bill, 1911.

34. International Institute of Agriculture, Rome. International Review of Agricultural Economics: "Minimum Wage for Agricultural Labor in England and Wales," Aug., Sept., Oct., 1919, 543-564. Holland-"Wages of Rural Labor," Aug., Sept., Oct., 1919, 564-568. Great Britain and Ireland, "Supply and Conditions of Agricultural Labor," Nov., Dec., 1919, 660-677. Spain-"Labor Exchange," Nov., Dec., 1919, 688-690. Australia-"An Interesting Award Affecting Labor in Sheep Farming" (same pay as city labor), March, 1918, 234-240. United States- "The Problem of Agricultural LaborSummary of Nine Discussions." June, 1918, 494-522. Denmark-"Average Working Hours and Wages in Agriculture in 1915," Nov., Dec., 1918, 921-928. France-"The Condition of Rural Labor in France," 1913-1914, July, 1917, 68-79. California- "Improvements of Conditions Among Immigrants into California," Dec., 1917, 66-74.

35. Wyckoff, Walter A.: "The Workers; An Experiment in Reality." IV, A Farm Hand. Scribner's, Nov., 1897, 549-560. With Iowa Farmers', Scribner's, May, 1901, 525-536. 


\section{APPENDIX}

\section{Falling off in Rural Population for the Decade 1900-1910 by Per Cents}

Table showing (1) total increase in population of each Statc; (2) total increase in urban population for each State; (3) total increase or decrease in rural population for the State as a whole; (4) decrease in rural population in certain counties. Any place having fewer than 2,500 inhabitants is called "rural."

This table shows that of our 48 States, only 6 show no decrease in rural population for the decade. These 6 States are Arizona, Connecticut, Idaho, Massachusetts, New Mexico, Rhode Island.

Alabama.

State increase.

16.9 per cent

Urban increase.

Rural increase.

County decreases in rural population.

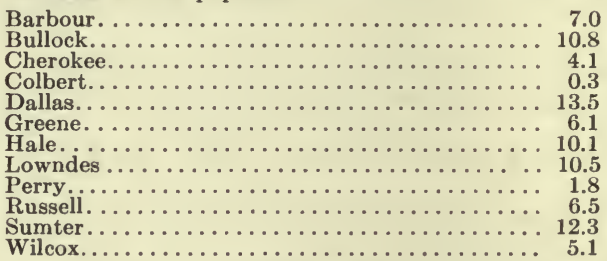

Arizona.

State increase. .

66.2 per cent

Urban increase. . . . . . . . . . . 195.5

Rural increase............... 39.0

County decrease in rural population, none.

Arkansas.

State increase.

20.0 per cent

Urban increase............. 53.9

Rural increase ..................... 16.3

County decreases in rural population:

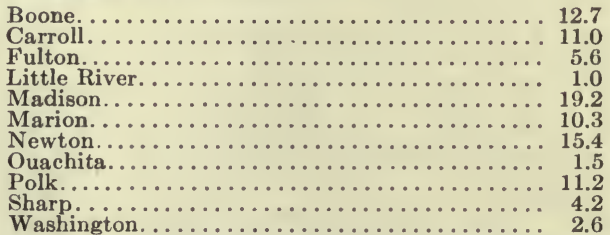

(Nots. - This table is to be completed by the student by adding statistics for the remaining 45 States. Also construct a similar table for the decade, 1910-1920.) 


\section{CHAPTER VIII}

\section{AGRICULTURAL MACHINERY AND THE TRUST QUESTION}

Agricultural labor, as we have seen, is scarce, and growing scarcer. Keeping pace with this growing scarcity of labor is an increase in labor-saving machinery. on the farm. Testifying before the Industrial Commission in 1900, a Georgia planter said that now one man and "a McCormick reaper and two mules do the work of eight good men." The same changed condition was pictured by M. F. Greeley of South Dakota, in these words: "When I first worked out it took five binders to follow a machine, one man to rake off, and one to carry the bundles together. Now the hired girl frequently drives a machine that does the whole business." Without accepting the literal truth of this rhetorical statement of Mr. Greeley's we can safely believe the basic fact that there has been a tremendous increase in the use of agricultural machinery in recent years.

Industrial Revolution in Agriculture.-The "Industrial Revolution in Agriculture" has come about one hundred years behind the revolution in the manufacturing industry. Since the Civil War we have witnessed a great increase in the use of farm machinery. The following interesting table shows the change in three decades:

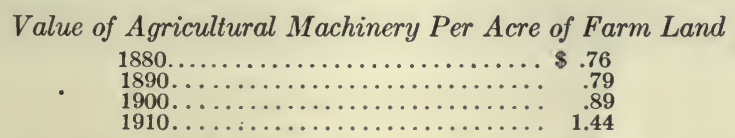

A calculation made by the Department of Labor in 1899 showed that improved agricultural machinery had reduced the labor cost of corn per bushel from 35.77 cents to 10.57 cents, or 70.5 per cent, and had reduced the time of human labor from 274 minutes to 41.3 minutes, or 84.9 per cent. David A. Wells estimated that the labor of three or four men in the Dakota wheat fields would annually produce 1,000 barrels of flour, delivered at the seaboard, or enough flour to furnish bread to one thousand persons for one year.

Effects.-Investing more money in agricultural machinery has made this industry more "capitalistic." There is now less of drudgery in farming and more of business. The capital investment of the farmer must now be rightly apportioned to each of 


\section{6}

the four factors, such as land, buildings, machinery, and livestock. The management of "capital," therefore, rather than the management of.land, becomes the uppermost consideration, and in that sense, agriculture becomes "capitalistic." Among the beneficial effects of improved machinery are two very important ones, namely, increased yields and lessened cost of production. Crude implements admitted only of crude tillage (Fig. 14). With improvements in tillage tools came increase in yields. An increase in the yield of the products of the farm, without an increase in the demand for such products, would of course, merely result in

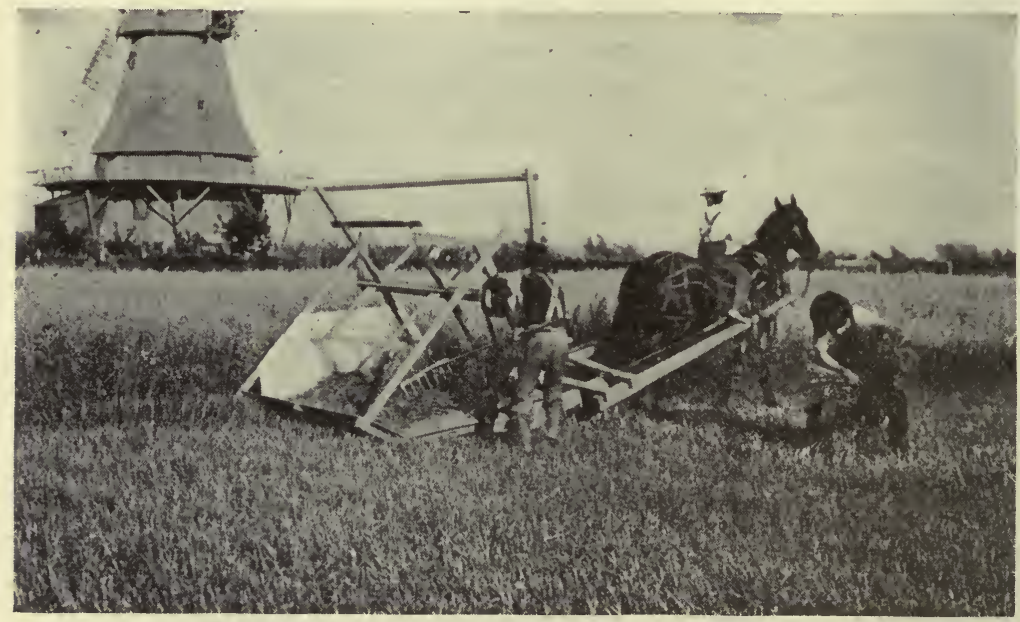

FIG. 14.-Evolution of the reaper. Cyrus Hall McCormick's first successful reaper, invented in 1831 and patented in 1834 .

lowering their price, and hence, in lowering the rent of the land or in putting the poorer grades of land out of use altogether. It is of course true that the consumer's demand for bread and meat may increase or decrease from decade to decade. Or the increase in production is disposed of by way of the foreign markets. Thus our great staples - wheat, meat, and cotton-feed and clothe many people in many foreign lands. These products in turn are exchanged in part for food products, in part for other things. But the result of increased production at home, therefore, is seen to be an increase in food consumption, but food of many varieties from many corners of the world. Tropical fruits that were once a luxury for the rich are now a commonplace on the tables of the working man. 
The Purchase of Farm Machinery.-Since the industrial revolution in agriculture, the farmer normally buys most of the tillage tools used on his farm. This fact is best appreciated when we contrast the situation to-day with that of the time of George Washington, when tillage tools and household supplies were made on the farm. For instance, a neighbor of Washington's has left us this description of the work done on a farm near Mount Vernon:

"My father had among his slaves carpenters, coopers, sawyers, blacksmiths, tanners, curriers, shoemakers, spinners, weavers, and knitters. His woods furnished timber and plank for the carpenters and coopers, and charcoal for the blacksmith; his cattle killed for his own consumption and for sale, supplied skins for the tanners, curriers, and shoemakers; and his sheep gave wool and his fields produced cotton and flax for the weavers and spinners, and his own orchards fruits for the distillers. His carpenters and sawyers built and kept in repair all the dwelling houses, barns, stables, ploughs, barrows, gates, etc., on the plantation, and the outhouses of the house ... The blacksmiths did all the iron work required by the establishment, as making and repairing ploughs, barrows, teeth, chains, bolts, etc."

As described elsewhere in this book, the division of labor between town and country has taken away from the farm most of the processes of manufacture. This has given rise, at frequent periods, to chafings and mutterings of discontent on the part of the farmer, particularly as to the quality and cost of the implements purchased by him, and the high cost of repairs. As described elsewhere, the farmers, through the National Grange actually contemplated entering upon the manufacture on a large scale of farm implements, placing the factories near the centers of farm crop production. This scheme however, finally fell through. The manufacture of most forms of farm machinery has therefore come to be in private hands. The exception to this rule may be found in those States where prison labor is used for making certain farm machinery. The sale of farm implements is chiefly in the hands of private dealers. However, the purchase of farm machinery collectively by organized groups of farmers, through various forms of coöperative associations, is gradually increasing. The outlook is very favorable for the use here of coöperative purchases by the combined farmers in dealing with the manufacturers or the distributors. Since farmers are slower to form combines than are manufacturers, the problem which has for some years confronted the farmer is this, namely: What is the correct economic policy for the scattered, unorganized farmers to adopt towards the combinations of manufacturers of tillage tools? Shall farmers combine and deal with the combined manufacturers on a basis of equality? Or shall farmers, through the processes of the courts, seek to dis- 


\section{AGRICULTURAL MACHINERY AND TRUST QUESTION}

solve the combines of manufacturers? Since this question is one of fundamental economic and social significance, it is here considered at length. And furthermore, farmers are now combining in large groups, and wisely so, for the purpose of collective activities, and hence this question has more than academic interest for them.

The "Harvester Trust." - Every farmer who uses tillage tools is interested in the so-called "harvester trust." No large industrial corporation has been more discussed in the farm press than the International Harvester Company. But a small part of this discussion has shed any light on the subject. Yet there are literally thousands of pages of sworn testimony available, setting forth the history and methods of this company in the minutest detail. The history of this company has wide economic and social implications.

Its History.-The International Harvester Company was organized in 1902 as a consolidation of five manufacturers of harvesting machines in the United States, namely, the McCormick Harvesting Machine Co., Deering Harvester Co., Plano Manufacturing Co., the Warder, Bushnell \& Glessner Co., and the Milwaukee Harvester Co. The companies thus consolidated had in 1902 about 90 per cent of the total production of grain binders in the United States and about $80^{\circ}$ per cent of the total production of mowers, the two chief kinds of harvesting machines. The interests included in the combination had previously been in keen competition. An attempt made in 1890 to establish a general consolidation of makers of harvesting machines was a failure, and from that time on until the merger, competition was severe, resulting in costly duplication of sales agents and traveling salesmen. After its organization, the International Harvester Company at once began to acquire competing makers of harvesting machines. In January, 1903, it acquired control of D. M. Osborne \& Co., its chief competitor. By 1904 control had been secured of several other concerns, including the Minnie Harvester Co., the AultmanMiller Co., and the Keystone Company. From manufacturing harvester machines the company pushed on into new lines. Among the most important of such lines were tillage implements, manure spreaders, farm wagons, gasoline engines, tractors, and cream separators. In order to obtain its raw materials more economically, efficiently and promptly, and to save the margins taken by useless middlemen, the company entered the fields of raw material and transportation. It secured control of ore lands in Wisconsin, Minnesota, and Michigan, coal lands and coke ovens in Kentucky; blast furnaces for the production of pig iron, steel mills and rolling 
mills at South Chicago; timber lands in Missouri and Mississippi; saw mills in Arkansas and Missouri; 27.18 miles of trackage of the Illinois Northern Railway, serving the McCormick works; 24.75 miles of trackage of the Chicago, West Pullman and Southern Railroad Company which serves the company's steel mills and the Plano Works at West Pullman. In 1905 the International Flax \& Twine Company of Minnesota was organized as a subsidiary company of the International Harvester Company, for the purpose of manufacturing binder twine from flax straw, so as to substitute in large measure fiber from American-grown flax straw for the sisal and manila fibers imported from Yucatan and the Philippine Islands. In addition to the foregoing steps, the company developed an important export trade in harvesting machinery. Over 30,000 local dealers handle the machinery of this company outside the United States. Agencies have been established throughout the various countries of Europe, in Northern and Southern Africa, in South and Central America, and in Siberia. For instance, the branch house at Omsk, Central Siberia, did a business for the company in the year 1912 amounting to more than three million dollars.

Investment and Capitalization.-The extraordinary overcapitalization which characterized most of the large industrial consolidations formed in the period of combines (1898-1902) was absent in the case of the International Harvester Company. The original capital stock was $\$ 120,000,000$. The cash stock of $\$ 60,000,000$ appears to have been paid up in full. The appraisal value of the plants, inventories, etc., for which the remaining $\$ 60,000,000$ of stock was issued was $\$ 67,000,000$. The bankers and promoters received $\$ 3,700,000$ stock for their expenses and services. In 1910 the capital stock was increased to $\$ 140,000,000$, by the issue of a common stock dividend of $\$ 20,000,000$. The purpose of the merger, according to the company's testimony, was "to reduce operating expenses and decrease competition." The federal government, reporting on this company, summarized its conclusions in these words: "It appears therefore, that the International Harvester Company's position in the industry is chiefly attributable to a monopolistic combination in the harvesting machine business, certain unfair competitive methods, and superior command of capital."

Exclusive Contract.-An objectionable competitive method was the use of the so-called "exclusive contract," or exclusive clause in agency contracts. This practice was discontinued after 1905 . 
Quality and Price.--In the ouster sut in Missouri, the Supreme Court of that State spoke on the subject of the price and quality of binders in this manner: "So in the case at bar, the price of harvesting machines has not increased in proportion to the increased cost of construction or the increased merit of the machines." In the suit before the Supreme Court of Kansas, the State referred the case to a Commissioner, to report his findings of fact, and his report includes the following statements as to quality and price: When the Harvester Company began business in Kansas in the fall of 1902 , certain reductions in price were made on binders and mowers. No increases in price were made till the season of 1908 , and then an increase of 5 per cent was made. In the same period the prices of commodities in general were in the State of Kansas considerably increased. The average increase in the costs of all raw materials for producing farm machinery, from 1902 to 1907, was from 16 to 42 per cent. Using exact figures (from the Missouri suit) we find the following price changes for the six-foot binder:

Average Prices for 6-foot Binder

$\begin{array}{lcc}\text { Year } & \text { Price to farmer } & \text { Price to dealer } \\ 1878 & \$ 360 & \$ 270 \\ 1879 & 340 & 278 \\ 1881 & 275 & 225 \\ 1884 & 240 & 195 \\ 1890 & 140 & 112 \\ 1891 & 125 & 100 \\ 1892 & 140 & 112 \\ 1895 \text { to '98 } & 135 \text { to } 130 & 105 \text { to } 95 . \\ 1900 & 130 & 100 \text { to } 105 \\ 1901 & 130 & 100 \\ 1902 & 125 & 97.50 \\ 1903 \text { to '08 } & 120 & 95 \\ 1908 & 125 \text { to } 130 & 100.00\end{array}$

The Kansas Commissioner gave retail cash prices for the period 1903-1907, as follows:

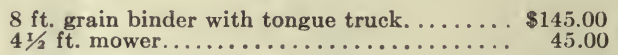

On the question of quality and improvements, the Kansas Commissioner finds as follows:

"Improvements in Machines.-The experimental department is maintained at an annual cost of from $\$ 300,000$ to $\$ 350,000$. The specific improvements of machines making for efficiency and durability have been too numerous to cite in detail. In brief the evidence shows that the basic patents on binders and mowers have all expired, but that the International Harvester Company of New Jersey constantly endeavors to procure new devices for improving the machines it manufactures for the company; that on an average it takes out seventy-five patents a year. The evidence shows that the local dealers and farmers in Kansas consider that the machines sold by the defendant are distinct improvements over the machines sold in the state prior to 1903 . The evidence further is clear that the machines are constantly improving, that they are now more efficient and durable. They do not have to be repaired as often, and are less complicated (Figs. 15, 16, and 17). 
"Repairs. - Prior to the time the defendant commenced doing business in Kansas, both the farmer and the retail dealer often experienced difficulty in obtaining machines and repairs during a busy harvest season. None of the companies doing business in Kansas prior to 1902 had general agents at Concordia, Hutchinson or Parsons. They were forced to send to Kansas City,

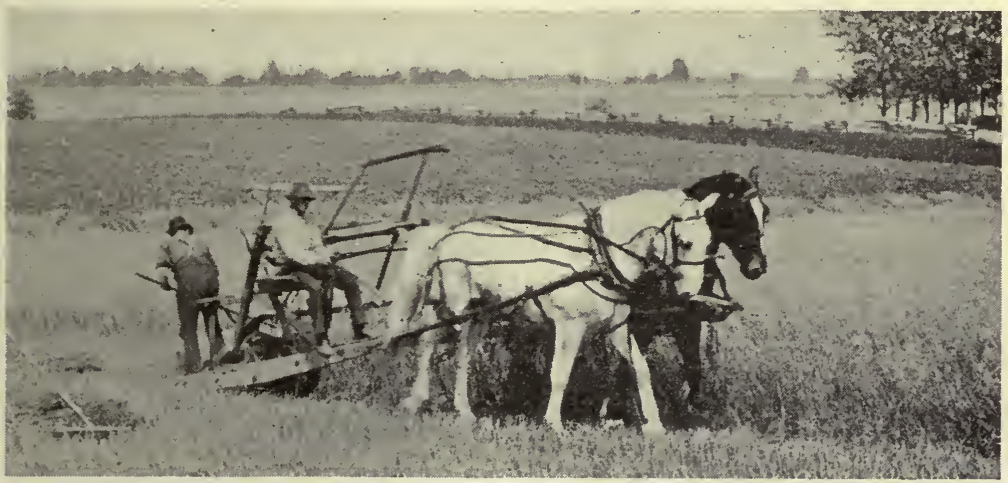

FIg. 15.-Evolution of the reaper. The 1847 model, McCormick reaper at work.

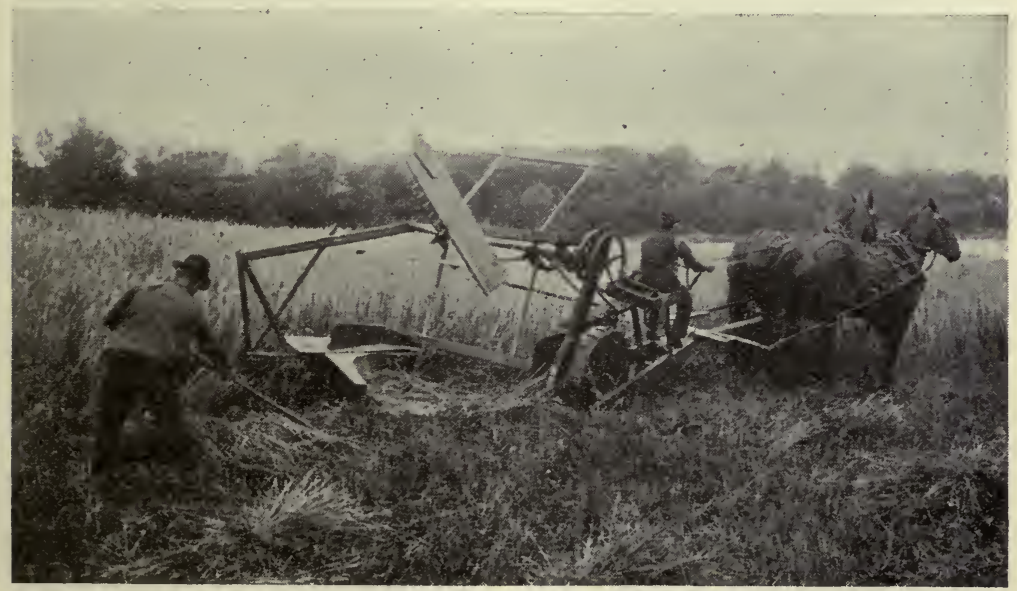

FIG. 16.-Evolution of the reaper. The 1858 model, McCormick automatic self-rake reaper.

Wichita or Topeka for repairs. The defendant is the only company doing a farm implement business in Kansas that adopts the system described. To get repairs from other concerns the dealer must send to Kansas City, Missouri. This often involves a delay from which damage to crops results."

Prices at Home and Abroad.-The Kansas findings are in these words: "The prices of the company on its goods sold in foreign countries are higher than those charged to the domestic trade." 
Earnings.-A correct table of earnings of this company for its first eight years is found in the Petition of the United States in the federal district court for Minnesota, and is as follows:

Dividends on Capital Stock
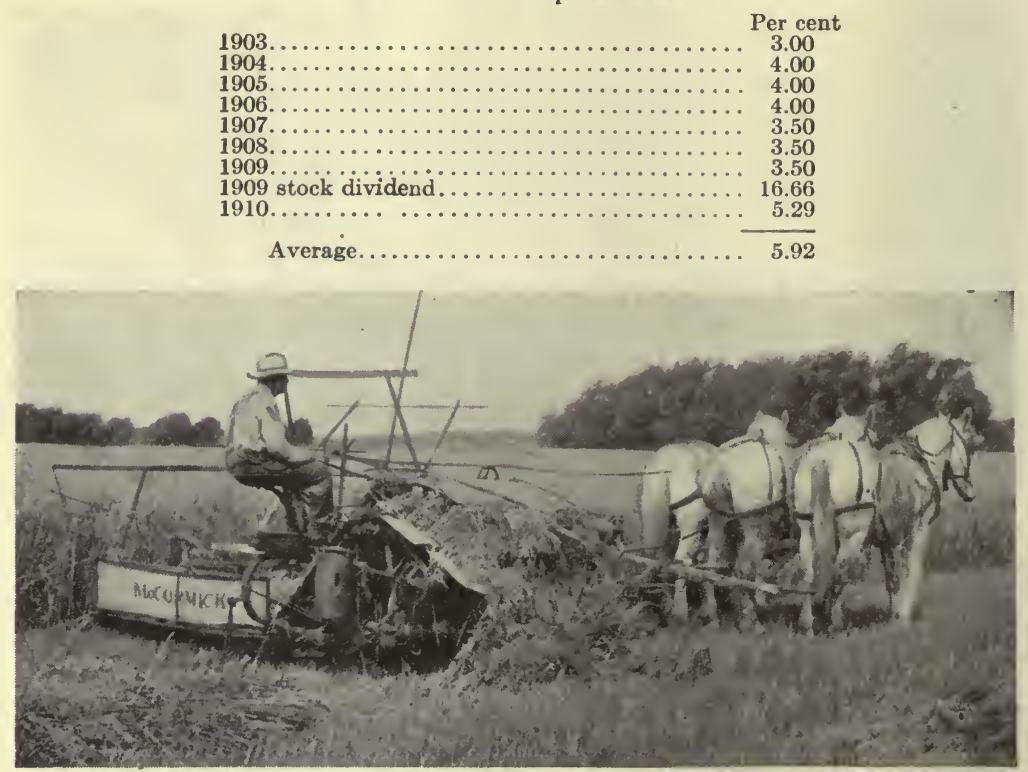

Fig. 17.-Evolution of the reaper. The modern self-binder.

The Case for and Against the Harvester Company.-As these lines are being written a suit is pending before the United States Supreme Court for the dissiolution of this Company. The dissolution is sought under the Sherman Anti-Trust Act, the official title of which is "An act to protect trade and commerce against unlawful restraints and monopolies." Attempted enforcements of the Sherman Act are putting the question squarely up to the voter, which one of four possible economic orders of society does he desire, namely, (1) Competition, (2) Combines, regulated by public authority, (3) Coöperation, (4) State Socialism. Since the aim of the pending suit, just mentioned, is to destroy a combine and restore competition, it is very timely at this point to state both sides of the controversy.

For the Harvester Company.-In its numerous lawsuits, the International Harvester Company has averred that it has caused the following distinct advantages to the public over the conditions 
and methods existing in the trade prior to the formation of the merger, nearly all of which benefits have grown out of its large resources, facilities, and organization:

(1) Harvesting machines have been improved in quality, durability and efficiency much more in the years since the merger than in the same number of years before the merger. The best features in each of the machines formerly made by the different companies have been incorporated in all the machines made by the Company, and the advance in improvements has been broad and rapid. The Company has maintained an experimental department to develop new machines and improvements at an average annual expense of more than $\$ 500,000$, which none of the old companies could or would sustain, and during its first nine years it expended, in improving its six types of binders and mowers more than $\$ 600,000$. By producing specially for its own uses the lumber, iron and steel for making harvesting machines, the Company has been able to eliminate certain expensive middlemen, to the advantage of the farmer, and thus to increase the efficiency and durability of the machines without a corresponding increase in cost.

(2) The methods and facilities of distribution have been greatly improved and enlarged; and, by the wider distribution of harvesting machines and all repair parts on a commission basis, local dealers are better enabled to carry large stocks of both. These repairs are more accessible to farmers than was formerly the case. A large corps of experts and repair men is maintained whose services are quickly available to the farmers and often without charge.

(3) Large economies have been made by the development of new lines of farm machinery. The harvester plants merged in 1902 were making only binders, reapers, mowers and rakes, and were practically idle several months of the year because the selling season in those lines in the United States is only about four months. By developing new lines an all-year employment has been given to very much larger manufacturing and selling forces than were employed by the old companies. Among the new lines developed are wagons, manure spreaders, gasoline engines, cream-separators.

(4) Foreign trade in agricultural implements has been developed and expanded from $\$ 10,000,000$ in 1902 to $\$ 42,000,000$ in 1911 (Figs. 18 and 19).

(5) Wages and conditions of employees have been improved by the Company. In the first nine years wages were increased twenty-seven per cent. Sanitary and safety appliances have been installed and maintained with the mast rigid system of inspection. 


\section{AGRICULTURAL MACHINERY AND TRUST QUESTION}

(6) The Company avers that, unlike the illegal trusts and combinations, it is controlled and managed by men whose fathers originally developed the harvesting machine business in which there has been continuous management and development for a

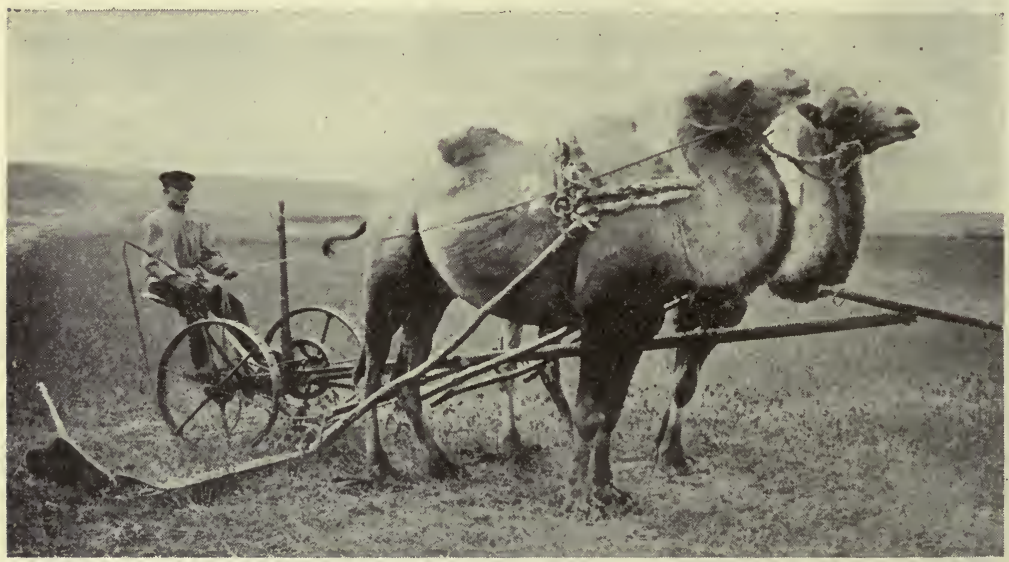

FIG. 18.-American farm machinery in Siberia.

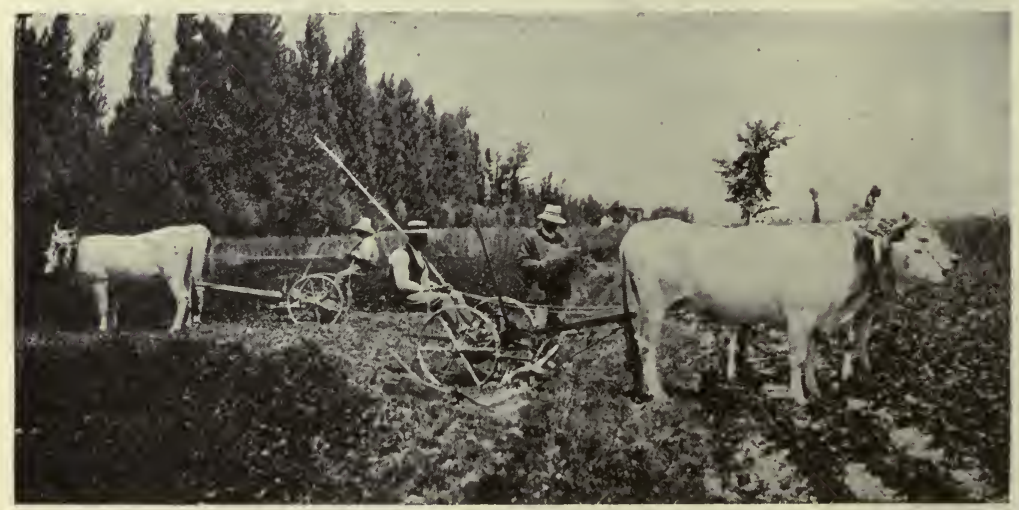

FIG. 19.-Farming in Italy-using American mowing machines.

period of more than fifty years; that it was organized without excessive capitalization and without any purposes of securing quick fortunes from stock sales or excessive earnings, and that beneficial results have been secured to the public in greater measure than to the stockholders. The company avers that during the twenty years prior to its organization in 1902, more than fifty competitors had been eliminated from the harvesting machine 
business, and that since that time there has been no such elimination of competitors. The cost of raw materials and labor increased fully 25 per cent since 1902 , yet the prices of harvesting machines were not raised until 1908, and then only 7 per cent, and for 1912 there was a reduction of about 5 per cent. The net earnings of the company for this time averaged 5.91 per cent.

In short, the Company says, "The Government ought not to be permitted to urge in a court of equity that such a corporation is in itself, and without regard to its practices and effects, illegal and should be destroyed."

In other words, a "good" trust is better than competition, and hence should not be dissolved.

Against the Harvester Company.-There is no such thing as a good or benevolent trust, the government contends. All combinations which break down the competitive system are in restraint of trade. It is apparent, says the government, that the objections to substituting a despotic organization of industry for the competitive system were quite as much social and political as economic, and therefore it would not have satisfied Congress to be told, as the Company now is saying, that the power which they feared was thus far being exercised benevolently, that prices had not been raised, nor wages lowered nor the quality of the products degraded, nor competitors oppressed. In their minds the mere existence of such powerful combinations was an evil-a continuing danger-from which in the long run, if not immediately, would come disaster. For, as in the organization of government, benevolence can never justify absolutism, neither can it do so in the organization of industry. The fundamental contentions of the company (that the anti-trust law prohibits only combinations injurious to the public by raising prices, limiting production, deteriorating quality, decreasing wages, or oppressing competitors) loses sight, says the government, of the broader purpose and basis of the act. It fails to take into account that the view of public policy upon which Congress legislated was not to wait until the evils of undue concentration of economic power have occurred or becomeimminent and then attempt to restrain them, but to prevent their occurrence by striking at undue concentration of economic power itself.

Here the reader has both sides. He will make his own choice, for or against competition. ${ }^{1}$

${ }^{1}$ Since the above statements were written, the International Harvester Company has voluntarily formulated a plan for dissolution satisfactory to the federal courts. 


\section{AGRICULTTURAL MÄACHINERY AND TRUST QUESTION}

The Independent Harvester Company.-A few years ago twenty-seven thousand farmers brought suit against the Independent Harvester Company of Plano, Illinois. These farmers held over six million dollars of stock in this company. Since this company was so widely advertised as a coöperative concern, and as a farmer's company, and in this guise secured the farmers' support, a brief account of its operations is in place here. It was neither a farmers' company nor a coöperative concern.

Troubles under the old management of this company came to a head when a committee of farmer stockholders in the summer of 1913 brought in a report and filed a bill in the United States District Court at Chicago, containing seventy-one counts against the management and praying for relief. Some of these counts set forth that the then management of the company had "organized a stock selling campaign, and for four years or more have devoted all the time and energy of the officers and a large number of employees of the corporation to selling stock, have expended large sums in advertisements, employed sales agents for stock, commissions as high as thirty per cent of the sales . . . That stock sales were conducted for the sole purpose of paying salaries, expense accounts, and profits to the individuals in the management; that more than $\$ 3,000,000$ worth of stock has been sold during the past two years; that the management diverted the corporation's purpose from manufacturing machinery to the sale of stock; that it conspired to continue stock sales and neglect manufacturing; that the mismanagement and fraudulent misrepresentations of defendants so injured the reputation of the company and its products that advertisements were refused by farm and other journals," etc.

This company gave the impression in its advertising that it was a farmer's coöperative company. Some so-called coöperative journals carried this fraudulent advertising. Many refused it. The president of the company in reply to a letter from the editor of a genuinely coöperative journal, wrote: "We do not consider ourselves strictly coöperative, and whether we can be made so is problematic. We have tried to figure it out from all standpoints, but it seems as though the law at the present time and the way in which we are organized would not permit of it in the same sense as the Rochdale plan ... On the other hand, we have about three thousand farmers that are voters of the company, and the balance, about thirteen thousand, are non-voters. ... We are expecting to spend $\$ 30,000$ in advertising between now and March 
1, and took it for granted that it would be patronizing men that we believe in, and, by sending you an advertisement, at the same time be a help in the efforts which you and your paper are putting forth." 2 The president of the company, in fact, acknowledged it to be not coöperative. One very widely circulated pamphlet issued by the company bore these words prominently on the front cover: "Coöperative Manufacturing of Implements. General Farm Machinery and Gasoline Engines-What the Farmer is Doing for Himself-The Farmer's Company-Not in the Trust." On the inside cover we read such sentiments as these:

"Buying from the Trust means prosperity for the Trust. Why not coöperate for your own independent profit? Chapter one in the battle for farmer's independence. Striking the blow for farm freedom at the psychological moment of history. Every fight has its crisis - the moment when a feather's weight one way or the other turns defeat into victory. The struggle of American farmers for freedom from trust tyranny is at that crisis to-day. The Harvester monopoly, by tightening its grip on the situation, has forced thousands of individual farmers to submit to its demands."

This same pamphlet, issued about the year 1912, describes the beginning of the Independent Harvest Movement, and goes on to describe its management. "From the beginning," says the pamphlet, "the same conservative methods have prevailed in the Independent Harvester Company's management - a conservatism that is ever alive for the latest progress in machinery manufacturing, but holds fast to the old fashioned ideals in its dealings with every customer."

About the time this pamphlet was issued, describing the company's "conservative management," a committee of three men, representing various groups of stockholders, made a "Committee's Report to Stockholders" under date of December 18, 1912, and set forth the details of a meeting which they had held with some representatives and stockholders of the company at Plano, Illinois. Among other things, the report states: "Various phases of the harvester company were discussed. The millions contributed by the investors, and the few machines to distribute after seven years of promise were data for serious consideration . . . It was apparent from the first, however, that there was no disposition to meet our inquiries with full and complete answers. No very definite estimate was made as to the company's output of machines for the present year, excepting that there was a substantial increase. Questioned as to the cost of the output of last year, Mr. B. elabor-

${ }^{2}$ Letter to Editor E. M. Tousley, "Coöperation" (Minneapolis), July, 1913, p. 275. 
ated on the necessity of a cost system, and the length of time required to put one in, saying it would take about a year. When pressed as to the per cent of profit in the manufacturing end of the business, nothing definite was forthcoming except beads of perspiration on the brow of the auditor. We do not know whether the business is on a paying or losing basis, so far as figures obtained . . Mr. T. (the president of the company) stated that he owned seven hundred and eight shares of the stock in the company. Upon being questioned as to his salary as president, he said, 'One thousand dollars per month, and that is not enough."

The suit against the former officials of the Independent Harvester Company came to an abrupt end in 1917, when the government, after four years of preparation, went down to defeat. The United States District judge took the case from the jury and threw it out of court. The court held that the government had failed to prove that there was any intent on the part of the defendants to defraud purchasers of stock in the company as charged, and that the evidence, on the contrary, showed that the defendants were sincere in their belief that the company would be a glowing success, a clear case of " sincere even if visionary optimism." When the company got into trouble, an entirely new management took charge of it (in June, 1913). The manufacturing end of the business was systematized, and a sales organization was built up. A "through-the-dealers-only" policy of distributing the products was adopted and adhered to. The twenty-four thousand farmer stockholders buy the product through regular dealers. A full line of binders, mowers, and general farm machinery is offered by the company. But the reorganized company is suffering from the handicap imposed by the early exploitation of the word "coöperation" in connection with heavy promotion costs. Damage was done both to the cause of real coöperation and to this company as a manufacturer and distributor of farm machinery.

The financial affairs of this company, however, went from bad to worse, after the company once got into the courts. In the year 1918 the assets of the Independent Harvester Company of Plano, Illinois, were sold to the Independent Harvester Company, Limited, for $\$ 604,506.21$. Other items of expense put the cost up to about $\$ 1,000,000$. Under this reorganization neither the preferred nor the common stockholders could hope for any return of any part of their investment unless they advanced 20 per cent of their original investment for notes of the new company, running one year. 
In some foreign lands the promoter is required to put forth his prospectus in printed form, and is then held civilly and criminally liable for all statements therein. Such a "Blue Sky Law" in this country would doubtless save the farmer from being victimized on many an occasion.

The question is still unsolved, however, of coöperation and combine, on the one hand, versus competition on the other hand.

\section{QUESTIONS ON THE TEXT}

1. Show briefly the increase in use of labor saving machinery. Cite concrete examples - the Georgia planter; M. F. Greeley's testimony.

2. Show increase in value of agricultural machinery per acre.

3. Show how this machinery lowers cost of production (figures for corn, hay, wheat).

4. Show in what sense agriculture is now "capitalistic."

5. Explain the probable effects of a greatly increased production.

6. Show the change, during the last hundred years, in the method of obtaining tillage tools. This change has brought forth what economic and social problems? State briefly different schemes used by farmers for improving the methods of obtaining tillage tools? What method or methods prevail to-day?

7. Give the history of the International Harvester Company.

8. Cite the six advantages in manufacturing and distributing farm implements claimed by this Company.

9. Cite the objections to this form of manufacturing and distributing, formulated by the Government in its suit against this Company.

10. What, in brief, is the issue involved?

11. Give the history of the Independent Harvester Company, and show what economic and social problems were involved.

\section{QUESTIONS SUGGESTED BY THE TEXT}

1. Show relation of increased production to an increase in rent; to a decrease in rent. Formulate a rule governing this relationship.

2. What would be the ideal method for farmers to obtain their tillage tools?

3. Should combines among manufacturers of tillage tools be prohibited or encouraged? Reasons for your answer.

4. State chief reasons for combines among farmers ("coöperative associations") for large-scale dealings. Do these same reasons apply to others than farmers? Reasons for your answer.

5. Should "all combinations" be prohibited? Should some combinations be prohibited? Formulate a rule in the interest of public policy.

\section{REFERENCES}

1. Report of the Industrial Commission, Vol. X, Washington, 1898-1902.

2. Quaintance, H. W.: "The Influence of Farm Machinery on Production and Labor." Publications American Economic Association, 3d series, Vol. 5, No. 4, Nov., 1904.

3. Report of the Bureau of Corporations on the International Harvester Company, Washington, 1913.

4. Briefs of the International Harvester Company and of the federal attorneys, in the various suits involving this company. 


\section{CHAPTER IX}

\section{MARKETING AND THE MIDDLEMAN}

Four Steps in Marketing.-In recent years the discussion of marketing has taken the form of a crusade against the middleman. However, the so-called "marketing problem," when studied, is found to break up into four separate problems, namely, production, storage, transportation, and credit. In other words, when these four problems are solved, the "middleman problem" will disappear. (1) The production of a good product is the first and most important step in marketing. It is never difficult to sell products of the best grade. The daily market reports and price currents indicate brisk demand at good prices for the better grades of farm products, but, at the same time, the markets are often glutted with poorer grades. To put a high-grade product on the market, particularly if it be inspected and graded and standardized, is to take the first and biggest step in marketing. (2) Storage is a step made necessary with most farm products by reason of their production in the summer time and their consumption at other seasons. These crops accordingly must be stored some place by somebody, and the middleman accordingly usually enters at this point to begin his services. Some highly perishable products show a tremendous shrinkage in storage. Thus the southern sweet potato, needing warm dry storage in winter, shows an annual loss in storage estimated at one hundred million dollars. The white potato of the north, calling for cool, dry winter storage, also shows a heavy waste. Other farm products, such as eggs, poultry, grain, cotton, and so on, all call for particular forms of storage to bridge the gap between time of production and time of consumption. In the last analysis, considering farmers' coöperative storage warehouses, public and private storage warehouses of all kinds, and the consumers' own cellars, the retailer is doubtless the chief storer of food products. The retailer must actually own and store nearly 100 per cent of the food products which the ultimate consumer buys. Here is an important function of the retailer. One investigator has estimated that the annual waste by decay of perishable food products is 40 per cent. (3) Transportation is, next to retailing, the most expensive link in the chain of marketing. And the most expensive phase of transportation is the haul over 
poor country roads before the product reaches the railroad station. Lower freight rates may be brought about by using fleets of motor trucks for short haul business, provided country roads are improved. An enormous leak in railway transportation is due to the shipper himself, namely, the shipping of poorly packaged perishable freight. It is appalling to witness the loss and damage in foodstuffs arriving at big city markets, losses due to shipping in frail containers, or to improper loading of correct containers. (4) Credit is the fourth step in marketing, and is vitally important under our present system of doing business with the smallest possible use of money. We live in a credit age. Credit is a promise to pay money. Farmers' crops go to market shortly after harvest, as a rule, and are paid for in cash-with money borrowed from the banks. Hence credit must carry the crop till it is bought and paid for by the consumer, months later in many cases. It is commonly the middleman or dealer who finances the farmer by securing credit from the bank. For this service a "toll" is charged. If the farmer, in buying his supplies, uses book credit ("charge" account at the store), he is using the most expensive form of credit known.

The reformer of our present market system must successfully solve the four problems named above, if he hopes to displace our present system. Getting the farm products from the producer to the consumer-in the right quantity, of the right quality, at the right time, at the right place (usually his kitchen door) is now carried on by the middleman in a remarkably efficient manner, when you take into consideration the whims and fancies of the consumer, and the more basic fact that consumption is not rational and never can be. (De gustibus non est disputandum-"There is no disputing about tastes.") . Let us now turn our attention to the concrete attacks being made on the marketing problem by the various States.

State Marketing Activities.-The year 1915 may be given as the date when the States of the Union began actual marketing activities. The high cost of living in recent years doubtless contributed to this step by the States. The long crusade against the "middleman" may be considered as a further cause for the States undertaking to deal with the marketing problem in a new and somewhat concrete way. A partial survey of the State marketing activities may be considered at this point, before examining the actual costs and services of the middleman.

Most of the States are now undertaking some marketing activity. It is a new field, and they are feeling their way, each 
trying its own ideas. Only a few of the typical State systems can be given in any detail here. Among the first States to enter this new field is Idaho.

Idaho.-The Idaho law creates the office of markets for the State of Idaho, in charge of a director appointed by the Governor. The law contemplates three chief activities: (1) a free State employment bureau; (2) supervision of land promotion schemes, particularly of misleading advertisements intended for homeseekers; (3) a State market department. The Director in charge of this work, W. C. Scholtz, confined his marketing activities at first largely to community and state-wide problems, working along broad and fundamental lines, leaving the individual work for later consideration. This work may be illustrated by the following two examples.

Dairy Products. - The Director found unsatisfactory conditions prevailing in the dairy industry, despite the State's natural advantages in this field. He founded a butter and cheese scoring organization, thereby leading to a standardized and higher quality of produce. Uniform accounting systems were introduced and likewise coöperative buying of supplies. Along with these activities went a vigorous campaign against the unscrupulous creamery promoter.

Potato Marketing.-The 1915 potato crop was large, in most sections of the country, and prices low. The Director found that Idaho buyers were getting the Idaho crop at from 45 to 50 cents per hundred. He circularized the growers and advised them to hold for higher prices, for 80 cents at least, assuring them that prices would soon rule higher. Within about two weeks the price actually rose to about 80 cents a hundred. It should be stated at this point that the actual forecasting of market prices is rarely undertaken by State marketing officials as part of their official duties.

California's law, passed June 10, 1915, is the one which, without doubt, has been enforced most vigorously of all of the State marketing laws. And California, like New York, has had its market bureau subjected to a torrent of very able and very continuous criticism. Nothing shows more clearly the strength, the weakness, and the limitations of California's market work than this battle of the critics. California's first law created a State Commission Market, so called, under the "management and control of a governing body of one person," known as the State Market Director, appointed by the Governor. The Governor appointed, 
as first Market Director, Harris Weinstock, a man of mature years and wide business experience. A State Senator of California began a fight against the administration of this Act, which battle of words throws much light on the question of correct State policy in engaging in marketing activities. The permanent value of this debate justifies its reproduction, in part, at this time.

"The Senator believes," says the Market Director, "that the end in view can best be achieved by State Markets, the creation of which he contends is made mandatory by this law. I contend, on the other hand, that the best results can be achieved by encouraging producers to keep on producing, by getting more people to produce, by cutting out speculation in farm products and by collective marketing. These things I hold can be best brought about by coöperative organization on the part of producers, rather than by State markets, which under the law are made discretionary on the part of the State Market Director-and not mandatory, as the Senator would have us believe." In other words, self help must not be weakened, but rather strengthened.

The Senator charged the Market Director with organizing the growers into marketing associations, and that these producers' "combines" were oppressing the consumer and increasing the cost of living.

The Market Director admitted having organized the following groups of growers: California Peach Growers; Poultry Producers of Central California; Poultry Producers of Southern California; Associated Milk Producers; Pacific Rice Growers Association; Prune and Apricot Growers; California Associated Olive Growers. The Director denied, however, that such organizations oppressed the consumer. The Director denied that these "combines" raised prices to the consumers. Collective marketing lessens the cost of distribution. The Director, in answering the Senator, claimed that products raised by unorganized farmers, such as onions; potatoes and beans, increased in retail price on the San Francisco market in the two years 1915-1917 one hundred and twenty-six per cent, but that, at the same time, products raised by the organized farmers, such as raisins and dried peaches, decreased in retail price five and one-half per cent. The market is stabilized, says the Director, by the organization of the producers. "While it is in the interest of the speculator in food products," he says "to squeeze out the highest possible price wherever this can be done, regardless of the welfare of the producer or the consumer, farmers' marketing associations are in quite a different position. The 
producer has much to lose and only a temporary advantage to gain should he, when working coöperatively, artificially force prices upward. The future welfare of the industry depends upon increasing consumption. Abnormally high prices diminish consumption, and the temporary profits due to abnormally high prices stimulate overproduction, both of which effects seriously react against the producer. Experience shows that coöperative selling on the part of producers has in no instance put any unfair burden on the consumer."

Considering that coöperative marketing is on trial in California, the Director gives these benefits which come to the consumer through this form of marketing:

Coöperative marketing stands for standardizing qualities, so that only products fit to eat are allowed to go to market.

Coöperative marketing stands for intelligent and more economic production, so that the cost of production is lessened.

Coöperative marketing stands for better packing so that products reach the consumer in better condition.

Collective marketing plans for collective buying of all things needed in production and in preparing products for market, thus again lessening costs.

Coöperative marketing stands for eliminating wastes in the cost of distribution.

Coöperative marketing spells the death-knell of speculation in food products, thus stabilizing prices.

Coöperative marketing means making national advertising possible, such as has been done by the Citrus Growers Association and the California Associated Raisin Company, which have enormously increased the consumption throughout the country for these California products, thus greatly adding to the prosperity of California and to its people.

The consumer must inevitably fall heir to his fullest share of all these savings, benefits, and advantages, as has been demonstrated in the California citrus industry, the raisin industry, the peach industry, the almond industry, the walnut industry, and others, not any of which movements have ever put one cent of unfair burden on the consumer; but, on the contrary, have been the means of furnishing him with products, the best of their kind, at the lowest prices.

Functions of a State Market Director.-The director, after study and experience, decides that the functions of a State Market Commission should include the following duties and functions: 
"( $a$ ) Gather and disseminate information concerning supply, demand, prevailing prices and eommercial movements of farm products, including common and cold storage.

"(b) Promote, assist and encourage the organization and operation of coöperative and other associations and organizations for improving the relations and services among producers, distributors and consumers, of any such products.

"(c) Foster and encourage coöperation between producers and distributors of any such products, in the interest of the general public.

" $(d)$ Foster and encourage the standardizing, grading, inspection, labeling, handling, storage and sale of any such products.

"(e) Investigate the practices and methods and any transaction of commission merchants and others who receive, solicit, handle on commission or otherwise, any such products, and to protect and conserve the interests of the consignor.

" $(f)$ Act as a mediator or arbitrator, when invited, in any controversy or issue that may arise between producer and distributor of any such products.

" $(g)$ Certify, for the protection of owners, buyers or creditors, when so requested, to warehouse receipts for any such products, verifying quantities and qualities thereof, and charge for such service fees sufficient to make the service at least self-supporting.

" $(h)$ Issue labels bearing the seal of the State Market Commission for any such products for which State labels have not otherwise been authorized by law, under such rules and regulations as the Director may deem necessary, and charge for such labels such fees as in the judgment of the State Market Director may be proper.

"( $i$ ) Act on behalf of the consumers of any such products in conserving and protecting their interests in every practicable way.

" $(j)$ Act as advisor for producers and distributors, assisting them in economical and efficient distribution of any such products at fair prices.

" $(k)$ Improve, broaden and extend in every practicable way the distribution and sale of any such California products throughout the markets of the world.

" $(l)$ Reduce in every practicable way the expense and cost of marketing said products, that the producer may secure more adequate returns and the consumer a lower cost.

" $(m)$ Promote in the interest of the producer, the distributor and the consumer, economical and efficient distribution and marketing of all or any agricultural, fishery, dairy and farm products produced, grown, raised, caught, manufactured or processed within the State of California."

The first California law was replaced by a new law, creating a "State Market Commission," embodying the principles laid down by Director Weinstock. The same director was continued in charge. In other words, the principles of self help and the collective bargain were endorsed and accepted.

Louisiana.-The Louisiana law provides for a Commissioner of Agriculture and Immigration, whose chief function is to foster direct dealing between producer and consumer. He secures lists of producers and their products for sale, and these lists are then published broadcast throughout the State press and also in the form of weekly bulletins, and in this form sent by mail to such persons as request them. Henry D. Wilson, the first appointee, considered the work not simply worth while, but very important. 
Michigan.-The Department of Markets in Michigan was organized under a $1915 \mathrm{law}$, and James N. McBride became the Market Director. The work is under official coöperation with the State Board of Agriculture, and the United States Department of Agriculture. The work consists largely in investigation and in giving advice. As in California, coöperative marketing is fostered, and particularly the standardization of products and their certification by the State. Price fixing by the Bean Growers associations

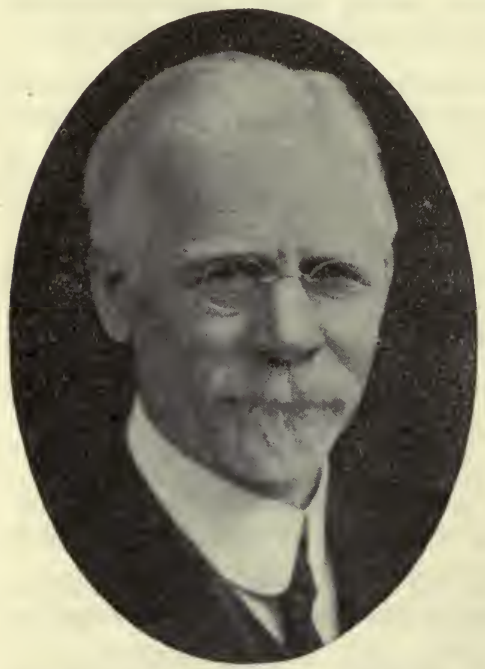

FIG. 20.-John J. Dillon of New York. (Underwood \& Underwood.) is one of the concrete problems which quite early confronted the Director of Markets.

The New York marketing work came into prominence through the vigorous efforts of its first director, John J. Dillon (Fig. 20), to conduct apple auction markets for the farmers. The State Department of Foods and Markets, located in New York City, in charge of Commissioner Dillon, began marketing work in 1915 under a law passed in 1914 . This department coöperated with the State Department of Agriculture, the State Agricultural College, the county farm bureaus, the granges and coöperative associations, and the United States Department of Agriculture. The chief functions were to investigate; to conduct auctions; to study transportation matters and delays; to establish markets, general and local; and to encourage coöperative association work. The direct marketing activities of this Department attracted nation-wide attention. By coöperating with the Fruit Auction Company, a considerable quantity of peaches and apples were sold at auction. Commissioner Dillon considered the auction method to be correct in principle, and entirely feasible and desirable in large market centers.

The New York Department of Foods and Markets pursued a militant course from the start. The New York bakers were forced to restore the five-cent loaf of bread, after raising it to six cents. The price of cold storage eggs was attacked. Jobbers and retailers were required to post signs on "cold storage" eggs. To help the 
milk production interests, an auction of dairy cows was held under the supervision of the Department. Farm shippers used the Department in investigating claims against transportation companies. A hay auction in New York City was undertaken but abandoned.

Commissioner Dillon conceived the need of his State to be as follows: "The first need of the producers of New York State is to help them to organize into geographical or industrial groups, and then to federate these units into one strong central agency. This agency, by the help of the Department, would catalog the principal crops of the State; know where they are located; know their condition and see that they are properly graded and packed. It would keep advised of the conditions of the markets in the principal cities of the country, and be in a position to direct shipments where the best prices prevail."

New York passed a new law in the year 1918, consolidating the old Departments of Agriculture, Foods and Markets, Weights and Measures, and the Cold Storage Administration of the Health Department into a new Department of Farms and Markets. This new Department in turn was divided into two Divisions, Division of Agriculture and Division of Foods and Markets. Under the Division of Fouds and Markets were created seven Bureaus, as follows: Bureau of Markets and Storage; Bureau of Coöperative Associations; Bureau of Food Standardization; Bureau of Food Products; Bureau of Licenses; Bureau of Weights and Measures; Regulative Bureau. Under this law the State of New York is equipped with the most complete administrative machinery in the field of marketing to be found in the United States. Aside from investigation, advice, etc., provided for in all recent market laws, this New York law provides for the establishment of public markets in cities, towns and villages, and for State financial aid to these markets to the extent of fifty per cent of the expense.

North Carolina.-This state is very active in its marketing work. This work is done by the Division of Markets and Rural Coöperation, located at the Agricultural Experiment Station, and its Chief is responsible to the Director of the Experiment Station. This marketing work is done in official coöperation with the State Department of Agriculture and the Bureau of Markets of the United States Department of Agriculture. The chief work falls under four heads-publication of weekly lists of farm products for sale; investigations into marketing practices; promoting coöperative organizations, particularly credit unions; and demonstrating proper cotton grading. 
Ohio's law, enacted in 1917, creates a Bureau of Markets under the supervision of the State Board of Agriculture. The law is apparently designed to insure cheaper products to the consumer rather than to aid the producer. This law provides for a bureau which shall investigate the cost of production and marketing of Ohio food products, to make rules and regulations for grading, handling, storage and sale of food; to investigate the practice and methods and any specific transactions of commission merchants and others who buy or handle food; to act on behalf of consumers in conserving and protecting their interests in every practicable way against excessive prices; to develop direct dealing between producers and consumers; to encourage consumption of Ohio grown products; to inspect and determine grade and condition of farm products both at receiving and shipping centers; to act as moderator or arbitrator in controversies between farmers and shippers which affect the interest of consumers; and to gather and disseminate information concerning supply and demand, prevailing prices and shipments, including common and cold storage of food products.

Pennsylvania.-This State was one of the many states which passed marketing laws in the 1917 sessions of the legislature. The Pennsylvania act creates a Bureau of Markets for agricultural products within the State Department of Agriculture, in charge of a Director of Markets appointed by the Governor upon the recommendation of the Secretary of Agriculture. The law aims to help both producer and consumer at the same time. The Director's duties include the following:

(a) Investigate methods and practices in the production, handling, standardizing, grading, classifying, sorting, weighing, packing, transporting, storing, inspecting and sale of agricultural products.

(b) Gather and disseminate market information to both producers and consumers.

(c) Publish market price bulletins.

(d) Publish lists of names of producers with produce for sale.

(e) Coöperate with the State College and with the Bureau of Markets of the United States Department of Agriculture.

$(f)$ Promote coöperative associations.

(g) Institute court proceedings to prevent unlawful combinations or agreements in restraint of trade or for fixing prices.

(h) Put into effect state grades and state certification of agricultural products.

In this act we find that the problems of standardization of products and a state label or certificate for the same is very carefully considered. 
Texas is a state which has made a very serious effort at solving its marketing problems. In 1915 a State Warehouse and Market Department at the State capital was created, and an appropriation of $\$ 66,000$ was made for its administration. The work began under two managers and fifteen lecturers. The Department is in official coöperation with the State Agricultural Department, the State Agricultural College, the farmers' union organizations, and the boards of trade. The law aims to help the producer, rather than the consumer. The principal activities are the promotion of coöperative warehousing and marketing in farm products.

In addition to this Department the Agricultural and Mechanical College maintains an Advisor in Rural Economics and four assistants, who work on such problems as these: storing and marketing sweet potatoes; farmers' clubs; organizing short time rural credit unions; promoting the organization of egg circles, with especial emphasis upon the need of infertile eggs for Texas. Other coöperative activities are also fostered and promoted.

Washington.-A law was passed in this state in March, 1917, creating the office of State Director of Farm Markets, the Director to be appointed by the Director of the Agricultural Experiment Station. The Director's duties include the following:

(a) To investigate and promote efficient distribution.

(b) A market news service (prices, supply, demand, freight rates, etc.).

(c) Organize coöperative concerns of producers and consumers.

(d) Examine under oath individuals, officers, and employers dealing in farm products.

(e) Investigate the parcel post.

(f) Conduct employment bureau for farm laborers.

(g) Investigate transportation (methods, delays, charges).

(h) Recommend legislation.

Enough has been said to show the various methods of attack on the marketing problem used by different States. Some States go so far as to do actual marketing. Others furnish state aid only as a means of promoting self help among the farmers. The States which are developing self help are obviously dealing more fundamentally with the problem, and consequently with better prospects of ultimate success.

Field Agents in Marketing.-Supported in part by the state and in part by the federal Government, there is now coming to be in each State a marketing official known as the Field Agent in Marketing. His work is done in official coöperation between the Bureau of Markets and the State University or State Agricultural College. The chief work of such an agent is to secure information. 
To a lesser extent he coöperates with producers in organizing coöperative associations and in promoting rural finance. The Field Agent in Marketing looks on the furnishing of reliable information as the first step in solving the marketing problem. The producers, it is supposed, when equipped with full and accurate information can organize their own marketing agencies and take care of themselves, freely using, of course, the advice and coöperation of the Field Agent.

National Association of Marketing Officials. - The state marketing officials and the various Field Agents in Marketing organized an Association which held its first two annual meetings in connection with the National Conference on Marketing and Farm Credit at Chicago in 1915 and 1916. This Association aimed to bring together in one group representatives of all shades of opinion and all varieties of practice in marketing matters. However, it failed to function. In 1920 a new organization, the National Association of State Marketing Officials, was formed at a Conference in New York City. The aim is similar to that of the old association.

Bureau of Markets. - The federal government in 1914 established in the Department of Agriculture the Office of Markets and Rural Organization. Since the creation of this office its scope and activities have been rapidly enlarged. It is now a Bureau. Primarily its aim is to investigate and present its facts to the public. But it has now gone much beyond that stage. It aims to help make history as well as merely to write history. It fosters coöperation, based on correct business practice. It formulates and installs correct accounting systems. It establishes standard and uniform grades for cotton and grains. It furnishes telegraphic market information on perishable products. The Bureau of Markets, as previously mentioned, is in coöperation with the market department of most of the States with such departments, and with the Field Agents in Marketing.

Parcel Post Marketing.-The parcel post was looked on by some voters as a promising method of introducing "direct marketing" and the elimination of the "middleman." The system has been tried very thoroughly in the United States, but it has had very little success in getting farm products direct from the farmer to the city consumer. The physical difficulties have been overcome. Containers have been devised, costing very little, which will safely carry eggs or other highly perishable commodities a thousand miles with a negligible per cent of damage (Figs. 21 and 22). 
But the marketing difficulties have not been overcome. If there is a saving in price, who shall get it? The farmer has felt that the margin belongs to him and should be added to his price. The city consumer wants the product cheaper when dealing direct with the producer. Only a small portion of farm products are suited to marketing by parcel post. The farmer, to succeed in parcel post marketing, must meet several standard market requirements: the supply must be fairly constant in both quantity and quality, in order to meet consumer's orders; there must be some

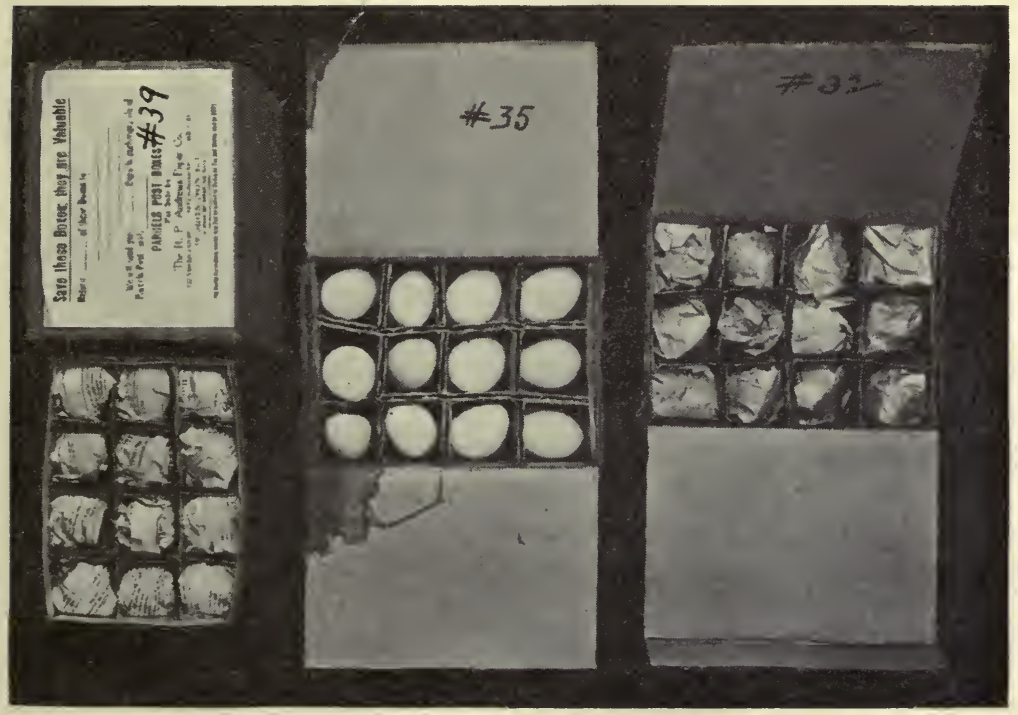

FIG. 21.-Shipping eggs by parcel post. (U. S. D. A.)

standard grade or brand by which both producer and consumer can designate the article; packing must be good in appearance and correct in preserving the goods properly; the question of price and the question of time and manner of payment must be mutually understood. The two big problems remain-How find the consumer? and How fix the price? Farmers who have tried parcel post marketing complain that the city consumers "want the stuff for nothing." The city consumer complains that the produce was of an inferior grade. Until standard grades and packs have been established, which will require coöperative associations among farmers, there is little prospects for success in parcel post marketing of farm products. 
The Cost of the Middleman.-A few years ago some writer put into circulation the superstition that the middleman gets fifty cents out of every dollar the consumer pays, and that the farmer, in consequence, received but half the price paid by the ultimate consumer. And in more recent times the middleman's "toll" is commonly given as sixty-five cents on the dollar. No earnest seeker after the truth will be satisfied with such sweeping assertions as these. Since the "toll" of the middleman varies greatly from one product to another, depending on the various factors involved,

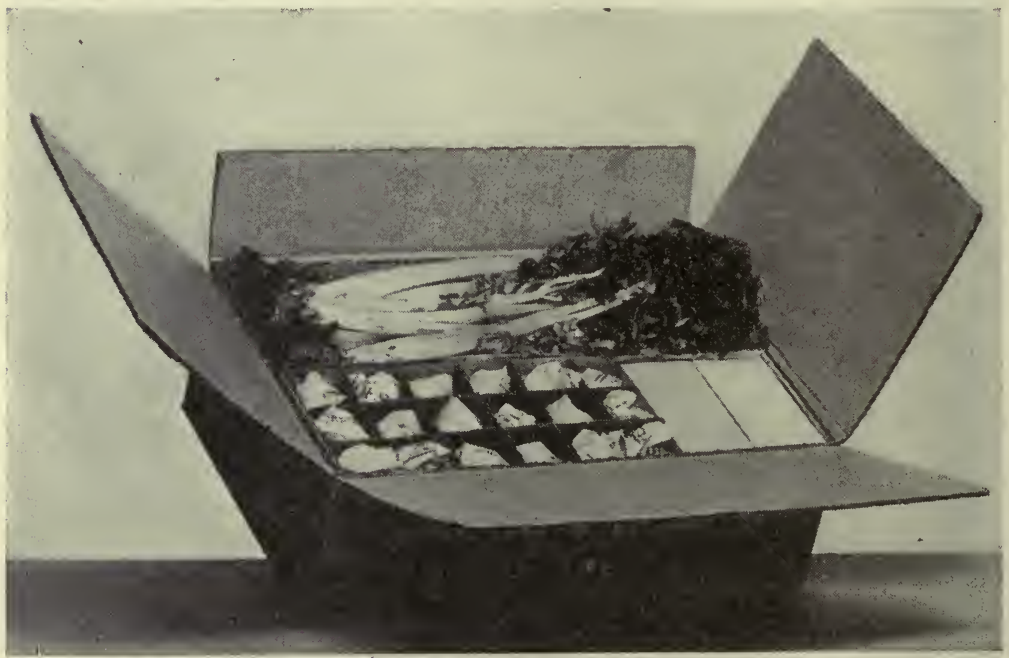

FIG. 22.-Shipping perishable farm produce by parcel post. (U. S. D. A.)

it is necessary-and it is also the honest way-to inquire separately into some of the commoner articles of consumption coming from the farm. Some of the common articles considered below are bread, meat, butter, eggs, potatoes and tobacco. Careful studies have been made in all these fields by federal and State government investigators.

Wheat and Flour.-We may trace wheat into export, till it reaches the hands of the Liverpool buyers, or we may trace it in domestic trade till it passes as flour from the retailer to the householder. Taking the Kansas wheat crop of 1914, we find that the Kansas farmer got seventy-five cents out of the dollar paid by the Liverpool buyer. The various margins between the Kansas wheat grower and the Liverpool buyer were as follows: 


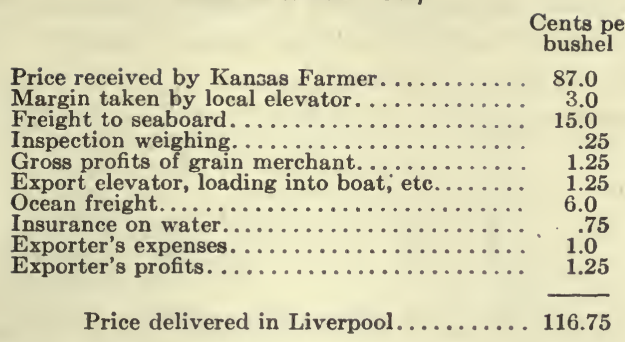

Here the biggest margin taken by any dealer is the three cents taken by the local elevator.

If we trace the wheat through the mill, and as flour, into the hands of the housewife; the margins are as follows:

The 1906 Wheat Crop-Producer to Consumer ${ }^{2}$

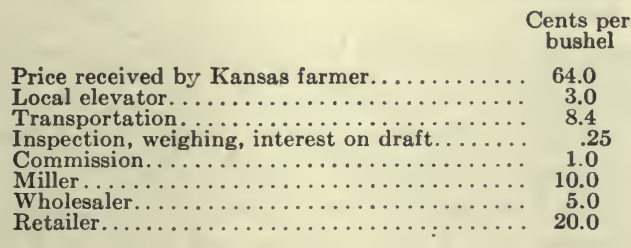

Price to householder of flour contained in one bushel of wheat......... 111.65

In this case, transportation and milling are expensive services which change the place or form of the wheat. The largest margin for "handling" the product is the retailer's margin. This is typical of all commodities, and this retailer's margin increases as the commodity becomes more perishable.

Meat.-Different investigations have been made by various market experts into the gross margins in the meat industry. One careful investigation gives us these margins:

Cattle

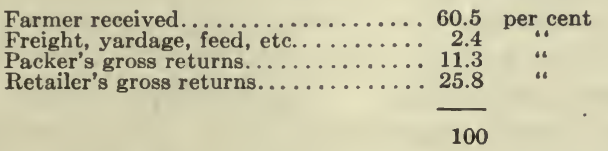

Hogs

\begin{tabular}{ll}
60.2 & per cent \\
2.1 & “" \\
15.4 & “" \\
\hline 100 &
\end{tabular}

${ }^{1}$ Prices of wheat to Producers in Kansas, etc. 63 Cong; 3 Sess. House Doc. No. 1271.

2 Bulletin of the United States Bureau of Labor Statistics, No. 130, "Wheat and Flour Prices from Farmer to Consumer." 
But individual shipments vary so much that it is rarely correct to speak in specific terms of the middleman's margin. For instance, here are nine lots of cattle:

Nine Lots of Cattle. Division of the Consumer's Dollar

\begin{tabular}{|c|c|c|c|c|c|c|c|c|c|}
\hline & 1 & 2 & 3 & 4 & 5 & 6 & 7 & 8 & 9 \\
\hline $\begin{array}{l}\text { Farmer............... } \\
\text { Freight, yardage, feed. } \\
\text { Packer. ............... } \\
\text { Retailer........... }\end{array}$ & $\begin{array}{r}79.29 \\
1.46 \\
8.44 \\
10.81\end{array}$ & $\begin{array}{r}85.67 \\
1.51 \\
4.35 \\
8.47\end{array}$ & $\begin{array}{r}54.69 \\
4.38 \\
7.64 \\
33.29\end{array}$ & $\begin{array}{r}79.49 \\
9.95 \\
8.68 \\
1.88\end{array}$ & $\begin{array}{r}78.88 \\
1.92 \\
3.92 \\
15.28\end{array}$ & $\begin{array}{r}81.64 \\
2.57 \\
1.86 \\
13.93\end{array}$ & $\begin{array}{r}67.97 \\
2.60 \\
6.53 \\
22.90\end{array}$ & $\begin{array}{r}67.18 \\
4.97 \\
6.02 \\
21.83\end{array}$ & $\begin{array}{r}77.78 \\
1.86 \\
6.53 \\
13.83\end{array}$ \\
\hline 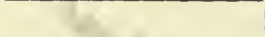 & 100 & 100 & 100 & 100 & 100 & 100 & 100 & 100 & 100 \\
\hline
\end{tabular}

Summary, Nine Lots

Farmer...................6 66 to 75 per cent

Freight, yardage, etc............ 3 to 4 per cent

Packer....................... 5 to 6 per cent

Retailer................... 15 to 30 per cent

Figures compiled on cattle handled through the South St. Paul market showed these margins:

Farmer...................... 58 per cent

Retailer............................ 30 per cent

The remaining 12 per cent is divided among packer, transportation, yardage, feed, etc. While the retail butcher gets a gross profit here of thirty per cent, yet he has but a small net profit, owing to his heavy expenses and small volume of business.

Butter.-The United States Department of Labor issued a series of bulletins on "Retail Prices and Cost of Living Series." Bulletin No. 164 of this series is entitled "Butter Prices from Producer to Consumer." Among the important findings in this bulletin are the margins as shown in the following table:

Butter-Margins, by Per Cents, 1904, 1910, 1911

\begin{tabular}{|c|c|c|c|c|c|c|}
\hline & \multicolumn{2}{|c|}{1904} & \multicolumn{2}{|c|}{1910} & \multicolumn{2}{|c|}{1911} \\
\hline & June & December & June & December & June & December \\
\hline 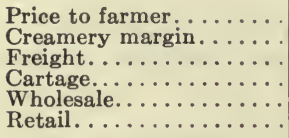 & $\begin{array}{r}62.5 \\
9.7 \\
3.0 \\
.1 \\
5.3 \\
19.4\end{array}$ & $\begin{array}{r}70.8 \\
10.3 \\
2.2 \\
.1 \\
4.7 \\
11.9\end{array}$ & $\begin{array}{r}74.5 \\
5.9 \\
2.1 \\
.1 \\
4.6 \\
12.8\end{array}$ & $\begin{array}{r}72.9 \\
7.1 \\
1.9 \\
.1 \\
4.4 \\
13.6\end{array}$ & $\begin{array}{r}70.0 \\
7.3 \\
2.4 \\
.1 \\
5.3 \\
14.9\end{array}$ & $\begin{array}{r}75.9 \\
6.7 \\
1.7 \\
.1 \\
4.3 \\
11.3\end{array}$ \\
\hline er's price. & 100.0 & 100.0 & 100.0 & 100.0 & 100.0 & 100.0 \\
\hline
\end{tabular}

The producer is here getting from two-thirds to three-fourths of the ultimate consumer's dollar. The retailer's margin is, of course, the largest single margin by far. The wholesaler's margin remains small and fairly constant, owing to his large volume of business.

A Wisconsin investigation is in substantial agreement with this one. The Wisconsin farmer receives two-thirds of the 
money paid by the consumer for Wisconsin butter. Here are the figures:

The Marketing of Wisconsin Butter. ${ }^{3}$ Who Gets the Money?

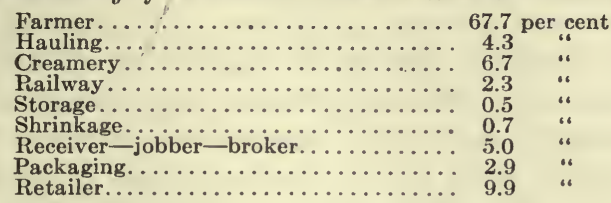

Eggs.- Tracing a dozen eggs from an Iowa farmer to the consumer in New York we have the following summary:

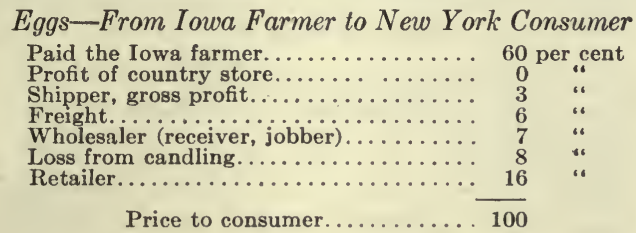

The bulk of the farmer's eggs are consumed nearer home, and hence bring to the farmer a larger margin. The loss from candling is an unduly large margin. With proper organization of producers' egg circles this margin could be entirely eliminated, and this saving would doubtless go to the producer in part, and in part to the consumer.

Potatoes.- One of our best discussions of marketing is that by L. D. H. Weld. ${ }^{4}$ He estimates that the farmer receives fifty cents of the consumer's dollar spent for potatoes. Here we have a highly perishable product. Farmers in the northern States (where most of the potatoes are grown) frequently store their own potatoes in the fall, rather than sell them to the "middleman." A shrinkage of from four to fifty per cent in such a case is common. Improved storage facilities will overcome this risk to a certain extent. But the ideal storage is difficult to secure, since this implies dry, wellventilated air, at a temperature remaining constant at about 33 degrees. An investigation into potato marketing conducted by the University of Wisconsin gives us this table of middleman's charges:

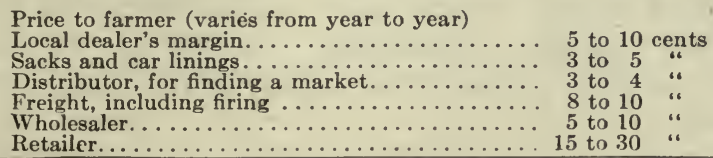

${ }^{3}$ Bulletin No. 270, Agricultural Experiment Station, University of Wisconsin, June, 1916.

${ }^{4}$ Weld, L. D. H., The Marketing of Farm Products. 
The average retailer's margin here $\left(22 \frac{1}{2}\right.$ cents) is typical of all retail margins, namely, the largest taken by any middleman. Small volume of sales and not large profits account for it.

Tobacco.-The Kentucky Agricultural Experiment Station has issued a report (Bulletin 202) on the Marketing of Burley Tobacco in central Kentucky. This study shows, as in other commodities, the largest handling charges are those of the retailer.

The distribution costs are divided into three main categoriesretailer's gross profits, jobber's gross profits, and the manufacturer's gross receipts. Here are the results of the interesting study: Where the Money Goes-Price 67.08 Cents, One Pound, Average Brand, Plug-cut Smoking Tobacco

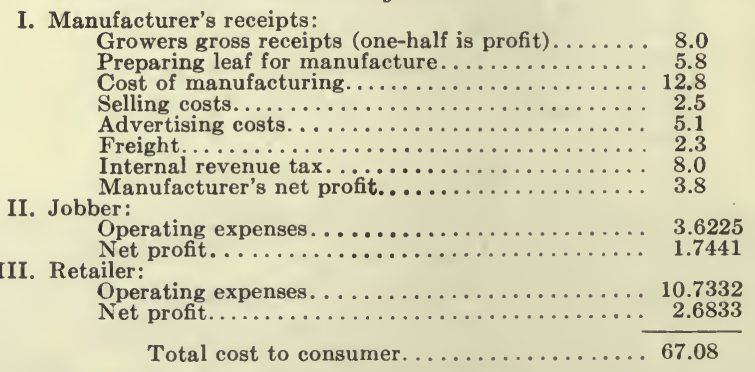

Citrus Fruits.-Oranges, lemons, and grape-fruit are among the very perishable commodities; are consumed thousands of miles from the point of production, and are consumed also at seasons of the year several months from the time of their being picked. The President of the California Fruit Growers Exchange has given us a careful statement of the various margins in this industry.

\section{The Consumer's Dollar 5}

(Thirty Citrus Fruit Markets: 5485 reports for the year 1914)

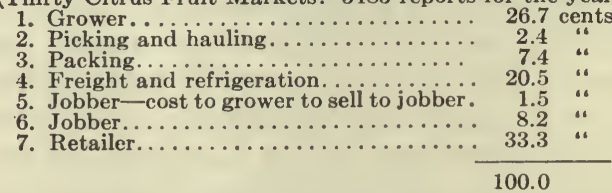

California Peaches.-Six thousand peach growers in California organized for collective marketing. According to their 1918 report, the producer received the following fractions of the consumer's dollar:

1916 crop. ................. 77 cents

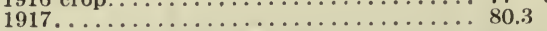

${ }^{5}$ Powell, G. Harold, Address delivered at the Eleventh Annual Meeting Western Fruit Jobbers Association. 
California Raisins.-The California Associated Raisin Company distributes its own product very widely. It was estimated that the producer, on the 1917 crop, received 61.2 cents of the consumer's dollar.

California Almonds.-The California Almond Growers disdistribute their crop in very distant markets. On the 1918 crop it was estimated that the producer received 53 cents of the consumer's dollar.

Risks in Price Fluctuation.-The middleman, dealing in perishable produce, is often spoken of in the press as a "food speculator." In a strict sense of the term, every owner of a perishable product is a speculator, since he has thereby assumed the risk incident to price fluctuation and incident to loss by decay.

Few producers realize the actual range of price fluctuation in one season on the common forms of perishable farm products. The following table, compiled in one northern city, is believed to be typical for the whole United States.

Price Fluctuations (Unhedged Products), Minneapolis Central Market, Season of 1907

\begin{tabular}{|c|c|c|c|}
\hline Name & Quantity & Low price & High price \\
\hline 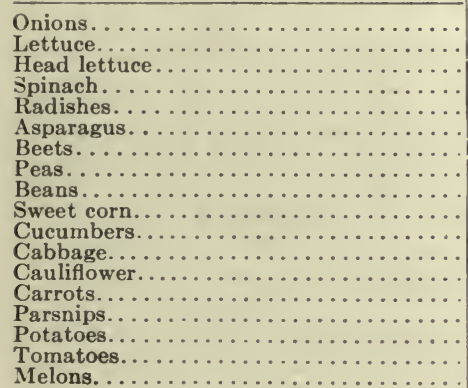 & $\begin{array}{l}\text { doz. bunches } \\
\text { doz. } \\
\text { doz. } \\
\text { bu. } \\
\text { doz. } \\
\text { doz. } \\
\text { doz. } \\
\text { bu. } \\
\text { bu. } \\
\text { doz } \\
\text { doz. } \\
\text { doz. } \\
\text { doz. } \\
\text { doz. bunches } \\
\text { doz. bunches } \\
\text { bu. } \\
\text { bu. } \\
\text { bu. }\end{array}$ & $\begin{array}{r}\$ 0.06 \\
.15 \\
.25 \\
.50 \\
.10 \\
.35 \\
.25 \\
.50 \\
.75 \\
.07 \\
.25 \\
.35 \\
.50 \\
.25 \\
.25 \\
.60 \\
.50 \\
.50\end{array}$ & $\begin{array}{r}\$ 0.15 \\
.34 \\
.75 \\
1.95 \\
.20 \\
.80 \\
.60 \\
2.00 \\
3.00 \\
.20 \\
.75 \\
.75 \\
2.00 \\
.60 \\
.60 \\
1.75 \\
5.00 \\
2.00\end{array}$ \\
\hline
\end{tabular}

(From an unpublished manuscript, The Growing and Marketing of Small Fruits and Vegetables, by D. W. Frear.) per cent.

The smallest fluctuation in price for the season was 100 per cent; the largest, 900

Risks from Perishability.-According to a careful study made by A. B. Adams, ${ }^{6}$ perishable farm products show losses from decay of thirty-five to forty per cent. Hence from 30 to 40 per cent of the margin between farm prices and retail prices of products passing through the middleman's hands is due according to this study, to losses from decay. This margin goes to pay for goods

${ }^{6}$ Adams, Arthur B., Marketing Perishable Farm Products. 
bought from farmers, but which never reach consumers. The loss, of course, is added to the price of the goods as a protection to the dealer. The middleman "hedges" or insures himself against loss by buying on a sufficiently wide margin to give him protection. Otherwise he fails in business. Mr. Adams also emphasizes the point that the number of middlemen concerned is not the ruling factor, but that there are four economic reasons for the present big spread in price, namely: (1) The perishability of the goods; (2) The great distance between the producer and consumerfrequently a thousand miles or more; (3) These goods are produced by small-scale units - the individual farm, and are consumed by small scale units - the individual family; (4) The high expense of caring for these perishable goods. Standard grading and standard packing, whether done by the progressive individual farmer, or by a farmer's coöperative association (like the California Fruit Growers Exchange Local Orange Packing Houses) is the first step towards reducing these spreads in prices. Further remedies suggest themselves - such as (1) cold storage facilities for each community producing perishables for market; (2) facilities for canning, preserving, manufacturing or otherwise processing these goods near the point of production, putting in the market only the high grade produce.

Services of the Middleman.-The middleman's service as a risk-taker has already been mentioned. By careful study and long practice he becomes better able to forecast and hence discount the economic risk. Time was, to be sure, when there were no middlemen. Then, by barter and by the great annual fairs and markets, producers and consumers enjoyed "direct dealing." But gradually the producers and consumers, of their own free will, gave up these forms of "direct dealing." The middleman came in, to bring goods from distant points to the place where the consumer wanted them and to collect and store goods, in such quantity and of such quality, as to supply them to the consumer at the right time, of the right amount, of the right kind.

In economic phraseology, the middleman produced "time" and "place" utility, which are just as important as the production of the raw material itself, and just as truly "productive." As one writer so ably. sums up the economics of the middleman system: "One of the most noteworthy ideas that results from a study of the present retailing system with all its complexities, is that it is the product of an evolution extending back over a great many years, and that during all the intervening time there has gone on 
a steady, relentless elimination of all forms of distribution found uneconomical." 7

Selling is a Service.-Farmers are slow to accept the fact that selling, like producing, is a service. The following quotation from a farmers' company illustrates the reality of the middleman's service - a department store being the middleman in this case.

"An effort was made, through advertising and personal solicitation, to sell direct to the consumer, but this was found more expensive than working through large department stores or companies owning a number of grocery stores. The Exchange had sale days for boxed apples in several cities, at which time it offered to deliver to any home in these cities at the flat rate of $\$ 2.25$ per box. It cost the Exchange a fraction over 36 cents a box to make deliveries, thus leaving $\$ 1.89$. Better prices resulted from an arrangement made with some department stores, which paid the exchange $\$ 2.00$ per box and sold on certain days to consumers at $\$ 2.25$ per box, the retail price advertised by the Exchange. The Exchange received 11 cents more per box in selling to large dealers than in selling direct to the consumer." 8

Probable Solution.-The middleman problem is largely a problem of the retailer, for here is where the large margins are taken. Coöperative associations of producers can eliminate many wastes involved in the first steps of marketing (getting a standardized, certificated, properly packaged product) into the hands of the wholesale distributors. But the retailing feature is the most serious part of the problem. Reformers have suggested various solutions.

"Carry your own bundles and save eight per cent," says a New York editor.

"I believe it will always be necessary," replies a business man, "to deliver goods to the purchaser. Women have come.up through thousands of years from slavery to where they are to-day. They are not going back. They can now pick up a telephone and have a yeast cake delivered to them in ten minutes. Any scheme to educate the consumer to save money at the expense of trouble and inconvenience is bound to fail." 9

The criticism is often made, and probably justly made, that we have entirely too many retail stores. Some careful investi-

${ }^{7}$ Nystrom, Paul H., Economics of Retailing, p. 357.

${ }^{8}$ Report of the Growers and Shippers Exchange, Rochester, N. Y., U. S. Dept. of Agriculture, Report No. 98, 1913, p. 236.

${ }^{9}$ Dudley B. Palmer in the Outlook, March 14, 1917, p. 460. 
gators, however, say that the burden of this does not fall on the public, but on the retailer himself. In other words, many men accumulate a little capital in other walks of life, go into retail trade, and fail. One writer expresses it in this way:

"In conclusion it may be stated that, from the standpoint of the entire public, there is nothing to indicate that the great number of retail stores adds anything to the burden of expense the consumer must bear. The high failure-rate in the retail business would seem to indicate that retail distribution is supported, in part at least, not by the consumers who patronize the stores, but by the great numbers who enter the business of retailing with capital accumulated in other occupations, and then lose it in the retailing venture. The losses of the dealers who fail are primarily the losses of the dealers themselves. Only in the most general way of speaking could one assert that the public must bear the burden. Certainly, no extra burden is added to the prices charged consumers because of the keenness of competition resulting from too many stores." 10

An Ideal Retailing System.-Nystrom pictures for us an "ideal" retailing system. Such a system, says he, would supply the people what they want, the way they want it, when they want it, and at as low a price as possible. The profits should be fair, and in accordance with the service rendered. And more than this, the salesman must be able to render an expert service. Is he a groceryman? Then he should be a specialist in food values, in dietetics, and in the preparation of foods. The man in dry goods should be a textile and style expert, able to lecture to women's clubs on these subjects. The rug dealer should be able to educate his customers in the intricate lore of the rug. The store room and store equipment must be up to the highest possible standard of cleanliness, sanitation, convenience, and artistic and architectural arrangement. Pure food laboratory tests (made in the store's own laboratory or in one supplied by the municipality or State) should protect the customer. Public regulation is now setting standards for inspection of foods, drugs, stores, restaurants, weights, scales, measures, etc. Untruthful advertising should come under State control next, says Nystrom.

Retailers' Conference.-In Winnipeg conferences have been held by wholesalers, retailers, and bankers, to determine what methods, if any, could improve the credit conditions of merchandising, and what reforms, if any, could be effected in wholesaling and

${ }^{10}$ Nystrom, Paul H., Economics of Retailing, p. 335. 
retailing. The consensus was that the retailers, particularly in the country towns, are needed by the farmers, and hence the mail-. order houses of the city should not supplant them. The country town, consisting largely of retailers, should prosper with the farmers, and not at the expense of the farmer. For, of course, the farmer knows that his land values are substantially raised by the prosperity and growth of the nearby village. The retailers, in the Winnipeg conference, blamed the wholesalers for high prices, claiming that the wholesaler would not sell goods to them at a low enough rate. The answer was that the retailers ought to combine in coöperative groups, and purchase jointly in larger volume, thus enabling the wholesalers to do business on smaller margins. The Conference had one beneficial effect, namely, to call public attention to the problem of the small town retailer.

Marketing Costs Money.-One important lesson which many farmers have apparently not yet learned is that marketing costs money, and is worth money. Indeed marketing in certain products must always represent a large margin of the consumer's cost. Where farmers have successfully organized in any part of the United States and done their own marketing, one of the first lessons they have learned is that the information service alone has cost them a large amount of money. Thus the produce growers in two eastern counties of Virginia (Eastern Shore of Virginia Produce Exchange) spend as much as twenty-five thousand dollars a year for telegrams and telephone service. The Orange farmers of California (California Fruit Growers Exchange) spend as much as seventy-five thousand dollars a year for telegraph and telephone service. An individual buyer of potatoes in North Dakota spends seven hundred dollars a month for wire service during the busy season. If a farmer in the United States to-day is asked to name one example of the highest possible efficiency in marketing, of marketing conducted on the lowest margin of "middleman's" . expense, he would probably name the Ford automobile. This is admittedly an example of a business which has been, up to the present writing at least, conducted with an idea of fair service to the consumer. And yet the "middleman's" margin, the profit taken by the retailer, is fifteen per cent. The so-called "direct marketing" is not encouraged in the distribution of this product. Indeed, if the consumer orders his car direct from the central house in Detroit, he pays his fifteen per cent commission just the same. And this method of doing business has had two results: It has caused a great expansion in the volume of the business. This 
volume of business, in turn, has made possible improvements in the product, a lowering of price to consumers, and an increase in profits to the manufacturer.

Ford Motor Company.-A person connected with the advertising department of the Ford Motor Company was asked to express his opinion on the subject of marketing costs. This he did in the following way:

"The fifteen per cent allowed to the agent for making the sale carries with it the certainty of considerable gratuitous service, which is rendered the owner of the car, not only at the time of the purchase but during the years that follow. It is as low a point as is safe or consistent with good reliable business judgment. For, out of this the agent must maintain his place of business up to a certain standard in the way of equipment for making replacements and repairs, for looking after the welfare, not only of the one owner, but of all the owners within his territory, and all Ford owners who may drive through with their cars that require attention and service. He must pay his overhead, he must pay on the investment in his business, and he has to be a mighty aggressive and energetic agent if he makes any considerable amount of money.

"It would seem to us there is a broad field for doing very valuable work in enlightening the farmer as to the necessity of business methods and business expenses. The primitive way will not do. There would be no progress. The reaping machine would never have come into existence-the farm tractor, the gang plow, the automobile and all the advantages of modern civilization and progress would never have been born-if it were not possible to develop a saving of time and a making of money through their use by farmers. All these advances that have come from the brains of active business men have been for the benefit, for the economy, for the profit of the farmer. And he should be the one to welcome them most eagerly rather than to be picayune and expect any man to do business for his interests or the interests of anyone clse without a profit ... The laborer is worthy of his hire, and nowhere else more worthy than in being that connecting link which brings to the farmer those larger possibilities for making money and clothing himself with comforts and luxuries. One trouble with the farmer is that he does not place any value upon time. He will drive milk two miles to a milk depot, and he will never estimate the cost of driving it from his house to the depot and back again. It might take him two hours with a team of horses whose labors are worth $\$ 4.00$ per day, and his own $\$ 2.00$, but he counts it no cost."

The Farmer's Middleman.-Farmers favor "direct marketing" as an ideal system. There is one place where the farmer's theory of direct marketing is put to the final test, and that is in the socalled "sales" or "auctions" held by farmers. At these "sales," where the farmer desires to dispose of his goods and chattels in quick time and on good terms, he has the privilege of selling "direct" to the consumer. Yet I have never known a farmer to do so. In practice he employs an expert middleman, known as an auctioneer, to sell his goods. The farmer does this because he saves time and money by it. The consumer, too, saves time by it, and since he buys the goods at his own price, he cannot object to paying for the services of this middleman. 
The middleman will disappear when we dispense with his services, and not till then.

Since "direct marketing" is an ideal which can never be realized in its entirety, the farmer's opportunity for improving his marketing, permanently and economically, seems to lie in the direction of owning or controlling the middleman, not in eliminating him. This, of course, signifies a high degree of organization on the part of the farmers, coupled with standardization of product, so that a group of farmers in one section can deal "direct" (through their proper representative agent, a "middleman") with an organized group (through its representative) in some other section, be the group farmers or city consumers. Progress in this direction is slowly being made. With the coming of the county agent in every county, and with a fuller development of the present "Country Life Betterment" movement, the farmers will be in a strong position for marketing their products.

Collective Bargaining.-The words "collective bargaining" have come into general use as signifying the dealings between organized laborers and capitalists in adjusting wages and conditions of employment. It is held to be legal for the laborers thus to dispose of their labor collectively. Collective bargaining is just arriving in agriculture. It is based on collective action, that is, the organization of a group of farmers. The most conspicuous examples thus far in agriculture in America are those of the organized dairymen in the New York and the Chicago districts, fixing prices with distributors by means of the collective bargain. The collective bargain has also been used by organized tenants in fixing rents; by organized producers, both in buying supplies and in selling farm products; the collective bargain has -also been used by farmers in fixing the wages of farm labor.

The "elimination of the middleman," so far as such a thing is feasible and desirable, will come about increasingly through the growth of collective bargaining in agriculture. This growth presupposes an increase in real coöperation, that is, coöperation which is for savings, not for profits.

\section{QUESTIONS ON THE TEXT}

1. Show the four underlying problems in marketing. When did the States begin marketing activities? Account for this new activity.

2. Show in detail how the marketing problem was attacked by each of the following States: Idaho, California, Louisiana, Michigan, New York, North Carolina, Ohio, Pennsylvania, Texas, Washington.

3. Going back to the California case, what principles of marketing were finally accepted as correct? 
4. Distinguish between temporary makeshifts and fundamental reforms.

5. Explain in detail the functions of the so-called "Field Agents in Marketing."

6. What is the National Association of State Marketing Officials?

7. Explain at length the functions and methods of the United States Bureau of Markets.

8. Show the success and the limitations of Parcel Post marketing.

9. Cite facts showing the costs of the middleman, i.e., the so-called "middleman's toll," in the following: wheat and flour; meat; butter; eggs; potatoes; tobacco; citrus fruits; California peaches, raisins, and almonds.

10. Show in detail the risks in price fluctuations, citing examples.

11. Show risks from perishability.

12. Show the economic functions of a middleman.

13. Cite the experience of the Growers and Shippers Exchange of Rochester, N. Y., and show what principle it illustrates.

14. What is the probable solution of the "middleman problem"? Will the consumer demand more or fewer services from the middleman, as time goes on?

15. Cite Nystrom's views on retailing.

16. State briefly the outstanding facts on the Winnipeg Conference of wholesalers, retailers, and bankers.

17. Cite the marketing costs involved in securing market information by farmers' organizations, and justify this expenditure.

18. What marketing principles are illustrated by the distribution methods of the Ford Motor Company?

19. Does the farmer's use of the auctioneer illustrate any principle in marketing?

20. When, if ever, will the middleman disappear?

21. What should be the future line of growth in market reform? Explain the present and probable future field of the collective bargain.

22. Comment on the Mail Order House question; Butter Marketing at Grand Rapids; California Almond Growers' Brokerage problem.

\section{QUESTIONS SUGGESTED BY THE TEXT}

1. To what extent should the State give aid to farmers in marketing their products?

2. To what extent should combines among farmers be legalized?

3. How should the selling price of farm products be determined and by whom?

4. Formulate an ideal system of storage, transportation, and credit for farm products.

\section{REFERENCES}

1. Brown, Buiss S.: "Modern Fruit Marketing." New York, 1916.

2. Filley, H. C.: "From Cardoor to Consumer," Circular No. 5, Nebraska Agricultural Experiment Station, January 1, 1918.

3. FitTs, EDward B.: "Marketing Hogs in Oregon." Extension Bulletin No. 214, Oregon Agricultural College, August, 1917. 1916.

4. WeLd, L. D. H.: "The Marketing of Farm Products." New York,

5. Holmes, George K.: "Systems of Marketing Farm Products and Demand for Such Products at Trade Centers." Report No. 98, United States Department of Agriculture. Washington, January, 1913. Contains accounts of all principal coöperative associations in the United States in 1913.

6. Adams, A. B.: "Marketing Perishable Farm Products," Columbia University studies, Vol. 72, No. 3, 1916.

7. KeRR, W. H., AND WeLD, L. D. H.: "Prices of Wheat to Producers in Kansas," etc. 63 Cong. 3 Sess., House Doc. 1271, Washington, 1914.

8. Huebner, Grover: "Agricultural Commerce, "New York, 1915. 
9. Benjamin, Earl W.: "Market Egg Problems," Bulletin 65, Department of Agriculture, Albany, 1914, 368-385.

10. Myrick, Herbert: "How to Coöperate." New York, 1891.

11. Nourse, Edwin Griswold: "The Chicago Produce Market," New York, 1918.

12. Poe, Clarence: "How Farmers Coöperate and Double Profits," New York, 1915.

13. Nystrom, Paul H.: "The Economics of Retailing," 1915.

14. BAIley, L. H. (Editor): "Cyclopedia of Agriculture," Vol. 4, 239-269.

15. American Economic Review, IX, No. 1, March, 1919. Papers and Proceedings of 35th Annual Meeting. Effects of Government Control on Marketing Methods and Costs: Discussions by Hibbard, Boyle and Smith, pp. 47-61. Some purposes of price fixing and its results: G. F. Warren. $233-246$.

16. "Minnesota Studies in Marketing Farm Produce," 1915, pp. 1-113. Discussion of following subjects: livestock; potatoes; poultry; milk; city market of Minneapolis; grain; food supply of the Iron Range.

17. "National Conference on Marketing and Farm Credits," Chicago, $1913 ; 1915 ; 1916$.

18. "Industrial Commission Report," Vol. VI, 5-297; 337-454, 1900, Vol. IX, xc-c, 1901; Vol. X, cexciii, 1901.

19. Yearbook Department of Ágriculture: 1899, "Dairy Development," 381-403; 1900, "Influence of Rye on the Price of Wheat," 167-183; 1901, "Wheat Ports of the Pacific Coast," 567-581; 1902, "Distribution and Magnitude of Poultry and Egg Industry," 295-309; 1904, "Consumers' Fancies," 417-435; 1909, "Methods and Costs of Marketing," 161-173; 1910, "Effect of Present Method of Handling Eggs on the Industry and the Product," 461-477; 1911, "Handling and Marketing of Eggs," 467-479; 1911, "Reduction of Waste in Marketing," 165-176; 1912, Corbetr, L. C.: "A Successful Method of Marketing Vegetable Products," 353-363; 1912, Pierce, H. C.: "How the Produce Dealer May Improve the Quality of Poultry and Eggs," 345-353; 1912, Pennington, M. E.: "The Handling of Dressed Poultry One Thousand Miles from the Market," 285-293; 1915, Wilcox, E. V.: "How Hawaii Helps the Farmers Market their Produce," 131-146; 1915, Clark, E. D.: "Shipping Fish Three Thousand Miles," 155-158; 1915, Wolfe, Stanley L.: "Pointers on Marketing Woodlot Products," 121-130; 1918, Folger, J. C.: "The Commercial Apple Industry of the United States," 367-379.

20. Butrer, Ralph Starr: "Marketing Methods" (Vol. 5, Modern Business, Alexander Hamilton Institute, New York, 1917), pp. 1-140; 206$225 ; 322-335$.

21. Swinney, John B.: "Merchandising" (Vol. 19, Modern Business, Alexander Hamilton Institute, New York, 1917), pp. 298-348.

22. On Milk Marketing.-Files of official organs of organized milk producers, as follows: (a) Dairymen's League News (Watertown, New York); (b) Oregon League Dairyman (Portland, Oregon); (c) The Milk News (Chicago); (d) Dairymen's Price Reporter (Youngstown, Ohio); (c) New England Dairyman (Boston). Independent paper: The Milk Reporter (Suffolk, New Jersey). Also following sources-BABCock, H. E.: "The Dairymen's League," Cornell Countryman, March, 1919; National Milk Producers Federation (By-laws), "Marketing and Farm Credits Conference," Chicago, 1916, 430432; Cavert, W. L.: "Milk Distribution in Minneapolis and St. Paul," Uni. of Minn. Studies in the Marketing of Farm Products, No. 4, Feb., 1915, 73-87; Horton, H. E.: "Marketing Whole Milk, Marketing and Farm Credits Conference," Chicago, 1916, 401-409; Bush, Gwendell: "New York Milk Fight" (same volume), 409-418; KirkPATrICK, K. A.: "Marketing Milk in the Twin Cities" (same volume), 418-421; Milk Producers Federation (same volume), 421-425; WheEler, Wilfred: "Marketing Milk in New England, 
Marketing and Farm Credits Conference," Chicago, 1915, 141-151; KrTtLe, W. J.: "Distribution of Whole Milk in Chicago" (same volume), 152-158; Chicago Milk Producers Association: "Marketing and Farm Credits Conference," Chicago, 1913, 128-131; Report of Fair Price Milk Committee of the City of New York and the Commission on High Cost of Living," Legislative Document No. 29, New York, 1920; "Primary Report of Joint Committee on Dairy Products, Livestock and Poultry," 1917 (So-called Wicks Report, Albany, N. Y.); "Development of the Coöperative Associations Controlling Dairy Production in the United States from 1906 to 1916," Hoard's Dairyman, Nov. 3, 1916. (Same, reviewed in International Review of Agricultural Economics, Feb., 1917, 37-39); Aввотт, Stanley H.: "Experience of the Boston Coöperative Milk Producers Company with the Sherman Anti-Trust Act, Bulletin 35, Dept. of Ag., Albany, 1912, 1127-1133; "Report of Governors' Tri-State Milk Commission to Governors of Pennsylvania, Maryland, Delaware," 1917.

Also following publications of milk product companies: "The Powder Magazine, Syracuse, N. Y., Published by Merrell-Soule Co. Also: "The Milk Dealer," Milwaukee, Wisconsin, The National Journal for the eity milk trade: official organ of the International Milk Dealers Association, and the Minnesota Milk Dealers Association.

Also following miscellaneous-WarBer, G. P.: "A Study of Prices and Quality of Creamery Butter," Bulletin 682, U. S. D. A., July, 1918; PotTs, Roy C., AND MEYER, H. F.: "Marketing Creamery Butter," Bulletin 456, U. S. D. A., 1917; PotTs, Roy C.: "Marketing Practices of Wisconsin and Minnesota Creameries," Bulletin 690, U. S. D. A., 1918; MACkLIN, Theodore : "The Marketing of Kansas Butter," Bulletin 216, Kans. Ag. Ex. Sta., 1917; LARKIN, M. LiPPIT: "The Butter Market," Journal of Political Economy, March, 1912, 267-274; "Butter Prices from Producer to Consumer," Bulletin 164, Bureau of Labor Statistics, Washington, 1914; HiBBARD, B. H., AND Erdman, H. E.: "Marketing Wisconsin Milk," Bulletin 285, Wisc. Ag. Exp. Sta., 1917; Taylor, H. C., Schoenfeld, W. A., and Wehrwein, G. S.: "The Marketing of Wisconsin Cheese," Bulletin 231, Wisc. Ag. Exp. Sta., 1913; "Investigation and Analysis of the Production, Transportation, Inspection, and Distribution of Milk and Cream in New England," prepared by the Boston Chamber of Commerce, Bulletin 22, Department of Ag. of Vermont, St. Albans, July, 1915; "British National Milk Policy," Hoard's Dairyman, Feb. 6, 1920, 126; "Coöperative Dairymen in Vancouver," Grain Grower's Guide, Oct. 22, 1919, 8; Holman, Chas.: "Ohio Milk Producers Jailed," American Coöperative Journal, Sept., 1919; “Detroit Milk Situation," Michigan Farmer, Dec. 8, 1917; Hedrick, W. O., AND ANDerson, A. C.: "The Detroit Commission Plan of City Milk Administration," Special Bulletin 99, Michigan Ag. College, 1919.

\section{APPENDIX}

The Mail Order House.-The mail order house is an agricultura problem $^{-}$ for two somewhat incongruous reasons. In the first place the big honest mail corder house renders the farmer a big service by bringing to his mailbox or to his nearest freight depot, a standard set of goods at a fair cash price. It also, however, by this same service, is a competitor of the nearby village merchants, and this competition may sap the life of the country town. And the country town is the one strong element in raising land values, bringing to the isolated farmer the services of doctors, dentists, bankers, merchants, and others, and adding in innumerable ways to the fullness of farm life.

This is not the proper place to enter into a prolonged dissussion of the merits and demerits of a mail order house. There is one way, at least, to meet the situation, fair to both sides. It is illustrated by the case of the housewife who made out her grocery order, amounting to $\$ 50.12$, from the latest 
price list of a great mail order house. She took this list to the local grocer who studied it carefully and then either duplicated or improved upon every item listed thereon, and filled the order for $\$ 48.12$ in cash. He met the mail order problem successfully.

"Eliminating the Middleman."-(Address by W. B. Liverance, before the 20th Convention of National Creamery Buttermakers Association, Milwaukee, 1917.) Speaking of the recent federation of coöperative creameries near Grand Rapids, Michigan, Mr. Liverance said:

"The one great idea in organizing our association was, by combining the output of our creameries and by improving the quality, to secure better markets for our butter. We, at the outset, had many wild theories of distributing butter direct to the consumer, of perfecting a marketing system in many of the large cities, of eliminating the middleman completely, etc. We were in the class of many of the impractical theorists of to-day. We worked out schemes of house-to-house disposal of butter, of distributing butter direct from the creamery to the retailer, and many others of similar nature. It took us a year or better to realize that it takes money to market butter ..."

Cutting Out the Middlemen, or Selling Through the Middlemen.-(The experience of the California Almond Growers Exchange, 1918 report, p. 12.) "The Eastern broker received $21 / 2$ per cent for his services, which consist of the following: Soliciting orders from customers; forwarding them to the Exchange; telegraphing when necessary; and unloading and aistributing our cars on arrival. Two and one-half per cent is a very reasonable brokerage for the service rendered." 


\section{CHAPTER X \\ COÖPERATION}

"CoöpERATION" in agriculture is one of those vague things which every writer, speaker, and politician usually endorses. The word has come to be used very loosely. It needs defining. The word is now used in a broad and in a narrow sense. It is well at this point to inquire into both the broader and the narrower use of the term.

In the Broader Sense.-Coöperation is the term often used to designate the working together for mutual benefit of the farmers, on the one hand, and the commercial clubs of the town, the bankers, the railroads, the big industries, etc., on the other hand. And, in the broader sense, this is true coöperation. This meaning can easily be illustrated.

For instance, the Binghamton Chamber of Commerce (of Binghamton, Broome County, New York) was among the first, if not the very first, to organize what is now known as a Farm Bureau. When organized and financed, the Bureau represented the Chamber of Commerce, the Delaware, Lackawanna \& Western Railroad Company, and the United States Department of Agriculture. The city of Binghamton and the railroad company both frankly recognized that their welfare depended fundamentally on the agriculture of the community. The Chamber of Commerce stated the case plainly to the farmers, and secured their endorsement, on the grounds that they would either all prosper together or all suffer together. A county agricultural agent-a genuine community farm expert-was employed. The Farm Bureau department of the Chamber of Commerce proved a success far greater than its organizers had hoped. Since its beginning in 1911 this broad experiment in coöperation of town and country has been an example for other towns to follow.

A second example of coöperation in this broader sense is that of the bankers of the State of Alabama with the farmers of that section. Alabama has produced one of the greatest agricultural leaders of the day in the person of Mrs. G. H. Mathis (Fig. 23), an actual farmer. She advised the bankers to take more interest in the farmer and less interest from him, to encourage the landlords to establish friendly and helpful relations with their tenants 
to the end that the tenants, through better farm management, might become land owners. The Alabama bankers employed Mrs. Mathis to give up part of her time to teach better farming to the farmers of the State, including the landlords and the tenants, and also the boys and girls of the farms. And hence Mrs. Mathis, by working with the bankers and farmers, with the landlords and tenants, is securing the harmonious working together of these different interests, and each interest is benefited by this coöperation. The bankers in other states are very active both as State Bankers Associations and as individual bankers, in coöperating with the farmer. The "BankerFarmer" is the official organ of this broad form of coöperation. ${ }^{1}$

The coöperation of railroads with farmers takes many forms. All important railroads now maintain agricultural departments whose chief aims are to improve agriculture in the territory traversed by the road. New plants, new methods of cultivation, better seed selection, rotation plans, better grades of livestock, better marketing methods-all these things and many more receive attention. The late James J. Hill, when president of the

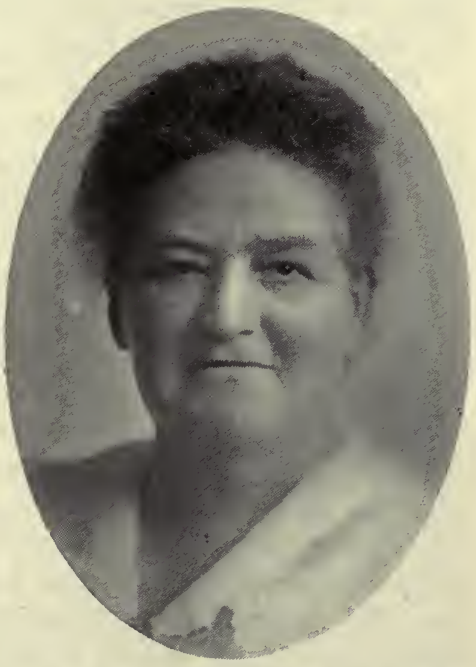

Fig. 23.-Mrs. G. H. Mathis, of Alabama. Great Northern Railway, improved the breed of beef cattle along his lines in North Dakota by awarding very expensive pure-bred sires free of cost to farmers meeting certain requirements. Thus, railroads in general, with a purpose which they frankly confess to be selfish, aim to improve the particular type of agriculture which is peculiar to their section. The Missouri, Kansas, and Texas Railway, for instance, like other roads in the fruit belt, is educating the farmer to grade and pack his produce in a standard marketable container. Special trains are sent by many roads, carrying exhibits of poultry or livestock or pure seeds or other demonstration material, accompanied by able lecturers and demonstrators, to carry the gospel of scientific agriculture to the farmer. And in numerous other ways railroads are coöperating with the farmers.

${ }^{1}$ The "Banker-Farmer" is published at Champaign, Illinois. 
The great industrial corporations likewise coöperate widely with the agricultural industry. The International Harvester Company, Deere and Company, the Universal Portland Cement Company, and many other large concerns now conduct experimental farms, maintain agricultural departments, issue literature, furnish speakers, and in many other ways coöperate with the farmer in bettering his financial condition.

In the same broad sense of the term coöperation, the State and federal governments coöperate with the farmer, through the Experiment Station, Agricultural Colleges, Departments of Agriculture, the Federal Bureau of Markets, and numerous other agencies.

Coöperation; in Narrow Sense.-As used in a narrower sense, coöperation means that form of business organization among farmers whose primary aim is savings and net profits. To carry out this aim our States have very generally enacted laws providing for the incorporation of farmers' coöperative associations. These coöperative corporations, while all aiming at economies and elimination of wastes, rather than at profits, fall into two general classes: those with capital stock and those without capital stock. The majority of States provide only for the capital stock type of organization. A few States provide for both forms. In either event, the true coöperative corporation must meet with one test, namely, its "earnings" (more correctly its savings) must be distributed to those whose business produces these earnings, and in some fair proportion to the business done. In other words, in case the coöperative corporation has capital stock, only a fair interest rate must be paid to stock in the form of dividends (usually from 6 to 8 per cent), and the balance of the net earnings, if any, to those patrons whose business produced the earnings. It has been customary, in many quarters, to lay down three hard-andfast rules or "essentials" for pure coöperation, namely: (1) One vote for one member regardless of the amount of stock held. This is known as the one-man-one-vote rule. (2) Distribution of earnings: dividends on capital stock limited to fair interest rate; patronage dividends on basis of business done by individual. This is known as the patronage dividend rule. (3) Limitations on shareholding: limited to real farmers; limited as to amount any one person can hold, such as, for instance, $\$ 1000$ per person. If these rules are ecnstrued strictly, then the United States affords but very few examples of successful coöperation. In almost every conspicuous case of success one or more of these elements is lacking. The real test is, who shares the benefits? If the benefits (whether 
in the form of stock dividends, patronage dividends, or other form) accrue to those who own the capital stock, and not also to those who furnish the business, then the concern is not coöperative, and if these benefits do go to those who produce the business, then the business is coöperative, whether the other "essentials," so called, are adhered to or not. The three best examples of large and successful coöperation in agriculture in North America are the United Grain Growers of Winnipeg, the California Fruit Growers Exchange of Los Angeles, and the Eastern Shore of Virginia Produce Exchange of Onley, Virginia. None of these adheres strictly to the three "rules" of coöperation named above.

A large number of farmers' corporations which call themselves coöperative have none of the elements of coöperation about them, and hence are not entitled to that name. And many corporations which begin as true coöperatives permit all their stock to drift into the hands of two or three individuals. Such an institution is not likely to remain long as a truly coöperative organization, whatever the name it may bear.

Purpose of Coöperation.-Coöperation, it must be emphasized, is for savings, not for profits. "Capitalistic" corporations, so called, are organized for profits, and for profits only. But coöperative corporations are organized to perform a service for their members, and this service usually takes the form of economic savings. It is not therefore in accord with the spirit of true coöperation to organize for the purpose of making profits from non-members. Since we now have $30,000,000$ persons on farms and 70,000,000 persons not living on farms, it is evident that the consumer must be reckoned with in forming any coöperative "combine." Otherwise the courts will hold such a combine to be contrary to public policy. In brief, coöperation in agriculture aims to eliminate wastes, introduce improvements, and hence realize savings in the various processes of production, marketing, buying, insurance, credit, etc. Increased profits have not been taken out of the consumer. The consumer is, rather, a beneficiary. Yet savings have accrued to the farmer. Mention has already been made in this work of the California Orange Growers, and how, by organizing the California Fruit Growers Exchange and advertising the "Sunkist" brand of citrus fruits, they have been enabled to furnish the consumer a bigger, better, and cheaper orange, with increased profits to themselves. But these profits have accrued through savings effected and wastes eliminated. 
An Example of Coöperation.-An example of successful coöperation is found among the farmers of Kentucky. The farmers of Warren County, in the territory adjacent to Bowling Green, have been able to bring to perfection a certain variety of strawberry known as the Aroma. But the marketing of this highly perishable fruit proved a task beyond the powers of the ordinary farmer, and hence under wise leadership the growers associated themselves together, and in 1909 incorporated the Warren County Strawberry Growers' Association, a coöperative corporation. This section of the Blue Grass State now has the renutation of being

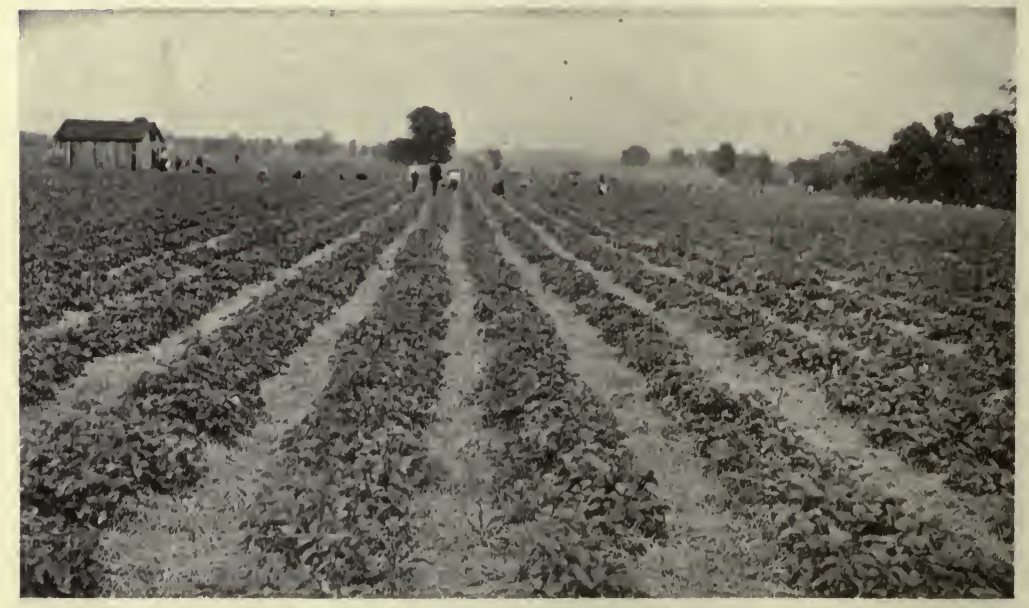

FIg. 24.-Warren County, Kentucky Strawberry Association, picking the berries. (U. S. D. A.)

the largest strawberry growing and shipping point in the world. The fruit is shipped in attractively labeled crates. For the 1917 crop ninety carloads of crate material was contracted for in advance. The railroad coöperated by building additional loading sheds and new trackage, and by running special strawberry trains of ten cars or more, to the northern markets, on regular passenger train time. The marketing of the berries is done by the Growers' Association, in charge of an efficient manager (Figs. 24 and 25).

The important link in the chain is the Inspection Service. All of the fruit put out by the association is inspected before loading, and is put up in three distinct grades. The association has adopted a very stringent code of rules on the grading of the fruit. By thus standardizing their product and truthfully labeling it they are able to sell this vast quantity of perishable stuff by wire on the 
f.o.b. basis. .It may be added also that money is freely spent in April and the early part of May in advertising widely these Kentucky strawberries. Dealers are informed by advertisements in the trade papers, and the market demand is properly cultivated by the time the heavy car-lot movement of strawberries begins.

This Kentucky example of coöperation-carried out where the farmers are rated as particularly individualistic-illustrates well certain correct principles and practices in coöperation. First, there is a specialized field where the need of coöperation is great. A highly centralized organization is effected under wise leadership,

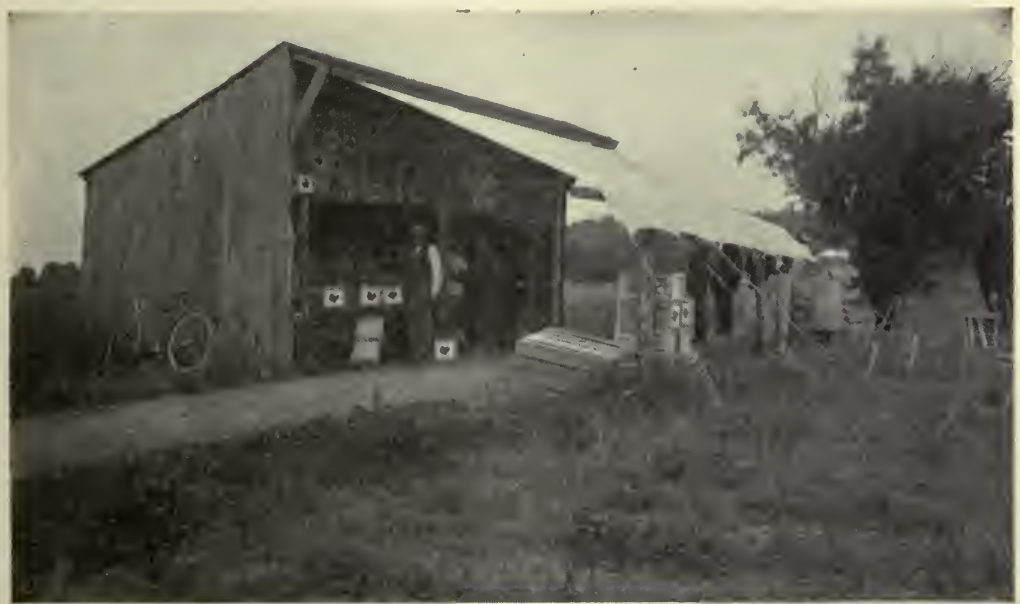

FIG. 25.-Grading and packing the berries for the northern market. (U. S. D. A.)

with no money worse than wasted in promoter's fees. (As coöperation becomes more popular, more and more counterfeit and bogus "coöperators" will rush in and organize farmers for the twenty per cent commission, more or less, which they can extract for their "services.") The product was standardized. That is, a certain distinct variety and quality was developed and properly labeled. This served as did the trademarks developed by some of our old, reliable, honorable business firms. Coöperation in this form brings savings to the produccrs through doing business on a large scale, and at the same time gives the consumer part of the benefits in the form of an improved product at a lower price, as happened in the case of the California oranges. In both cases the wider distribution of a highly perishable product was the underlying problem. 
Some Causes of Failure.-The strawberry growers and orange growers have shown us some of the correct principles and practices of coöperation. Other experiments have shown us the wrong principles and practices. The death-rate of coöperative enterprises in America is entirely too high. First in the list of failures come the coöperative stores. Most of these institutions have been failures. Successes have been too few to point out the road to success. The farmers' coöperative elevator, on the other hand, seems to have run the gamut of failure, near failure, fair success and success. The causes of failure in the farmers' elevators that

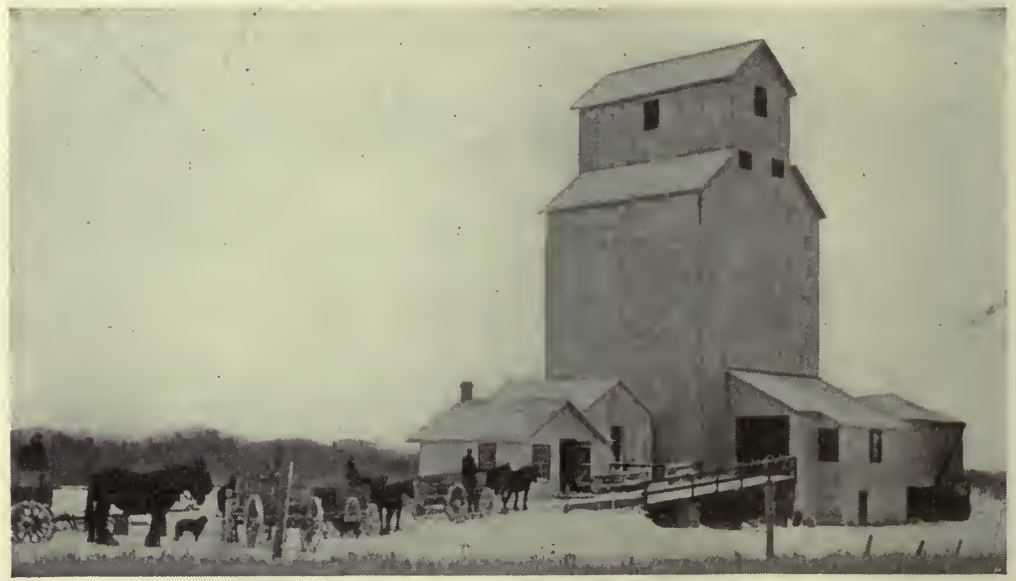

FIG. 26.-Country elevator owned by the United Grain Growers. This company operates 350 elevators like this.

have gone down may be reduced to four general weaknesses: (1) Poor management, including lack of accounting and auditing; (2) Competition; (3) Emigration of original stockholders; (4) Disloyalty of stockholders. But these failures of the past have become stepping stones to success for the present and future. The coöperative packing house is now on trial in the United States. A conspicuous failure in this field occurred at La Crosse, Wisconsin. But here promotion fees were too high for any corporation to stand. Many bogus "coöperative" enterprises have come to disgrace and failure, thus casting a shadow on efforts at genuine coöperation. Thus, the so-called Northwest Trading Company, operating in the State of Washington chiefly, and masquerading as a farmers' concern to "eliminate the middlemen," fell into the 
hands of the federal courts, and its leaders were convicted of criminal practices and imprisoned.

United Grain Growers.-The largest example of coöperation among farmers in North America is that of the grain growers of western Canada. The United Grain Growers, as their company is called, has an annual turnover of well over a hundred million dollars. This company, like all successful coöperatives, was the child of necessity. Beginning in 1906 under farmer leadership,

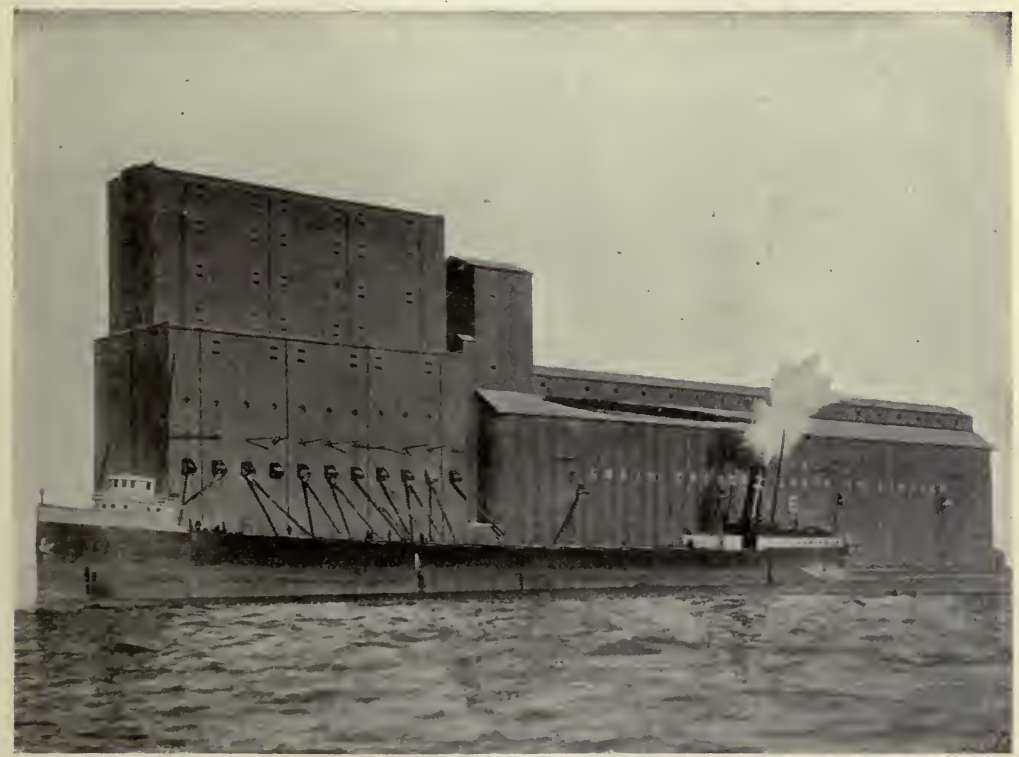

FIG. 27.-Terminal elevator, 2,500,000 bushels capacity. Operated by United Grain Growers at Fort William, on Lake Superior.

purely as a farmers' economic movement for the better and cheaper handling of western grain, the company has now developed several collateral lines of activity. The business of the Company, briefly stated, is now as follows: (1) Grain commission department for selling the grain; (2) Country elevator department which operated 343 country grain elevators (Fig. 26), 231 flour warehouses, and 181 coal sheds; (3) Livestock department, for selling livestock: (4) Terminal elevator department, operating both owned and leased terminal elevators and a hospital elevator "(Fig. 27); (5) Coöperative supply department, for buying farm machinery and other supplies (Figs. 28 and 29); (6) Export company, for hand- 


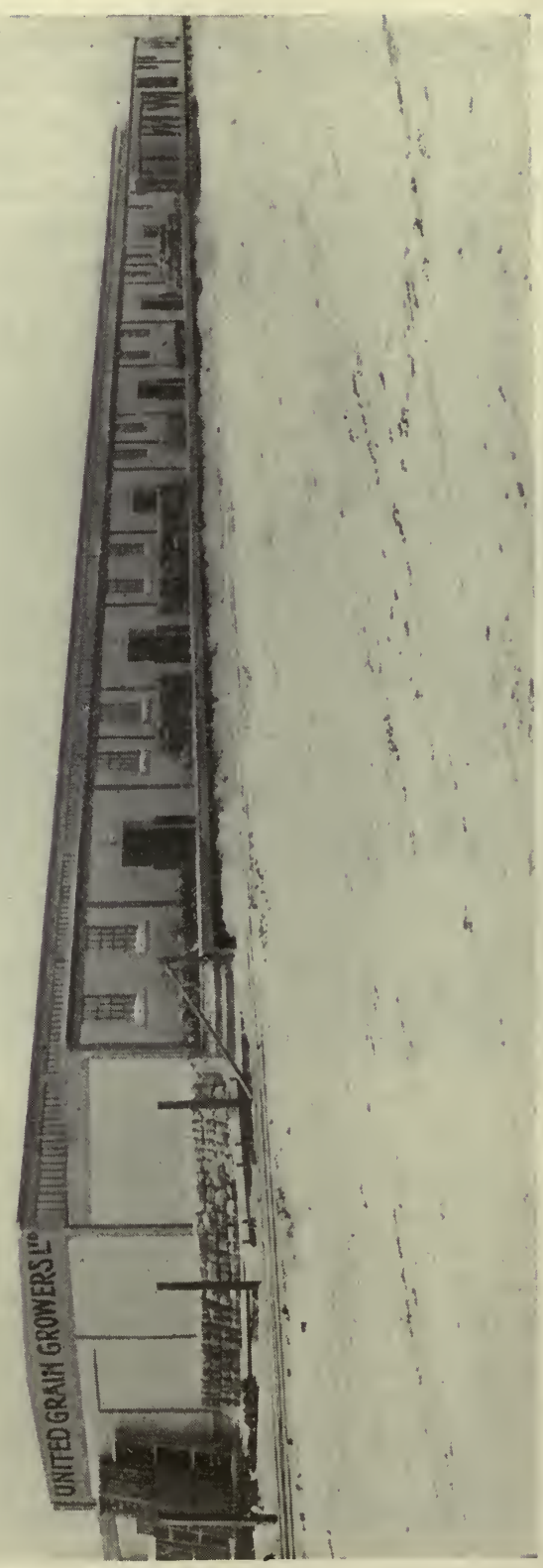

:

항

움

능

造

o

낌므

요

8.

아염

miำ

둘

हैํํำ

我

过

내

.

ㄹ. .ี

สึ

范

2.

음

5 के है?

피

สี สี

.

ธัด สี

卷芯

क

넌

a

등

ช3

马ृ్ّ

)

ह ํํㅇ

윤

능

ष्ञ

כै.

ํㅡㄹ

ํํㅇ

so

를

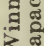

उ

ล

ธิن 
ling the grain export business; (7) Public Press, Limited-a printing company to print the official organ, "The Grain Growers' Guide," catalogs, educational and propaganda literature; (8) Sawmills and timber lands in British Columbia; (9) Land department, for selling farm land on a commission basis, offering protection and service to both buyer and seller.

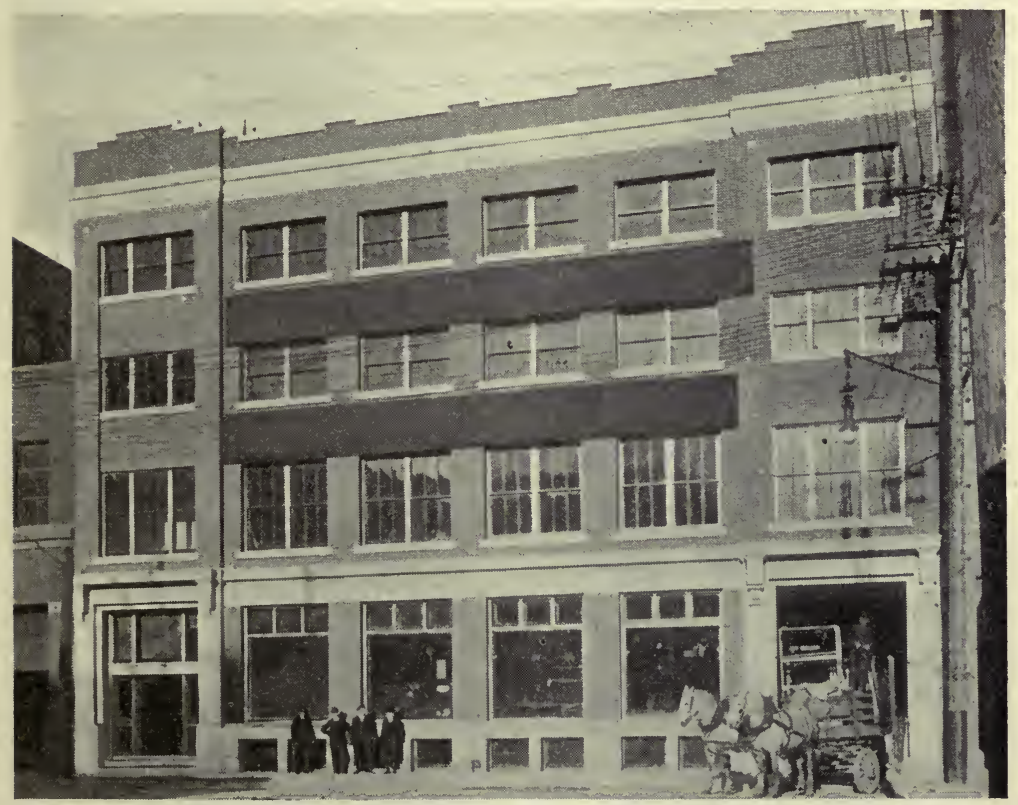

FIG. 29.-Winnipeg machınery showrooms of the United Grain Growers.

In its form of organization this company is highly centralized, and is therefore efficient. This centralization may be represented in this form:
40 farmers.
when $\{6000$ acres in grain.
$\$ 8000$ of stock subscribed in the United Grain Growers.
then $\left\{\begin{array}{l}\text { United Grain Growers will erect a } 30,000 \text { bushel house (or } \\ \text { larger), equipped with cleaning machinery. Farmers } \\ \text { will own stock in the big central corporation-not in } \\ \text { a local company. }\end{array}\right.$

This company has now 35,000 shareholders, a paid-up capital of $\$ 2,159,763.16$, and a reserve fund of $\$ 1,600,000$. Shares of stock have a par value of $\$ 25$, and a book value of $\$ 41.50$. When first 
organized, under a Manitoba charter, shareholding was limited to 4 shares to one person. Under the present Dominion charter, the limit is 80 shares to one person.

The one-man-one-vote rule prevails. No proxy voting is allowed. No patronage dividends have thus far been paid, surplus earnings going into reserves and into developing collateral activities. Patronage dividends on purchases are now under consideration. Patronage dividends on grain sold are forbidden by the anti-rebate rule of the Winnipeg Grain Exchange, of which this

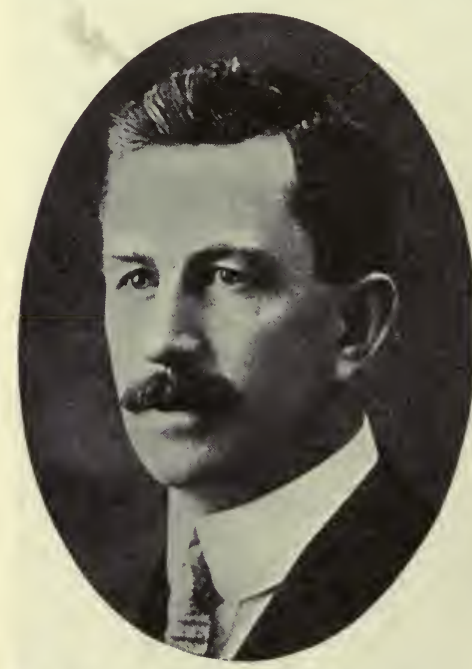

FIG. 30.-President T. A. Crerar, United Grain Growers, Ltd., Winnipeg. Company is a member.

The United Grain Growers is an amalgamation of two centralized farmers' companies, the Grain Growers Grain Company (organized in 1906 and operating chiefly in Manitoba and Saskatchewan), and the Alberta Farmers' Coöperative Elevator Company (organized in 1914, and operating in Alberta). The amalgamation was effected in 1917. A Board of 12 directors, all farmers, manage this huge enterprise. The same president, T. A. Crerar, has been kept in power since 1901 (Fig. 30). The annual meeting of stockholders is a delegate body, the locals being represented by duly chosen delegates. The company pays the expenses of the delegates to insure democracy in representation.

The reader will bear in mind that many farmers in the province of Saskatchewan are members of the Saskatchewan Coöperative Elevator Company - a company competing with the United Grain Growers-having a business very similar to that of the Winnipeg company, and having seats in both the Winnipeg and Minneapolis grain exchanges. These two companies have given the farmers a powerful voice in controlling the grain trade of the three prairie provinces.

Success of Coöperation.-The friends of coöperation are satisfied that the movement is slowly winning success. In comparison with Europe, this success, to be sure, is small. But Europe presents 
three very important differences in the environment of coöperation: (1) In Europe farmers live by the graves of their ancestors, while in the United States many neighbors come and go with each passing year; (2) In Europe a coöperative community enjoys unity of race, religion and language, whereas the average American community has not unity of race, language, or religion; (3) Dire

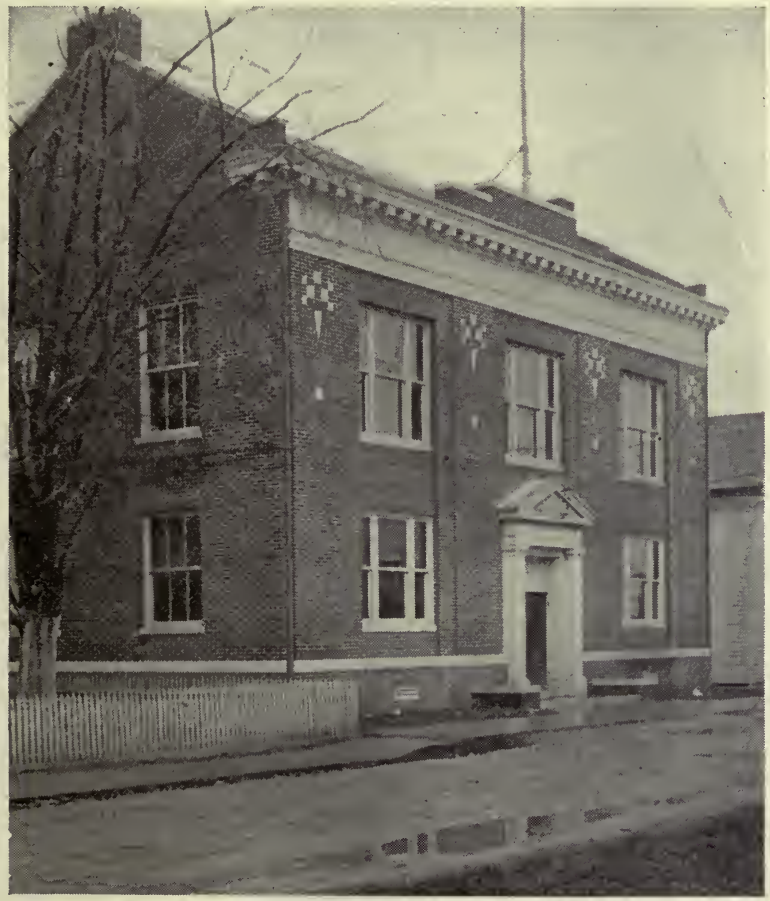

FIg. 31.-Eastern Shore of Virginia Produce Exchange, Onley, Virginia.

necessity among the peasants of Europe have driven them into coöperation, while in America waste and exploitation of natural resources still prevail in most agricultural communities. It is fair to state, however, that coöperation is a success in the following six broad fields:

(1) Production. - In this field coöperation has registered conspicuous success in the coöperative creameries and cheese factories in Wisconsin, Minnesota, and other sections. In livestock breeding too, the success has been very gratifying.

(2) In Selling.-The marketing of citrus fruits and strawberries has already been named. Another conspicuous success in this 
field is the Eastern Shore of Virginia Produce Exchange (Fig. 31). Here the farmers in two small counties market through their central organization as much as ten thousand carloads of produce in a season, putting it on the market under their own inspection and label. This enables them to make their sales largely on the f.o.b. loading station basis, securing a wider distribution and avoiding market gluts. Only the poor quality of produce is consigned, and that without the "Red Star" label. One important feature of the sales service is the liberal use made of the telegraph and telephone wires in securing market information. Farmers' coöperative organizations have also made successes in marketing in many other fields, including the following: Egg circles, livestock shipping associations, potato warehouses, fruit and vegetable organizations of various kinds, milk, and grain. The great success of the farmers' coöperative elevator movement is discussed in the chapter on the Grain Trade.

(3) In Buying.-Incidental to some other form of coöperation we find buying developed successfully. Thus the Farmers' Union of Maine sells potatoes and incidentally buys and distributes fertilizer. The farmers' elevators sell grain, and quite generally carry "side lines" purchased by the farmer, such as grain cleaners, fertilizer, coal, twine, fencing and many other lines. Buying, however, as a major operation, such as the coöperative store, has not proved a success, but quite the contrary, up to the present.

(4) Insurance.-Farmers' mutual insurance companies, particularly hail insurance, fire insurance, and livestock insurance, have spread widely over the country and have met with general success.

(5) Telephone.-The farmers' telephone company is perhaps the most widely known form of farmers' business undertaking. Information is lacking, however, to say to what extent these corporations are coöperative, and to what extent they are common joint-stock or "capitalistic" corporations. But it is likely that they are not, in most cases, coöperative in the strict sense of the term.

(6) Credit.-Coöperative credit has been indeed slow to take root on this continent. Credit must be given to Mr. Alphonse Desjardins of Quebec for establishing in that Canadian province our first real coöperative credit in America, in his Caisse Populaire. A few States in the Union have now undertaken to provide the legal machinery for coöperative credit. It is hardly necessary to remind the reader in passing that credit based on first mortgages 
on land-as is the case with our Federal Farm Loan Act-is land credit and not coöperative credit. North Carolina is building up a most promising program of success in the field of coöperative credit, under the leadership of the State Market Director, Wm. R. Camp (Fig. 32). The subject of credit is treated at length in the next chapter.

Economic Significance of Coöperation.-While agricultural coöperation in the United States is indeed small when compared with Europe, yet it is growing greater day by day. But a very small fraction of our total business, measured in dollars and cents, is carried on through cooperative channels. But the future is full of promise. The states are one by one creating State Market Bureaus, and these Bureaus are under directors who quite generally agree in promoting sound coöperation, and putting it in the hands of wise leaders. And soon the three thousand counties of the United States will each have a county agent who will also be a promoter of real coöperation in agriculture, and finally the United States Department of Agriculture has the Bureau of Markets which through its chief, its field agents

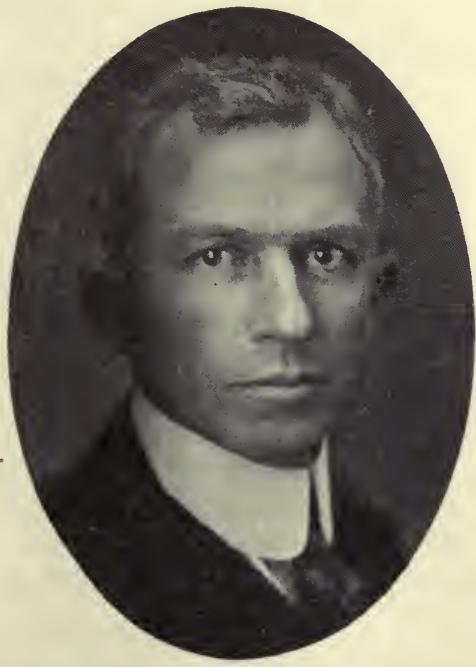

Frg. 32.-William IR. Camp, of the successful North Carolina Credit Union Movement. in marketing, its various experts, and its publications, is becoming a tremendous influence in favor of coöperation among farmers. Hence the future of coöperation in agriculture seems bright with promise.

The N. A. O. S.-The National Agricultural Organization Society aspires to do as much for American Agriculture as Sir Horace Plunkett's Irish Agricultural Organization Society did for Ireland. The one real clearing-house of ideas, principles and practices in coöperative and other forms of agricultural organization is found in the conferences on marketing and farm credits held by this society. The published volumes of the proceedings of these conferences contain the principal papers read, but not the full report of debates, discussions, and round table talks. This 
society works in harmony with the various voluntary and governmental agencies which are seeking to promote true coöperation in American agriculture. These meetings were interrupted by the World War. The work of the N. A. O. S. was likewise suspended. It remains to be proved whether such an institution will take root on American soil.

Essentials in Coöperation.-Some of the chief factors in successful coöperation are the following:

A manager who is honest, efficient, and well paid.

Ample working capital and sound financial reserves and strict auditing.

A specialized field of operation.

A large volume of business.

Strong, centralized control.

Pooling arrangements (in most selling associations) whereby an occasional loss is distributed.

A wider and better distribution of the produce sold.

The goal, always in mind, is to improve the quality of the product marketed, to standardize the pack, advertise and maintain the label or brand, and to introduce economies and savings, so that both consumers and producers are the beneficiaries.

Farmers organized in a coöperative association according to the above principles are mobilized for their own protection. They can conduct collective bargaining where they control the supply of the product, and thus have a voice in price-making.

\section{QUESTIONS ON THE TEXT}

1. Give two a'efinitions of coöperation.

2. Illustrate by several concrete examples the broader use of the term.

3. Distinguish between stock and non-stock corporations.

4. Give the test of a real coöperative corporation.

5. State the usual tests applied to coöperative corporations. Give reasons for not applying these tests strictly.

6. Show abuse of the name "coöperative."

7. What is the purpose of coöperation?

8. Show how public policy is involved here.

9. Show how both producer and consumer may be beneficiaries of coöperation among producers.

10. Describe the coöperative association in the strawberry district of Kentucky.

11. Show where coöperative corporations have failed, and why.

12. What is the status of coöperative packing houses?

13. What was the Northwest Trading Company?

14. Describe at length the United Grain Growers.

15. Speak of the extent of the success of coöperation. Compare with success in Europe.

16. Comment on coöperation in these fields: production; selling; buying; insurance; telephones; credit. What principles are illustrated by the Eastern Shore of Virginia Produce Exchange? 
17. State the economic significance of coöperation and its future outlook.

18. What is the National Agricultural Organization Society?

19. State the essentials in successful coöperation.

\section{QUESTIONS SUGGESTED BY THE TEXT}

1. Give arguments for, and outlook for, consumers' coöperation in the United States.

2. Secure the last annual report of some coöperative association, and analyze its business. From this report answer the following questions: What is the marketing cost per unit (bushel, box, dollar, etc.)? What is spent for market news service? For advertising? How widely is the product distributed?

\section{REFERENCES}

1. Annual Report, 1918, United Grain Growers, Winnipeg, Canada. (Contains also Report of Committee appointed by Board of Directors to visit the Farmers' organizations of 'the United States, with special reference to coöperative trading).

2. Coöperative Societies in Finland, reported by Consul Thornwell Haynes, Helsingfors, Daily Commerce Reports, Washington, July 19, 1919, p. 393.

3. Jessness, O. B., And Kerr, W. H.: "Coöperative Purchasing and Marketing Organizations Among Farmers in the United States." Bulletin No. 547 United States Department of Agriculture, Washington, September, 1917. Contains selected list of publications on coöperative purchasing and marketing.

4. Minnesota Farmers' Institute Annual, Coöperation Number, No. 26, St. Paul, 1913.

5. See also printed reports of important coöperative associations, such as California Fruit Growers' Exchange, Los Angeles; United Grain Growers, Winnipeg. Consult also official papers issued by farmers' organizations.

6. Yearbook Department of Agriculture: 1910, PowELL, G. H.: "Coöperation in Handling and Marketing Fruit," 391-407; 1914, BASSETT, C. E., Moomaw, C. W., KerR, W. H.: "Coöperative Marketing and Financing of Marketing Associations," 185-211; 1915, BASSETT, C. E.: "Coöperative Purchase of Farm Supplies," 73-83; 1916, Macpherson, Hector; KerR, W. H.: "A Federated Coöperative Cheese Manufacturing and Marketing Association," 145-159; 1917, Jesssness AND BASsETT (Coöperative Marketing -Where-When-How?), 385-395.

7. Adams, H. B.: "History of Coöperation in the United States," Johns Hopkins University Studies, Vol. 6, 1888.

8. International Institute of Agriculture, Rome. International Review of Agricultural Economics. Siberia.- "Agricultural Coöperation," April, 1919, 167-185; Russia.- "Eggs," Sept., 1917, 7-12; "Flax," July, 1917, 14-22; June-July, 1919, 351-352; "Butter," January, 1918, 18-22. Galicia.-"Forestry," Feb., 1918, 110; Ireland.- "Irish Agricultural Organization Society," March, 1918, 205-208; Saxony.- "Twenty-fourth Year of coöperation," January, 1917, 1-6; Denmark.- "Abattoirs," May, 1916, 1-16; June, 1916, 1-19; "Eggs," Dec., 1916, 11-30. Norway.- "Brief History of Agricultural Coöperation in Norway," Aug., 1916, 16-33; United States.-Weld, L. D. H.: "Coöperation in Minnesota," Feb., 1916, 12-28; March, 1916, 25-33.

9. Powell, G. Harold: "Coöperation in Agriculture," New York, 1914. 1914.

10. Coulter, John Lee: "Coöperation Among Farmers," New York,

11. "Special Report of New York Delegates on American Commission for the Study of Agricultural Coöperation in Europe," Department of Ag., Albany, Bulletin 56, Feb., 1914. 


\section{CHAPTER XI}

\section{CREDIT}

Debt.- "Many neighbors have sold out and quit farming," writes a northwestern farm woman, "because they had to. We will have to sell this fall, because we are so deep in debt-it will nearly kill me if we have to leave the farm. I do so want to keep my husband and children there. I don't see how I can part with the horses. I hate the cities and am afraid of them, so I hope that the lawmakers will believe that ours is a real need. I am 25 years old and our children are aged 6,4 , and $21 / 2$ years. I don't belong to the 'I Won't Works,' but would like a little pay."

This letter is one from a collection of many received from farm women in response to an inquiry on "How the U. S. Department of Agriculture can better meet the needs of farm housewives?"

It illustrates in a concrete way the very disagreeable fact that the farmer's credit problem is, in certain cases, a real one. The letter suggests that our lawmakers "do something" to meet the credit needs of the day.

New View of Credit.-The attitude of the public mind has undergone a tremendous revolution on the subject of credit. About two hundred years ago a French king said, "Credit supports agriculture as the rope supports the hanged." In our own history the New England idea of thrift and the teaching of Poor Richard's Almanac were both to the effect that debt is a disgrace and must be avoided like the plague. Hence a mortgage came to be looked on as a disgrace, a sort of skeleton in the family closet. There was some excuse for this attitude in the days of free land, of homespun clothing, of homemade tillage tools. Farming then was really an investment of labor on free land. But now farming represents the balanced investment of three factors of production-land, labor, and capital. In short, agriculture is now on a capitalistic basis. The land has a large cash value. The farm equipment has a large cash value. Agriculture has come to be a business involving the administration of capital. According to the 1910 census, the average Iowa farm represented an investment in land and farm buildings of $\$ 15,008$, in farm machinery of $\$ 440$, and in livestock of $\$ 1811$. In other words the Iowa farmer has a business investment of $\$ 17,259$. The village merchant can no longer proudly 
arrogate to himself the title of "business man" and look down on the farmer as a mere tiller of the soil.

Capitalistic Agriculture.-When agriculture in America became a capitalistic business, there came also a new attitude towards credit. The word "credit" came into use in place of the old word "debt." Debt was no longer considered a badge of dishonor, a mark of non-prosperity, or even as something to be avoided. The practice of the great public utility corporations, particularly the railroads, of piling up big debts, at low rates of interest, in long term bonds, invested in income yielding property, and with the fixed business policy of never paying off these debts (but of refunding them) proved suggestive to agriculture. Why should a railroad, for instance, keep out of debt, when it can borrow at 4 per cent and make a return of 8 per cent on this money? Evidently, the more a railroad could increase its debt-provided always the interest rate was low, the investment safe, and the return large - the better off it would be financially. The instinct of the individual farmer, however, leads him to desire to own his farm in fee simple and free from encumbrance. But for the sake of securing the balanced investment of land, labor, and capital, it has come to mean in many cases that the farmer must borrow. The social significance of farm credit and a permanent agriculture is apparently grasped by but few writers and speakers. The country is under obligation to Dean Thomas Forsyth Hunt of the University of California for clearly seeing this problem and in clearly stating it to his country. ${ }^{1}$ Quoting from his remarks on this subject we have the following excerpts:

"As long as the people in the country raise larger families than those in the cities, and the cities continue to grow faster than the country, it follows that in the cities every generation must be affected by the character of the previous generation in the country.

"New York and Boston are rapidly becoming un-American cities for the simple reason that they do not raise enough children to maintain, let alone increase, their population. Almost exactly one-half of the people of Manhattan are foreign-born. Less than 15 per cent have two American-born parents. Los Angeles has become the puritanic center of America; Boston is now the second Dublin of the world. Hoboken does not dare to have a parade on the Fourth of July. Unless our children occupy the country, our grandchildren will not occupy the cities. It is the people who occupy the land who will eventually inherit the earth . .. If farms must be recapitalized at least three times in a century; if young men are born into the world without capital to finance them; if the permanence of society is dependent upon a rural population, not merely because it creates wealth, but because it grows children, then what are we going to do about it? ... . For years the savings of the people have been used in developing railways, manufacturing plants, department

${ }^{1} 64$ Cong. 1 Sess. Senate Doc. 239. 
stores, public buildings and city streets. A large part of the development of private corporations as well as the public improvements of cities, has been due to the savings of the people, borrowed largely at 4 to 5 per cent. The land-credit plan is intended to allow the savings of the people to be invested in the land in order that a permanent agriculture may develop.

"Men in cities now conduct great enterprises, enjoy comfortable transportation facilities, occupy luxurious offices, and eat in sumptuous restaurants without having a dollar of their own money invested in these agencies except as they may carry life insurance or invest in stocks and bonds. The phenomenal development of the cities within recent years would have been impossible were this not so. Farming is the one great industry remaining in which men commonly invest their own money in order to engage in the business."

\section{United States Studies Credit in Europe.-Rural credit became} an issue in American political life about the vear 1912. In that year President Taft addressed letters to the State Governors, inviting them to a conference at the White House for the purpose of discussing agricultural credit. In this letter, among other things, President Taft said:

"For some months past, at my direction, the Department of State, through its diplomatic officers in Europe, has been engaged in an investigation of the agricultural credit system in operation in certain of the European countries. Although the investigation is still under way, a preliminary report has been submitted, together with the recommendations of Ambassador Myron T. Herrick in connection with my proposal to adopt this system in the United States.

"A study of these reports and of the recommendations of Ambassador Herrick, which I am sending you, convinces me of the adaptability to American conditions of the coopperative credit plan as set forth in the organization of the Raiffeisen banks of Germany. The establishment and conduct of such banks, however, are matters for State control. I suggest also the establishment of land mortgage banks ...

"The need for the establishment of an adequate financial system as an aid to the farmers of this country is now quite generally recognized. The governmental initiative, taken by the Department of State under instructions issued by my direction to the diplomatic officers in Europe on March 18 last, have been effectively supplemented by the American Bankers Association, the Southern Commercial Congress, and by many other bodies by whom this question has been agitated, and valuable work has been done in studying and disseminating knowledge of those great instrumentalities which have been created in foreign lands to extend to their agriculturists credit facilities equal in benefits to those enjoyed by their industrial and commercial organizations. The handicap placed upon the American farmer through the lack of such a system, and the loss sustained by the whole citizenship of the nation because of this failure to assist the farmers to the utmost development of our agricultural resources, is readily apparent.

"The ... farmers of the United States add each year to the national wealth $\$ 8,400,000,000$. They are doing this on a borrowed capital of $\$ 6,040,000,000$. On this sum they pay annual interest charges of $\$ 510,000,000$. Counting commissions and renewal charges, the interest rate paid by the farmers of this country is averaged at $8 \frac{1}{2}$ per cent, as compared to a rate of four and a half to three and a half per cent paid by the farmer, for instance, of France or Germany.

"Again, the interest rate paid by the American farmer is considerably higher than that paid by our industrial corporations, railroads or municipali- 
ties. Yet, I think, it will be admitted that the security offered by the farmer on his farm lands is quite as sound as that offered by industrial corporations. Why, then, will not the investor furnish the farmer with money at as advantageous rates as he is willing to supply it to the industrial corporations? Obviously the advantages enjoyed by the industrial corporation lie in the financial machinery at its command, which permits it to place its offer before the investor in a more attractive and more readily negotiable form. The farmer lacks this machinery, and, lacking it, he suffers unreasonably."

This quotation is given at length because it so clearly states the credit problem of the United States and at the same time suggests its solution-land mortgage credit and coöperative credit. These principles announced by President Taft bore fruit in the year 1916. This is the date of a new era in credit in the United States on account of the Federal Farm Loan Act enacted then.

Long- and Short-Time Credit.-The farmer uses two kinds of credit, long-time credit and short-time credit. The long-time credit generally takes the form of a mortgage on real estate. The short-time credit is commonest found in the form of a book account at the village stores. Less frequently the farmer signs notes at the bank. It is impossible to state the rate of interest charged on short-time loans for the whole United States, so much do conditions vary in different sections. In the newer sections, and in the cottoncrop sections of the South, conditions are burdensome almost beyond belief. Take Texas as an illustration. "Texas debtor farmers," says an official bulletin from the Agricultural and Mechanical College of that State, "have been paying to banks 10 to 40 per cent interest per annum, or to credit merchants 10 to 60 per cent above cash prices. This credit system, either as cause or effect, uniformly prevails with all-cotton farming, or all-wheat farming or any other form of one-crop farming." There are parts of the South, particularly the Delta, where the cotton crop lien system has produced a credit condition even worse than that described in Texas. As the farming becomes more diversified, especially where livestock is raised extensively, credit conditions on short-time loans become better. In old and prosperous farming sections the farmer is able to secure short-time loans from the bank at the same rate as the town merchant. And in all sections the more prosperous farmers get all the credit from local banks that they are entitled to, and at regular banking rates.

Beginning of Coöperative Credit in America.-Alphonse Desjardins was the first to introduce coöperative credit on the American continent (Fig. 33). He began his coöperative people's bank among the French Catholics in the province of Quebec in the year 1900. Thus he was favored at the outset with unity of race and 
religion. At the small town of Levis he organized among laboring men and farmers his first credit union, or "La Caisse Populaire de Levis" as it is called there. The success of this first experiment caused the idea to spread throughout all French Canada, so that in less than five years 154 similar coöperative banks had been formed in other parishes. The total turnover in the first 16 years was $\$ 3,519,123.84$ with gross profits amounting to $\$ 107,719.05$, and a total working expense of $\$ 8,832$. The working men and farmers choose their own management, provide all the funds them-

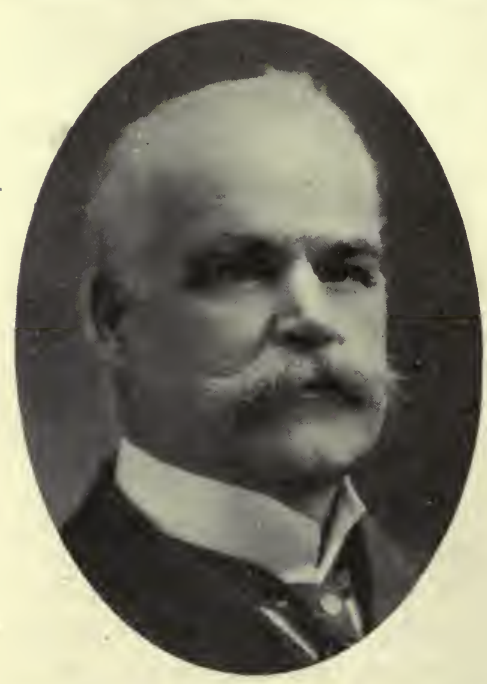

FIG. 33.-Alphonse Desjardins, father of the People's Banks of Canada. selves, loan the money to themselves, and in most cases their honor alone is the main security.

The Credit Union.-The success with coöperative credit in Quebec led first Massachusetts and then other American States to try to introduce this Canadian system under the name of Credit Union. But as usually happens, the taking over of a foreign system did not prove very successful. Massachusetts set the example (in 1909), being followed promptly by eight other States, as follows: Texas (1913), Wisconsin (1913), New York (1914), Rhode Island (1914), North Carolina, Utah, South Carolina, Oregon-all four in 1915. As these lines are being written (1920), Massachusetts has nearly 60 credit unions; New York, 40; North Carolina, 30; Rhode Island, 1; and the other five States none. The credit unions in Massachusetts and New York are almost wholly in cities, and hence have no significance for agriculture. In North Carolina, however, the credit union is largely rural, and hence constitutes agricultural coöperative credit. For our purpose, then, we will analyze in detail the North Carolina system.

North Carolina Method.-The first financial statement issued by the Credit Unions of North Carolina appeared in March, 1916. One year later a second statement was issued, making a comparison of conditions at the two dates, and showing one year's growth. The number of credit unions grew from 6 to 14 ; the membership 
increased from 201 to 505; depositors from 29 to 146 ; payments on shares from $\$ 1,13225$ to $\$ 4,327.53$; deposits from $\$ 959.76$ to $\$ 3,763.40$; cash in banks from $\$ 1,299.78$ to $\$ 2,666.15$; amount borrowed from banks from $\$ 100.00$ to $\$ 1,450.00$; and total resources from $\$ 2,264.89$ to $\$ 11,448.31$. This shows a growth in resources of over 500 per cent in one year. The secret of the success of the leading Credit Unions, says their Superintendent, is that they have helped finance their members in the coöperative purchase of supplies. Emphasis should also be laid on their encouragement of thrift.

The North Carolina Credit Union is a society with a dual purpose, namely, to encourage savings and to utilize these savings for productive agricultural purposes. Loans are made to members only and for productive purposes only. Leadership in organizing all the early credit unions in this State came, as the law provided, from the Division of Markets and Rural Organization of the State Agricultural Experiment Station and Extension Service. This explains their growth in rural communities. The funds of the union, as seen from the financial statement (Appendix) come from share capital, deposits, and loans from banks. The par value of a share is usually $\$ 10$, but may be higher, up to $\$ 25$. Boys and girls are permitted to pay for shares on the installment plan at 25 cents a month, and adults at $\$ 2.50$ semi-annually. Deposits may be received from members and non-members. Four per cent interest is paid on deposits. The rate charged borrowers is 6 per cent. At the same time the rate charged by supply stores for book credit averages 38.4 per cent. Most of the loans made by the North Carolina credit unions have been for fertilizer. The Superintendent of Credit Unions in that State expects to see two very important results follow from a general introduction of credit unions: (1) Farmers should buy supplies in large quantities at wholesale prices; (2) If the farmer can get credit on the same terms as the middleman, he can afford to store his products and hold them off the market till a favorable time arrives for disposing of them. One apparent tendency is for the Credit Union to borrow more and more from the banks, thus acting as a mere middleman in buying and selling credit.

Myron T. Herrick's Criticism.--Very high hopes were entertained by many thoughtful persons that at last the Credit Unions had arrived to solve the problem of coöperative credit in American agriculture. But our greatest critic in this field, Ex-ambassador Myron T. Herrick, pronounced these various State laws, as soon. 
as they appeared, wrong in principle. He advocated the principle of an association or voluntary union of persons, preserving the equality and personal responsibility of members, on the one-manone-vote plan; with or without share capital; liability limited or unlimited; shares payable in installments and withdrawable at any time. He claims that such a plan would in the beginning produce small results, but it would grow rapidly. The community would finally finance itself. The three sources of loans would be share capital, savings deposits, and occasionally borrowed funds. This plan is very much like the Canadian system. In many respects it resembles the North Carolina plan, particularly in that it provides for receiving savings deposits from both members and non-members. Deposits from non-members are forbidden in most of the State laws. It is an interesting question for the student investigator, why States like Wisconsin, with a model law on credit unions, have no credit unions. Does it mean that the present banking system furnishes the farmer all the credit he is entitled to?

Land Credit-The Federal Farm Loan Act.-The distinction should be borne in mind between long-time credit and short-time credit, between land credit and coöperative credit. Both are needed. Each supplements the other. One is needed for permanent investment in the purchasing, equipment, and improvement of farm land; the other is needed to finance the farm operations from one harvest to another. One can be used only by the land owner; the other can be used by the landless man or by the insolvent farmer.

The Federal Farm Loan Act became a law July 17, 1916. It is, in principle, self-help plus government aid in getting the system into operation. But, once in operation, the government merely supervises the system, but grants no State aid to it. A careful examination of the main provisions of this epoch-marking Act shows that the government merely "primes the pump," but does not furnish the money.

The Federal Farm Loan Act provides certain channels for the farmer through which he obtains cheap money, on the long-time, easy payment plan. It introduces the amortization principle into agricultural finance in America. This law furnishes to the investor on the money market a standard liquid security, in place of the old farm mortgage, which is neither liquid nor standard, as the old-time farm mortgage could not readily be turned into cash and no two farm mortgages were exactly alike. Hence the general 
investing public never familiarized themselves with them. This new law offers to the investor a debenture known as a farm loan bond-standard and liquid, and destined to become familiar to every investor. Underlying the bond is the first mortgage, and underlying the mortgage is farm land worth twice the amount of the mortgage. Hence the farmer is put in the same financial condition, as regards the money market, as the great industrial corporations. Before the World War disturbed credits the farmer was paying five per cent on his loans under this Act, and this was the rate paid by the United States Steel Company on its bonds, and this is the largest business corporation in the world. Financing the World War embarrassed somewhat the country's early administration of this Act, hence it became necessary to raise the rate.

The machinery of this Act is very simple. To get the benefit of cheap land credit the law provides that farmers must band themselves together in corporations, at least ten farmers in the group. The federal government located and established twelve land banks, and advanced the original capital to each one, namely $\$ 750,000$. The government appointed temporary directors to serve the system. The next move was for the farmer to make. They incorporated their local loan associations. They applied for loans, furnishing as security first mortgages on farm lands of twice the value of the loans sought. These mortgages were then deposited in the district land bank and safely placed in the vaults. Against these five per cent mortgages the Land Bank sold 41/2 per cent farm loan bonds, receiving a premium of one and one-eighth for them. Customers for these bonds comprise banks, insurance companies, savings banks, private parties, and any other investor seeking a safe, liquid, tax-free four and one-half per cent security. The District Land Bank thus had a profit of one-half per cent plus any premium received - a big profit in all, considering the volume of the business. These two provisions of the law are worthy of note: (1) When the farmers in one district take out loans amounting to two million dollars, they take control of the district Land Bank. They choose six of the nine directors, and these six must be actual borrowing farmers. (2) When the farmers of the district take out loans amounting to fifteen million dollars, the government capital must all be paid back. At this writing loans greatly in excess of this amount have already been applied for. Hence, under this Act, the farmers are to own and operate the Land Banks. The government, in short, is simply helping the farmer help himself. 
The president appoints a board of four men, who, acting with the Secretary of the Treasury, constitute the Federal Farm Loan Board and exercise general supervision over the whole system.

This Act also provides that after it has been in operation one year and it appears that a community does not have and is not likely to have a local loan association, then the district land bank may appoint as agent a local bank. The local bank will then undertake to act as intermediary between the borrowing farmer and the land bank, receiving a commission of one-half of one per cent on the loan.

Joint Stock Land Banks.-This act also provides that private individuals may incorporate land banks, similar in general outlines to the District Land Banks, and that these joint stock land banks may loan to farmers on first mortgage security, obtaining the necessary funds by selling on the money market farm loan bonds, tax free. In short, the joint stock land banks secure and administer funds, in substantially the same method as the District Land Banks. In loaning funds, however, they deal direct with the individual farmer in their territory. Already the number of these joint stock land banks exceeds the number of District Land Banks.

Significance of Cheap Credit.-The Farm Loan Act has had two marked effects, namely, it has greatly reduced the interest. rate on farm mortgages in all newer sections of the United States; it has introduced the long-time, amortization plan of repayments The Act has been in operation too short a time to permit of extensive criticism of it. Certain questions arise, however. The Act was designed to help the needy farmer in particular. But who borrows first--the prosperous, shrewd farmer, who sees a chance to enlarge his holdings and buy out his unprosperous neighbor by means of a loan under this Act? Or is it the struggling farmer who is not classed as a good manager? Since a loan is made only on the security of a first mortgage on land, a landless man cannot borrow. He must first secure title to the land in order to give a first mortgage.

This Act makes the farm loan bonds tax free; it also declares them to be "instrumentalities of the government" - whatever that may mean; it therefore confers special privileges on the borrowers. From the social viewpoint the large and fundamental question involved is this: Will not this law, by making borrowers a favored class, in the end enable the already prosperous land owner to be more prosperous and buy more land at the expense of the so-called poor farmer? Poor men have poor ways, says the old proverb. Probably no law can make them richer. 
Again, "cheap money means dear land," just as "dear money" has' meant "cheap land" in the West. The Act will therefore tend to raise land values. If therefore the Act was designed to help the landless man and the tenant get a farm with cheap money, and the farm land becomes high in price because of the Act, it clearly defeats its own end. But such is the paradox of cheap money.

As originally passed, the Act permitted one borrower to borrow but ten thousand dollars. With such a small sum, a prosperous farmer could not, of course, buy out many weak neighbors. But already the "large farmers" are asking to have the loan limit changed to $\$ 25,000$. This change would facilitate the concentration of land ownership in the hands of those who are prosperous and successful as landowners. In fact one is tempted to ask the brutal question: Is it possible or desirable to prevent, by legislation, the workings of the law of the survival of the fittest?

The Life Insurance Companies.-The four chief sources of loans on farm mortgages, before the establishment of the Federal Land Banks, were life insurance companies, banks, mortgage companies, and private lenders. The Farm Loan Act forced the insurance companies to meet a new form of competition, namely, lower interest rates and long-term, amortization-plan loans. The insurance companies promptly met this competition, and even, in some cases, offered better terms than the Federal Land Banks could. The insurance companies offered two distinct advantages: loans secured direct from the company without joining any association; (2) money loanable on second mortgages as well as first mortgages. The public has the benefit of testing the two systems, side by side.

The Federal Reserve System and Agriculture.-The long campaign for reforms in our commercial banking system finally produced our Federal Reserve Bank Act. This act, with its later amendments, provided for an elastic currency based on commercial assets, and for the pooling and mobilizing of bank reserves. All national banks must and all State banks may join the Federal Reserve system. Under this act, for the first time, national banks are permitted to loan money on farm mortgages. However, what is doubtless far more important to agriculture is the provision for short-time agricultural credit. Ordinary commercial borrowers limit their loans to a period of three months. Whereas the farmer is permitted to borrow for six months. Under this act there is now developing that form of commercial paper known as the Trade Acceptance. 
Trade Acceptance.-The greatest reform in short time rural credit in recent years is that promised by the use of the trade acceptance. It is the cheapest and best form of credit known and is, it is hoped, destined to take the place of "open account" or book credit-the most expensive form of credit known. It should take the place of the promissory note where the term is not over six months. The farmers' coöperative store or the individual farmer, when buying fertilizer, feeds, seeds, agricultural machinery, livestock, or other agricultural supplies, may sign a trade acceptance, running as long as six months if necessary. This acceptance he will pay when due, at his bank, like a promissory note. It is, however, far superior to the promissory note, when the holder of it seeks to rediscount it or realize on it in paying his own accounts, since on the face of it it shows that an actual transaction has taken place in productive material. A promissory note fails to do this. In other words, here is a form of standard, liquid security which can be turned into money at the Reserve bank in the large city with the maximum of safety and the minimum of expense. Already the large farmers are using the trade acceptance rather than ask their local dealer to carry them. And when trade acceptances are once used their success and popularity are assured. Country bankers are urging their patrons to use this credit instrument. For some psychological reason the trade acceptance is paid promptly at maturity, whereas a promissory note is, in many sections, not so paid.

\section{QUESTIONS ON THE TEXT}

1. Quote the "northwestern farm woman" as to the economic conditions of farmers.

2. Show the attitude of mind towards credit. now, and formerly, in this country.

3. Show the relation of capitalistic agriculture to credit: Size of the Iowa farmer's investment.

4. What is the business corporation's attitude towards credit?

5. Cite Hunt's statement on the social significance of credit.

6. When did rural credit become a public question here?

7. Quote at length from President Taft. Summarize.

8. Distinguish clearly between land credit and coöperative credit.

9. Discuss our credit situation prior to 1916.

10. Explain the beginning of coöperative credit in America: Quebec; United States (nine States with detailed account of the North Carolina experiment): Herrick's criticism.

11. Explain at length the Federal Farm Loan Act.

12. Discuss the Joint Stock Land Bank.

13. What is the social significance of cheap credit? From the social standpoint, point out the probabilities and possibilities of this act.

14. State four additional sources of mortgage loans, and discuss in detail Life Insurance Companies. 
15. Explain briefly the Federal Reserve System, and in detail the Trade acceptance.

16. On a map locate the 12 Federal Land Banks.

17. What is the average size of a loan?

18. Locate the Joint Stock Land Banks.

\section{QUESTIONS SUGGESTED BY THE TEXT}

1. Show how land laws in New Zealand, designed to help the poor, helped the rich. Show whether it is probable or improbable that our Federal Farm Loan Act will make the rich farmer richer and the poor farmer poorer.

2. Examine the records of your local Farm Loan Association, and determine the classes of borrowers, and the purposes for which they borrowed. Show the individual benefits received. Show the social benefits (or injury, if any).

3. Show the possibilities and the limitations of the North Carolina Credit Union plan. Explain failure of credit union idea in 5 states.

4. Secure from your local banker samples of trade acceptances.

\section{REFERENCES}

1. "Agricultural Coöperation and Rural Credit in Europe, secured by the American and United States Cornmissions, 1913," 63 Cong. 1 Sess. Sen. Doc. 214, same part 2.

2. CAhill, J. R.: "Report to the Board of Agriculture and Fisheries of an Enquiry into Agricultural Credit and Agricultural Coöperation in Germany, with some notes on German Live-stock Insurance," London, 1913.

3. "Evolution of Credit and Banks in France." Report of National Monetary Commission. 61 Cong. 2 Sess. Sen. Doc. 522.

4. "Federal Farm Loan Board, Washington. First Annual Report, 1918. Annually thereafter." See also circulars issued irregularly by same Board.

5. "German Bank Inquiry, National Monetary Commission Report," 61 Cong. 2 Sess. Sen. Doc. 407.

6. Herrick, Myron T.: "How to Finance the Farmer-Private Enterprise-not State aid," 64 Cong. 1 Sess. Sen. Doc. 396.

7. - Banker and Farmer: Dealers in Pork and Beans. Outlook, New York, May 2, 1917, p. 21.

8. - AND Ingalls, R.: "Rural Credits-Land and Coöperative," New York, 1914.

9. "Miscellaneous Articles on German Banking. Report of National Monetary Commission." 61 Cong. 2 Sess. Sen. Doc. 508. 1915.

10. Mopman, James B.: "The Principles of Rural Credit," New York,

11. Weir, E. A.: "Rural Credit in Western Canada." Grain Growers Guide, Winnipeg, March 26, 1919, p. 25.

12. WolfF, Henry W.: "Coöperative Credit for the United States." New York, 1917.

13. — "People's Bank," London, 1910.

14. “Coöperation in Agriculture," London, 1914.

15. International Institute of Agriculture, Rome; International Review of Agricultural Economics: Italy- "National Conference of Rural BanksWork of the Italian Federation," May, 1919, 241-250; Roumania- "Agricultural credit," May, 1917, 49-63; Germany - "Landschaft of Piosen, 1914 to 1916," Dec. 1917, 1-9. "Raiffeisen Federation of Heuwed in 1914-1915," Feb., 1917, 1-14; March, 1917, 1-11. Austria-Hungary-" Agricultural Credit in Bosnia and Herzegovina," Feb., 1917, 55-67; Denmark-April, 1911, Jan., 1913; Feb., 1914; Jan., 1916; Jan., 1917. Russia - "Popular Coöperative 
credit," May, 1916, 31-46; June, 1916, 24-40; July, 1916, 14-24; "Popular Bank of Moscow," Nov.-Dec., 1918, 861-873. Uruguay - "Mortgages," July, 1918, 565-585; Jan., 1917; 65-70. United States-"Organization of Credit Unions" (in 9 States, namely: Mass., N. Y., R. I., Tex., S. C., N. C., Wisc., Utah, Ore.). June-July, 1919, 356-358.

16. "Annual Reports, on Savings and Loan Associations, Land Bank of the State of New York, and Credit Unions," Superintendent of Banks, Albany. 17. "Annual Reports, Inspector of Ohio Building and Loan Associations," Columbus.

18. Rosenthal, Henry S.: "Building, Loan and Savings Associations: How to Organize and Successfully Conduct Them," Chicago, 1911, 3d edition. 19. "Annual Reports, Rural Credit Societies of Manitoba, Parliament House," Winnipeg.

20. "Loans under Rural Credit Law of South Dakota, State Banking Department, Pierre."

21. "Loans under Rural Credit Law of North Dakota, Monthly Report, Bank of North Dakota, Bismarck."

\section{APPENDIX}

The Twelve Federal Land Banks. - Numbered by Districts.- 1. Springfield, Mass. States served-Maine, Massachusetts, Vermont, New Hampshire, Rhode Island, Connecticut, New Jersey, New York.

2. Baltimore, Md. States served-Pennsylvania, West Virginia, Maryland, Delaware, Virginia, District of Columbia.

3. Columbia, S. C. States served-North Carolina, South Carolina, Georgia, Florida.

4. Louisville, Ky. States served-Indiana, Ohio, Kentucky, Tennessee.

5. New Orleans, La. States served-Louisiana, Mississippi, Alabama.

6. St. Louis, Mo. States served-Illinois, Missouri, Arkansas.

Michigan.
8. Omaha, Neb. States served-Wyoming, Nebraska, South Dakota, Iowa.

7. St. Paul, Minn. States served - North Dakota, Minnesota, Wisconsin Oklahoma.

9. Wichita, Kansas. States served-New Mexico, Kansas, Colorado,

10. Ho iston Tex. State served-Texas.

11. Berkeley, Calif. States served-California, Nevada, Utah, Arizona. Oregon.

12. Spokane, Wash. States served-Idaho, Washington, Montana,

Federal Land Banks. Loans Made up to February 1, 1919

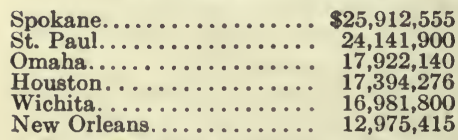

St. Louis.............. \$11,830,410

Louisville. . . . . . . .

Berkeley............... 10,013,200

Columbia.......... $8,321,090$

Baltimore.............6. $6,531,850$

Springfield............... $6,225,295$

Total loans, $\$ 168,213,931$; number of borrowers, 71,204 ; average per loan $\$ 2,362$. 


\section{APPENDIX}

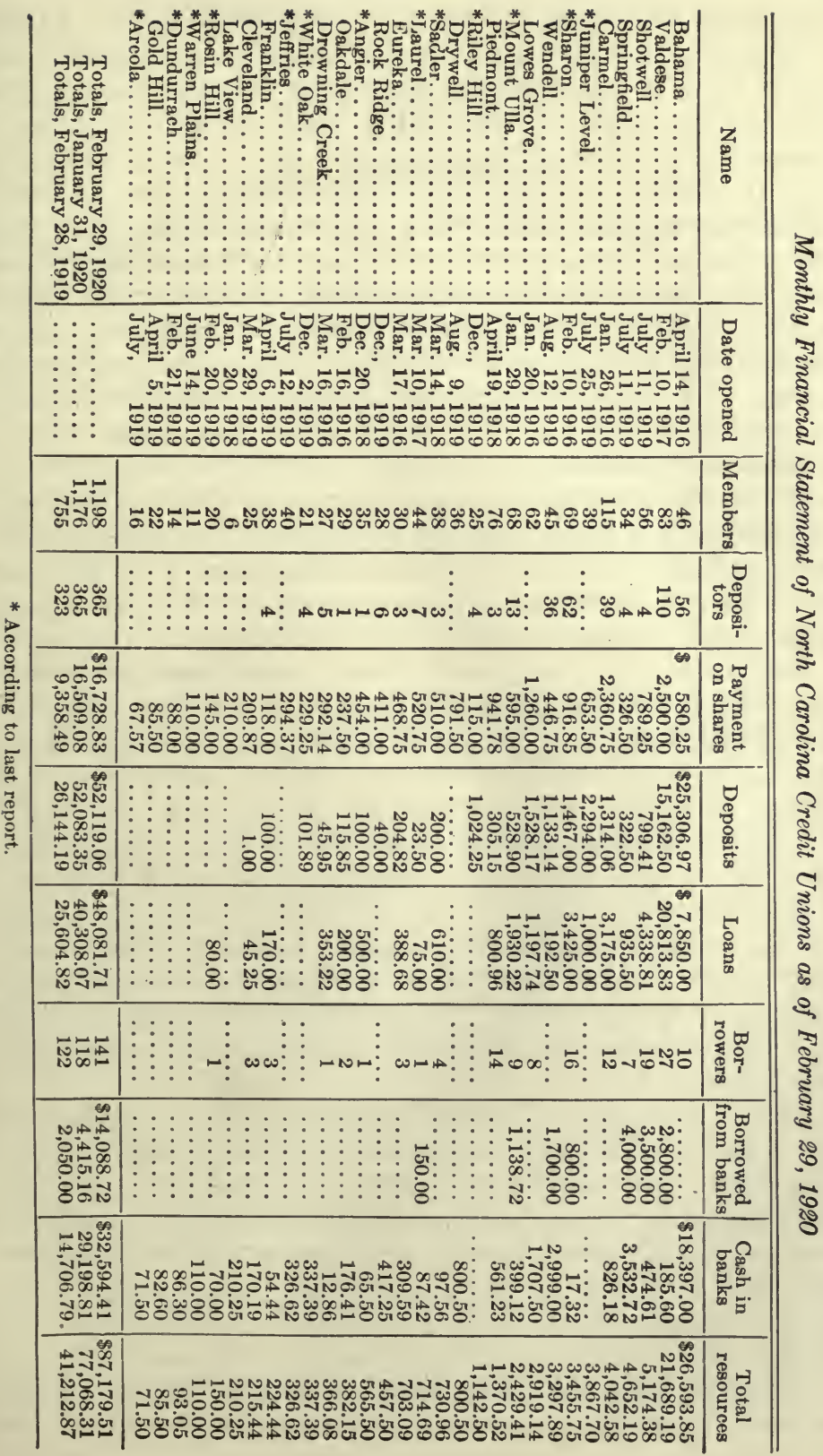




\section{CHAPTER XII}

\section{TRANSPORTATION}

Transportation, like credit, is now one of the vital forces in agriculture. It is part of the very life of the agricultural industry. The two, transportation and agriculture, must develop together, with equal steps, prospering together, suffering together. The State itself would not develop in a healthy and well-balanced manner without a concomitant development of a well-rounded transportation system. One speaker has called the road the foundation of the State.

We have a six-fold transportation system at the present time, not counting the airship and the submarine. Our system; in brief, includes transportation by ocean, rail, lake, river, canal, and wagon road. And of these six, the one showing the highest degree of development and progress in the United States is the railroad.

Railroads. - In the United States, as in England--the two countries where the railroad was first and is now best developedthe railroad began as a private institution, and so remained up to the time of the World War. In some foreign lands, however, the railroad is owned and operated by the government. In the United States, when railroads were first built, the accepted economic theory was to the effect that competition would be adequate to govern both service and rates. It was discovered, however, that the railroad is a natural monopoly and is therefore not governed by competition. This left to the government the alternative of regulation or ownership. Hence, in the course of fifty or sixty years, the government adopted the policy of regulation both of rates and services.

Evils.-Like any other great institution, the railroads change their business standards and practices with the changes in society about them. In the past the most crying evils of the roads were their rebates to favored shippers, their discriminations in freight rates (between persons, between localities, and between commodities), and their corrupt participation in party politics. These evils were finally eliminated or scotched, due to legislation, to the administration of the Interstate Commerce Commission, and to the changing sense of business honor among the railway magnates themselves. At the present time, however, there seems to be a 
swelling chorus of discontent against the railroads. Part of this public discontent, as of all popular dissatisfaction, is due to the ambidextrous efforts of the ubiquitous demagog. A part is based on real grievances in connection with the service and the rates. Railroad rates, it may be safely assumed, will never give popular satisfaction, no matter whether they are made higher or lower, whether they are made under government or private ownership. The chief grievances at the present time, so far as service is concerned, have to do with two things, namely, the speed of freight trains and the supply of cars. The serious losses in the transportation of poorly packaged freight has already been mentioned.

These two subjects have had repeated airings before committees of Congress and before State Railroad Commissions. One illustration will serve to show the concrete situation. At a hearing before the United States Senate Committee on Interstate Commerce in 1908, on the subject of Prompt Furnishing of Transportation Facilities, the largest live-stock growers in the United States were present. Among these was Murdo Mackenzie, one of the greatest stockmen of North and South America. Some of his testimony ran as follows:

"I will first touch on the shortage of cars and my own experience in this direction. A year ago last fall I ordered cars from the Fort Worth and Denver Railroad for shipment to Kansas City, either over the Rock Island system or the Santa Fe. I gave the railroad from two to three weeks' notice to supply the cars, and after that time had expired, and I had my cattle ga thered, they kept me from day to day waiting for cars until two months had expired ... On the 15th of September, 1907, I ordered cars for shipment to Kansas City and St. Joe, and on the 5th and 6th of October to ship from the same points in the Pan Handle. I proceeded to gather our cattle, and after I had them on the trail for 30 miles, I was only then informed by the railroad that I could not get the cars. I was compelled to turn the cattle back and turn them loose again. This was on the 18 th of October. I was informed by the superintendent of the Fort Worth and Denver that there was no hope for my getting the cars to ship over the Rock Island or Santa Fe before the middle of December . . . I came down to Chicago from home; I saw the Rock Island people and the Santa Fe people. I put my case before them and asked them if they could not, even on personal grounds, help me out. They remarked that they could not do it; that they had more business on their own systems, a part of which runs through Texas, than they could supply cars for; that they were not going to supply cars to connecting roads. Now here I was, between the devil and the deep sea, located on the Fort Worth and Denver road, that is presumably a road engaged in interstate commerce. They publish schedules for carrying our cattle. They refused to supply me with cars, because they did not want to let their cars go off their own system, fearing, as they stated, that if they did so they would not get their cars back. The Rock Island would not supply cars to connecting roads because they had more than enough to do with their cars on their own system. Now, what is a man going to do who is in this kind of a business? We have to ship our cattle. We cannot walk them, we cannot put them on the trail. as we used to in years gone past. We are com- 
pelled to ship them over the roads. Are we to be compelled to wait until the season is over, until our cattle are shrunk, so that we can not get the price for them which they would otherwise bring? Or what are we going to do?"

Murdo Mackenzie now takes up the question of the speed of trains. He speaks in part as follows:

"Now, I have said enough about the car supply. I want to show you what speed. we get over the railroads. I had a shipment of cattle in June coming from Estelline, Texas, going up into the northwest. It took me 51/2 days to get those cattle hauled 1000 miles. The first 172 miles took me 36 hours (about 5 miles an hour)."

Mr. Mackenzie then speaks of three other shipments of cattle, which made the following speeds, respectively: $91 / 2$ miles per hour; 71/3 miles per hour; $51 / 4$ miles per hour. He introduced as evidence a letter from the Solicitor of the United States Department of Agriculture containing further material on the average speed of stock trains. In a group of 42 cases on one road, the average speed was $91 / 2$ miles per hour. In a group of 24 cases on another road the average speed maintained was 12.3 miles per hour. Other cases ran as follows: third road (22 cases), average speed 5.4 miles per hour; fourth road (28 cases), 10 miles; fifth road (122 cases), average varying from 1.9 miles to 15.6 miles per hour; sixth road (14 cases), 6.4 miles; seventh road (15 cases), 11 miles; eighth road (166 cases), 9.7 miles per hour. In seven or eight hundred cases the average running time of stock trains was 9.4 miles per hour.

An investigation of the speed of freight trains carrying potatoes in refrigeration cars from the region of the Red River of the North to markets East and South showed that the average speed is $41 / 12$ miles per hour.

Delays in freight shipments largely occur at sidings and junction points, where other trains must be met, and at the city terminals, which are grossly inadequate to handle the business passing through them. The remedy here would involve not merely the coördination and reconstruction of city terminals, but the double tracking of all important main lines. Improvements of this kind, however, as well as the addition of new rolling stock involves vast increases in capital expenditures on the part of the railroads. In the face of this situation, it does not seem likely that railways can make these increased outlays and at the same time lower rates on agricultural products. What way is left, then, for the American farmer to secure better rates and services?

Some light on this question comes to us from England, where a similar system of private ownership prevails. The British 
farmers felt aggrieved to learn that the British railroads were carrying large quantities of foreign eggs at lower rates than the British farmer was paying for sending his own eggs to market. This seemed like a bad case of discrimination. The individual English farmer, with his comparatively small supply, forwarded his eggs to market from day to day in small consignments. The foreign eggs came in in large lots. One of the English railway companies replied to the National Poultry Organization Society's request for lower rates in this fashion:

"If you will only send us eggs in 4-ton lots, as against the very much larger quantities we received from abroad, we will give you a rate which will be 25 per cent lower than we get as our share of the through rate charged to the foreigner." The offer was declined, because the farmers were not yet ready to deliver this volume of business. When these farmers are able to deliver this amount of business with some certainty both as to the volume and the regularity of delivery, they will be able to secure service and rates on the most favorable terms possible. We have already seen, in the case of the Warren County (Kentucky) Strawberry Growers, that as soon as they could guarantee quantity and time of shipment, adequate transportation service was forthcoming.

Railway Finance.-American railroads are capitalized at much lower figures than railroads in foreign lands. Here is the situation:

American railroads are capitalized at.............\$ 60,000 a mile

British railroads are capitalized at. . . . . . . . . . . . . . . 275,000 a mile

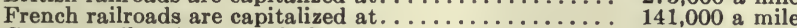

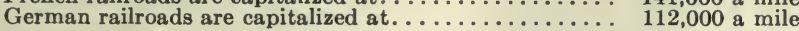

On the other hand wages are higher in America than in foreign lands.

Average pay of American railway employe (before the war) \$668 per year Average pay of British railway employe (before the war).. 251 per year Average pay of French railway employe (before the war).. 260 per year Average pay of German railway employe (before the war).. 382 per year Average pay of Austrian railway employe (before the war). 260 per year

And the freight rates are much lower in America. Here are the figures:

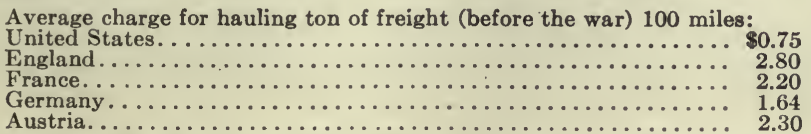

Railroads and the Farmer.-The railroads are devoting a great deal of attention to the subject of agriculture. Their reason is frankly a selfish one - to make more prosperity for the railroad. The roads with a federal land grant were interested in selling this land. These grants amounted to $115,500,000$ acres. All roads 
derive considerable freight traffic from agricultural products and from products sold to the farmer. The five chief methods now employed by the railroads in aiding agricultural progress are these: (1) Securing new settlers; (2) Agricultural education; (3) Marketing coöperation; (4) Supply of farm labor; (5) Forestry and landscape gardening.

(1) Securing New Settlers.-Many railroads now have an official called "immigration agent" whose duty it is to bring settlers from the crowded sections of the United States to the sparsely settled parts. A few decades ago settlers were brought largely from foreign countries. Thus the Santa Fe solicited settlers from Germany in the seventies. In Barton County, Kansas, along this line, there were 2 persons of foreign birth in 1870 ; in 1880 there were 2,216 foreigners here. Similarly in Marion County, Kansas. Here the Russian Mennonites were brought in. In 1880 there were 2 in Marion County; in 1890 there were 3,116. A later illustration can be given for North Dakota. The Great Northern railroad made a systematic attempt to bring in American farmers, opening its campaign in the State of Indiana, and making Cando, North Dakota, the objective point of settlement. On March 21, 1893, a party of 300 men, women and children, in a special passenger train, left Walkerton, Indiana, for Cando, North Dakota. The household goods of these settlers came along in a special freight train of forty cars. It is estimated that the movement from the central states rapidly increased in the following years, reaching 1800 the first year, and, after some ten years, averaging 20,000 a year.

(2) Agricultural Education.- In this line of endeavor the railroads are now generally coöperating with the State and Federal governments. For instance, instruction trains are a good example of this form of coöperation. A "Better Farming Special" is sent out by one road, including cars and coaches equipped so as to take the best ideas of the Agricultural College to the farmers. Certain cars are equipped with live stock, heavy horses, beef and dairy cattle, poultry, swine, and sheep, while other cars contain illustrative and demonstrative material relating to seed improvement, identification of weeds, drainage, alfalfa, silage, insects, dairying, poultry raising, bacteriology, etc. This is merely a sample of the work being done by many of the railroads. With these trains go lecturers and demonstrators. The country folk come in many miles to attend the lecture or demonstration. Some "Better Farming Specials" devote their whole attention 
to one topic, such as beef cattle. Railroads also employ agricultural experts to visit the farms and instruct the farmers. Some roads maintain demonstration farms, or maintain demonstration

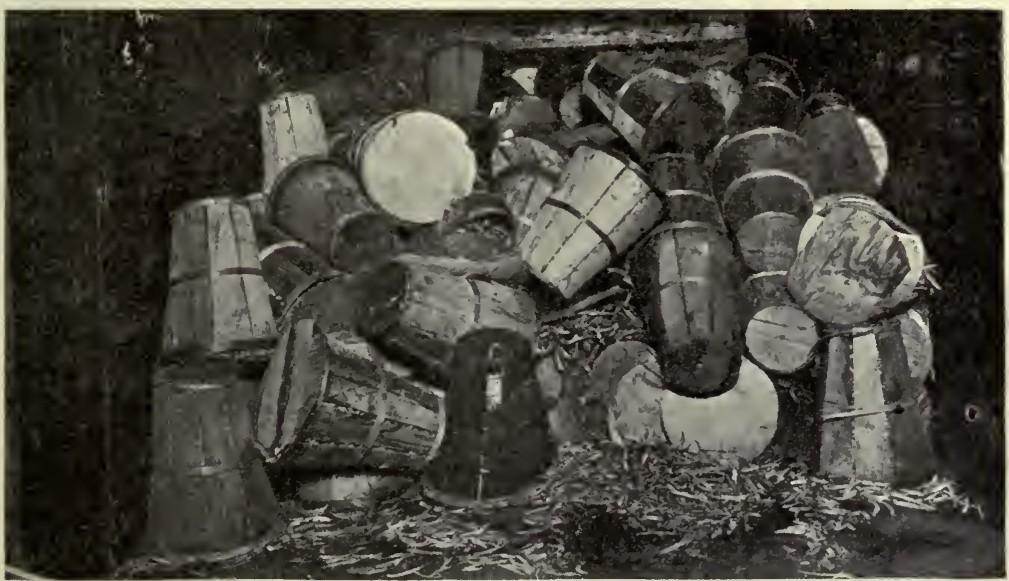

FrG. 34.-Beans in hampers, loading not properly braced.

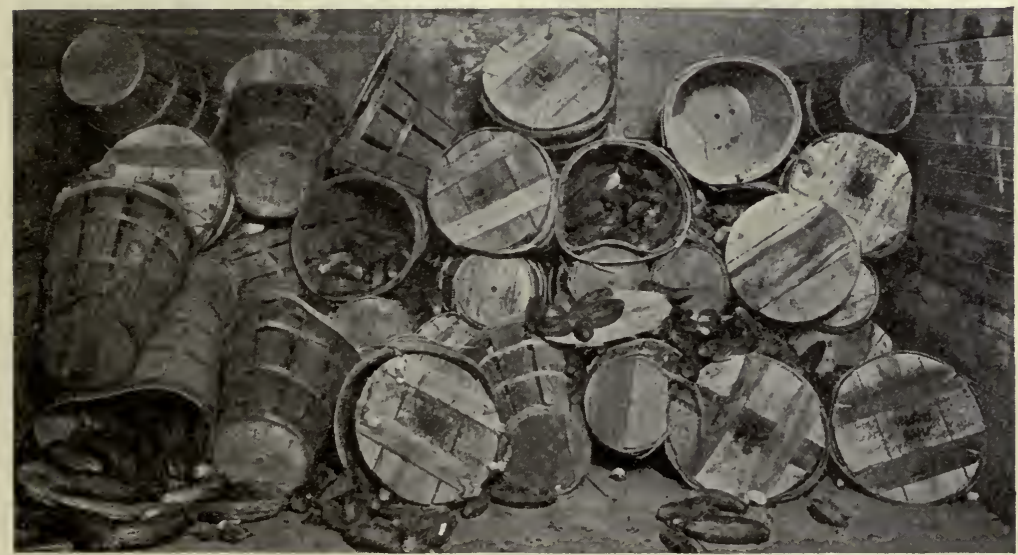

Fra. 35.-Cucumbers should not be loaded in a hamper.

plots on private farms. Prizes are given for farm products or for live-stock production.

(3) Marketing Service.-One large railroad system employs men experienced in produce marketing, and sends them among the 
farmers and advises them as to how and where to sell produce. Other roads help organize the farmers into coöperative associations and give them instructions on packing and grading, showing the need of the standardized pack. One of the greatest preventable leaks in our marketing system is the loss in shipping foodstuffs in frail and insecure containers or in containers not properly loaded. The accompanying figures illustrate this loss (Figs. 34, 35, and 36).

(4) Supply of Farm Labor.-Some roads now coöperate with the State departments of agriculture in supplying labor for jobs and jobs for labor. The railroad works largely through its local

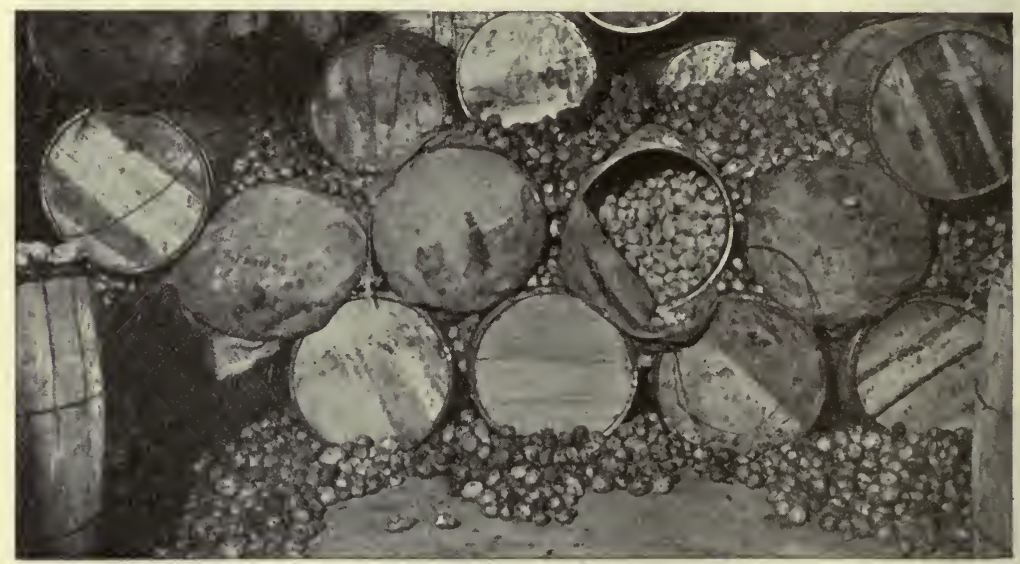

FIG. 36.- Potatoes in barrels loaded on bilge and no head liners used.

ticket agent. The local agent is in touch with the farmer, on the one hand, and with the central office on the other. He receives the farmer's application for hiring help; he also learns of places on the farm for labor. The central office of the railroad collects and classifies the applications and reports, and presents them in quantities to the State officials.

(5) Forestry and Landscape Gardening.-One railroad has put $1,000,000$ acres under systematic forestry management. Another railroad has planted a large acreage to trees, including the following trees: red oak, 2,067,529; locust, 1,915,235; Scotch pine, 371,711; European larch, 47,045; Norway spruce, 46,500; catalpa, 40,605; pin oak, 26,220; white pine, 14,372; black walnut, 10,885; other species, 27,524; making a total of 4,617,626 trees. Railroads also contribute money and services in the work of prevention of forest fires. Landscape gardening is carried on about the railway 
stations of some roads, under the supervision of an expert in this line. This encourages ornamental gardening in the villages and cities along the road. Some roads maintain nurseries in the prairie states, where young trees, fitted to the climate, are sold at very low prices to farmers. Farmers are encouraged to plant such trees as will protect and beautify their farmstead.

It is to be earnestly hoped that the railroads will develop two additional lines of coöperation with farmers in certain wide sections of the country. (1) Crude material for road building, such as gravel, is lacking in many sections and can only be shipped in at prohibitive costs. (2) Farm labor cannot flow to the fields where needed owing to heavy charges for passenger fare. These two situations should be understood and adjusted by the railroad companies.

Express Business.-The express companies utilize all forms of transportation. They have grown into their present position of prominence and power by rendering a special kind of service. The historical growth of these companies is interesting. The federal government has published a special census report on this subject, prepared by R. H. Snead, ${ }^{1}$ from which the following information is gleaned.

The beginning of the express business goes back to 1839, when one William F. Harnden, valise in hand, made four trips a week between New York and Boston carrying valuables and small packages for his customers. There was a demand on the part of the public for such a service, consequently a number of small companies were soon engaged in express business. The American Express Company was formed in 1850; in 1854 there were formed the United States and the Adams Express Companies. An express company, says one writer, purchases the right of transportation at wholesale and sells it at retail. In addition to transportation, calling for packages, and delivery of packages, the express companies now render among other services the following: issue money orders and letters of credit; exchange foreign money; enter and clear goods at custom houses.

"Ever on the alert to extend its business, long before the railroad reached a new section of the country, an express company would have an established service by means of stage or pack animals. Indeed, no more romantic or interesting figures are to be found in the history of the West than the Pony Express Riders, who carried letters and valuables across half a continent."

Railroad companies now furnish and haul the necessary cars for the express business on the contract basis, the express company

${ }^{1}$ Bureau of Census. Special Report Express Business in the United States, 1907. 
paying a per cent of its gross earnings. While there are now 34 express companies operating in the United States, only six of them are large companies. The original investment in this business was small. While the six large concerns have assets of $\$ 85,613,809$, only $\$ 6,267,184$ represents equipment and fixtures used in the express business. The balance of the assets consists largely in the investments purchased out of surplus earnings. These investments are largely in railroads and in other express companies. The six big companies have 90 per cent of the assets of the 34 companies.

Express rates are graduated according to weight of package and distance carried. Since the enactment of the Federal Parcels Post law the rates have been put on a competitive basis with the post office.

Parcels Post.-Like the express business, the parcels post now operates over transportation routes of all kinds. The Post Office Department is making a campaign of publicity in order to popularize and to increase the service now rendered by the parcels post. Exhibits are held at the various State fairs. Thirty-five important cities of the country were selected for a more thorough and intensive campaign, the immediate aim of which was to foster direct marketing between farmer and city housekeeper. The postmasters prepare and circulate lists of producers and lists of consumers.

What service does the parcels post actually render? In one sense it is very much like the express business, except that the weight limit is imposed in the parcels post but not in the express business. Both have a delivery service in cities of a size to justify it. Both transport highly perishable commodities and the cost is very much the same, both using a zone system. The growth of the parcels post has been encouraging, although not up to the high expectations of some of its enthusiastic friends. Containers, strong, light, and cheap, have been developed by private commercial concerns, thus overcoming one of the initial weaknesses of the system. Fresh eggs may now be shipped a thousand miles by parcels post with comparative safety. In short, the physical difficulties of parcels post marketing have been overcome. There remain only the business difficulties. But these have proved the hardest to overcome. The first difficulty is the agreement on price. The farmer's wife was selling butter at the country store at 20 cents a pound, but wanted 50 cents a pound when sent by parcels post to the city. Credit arrangements are also difficult to make. The city housewife does not want to pay cash in advance for goods she has not seen and about whose quantity, quality, 
and time of arrival she is uncertain. Neither does the farmer want to forward goods to a stranger who may reject them or may fail to pay for them. Parcels post marketing thus means entirely new business habits on the part of the public who may use it. This process will take time, much time.

Interurban Electric Lines.-Certain sections of the country, such as that about Indianapolis, for instance, suggest the probability of a great development of electric lines as freight and passenger carriers from country to city. The initiative for such lines seems to come entirely from the city end. It would seem feasible for farmers themselves to organize corporations and construct their own lines in case their community is not already adequately served. This form of transportation is yet in its early stages, but is full of promise for the future.

Lake Transportation.-While there are numerous lakes in the United States employed in transportation of passenger and goods, yet these all dwarf into insignificance in comparison with the traffic borne on the Great Lakes. There is no more important highway of commerce in the world than the chain of northern lakes. One aspect of this economic condition is the phenomenal growth of the large cities situated on the shores of the Great Lakes. While lumber, coal, and iron ore figure prominently in this lake traffic, yet grain is one of the commodities of first importance.

A large share of our surplus grain is produced in the region tributary to the Great Lakes. The transportation facilities of this waterway have given better and cheaper service than is possible by rail. A large freight vessel, loading in bulk from an elevator in Duluth will load 300,000 bushels of wheat in three hours. Some of the larger boats carry over 400,000 bushels. Freight rates by water, like freight rates by rail, have tended downward for the last forty years. The average rate on wheat from Chicago to Buffalo by lake was, in 1901, one-fourth of what it was in 1871. The all-rail rate on wheat, Chicago to New York, was in 1901 only forty per cent of what it was in 1871 .

In 1871 the rate on wheat per bushel by lake from Chicago to Buffalo was 6.3 cents. In 1909 the average rate was 1.4 cents. The water rate fluctuates from day to day, with the supply and demand of vessels. The rail rate is about twice the average lake rate.

River and Canal.-There is little to be said on this subject at the present time. Once our inland boat service was an impressive thing. Now these canals are almost as extinct as the stage 
coach and the ox cart. The Erie Barge Canal is a disappointment. The Ohio and Mississippi Rivers do float some commerce, but it is mere dust in the balance compared to the traffic borne by the railroads that parallel their banks. Steamboat traffic on the Missouri River, once important, may now be pronounced dead. Aside from a few especially favored cities, like Washington, St. Louis and New Orleans, the ordinary American River city derives little or no transportation benefits from its river.

The river is a public highway. Any person, even with small capital, can enter the competition thereon. Yet the field remains practically unoccupied, while the railroads continue to handle the traffic. The public are doubtless a little slow to take a serious and hopeful interest in river improvement since for a long period of years the worst "Pork Barrel" legislation of the United States Congress has centered about the appropriation for "Rivers and Harbors." Doubtless this mishandling of an important matter has set back the cause of real river improvement a good many years.

Good Roads.-The term "Good Roads" is now coming to be applied to improved country highways. The implication is that ordinary country roads are not good roads. In other words, we are just now developing a road system which compares favorably with the good roads of European countries. For many decades the roads in rural America were left to the strictly local units of government as one of their sacred "functions." In practice this meant that roads were rarely constructed with scientific or permanent improvements, but were generally left in a "state of nature." True, the owners of adjoining farms were permitted to "work the roads" once a year in lieu of paying their so-called road tax. This farcical performance is now happily extinct except in a few backward and hidebound communities. With the coming of the automobile to both city and country, the farmer and the city dweller are both of the same opinion as to good roads, namely, that State and national systems of highways are a necessity. Hence to-day we have the various transcontinental highways, such as the Lincoln Highway east and west, the Jefferson Highway north and south, and many other great trunk highways; we have also the federal office of good roads and a huge federal appropriation to subsidize State highway systems; we have also in most of the States a central commission or board of engineers in administrative charge of the construction and repair of public roads. Centralized administration is bearing good fruit. Big transportation 
costs, formerly thought of solely in connection with railroads, are now seen to go with the local haul on the country roads (Fig. 37). An expert in transportation in the Department of Agriculture published some statistics in 1906, comparing costs of hauling cotton and wheat from farms to shipping point, hauling on the railway, and the ocean haul. The average local haul of cottonfarm to shipping point-was 11.8 miles, and cost 16 cents per 100 pounds for this haul; for wheat the average local haul was 9.4 miles, and the cost of this haul was 9 cents per 100 pounds (5.4 cents per bushel). The railway charge for hauling to seaboard was 40 cents per 100 pounds of cotton and 20 cents per 100 pounds

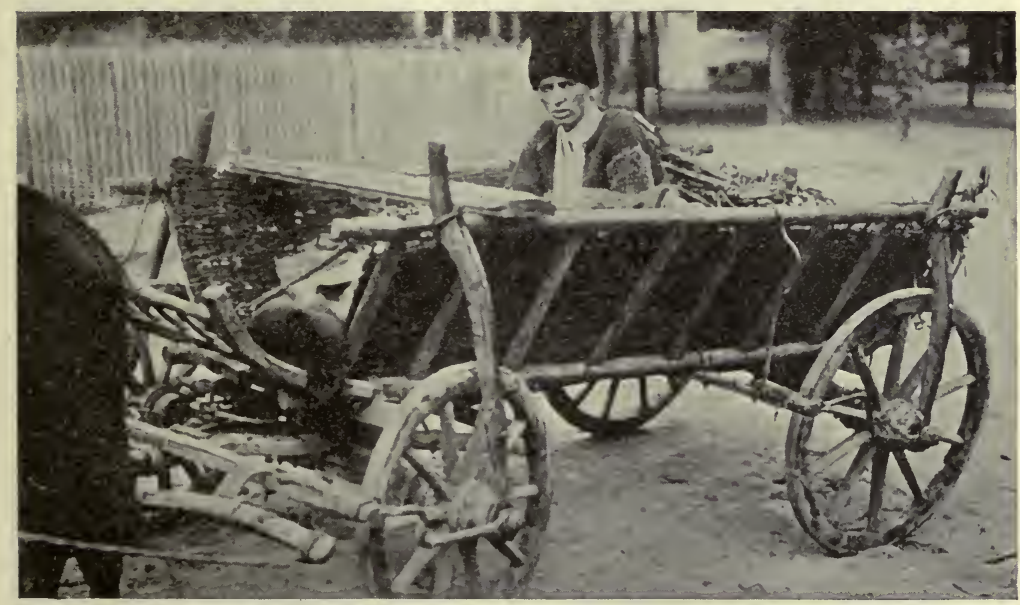

Fic. 37.-Transportation by wagon road as seen in Russia.

of wheat. The ocean carry was, of course, far the cheapest. Thus England took 3,000,000 bushels of wheat in 1905 by sailing vessel from Puget Sound, down the west coast of America and around Cape Horn, a voyage of 15,000 miles. The average charge for carrying wheat to England for the year, the hauls varying from 3000 to 15,000 miles, was 9 cents a bushel, or only one and two-thirds times the cost of hauling nine miles over a country road.

Rural Motor Express.-That country roads are soon to be important factors in transportation is now evidenced by the train of huge motor trucks that carry freight between important urban centers in the eastern part of the United States. The railroad is destined to be used principally for the long haul. Motor vehicles operating over graded and surfaced highways will be the feeders 
for the railways. With a dense population the greater part of the farm produce is consumed within the range of the short haul.

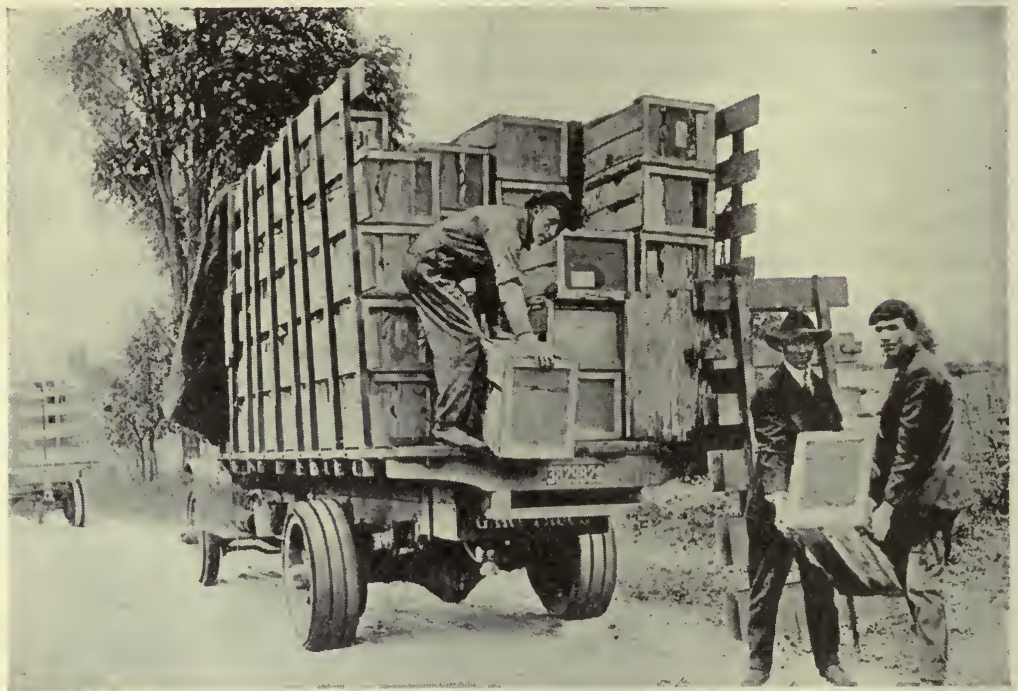

FIG. 38. - The motor truck at onion and celery farm of Hartville, Ohio, being loaded. Shipments are carried to Pittsburgh, $\mathrm{Pa}$.

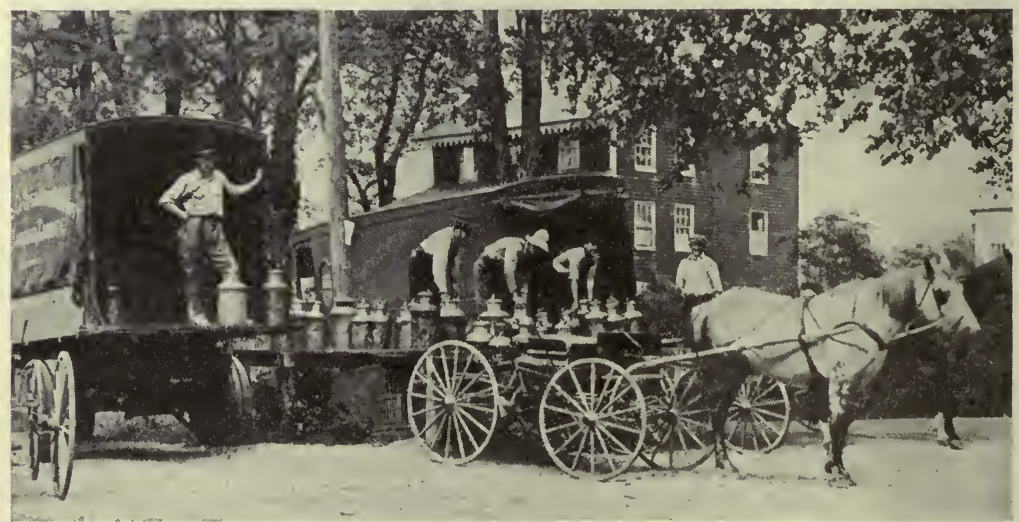

Fig. 39.-Farmers at Harford County, Md., delivering milk to roadside platforms from which it is taken to the city dairies by the farmers' coöperative trucks.

It will manifestly be economical for the motor vehicle to haul this local produce for local consumption (Figs. 38 and 39). 
The value of good roads to the farmer is manifest in many ways. For instance, travelers along the famous pike in Indiana known as the Michigan Road years ago noted the spirit of pride farmers along this road took in the upkeep of their farmsteads. The fences were woven wire, in contrast with the rail fences just off the pike; the barns were painted, and usually had the farmer's name or his farm name in big letters on the roof; the houses and lawns showed that the esthetic sense of the farmer and farmer's wife appreciated beauty. Farm life had become more dignified. The social value of good roads in annihilating isolation is easy to comprehend, but difficult to measure. Many serious efforts have been made to measure the economic value of good roads as a factor in raising land values. The Federal Office of Good Roads and Rural Engineering made surveys in eight counties in five States for a period covering six years, 1910 to 1915 inclusive. The study revealed the interesting fact that following the improvement in the highways, the selling price of the adjoining land amounted to from one to three times the cost of the improvements. These studies were conducted in the following States: Virginia, New York, Alabama, Mississippi, and Florida. In Franklin county, New York, the figures seem to indicate that the change from earth, sandy and loam roads to bituminous macadam was followed by increases averaging $\$ 12.50$ per acre, or about 30.7 per cent. The economic value of good roads includes other factors than increased land values, such as lessened wear and tear on vehicles, harness and teams, increase in size of load hauled, and decrease in time consumed in hauling.

Ocean Transportation.-At the opening of the World War in 1914 ocean transportation afforded a good example of the economic theory of competition. In other fields of transportation governments had gradually come to sct aside the competitive system as a regulator of rates and services.

A Royal Commission in Great Britain appointed in 1909, and the Committee on the Merchant Marine and Fisheries of the United States House of Representatives, under House Resolution 587, passed in June, 1912, both investigated the workings of competition in ocean shipping, and both reached the same conclusion. Competition has destroyed competition. A summary of the facts found by the United States investigators is as follows:

First-that the evils arising from former unrestricted competition in ocean carriage have driven the steamship companies to form understandings, conferences, combinations, "rings." 
Second-that these combinations and rings have led to the formation of great shipping trusts. These trusts control not only the lines directly owned by them, but also control, to a great extent, the traffic of the tramp ships, which gives them a powerful monopoly.

Third-that these monopolies give rise to and maintain excessive and unjust rates, and by use of "fighting ships" and by rebates to large shippers, tend also to bring forth other and dangerous monopolies, monopolies in buying and monopolies in selling.

Competition is spoken of in these words:

"Unrestricted competition, based on the survival of the fittest, tends to restrict the development of the lines, and in the end must result in monopoly . . . Competition in the steamship business was regarded as the demoralization rather than the life of trade; as the means of introducing uncertainty instead of certainty, and inefficiency instead of efficiency." The steamship companies advanced this statement, on the same subject: "Competition has never established a reasonable rate nor maintained a stable rate ... Rate wars tend to the monopolization of trade by the larger shippers. Unless the warring steamship factions come to some agreement, the result is more or less of a monopoly on the part of the most powerful carrier engaged in the conflict."

These rings gave stability to rates on high-priced freight. But these rings did not cover heavy bulk traffic, such as grain, flour, oil cake, cotton, and similar commodities. The "package traffic" (the high-priced freight) constituted 22 per cent of the tonnage, while the bulk traffic constituted 78 per cent. That is, 78 per cent of the tonnage, unregulated by agreements, consisted mainly in the staples of agriculture. On the staples, ocean freight rates varied not merely from month to month, but from day to day and from hour to hour. This introduced an element of risk, which in turn necessarily reflected itself in the price of the commodity. In other words, the foreign buyer or American exporter would be forced to hedge his risk, so far as possible, by paying a lower price for the commodity.

The situation is beyond the reach of any one nation. An International Commerce Commission, strongly urged by Hon. David Lubin, Delegate of the United States to the International Institute of Agriculture at Rome, offers one feasible solution to the problem.

The World War brought a new element into the situation, when the United States entered the field of ocean transportation. 
But whether this activity on the part of the United States government is to be permanent or temporary is, at the present writing, in doubt.

The World War also caused the United States to take possession of the railroads, and to operate them as a unit. The law provided that this government control should cease within 21 months after peace was declared. The government made the single dominating principle of its operation of the road the winning of the war; consequently service to private shippers was strenuously curtailed; rates were greatly increased; costs of operation were enormously increased by reason of wage increases. In short, the public paid more and got less. While the war was in progress the public cheerfully acquiesced in this condition on the ground that any sacrifice was worth while so long as it contributed towards victory. With the coming of peace, however, the public demand was irresistible that the roads be returned to private ownership.

\section{QUESTIONS ON THE TEXT}

1. Show the fundamental importance of transportation.

2. Name the six elements in our transportation system.

3. What economic theory first prevailed concerning our railroads? Show failure of this theory.

4. State the evils in connection with early railroad operations. What is the present status?

5. What are the two main grievances now against railroads?

6. Summarize the testimony of Murdo Mackenzie.

7. Summarize conclusions as to speed of freight trains. Explain these delays. State remedy.

8. Cite British experience.

9. Comment on railroad capitalization and freight rates here and abroad.

10. Show relation of railroad to farmer in six important respects.

11. Name two additional activities needing attention.

12. Discuss at length the express business.

13. Show growth, success, and limitations of the Parcels Post.

14. Show status and prospects of the Interurban Electric service.

15. Comment at length on lake transportation.

16. Describe and account for status of river and canal transportation.

17. Describe in detail the Good Roads movement in this country. Compare haulage costs on country roads, railroads, and ocean.

18. Show the Rural Motor Express situation.

19. Comment at length on value of good roads to the farmer.

20. Show how the theory of competition worked out in ocean transportation.

21. What action, if any, should the government take as to ocean transportation?

22. Show what effects the World War had on American railway transportation.

\section{QUESTIONS SUGGESTED BY THE TEXT}

1. Prepare a chart showing the amount of federal aid to good roads allotted to each State.

2. Would it not be as logical for a farmer to work out his school tax by teaching in the local school house a few days, as to work out his road tax? 
3. Prepare a chart showing main highways across the United States.

4. Prepare a chart showing main Rural Motor Express lines in your State. (Consult National Automobile Chamber of Commerce, 7 East 42d Street, New York City.)

5. What solution have you for the railroad problem in the United States?

\section{REFERENCES}

1. Andrews, Frank: "Freight Costs and Market Values. Yearbook of the Department of Agriculture," 1906.

2. - - "Grain Movement in the Great Lakes Region." United States Department of Agriculture, Bureau of Statistics, Bulletin 81, Washington, Nov., 1910.

3. - "Railroads and Farming. Some Influences Affecting the Progress of Agriculture," United States Department of Agriculture, Bureau of Statistics, Bulletin 100; Washington, October, 1912.

4. - : "Inland Boat Service, Freight Rates on Farm Products and Time of Transit on Inland Waterways in the United States," Bulletin 74, United States Department of Agriculture, Washington, December, 1914.

5. "Comparison of Capital Values-Agriculture, Manufactures, and the Railways." Bureau of Railway Economics, Bulletin 39, Washington, 1912.

6. ElLIOTT, Howard: "Relation Between the Farmer and the Railroad." Address at the Tri-State Grain and Stock Growers Association, Fargo, N. D., January 17, 1912. (Mr. Elliott was at that time president of the Northern Pacific Railway.)

7. Lubin, David: "Proposal for an International Conference on the Regulation and Control of Ocean Carriage." International Institute of Agriculture, Rome, 1914.

8. be under public control"? International Institute of Agriculture, Rome, December, 1916, No. 35.

9. McPherson, Logan G.: "The Farmer, the Manufacturer and the Railroad." North American Review, New York, November, 1907.

10. "Prompt Furnishing of Transportation Facilities. Hearings Before the Committee on Interstate Commerce, United States Senate," February 21, 1908.

11. "Railways and Agriculture," 1900-1910. Bulletin 45, Bureau of Railway Economics, Washington, 1913.

12. Snead, Russell H.: "Express Business in the United States." Bureau of the Census. Special Reports, Washington, 1907. $\mathrm{XC}, \mathrm{CCLXXXV.}$

13. "Industrial Commission Report," Vol. 4, 5-109; Vol. 9, LXXXII,

14. Yearbook Department of Agriculture: 1899- "Development of Transportation in the U. S."; 1900- "Influence of Transportation on Fruit Industry," 561-580; 1905-"Handling of Fruit for Transportation," 349-363; 1906-"Freight Costs and Market Values," 371-387; 1908-"Cost and Methods of Transporting Meat Animals," 227-245; 1917- "Federal Aid to Highways," 127-139.

15. "Rural Motor Express." (See Automobile Chamber of Commerce of the United States, New York City.) 


\section{CHAPTER XIII}

\section{INSURANCE}

IN the insurance of his dwelling and other farm buildings, the farmer is in the same position as any other owner of buildings. This risk is very commonly carried by a farmer's coöperative insurance company, or a joint stock company, a large number of which do business in each State and are subject to the laws and supervision of that State.

But the growing of crops and of live stock place on the farmer a risk peculiar to the agricultural industry. Insurance in these fields has developed in three general forms, namely, the joint-stock company (the ordinary corporation), the mutual company (a coöperative enterprise), and, in recent years, State insurance.

The joint stock companies have long occupied most of the field. Yet discontent with this form of insurance is steadily growing among the iarmers. The chief criticism seems to be, not that these companies have failed to pay their losses, not that they have been unduly harsh in their methods of adjustment, but that they have collected too large a toll from the farmer. These companies reply that their charges have been fair considering the service rendered and the coverage afforded, and that they have collected no more "toll" in good years than was needed, on business grounds, to build up a safe and adequate reserve against the bad years.

Farmers' mutuals, coming into the field, commonly use the assessment method of paying their losses. Where they have tried a level premium plan, they have committed the error of making it too low, and hence of having heavy unpaid losses in bad years. Where the assessment plan has come into use, as it has very widely, it often operates under two handicaps: the area covered is ton small, placing in consequence too much risk on each member; the volume of business is small, making an overhead expense too high. A mutual company operating over an entire State, with risks well distributed, and having a large volume of business, is able to carry insurance to the farmer at actual cost, including, of course, a small overhead expense. But there are no dividends to be declared. 
In recent years the demand for certain forms of State insurance, particularly State hail insurance, has become very insistent. A good example of this is the Saskatchewan hail insurance conducted by the rural municipalities of that province.

Saskatchewan's Experience.-In the United States speakers and writers in recent years paint glowing pictures of Saskatchewan's success with state hail insurance. The experience of this province is therefore worthy of some attention. Saskatchewan, justly famous for its farmers' coöperative grain elevators and for other successful coöperative enterprises, is a prairie province, only a small fraction of whose area is as yet under tillage. Out of an area of $155,764,000$ acres, only $2,900,000$ acres are "in farms." The area in grain is of course but a small fraction of the farm area. Here a law was enacted in 1912 providing a system of insurance of the standing crops of wheat, oats, barley, flax, rye, and speltz against loss by hail. The law was revised in 1915, and again revised in 1917. Let us first examine it before the 1917 changes were introduced. The maximum amount of compensation allowed, in case of total loss, was $\$ 5$ an acre, and the minimum, 25 cents an acre. A tax of four cents an acre on all lands (except such as might be withdrawn) was levied to cover the losses. That is, a farmer paid $\$ 6.40$ to secure $\$ 800$ protection on a quarter section, i.e., 160 acres. The levy of the four cents an acre applied to all lands except those formally withdrawn by written notice prior to June 1. One or more quarter sections could be so withdrawn provided $(a)$ they were fenced in and used by the owner for grazing and hay purposes; (b) unpatented quarter sections on which the settler has less than 25 acres under cultivation; $(c)$ any fenced quarter section having less than 25 acres under cultivation. Each rural municipality enjoyed complete home rule as regards the adoption or rejection of the scheme. A majority vote for the scheme, at a referendum for that purpose, made it operative in the municipality till a further referendum should be had. The moneys collected were paid into a common pool and administered by a commission of three persons, two of whom represented the municipalities, and one the government. Some statistics will show the workings of the law during its first few years.

At the first elections after the Act, 115 rural municipalities voted to come under it, representing 20,000,000 acres of land. The first year's business showed losses and administration expenses of $\$ 777,697.59$, and a net revenue of $\$ 788,389.50$, thus leaving a surplus for reserve of $\$ 10,691.91$. 
The second year three municipalities withdrew and fourteen new ones came in, making 126 municipalities under the Act. This year the losses and expenses amounted to $\$ 543,665.62$, and the net revenues to $\$ 896,365.26$. After setting aside a tax adjustment reserve fund, the surplus to reserve became $\$ 348,391.55$.

The year 1915 found 127 municipalities under the Act, with $22,000,000$ acres of land, of which 5,000,000 was in crops.

The year 1916 proved to be the inevitable "bad year" that comes to all hail insurance companies. The strain was too severe for the system to stand. The hail losses were ten per cent of the crop, amounting to a loss of $\$ 3,600,000$. The revenue was only $\$ 1,500,000$, or a little over two million dollars short of paying the losses.

The Saskatchewan legislature, accordingly, in 1917 made a thorough revision of the Municipal Hail Insurance Act. As revised, the Act provides for a system of management similar to that of the Coöperative Elevator Company of that province. Each municipality votes on the question of coming under the scheme. Each municipality so voting appoints a delegate to represent it at the annual general meeting of the organization. At this general meeting the directors are chosen, the scheme providing for nine in all, three to retire each year. This puts the management completely into the hands of the municipalities. The general meeting, in reality a legislative body on this one economic matter, has power to make provision for a crop acreage assessment in addition to a flat rate if it so desires, but such action on the part of the general meeting cannot become operative in the current year, thus giving opportunity to any dissatisfied municipality to withdraw from the scheme at the intervening election.

Thus the principle of state hail insurance has not been abandoned, or even discredited in the eyes of the Saskatchewan farmers. Apparently they have committed themselves for good to this principle.

North Dakota State Hail Insurance.-The State of North Dakota may serve as a type of state experimentation with hail insurance. In 1911 a law was passed providing for a State administered system of hail insurance, under the jurisdiction of the State Commissioner of Agriculture and Labor. The insurance fund was derived from a charge of 20 cents an acre on the insured crops. Farmers were offered the opportunity in April or May, when the local tax assessor came around to value their property, to buy hail 
insurance. The assessor was allowed 25 cents per quarter section and 10 cents for each additional quarter to one owner for all such insurance written by him. But this compensation proved too small, and hence he made little effort to sell insurance. In 1913 the law was revised. The assessor was allowed a fee of one-half cent per acre - a very substantial increase. The charge for insurance was raised to 30 cents an acre. The maximum protection allowed was $\$ 8.00$ an acre. The assessor was required to collect his fee and the entire cost of the insurance in cash from the farmer at the time the application for insurance was written. This proved a very serious handicap, since the farmer's habit is to pay his bills in the fall, after the grain harvest. Consequently the number of farmers taking out State hail insurance was small. In actual operation this law worked as follows:

North Dakota State Hail Insurance-1911-1916. Maximum Protection, \$8 an Acre

\begin{tabular}{|c|c|c|c|c|c|c|}
\hline L & 1911 & 1912 & 1913 & 1914 & 1915 & 1916 \\
\hline $\begin{array}{r}\text { Number of policies } \\
\text { issued. . . ..... } \\
\text { Number of losses.. } \\
\text { Premium receipts. } \\
\text { Losses paid: } \\
\text { Dollars....... } \\
\text { Per cent. .... } \\
\text { Cost of operation.. } \\
\text { Per cent of operat- } \\
\text { ing expenses. }\end{array}$ & $\begin{array}{c}1011 \\
139 \\
\$ 26,104.64 \\
\$ 21,510.03 \\
70 \\
\$ 3,345.08 \\
12.9\end{array}$ & $\begin{array}{c}2505 \\
443 \\
\$ 64,840.37 \\
\$ 57,936.69 \\
55 \\
\$ 4,882.02 \\
7.5\end{array}$ & $\begin{array}{c}773 \\
91 \\
\$ 27,214.37 \\
\$ 24,890.78 \\
88 \\
\$ 3,074.11 \\
11.3\end{array}$ & $\begin{array}{c}761 \\
114 \\
\$ 27,771.72 \\
\$ 24,985.39 \\
65 \\
\$ 2,876.70 \\
10.4\end{array}$ & $\begin{array}{c}580 \\
95 \\
\$ 20,853.22 \\
\$ 18,701.34 \\
75 \\
\$ 2,181.53 \\
10.5\end{array}$ & $\begin{array}{c}845 \\
257 \\
\$ 33,113.10 \\
\$ 30,161.26 \\
38 \\
\$ 3,098.44 \\
\\
9.4\end{array}$ \\
\hline
\end{tabular}

The operation of this law proved both inconvenient and costly to the farmers. Hence the demand arose that state hail insurance be made compulsory and a tax be levied on all agricultural land to defray the cost. This demand involved an amendment to the State Constitution. Such an amendment, following the devious course provided by law, passed the 1915 legislature, the 1917 legislature, and went before the people, for their ratification, in the regular election of 1918 and was then ratified.

Mutual Hail Insurance.-Coöperative hail insurance, or mutual hail insurance as it is generally termed, is successfully conducted in many parts of the country. The peculiar problems of this form of insurance may best be seen by taking a concrete example. For our study let us take the Alliance Hail Association of North Dakota, which completed the twenty-eighth year of service in 1918. It is an example of a successful insurance company all of whose officers and directors are practical farmers. It is incorporated under North Dakota laws and is subject to the strict super- 
vision of the State Insurance Department. It claims as its five cardinal principles the following: fair treatment; best protection at lowest cost; fair adjustment of losses; prompt payment; a thorough annual audit. The nominal rate of premium is 6 per cent of the risk. But the amount of the risk is strictly limited, $\$ 100$ being the minimum; the maximum on any one quarter section is $\$ 800, \$ 1600$ on any one section, and $\$ 20,000$ on any one township. Insurance in no case shall exceed $\$ 8.00$ an acre. There is a so-called "contingent liability" of 6 per cent in addition to the nominal 6 per cent premium. The amount of premium collected, usually four or five per cent, depends of course on the losses for the year. If 12 per cent should prove inadequate (i.e., ninety-six cents an acre), the losses are to be paid pro rata and this to constitute a full settlement of the insurance. No unpaid losses are to constitute a liability in the next year's accounting. Applicants for insurance in nearly all cases give their note due October 1 . Insurance is written solely on the mutual plan, and only one assessment can be made in any one year, and that only for the current year's business.

Only four times in the history of this company were there unpaid losses, these amounting to $\$ 64,428.91$, or less than onefourth of one per cent of the risks carried. There is no "table of mortality" in the hail insurance business, and each company must be its own actuary. The cost per $\$ 1000$ of insurance varies widely from year to year. Had this company met all its losses during the first 19 years of its existence, the actual cost would have been $\$ 46.82$ per $\$ 1000$. Hence a six per cent assessment, if collected, would be more than ample. This company passed through two crises in its history, but managed to survive both. Only twice did the administrative expenses exceed the losses paid. These occasions were when the business was at a low ebb and the losses unusually light. The chief item of expense is the commission paid to agents. And here is the paradox of the middleman again! By experience this farmer's company has found out that the more it pays to agents (to the "middlemen"), the less it costs the farmer for operating expenses. For exactly as more agents are employed and the volume of business becomes greater, the less becomes the portion of the total outlay going into operating expenses, and the greater becomes the portion of outlay going into the payment of losses. In short, the more the farmers pay these middlemen the less the farmer's insurance costs him. Yet, according to the theory of "direct marketing" there should be no costs at all for 
agents to sell insurance to the farmer, but a saving of these costs of many tens of thousands of dollars a year. The farmers, in theory, will come up without solicitation and apply to their own mutual company for insurance - a two-cent letter as a reminder being sufficient for the purpose. This theory was indeed even tested by this Association. By taking their agents off the road, the volume of business was contracted to near the zero point. Few farmers took out insurance. But almost the same overhead office expenses had to be borne by the few farmers as by the many in the years of big business, and hence the cost of the insurance was increased, not reduced, by this pseudo-economy.

One "economy" practised by this company is the payment of low salaries, farmers disbelieving in the theory of high priced officials. In 1896 salaries were cut from $\$ 2400$ (for two officers) to $\$ 2200$. In 1903 the president was put on a no-salary basis. Later, however, he was given a compensation of $\$ 1200$ a year, which covered his services as adjustor also. Stock companies, at the same time, were paying from two to ten times as much for the same class of men.

Collection of premiums is slow. Farmers give their notes without interest for the full six per cent premium, thus making the insurance just as cheap on time as for cash. From 70 to 95 per cent of the premiums is the most that can be collected, and much of this runs two and three years. This is perhaps one of the weak features of a mutual company. Harsh measures of collection would alienate the good-will of rural communities.

This company has a thorough and complete audit once a year. For the delicate work of adjusting losses only the most competent men are used. For several years this work was done by the president himself, a large farmer and a man peculiarly well fitted for the task.

Wide distribution of losses is secured by carrying insurance in every county in the State. Agents are sent out who can speak the various languages of the North Dakota farmers. The chief nationalities now reached are the Germans, French, Russians, Norwegians, Bohemians, Poles; also the Jewish farmers.

One lesson has been taught by this Association, and that is the folly of making the assessment too low. The heavy loss is sure to come, and it should be provided for. Under the present by-laws (for there is no established policy yet in the matter) there is no provision for a surplus or reserve fund, each year's receipts being applied to the same year's expenditures only. The experience of 
the vears 1904-1908 would seem to show the wisdom of a different course. In 1904 an "expense fund" was provided for. This reserve-for such it was-grew to $\$ 46,106.46$ in 1906 , after all losses of that year had been paid. The 1906 losses were $\$ 38,121.24$, while the losses the next year were $\$ 312,085.72$, or over eight times as much. Consequently the reserve was wiped out, an 8 per cent assessment used up, and still an unpaid balance of losses of over $\$ 30,000$ was left over to the next year. The by-laws at present do not permit a carryover of unpaid losses. A larger assessment in good years and a lower assessment in bad years would equalize the burden and promote the welfare of the Association. If the total volume of business could be greatly increased, thus reducing the share of operating expenses-and if a level premium or at least some nearer approach to a level premium of, say, five per cent could be charged - it is likely that a big reserve could be built up against the bad years. Future crises could then be met. As it is, a mutual company is always walking on the brink of dissolution.

Present Tendency.-The state of mind of the farmer to-day is turning him, instinctively, to State administered, compulsory hail insurance. He knows that his own mutual company is paying to its "middlemen" from 10 to 70 per cent of the total outlay for hail insurance, but that without these middlemen he would either have no insurance at all or much costlier insurance. Hence he is wondering why the State cannot undertake this service. The farmer's position has peculiar strength and force here, since the State now has in working order complete machinery for levying and collecting taxes and assessments of various kinds. With a negligible increase in expense, it could collect a compulsory hail insurance tax.

In actual practice, as this chapter shows, neither State hail insurance nor mutual hail insurance is at this stage of affairs a complete success. But experience with State hail insurance makes the farmer want more of it, not less of it.

Those desiring to trace in detail the vicissitudes of a mutual hail insurance company through a period of a quarter of a century can do so by studying the following table. The great fluctuation in losses from year to year is a striking feature of the table. 
A Farmers' Mutual Hail Insurance Company.-The Alliance Hail Association of North Dakota

\begin{tabular}{|c|c|c|c|c|c|c|}
\hline Year & $\begin{array}{c}\text { Number } \\
\text { of } \\
\text { policies }\end{array}$ & $\begin{array}{l}\text { Amount of } \\
\text { insurance }\end{array}$ & $\begin{array}{l}\text { Paid to } \\
\text { agents }\end{array}$ & $\begin{array}{c}\text { Salaries } \\
\text { and clerk } \\
\text { hire }\end{array}$ & $\begin{array}{c}\text { Total } \\
\text { adminis- } \\
\text { trative } \\
\text { expense }\end{array}$ & $\begin{array}{l}\text { Losses paid } \\
\text { and unpaid }\end{array}$ \\
\hline 1891 &, 1812 & $\begin{array}{r}\text { Acres } 170,295 \\
\$ 1,362,360\end{array}$ & $\$ 3,503.22$ & $\$ 2,149.00$ & $\$ 8,419.27$ & $\begin{array}{r}31,578.49 \mathrm{p} \\
7,383.22 \mathrm{u}\end{array}$ \\
\hline 1892 & 987 & $\begin{array}{c}\text { Acres } 96,115 \\
\$ 768,922\end{array}$ & $2,105.99$ & $2,674.00$ & $7,142.92$ & $11,259.42$ \\
\hline 1893 & 999 & $\begin{array}{c}\text { Acres } 110,853 \\
\$ 886,821\end{array}$ & $2,265.23$ & 292000 & $7,626.36$ & $9,778.43$ paid \\
\hline & & Acres 118,411 & & & & $9,123.46$ paid \\
\hline 1894 & 1140 & $\$ 947,288$ & $2,505.36$ & .00 & $8,468.97$ & 0 \\
\hline 1895 & 2141 & $\$ 1,797,848$ & $4,795.31$ & $3,107.00$ & $12,169.34$ & $\begin{array}{l}0 \\
0\end{array}$ \\
\hline 1896 & 992 & $\begin{array}{c}\text { cres } \\
\$ 77,880 \\
\$ 77,040\end{array}$ & $1,866.32$ & $2,449.50$ & $7,173.42$ & $\begin{array}{l}20,688.03 \text { paid } \\
13,465.29 \text { unpaid }\end{array}$ \\
\hline 1897 & 725 & $\begin{array}{c}\text { Acres } 56,253 \\
\$ 450,024\end{array}$ & $1,323.65$ & $2,215.75$ & $5,624.29$ & $\begin{array}{r}5.10 \\
0\end{array}$ \\
\hline 1898 & 1126 & $\begin{array}{r}\text { Acres } 99,302 \\
\$ 792,416\end{array}$ & $2,675.36$ & $2,265.50$ & $7,587.20$ & $\begin{array}{c}29,907.85 \text { paid } \\
0\end{array}$ \\
\hline 1899 & 1686 & $\begin{array}{r}\text { Acres } 144,830 \\
\$ 1,198,640\end{array}$ & $4,586.79$ & $2,387.75$ & $10,914.69$ & $\begin{array}{l}51,465.68 \text { paid } \\
36,112.69 \text { unpaid }\end{array}$ \\
\hline 1900 & 234 & $\begin{array}{c}\text { Acres } 13,738 \\
\$ 109,904\end{array}$ & 434.43 & $2,200.00$ & $3,615.56$ & $26,631.90 \mathrm{p}$ \\
\hline 1901 & 624 & $\begin{array}{c}\text { Acres } 43,659 \\
\$ 349,272\end{array}$ & 1, & 1 , & 4,5 & 10,338.50 paid \\
\hline 1902 & 145 & $\begin{array}{c}\text { Acres } 62,523 \\
\$ 500,184\end{array}$ & $3,013.48$ & $2,141.50$ & $7,234.90$ & $\begin{array}{l}21,356.32 \text { paid } \\
7,467.71 \text { unpaid }\end{array}$ \\
\hline 1903 & 600 & res 46,299 & $\ddot{2}, \ddot{129} \dot{32}$ & $1,768.00$ & $6,594.18$ & $\begin{array}{r}5,747.08 \\
0\end{array}$ \\
\hline 1904 & 1484 & $\begin{array}{c}\text { Acres } 178,317 \\
\$ 933,755\end{array}$ & $8,087.79$ & $2,041.90$ & $14,011.74$ & $\underset{0}{7,675.59} \mathrm{pr}$ \\
\hline 1905 & 2710 & $\begin{array}{r}\text { Acres } 263,488 \\
\$ 1,828,631\end{array}$ & $16,587.73$ & $2,389.25$ & $23,959.55$ & $4,257.57$ paid \\
\hline 1906 & 42 & Acre & 27,4 & $3,031.55$ & $\ddot{36,778.09}$ & $\begin{array}{c}38,121.24 \\
0\end{array}$ \\
\hline 1907 & 5217 & $\begin{array}{r}\text { Acres } 4 \\
\$ 3,9\end{array}$ & $35,834.69$ & $\ddot{3}, 982.60$ & $\ddot{49,637.40}$ & $312,085.72$ paid \\
\hline 1001 & & Acres 3 & $\ddot{2} \ddot{8} 231 . \dot{4} 3$ & & 4i,389.02 & $101,519.68$ paid \\
\hline 190 & & Acre & $\begin{array}{l}28,231.43 \\
\therefore \cdots \cdots\end{array}$ & & 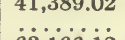 & 244,546.32 paid \\
\hline 1909 & 8005 & of $>$ & $47,281.92$ & $5,541,30$ & $63,166.12$ & 0 \\
\hline 1910 & 4192 & 4 & $22,415.78$ & $5,672.75$ & $37,417.82$ & 0 \\
\hline 1911 & 6138 & 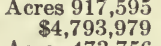 & $32,599.72$ & $6,636.66$ & $51,619.38$ & 118.62 \\
\hline 1912 & 3975 & $\begin{array}{l}\text { Acre } \\
\$ 2\end{array}$ & $20,661.01$ & $6,301.05$ & $35,977.66$ & $27,112.72$ paid \\
\hline 1913 & 2288 & $\begin{array}{r}\text { Acre } \\
\$\end{array}$ & $19,809.23$ & $6,383.25$ & $33,830.69$ & $\begin{array}{c}0,138.66 \text { paid } \\
0\end{array}$ \\
\hline 1914 & 3747 & $\underset{\$}{\operatorname{Acr}}$ & $23,054,49$ & $7,604.83$ & $40,083.55$ & $89,843.85$ paid \\
\hline & & $\begin{array}{l}\$ 2,615,513 \\
\text { Acres }\end{array}$ & & & & $157,807.05$ paid \\
\hline 1915 & 4107 & $\$ 3,327,061.62$ & $27,732.73$ & $7,572.98$ & $45,653.69$ & $\begin{array}{c}0 \\
21171930 \text { paid }\end{array}$ \\
\hline 1916 & 3390 & $\$ 2,890,794.10$ & $3 i, 242.7 \dot{5}$ & $8,304.89$ & $49,818.26$ & \\
\hline
\end{tabular}

\section{QUESTIONS ON THE TEXT}

1. Distinguish between agricultural insurance and general property insurance.

2. What grievance, if any, has the farmer against the joint stock insurance companies? How is the farmer answered by the joint stock company?

3. What mistakes have farmers' mutuals commonly made?

4. Explain in detail the Saskatchewan experience with state hail insurance.

5. Show why such a low assessment is used in Saskatchewan.

6. Has the principle of state hail insurance been discredited in Saskatchewan?

7. Discuss in detail North Dakota's experience with state hail insurance. 
8. Point out the chief flaws in the early Dakota scheme. Why was the State never able to pay the losses in full?

9. Explain at length the workings of the Alliance Hail Association. What principles are illustrated by the experience of this company? What about the use of "middlemen" in selling insurance?

10. What is the present tendency in hail insurance administration?

\section{QUESTIONS SUGGESTED BY THE TEXT}

1. Should state hail insurance of growing crops be assessed on all farm lands, including pasture lands?

2. Is insurance a proper function of the State? If so, should it be voluntary or compulsory?

3. Should mutual companies operate on the level premium plan or on the assessment plan?

\section{REFERENCES}

1. For North Dakota experience with State Hail Insurance, consult biennial reports of Commissioner of Agriculture and Labor, Bismarck, 1911 and following years.

2. VALGREN, V. N.: "The Organization and Management of a Farmers' Mutual Fire Insurance Company." Bulletin 530, United States Department of Agriculture, Washington, May, 1917.

3.' - "Prevailing Plans and Practices Among Farmers' Mutual Fire Insurance Companies." Bulletin 786, U. S. Department of Agriculture, 1919.

4. Other publications of the U. S. Department of Agriculture: "Cotton Warehouse Construction" (Dept. Bulletin 277); "Modern Methods of Protection Against Lightning" (Farmers' Bulletin 842); "Fire Prevention and Fire Fighting on the Farm" (Farmers' Bulletin 904); "Farmers' Mutual Fire Insurance" (Separate 697, Yearbook 1916). 


\section{CHAPTER XIV \\ COLD STORAGE}

The series of inventions during the last one hundred and fifty years giving us our modern system of mechanical refrigeration and cold storage marks one of the great triumphs of civilization. The preservation of food by canning was an important step. But the present use of refrigeration in the saving of food is a vastly more important advance. Perishable foodstuffs, fresh and in good condition, may now be found on the tables of the poorest of our people, foodstuffs hundreds or even thousands of miles from the place of their production, and many weeks or months after the time of their production. The seasonal nature of certain farm products makes it advisable to store them in the time of plenty that they may be consumed in the time of relative scarcity. Thus half the fresh butter produced in the country goes to the market during the four summer months, May, June, July, August. The heavy producing season for eggs is the three-month period, April, May, June, equalling the remaining nine months.

The seasonal production of foods and the consequent seasonal ebb and flow of these goods in and out of cold storage is illustrated by the case of butter and eggs. The graphs (Figs. 40 and 41) show receipts and deliveries of butter and eggs in the Quincy (Massachusetts) Cold Storage and Warehouse Company's plant for two years.

The graphs clearly illustrate the chief function of cold storage, namely, to equalize the distribution of seasonal products throughout the year. In other words, cold storage acts like a reservoir, receiving the surplus flow of goods when production exceeds demand and a market glut is impending, and giving out these same goods when production has fallen off and a market scarcity is impending. The public is thus benefited by having a greater variety of food during all seasons of the year. A second function of cold storage, equally important, is the transportation, under refrigeration, of perishable foods in good condition to the consumer. Thus Imperial Valley cantaloupes reach the New England consumer's table without harmful exposure to heat and without deterioration of quality. In the same manner lemons from Italy, oranges from California, pineapples from Hawaii, all reach the distant consumer in a fresh condition. Similarly, mutton from Australia and beef from Argentine are served in a wholesome con- 
dition on the table in England. Obviously the producer benefits by thus finding markets, and at the same time the consumer bene-

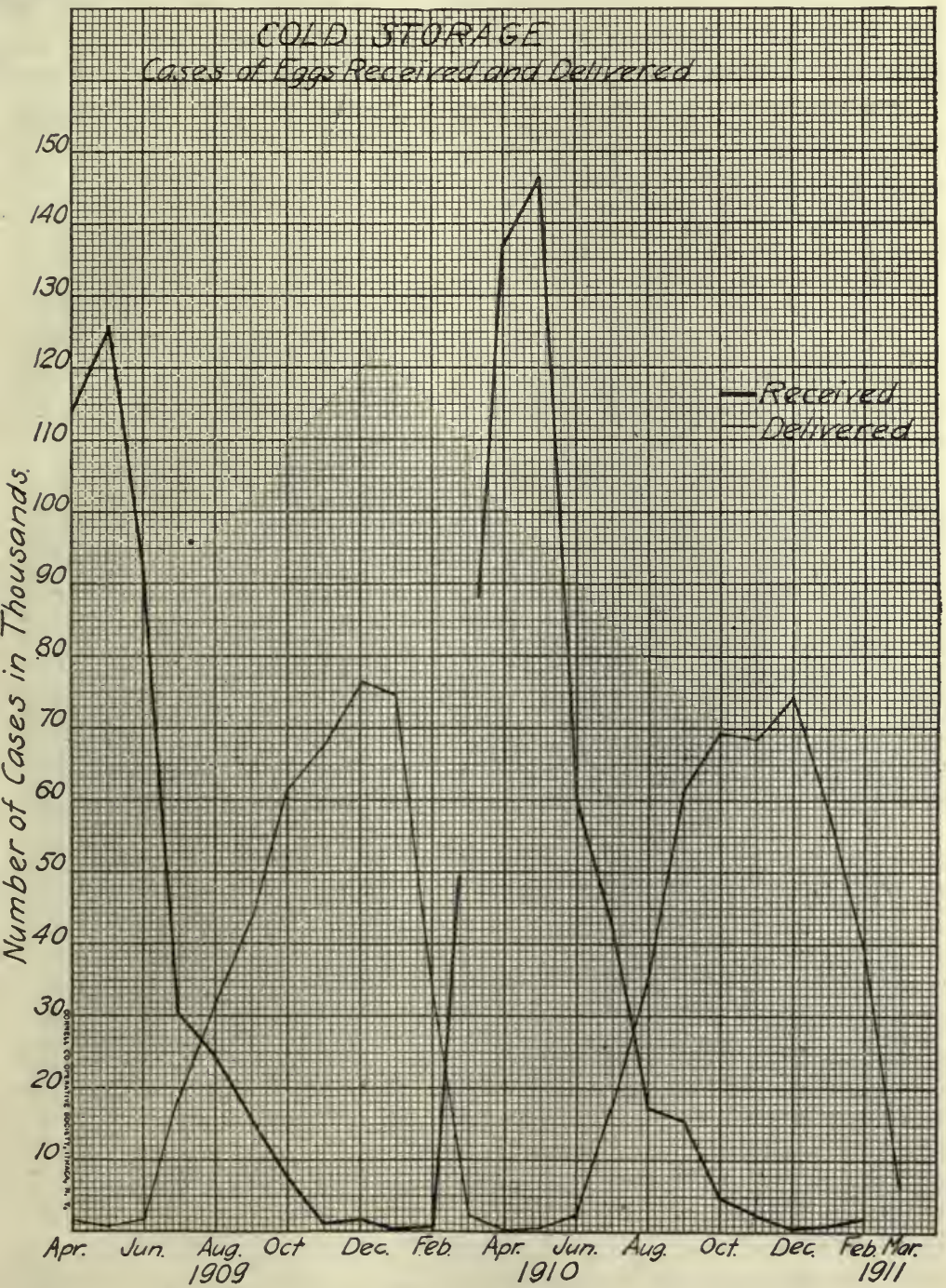

Fig. 40.-Cold storage. Cases of eggs received and delivered.

fits by having a large volume of food reach the market without waste or decomposition. The importance of this factor in time of 
great emergencies and national crises is well illustrated by our experience. in exporting fresh meat to our soldiers and to most of our allies during the World War. Hundreds of carloads of fresh meats were rushed from the packers to the seaboard. Owing to freight congestion and shortage of ships, much of this meat had

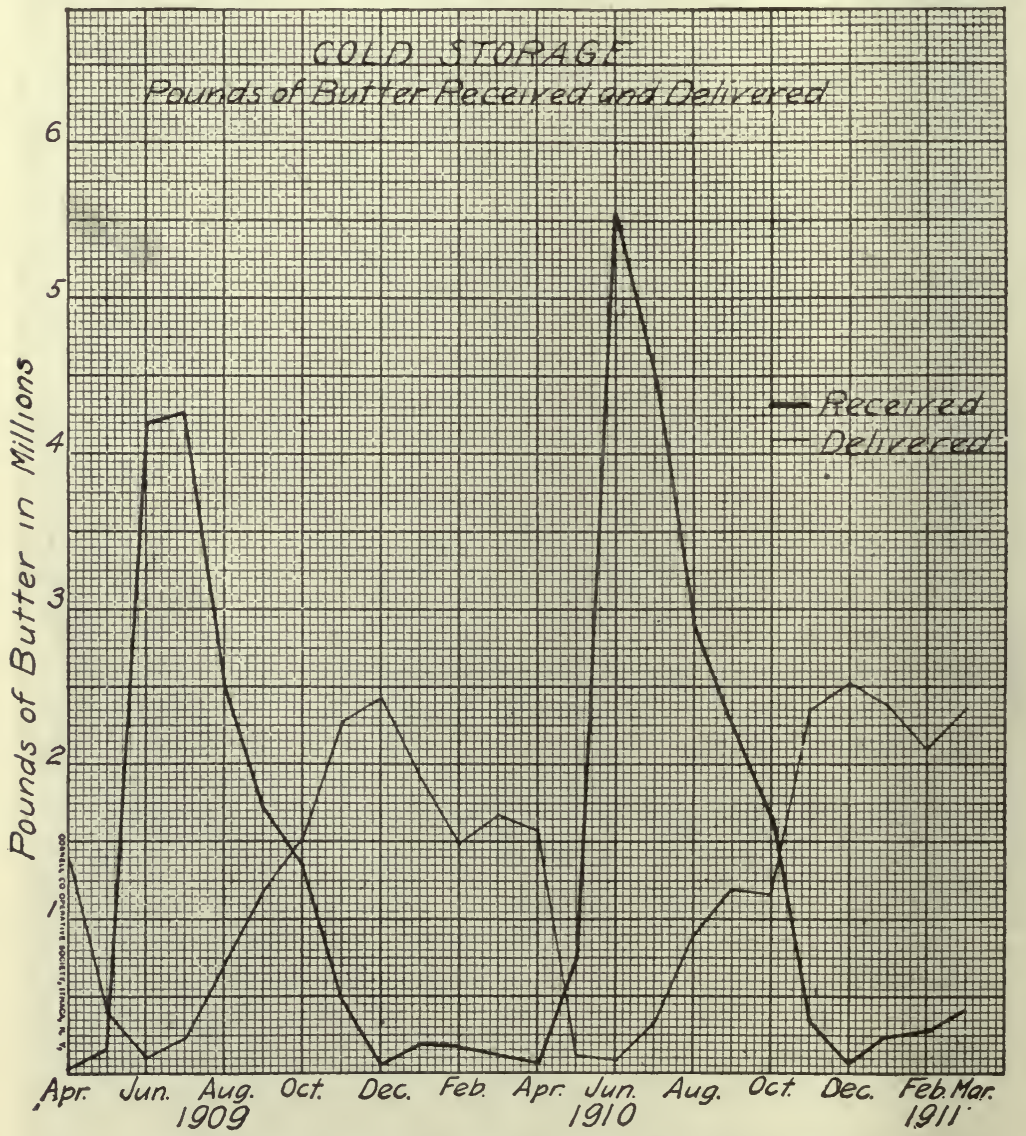

FIG. 41.-Cold storage. Pounds of butter received and delivered.

to be held weeks and even months before going overseas. Consequently it was placed in cold storage warehouses, much of it going into the empty apple warehouses in the neighborhood of Buffalo and Rochester, New York. Here it was kept at several degrees below the freezing point till shipping space was available, and then it was forwarded to its destination without waste and without dete- 
rioration. Thus in the wartime mobilization of our industrial resources an important place must be accorded to cold storage.

Extent and Use of Cold Storage.-It is very likely that the United States leads the world in the number of cold storage warehouses (Figs. 42 and 43). There are approximately 1500 of such warehouses in this country. There are three classes of cold storage warehouses, namely: (1) public cold storage warehouses in which food products are stored for hire, and the owner of the house is not interested in the foods stored; (2) private cold storage warehouses, in which the owner of the house stores food products of which he is the owner; (3) combined public and private ware-

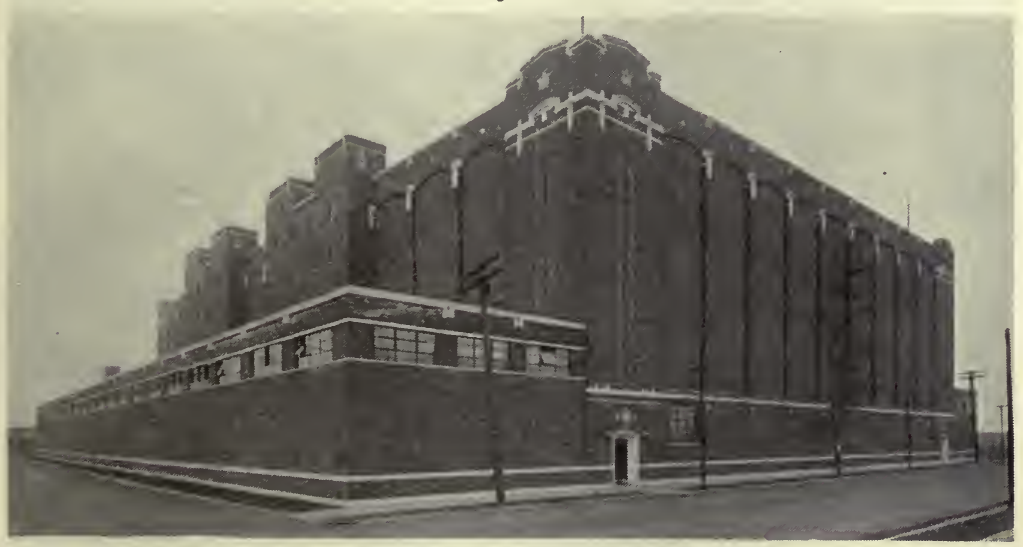

FIG. 42.-Cold storage warehouse in Chicago.

houses, in which the owner stores both his own commodities and also the commodities of others.

The chief products now subject to cold storage are the following: apples, butter, cheese, eggs, frozen and cured meats and lards, and fish (Figs. 44 and 45). The significance of cold storage is suggested by the amount of meats in storage on June 1, 1919, namely, $1,348,000,000$ pounds - a 20 days' supply for the whole country. These meats were on their normal course from producer, through the packing houses, to the consumers, in the following manner:

65 per cent: hams, bacon, etc. In process of curing (a process requiring from 30 to 90 days).

10 per cent: frozen pork. To be cured later in the year.

6 per cent: lard.

19 per cent: frozen beef and lamb. In part owned by the

$\overline{100}$ Government and intended for overseas shipment. 
It will be noted that the large volume of "meats in storage" represents in part unfinished goods in process of curing and in part the normal working supply to assure a steady volume.

The cold storage business is growing rapidly, not only in the United States, but in many other countries. Indeed, so important

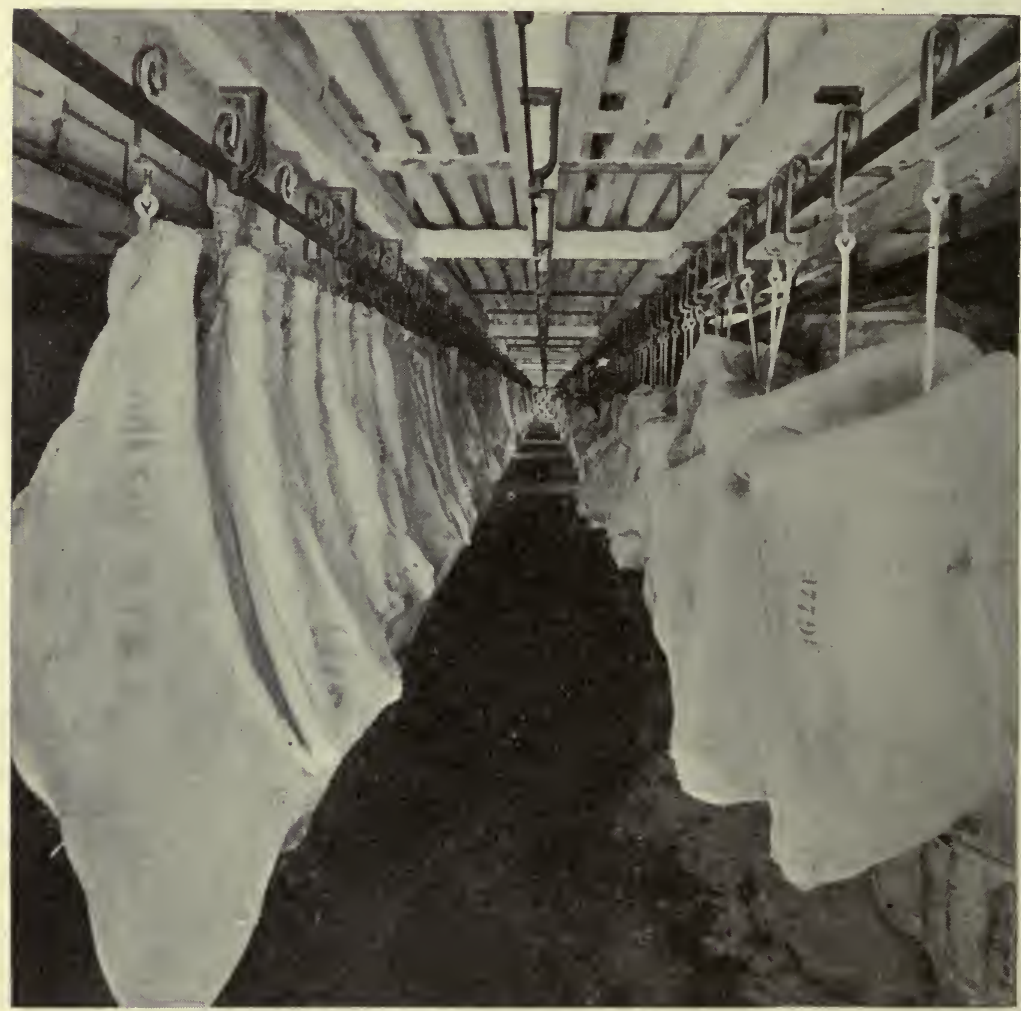

Fig. 43.-Packing-house products stored in a public cold storage warehouse in Chicago.

is the business to public welfare that various countries are now promoting the building of cold storage warehouses. Thus a consular agent of our government reported recently that the Swedish State was building a refrigerating plant at Hallsberg, Sweden, for the freezing of meat, fish, and other foods, having a capacity of four thousand tons. The backward state of cold storage in Russia during the World War was described by our consular general at Moscow in these words: 
"Prior to the War, only the following towns were provided with slaughterhouse refrigeration plants: Tiflis, Astrakhan, Rostof-on-Don, Taganrog, Riga, Tashkent, Minsk, Moscow, and Petrograd. Most of the big cities are still unprovided with these facilities. The various municipal councils have become conscious of this unsatisfactory state of affairs, and projects for building improved slaughterhouses, provided with refrigerating plants, are now presenting themselves everywhere.

"The great cities and meat-consuming centers were supplied by transporting live cattle from the breeding districts in Siberia, the Northern Caucasus, and the Steppe district. Only during frosty weather were the cattle killed and frozen by natural means at the place of production. The frozen meat was then carried in trucks to the capitals and industrial districts in Russia. This primitive way of preserving and transporting the meat is rather dangerous, especially if a thaw sets in on the way. It often happens that millions of rubles' worth of meat is damaged owing to defective cold storage en route and at the place of consumption.

"The war, as has been said, gave rise to endeavors to find a satisfactory solution of the refrigeration question. The Government has decided to build 25 slaughterhouses with refrigerating plants in different districts of Russia, and the building of 15 more is under consideration. During the war, the Government is to organize and run these establishments. After the war the movement now started will necessitate the organization of several meat-trading companies. The big Petrograd Goods Storing, Refrigerating Rooms, and Elevator Company has already started to build large slaughterhouses with refrigerating plants, in the town Biyisk of Siberia. This fact shows that people have begun to realize that there is plenty of room for private enterprise in the systematic meat trade." 1

The Canadian government several years ago enacted a law providing for subsidizing the building of public cold storage warehouses, in the interest of both produeers and consumers. The administration of the act was placed under the Minister of Agriculture.

From the public welfare standpoint, the two paramount questions concerning cold storage are its effects on health and on prices. A great deal of the press comment on cold storage propagates the charge that goods preserved by the cold storage method are not only inferior, but are dangerous to public health. Equally common is the press comment that cold storage enables food speculators to withdraw food from the market, hoard it, and force prices up to artificially high levels. The laws of supply and demand, it is charged, are thus set aside. Both these charges are serious and demand attention.

Influence of Cold Storage on Health.-A few abuses have at times arisen in the use of cold storage, as in the use of everything else. But impartial investigations of the subject by eminent chemists and hygienic experts have repeatedly brought in the verdict that cold storage is an important and beneficial method

${ }^{1}$ Summarized from a report made in December, 1916, by M. T. Zarochentzeff, secretary of the Moscow Refrigerating Committee, and reported in Daily Commerce Reports, Washington, June 18, 1918, p. 1064. 


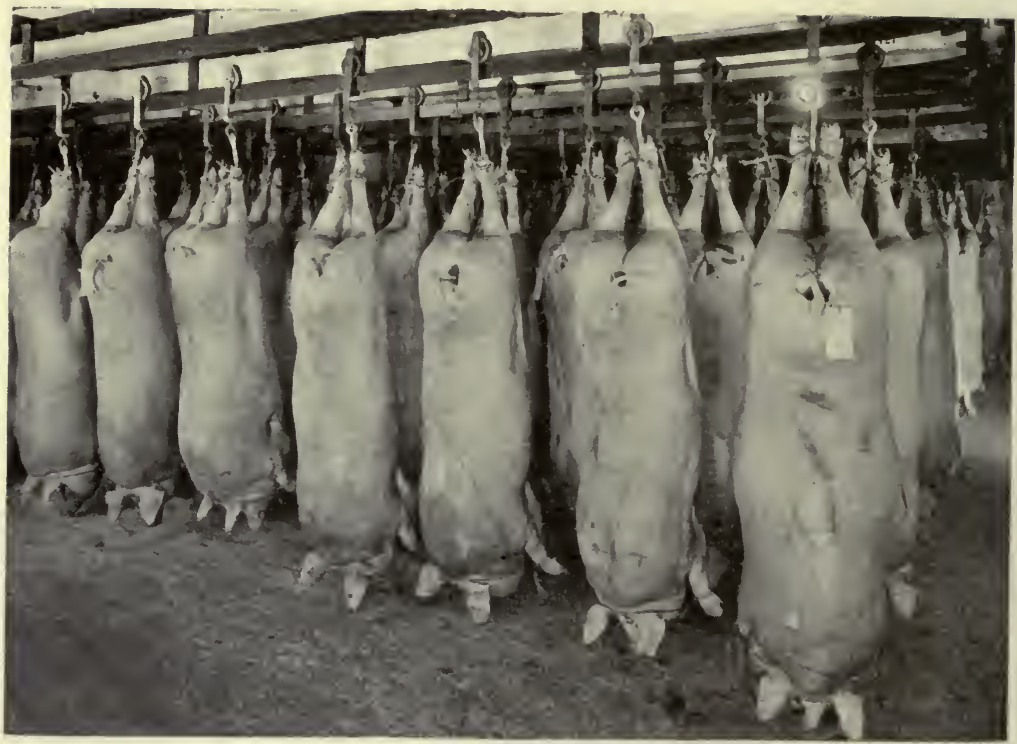

Frg. 44.-Fresh pork in cold storage in Chicago.

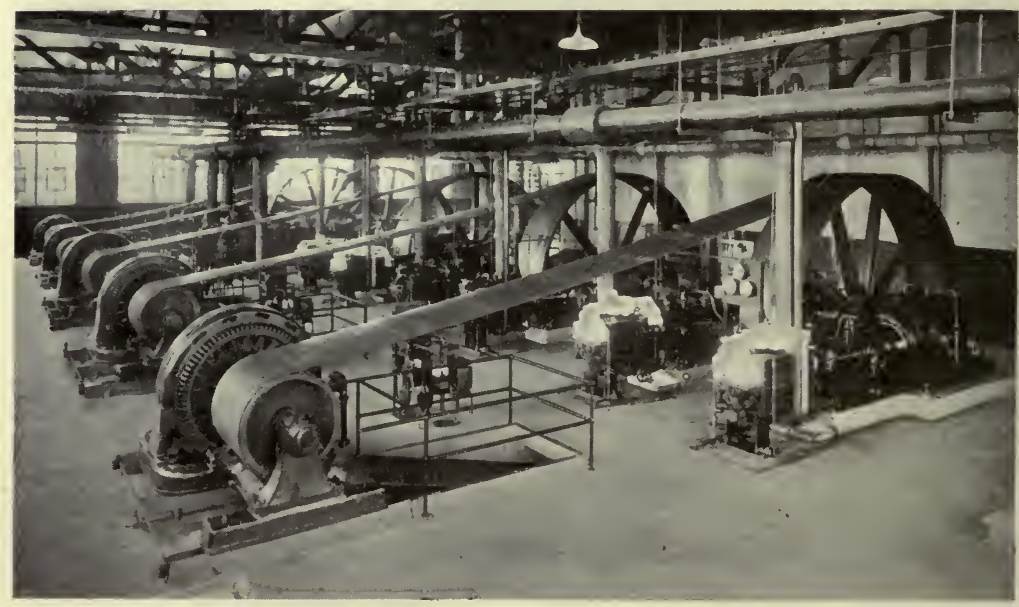

FIG. 45.-Direct refrigeration system of a large cold storage warehouse in Chicago.

of food preservation. It seems to be an established fact that food entering into cold storage in good condition is normally delivered from cold storage in the regular course of business in 
good condition. Professor William T. Sedgwick, Massachusetts Institute of Technology, testifying October 24, 1911, before the hearings on cold storage, conducted by the Massachusetts Commission to Investigate the Subject of Cold Storage of Food and of Food Products kept in Cold Storage, spoke in part as follows:

"So far as I am aware, there is no evidence whatever that cold storage is in any way prejudicial to the public health. On the contrary, it is one of the greatest aids to public health, in that it makes food more abundant, and thus enables people to keep up their strength and to avoid such diseases as scurvy, from which the human race formerly suffered so intolerably. Various allegations, of course, have been made touching the wholesomeness of cold storage materials, such as that deterioration takes place during cold storage, whereby people are poisoned or otherwise badly affected, but I have yet to hear of a single instance of carefully investigated and well-authenticated food poisoning due to the effects of cold storage, to deterioration during proper cold storage. I have myself, like everybody else, repeatedly consumed cold storage materials, and while I am ready to admit that the flavor is sometimes changed, and not always for the better, I do not know of any well-authenticated, carefully investigated case of food poisoning, or other ill effects. due distinctly to cold storage."

From the above testimony, and from that of other qualified persons, the conclusion seems fair that cold storage has no ill effects on public health.

Effect of Cold Storage on Prices.-It is charged that cold storage lends itself to speculation in food products. The charge contains an element of truth. Any person who buys food products and holds them for sale at a rise in price is a speculator. This form of speculation is both legitimate, and, as marketing is now organized, necessary and inevitable. Back of the charge, however, is the implication that there is too much illegitimate speculation, meaning thereby price manipulation and cornering of the market. Any intentional cornering of the market is to be thoroughly condemned. But looking at the actual facts of the case, there seem to be fewer cases of cornering the market under our present cold storage system than there were before the days of cold storage. A large per cent of our present cold storage is what is known as public storage. This means that the food in these warehouses does not belong to the owner of the warehouse but to many competing dealers. For instance, consider the case of the Quincy Market Cold Storage and Warehouse Company, the largest in existence. Here the number of persons storing goods was found to be over 3,000 , when an inquiry was recently made by the Massachusetts Cold Storage Commission. A combination in such a case to control prices or corner the market would be difficult.

It is difficult to state definitely the effect of cold storage on 
the price level of food products. It is obvious that the first effect is to make prices higher to both producer and consumer during the three or four months of heaviest production, and to make the prices lower to producer and consumer during the season of lightest production. In other words, cold storage tends to equalize prices during the year. However, there is a larger question involved, and one not easy of statistical proof or disproof. That is, the effect of higher prices on production. For it is evident that the producer does find a larger market and better prices during the heavy producing season when his surplus is disposed of for cold storage purposes. The necessary effect seems to be that cold storage increases production. And the total effect of this increase in production is to lower the cost of living. The situation was summed up by the Massachusetts Commission on the Cost of Living, 1910, in these words (p. 179):

"Before cold storage facilities were available, during the time of plenty, prices were extremely low for the producer. Conversely, during the season of scarcity prices rose rapidly and were extremely high to the consumer. Many classes of perishable products were not procurable, even at the extreme prices. The cold storage warehouse acts as a balance. It insures that a fair supply of the products of plenty, produced in their seasons, shall be available throughout the year. It materially lessens the extreme between the former minimum and maximum selling prices, which is a decided advantage to both producer and consumer."

Government Regulation.-Little attention was paid to the cold storage question by legislative bodies prior to 1910 . The period of agitation concerning the high cost of living had succeeded by that time in focussing public attention upon several real or imaginary causes, and the cold storage was hit upon as one of these causes. In 1911 five States passed cold storage legislation; these were California, Delaware, Indiana, New Jersey, and New York. Kansas alone, prior to this date, had any such legislation. These State laws have to do with these subjects: (1) inspection of cold storage warehouses; (2) marking or tagging of cold storage products; (3) limitation of the time of cold storage; (4) regulation of the sale of cold storage goods. The public has now come to demand, and the warehousemen to expect a certain amount of inspection in the interests of public health. Beyond this activity, however, the wisdom of State regulation is open to serious question. The situation was well summed up by a cold storage company of Worcester, Massachusetts, in reply to the Cold Storage Commission of that State, in these words:

"The local board of health makes inspection of our plant, we think, about twelve times a year. We do not think there is much need of legislation on 
this cold storage question, as self-protection demands that goods shall not be kept too long, and dealers are coming to realize more fully each year that it does not pay to hold goods too long. If the local inspectors would inspect the goods when they go into storage, it would do a great deal more good than any new laws will do." ${ }_{2}$

The federal government, through its Bureau of Markets, now makes public twice a month the total holdings of food products in cold storage warehouses in the United States. The aim is to protect the public and the dealers by wholesome publicity. If such a service could be made fairly complete as to actual volume of goods in cold storage, and could be issued promptly it would prove helpful. Extreme deliberation and slowness characterize most governmental activities, and this one may or may not prove an exception, However, wholesome publicity of this kind would afford the dealers and the public alike, protection against undue manipulations of the market.

Suggested Inprovements.-The need now is for more cold storage, not less. The large centers of population are becoming supplied with cold storage facilities. The farmers may now well consider the question of erecting their own cold storage near the sources of supply. This would help them avoid market gluts in the early marketing season-an annual occurrence under present unorganized, primary marketing conditions. In some sections of the country coöperative fruit packing houses are equipped with refrigerating facilities. Cold storage at such primary points, together with precooling of perishable foodstuffs before shipment, would go a long way towards eliminating the leaks between producer and consumer, leaks, it is interesting to note, that the producer now charges up to that convenient scapegoat-the middleman.

\section{QUESTIONS ON THE TEXT}

1. Show the nature and importance of cold storage.

2. Show relation of cold storage to seasonal nature of food production.

3. Name the two chief functions of cold storage.

4. Show relation of cold storage to mobilization of our food resources in time of war.

5. Show extent and use of cold storage.

6 . Classify cold storage warehouses.

7. Name the chief products entering cold storage.

8. Give amount of meat in cold storage June 1, 1919, and explain the large volume.

9. Show the growth of cold storage in other lands: Sweden; Russia; Canada. 10. State the evidence and the conclusions as to the effect of cold storage on health; effect on prices.

11. Define speculation, and distinguish different kirids.

12. Explain in detail the extent and value of government regulation of cold storage. Is health inspection sufficient?

${ }^{2}$ Report, Massachusetts Commission on Cold Storage, Boston, 1912. 
13. Show the activities of the United States Bureau of Markets in the matter of cold storage.

14. Suggest improvements in our cold storage situation.

\section{QUESTIONS SUGGESTED BY THE TEXT}

1. What per cent of the apple crop goes into cold storage? Of the butter production? Of farm egg production?

2. Prepare a chart showing total cold storage in your State, and classify this storage as to whether public, private, or combined public and private.

\section{REFERENCES}

1. Armour, J. Ogden: "The Packers, The Private Car Lines and the People."

2. Holmes, George K.: "Cold Storage Business Features." Bulletins 93 and 101, Bureau of Statistics, United States Department of Agriculture. Washington, 1913.

3. BELL, JoHN O.: "Reports of Storage Holdings of " Certain Food Products," Bulletin 709, United States Department of Agriculture, Washington, 1918.

4. "Daily Commerce Reports," Washington, June 13, 1918; June 18, 1918. 1912.

5. "Reports of Massachusetts Commission on Cold Storage," Boston,

6. Cooper, Madison: "Use of Cold Storage," 61 Cong. 2 Sess. Sen. Doc. 486, pp. 4,5 .

7. Pennington, M. E.: "Changes Taking Place in Chickens in Cold Storage." Yearbook of Agriculture, Washington, 1907, p. 206.

8. Lane, Clarence B.: "The Cold Storage of Cheese," Bulletin 83; Bureau of Animal Industry, United States Department of Agriculture, Washington, 1906.

9. Gray, C. E.: "The Keeping of Butter Made Under Different Conditions and Stored Under Different Temperatures," Bulletin 84. Bureau of Animal Industry, United States Department of Agriculture, Washington, 1906.

10. "Report of Massachusetts Commission on the Cost of Living," Boston, 1910.

11. Groesbeck, B. and Urner, F. G.: "Economic Effects of Cold Storage Upon the Average Price of Eggs." Joint Committee Cold Storage Warehousemen and Affiliated Industries, New York, 1916.

12. Jenkins, W. C.: "The Truth About Cold Storage," National Magazine, August, 1911.

13. "Report of Investigation Relative to Wages and Prices of Commodities, Senate Committee on Wages and Prices of Commodities," 61 Cong. 1910.

14. "Findings of the Joint Select Committee of the 78th General Assembly of the State of Obio, Appointed to Inquire into the Purchase, Storage, Sale of and Traffic in Food Products, Commodities and Supplies." Columbus, 1910.

15. "Report of the Industrial Commission," Washington, 1898-1902, Vol. 6, pp. 297-307.

16. "Report of London County Council on Ice and Cold Storage," London, 1904.

17. Proceedings of the National Poultry, Butter and Egg Association" (Annual meetings).

18. "Proceedings of the American Warehousemen's Association" (Annual meetings).

19. Franklin, I. C.: "The Service of Cold Storage in the Conservation of Foodstuffs." Yearbook Department of Agriculture, 1917, 363-371.

20. "Cold Storage in Canada," Labor Gazette (Canada), August, 1917; also International Review of Agricultural Economics, Dec., 1917, 53-66. 


\section{CHAPTER XV}

\section{AGRICULTURAL PRICES AND VALORIZATION}

THERE is lack of agreement among men of affairs and among professional economists as to the factors which actually do determine price, or the factors which should determine price. As to the factors which should determine price there are, roughly speaking, two schools of thinkers, those who incline to the belief that prices should be artificially determined by some social authority, and those who incline to the belief that prices should be left to the play of economic forces of supply and demand. Price history, however, is a more fruitful field to explore at this point than is price theory.

Do Agricultural Prices Fluctuate According to the Law of Supply and Demand?-The demand side of the market is difficult to trace, for the market reports now prove that the demand for staple products is never constant. The supply side, however, may be traced by tabulating the yields for a series of years. The question then resolves itself into this: Do prices go up and down as yields go down and up? Many tables of statistics have been published on this subject, but the figures collected and published by the federal government are doubtless most widely accepted.

The following diagram is a reproduction of one prepared by the Bureau of Crop Estimates, and covers crop yields per acre and crop prices for fifty years. ${ }^{1}$ This table shows strikingly that prices tend to advance when yields decline, and to decline when yields increase. Ten crops are combined, namely, wheat, corn, oats, barley, rye, buckwheat, potatoes, hay, cotton, and tobacco. Prices and yields of each crop are reduced to their percentage of the fifty-year averages (Fig. 46.)

Are Agricultural Prices Higher in the Spring than in the Fall?In many popular discussions of the "middleman"-particularly in political campaign oratory-the middleman is pictured as storing or "hoarding" food supplies in the fall of the year, when they are cheap, and selling them in the spring when prices are high. Or, put in another way, the unhappy farmer must hurry his crop to market as soon as harvested in the fall, in order to pay his debts, and in this manner sells it at big sacrifice in price. Then, the story runs, this same farmer often is forced to buy back part of his supplies in the spring at a greatly enhanced price.

${ }^{1}$ Monthly Crop Report, Washington, February, 1917, p. 16. 
One of those strange popular fallacies which persist through the years is this one that the price of the important agricultural products is lowest in the fall when the farmers sell the bulk of the crop. An interesting study of this subject was made by an economist, J. E. Pope, and published under the title, "Can the farmer realize higher prices for his crops by holding them?" 2 After studying the variation in the monthly prices of important agricultural products, the cost of storage, interest, shrinkage, loss and damage, and other expenses of holding the crops, he concludes that in the long run it will not pay the farmer to hold his crops.

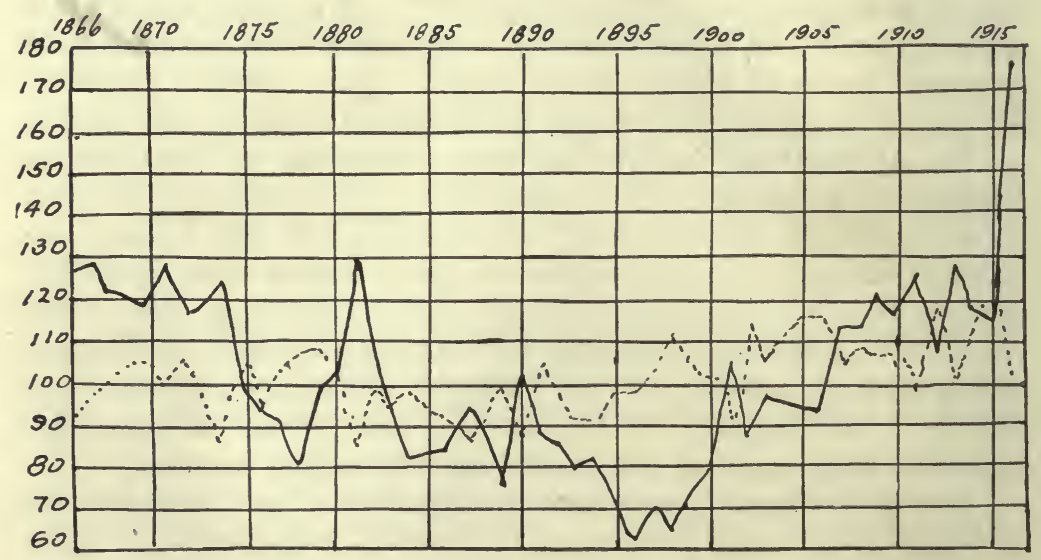

$\longrightarrow$ prices

....... = yields

Fig. 46.-Trend of farm prices and yield per acre of crops combined. 100 represents the average of 50 years, 1866- 1915 .

Further light is thrown on this question by an examınation of the price ranges on the Chicago market of wheat, corn and oats for the past fifty years and more, taking into consideration the months when lowest prices were reached and the months when highest prices were reached. See charts in Appendix to this chapter.

Interpreting these charts, we find that in the case of wheat the high price of the year was reached in the six months following harvest in 24 years out of 51, and that the low price was reached 33 times in the six months following harvest. This indicates that a farmer would do about as well by selling his wheat at or near harvest time as by holding. it for six months or over.

${ }^{2}$ Quarterly Journal of Economics, Vol. 30, pp. 805-831. 
In the case of corn during 52 years, the low price was reached 45 times in the six months following harvest, and the high price was reached 19 times in the same six months.

In the case of oats for 52 years, the low price was reached 37 times in the six months following harvest, and the high price was reached 23 times in the same six months.

Some Price Theory.-The generally accepted principle or theory of price is that supply and demand determine price. This theory generally presupposes the free play of competition. There can be no doubt that supply and demand are the basic factors in determining price. These are the most powerful and most permanent factors. Supply, however, may be temporarily cornered, or monopolized. Demand may be artificially stimulated. For the consumers' wants are based to a great extent on whims and fancies rather than on any rational consideration. Custom and bargaining power are two very significant factors in price making. That supply and demand are the basic factors in price fixing, however, is shown by our own economic history. Large yields have meant lower prices, and short yields have meant higher prices. Yet it is obvious that only within large limits do supply and demand fix the price. It may be said that supply and demand fix the upper and lower limit of price, and between these limits the actual price is set by other factors. Or, to put it another way, supply and demand stake out a prize ring, and within this ring other factors such as custom and bargaining fight out the actual price. Thus supply and demand may fix the price of the bean crop to the Michigan farmer between four dollars and six dollars a bushel. The actual price may be set at five dollars, especially if the farmers have a strong, enough organization to bargain for themselves collectively. The power of the stronger bargainer to influence price is well illustrated by the story of General Grant, as told by himself, when he once bought a twenty-dollar colt for twenty-five dollars. ${ }^{3}$

${ }^{3}$ "There was a Mr. Ralston living within a few miles of the village, who owned a colt which I very much wanted. My father had offered twenty dollars for it, but Ralston wanted twenty-five. I was so anxious to have the colt, that after the owner left I begged to be allowed to take him at the price demanded. My father yielded, but said twenty dollars was all the horse was worth, and told me to offer that price; if it was not accepted I was to offer twenty-two dollars and a half, and if that would not get him, to give twenty-five dollars. I at once mounted and went for the colt. When I got to Mr. Ralston's house, I said to him: 'Papa says I may offer you $\$ 20$ for the colt, but if you won't take that I am to offer you $\$ 22.50$, and if you won't take that, to give $\$ 25 . ’$. I kept the horse till he was four years old, when he went blind, and I sold him for \$20."-Grant, U. S., Personal Memoirs, 2 vols., New York, 1885, Vol. 1, p. 29. 
In the organized markets, such as the grain exchanges, and cotton exchanges, the market price is set by a bargaining process, where both sides-buyers and sellers-are fairly equal in strength and in knowledge of the supply and demand factors. But as the market becomes more decentralized, more local, and more unorganized, the factors of bargaining power and custom gain more importance and the limits set by supply and demand spread farther apart-the ring becomes larger.

A "Just Price."-It is likely that the individual farmer's weakness as a bargaining factor in price fixing has given rise to considerable discontent and suspicion towards the market on the part of the farmer. He feels that certain "middlemen" who merely "handle" his product have grown wealthy. So the farmer comes to picture to himself an economic system wherein "big business" has waxed fat, in sloth and ease, by exploiting the farmer and keeping him toiling at his hard and strenuous tasks. Of course this picture leaves out of view the many "middlemen" who have failed in their enterprises and lost their capital, and also leaves out that other consideration, namely, that the successful "middlemen," surviving strong competition, do it by supplying a service. Some destructive agitators tell the farmers to abolish "big business." Some advisers tell them to organize, bargaining collectively, and thus conduct big business themselves. It is interesting to note in this connection that in western Canada where the farmers have scored such a success along coöperative lines through their United Grain Growers Company (see page 165) the consumers are already applying to these farmers such appellations as "big business" and "profiteers." " It is no wonder, therefore, that in the existing confusion concerning price making and price ethics, more and more voices are being raised asking for governmental interference in price fixing or actual price fixing by the government. This demand for a "just price" is easy to comprehend. But "letting the Government do it" is a solution which may not be as easy and simple as many a person seems to think. Price fixing by the government as a war measure, but not as an economic measure, was thoroughly tested in the World War, by Germany, Italy, France, England, United States, and other countries. The policy was tried and adhered to, as part of the military strategy of the warring country. As an economic measure it was admittedly clumsy and wasteful, and did not result in "just prices"-prices

${ }^{4}$ Debate in House of Commons, Ottawa; See Grain Growers Guide, Winnipeg, July 2, 1919. 
fair to producer and consumer. Since "regulation begets regulation," these price-fixing measures entailed the need of government regulation of consumption and production. But as a war measure they were borne cheerfully by all parties.

Price fixing affects first of all the demand side of the market, not the supply side. Thus, fixing the price low increases consumption (and decreases production, in the end); fixing prices high lessens consumption (and increases production in the end). Thus the Federal Food Adrninistration in the United States, in 1917, fixed the price of wheat at a low figure, compared with its market value, thus stimulating the consumption of wheat. This led to the regulation of consumption also, and finally to an extensive system of rationing. In other words, the control of demand led to an attempt at control of supply, first of one product, then of other products. Each added.regulation begot another regulation. Regulation had extended only: to the necessaries of life when the war closed. Concerning the non-essential industries, Profesșor Warren made this pertinent comment.

"The present policy of regulation of prices of necessities is working about as follows: The cost of living is lower than it would be. This leaves more money to spend for luxuries. The luxuries rise in price. The manufacturers of luxuries pay better wages. Labor is attracted from farms and other regulated industries." 5

This is a good illustration of how the consumer's clamor for cheap food, when headed by a price fixing body, may actually result in food scarcity by diminishing production.

Just Price; Fair Price; Equilibrium Price.-The terms "just price" and "fair price," have no clear-cut definition in the popular mind. As viewed from the individual producer's viewpoint, a fair price connotes a price rewarding him for all his costs of production. But this cannot be the social viewpoint, since many commodities produced do find a demand at a price much above cost of production, and others do not find a demand strong enough to cover cost of production. In other words, there is a class of marginal producers, producing at cost, and there is a class of sub-marginal producers putting the product on the market at less than cost. As viewed by society, a just price is that price which will maintain the industry or enterprise which society wants maintained. Does a big city want a supply of fresh milk? Then it must pay the price which will maintain the dairy industry - the dairy enterprises of the indi-

${ }^{5}$ Reprint from the Proceedings of the American Farm Management Association, December, 1917; The Food Supply, G. F. Warren, p. 18. 
vidual farmers who produce the supply needed. Obviously the cost of production of milk varies from farm to farm, and on the same farm from month to month and from year to year. The city must pay, not only for the cheapest portion of milk produced, but the whole supply, including the marginal milk, i.e., the milk produced at greatest expense. For instance, if fifty farmers can produce milk at 10 cents a quart, and fifty farmers can produce milk at 8 cents a quart, the city must and will pay these one hundred farmers ten cents a quart, if the supply of these 100 farmers is consumed by the city. That is, the city will pay ten cents a quart if it wants to keep up its customary supply of milk. A "fair price" maintains the most expensive units of the supply; otherwise this part of the supply is not forthcoming, and the price will rise with the fall in supply till the demanded supply is forthcoming. One danger in price regulation by any commission is the ignoring of the economic law of marginal production and marginal utility. Any price control is likely to stimulate consumption and reduce production. Price fixing on the "average cost of production" is a foredoomed failure, even if it be not a calamity. Thus average cost of producing crops commonly ignore the factor of abandoned acreage. In 1917,31 per cent of the winter wheat acreage was abandoned. In Nebraska, 75 per cent was abandoned. ${ }^{6}$ The average cost of producing milk ignores that portion produced at a loss. A Tompkins County, New York, survey contains this statement: "Cows are the most profitable kind of live stock in the county, but the average cow does not pay. A very large proportion of the cows are being kept at a loss. The most profitable farms are keeping cows that give 50 per cent more than the average cow." 7 Yet the city consumes the milk from the average cow, and pays for it. And the price paid is the same as for milk from cows above the average. In short, if milk from the "marginal cow" is wanted, a fair price must pay for this marginal milk, and so also for any other marginal product.

Price Fixing, in Practice.-In recent years, due to the development of the coöperative movement among farmers and their concomitant advance. in collective bargaining power, there have been many cases of price fixing by representative groups of farmers bargaining with representatives of the distributors, or with a com-

${ }^{6}$ United States Department of Agriculture Monthly Crop Report, May, 1917, p. 38. p. 564 .

${ }^{7}$ Bulletin 295. Cornell University, College of Agriculture, March 1911, 
mission representing the consumer. Thus the Dairymen's League, in the New York City territory, has for some years fixed the price of liquid milk by bargaining with the large distributors. The Wisconsin Milk Commission of October 1917 fixed the price of milk for the Chicago-Milwaukee district. In most efforts at price fixing cost of production is assumed to be the correct basis of price. But in practice it is found impossible to ignore the demand side of the question.- Furthermore the cost of production varies so much from farm to farm and from year to year on the same farm that it is not a definite and clear-cut item. One of the sanest discussions of this complex matter is that of Professor H. C. Taylor of the University of Wisconsin, in his bulletin entitled "Price Fixing and the Cost of Farm Products." 8 In this he develops the theory of joint costs for farm crops, showing that certain crops have a joint cost-like gasoline and kerosene-and that the selling price varies as the demand varies-just as the price of gasoline in 1918 was nearly twice as high as that of kerosene although the two were produced at a common cost. Professor Taylor's conclusions are that when Price Commissions attack the problem of price fixing they ought to consider the demand side along with the price side and thus endeavor to keep supply and demand balanced, that is, they ought to aim at an "equilibrium price." Ought not the farmer to aśk for an "equilibrium price" rather than a "just price"? Professor Taylor further concludes that a Price Commission might function wisely as a mere medium for collective bargaining. Illustrating the principle of collective price fixing, and its relation to cost-of-production and to demand, two examples from California may be cited.

Collective Price Fixing by California Walnut Growers.9 Fixing the "Offering Price."-"The prices of the various grades of walnuts produced by the California growers must necessarily be based upon the law of supply and demand. If prices are set so high as to prevent normal consumption a carryover must necessarily result, which always tends to demoralize the market and makes necessary a material price reduction. In order to move an entire crop valued at from five to seven million dollars within a period of two months, and to move it as fast as the goods are packed and ready for shipment and at an absolutely uniform price, it is necessary that that price be a trifle under what is absolutely justified by the laws of supply and demand, for if the wholesale purchaser cannot figure on a slight advance in price as the season wears on he will purchase only his minimum requirements and will not stock up with several months' supply, but will purchase lightly at first, forcing the growers to store such goods as are not necessary for immediate consumption,

${ }^{8}$ Agricultural Experiment Station, University of Wisconsin, Madison, Wisconsin, Bulletin 292, May, 1918.

${ }^{9}$ California Walnut Growers Association, General Report, April 30, 1918, pp. 34,35 . 
and the wholesaler will buy later and usually at a lower figure. The method now pursued in determining the proper prices is through advices received from salaried agents that the Association maintains in France and Italy, the principal countries producing walnuts which come into competition with the California line. Advices are constantly received through these agents as to the extent of the foreign crops, the quality, prices being paid, whether the harvest is early or late, etc. The Association's sales department then gathers all possible information regarding the consumer's demand in America. Accurate estimates of both domestic and foreign walnuts carried over in this country are secured, the purchasing power of the nation considered, then a careful and accurate estimate of the quantity and quality of the California crop is made, and all of these matters laid before the board of directors about the time the shipping campaign opens. The directors first examine and crack samples of walnuts gathered from practically all districts, and determine the average percentage of sound merchantable nuts that can be guaranteed to the purchasers of Diamond BRAND goods. They then consider all factors that enter into the value of the product, and name prices at which the Association's various grades and brands of walnuts will be offered the trade. And for reasons above stated, these prices must be slightly below the figure justified by the actual supply and demand as long as the policy of selling at one uniform price throughout the entire season is deemed advisable."

Collective Price Fixing by California Almond Growers. ${ }^{10}$ " At an opportune time the Association's representatives are called together for the purpose of considering prices.

"The latest information as to the foreign and domestic crops, as well as general market conditions, is fully discussed.

"The result is a price that in the opinion of all will move the crop promptly.

"It must be fully understood that the price named by the Exchange is the best estimate as to the value of the crop to be harvested. Later market, financial and foreign conditions may materially raise or lower that value. The Exchange maintains a salaried representative in Europe, who reports from time to time on the European almond crop, and market conditions. Thus the Exchange is well posted on world-wide conditions affecting our industry."

A very illuminating example of the force of demand in fixing the price of wheat was given by the market in the early part of the year 1917. In Canada and in the United States the farmers were complaining that the spread in price between different grades of wheat-one dollar and over-was too great and was not.justified by milling values or any other economic conditions. The companies dealing in wheat accordingly were blamed. Yet, when the facts were once clearly stated, it was understood that economic factors did account for this wide spread. The situation was explained to the Manitoba Grain Growers Association at their 14th Annual Meeting by Robert Magill, former Chairman of the Canadian Grain Commission, in the following succinct manner: ${ }^{11}$

"Russian supply is cut off. India, the Argentine, and Australia are too far away. Several trips could be made to America for one to the former countries.

${ }^{10}$ Report for 1918, California Almond Growers Exchange.

11 Magill, Robert, 14th Annual Meeting Manitoba Grain Growers, Brandon, January 10, 1917. Grain Growers Guide, Winnipeg, January 17, 1917. 
"The Allies Wheat Commission in London do all the buying on this continent, and have only one buyer on this side. Everything must pass through his hands. The allies want no wheat but that which will make the most loaves, and the lack of tonnage makes it imperative that they take only the higher grades.

"Thus no market is left for our grades below No. 4, and the spreads are enormous between these and the higher. Even at that, many companies are losing money."

Summary on Cost of Production and Price.-The present agrarian demand that price of farm products be fixed on the basis of cost of production plus a reasonable profit is only in part sound; it contains one element of weakness by overlooking the demand side of the market. The manufacturer who knows his cost of production aims to sell at a certain margin above this cost. However, if demand falls off he must seek to lower his cost of production, stimulate the demand, or both. Inefficient manufacturers are constantly failing and being weeded out; and successful manufacturers do at times market a part of their production at less than cost. The same principles hold out in agriculture. All farmers ought to know their production costs so far as possible. However, when consumers refuse to buy the product of the inefficient farmer at the cost-of-production-plus-a-profit basis, such a farmer is in the same position as the inefficient manufacturer. Cost of production, therefore, should be one fundamental factor in price making, but not the sole factor. Otherwise an equilibrium price is not established. And a surplus or a shortage may result. The "cost-of-production" price always fails when a surplus is produced.

For governmental interference in price fixing in ordinary times, and the results to the producer and consumer, we may wisely turn to Brazil and the so-called Valorization of Coffee.

Valorization in Brazil.-Valorization is defined in our consular reports as "giving by law a fictitious or artificial value above or apart from the normal or ordinary market value." The valorization of coffee was a plan carried out by Sao Paulo, a State in Brazil, to enhance the market price of coffee. The world's coffee consumption is about $18,000,000$ bags a year. Most of this coffee comes from Brazil. The United States consumes 80 per cent of the Brazil crop. An extra large crop in 1901 brought disaster to many planters in Sao Paulo, the principal coffee growing State in Brazil. In 1906, the date the valorization scheme was developed, another big crop threatened to reduce prices below cost of production. The yield was 20,000,000 bags in Sao Paulo-more than fivesixths of the world's supply. Hence the plan was developed 
and carried out for having Sao Paulo enter the market, buy up enough coffee to secure a partial corner of the market, and thus enhance the price. At the same time an effort was made to prevent over-production in the next few years by keeping down any increase in acreage. A heavy tax was levied on new acreage. In this manner, both the supply and demand factors were to be regulated.

Past experience had taught that a big coffee crop was usually followed by a series of short crops. Coffee is not a perishable product, but, like wheat, may be carried over for several years. Hence, a surplus bought by the State could be gradually worked off in succeeding years without disturbing prices. Thus it came about that Sao Paulo borrowed the funds, entered the coffee market as a buyer, and bought $10,000,000$ bags, aiming by this partial corner to maintain the domestic market price at a minimum of 7.9 cents per pound. Before putting the scheme into operation, the minimum price was set at 13.2 cents. Such a gigantic scheme as this required many tens of millions of dollars to finance it. How was this venture financed? How was this State coffee marketed? What were the effects, beneficial and otherwise, of valorization? These three questions need answering.

Sao Paulo experienced considerable difficulty in securing the necessary funds to buy and hold the coffee. Temporary credits were used at first. An arrangement was made with the Brazilian Bank for Germany for the discount of $£ 81,000$. Next a loan of $£ 3,000,000$ was made through J. Henry Schroeder, of London, and the National City Bank of New York. A loan of $£ 3,000,000$ was made by the federal government of Brazil, under contract with N. M. Rothschild \& Sons, through the agency of Eugene J. J. Hollender, Jr. It soon became necessary for Sao Paulo to call upon a syndicate of bankers to take charge of the transaction and hold the coffee off the market. It was also necessary to have the Republic of Brazil guarantee the loan. In this manner $£ 15,000,000$ was borrowed from the bankers. These powerful financiers demanded certain liberal terms for themselves, both in regard to financing the plan and in the marketing of the coffee. This loan was to run 10 years (to January 1, 1919), and to be used, "For the completion of the measures necessary for the defense of coffee, and for the conversion into a consolidated debt of the various temporary operations undertaken with the same object in view." It is interesting to note that in the preliminary arrangements concerning the first $£ 3,000,000$ loan the National City Bank of New 
York was represented by Mr. Herman Sielcken; also that when the purchase of coffee began for the State of Sao Paulo, August 20 , 1906, among the large firms through whom the purchases were made was Crossman and Sielcken of New York City, a partnership composed of George W. Crossman and Herman Sielcken. The expenses of valorization came in for a great deal of criticism. The bonds for the first $£ 3,000,000$ loan were to run $3,4,5$, and 6 years, and bear five per cent interest, but yet they were sold at 93 . The discount amounts to $\$ 1,016,400$. The bonds were in fact paid off within three years, the interest thereon amounting to about $\$ 2,178,000$. In addition to this the bankers received 1 per cent upon the face value of the bonds, and also one per cent upon the interest paid, which amounted to about $\$ 167,000$, and they were also paid $1 \frac{1}{4}$ per cent, or about $\$ 181,500$ for stamps, taxes, and other expenses. Hence the total cost of this loan of $\$ 14,520,000$ was about $\$ 3,542,000$, or more than 24 per cent.

The bonds for the $£ 15,000,000(\$ 72,600,000)$ were to run 10 years at five per cent interest, and were sold at a discount of 15 per cent, which was a loss to the State of $\$ 10,890,000$. According to the report of the Sao Paulo minister of finance, dated September 10,1910 , these loans up to that date had already cost the State in expenses and charges of various kinds, in difference of types of various loans (discounts), freights, insurances, buying and selling commissions, interest on advances, warehousing charges, collection and remittance fees, and other expenses in connection with State-owned coffee $\$ 52,591,976$ in gold. This meant a cost of $31 / 2$ cents a pound in administrative expenses for all the coffee purchased by the Government. The Government could much more cheaply have paid a direct bounty to the producers provided that coffee sank below a reasonable price.

The marketing of the $10,000,000$ bags of coffee withdrawn from the market was left to a committee of the bankers. The government of Sao Paulo obligated itself to offer for sale through this committee at public auction or by sealed proposals, at the price of the day, 500,000 bags in $1909 ; 600,000$ bags in $1910 ; 700,000$ bags in 1911; and 700,000 bags in each succeeding year. The government conceded to the committee full and irrevocable power to determine the times of sale, the minimum obligatory quantities mentioned, the markets in which to sell, to make the sales in the name of the government, and exercise control over the transactions. The Committee was to be paid 1 per cent- upon the net 
product of the sales. On September 30, 1909, this committee had in its custody and stored in the following amounts and places:

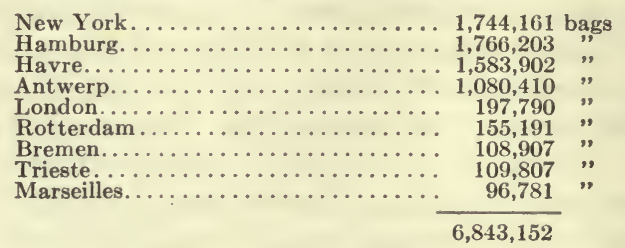

To market this coffee without disturbing the market was a problem for the Committee. Since several members of the Committee were personally interested in the coffee trade, the higher the price of coffee the greater the profit realized by them therefrom. Minutes of the meetings of this Committee show that they were greatly perturbed at times as to the marketing problem. At their first meeting, January 5, 1909, it was determined that not more than 500,000 bags should be sold during 1909, and that at not less than 7.2 cents per pound. At the April 27, 1909, meeting the Committee considered favorably a proposal of the government that an additional export duty be imposed on coffee of 10 per cent, payable in coffee, such coffee to be destroyed under the control of the Committee. Whether such coffee should be burned or dumped in the sea was debated. The government later decided to withdraw this proposal. At the January 5, 1911, meeting of the Committee it was determined that $1,200,000$ bags should be sold between the 1st and 30th of April, 1911, and that no more should be sold during the year. The Committee made sales during 1911 as follows: 300,000 bags at 123/4 cents; 300,000 bags at $123 / 4$ cents. On January 25, 1912, the Committee announced that 400,000 bags had been sold that day in New York at 15 cents a pound. When the World War broke out there were $3,000,000$ bags in store in Europe. This was promptly seized by the belligerents. This closed out the last of the valorized coffee.

The effects of valorization are viewed in different lights by different persons. Some claim it was an economic and financial success. The facts are a little difficult to unravel. One unforeseen result was a suit in equity brought by the United States Government against Herman Sielcken and the other members of the bankers' Committee, praying that the valorization scheme with its several "conspiracies, contracts and agreements" be declared violative of the American Anti-trust Act, and that any claims to ownership of said coffee by any member of committee be declared 
illegal and null and void; second, that defendant Herman Sielcken be perpetually enjoined from further withholding from the market the coffee held by him and stored in New York, and that he be enjoined from selling the same on condition that the purchaser will not resell same; third, that defendants be enjoined from parting with the custody of said coffee except to deliver same to a receiver of the court, to be sold by him; fourth, that a receiver be appointed forthwith to take charge of said coffee. The brief, in this same lawsuit, states:

"The immediate effect of valorization was to withdraw from the natural course of commerce more than $10,000,000$ bags of coffee, and thus to reduce the available supply and to increase its market price ... Shortly thereafter the prices began to rise and continued to rise although in the season of 1909 1910 the production exceeded the consumption by more than a million bags, with the result that whereas when the scheme of valorization was adopted, Rio No. 7 was selling in New York at about $71 / 2$ cents per pound. It is now (1912) selling at $143 \% 4$ cents per pound, an increase in price of nearly 100 per cent. Within the last year, conditions have become especially acute, because the consumption has exceeded the production, and hence the deficiency had to be drawn from the supply already on hand, while a very large part of that supply was and is in the hands of said committee, who were careful to sell therefrom only in such quantities and in such a way as not to reduce the market price. As a matter of fact said committee are masters of the coffee market. They have under their control such a quantity of coffee, that by placing the same upon the market the price of coffee would be greatly reduced, while withholding it from the market maintains a price which is abnormally high ... The real intent and purpose of the valorization scheme was through a restraint of the commerce in coffee between Brazil and other countries, including the United States, by monopolizing the same to increase the price thereof to the enrichment of those instigating the scheme. This fact is made manifest by the amount of money realized by individuals therefrom and from the expense thereof directly to the State of Sao Paulo, but indirectly to the consumers of coffee . . These figures show that it was not for the welfare of the producers that this valorization scheme was concocted and carried out ..."

The first aim of the scheme was to raise the price of coffee to the producers. This was undoubtedly accomplished. However, it is open to debate whether the increase in price equaled the increase in taxes required to finance the scheme and reward the bankers. Under an agreement of August 6, 1906, the Sao Paulo government obligated itself to create a "surtax" of 3 francs,.subject to increase or reduction, upon each bag of coffee exported. The law of August 25, 1908, provided that an additional tax of 20 per cent ad valorem should be collected on all coffee exported in excess of $9,000,000$ bags for the first, $9,500,000$ bags the second year, and 10,000,000 bags each year thereafter. The 3 franc surtax above was changed to 5 francs. In September, 1908, the 20 per cent tax, was made 29 per cent. That this system of taxing was unduly burdensome to the coffee trade was recognized by the Sao 
Paulo minister of finance, as evidenced in a communication of his to the Brazilian embassy in Washington under date of April 1, 1909, wherein he states:

"The taxes collected by the State were given in guaranty of the loan and will be reduced, once the loan is redeemed. The tax of 20 per cent ad valorem on the export beyond the amount marked by law $(9,000,000,9,500,000$ and $10,000,000$ bags for first, second and subsequent years respectively) was created by exigency of the bankers, but the Government is negotiating with them to replace it by another more acceptable to the markets."

The artificial enhancement of price of coffee and the placing of export duties on it stirred the American Congress. There was even some idea of modifying the American policy of free trade in coffee in retaliation. At this juncture the finance minister of Sao Paulo officially disclaimed further interest in the valorization operations. He said (April 1, 1909):

"The Government of Sao Paulo is no longer engaged in any valorization operations and has ceased entirely with its intervention in the market with the signing of the $15,000,000$ pounds sterling loan. All the coffee stock belonging to the State has been delivered to the committee of bankers authorized to sell it."

There is no doubt that the Brazilian planter, being denied the privilege of increasing his acreage of coffee cultivated his crop more intensively. The trees were given better attention. Not only that, but the high prices stimulated planters in Java and elsewhere to increase their output. In this manner valorization did lead to over production. The Wall Street Journal of March 18, 1916, comments as follows on the low price then prevailing:

"Coffee prices are low, inexplicably low, to even the best trained specialists in the world's leading markets. At about $7 \% / 8$ cents the market hangs at the mercy of liberal supplies coming from producing sources ... The price depression is sufficiently explained by trade dislocation and by surplus production, of which last year the world had 1,055,000 bags left over out of a total supply of $19,612,000$ bags .. . Last year's big crop of $19,612,000$ included 13,816,000 bags from Brazil and 5,796,000 bags from all other sources, including mild Central American and East Indian coffees. The non-Brazilian coffees were 30 per cent above the average in yields, and therefore had some perceptible effect in reducing the coffee prices. But Brazil's 65 per cent of the world's production is still the dominating influence. Last year's supply was the largest since the valorization plan helped to hold prices up. The supply situation there, after several poor years intervening, is the main reason for low-priced coffee."

It is quite generally held that the cure for low prices is low prices; the cure for high prices is high prices. But in applying a remedy to low prices in Sao Paulo, the government applied a remedy certain in the end to increase the disease. A temporary gain was secured which was a pseudo gain, for the later losses and expenses more than offset the temporary gain. New eompetitors 
were created in producing coffee. Doubtless the temporary high price for coffee caused many consumers to seek substitutes for this drink, of which there are many on the market. The valorization scheme led to a severe collision with the legal authorities of the United States. Evidently the chief advantage of the scheme accrued to the bankers who managed it. These bankers were beyond the reach of our legal machinery. As Wm. T. Chantland, Special Assistant to the United States Attorney General, says in his detailed report on valorization:

"Of a violation of this law (United States Anti-trust Act) the members of the so-called valorization Committee, who are among the best-posted coffee men in the world, were and are guilty, but of them we can deal only with the American member, Mr. Herman Sielcken, who is now, and has been since before this investigation was begun, living out of the United States, to wit, on his estates in Baden-Baden."

That a state may corner the market and raise prices ("valorize") is a doctrine that has a certain glamor about it among law-makers in the United States. As evidence of this, the cotton situation in 1917 is an example. Texas seriously considered valorizing its cotton crop-or attempting to do it. The Houston Chronicle of February 8, 1917, contains this news item:

"The house committee on constitutional amendments met last night and reported favorably the Clark resolution for a constitutional amendment authorizing the Legislature to create a governmental agency with powers to fix a minimum price for cotton each year. The resolution also provides an additional State tax of 10 per cent to raise a fund which would enable the State to buy cotton or lend money on the staple in order to maintain the minimum price determined upon."

Price and Value.-Price is value expressed in terms of money. Values fluctuate from two sets of causes, those affecting the supply side and those affecting the demand side. Utility is the power to satisfy a want. Value does not depend on utility, but on utilityplus-scarcity, or what is generally called marginal utility. Water has high utility, is in fact indispensable to life. Yet in most places drinking water is so plentiful as to be free that is, has no value, no price, no marginal utility. But just to that degree that the want for water is unsatisfied, to that degree its value increases. No principle of economics has wider acceptance than this marginal utility theory of value. This being true, it is obvious that value does not depend on cost of production. But it is related to it. Value does not depend on demand, but is related to it. The true conception of value is that of the keystone of an arch, the keystone being labeled value or marginal utility, and one side of the arch being labeled "Supply" and the other side "Demand." 
The figure (Fig. 47) correctly shows the relation of value to cost of production. Price fixed on cost of production alone therefore may work disaster by ignoring the demand side. When supply and demand are permitted to work, unfettered by artificial influences, governmental or otherwise, then high prices are the cure for high prices (by affecting both the supply and demand side); and low prices are the cure for low prices (by affecting both the supply and demand side).

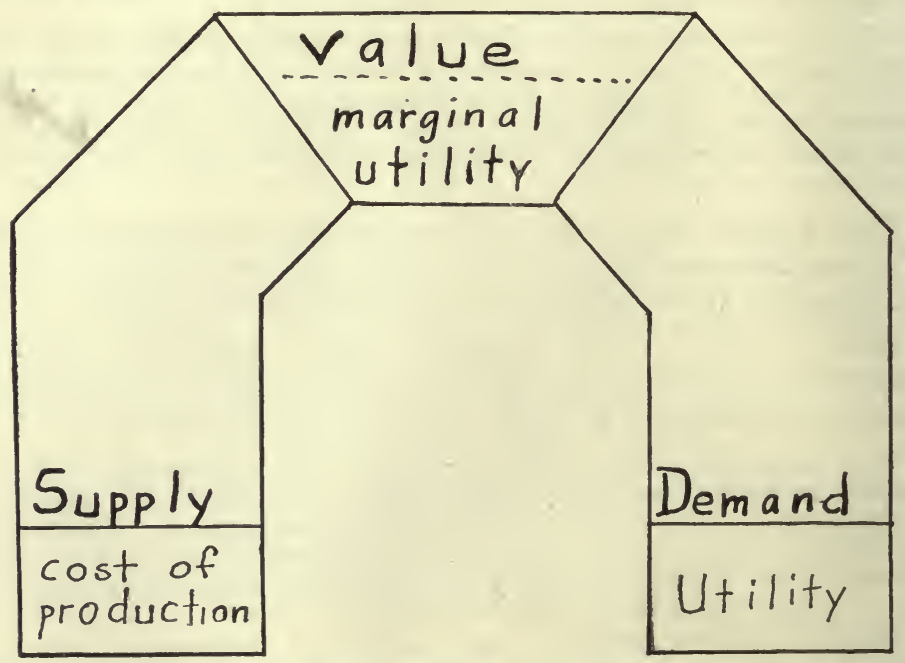

Fia. 47.- Relation of value to cost of production and to demand. Value depends on marginal utility. Marginal utility depends on supply and demand. Supply depends on cost of production. Demand depends on utility. Any change, therefore, in supply or demand affects value. Any change in cost of production or utility affects supply and demand, and hence value.

Conclusions.- The question of a fair price is coming more and more to be a social question. Among our social forces to-day are government, public opinion, economic organizations of producers and consumers, the press, and so on. The metropolitan press at present sheds more heat than light on the price question, catering to the supposed wants of its readers. However, a few big city dailies now maintain a market information service for the honest purpose of educating the consumers in the problems of: markets and prices. Here is a vast opportunity for service leftr untouched by most city papers, however. Public opinion, unless fed on the truth, is a force for evil as much as it is a force for good! The government may do much, and in fact is doing much, to spread" 
information about.markets, market practices and market prices. It may do much in the way of efficient publicity on the important steps in marketing, particu larly transportation, grading, standardization of pack, storage, processing and labeling, credit, and so on, and still leave free play to individual initiative and industry. But the heavy, paralyzing hand of bureaucracy should never be permitted to displace the nice adjustment of economic forces seen in the open market where keen buyers meet keen sellers face to face and fix the market price under free play of supply and demand. In the realm of organized labor the collective bargain has now established its place, rather than government fixing of wages. It is altogether probable and desirable that a legal method of collective bargaining be also worked out in agriculture in the immediate future for those more specialized products when the plan promises success. Such a collective bargain, were producers, distributers, and consumers equally well organized and represented, would prove a useful adjunct to the open market in establishing fair prices. Its educative value would be great. Its economic value would be small at first, but would doubtless increase with time. At any rate, the growing demand by both consumer and producer for "price fixing," and that "something be done" by "somebody" requires that the situation be met. And the collective bargain method would be vastly preferable to governmental price fixing. The farmer would be given a voice in price making, thus salving a very sore spot. In the language of our political formula, the "consent of the governed" is basic; it is equally expedient in our economic life.

Collective Bargaining as Price Fixing.-The term collective bargaining is used in agriculture with some vagueness of meaning. In mining and in railroading, whence the term comes, the meaning is clear-namely the fixing of the wage rate (and other conditions of employment) by a sort of parliament or congress of representatimes of labor and of capital. In agriculture the essence of the term is price fixing. Therefore collective bargaining differs from coöperative buying and selling. Coöperative selling means the mere pooling of supplies and selling at the market price from day to day. Collective bargaining means fixing the market price usually for a definite period, such as one year or one month. And price fixing also implies control of the supply by the producers those representatives are making the collective bargain.

The farmer desires collective bargaining, and is entitled to , because of the voice it gives him in fixing the price on his wn products. 
The field now successfully covered by collective bargaining in agriculture is that of whole milk for certain large metropolitan districts, particularly New York, Pittsburg, Cleveland, Chicago, Detroit, Minneapolis, St. Paul, and San Francisco. Here the dairymen control the raw milk supply. Representatives of the organized dairymen bargain with representatives of the organized distributors, and a price is fixed. If consumers ever organize, the farmers may bargain collectively with organized consumers. At present, the problem of protecting the consumer against a "combine" of farmer and distributor is being solved in different ways in different cities. Evidently the consumer is entitled to a "voice" in price fixing on the produce he buys. In Detroit, Pittsburg, and elsewhere, he "sits in" with the representatives who do the price fixing.

The chief problem involved, however, is not by whom shall the price be fixed, but at what point. The farmer asks for "cost of production plus a profit," in other words, a guarantee of dividends. But he is never able to sell all his product in this way for a very long time, if he produces a surplus. As the supply increases beyond the consumer's wants, the price must drop; conversely, when the supply decreases below consumer's wants, prices rise. Hence a sliding scale is the solution, representing both cost of production and demand. In other words, collective bargaining will work if and when it follows the law of supply and demand.

\section{QUESTIONS ON THE TEXT}

1. What factors determine price? What factors should determine price?

2. Do agricultural prices fluctuate according to the law of supply and demand?

3. Are agricultural prices higher in the spring than in the fall?

4. Show the limitations of the theory of supply and demand in price fixing.

5. Show the attitude of some farmers towards so-called "big business."

6. Show the farmer's demands for a "just price."

7. Discuss the theory of price fixing by the government, and show its limitations.

8. Show relationship of "just price," "fair price," and "equilibrium price." Define each term.

9. Define and illustrate marginal producer.

10. Show how price fixing is sometimes done by collective bargaining.

11. Quote the conclusions of H. C. Taylor on the use of price commissions in price making.

12. Cite the experience of the California Walnut Growers in making an "Offering Price," and show what price factors are given most weight.

13. Cite experience of California Almond Growers, and show what price factors they take into consideration.

14. Give illustration from wheat market showing where demand may temporarily be the dominating factor in price making.

15. Show limitations to the theory of basing farm prices on cost of production. 
16. Give in detail the experience of Brazil in valorizing coffee, and show what principles of price making are here involved.

17. Define price, and distinguish from value. Define utility; marginal utility.

18. Show relation of price to cost of production; to utility; to demand; to supply; to marginal utility.

19. Compare price fixing by governmental agencies and by collective bargaining. Which is preferable?

20. What are the arguments advanced by Swift and Company against the cost-of-production theory in fixing prices for cattle?

21. Show some of the difficulties met in price control during the war by Germany.

\section{QUESTIONS SUGGESTED BY THE TEXT}

1. Give an account of a case of collective bargaining in agriculture in your State.

2. What is the legal status of collective bargaining? Give an account of some court proceedings wherein the legality of collective bargaining in agriculture has been called in question.

3. To what extent is it true that manufacturers fix the price at which their goods are sold?

4. What is the truth of this complaint recently published in a farm paper: "The farmer is the only person on earth having no voice in fixing the price of his own products"?

5. To what extent do laborers name their own wages?

\section{REFERENCES}

1. Pope, J. E.: "Can the Farmer Realize Higher Prices for His Crops by Holding Them?" Quarterly Journal of Economics, Vol. 30, pp. 805-831.

2. Yearbook of Agriculture, "Causes Affecting Farm Values," 1905, pp. 511-533; also, "Agricultural Production and Prices," 1897, pp. 577-607, Washington, 1905 and 1897.

3. "Industrial Commission Report," Vol. 10, p. CCLXXXVII; also Vol. 19, pp. 134-146, Washington, 1898-1902.

4. "Monthly Crop Report," United States Department of Agriculture, Washington, February, 1917, p. 16. Figures showing relation of supply and demand in price changes.

5. "Digest of Report of British Board of Trade on Cost of Living in the Principal Industrial Towns of the United States": "Comparative Summary of Reports of the British Board of Trade on Cost of Living in the Principal Industrial Towns of England and Wales, Germany, France, Belgium, and the United States," 63 Cong. 1 Sess. Sen. Doc. 38. 1912.

6. "Report of Cost of Living Commission," Wellington, New Zealand,

7. Warren, G. F.: "Some Purposes of Price Fixing and Its Results," American Economic Review, March, 1919, pp. 237-245.

8. TAYLOR, H. C.: "Price Fixing and the Cost of Farm Products," Bulletin 292, Agricultural Experiment Station, University of Wisconsin, May, 1918. A practical and comprehensive treatment of the whole subject. p. 836.

9. "Are Prices too High?" Editorial in Wallace's Farmer, May 25, 1917,

10. Bradford, Edward A.: "The Question of Price Regulation." The Annalist, June 11, 1917, p. 787.

11. McBride, James N.: "New School of Agricultural Thought." The Annalist, June 25,1917, p. 848 . An argument for price fixing on agricultural products by the farmer. 
12. "Monthly Review of the United States Bureau of Labor Statistics," Washington, May, 1917. Contains articles on government control of food supplies in Germany and government control of food supplies in Italy.

13. Rogers, F. E.: "Wholesale Prices and Receipts of Apples in Boston for 36 years," Cornell Extension Bulletin 28, April, 1918, Ithaca, N. Y.

14. Mitchell, Wesley C.: "History of Prices During the War-International Price Comparisons," Price Bulletin No. 2, War Industries Board, Washington, 1919.

15. "Some Unforeseen Results of Coffee Valorization," Review of Reviews, New York, January, 1914, p. 111.

16. "Truth About Coffee," Wall Street Journal, March 18, 1916.

17. Chantland, WM. T.: "Valorization of Coffee-a Detailed Report of the Transactions and Facts Relating to the Valorization of Coffee," 63 Cong. 1 Sess. Sen. Doc. 30.

18. Brief: "In the District Court of the United States for the Southern District of New York. United States of America, Petitioner, versus Herman Sielcken et al, Defendants," Washington, 1912.

19. Daily Consular and Trade Reports, Washington, as follows: Jan. 28, 1908; Oct. 1, 1908; Oct. 19, 1908; Aug. 13, 1909; Nov. 2, 1909; Feb. 16, 1911; Feb. 7, 1916; July 12, 1916; Supplement for Aug. 20, 1916. (Valorization of coffee.)

20. "Monthly Consular and Trade Report," March, 1907.

21. Warren, G. F.: "Why Prices are High; Causes of High Price Levels: Probable Future Prices," Grain Growers' Guide (Winnipeg), Feb. 4, 1920.

22. Rogers, Thorold: "History of Agricultural Prices in England."

\section{APPENDIX}

From an advertisement of Swift and Company, published in the press of the United States, August, 1918.

\section{Why the Cost of Producing Cattle Does not Determine Their Selling Price.}

To produce a steer for meat purposes requires, as you know, a period of from one to three years.

The prices the producer has to pay for feed, labor and other items during this period, together with weather conditions, determine what it costs to produce the steer.

But the price the producer receives for the steer depends on conditions existing at the time it is sent to market.

If the supply of cattle coming on the market at this time is greater than the consumers demand for dressed meat, the prices of meat and live stock go down.

On the other hand, if the number of cattle coming to market is less than enough to supply the consumer demand for meat, the prices of meat and live stock go up.
Not only do the receipts of animals vary from week to week but the consumer demand for meat also fluctuates.

The rise and fall of prices results from an economic law that operates in every business. It is the packer's task to turn live stock into dressed meat and by-products and distribute them to the consumer under control of this law.

Market conditions and competition establish the prices the producer gets for his cattle. When meat prices go up or down, so do cattle prices.

The packer can't pay out more money for animals than he takes in from the sale of meat and by-products.

Swift \& Company will gladly coöpera te in the carrying out of any national policy that will tend to steady the prices of live stock and meat.

\section{Government Control of Food Supplies in Germany During the Early} Years of the World War. - Shortly after the War was declared the German Government appointed a commission of scientists to prepare a report upon which to base defensive food measures. This Commission, commonly called the Eltzbacher Commission, devoted several months to the study of the production, distribution, and consumption of food. 
An account of the German experience, from which the following excerpts are taken, is printed in the Monthly Review of the Bureau of Labor Statistics, Washington, May, $1917 . .^{12}$

"The recommendations of the Eltzbacher Commission for the reduction of swine and cattle were carried out during the first four months of 1915. Approximately one-third of the swine and 10 per cent of the milch cows - supposedly about a million and a half - were killed. About the time when the killing of the swine was under way, in March, an inventory of the potato stocks led to the official statement that these were low. Since the potato in Germany was one of the staple swine feeds, it was decided to kill rather more than the denominated number of swine in order to meet the loss in potatoes. Two months later another potato inventory was taken, revealing the fact that the previous inventory had been in error and that the killing of the additional swine had been entirely unnecessary, since the potatoes were available; and these potatoes were thrown upon the market at a huge loss in price and to a large extent underwent decomposition.

"No oxen were killed, and the killing of calves was not in excess of the usual number; the slaughter did not extend to sheep and goats, which, on the contrary, were conserved with foresight. The presence of such huge amounts of meat upon the market unquestionably resulted in increased consumption during the first six months of 1915. According to the plan, by far the largest portion of the meats thus obtained was to be conserved for future use, and should have represented a very large stock of conserved meat. The processes of conservation were, however, carried out very inefficiently, with the result that a large portion of this meat underwent decomposition and became a complete loss .

"In the autumn of 1915 , within six months after one-third of the swine and a million and a quarter of milch cows had been killed, two meatless days (Tuesday and Friday) and two fatless days (Monday and Thursday) were introduced by decree. Maximum prices were decreed for retail sales, but without correlation and usually without result.

"Gradually the lines became drawn between cities and industrial districts, on the one hand, and the country districts, on the other. To protect themselves the country districts prohibited export. The authorities attempted, in a half-hearted manner, to oppose such regulations and to reëstablish the flow of foodstuffs in the channels of trade by increasing the maximum prices. A maximum price, once established, became, of course, the only price. As opposed to the regulations of the cities and of the imperial authorities, the regulations of the smaller districts were naturally more effective. Restrictive regulations spread over the entire land, each community looking out for its own interests, and it was soon apparent that the industrial cities were at a disadvantage.

Establishment of the War Nutrition Office.- "Control over the food supply of the Empire was, up to June, 1916, vested in the imperial department of the interior (Reichsamt des Innern), of which von Delbrück was secretary. Dissatisfaction with the measures taken by this department became general during the second year of the war.

"The worst mistake of the Delbrück regime was in trying to regulate the sale and use of food without knowing how much food existed. The food-card system in particular evoked the severest criticism, this criticism being caused not so much by the rationing of food as by the long waiting in front of shops for the sale of foodstuffs. The food-cards, with the exception of the bread cards, did not carry any guarantee, but merely gave the holder the right to stand in line for hours and take the chances. When the supply for the day was exhausted the remaining shoppers were turned away. Disturbances of the peace were frequent, and it was felt as a grievous injustice that by this waiting in front of shops the women were withheld from household duties for hours.

"When Delbrück resigned, a separate department called the war nutrition office was created directly under the Chancellor. The president of this office was given absolute police powers under martial law, with a standing committee of experts representing the producers, transporters, middlemen, consumers, and the army. The new system was installed on June 1, 1916, with Adolph von Batocki as president of the war nutrition office . . "

Control of the Potato Crop.- "Late in January, 1916, scarcity of potatoes developed in the cities. An inventory showed that only 18,000,000 tons remained, from which the seed had still to be reserved, leaving only $11,000,000$ tons to last for six months. Thereupon potato cards were introduced, and the attempt was made to limit the feeding of potatoes to live stock. When the authorities attempted to uncover and seize the stock of stored potatoes unexpected losses by decomposition became apparent. Von Batocki, on assuming office, June, 1916, promptly prohibited any feeding of potatoes to live stock. The potato cards introduced earlier in the year were not guaranteed, and in the large cities the intake for each person during the spring months was often as low as a quarter of a pound a day. Then the crop of summer potatoes came upon the market with a rush, as the maximum prices were high and scaled downward to increase the offerings. Early in August the cities were flooded with potatoes in carload lots. The poor, however, because of the announcement that prices were scaled to fall, bought only from hand to mouth. As a result thousands of tons decomposed and were lost. Nevertheless, even at this time the potato card and the prohibition of feeding to swine were not suspended. Two weeks later the cities were again empty of potatoes. The growers had ceased to harvest potatoes when the prices fell; they

12 United States Department of Labor, Monthly Review of the United States Bureau of Labor Statistics, Vol. IV, No. 5, May, 1917, pp. 710, 711, 712, 716, $717,718$. 
were engaged in the harvesting of grain, and the urban populations had to wait for regular rations of potatoes until the digging of potatoes could again be resumed.."

Measures Relating to the Production and Sale of Vegetables and Fruit._- "The retail prices for fruit reached unheard-of heights during the summer of 1916. The growers' prices were high, in extenuation of which the high cost of fertilizers, cultivation, picking, and packing was adduced. The maximum prices first set were low. Then the growers refused to pick. The prices were raised, and thereupon green fruit was sent to the market. The people were encouraged to put up fruit by sterilization by heat and with saccharine; but the housewives were not inclined to experimentation. Thereupon the war nutrition office confiscated the entire crop of early apples and plums, supplied the sugar, and had them converted into jam."

Example of Agricultural Advertising to Create Demand and Increase Consumption.- (Printed in American Newspapers, fourth week in July, 1919. Republished by the American Meat Packers' Association. Reprinted from New York Tribune, July, 23, 1919.)

"There is Now Plenty of Beef and Lamb for Everybody - At the present price levels these are the cheapest of the meat foods. It is now possible to advise the American people that it is no longer necessary to conserve beef and lamb. Right now, there is plenty of these meats for everybody and this will be the situation for many months to come. Here are the reasons:

“1. Demobilization of our armies has gone ahead so rapidly that they now require very little beef and lamb.

"2. England and the other European countries no longer look to us for their beef supplies.

"3. When war was declared the American live stock raiser started to produce more meat. The result has been a large increase in live stock production.

"Therefore, you may now buy beef and lamb-and buy freely.

American National Live stock Association.

National Wool Growers' Association.

Cattle Raisers' Association of Texas.

Corn Belt Meat Producers' Association of Iowa.

Kansas Live stock Association.

Southern Cattlemen's Association.

Panhandle and Southwestern Stockmen's Association.

Nebraska Stock Growers' Association.

Missouri Live stock Feeders' Association.

Illinois Live stock Association.

Indiana Cattle Feeders' Association.

West Virginia Live stock Association.

Wyoming Stock Growers' Association.

Montana Stock Growers' Association.

California Cattlemen's Association.

Colorado Live stock Association.

Idaho Cattle Growers' Association.

Arizona Cattle Growers' Association.

New Mexico Cattle Growers' Association.

Cattle Raisers' Association of Oregon."

Extreme Prices of Wheat, Corn and Oats.-The following table is a statement of the extreme prices in Chicago of Contract Wheat (spot) each year for the period of fifty-two years, indicating the month in which such prices were obtained.

Wheat

\begin{tabular}{|c|c|c|c|}
\hline Year & $\begin{array}{l}\text { Months the lowest prices were } \\
\text { reached }\end{array}$ & $\begin{array}{l}\text { Range for the } \\
\text { entire year }\end{array}$ & $\begin{array}{l}\text { Months the highest } \\
\text { prices were reached }\end{array}$ \\
\hline $\begin{array}{l}1867 \\
1868 \\
1869 \\
1870 \\
1871 \\
1872 \\
1873 \\
1874 \\
1875 \\
1876 \\
1877 \\
1878 \\
1879 \\
1880 \\
1881 \\
1882 \\
1883 \\
1884 \\
1885\end{array}$ & 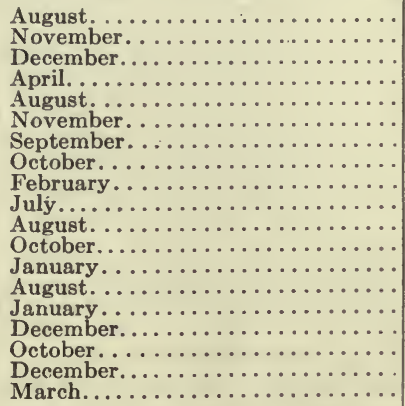 & 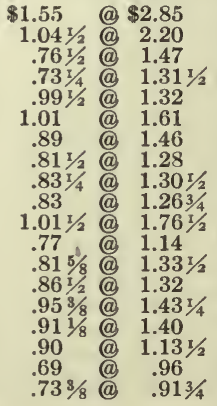 & $\begin{array}{l}\text { May. } \\
\text { July. } \\
\text { August. } \\
\text { July. } \\
\text { Feb., April and Sept. } \\
\text { August. } \\
\text { July. } \\
\text { April. } \\
\text { August. } \\
\text { December. } \\
\text { May. } \\
\text { April. } \\
\text { December. } \\
\text { January. } \\
\text { October. } \\
\text { April and May. } \\
\text { June. } \\
\text { February. } \\
\text { April. }\end{array}$ \\
\hline
\end{tabular}




\section{Corn-Continued}

\begin{tabular}{|c|c|c|c|}
\hline Year & $\begin{array}{c}\text { Months the lowest prices were } \\
\text { reached }\end{array}$ & $\begin{array}{l}\text { Range for the } \\
\text { entire year }\end{array}$ & $\begin{array}{l}\text { Months the highest } \\
\text { prices were reached }\end{array}$ \\
\hline $\begin{array}{l}1894 \\
1895 \\
1896 \\
1897 \\
1898 \\
1899 \\
1900 \\
1901 \\
1902 \\
1903 \\
1904 \\
1905 \\
1906 \\
1907 \\
1908 \\
1909 \\
1910 \\
1911 \\
1912 \\
1913 \\
1914 \\
1915 \\
1916 \\
1917 \\
1918\end{array}$ & 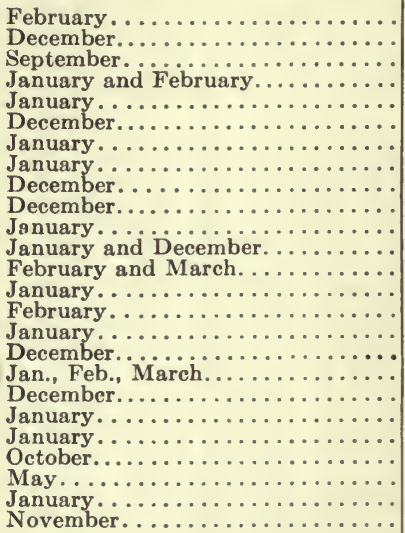 & 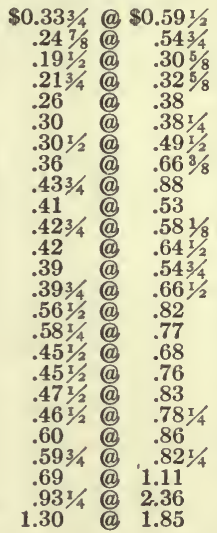 & $\begin{array}{l}\text { August. } \\
\text { May. } \\
\text { April. } \\
\text { August. } \\
\text { December. } \\
\text { January. } \\
\text { November. } \\
\text { December. } \\
\text { July. } \\
\text { July and August. } \\
\text { November. } \\
\text { May. } \\
\text { June. } \\
\text { October. } \\
\text { May and Sept. } \\
\text { June. } \\
\text { January. } \\
\text { November. } \\
\text { August. } \\
\text { Aug. and Sept. } \\
\text { August. } \\
\text { August. } \\
\text { October. } \\
\text { August. } \\
\text { January. }\end{array}$ \\
\hline
\end{tabular}

1, No. 2 white sold at $\$ 2.03$.

Oats

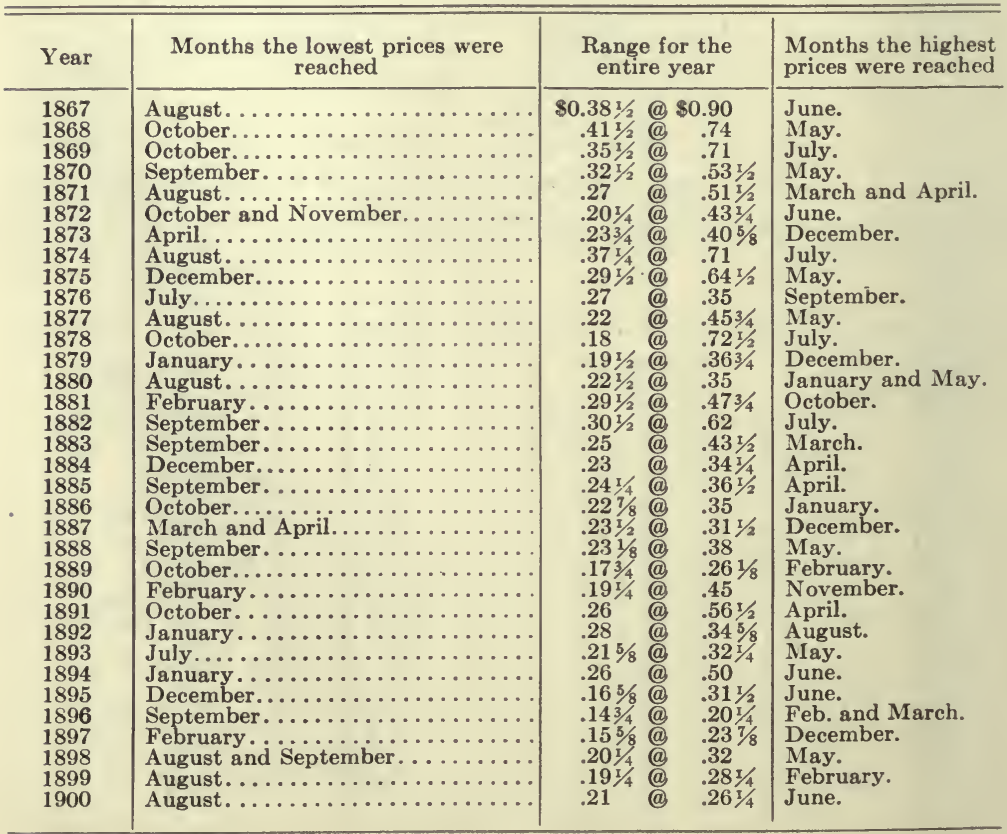




\section{Oats-Continued}

\begin{tabular}{|c|c|c|c|}
\hline Year & $\begin{array}{l}\text { Months the lowest prices were } \\
\text { reached }\end{array}$ & $\begin{array}{l}\text { Range for the } \\
\text { entire year }\end{array}$ & $\begin{array}{l}\text { Months the highest } \\
\text { prices were reached }\end{array}$ \\
\hline 1901 & January . . . . . . . . . . . . & $\$ 0.231 / 4 @ \$ 0.481 / 4$ & December. \\
\hline 1902 & 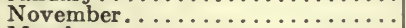 & $.293 / 8 @ .71$ & July. \\
\hline 1903 & March............ & .311/4@ & July. \\
\hline 1904 & October and December.......... & $.281 / 4 @$ & February. \\
\hline 1905 & 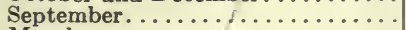 & $.25 @$ & July. \\
\hline 1906 & 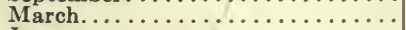 & $.287 / 8 @$ & June. \\
\hline 1907 & January $\ldots \ldots \ldots \ldots \ldots \ldots \ldots \ldots$ & .331/2@ @ & September. \\
\hline 1908 & August. $\ldots \ldots \ldots \ldots \ldots \ldots \ldots$ & $.46 @$ & July. \\
\hline 1909 & August. . . . . . . & $.361 / 2 @$ & May. \\
\hline 1910 & 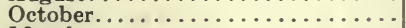 & $.293 / 4 @$ & February. \\
\hline 1911 & 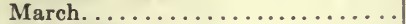 & $.287 / 8 @$ & November. \\
\hline 1912 & November............ & $.301 / 4 @$ & April. \\
\hline 1913 & 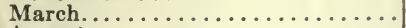 & $.315 / 8 @$ & September. \\
\hline 1914 & August. . . . . . . . & $.331 / 2 @$ & September. \\
\hline 1915 & 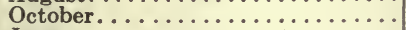 & $.353 / 4 @ .601 / 8$ & March. \\
\hline 1916 & June. . . . . . . . . . . . . & $.37 \frac{3}{8} @$ & November. \\
\hline 1917 & August. . . . . . . . . . . . . & $.51 @ .85$ & July. \\
\hline 1918 & October.................. & $.663 / 8 @ .93$ & February. \\
\hline
\end{tabular}




\section{CHAPTER XVI}

\section{COST OF PRODUCTION AND FARM ACCOUNTING}

IN manufacturing, cost of production is one of the factors claiming the consideration of the manager. In this field, certain standardized units of costs have been worked out, and cost accounting systems fairly well developed. An era of "scientific management" has been introduced. But in the field of agriculture rare indeed has been the farmer who kept any cost accounts or had any definite idea of the cost of producing his crops. In the language of political economy the farmer is the manager or organizer in charge of the three factors of production-land, labor, and capital. He seeks that particular organization of the three factors that will give him the highest net return. Considering the possible combination of land, labor, and capital that can be made by a farmer, ranging all the way from an intensive agriculture to an extensive agriculture, it is obvious that knowledge of cost of production is a very vital factor in success. This is illustrated by the introduction of the Babcock milk test some years ago, which made possible a cost accounting against each dairy cow. The simple apparatus enabled many a farmer to weed out of his herd cows which were not earning their board, although they were giving a large quantity of milk. This is a hint, at least, that some system of cost accounting is needed to apply to the various factors of production. It is perhaps correct to say that there are now four factors of production -land, labor, capital and management or organizing ability.

The Federal Department of Agriculture and the State Experiment Stations have in recent years done a great deal in meeting the need for information on the cost of producing crops, and in devising workable schemes of cost accounting for farmers.

The most noteworthy study in costs of producing crops was that undertaken jointly by the Federal Department of Agriculture and the Agricultural Experiment Station of Minnesota. This study began in 1902, the aim being to 'continue it over five cycles to four years each. ${ }^{1}$ This continuous detailed study of actual

1 The Cost of Farm Products: Hays, W. M., and Parker, E. C., United States Department of Agriculture, Bureau of Statistics, Bul. 48, and Minnesota Experiment Station, Bul. 97, 1906.

The Cost of Producing Minnesota Farm Products: Cooper, Thomas and Parker, E. C., United States Department of Agriculture, Bureau of Statistics, Bul. 73, and Minnesota Experiment Station, Bul. 117, 1910.

The Cost of Minnesota Dairy Products: Cooper, Thomas, United States 250 
farms has incidentally afforded valuable information on systems of farm management, types of farming and labor requirements. Bulletin 117 of the Minnesota Experiment Station, in this series, gave data on farm labor, horse labor, and depreciation of farm machinery. This bulletin served a very useful purpose in defining the problems involved in such cost investigations, and in establishing certain standardized units in cost analysis. In the same series, bulletin 157 shows the actual labor requirements of farm crops in terms of man- and horse-hours per acre and defined some of the principles underlying the use of man labor on the farm. Since the cost of man- and horse-labor bears a fairly constant relation to total cost of crop-production, man-hour and horse-hour labór form units of cost which can safely be used in different places and in different times, and yet remain comparable. These units can easily be translated into dollars and cents.

Five Items. - In addition to the labor costs of crop production, five items of expense are usually considered, namely: (1) cost of seed, (2) cash cost of threshing, (3) interest and depreciation on machinery and special cash operating expense, (4) land rental or interest on investment in land, and (5) taxes. When rent is omitted, labor constitutes more than half the cost of producing farm crops. And, to quote Minnesota bulletin 157, "Cheap labor is not desired in the sense that low wages indicate an opportunity to lower cost of production. Such labor is often very expensive. The use of well paid labor on highly productive enterprises over an extended period of time makes for a far more prosperous industry than cheap labor."

The acre is considered the basis or standard unit, and not the yield, in studying labor requirements. The yield may be easily introduced and the acre-unit translated into a bushel-unit for purposes of comparison. Man-hour means the labor of one man for one hour. Horse-hour means the labor of one horse for one hour. Land rental is considered an item of cost because the value of the farm if invested in ordinary securities would yield an income. In some sections, such as North Dakota, this yield is reckoned at 6 per cent. In Wisconsin land rental, including taxes, is charged Department of Agriculture, Bureau of Statistics, Bul. 88, and Minnesota Experiment Station Bul. 124, 1911.

The Cost of Producing Minnesota Farm Products: Peck, F. W., Minnesota Experiment Station Bul. 145, 1915.

Labor Requirements of Crop Production: Cooper, Thomas, Peck, F. W. and Boss, Andrew, Minnesota Experiment Station, Bul. 157, 1916.

The Cost of Producing Minnesota Field Crops, 1913-1917: Peck, F. W., Minnesota Experiment Station, Bul. 179, 1918. 
at 5 per cent. Some Experiment Stations give the item of rent to correspond as nearly as possible to actual cash rent paid by tenants.

Cost of Growing Grains.-Wisconsin Experiment Station at Madison carries on cost accounting work. Figures in that State in the year 1917, based on a six-years study, give the following data on cost of growing grains:

\begin{tabular}{|c|c|c|c|c|}
\hline Crop & $\begin{array}{l}\text { Number } \\
\text { of fields }\end{array}$ & $\begin{array}{l}\text { Average } \\
\text { cost per } \\
\text { acre }\end{array}$ & $\begin{array}{c}\text { Average } \\
\text { yield }\end{array}$ & Rental \\
\hline 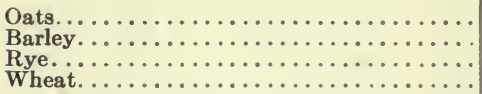 & $\begin{array}{r}92 \\
37 \\
12 \\
14\end{array}$ & $\begin{array}{l}13.35 \\
13.38 \\
11.22 \\
12.10\end{array}$ & $\begin{array}{l}35.7 \\
22.2 \\
16.2 \\
17.0\end{array}$ & $\begin{array}{l}4.70 \\
3.98 \\
8.94 \\
8.48\end{array}$ \\
\hline
\end{tabular}

Other Cost Accounting.--These costs are seen to run very close to the Iowa costs, found in Appendix to this chapter.

Referring again to the Minnesota studies (1908 to 1912, bulletin 145), we find the following summary of costs:

Average monthly cash wages paid farm laborers during the 8 crop season months, April to November,

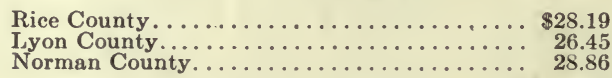

During the 4 winter months, these counties ran as follows, respectively, $\$ 17.85 ; \$ 21.20 ; \$ 17.27$.

The average monthly cost of board per man, same years, same counties, was $\$ 15.43 ; \$ 14,17 ; \$ 12.36$.

Reduced to an hour basis, the average rate of wages per hour for monthly man-labor, same years, same counties, was 14.9 cents; 13.9 cents; 13.5 cents.

The average annual cost of maintaining a horse, same years, same counties, was respectively, $\$ 103.41 ; \$ 99.67 ; \$ 84.16$. The hours worked annually by a horse averaged $1038 ; 1106 ; 976$; or, on a daily basis, the average hours worked by a horse was, 3.46 ; $3.68 ; 3.25$. This made the average cost of horse-labor per hour 10.1 cents, 9.01 cents, 8.63 cents, respectively.

The annual depreciation on farm machinery was estimated, and likewise the "annual value consumed" for farm machinery. Statistics were carefully gathered to determine the average depreciation. The inventory value of a machine was based on the following considerations: Number of years used, manner cared for, amount of work done, repairs during the year, present condition, and apparent future usefulness; also possible auction or exchange value of the machine. In order to charge properly machinery values con- 
sumed in producing crops it was necessary to determine the acre cost of each class of machinery and distribute it to the various crops. The values consumed in farm machinery, according to these studies, are made up of depreciation, labor, and cash repairs, and interest on the average annual investment. The sum of these items for each machine divided by the number of acres on which the machine is used gives the value consumed per acre per year. For the period 1908-1912 the average annual depreciation of machinery amounted to 6.7 per cent as an average of all farms for all machines. For some of the commonly used machines the annual depreciation was as follows: grain binders, 6.5 per cent; grain drills, 5.0; corn binders, 7.97; mowers, 6.8; gang plows, 6.4 ; manure spreaders, 10.3 ; gas engines, 5.7. The annual values consumed per acre for commonly used machines were as follows: grain binders, 16.8 cents; grain drills, 7.2; corn binders, 60.4; wagons 19.5; mowers, 16.7 ; plows; 9.5 .

The total cost per acre of producing field crops in three Minnesota counties, including seed, man- and horse-läbor, twine, machinery charge, general expense, and land rental, was as follows (1908-1912):

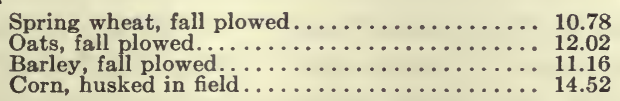

Taking the average farm prices on December 1 for each of these 5 years, a comparison is easily made between the yields necessary to cover cost of production and the yields actually obtained:

\begin{tabular}{|c|c|c|c|}
\hline & \begin{tabular}{|c} 
Average farm \\
prices, Dec. 1, \\
$1908-1912$
\end{tabular} & $\begin{array}{l}\text { Yield necessary } \\
\text { to cover costs }\end{array}$ & $\begin{array}{l}\text { Actual crop } \\
\text { yields }\end{array}$ \\
\hline 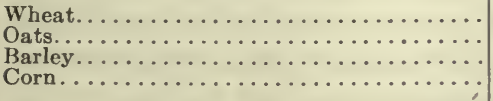 & $\begin{array}{l}89.8 \\
35.0 \\
58.6 \\
47.8\end{array}$ & $\begin{array}{l}12 \text { bu. } \\
34 \\
19 \\
30\end{array}$ & $\begin{array}{l}17 \\
38 \\
22 \\
41\end{array}$ \\
\hline
\end{tabular}

Items of Cost for Grain Crops.- One of the most interesting features of the Minnesota reports is the distribution of cost per acre, showing the very high per cent absorbed by labor and rent. The following tables are selected from the list:

Distribution of Cost Per Acre in Dollars and in Per Cents of Minnesota Crops, Wheat: 1908-1912

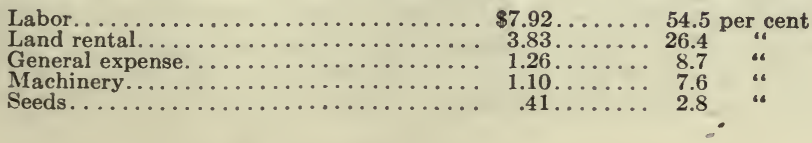


Distribution of Cost Per Acre in Dollars and in Per Cents of Minnesota Crops, Oats: 1908-1912-Continued

\begin{tabular}{|c|c|c|c|}
\hline 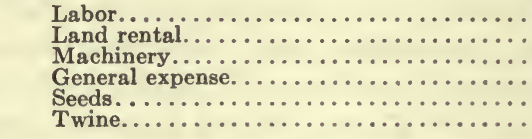 & 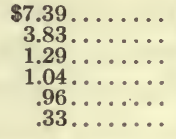 & $\begin{array}{r}49.8 \\
25.8 \\
8.7 \\
7.0 \\
6.5 \\
2.2\end{array}$ & $\begin{array}{c}\text { er ce } \\
\dddot{.} \\
\dddot{~}\end{array}$ \\
\hline rrev. & & & \\
\hline 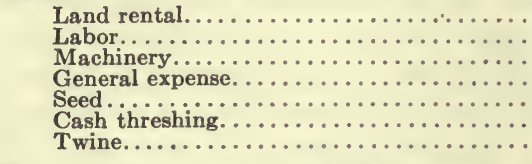 & $\begin{array}{l}3.83 \ldots \cdots \cdots \\
1.64 \ldots \cdots \cdots \\
.935 \ldots \cdots \cdots \\
.696 \ldots \cdots \\
.61 \ldots \cdots \cdots \\
.185\end{array}$ & $\begin{array}{r}50.9 \\
22.0 \\
12.4 \\
9.3 \\
5.4 \\
5.9 \\
1.7\end{array}$ & “" \\
\hline 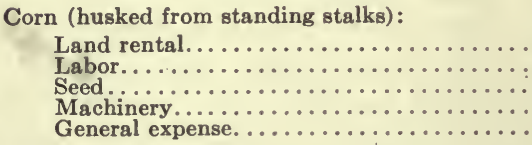 & $\begin{array}{l}3.83 \ldots \ldots \\
3.36 \ldots \ldots \\
1.37 \ldots \ldots \\
.74 \ldots \ldots \\
.658 \ldots \ldots\end{array}$ & $\begin{array}{r}35.5 \\
31.3 \\
12.7 \\
6.9 \\
6.0\end{array}$ & “" \\
\hline
\end{tabular}

Miscellaneous Factors.-The cost of producing crops depends on a number of factors, among which are weather conditions and crop yields. A record showing costs of production should contain tables giving annual precipitation and temperatures during the crop season. Crop yields should also be presented in appropriate tables. In considering farm wages, the cost of board should be added to the wage. The item of "general expense" is used to cover insurance, taxes, and labor and other expenses which are not chargeable to any one crop or productive enterprise.

Losses in Soil Fertility.-Loss in soil fertility caused by crop production is not a proper charge in cost-of-production data. Where such a loss occurs, there is no proper basis for calculating the loss. Some crops, such as clover and other legumes, restore nitrogen to the soil. The soil cannot be compared with machinery, horse-power or buildings which depreciate constantly, regardless of management, while the soil may be kept up and even enriched by proper management. It is a well-known fact that there are many fields in use to-day in the Old World which have been in use since a thousand years ago, and yet which have more fertility now than they had then-at any rate their yield is many times greater now. ${ }^{2}$ It is neither feasible nor desirable to consider loss of fertility

2 "We had long desired to stand face to face with Chinese and Japanese farmers; to walk through their fields and to learn by seeing some of their methods, appliances and practices which centuries of stress and experience have led these oldest farmers in the world to adopt. We desired to learn how it is possible, after twenty and perhaps thirty or even forty centuries, for their soils to be made to produce sufficiently for the maintenance of such dense populations as are living now in those countries. We have now had this opportunity, and almost every day we were instructed, surprised, amazed at 
as a "cost" in crop production. Fertilizers applied to the soil form an item of cost which is definite and properly chargeable to costs.

Signs of Progress. - Now that the various Agricultural Experiment Stations and their substations and their demonstration farms are carrying out detailed and continuous investigations of costs of producing farm crops there is ground for the belief that standard units of cost for the various factors will be worked out. These units will consist largely in man-labor hours and horse-labor hours. The acre will be the basis for both yields and costs. In the end the industrial term "scientific management" will come to be applied to farm management, in the sense that more efficient systems of farm management are to be established, using better machinery, better seed selection, better crop rotation, better soil management, better organizations of the factors of land, labor and capital. The increasing efficiency of human labor, working under proper organization, is illustrated by the figures published by the United States Department of Agriculture, according to which, in the year 1855 it required 4 hours and 34 minutes of human labor to produce one bushel of corn, while fifty years later it required but 45 minutes. Studies in cost of production under varying conditions will, it is hoped, point out the economic limitations of both extensive cultivation and intensive cultivation.

Farm Accounting.-Among the Experiment Stations that have worked out cost accounting systems for farms mention must be made of two-Minnesota and Cornell. Various commercial sets are now on the market. It is difficult, however, to interest the older generation of farmers in farm bookkeeping, especially in any system of bookkeeping which involves much time or labor. The Experiment Stations are making a vigorous and partially successful effort to install systems on progressive farms. The main hope must lie with the younger farmers, particularly with those who have had courses at the State Agricultural Colleges.

Problems in Cost Accounting.-As indicated in the chapter on the Economic Conditions of the Farmer, there are many factors in the farmer's "labor income" that need more scientific treatment by trained accountants. If the farmer's income is to be stated in dollars, it thereby becomes necessary to place money the conditions and practices which confronted us whichever way we turned; instructed in the ways and extent to which these nations for centuries have been and are conserving and utilizing their natural resources; surprised at the magnitude of the return they are getting from their fields . . "-King, $F$. H., Farmers of Forty Centuries, p. 2, (Madison, Wisconsin, 1911). 
values on his total income, including house rent and vegetable garden. The capital value of the investment is a problem of fundamental importance, just as it is in the realm of public utilities and in the public regulation of rates of these utilities, particularly railroads. The "vicious circle" may repeat itself here: high rates mean high earnings; high earnings mean high capitalization; high capitalization justifies higher rates. Why not the same circle in agriculture: high priced product means high priced land; higher priced land means larger capitalization; higher capitalization justifies higher costs of production and higher prices. Since "cost of production" is destined to figure so prominently in public discussions, the question of the value placed on the land is of high importance. The "market value" is now used by various farm management specialists. But market value of farm land depends on the market value of the product of this land. It will therefore be but going in a circle to use the market value of the land to determine one important element in the "cost of production." Yet in the "cost-of-production" figures thus far published "rent" (called interest on the investment) forms a very important fraction of the cost. Economic theory and accounting practice, now wide apart in this matter, must be harmonized, and some agreement or compromise reached.

Another practice in vogue among farm cost accountants, and which runs counter to principles enunciated by the Federal Trade Commission, is that of counting at market value farm products used on the farm in further production. An example of this is hay and corn fed to dairy cows to produce milk for the market. It is highly probable, however, that the farm accountants are correct in taking the farm value of such products, rather than their cost of production. Of course it usually happens that the farm value is above the cost of production, although this is not always the case. Price statistics show that the price of farm products frequently falls below the cost of production. The farmer is entitled to suffer his losses or enjoy his gains, as the case may be. If the farmer can make more, in the case above, by selling his feedstuffs on the market than by selling the milk for the market, then he will and ought to curtail his milk production and sell his raw materials. The consumer bidding for fresh milk must compete with the hay market and corn market bidding for raw corn and hay. If the consumer cannot pay this competitive price, the milk will not be produced, and the market for "culls" will see a few more dairy cows culled from the herds and sent to the butcher. 
In fact the New York stockyards form a fair index to the status of the dairy industry in the States surrounding that city. Here the number of milk cows destined for slaughter fluctuates as the balance between feed-costs and milk-price fluctuates.

Why Study Cost of Production?-Knowledge of cost of production in agriculture is important both from the individual and the social viewpoint. Society at large is becoming more and more. interested in price fixing by commissions, by governmental regulations, or by collective bargaining, as outlined in the preceding chapter. And cost of production is one of the important factors in this problem of price fixing. From the standpoint of the individual farmer cost of production studies should show what particular farms or what enterprises on any farm are being operated at a loss. The following questions could be answered:

How many marginal producers are there?

How many producers are lower than marginal producers, and what amount do they produce?

How many producers are higher than marginal producers and what amount do they produce?

The submarginal farmer, like the submarginal manufacturer; knowing his cost of production, could lower the unit cost of his product, improve his marketing methods, or promptly shift to some other enterprise. As agriculture is now organized, many submarginal farmers actually continue year after year to farm at a loss, before definite and conscious insolvency drives them from the unprosperous acres. Perhaps in no other business does anyone or can anyone continue so long to labor at a net loss.

\section{QUESTIONS ON THE TEXT}

1. Compare manufacturing and agriculture as to the use made of cost accounting.

2. Show that the farmer is an entrepreneur.

3. What principle does the Babcock test illustrate?

4. Show what is being done to-day in studying cost accounting in agriculture.

5. What cost units were used in the Minnesota studies? Define each.

6. Show the factors in cost of production in addition to labor costs.

7. Which factors are most important?

8. Is "cheap labor" desirable?

9. Give some cost figures for Iowa corn, barley, oats, wheat.

10. Give some Wisconsin cost figures for oats, barley, rye, wheat. How do they compare with the Iowa figures?

11. Explain the Minnesota method of accounting for annual depreciation of farm machinery and annual value consumed.

12. Compare cost of producing Minnesota field crops with same crops in Iowa and Wisconsin.

13. Should loss of soil fertility be included in costs of production? Reasons for your answer.

14. What are the signs of progress in cost accounting in agriculture? 
15. State some unsettled problems in farm accounting.

16. Show danger of the so-called "vicious circle" in farm accounting.

17. What is the correct accounting practice for value of farm products used on the farm for further production?

18. State the objects to be gained by knowledge of cost of production on farms.

19. Show why farmers may unconsciously continue for years to farm at a loss.

20. Compare hours of labor per acre (man-hours and horse-hours) required in Minnesota to produce wheat and potatoes.

\section{QUESTIONS SUGGESTED BY THE TEXT}

1. What principle should govern in calculating the value of the land used in crop production?

2. From the standpoint of political economy, is "rent" an item in the cost of production?

3. From the standpoint of the Single Taxer, the private appropriation of ground rent is a special privilege which should be abolished. Briefly state the main reasons for or against this theory.

\section{REFERENCES}

The Experiment Stations and the 48 Agricultural Colleges are constantly studying the costs of producing farm crops. Results of these studies are published from time to time in bulletins and distributed gratis to those requesting copies. These bulletins constitute the best sources of information on this subject. Only a few of these can be listed here.

1. "Industrial Commission Report," Vol. 10, p. CCXII, Washington, 1898-1902.

2. Hays, W. M., and Parker, E. C.: "The Cost of Farm Products," Bulletin 48, Bureau of Statistics, United States Department of Agriculture, Washington; and Bulletin 97, Minnesota Experiment Station, St. Paul, 1906. (This is a pioneer study in this field.)

3. Parker, E. C., and Cooper, Thomas: "The Cost of Producing Minnesota Farm Products," Bulletin 73, Bureau of Statistics, United States Department of Agriculture; and Bulletin 117, Minnesota Experiment Station, St. Paul, 1910.

4. PECK, F. W.: "The Cost of Producing Minnesota Farm Products," 1908-1912. Bulletin 145, Minnesota Agricultural Experiment Station, St. Paul, 1914.

5. Peck, F. W.: "The Cost of Producing Minnesota Field Crops," 19131917. Bulletin 179, University of Minnesota Agricultural Experiment Station, St. Paul, November, 1918.

6. PeCK, F. W., AND Boss, ANdrew: "The Cost of Milk Production," Minnesota Agricultural Experiment Station, Bulletin 173, 1918.

7. Cooper, T. P., Peck, F. W., ANd Boss, Andrew, Bulletin 157, Minnesota Agricultural Experiment Station, St. Paul, 1916.

8. Cooper, Thomas: "The Cost of Minnesota Dairy Products." United States Department of Agriculture, Bureau of Statistics, Bulletin 88, and Minnesota Agricultural Experiment Station, Bulletin 124, 1911.

9. Boss, ANDrew, PECK, F. W., AND Cooper, T. P.: "Labor Requirements of Live Stock." Minnesota Agricultural Experiment Station, Bulletin $161,1916$.

10. Boss, Andrew, Benton, A. H., and Cavert, W. L : "A Farm Management Study in Southeastern Minnesota." Bulletin 172, University of Minnesota Agricultural Experiment Station, October, 1917.

11. WARren, G. F.: "Farm Management," New York, 1916.

12. DunCan, C. S.: "Mercantilo and Agricultural Economics," Journal of Political Economy, October, 1918, pp. 769-806.

13. Orwin, C. S.: "The Determination of Farming Costs," Oxford, England, 1917. 
14. Thomson, Edward H.: "Farm Bookkeeping," Farmers Bulletin 511, United States Department of Agriculture, Washington.

15. Bexell, J. A.: "The Business Side of Farming," Farm Records, Oregon Agricultural College, Corvallis, 1909.

16. Anderson, A. C., AND Riddell, F. T.: "Studies in the Cost of Market Milk Production," Bulletin 277, Michigan Agricultural College, December, 1916.

17. LAdD, C. E.: "Cost Accounts on Some New York Farms," Bulletin 377, Cornell University Agricultural Experiment Station, June, 1916.

18. Hennis, C. M., and Willard, Rex E.: "Farm Practices in Grain Farming in North Dakota," Bulletin 757, U. S. Dept. of Agriculture, 1919.

19. "Cost of Producing the 1918 Cotton Crop." By the Department of Agriculture of Texas. Austin Texas, 1918.

20. Farm Account Book. Prepared by Ohio Bankers Association and the Agricultural Extension Service of the Ohio State University, Columbus, Ohio.

21. "Report of the Governor's Tri-State Milk Commission" (Pennsylvania, Maryland, Delaware). Bulletin 287, Department of Agriculture, Harrisburg, Pennsylvania, 1917.

22. LAdD, C. E.: "A System of Farm Cost Accounting," Farmers' Bulletin No. 572, U. S. Department of Agriculture, 1914; Reprinted 1915.

\section{APPENDIX}

Cost of Production of Corn, Barley, Oats and Wheat.-As an example of the work being done by the leading state experiment stations in determining cost of producing farm crops, the following tables are given, taken from the station at Ames, Iowa. The figures were compiled in 1917 , using $\$ 2.00$ as the cost of man labor per day, and $\$ 1.50$ as the cost of horse labor per day.

Cost of Producing Corn Per Acre (Iowa) 1917

Rent................................\$5.44

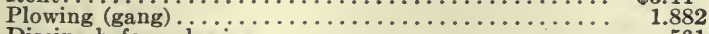

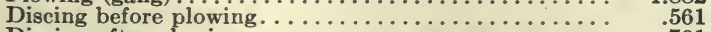

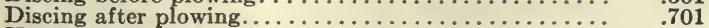

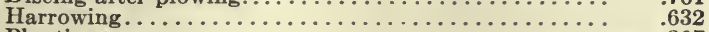

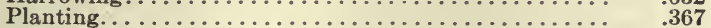

Harrowing after planting. . . .

Cultivating, first time.................... $\quad .915$

Cultivating, second time.......................... $\quad .798$

Cultivating, third time............................... $\quad .676$

Cultivating, fourth time................................

Depreciation and interest:

wagon............................... 072

rack................................... $\quad .024$

harrow. . . . . .

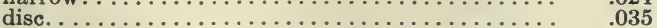

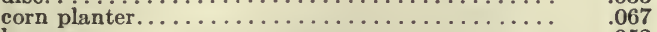

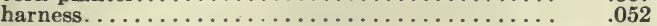

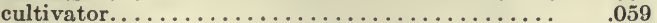

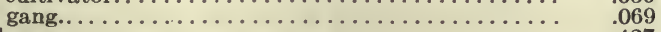

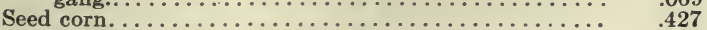

Testing seed corn........................ $\quad .058$

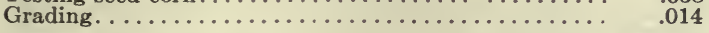

Total (growing the crop) $\ldots \ldots \ldots \ldots \ldots \ldots \ldots \ldots \ldots \ldots \ldots \ldots \ldots \ldots$ Average yield-54.64 bu.

Cost of growing the crop per bu.-.248.

Harvesting the Crop (Per Bu.)

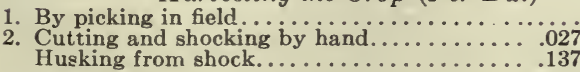

3. Cuttirg with binder............... .021

Shocking............................ 010

Husking from shock...................

4. Cutting with binder.. .......... . .021

Stacking. 


\section{Cost of Producing Barley Per Acre (Iowa), 1917}

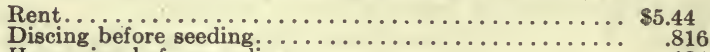

Harrowing before seeding. . . . . . . . . . . . . . . . . . . .

Seeding with drill. ................................ $\quad .578$

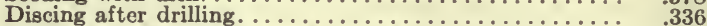

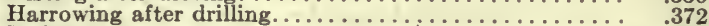

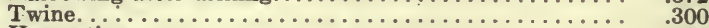

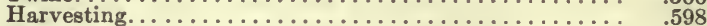

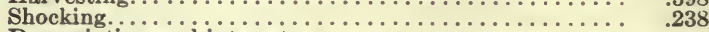

Depreciation and interest:

harrow...............................$_{024}$

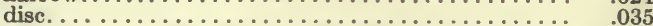

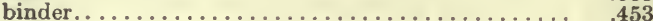

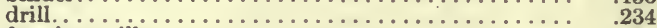

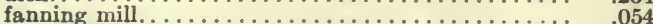

wagon............................... 072

rack..................................

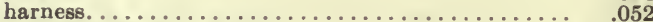

Seed (2.13 bu @ .619 per bu.)..................... 1.318

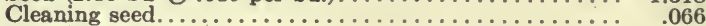

Threshing.......................................

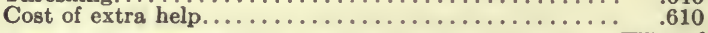

Total cost per acre..................... $\overline{\$ 12.40}$

Yield-26.93 bu. Cost per bu.-.46.

Cost of Producing Oats Per Acre (Iowa), 1917

Rent............................... \$5.44

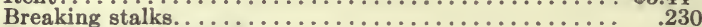

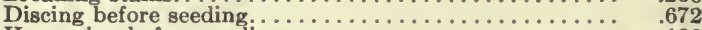

Harrowing before seeding. ........................ 100

Seeding with drill ......................... $\quad .578$

Discing after seeding..............................

Harrowing after seeding. ...................... 309

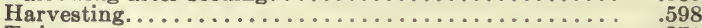

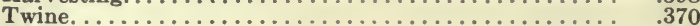

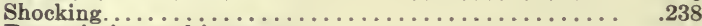

Depreciation and interest:

binder............................ $.4^{453}$

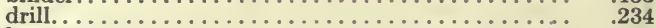

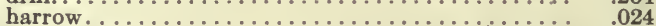

fanning mill............................... .054

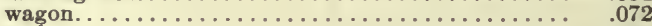

rack..................................

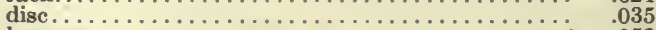

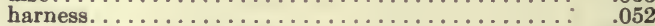

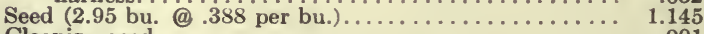

Cleaning seed ................................. ${ }^{.091}$

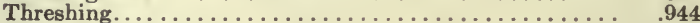

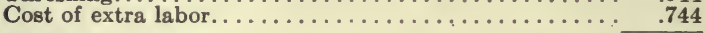

Total cost per acre...................... $\overline{\$ 12.945}$

Yield -42.89 bu. Cost per bu. - 302 .

Cost of Producing Winter Wheat Per Acre (Iowa), 1917

Rent............................ \$5.44

Discing before plowing............................. 145

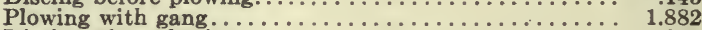

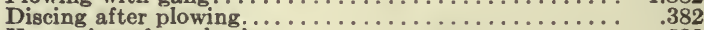

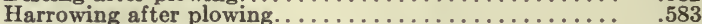

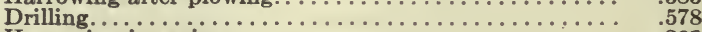

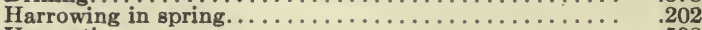

Harvesting............................. ${ }_{.598}$

Twine ................................. $\quad .300$

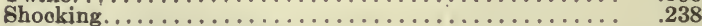

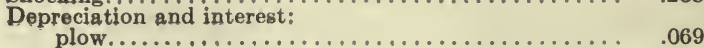

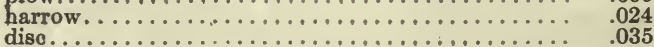

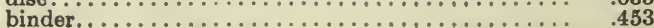

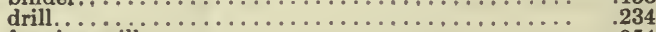

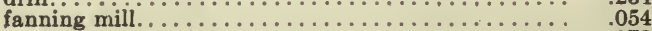

wagon..........................., .072

(Carried forward) 
Depreciation and interest:-Continued.

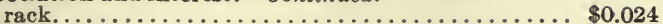

harness. . . . . .

Seed $(1.58$ bu. @ .938 per bu. $) \ldots \ldots \ldots \ldots \ldots \ldots \ldots \ldots \ldots \ldots 1.482$

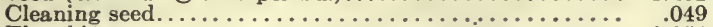

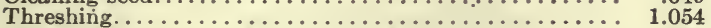

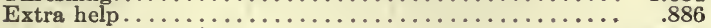

Total cost per acre..................... $\overline{\$ 14.836}$ Yield per acre-25.09 bu. Cost per bu. $\longrightarrow 591$.

Cost of Producing Spring Wheat Per Acre (Iowa), 1917

Rent............................ $\$ 5.44$

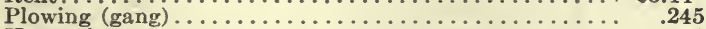

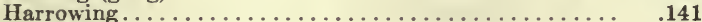

Discing. . . . . . . . . . . . . . . . . . . . . . . . 886

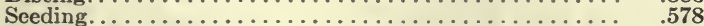

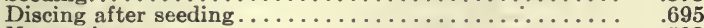

Harvesting. . . . . . . . . . . . . . . . . . . . . . . . . .

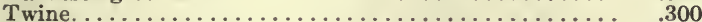

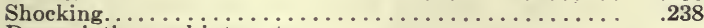

Depreciation and interest:

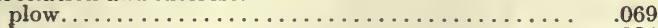

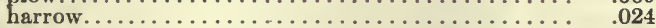

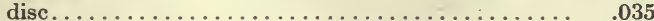

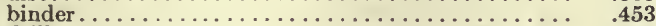

drill. . . . . . . . . . . . . . . . . .

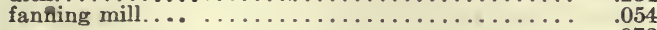

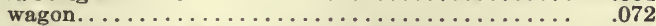

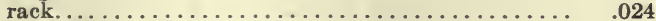

harness. . . . . . . .

Seed (1.68 bu. @ 942 per bu.)....................

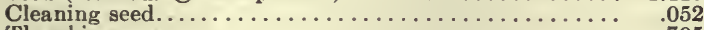

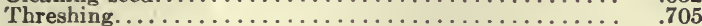

Cost of extra help...................... 572

Total cost per acre.....................\$12.882

Yield per acre-16.79 bu.

Cost per bu. -.767 .

Average Annual Hours of Labor Per Acre in Producing Field Crops, 1902-1912 (Minnesota)

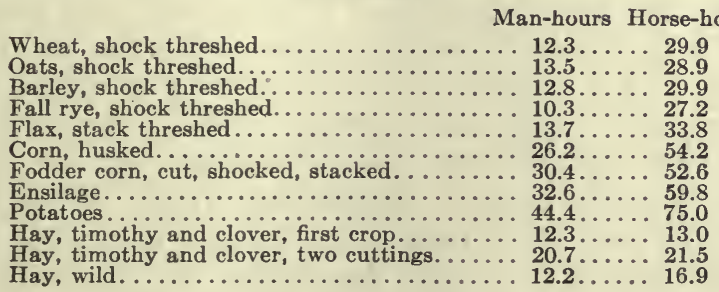

Farm Accounting - a Backward Science.-An Example from England."The general absence amongst farmers of any system whatever of bookkeeping is a deplorable fact. The Royal Commission on Agricultural Depression of 1897 clearly showed that this bad habit was very general. In one district of about 50,000 acres, only one farmer could be found who kept accounts. Some years ago the agricultural correspondent of the Yorkshire Post inspected a large number of farms in Yorkshire, and only in one case out of a hundred farms visited were any accounts whatever kept. This is sad, and all the more so as the art of bookkeeping is an easily acquired one."-Jackson, T. C., The Agricultural Holdings Acts, 1908-1914, and Tenant-Right Valuation. London, $1917, p .181$. 


\section{CHAPTER XVII}

\section{SPECULATION}

THERE are in the higher courts in the United States to-day one thousand judges, more or less, whose duty it is to interpret the Federal and State laws. That such a large body of specially trained men is necessary to construe the meaning of carefully-framed statutes illustrates very strikingly the looseness of meaning which is likely to attach to even deliberately chosen words. Little wonder is it, therefore, that many words current in the daily speech of the people have such a looseness and vagueness of meaning that they mean different things to different people, and to the same people at different times. The word speculation is a word which stands out conspicuously in this class of popula but indefinite terms. This means that there is confused thinking on this important topic, where clear thinking is needed. There is vagueness where there should be sharp distinctions. Before discussing what speculation is, what its services are and its evils, it will be the wisest course for us to differentiate sharply a few terms which are frequently confused with speculation.

Some Misused Terms.-(1) Hoarding.-In times of stress, particularly in war times or in times of great scarcity of any focd commodity, the word "hoarding" is freely used in a depreciative sense. It is true that in ordinary times, when the thrifty housewife stocks up her cellars in the autumn with an ample hoard of apples, potatoes, cabbages, turnips, pickles, preserves, jellies, jams, butters, canned fruits and vegetables, and so on, she is considered as doing a highly praiseworthy thing. When a dealer, however, buys from the farmer in the autumn apples and potatoes and stores these in a suitable warehouse, for use later on, this dealer is likely to be denounced as a speculator and guilty of "hoarding." If apples and potatoes are harvested only in the warmer months of the year, which is nature's provision, and if these same products are to be eaten in part in the cold months of the year, which is man's custom, manifestly these products must be "hoarded" by somebody, who is performing thereby a public service. In the ancient sense of the word, hoarding implied secrecy, but as the term is now applied to the dealers in agricultural products it has no such connotation. Potatoes stored in a 262 
warehouse for the winter by a farmers' coöperative potato growers' association or farmers' coöperative elevator company, is, in popular speech, not hoarding; potatoes stored in an adjoining warehouse owned by a dealer is, in popular speech, hoarding. Evidently the term is used to connote a practice tainted with evil. Such a word, used in such a manner, may shed much heat and but little light on the subject under discussion. The term does not correctly define or describe. On the contrary, it is a subtle appeal to the feelings, to prejudice. The "hoarder" of potatoes in the fall of 1918 paid the growers one dollar a bushel, and sold these same potatoes (if they had not decayed in the winter) for seventy-five cents a bushel in March following. Such a decline in price in the spring happens with unpredictable regularity with all farm crops. "Hoarding," therefore, is a word which should be no longer used in the present heedless and unthinking manner.

(2) Cornering the Markets.-Under primitive market conditions, particularly where means of transportation were lacking, shrewd and bold dealers were wont to corner the market for short periods. Many the laws, ancient and modern, against this antisocial practice! Under twentieth century conditions this condemned practice is of sporadic occurrence, particularly in the unorganized markets. On the organized grain exchanges, in contrast, where strict rules exist against this practice, it is now practically extinct. The last cornering of the wheat market occurred during the World.War, and was done quite unintentionally by the Allies in buying certain grades of wheat in excess of the supply of these grades. In other words, contracts for the best grades of wheat were made, not to corner the market and affect price, but to secure actual wheat in large and certain quantities. Cornering, long under the social and legal ban, is still confused by many writers and speakers with speculation. Speculation is going on every day, and much of it unavoidably so, while cornering exists in but rare and isolated cases. The two terms should not be used as synonyms, although this slovenly habit of thinking and speaking is all too common.

(3) Cash and Future Trading.-Again, the popular vocabulary betrays an irresponsible looseness of thinking concerning that phase of the grain trade having to do with cash as.against future trading in grain. The phrase "speculation in grain" is quite generally applied to future trading. And, conversely, trading in cash grain is quite generally regarded by the public as free from "speculation." Many bills introduced in State legislatures indi- 
cate this state of mind. But it is obvious that it is just as specu- lative to buy cash grain, expecting to hold it for a rise in price, as it is to contract to buy grain in the future, expecting a rise in price. Both transactions give title to grain. Both are based on the belief that the market is too low. The following concrete case illustrates a speculation in cash grain. The Superior (Nebraska) Corn Products Company became a heavy dealer in corn in the spring of 1917. From February on for some months the business was reported as "big." Corn was bought and sold in car lots. Futures were not traded in. On August 18, 1917, occurred the failure of this concern. The cause of this failure was speculation in cash grain, long on corn when the market slumped. This slump occurred on August 8, and continued to August 11, amounting in all to fifty cents a bushel. On Wednesday, August 8, the buyers of this company bought 75,000 bushels of corn by telephone at the closing price of the day before, before the Grain Exchanges had begun the day's trading and wired the new prices to the country. The break began, as noted, and continued four days. This drop in price found this company long 175,000 bushels of cash corn. This meant the financial ruin of the company, and a consequent wiping out of all its assets. The case is interesting as showing that speculation is speculation, whether in cash or future grain. It is also interesting in showing what may happen to a grain business that does not hedge, i.e., protect its cash purchaser by corresponding future sales, and thus avoid speculation by the ordinary use of futures.

Two Social Classes.-There are now, and apparently always have been, and always will be, two classes in society, the conservatives and the liberals. That this is true in politics and religion is a matter of common observation. It is equally true in our economic life. Deposits in our savings banks, investments in government bonds, and in other safe and low-interest rate securities show the existence of a numerous class of economic conservatives. Many strong bond houses had, before the World War, a large purchasing clientele seeking four and five per cent investments. Safety of principal rather than size of return is the desideratum with these investors. Other financial houses advertise investments yielding ten or twelve per cent. These investments attract a less conservative group or a group less sophisticated in investment economics. Lastly there is the group of securities with no past record of performance, but with a promised "assured future" of high yields, varying according to the imagination and 
restraint of the promoter. This class appeals to the speculators, especially to those "economic illiterates" in our society. It is an obvious fact that society does include the two classes, conservatives and liberals, risk takers and risk avoiders. Each class plays an important and necessary part in opening up and developing the resources of the country. For even the much-haloed Pilgrim Fathers were settled in America by a company of merchant "Adventurers," as speculative risk takers were then termed.1

We have with us now, as society had in times past, a class willing to take risks, ready and willing to speculate. It may be stated as a correct principle that an American citizen, with intelligence and means, has a right to speculate in town lots, in agricultural lands, in grain, or in anything else, as long as his conduct does not interfere with the rights of others or damage society in any way.

What does society want, then, in the field of speculation? To abolish speculation? That is clearly impossible, as well as undesirable. The answer must be, to retain the good in speculation and curb the evil.

1. What is Speculation?-As stated earlier in this chapter the popular understanding of this word is somewhat vague. The word is commonly used in a depreciative sense, and not in the honorable sense of the old word "adventurers." The definitions found in Webster's dictionary are interesting to note. They run as follows:

Speculate.-To purchase with the expectation of a contingent advance in value, and a consequent sale at a profit; often, in a somewhat depreciative sense, of unsound or hazardous transactions; as, to speculate in coffee, in sugar, or in bank stock.

Speculation.-The act or practice of buying land, goods, shares, etc., in expectation of selling at a higher price, or of selling with the expectation of repurchasing at a lower price; a trading on anticipated fluctuations in price, as distinguished from trading in which the profit expected is the difference between the retail and wholesale prices, or the difference in price in different markets.

Gamble.-To play or game for money or other stake. To play for a stake or prize; to use cards, dice, billards, or other instruments, according to certain rules, with a view to win money or other things waged upon the issue of the contest.

These definitions are substantially in agreement with the accredited economic usage of these terms. According to these definitions, a retail merchant is not a speculator, since he buys and sells with little or no regard to price fluctuations. His margin

${ }^{1}$ See Appendix to this chapter for an excerpt from the original charter of this company, showing its speculative commercial nature. 
is the difference between wholesale and retail prices. On the other hand, the speculative buyer is one who expects the price to rise, and is willing to back up his belief with his money. His profit, if any, must come from a rise in price. Or conversely, the speculative seller (short seller) is one who believes prices are going to fall, and who sells for future delivery, expecting to buy at or before delivery time at less than his sale price. These definitions omit the original grower of farm products from the eategory of speculator. This is an arbitrary rule. For the essence of speculation is risk, and the grower is the first risk taker.

Webster's definition of gambling is also given, since these two terms are commonly juggled together as though they were synonyms. This confusion should not be tolerated. Professor Emery's distinction between speculation and gambling is now quite widely aceepted. Speculation he makes the assumption of inevitable economic risks. In other words, if the crop is produced, the price is likely to change-is, in fact, certain to rise or fall, and hence the owner for the time being is the risk taker. The risk may be shifted to a speculator, who is the person who prefers to assume the risk. Such risks may be shifted or distributed, but can never be abolished. Gambling is, according to Emery, the assumption of a "chance" or "risk," which risk the gamblers themselves have manufactured. It is artificial. Thus two men may sit down in a back room and bet, for instance, one hundred dollars each on the outcome of a horse race, or on a foot ball game, or on the clection of the President of the United States, or on the price of grain next week, or on the state of tomorrow's weather. Obviously the risk of winning or losing the hundred dollars was manufactured by the wills of these gamblers themselves, and that without the bet, the money would have remained safe in their poekets. But the owner of a commodity is by his ownership the bearer of an inevitable risk, whether he wills it or not. To the superficial observer, trading in futures on the great Grain Exchanges is mere betting on the price of grain. This was true of the late bucket shops of the country, for in these places "orders" to buy and sell grain were not executed on any market. These fake "orders" were bets, and hence gambling transactions. The five or six important grain exchanges, where future trading in grain is carried on in the United States, do not come in this class, since every buy or sell order is actually executed, and thus has its proportionate influence on the market. Each order is payable in actual grain, although most of them will not be so paid, just as the twenty 
billion dollars of bank deposits, subject to check, and payable on demand in gold will not be so paid (except in small part), and do not need to be so paid to meet the needs of sound business. That these demand deposits are actually six or seven times the whole amount of gold in the country in no way reflects on the ethics or soundness of American banking. Quite the contrary. It is an evidence of a properly functioning banking system. It will be necessary to defer until the chapter on the Grain Trade any further explanations of the methods of settling the large volume of future trading in grain by the delivery of a relatively small amount of grain.

Two Kinds of Speculation. - In the field of Agriculture to-day speculation is of two kinds, organized and unorganized. Organized speculation is that form of speculation conducted on the organized exchanges of the country; it is under strict rules, which are published and open and known to all interested; it is conducted openly before the public gaze; the volume of it, together with actual prices involved, is made a matter of formal record and is also very largely given to the public by means of the daily press and the trade papers. Unorganized speculation, on the other hand, is not conducted under any particular rules; it is not carried on in the open light of full publicity; the yolume and nature of it are not a matter of record, and are not known.

Organized speculation is best illustrated by the trading in grain and cotton on the organized exchanges. Unorganized speculation is illustrated by trading in farm lands-particularly the promotion of land sales by real estate agents, so-called. It is also illustrated by the trading in the various forms of farm produce not handled on the exchanges, such as fruits, vegetables, poultry, etc. Since there are, in the case of these products, no great organized exchanges, with severe membership qualifications both ethical and financial, as is the case with grain exchanges, it is exactly in these products that we find most frequent market abuses. As an extreme illustration of this may be cited the poultry market in New York City which for some years remained an open seandal. Live chickens would be bought by a certain class of dealers, kept without food for two or three days, and then be fed heavily with sand, gravel, and cement. In this manner consumers were buying daily thousands of pounds of sand, gravel, etc., at fresh chicken prices. This abuse, great as it was, cannot be attributed solely to the speculative nature of the business. Doubtless there have been and now are a few farmers who follow similar 
practices, and the farmer, thus far has not been called a "speculator."

The butter exchanges in the United States have thus far fallen far short of complete success, owing to their small membership and small volume of trade.

2. Speculation: Its Services.-At the very outset it must be stated and emphasized that the code of ethics of the speculator, organized and unorganized, is exactly as high as that of the producers and consumers about him. This means that a very large majority of the so-called speculative traders (commission merchants, jobbers, "middlemen" in general) are honorable and constructive members of society and of their community; that a very small minority of them are "black sheep" - the traditional rule for all flocks. And in the second place it must be stated and emphasized that the large manufacturers of food products cannot deal with widely scattered, unknown individual farmers, and cannot do collective bargaining with unorganized farmers, and hence the farmer's market at the present stage of economic evolution must be with the men who stand between him and the miller, the packer, the canner, the spinner, and so on. In other words, the speculator makes the market for the farmer's products. The chief service of the speculator is to create this continuous market. This function is not appreciated till it is interrupted by war or other calamity. This truth, recorded in the proverb, "You never miss the water till the well runs dry," may be illustrated by the case of the California Bean Growers. In December, 1918, the California Market Director reported the following situation among the farmers of that State, when the speculator was partially forced out of the market:

". . It has been pointed out that had there been no bean growers' association in 1918, the results would have been most disastrous to the California bean industry. The conditions facing the growers were in the nature of an unprecedented combination of unfavorable circumstances.

"The small limit which the Federal Food Administration has placed on the profits to be allowed to the speculative buyer, had completely destroyed his speculative interest in the product. As a consequence, he was unwilling to buy except from hand to mouth. This left the producer with no buyers except for the merest handful of his product. Furthermore, the banks, with abnormal demands made on them by the government, with large advances made by them to barley and to other growers, with a weak and declining bean market staring them in the face, were in no frame of mind to look with favor upon requests for financial accommodations coming from bean growers. On top of it all, the bean grower found himself faced with demands upon him for ready cash to meet his abnormal cost of production that stressed him to the limit. ${ }^{2}$

${ }^{2}$ Third Annual Report, State Market Director of California, 1918, pp. 68,69 . 
This quotation also illustrates the truth that to the extent that producers are organized and able to conduct collective bargaining, to that extent the need of speculative buyers is lessened and to the same extent "direct marketing" with manufacturers, canners, exporters, wholesalers, etc., is made possible. Obviously, however, the speculator by making a market is thereby performing a service and deserves credit rather than condemnation for it.

A second function of the speculator may be called his financial or banking function. In many lines of trade the speculator may be called on to finance the movement of the crop from the primary point to the larger, central markets. He becomes, in a sense, the banker for his shippers, commonly advancing them money before the arrival of the goods, and in some cases, many weeks before the goods are shipped. ${ }^{3}$ This financial relationship is one of importance to the farmer himself, for he is anxious to receive his money when his produce reaches the primary shipping point, although this point may be separated in time and distance a long way and a long time from the final consumer. Even where organization is efficient and coöperative selling well-nigh perfected among the farmers, as in the case of the Eastern Shore of Virginia Produce Exchange - 3,000 growers selling through one central office- the banking or financial aspect of marketing is held to be of more importance than the so-called "direct marketing." This farmers' company does not market direct to small dealers in small towns, near large distributing centers, but markets through the large regular dealers, who in turn re-sell to the smaller cities. Considering financial risks involved in dealing with a vast number of distant small dealers, the added expense of more bookkeeping and more credit-rating investigations, it is cheapest in the long run to deal with the large dealers as above noted. Since the large dealers in this case make a practice of buying for cash f.o.b. shipping station, they are performing a very real service of a financial nature. Although produce is shipped into forty States and two foreign countries, the grower gets his pay at the latest within ten days of delivering his produce at the shipping station.

A third function performed by many speculative middlemen is that of warehousing or storing. In a few cases at the present time we have public warehouses, but even in that case the title to the

$s$ The most conspicuous and extreme case of this credit relationship is that furnished by the old cotton "factor" of the South, who advanced part of the money before the crop was planted. This was clearly an awkward and expensive form of credit, fitted only to a primitive condition of agriculture. 
stored goods is private, and consequently the speculative risk remains. Coöperative organizations of farmers frequently erect warehouses, and thus provide storage without asking this service of the speculator. There is an increasing number of farmers' organizations that provide storage and pool the product over a period of time, so that all price fluctuation-speculative risksare distributed among those using the organization. But the fact remains that at the present time the bulk of our storage facilities for food products is provided by speculators, and that these persons are thereby performing a necessary social service. If the farmers can perform this service through coöperative organizations in a cheaper and better manner, and thus introduce savings, they are at liberty to do so and ought to do so.

These three functions of the speculator in food products hold true for both organized and unorganized speculation. Unquestionably the great bulk of speculation in the United States is unorganized speculation; unquestionably also the bulk of the public attention and discussion of speculation centers around organized speculation, the lesser of the two forms. This is due to the concentration of organized speculation in a few great exchanges, and to the superficial spectacularity of its methods.

Speculation on the Organized Exchanges.-Before considering the services of speculation on the organized exchanges, it is well to look at three common errors in the public mind on this question. (1) Does speculation cause high prices? In the popular mind it does. "Cornering the market"-a form of speculation now practically extinct on the organized exchanges-may cause a temporary rise in price, but speculation as defined in this chapter does not cause high prices. (2) Does speculation cause low prices? Oddly enough, speakers who accuse speculation of causing high prices when addressing city audiences, will, when addressing producers, make the claim that speculation makes low prices. The superficial theory here seems to be that Mr. A. by selling short one hundred thousand bushels of wheat to Mr. B. (wheat that A. does not at the moment own) thereby depresses the market by this artificial supply. But Mr. B. can equally well say that by buying this wheat he has thereby created a demand, strengthening the market. Obviously the amount bought equals the amount sold. Speculation on the organized exchanges does not cause low prices. (3) Does speculation cause prices to fluctuate? Here is the most persistent fallacy of all, the most widespread confusion of cause and effect. The one and only reason why men speculate is because 
prices are sure to fluctuate. If all speculators were to cease activities entirely, or were to become an extinct species, price fluctuations would continue. For instance, the price of United States Government bonds fluctuates from day to day, and surely no one believes speculators are trading in these low-interest, high grade investment securities. ${ }^{4}$ If the least speculative commodity in the world-a United States Government bond-fluctuates in price daily, as it does, it is clearly evident that price fluctuation is not the result of speculation. Instead of causing price fluctuations; speculation in the pit tends to check price fluctuations. Speculation in the pit is a process of putting on brake, checking a rapid rise in price (a "bulge") and checking a rapid fall in price (a "break"). As evidence of this, it is a noteworthy fact that barley, which is not subject to future trading (pit speculation), fluctuates much more widely in price than does either wheat or oats. Wheat and oats are both traded in the pit; both, like barley, are world-wide crops, grown and consumed very widely for a variety of purposes.

Price Fluctuations.-Taking Chicago Board of Trade figures for a period of 18 normal years, when we were not engaged in any war, we find price fluctuations in these three grains (spot prices) to fluctuate as follows, by per cents:

Cash Price Fluctuations, by Per Cents, for 18 Years, of Wheat, Barley, and Oats, Chicago-Showing Widest Fluctuations in Barley.

\begin{tabular}{|c|c|c|c|}
\hline Year & Wheat & Barley & Oats \\
\hline 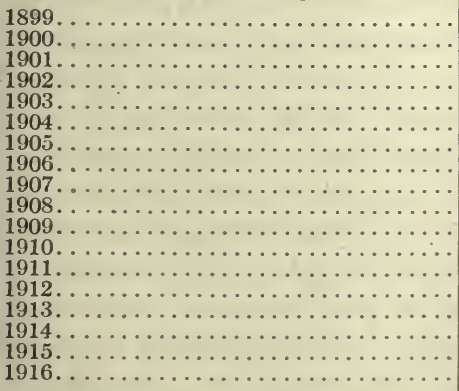 & 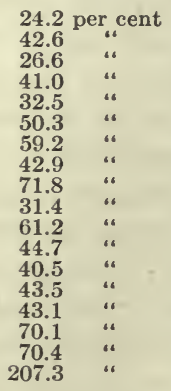 & 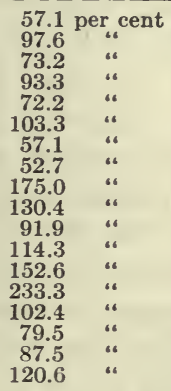 & 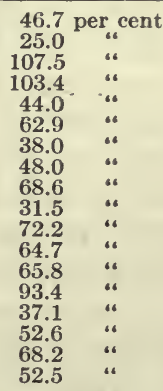 \\
\hline
\end{tabular}

From the above table it will be observed that wheat only once showed a variation in price in any one year of over 100 per cent,

${ }^{4}$ See Appendix to this chapter, showing fluctuations in prices of United States Government bonds. 
namely, in the year 1916; that oats showed a similar variation but twice, namely, in the years 1901 and 1902; but that barley showed such a price variation eight times in eighteen years, namely, in the years 1904, 1907, 1908, 1910, 1911, 1912, 1913, and $1916 . .^{5}$ Wide price fluctuations are thus seen to be, in part, prevented by speculation. Instead of the wider swings of the market which occur yearly in barley, oats and wheat show many small-price fluctuations. In the sense that speculation prevents wide swings, it stabilizes prices. Since speculation is carried on in the open market, it is, in a very true sense of the term, a great auction market, where buyers and sellers (of grain for future delivery) are making bids and offers, and hence this form of speculation is a correct register of values - not a maker of values. Supply and demand are here reflected, each instantly manifesting itself either through the bids or the offers, and hence in the price. Prices fluctuate according to this pressure of supply or demand. The speculator is in the market and is governed by these forces-if he survive long as a speculator. And his speculations, as stated above, tend to put the brake on both bulges and slumps in the price. The many small fluctuations in price in oats, wheat, and corn (on the future market, i.e., in the pit) accompany trading by many traders at small profits (or losses) on each trade. Where there are no organized exchanges, a few big traders absorb the profits or losses (bigger profits or bigger losses, and bigger margins).

The services of speculation on the organized exchanges take three principal forms: (1) It furnishes a wide market. The speculators stand ready, any hour of any day, to take any trade regardless of the size, without having the market upset by the transaction. This was amply illustrated during the World War, when the Government was forced to place order for large quantities of oats for future delivery. Some markets could not receive an order for 300,000 bushels of oats, without having the price forced up unduly thereby, whereas the Chicago pit, by reason of its heavy speculative trade, was able to absorb orders for many hundreds of thousands of bushels of grain without causing a bulge in price. This could only happen in a wide market. And now that our country is so large, such a wide market is a commercial convenience of great value. (2) A constant market is afforded

${ }^{5}$ For the complete price table on barley, see Appendix to this chapter. As to grades of grain used in above tabulations: for wheat and oats. contract grades are used; for barley, brewing barley. 
by the speculators. For instance a large feeder in Texas wires an order to his dealer in Kansas City for 200,000 bushels of oats, December delivery. The order is accepted and placed in part in the Kansas City market-a market too narrow to absorb instantly such a big order - and in part in the Chicago pit. The first seller is the speculator, ready to sell at any instant, at his, price. Later he buys back from a dealer who is interested in handling the oats, and thus the speculator, after absorbing the order, passes it on to others ready to take it. This practice keeps the market constantly open for the actual commercial needs of the country. (3) Wheat, oats, corn, and cotton are handled at a lower margin of cost because they are hedged in the pit. The risk is shifted to the speculator, whose choice is to bear the risk, with the profit or loss going with it.

The actual mechanics of speculation must be discussed in the chapter dealing with the grain trade (Chapter XXII).

3. Speculation: Its Evils.-The chief evil of speculation, particularly on the organized exchanges, is the participation therein by the unfit. The financially unfit constitute the bulk of this class of unfit persons. It is true that some speculative housesan increasing number-carefully scrutinize the record of each customer and would-be customer, to determine his financial ability to speculate and stand the probable losses. A few houses are lax in this. Again, some persons are unifit to speculate by reason of the position of trust which they occupy, such as bank clerks, or cashiers in banks. These should be rigidly excluded from opening a speculative account with any member of any organized exchange. No member, in turn, can afford to enter such an account on his ledger.

The cornering of the market is sometimes mentioned as one of the evils of speculation. But since this activity is strictly forbidden by the rules of the organized exchanges, it cannot in fairness be considered as a part of the activities of these exchanges. It is an activity the importance of which, so far as it has any, is practically confined to the unorganized markets.

4. Speculation and the Public Interest.-Under our present system of producing crops in the summer time, of financing them, of storing them, and of consuming them during twelve months of the year, speculation is an inevitable economic necessity. Therefore efforts aiming to reform or abolish speculations should be directed towards the foundation of the system, namely, the system of distributing, warehousing and financing those-products in 
which most speculation occurs. Perishable crops, such as fruits and vegetables, should be directed by the organized growers themselves to those markets that are not already glutted. For instance, consider the case of ripe peaches. Growers in New York, Pennsylvania, Ohio, and Maryland ship to Pittsburgh, which is a very important distributing point to the mining towns in that region. The market reports show that Pittsburgh's consuming capacity is about 15 carloads of peaches a day in the peach moving season. But, as illustrating market glutting by shippers, mention may be made of one week's record recently in that market. The week's receipts ran from Monday to Friday inclusive on the normal basis. But on Saturday 78 cars arrived. Of course these cars were bought-by speculators (who performed thereby an important market function)-but the glut forced the price down, not the speculators. The shipment of peaches to any particular destination lies wholly in the hands of the shippers, and the growers, if they are not suited with present methods, have the power in their own hands to change things. They have the liberty and the encouragement to organize and distribute their crop where speculative risks will be greatly reduced. In reality, it is the grower who is employing the speculator to market his fruits and vegetables for him, in cases like the above, and hence if criticism is due, it is due in part to the grower himself.

The more non-perishable crops, such as grains and cottons, must be stored for a period of months, and in some cases over into the next crop season, before they enter into consumption. This storage problem brings with it the credit problem, since the grower in most cases must have his money when he parts with his crop. In many cases the "middleman" is the banker for the grower, functioning through some local elevator, merchant or dealer. But in any event, the middleman commonly borrows from the big money markets and gets the money to the point of production-a banking function. Fireproof warehouses, under private management, with low insurance costs, issuing negotiable warehouse receipts, all under public supervision and regulation, are coming into general use. Under the Federal Reserve Banking system the use of trade acceptances is likewise growing rapidly in favor. But the point to be emphasized here is that a solution of the warehousing and the credit problems will go far towards solving the speculation problem. To spend time denouncing speculation and speculators is about as futile and barren an occupation as can well be imagined, unless it be followed with 
constructive suggestions. The business world recognizes that many risks cannot be eliminated but can be distributed, as is evidenced by fire insurance, rent insurance, liability insurance, and the many other forms of insurance. In agriculture, crop insurance, hail insurance, live-stock insurance, and the other forms of agricultural insurance go a long way towards distributing the risks of production. In marketing, however, some risks and some speculation seem difficult to distribute, and hence remain to be shifted to the shoulders of the speculator.

To Sum Up.-Gambling, in the form of lotteries, has been long since outlawed and abolished. Gambling in many milder forms is falling into social disrepute. The social instinct is against it. Unorganized speculation is now a matter of public clamor and popular concern. It is a symptom, rather than a fundamental condition. But "the people hath spoken," and the ban of disapproval has been placed on some forms of unorganized speculation but not on others. Confusion exists. No sharp definitions have been evolved. The farmers themselves, while generally condemning "speculation in food products," unblushingly speculate in the land itself. And the land question is more fundamental and more serious than the food question. Less attention should be paid to speculation, and more to proper distribution, storage, and credit. As to organized speculation, it is working out its own rules, under the glare of publicity. It is performing an economic function which should be continued till a better and cheaper substitute can be found. Then it will cease to be a "problem."

\section{QUESTIONS ON THE TEXT}

1. Cite evidence from common observation that important words are often used with ambiguous meaning.

2. Discuss the usage and meaning of the following terms: hoarding; cornering the market; cash and future trading and speculation.

3. Distinguish two social classes, from the economic standpoint.

4. To which class was the founding of the Plymouth Colony due? Cite evidence from the Charter of this colony.

5. Formulate a principle covering the right to speculate.

6 . What does society want in the field of speculation?

7. Define speculation. Compare the dictionary definition with the ordinary economic usage.

8. Is the retail merchant a speculator?

9. Define short seller.

10. Is the farmer a speculator?

11. Define gambling. Distinguish from speculation.

12. Compare the volume of future trades with the volume of bank deposits, and show economic significance.

13. Distinguish two kinds of speculation. Illustrate each.

14. In which form do most frequent abuses occur? 
15. What role is played by butter exchanges?

16. Comment on the ethics of the speculator.

17. What are the services of speculation! Three functions.

18. Show, by the case of the Eastern Shore of Virginia Produce Exchange, the significance of the banking function in distribution.

19. The bulk of speculation in the United States is of what kind?

20. Discuss three popular fallacies concerning speculation in the organized exchanges.

21. Compare fluctuations in price of oats, wheat and barley, and explain the differences.

22. In what sense is it true that future trading stabilizes prices?

23. Show the three chief services of speculation in the organized exchanges

24. What are the evils of speculation?

25. What is being done now to reduce these evils?

26. Show what the public interest requires in the matter of speculation.

27. Distinguish clearly between fundamental reforms and mere treatment of symptoms.

28. Summarize the main points of the chapter, showing the problems which underlie speculation.

\section{QUESTIONS SUGGESTED BY THE TEXT}

1. Should prices fluctuate, or should they be "stabilized"? Reasons for your belief. If prices are stabilized, at what point should they be stabilized? And by what authority? Should the price be a "just price" or an "equilibrium price"? Define "just price." Since the consumers in the United States have a majority of two to one over the producers, price fixing by governmental authority would likely be shaped in whose interests?

2. Outline a practicable system of production, warehousing, financing, and distribution that would contain the minimum of speculation. Would such a system work under the present limitations and imperfections of human nature?

\section{REFERENCES}

1. Anderson, B. M., Jr.: "Grain Speculation and Food Control," The Annalist, May 21, 1917, pp. 689-690. A discussion of the functions of speculation, with particular reference to the grain market.

2. "German Law Against Exchange Speculation." In Consular Reports (Washington) as follows: Vol. 52, No. 194, Nov., 1896. Vol. 62, No. 235, April, 1900. Vol. 64, No. 243, Aug. 28, 1900.

3. "Good and Evil in Speculation." Industrial Commission Report (Washington) as follows: Vol. 10, pp. xxxvii-lxiv, p. 188. Vol. 6, pp. 89-224. Vol. 19, pp. 185-186.

4. HANey, Lewis H. (Editor): "Studies in Agricultural Economics." Bulletin 298. University of Texas, Austin, October, 1913.

5. Hill, John, Jr.: "Gold Bricks of Speculation." Chicago, 1904.

6. Howland, Harold J.: "Speculation and Gambling." The Independent, New York, October 2, 1913, pp. 15-18.

7. Pickell, J. Ralph: "The Problem of Food Distribution," Rosenbaum Review, Chicago, April 14, 1917, pp. 1-3.

8. Pickell, J. Ralph: "Rural Speculation," Rosenbaum Review, Chicago, January 27, 1917, pp. 1-2.

9. Price, Theodore H.: "Short Selling and the Speculator," Commerce and Finance, New York, November 20, 1918.

10. Price, Theodore H.: "On Licensing Speculators," Commerce and Finance, New York, December 4, 1918. 
11. "Wall Street's Fair Price Law"-A Discussion of the Use and Ethics of Manipulation, Conducted in a New and Very Open Spirit by Members of the Stock Exchange-The Intent Determines the Quality of the Act. The Annalist, New York, April 19, 1915, p. 372.

12. "Why we Stopped Buying at our Elevators." (Editorial). The Saskatchewan Coöperative Elevator Newis, Regina, June, 1917, pp. 7-9.

13. Emery, H. C.: "Speculation on the Stock and Produce Exchanges of the United States." Columbia University Studies, New York, 1896.

14. ㄴ. "Legislation Against Futures." Political Science Quarterly, $\mathrm{x}, 62-86$.

15. Stevens, Albert C.: "Futures in the Wheat Market." Quarterly Journal of Economics, II, 37-63.

16. "Speculation on the Stock Exchanges and Public Regulation of the Exchanges, Papers and Discussions at the 27th Annual Meeting of the American Economic Association, Princeton, New Jersey, Dec., 1914." Papers by Samuel C. Untermyer and H. C. Emery: Discussions by. Albert W. Atwood, Walter E. Lagerguist, A. R. Marsh, Joseph H. Underwood, Wm. C. Van Antwerp, Wm. Z. Ripley. American Economic Review, Vol. V, 24-111. Same in condensed form, in Market World and Chronicle (New York), January 16, $1915,70-84$.

17. Brace, Harrison H.: "The Value of Organized Speculation," Boston, 1913.

For additional references, see. chapter on the Grain Trade.

\section{APPENDIX}

"The Charter of New England-1620."-As illustrating the interesting fact that "adventurers" (speculators) founded the New England Colony (the Plymouth Colony) and sent the early settlers there, the following extended quotation is given from the original King James Charter of 1620.

"James, by the Grace of God, King of England, Scotland, France, and Ireland, Defender of the Faith, etc., to all whom these Presents shall come, Greeting, ... Whereas, since that Time, upon the humble Petition of the said Adventurers of the said first Collonye (i.e., London Colony), We have been graciously pleased to make them one distinct and entire Body by themselves, giving unto them their distinct Lymitts and Bounds... Now forasmuch as We have been in like Manner humbly petitioned unto by our trusty and well beloved Servant, Sir Fferdinando Gorges, Knight, Captain of our ffort and Island of Plymouth of the said Second Collonye, and by divers other Persons of Quality, who now intend to be their Associates, divers of which have been at great and extraordinary Charge, and sustained many Losses in seeking and discovering a Place fitt and convenient to lay the Foundation of a hopeful Plantation ... We would likewise be graciously pleased to make certaine Adventurers, intending to erect and establish ffishery, Trade, and Plantation within the Territoryes, Precincts, and Lymitts of the said second Colony, and their Successors, one several distinct and entire Body, and to grant unto them such Estate-Prvieligesthere, as in these our Letters-Patent-expressed. Divers of our good Subjects... have for these many Years past frequented those Coasts .. . In Contemplacion and serious Consideracion whereof, Wee have thought it fitt according to our Kingly Duty, soe much as in Us lyeth, to second and follow God's sacred Will, rendering reverend Thanks to his Divine Majestie for his gracious favour in laying open and revealing the same unto us before any other Christian Prince or State, by which Meanes without offence, and as We trust to his Glory Wee may with Boldness goe on to the settling of soe hopefull a Work, which tendeth to the reducing and Conversion of such Savages as remaine wandering in Desolacion and Distress, to Civil Societie and Christian Religion, to the Inlargement of our own Dominions, and the Advancement of the Fortunes of such of our good Subjects as shall willingly intresse themselves in the said Imployment, to whom We cannot but give singular Commendations for their soe worthy Intention and Enterprize."

The Hudson's Bay Company. - The oldest corporation in the World is the Hudson's Bay Company. It was chartered in 1670 by King Charles II, under the title "Governor and Company of Adventurers of England, Trading into Hudson's Bay."

Thus the word "adventurer" was once used to denote a "speculator" in the better sense of the modern term.

Speculators of the kind named in the two cases above are necessary in society in order to have any social progress. 
Barley Price Ranges, 18 Years, Chicago.

\begin{tabular}{|c|c|c|c|c|}
\hline Year & I,ow & High & Range & $\begin{array}{l}\text { Per cent } \\
\text { of fluctu- } \\
\text { ation }\end{array}$ \\
\hline 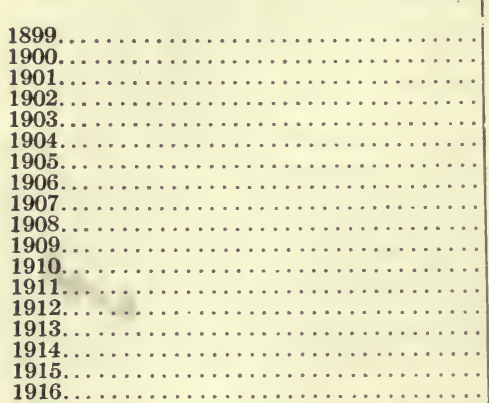 & $\begin{array}{c}\text { Cents } \\
35 \\
34 \\
38 \\
37 \\
36 \\
30 \\
35 \\
38 \\
40 \\
46 \\
43 \\
42 \\
55 \\
42 \\
42 \\
44 \\
48 \\
58\end{array}$ & $\begin{array}{l}\text { Cents } \\
55 \\
67 \\
66 \\
73 \\
62 \\
61 \\
55 \\
58 \\
110 \\
106 \\
821 / 2 \\
90 \\
139 \\
140 \\
85 \\
79 \\
90 \\
128\end{array}$ & $\begin{array}{l}\text { Cents } \\
20 \\
33 \\
28 \\
36 \\
26 \\
31 \\
20 \\
20 \\
70 \\
60 \\
391 / 2 \\
48 \\
84 \\
98 \\
43 \\
35 \\
42 \\
70\end{array}$ & $\begin{array}{r}57.1 \\
97.6 \\
73.2 \\
97.3 \\
72.2 \\
103.3 \\
57.1 \\
52.7 \\
175.0 \\
130.4 \\
91.9 \\
114.3 \\
152.6 \\
233.3 \\
102.4 \\
-79.5 \\
87.5 \\
120.6\end{array}$ \\
\hline
\end{tabular}

Fluctuations in Prices of United States Bonds.- "Since November, 1916, the 2 per cent consols have declined in market from $991 / 2^{-100}$ to $963 / 4$ in October, 1917; the $3 \mathrm{~s}$ of 1918 from $1003 / 4-1011 / 4$ to $99-100$; the $4 \mathrm{~s}$ of 1925 from 110 $1103 / 4$ to 105-1051/2." Vol. 1, p. 76.-Annual Report of the Comptroller of the Currency, Washington, Year ending October 31, 1917.

Monthly Range in Price in New York, November, 1916 to October, $191 \%$.



(Vol. 2, pp. 52, 53.) 


\section{CHAPTER XVIII}

\section{THE AGRICULTURAL PRESS}

THERE are at present nearly five hundred agricultural papers in the United States. While the bulk of these have an average circulation of fewer than one hundred thousand copies, yet there are about fifty papers with a circulation of over one hundred thousand each. There are seven farm papers with an average circulation each of over five hundred thousand. It is obvious, therefore, that a majority of the farmers read at least one agricultural paper, and many of them more than one paper.

The agricultural press is now a highly differentiated institution, so that even the most highly specialized farm interest has its organ. For instance, not merely does the stock grower have his paper, but there is a particular paper for a particular kind of stock, such as Holstein cows or Percheron horses. Similarly, with the growers of field crops. Not only are there hay journals, but journals dealing with alfalfa. However, the agricultural press, considered from the broader standpoint, is made up not merely of these specialized journals dealing with live stock, horticulture, bee keeping, etc., but also and chiefly of that type of farm paper which is written for the farmer's entire household.

Point of View.-The best type of farm paper to-day looks on the farmer first as a citizen. Such a paper is nonpartisan and nonsectarian. Yet, in a very real sense, such a paper is much concerned with the broader political and religious questions of the day. The farmer is regarded first of all as interested and concerned with the civil, social, economic, political, educational and moral forces about him - the general questions of good citizenship. And in the second place the farmer is looked upon as interested and concerned about good farming. A careful examination of a number of our largest and best farm papers shows that their editorial point of view towards farming is, first, a good man, and second, a good farmer. ${ }^{1}$

Best Type of Farm Paper.-The best type of farm paper is of course that one which best serves the real and permanent interests of its readers. It performs a real service, not merely to the farming "class" but also to the State and nation. It has a deep responsi-

${ }^{1}$ See Appendix to this chapter for different viewpoint 
bility, and is meeting that responsibility, in making better and more prosperous farmers and better and more intelligent citizens. The paper that caters in a narrow sense to the mere economic needs of the farming class is not the best type of farm paper. It is a mere trade paper. Likewise does that type of farm paper fail of high success which attempts to take part, in a partisan way, with the momentary and passing issues of politics. The best type of farm paper-and there are now several farm papers in this class - is performing service for its readers. It is published in the heart of the section which it serves. It has an editorial staff large enough and able enough to keep in contact with the farmer and the farm home. Its leading articles fit local conditions. The individual farmer is reached and helped. The farm community receives more help than the individual farmer. The social side of rural community life is properly evaluated and treated. The significance is recognized of the slogan "Better farming, better business, better living." This type of paper is truly a houschold paper, since it contains departments and articles of interest to each member of the farm household. A maximum number of articles appear fresh in this paper and a minimum number are clipped from other sources. It maintains a clear, wholesome moral tone. The farmer prefers this tone in a paper. ${ }^{2}$ The advertising pages of this type of paper are a good index to the service it is rendering its readers. No patent medicine advertising is carried. No financial advertising is carried. In fact, so far are the interests of the subscribers protected that now the papers of this type are adopting the policy of guaranteeing their own advertising. In short, these papers are rendering service and protection of a high order to their patrons. They are rural institutions of first importance.

Worst Type of Farm Paper.-There are a few farm papers scattered over the country that apparently have not taken deep root in the soil. Their editorial staff is not rural minded. Their contents are collected mostly by the scissors. They prostitute their advertising pages, teaching the farmer to spend his money for "cancer cures," "rheumatism cures," and other fake remedies, as well as for brass jewelry, gimcracks, gewgaws, frauds, shoddies and other bogus merchandise. These papers are parasitic in their

${ }^{2}$ Agricultural communities were the first to vote for prohibition-of the liquor traffic - the cities the last. Farmers look upon the cities as being somewhat cynical on moral and religious questions. In these matters the farmers are fundamentally conservative. 
nature, taking from the farm community, and leaving nothing or less than nothing in return.

Other Types of Farm Papers. - Very few farm papers attempt to be national in scope. Yet what may be termed the national type is exemplified by the Farm Journal of Philadelphia. Published in a great eastern city, this paper now circulates in every State, and particularly in the West and far West. Its editorial staff has been able to sense those questions and policies which are primarily interesting to the farmer as a good citizen; the questions of technical farming-horticulture, live stock, farm crops, market-

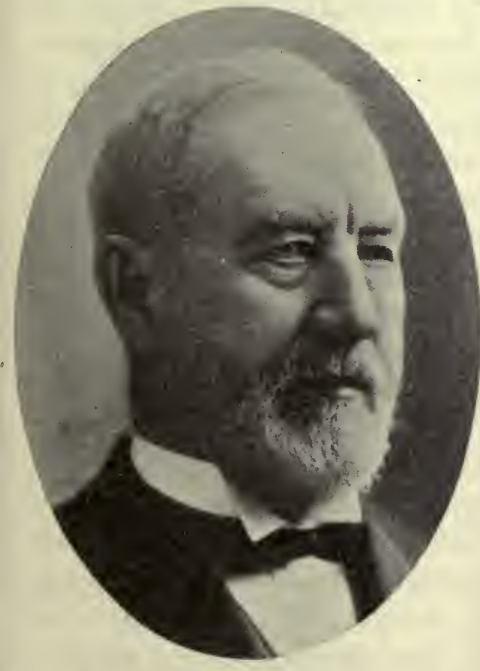

Frg. 48.-Henry Wallace, founder of Wallace's Farmer.

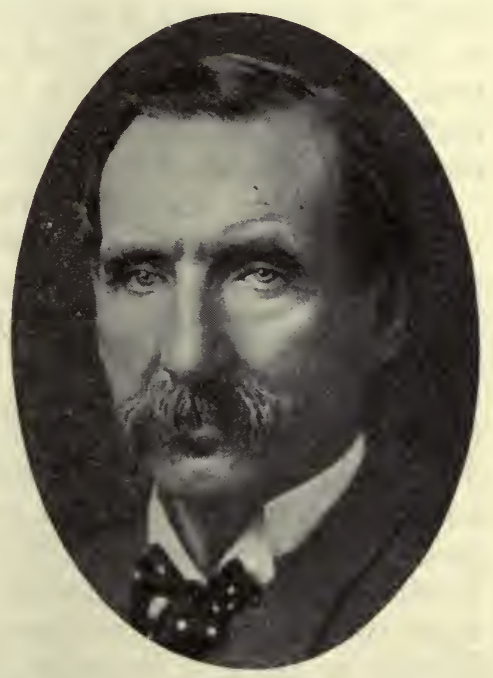

FIG. 49.-W. D. Hoard, founder of Hoard's Dairyman.

ing, etc.-have likewise been found to be of sufficiently nationwide interest to hold the readers. Hence this somewhat unique journal has prospered and grown to over a million subscribers. Another type of farm paper is that which reflects the outstanding personality of one man. In such cases the original founder has been a man of power and significance in the farming world-a real agricultural statesman. Two familiar examples of this are the papers founded by Henry Wallace (Fig. 48) of Iowa and W. D. Hoard (Fig. 49) of Wisconsin. ${ }^{3}$ Each of the papers founded by these two men became an institution in its community and in the

${ }^{3}$ Wallace's Farmer, Des Moines, Iowa. Hoard's Dairyman, Ft. Atkinson, Wisconsin. 
nation, and each paper reflected the fineness of mind and the clean, wholesome constructive personality of its founder.

The Specialized Farm Paper.-The differentiation of the farm press, as mentioned above, has been carried to a very high degree. No sooner does a specialized farming interest develop, apparently, than a paper is organized to meet that need. As an example of this fact the case of the Lake Erie grape belt may be mentioned. Grape culture was instituted here and finally spread to an area some three miles wide and sixty or seventy miles long. At once there was established the paper to fit this industry, "The Grape Belt" by name, and it continues to reflect faithfully conditions in that small district. Thus the farmer interested in pigeons, bees, any breed of poultry or live stock, any kind of tame hay or field crop, any kind of fruit or berry, or any social aspect of rural life, will be able to find a paper to suit his needs.

The Country Weeklies.-The country weekly newspaper, up to recent date, has taken its color and ideals largely from the city press. It has aimed to furnish the farmer primarily and frankly a political newspaper, with all the advantages and limitations of that aim. In other words, it considered the farmer as first, last and all the time a voter and a partisan. His class interest as a farmer was not recognized, in most cases. However, in late years, due chiefly to the county agricultural agent movement, a change has come over the wide-awake country weekly. The interests of permanent agriculture begin to give color to the paper. A "literary revolution" is taking place in the editorial make-up of these papers. Since these papers are published in every rural community, and literally go back to the grass roots, the significance for good of this revolution is hard to measure.

Agricultural Press and Scientific Farming.-The agricultural press forms the most important medium between the farmer on the one hand, and on the other hand the United States Department of Agriculture, the State Departments of Agriculture, the State Agricultural Colleges and State and Federal Experiment Stations. Scientific bulletins are translated into the language of the farmer. And conversely successful practices worked out and applied by individual farmers, are examined and described by the agricultural press so that all farmers may be acquainted with what each successful farmer is doing.

Agricultural Publishers Association.-The agricultural press has developed an organization of its own known as the Agricultural Publishers Association. It is hoped that one effect of this organiza- 
tion will be to raise the standard of those agricultural papers that are not serving their community until they approach the high type of service rendered by the best class of farm papers.

\section{QUESTIONS ON THE TEXT}

1. How many agricultural papers are published in the United States?

2 . How many of these have over 100,000 eirculation? How many over 500,000 ? How many over $1,000,000$ ?

3 . Discuss the differentiation of the agricultural press.

4. Discuss the point of view of our agricultural press. Cite a case of the opposite view.

5. Describe the best type of farm paper.

6. Describe the worst type of farm paper.

7. Describe and illustrate some outstanding, individual types.

8. Show to what extent the specialized farm paper has been developed.

9. Comment on the country weeklies.

10. Show the relation of the agricultural press to scientific farming.

11. What is the Agricultural Publishers Association?

12. Arrange in proper rank a list of the States having the largest number of agricultural papers.

\section{QUESTIONS SUGGESTED BY THE TEXT}

1. Secure copies of farm papers of different classes, and compare them as to their relative merits. Include in this study the following points: editorial policy; amount and character of advertising; amount of original matter and amount of reprint; appearance of paper; departments; moral tone.

2. Make a similar study of some representative country weeklies.

\section{REFERENCES}

1. Advertising and Selling Magazine, 95 Madison Ave., New York City. Publishes an annual directory of farm papers.

2. Tucker, Gilbert M.: "American Agricultural Periodicals." An Historical Sketch. Privately printed. Albany, New York, 1909.

\section{APPENDIX}

The Agricultural Press of the United States.-The following is a partial list of farm papers of 100,000 circulation and over, for the year 1916 .

1. 1,000,000 circulation and over.

Pennsylvania. Farm Journal, 1,085,000, Philadelphia.

2. 500,000 to $1,000,000$.

Iowa. Successful Farming, 788,000, Des Moines.

Kansas. Missouri Valley Weekly, 501,000, Topeka.

Kansas. Household, 777,000, Topeka.

Massachusetts. Farm and Home, 686,000, Springfield.

Minnesota. Farmers Wife, 757,000, St. Paul.

Ohio. Farm and Fireside, 631,000, Springfield.

3. 300,000 to 500,000 .

Illinois. American Fruit Grower, 300,000, Chicago.

Illinois. Better Farming, 324,000, Chicago.

Indiana. Farm Life, 405,000, Spencer.

Minnesota. Rural Weekly, 309,000, St. Paul.

Missouri. Kansas City Weekly Star, 350,000, Kansas City.

Ohio. Farm News, 387,000, Springfield.

Pennsylvania. Country Gentleman, 324,000, Philadelphia.

4. 100,000 to 300,000 .

Alabama. Progressive Farmer, 206,000, Birmingham.

Colorado. Great Divide, 104,000, Denver.

Georgia. Southern Ruralist, 272,000, Atlanta.

Illinois. American Farming, 200,000, Chicago.

Illinois. Orange Judd Farmer, 153,000, Chicago. 
Illinois. Prairie Farmer, 104,000, Chicago.

Illinois. Farming Business, 103,000, Chicago.

Illinois. Farmer's Review, 105,000, Chicago.

Illinois. The Breeder's Gazette, 100,000, Chicago.

Indiana. Up-to-date Farming, 191,000, Indianapolis.

Iowa. Kimball's Dairy Farmer, 184,000, Waterloo.

Iowa. Iowa Homestead, 156,000, Des Moines.

Iowa. Wallace's Farmer, 100,000, Des Moines.

Kansas. Farmer's Mail and Breeze, 112,000, Topeka.

Kansas. Capper's Weekly, 257,000, Topeka.

Kentucky. Inland Farmer, 129,000, Louisville.

Michigan. Gleaner and Business Farmer, 101,000, Detroit.

Minnesota. Farm, Stock and Home, 138,000, Minneapolis.

Minnesota. Farmer's Dispatch, 104,000, Minneapolis.

Minnesota. Northwest Farm stead, 112,000, Minneapolis.

Minnesota. American Home Weekly, 269,000, St. Paul.

Minnesota. The Farmer, 142,000, St. Paul.

Missouri. Farmer and Stockman, 107,000, Kansas City.

Missouri. Missouri and Kansas Farmer, 112,000, Kansas City.

Missouri. Journal of Agriculture, 154,000, St. Louis.

Missouri. National Farmer and Stock Grower, 150,000, St. Louis.

Missouri. Kansas City Weekly Journal, 261,000, Kansas City.

Nebraska. Nebraska Farm Journal, 103,000, Omaha.

Nebraska. Twentieth Century Farmer, 111,000, Omaha.

New York. American Agriculturist, 131,000, New York.

New York. Rural New-Yorker, 172,000, New York.

Ohio. Ohio Farmer, 136,000, Cleveland.

Oklahoma. Oklahoma Farmer and Stockman, 113,000, Oklahoma City.

Pennsylvania. National Stockman and Farmer, 140,000, Pittsburgh.

South Dakota. Dakota Farmer, 100,000, Aberdeen.

Tennessee. Southern Agriculturist, 153,000, Nashville.

Wisconsin. Hoard's Dairyman, 100,000, Ft. Atkinson.

Reliable Advertising Only.-Group of six farm papers printing following guarantee: "We positively guarantee that each advertiser in this issue is reliable. We agree to refund to any subscriber the purchase price of any article advertised herein if found to be not as advertised."

\footnotetext{
Farm and Home, Springfield, Mass., and Chicago, Ill.

Northwest Farmstead, Minneapolis, Minn.

Orange Judd Farmer, Chicago, Ill.

American Agriculturist, New York City.

New England Homestead, Springfield, Mass.

Dakota Farmer, Aberdeen, S. D.
}

Two Policies in Editing a Farm Paper.-(1) Give the farmers what they want; (2) Give the farmers what they need.

Farm papers roughly fall into two groups, as classified in the above heading. As illustrating group No. 1-"giving the farmers what they want"- the following quotation may be given from an editorial in the June 1, 1919, issue of a prominent farm journal:

"In short, my idea (of editorial policy) is to find what the farmers want and then help them get it. I regard (name of paper) as being in the position of an attorney for the farmers and that all public questions should be considered from the standpoint of the farmers, and every effort made to have them answered, so that the best interests, both economic and social, of the farmers shall be served." editor:

A different view is expressed in the following quotation from a successful

"Just what is a farm paper? Judging from the letters received at the editor's desk, it ranges all the way from a class sheet that praises everybody connected directly with farming and damns everybody else, to a paper that gathers its ideas and ideals with the scissors and assembles them with the paste pot. Now our idea of a farm paper has been in process of growth some thirty odd years, and is still growing. It cannot all be expressed in a paragraph, but here is one point to consider. The farm paper that is of real service to the farmer is one that seeks at all times to find the facts and tell the truth. In order to serve its farmer readers well it must have more than a class vision. It must deal directly and fairly with those problems that relate to the well being of farming and not of farming alone, but of State and national life as well. We cannot get away from our neighbors, and our neighbors constitute all the rest of the folks in the country. We cannot do without them any more than they can do without us. Tolerance and charity and good-will are essential elements of growing successful farm management because good-will and charity and tolerance make for neighborhood and national life and happiness."-Hugh J. Hughes. 


\section{CHAPTER XIX}

\section{FARMERS' ORGANIZATIONS}

IN February, 1919, fifty bankers, delegated by 37 State Bankers' Associations in thirty-seven States, were in session in Washington, D. C., with the heads of the United States Department of Agriculture, the Farm Loan Board, and the Bureau of Education, mapping out a program for agricultural development, better rural education and the general. improvement of rural social conditions. There was no farmer present delegated to voice the farmers' views or state their wishes. This case is typical. Many efforts have been made to "uplift" the farmer without consulting the farmer. This distinguished gathering in Washington represented a very large share of the wealth and the brains of the United States, and very able leadership. A very comprehensive program for improving rural life was adopted. This program was next offered, readymade, to the farmers. Whose fault was it that farmers were not directly represented at this conference and at many other similar conferences devoted to the serious and worthy cause of improving rural conditions? The farmers themselves are to blame. Lack of organization among the farmers explains it. Bankers' organizations in 37 States were directly represented. There was no one organization of farmers covering 37 States. There are many different organizations of farmers in all the States, but thus far they have not federated or coördinated their efforts or mobilized their forces.

Means of Securing Benefits.-Farmers' organizations have two general means of securing benefits for themselves, through selfhelp and through State aid.

President Wilson, in addressing the fiftieth annual session of the National Grange, commended the Grange for following the principle of "self-help." It is a significant fact that the Grange has followed the principle of self-help, and that it is the sole survivor of fifty years' standing of the many national farmers' organizations in the United States. Those organizations which have worked on the principle of State aid-except State aid as a temporary means towards self-help-have succumbed.

Class Organization.-The comment is frequently made that our various economic classes are all well organized, except the farmer. Thus, it is said, the manufacturers have their organizations; the wholesalers theirs; the jobbers theirs; the commission 
merchants theirs; the credit men theirs; the bankers theirs; and so on, and that these various interests in any one city are united into a local Chamber of Commerce, and these local chambers are federated into one grand central organization at Washington known as the Chamber of Commerce of the United States. Similarly, the comment is heard that various trades or crafts of laboring men are organized into unions, and that these large unions are federated into one grand central organization, the American Federation of Labor, also with headquarters at Washington. The farmer is commonly spoken of as individualistic, as inarticulate as a class, without voice and without protection. In a superficial sense of the word these comments are all true. The farmers are slow in forming any one great national federation of farmers' organizations comparable with those of labor or capital. But neither does the American Federation of Labor comprise all the great labor unions of the country. Neither do all so-called "capitalist" enterprises come within the purview of the Chamber of Commerce of the United States. At the present stage of economic development, organized capital and organized labor are able to mobilize their forces quickly and effectively, while the farmers can mobilize themselves but slowly and with indifferent success. ${ }^{1}$

Difficulty of Classifying Farmers' Organizations.-A logical classification of farmers' organizations is desirable, but difficult to make. This is true, whether the discussion be of the living organizations or the dead ones of the past. Among living organizations which ones, for instance, are doing most for their communities? Two representative farm papers, one in the Pacific Northwest,

${ }^{1}$ As a typical example of strong organization and effective mobilization, take the following case of the National Association of Credit Men, an Association of 25,000 members:

"The Association Acts in an Emergency.-The adaptability and facility with which the National Association of Credit Men, because of its peculiar composition, can act in a threatening situation was well illustrated during the last fortnight. A strike of the fire fighting forces of the city of Cleveland had lett it with practically no fire department protection. The National office was seen by leading insurance interests in New York, and their position explained - that, of course, a seriously increased hazard not contemplated in the policies covering property in Cleveland had been injected by the strike, that it was not a matter of rates, but that the companies were in no position to risk the chance of a small fire starting in the congested district of the city becoming a conflagration. Hence they would have to withdraw.

"The National office asked if time could be had to communicate with the Cleveland Association of Credit Men. This was readily granted, and President Klingman fully informed by wire. In a few hours the National office was informed that the officers and directors of the Cleveland Association had met certain city officials, and it was felt that within seventy-two hours conditions would be righted.

"This reply was communicated to the insurance interests, which said that no adverse action would be taken pending deliberations.

"Within forty-eight hours President Klingman had wired that the mayor had arranged for the return of the fire department force, and that the city at that moment had had restored the normal fire protection. The insurance companies were immediately notified and expressed their sincere appreciation."-From Goneral Letter No. 8, Feb. 1, 1919, National Association of Credit Men, to Members. 
one in the Mississippi Valley, made extensive inquiries in this field, and drew from their readers many interesting replies. ${ }^{2}$ Readers in the Pacific Northwest named various organizations, including among others the following: the Grange; Farmers' Educational and Coöperative Union; village and city Commercial Clubs; Fruit Growers' Associations; local church; organizations within local churches. The paper in the Mississippi Valley conducted a "Country Life Betterment" contest, offering substantial prizes for the best articles written on the subject. The five winning contestants named the following organizations: A Farmers' Club in Montana; A Community Club in Wisconsin; A Ladies' Auxiliary Society of a Farmers' Club in Michigan; A County Improvement Association in Iowa; A Farmers' Coöperative Creamery in Minnesota. Honorable mention was also given to a church congregation in Minnesota, and a Town and Country Community Club in New York. The above lists include two national farmers' organizations - the Grange and the Farmers' Union-and a great many purely local farmers' organizations. For the purposes of this chapter living farmers' organizations are first classified as local, national, and federation.

1. Federation of Farm Organizations.-Many efforts have been made to federate the farmers. The most popular plan has been to establish at Washington a central headquarters located in a Temple of Agriculture. And now that the American Federation of Labor is occupying its own Labor Temple the idea has gained more potency. As evidence of the growing popularity of a national federation of agriculture, ten recent efforts may be named, although only three may be discussed in any detail: (1) National Agricultural Society; (2) National Chamber of Agriculture Commission; (3) National Chamber of Agriculture; (4) American Agricultural Association; (5) National Agricultural Association; (6) National Agricultural Organization Society. This last is a frank attempt to transplant Sir Horace Plunkett's Irish Agricultural Organization Society bodily in American soil. Hence its slowness in taking root; (7) National Milk Producers' Federation; (8) Farmers' National Headquarters; (9) National Board of Farm Organizations; (10) American Federation of Farm Bureaus. The last three will be considered in turn.

(a) The Farmers' National Headquarters. - In the year 1910 a group of farmers, coming from a number of State farmers' organ-

${ }^{2}$ The papers referred to are The Washington Farmer, Spokane; and The Farm, Stock and Home, Minneapolis. 
izations of somewhat progressive or radical tendencies, met in Conference in Washington, and decided upon a plan of national federation. Their widely circulated prospectus announced:

"The end kept steadily in view is a Temple of Agriculture as the National home of the associated farm organizations, thus providing for the fitting representation of the great foundation industry of agriculture at the nation's capital."

The Conference decided in favor of establishing a Farmer's National Headquarters in Washington. One plank in the platform adopted there read as follows:

"To establish National Headquarters at Washington, to include everything needed to enable farmers to keep a close watch on how theiv business is attended to by Congress and the Departments. Such headquarters are needed not only to attend to the farmers' interests and to insure their securing a square deal, but they are needed to give the right support to the Representatives in Congress who actively support the farmers' program, and as a clearing house for all who desire to coöperate with the organized progressive farmers in public welfare work. We appeal to all farmers and all other public-spirited citizens, to assist in making this effort to establish a people's legislative clearing house a success."

The purpose and scope of this federation's work are clearly foreshadowed in the plank and prospectus quoted above. Officers are maintained at the capital, in charge of a permanent manager. An official organ is issued. ${ }^{3}$ The chief activity is in the legislative field-to promote desired legislation, to oppose undesired legislation. Among measures supported in the past are these: Parcels Post; Direct election of United States Senators; Federal Farm Loan Act. Among pending measures for which this federation is now working are these: Government owned and operated merchant marine; Government ownership and operation of the railroads; Government ownership and operation of natural resources now in private hands. The method of work by this federation consists largely in two things-in conferences and in farmers' national committees. Conferences bring together representatives from organizations specifically concerned in pending governmental policies. Farmers' National Committees likewise represent these same organized farm interests, and thus form a temporary subfederation. In this sense the Farmers' National Headquarters becomes the joint Washington office of various active farm organizations. In some cases the affiliation is temporarywhile the emergency lasts; in other cases a definite relationship is established. The published list of farm organizations having their Washington offices in the Farmers National Headquarters

\footnotetext{
${ }^{3}$ The Farmers' Open Forum, Washington, $\$ 1.00$ a year.
} 
includes the following: Farmers' National Legislative Council; American Society of Equity; The Gleaners; The National Dairy Union; National Creamery Butter Makers Association; American Association of Creamery Butter Manufacturers; Rural Credit League of America; the Postal Express Federation.

(b) The National Board of Farm Organizations. - This Federation was formed in Washington in 1917. It is laboring to secure a Temple of Agriculture in Washington, as the home of the organization. Conferences are held from time to time; policies are formulated and adopted; propaganda for or against legislative measures is carried on. Advice is given to the president of the United States on matters concerning the farmers' welfare. Protection is given to the farmers' interests. The published list of affiliated societies includes the following: (1) Farmers' Educational and Coöperative Union of America (generally known as the Farmers' Union); (2) National Council of Farmers' Coöperative Associations; (3) National Dairy Union; (4) Pennsylvania Rural Progress Association; (5) National Agricultural Organization Society; (6) National Conference on Marketing and Farm Credit (which met in Chicago in 1914, 1915, and 1916); (7) 'Farmers' National Congress; (8) National Milk Producers' Federation; (9) Federation of Jewish Farmers of America; (10) Farmers' Society of Equity. Of the above ten organizations not all are active. And the American Society of Equity, as a national body, is not affiliated with the above federation. These two federations of farmersFarmers' National Headquarters and the National Board of Farm Organizations - are both located in Washington, but they do not work together. Both represent very earnest attempts to organize a federation from the top down. It is a very difficult matter to organize a federation of farmers from the ground up-from the individual farmer, through his local unit, up through the State body into a national federation or council, following the example of the political organization of our government. The County Agent movement, with its supporfing Farm Bureau, prepared the way for such a democratic organization.

(c) American Federation of Farm Bureaus.-A separate chapter (XXI) is reserved for a discussion of the County Agent movement, and in that chapter the County Farm Bureau is described as the organization of farmers within the county which has immediate charge of the County Agents' work. The Farm Bureau, therefore, may be briefly described here, in anticipation, as a voluntary organization of individual farmers, supported by the 
annual nembership dues of these farmers. These membership fees vary in different States, from one dollar a year to ten dollars a year per member. The organization is clearly one of farmers, by farmers and for farmers, free from undue domination by any outside interests, governmental, commercial or otherwise. As these local county units became strong, it was a logical step to federate the county units within a State into a State Federation of Farm Bureaus. By the beginning of the year 1919 the following 18 States had such State Federations: California, Colorado,

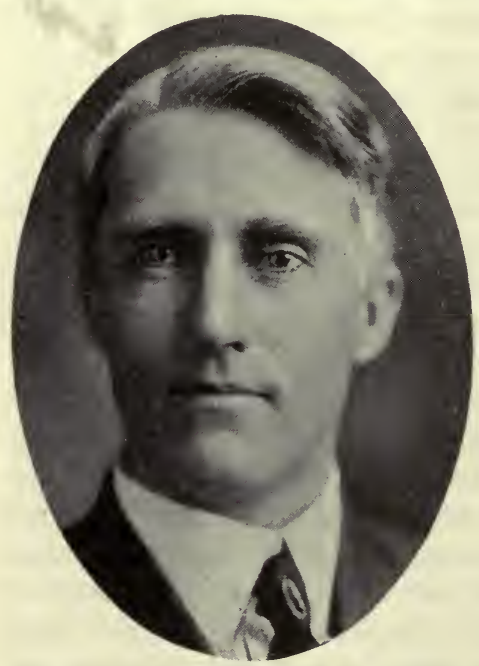

Fig. 50.-J. R. Howard, of Iowa, first president of the American Federation of Farm Bureaus. Delaware, Idaho, Illinois, Iowa, Massachusetts, Michigan, Missouri, Montana, Nebraska, New Hampshire, New York, Ohio, Pennsylvania, South Dakota, Vermont, West Virginia. Clearly, the next logical step was to unite the State federations into a National Federation of Farm Bureaus. This was done in the year 1919 under the presidency of J. R. Howard of Iowa (Fig. 50). Then for the first time, agriculture as a single great industry, became organized, mobilized, provided with a voice in national affairs. In this organization the farmers have a means of formulating and announcing policies; they have the machinery for formulating demands for legislation; they have an institution which will encourage them to organize for the study of educational, economic,social,and political problems; they have constituted a medium through which the membership may act collectively. They are on a par with so-called "organized labor" and "organized capital."

2. National Farmers' Organizations.- - It is not the purpose of this chapter to give an encyclopedic list of all farmers' national organizations, for their number is too great for that. Only a few are named here, and only one is discussed in detail, the oldest one being selected for that purpose. Among the national organizations which have survived a period of ten years and over may be listed these larger ones: Farmers' Union, Equity Union, American Society of Equity, The Gleaners, and the Grange. 
The Grange.-The Grange is to-day a powerful organization of farmers, active in thirty-three States, with its own press, its own body of organizers, its own lecturers, its own literature, poems, music, and traditions. The story of its rise to power, its decline, its new growth, and its achievements forms an interesting chapter in the annals of rural life. Perhaps no other organization ever showed such rapid changes from prosperity to depression and back to prosperity, such rapid shifts in the geographical territory it occupied. A glance at the table below illustrates in a measure these two points - a shifting from the South to the North; a decline in organization in some States and a growth in organization in other States.

Grange States (States Having State Granges)

\begin{tabular}{|c|c|c|}
\hline 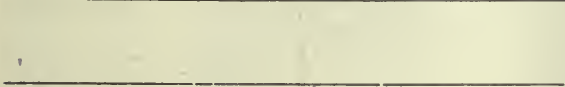 & $\begin{array}{c}\text { State granges } \\
\text { in } 1875 \\
\text { bulk in the South }\end{array}$ & $\begin{array}{c}\text { State granges } \\
\text { in } 1917 \\
\text { bulk in the North }\end{array}$ \\
\hline 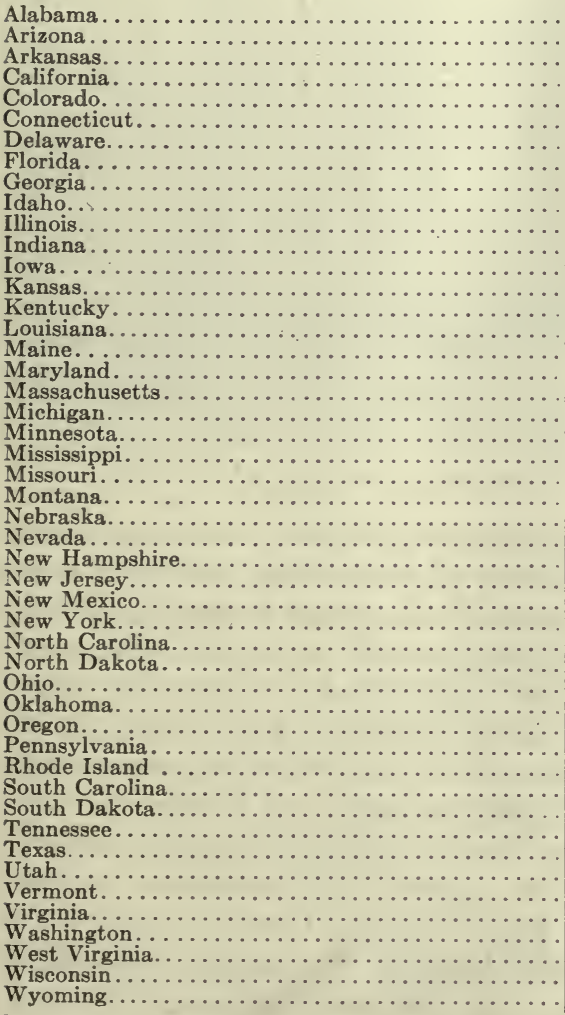 & \begin{tabular}{c} 
Grange \\
Grange \\
$\ldots \ldots$ \\
$\ldots \ldots$ \\
$\ldots \ldots$ \\
Grange \\
Grange \\
Grange \\
Grange \\
Grange \\
Grange \\
Grange \\
Grange \\
Grange \\
Grange \\
Grange \\
Grange \\
Grange \\
$\ldots \ldots .$. \\
$\ldots \ldots$. \\
$\ldots \ldots$. \\
\hdashline$\ldots .$. \\
Grange \\
Grange \\
Grange \\
$\ldots \ldots .$. \\
Grange \\
Grange \\
\hdashline$\ldots .$. \\
Grange \\
Grange \\
Grange \\
Grange \\
Grange \\
$\ldots \ldots$.
\end{tabular} & $\begin{array}{c}\ldots \ldots . \\
\ldots \ldots . . \\
\text { Grange } \\
\text { Grange } \\
\text { Grange } \\
\text { Grange } \\
\ldots \ldots . . \\
\text { Grange } \\
\text { Grange } \\
\text { Grange } \\
\text { Grange } \\
\text { Grange } \\
\text { Grange } \\
\text { Grange } \\
\text { Grange } \\
\text { Grange } \\
\text { Grange } \\
\text { Grange } \\
\text { Grange } \\
\text { Grange } \\
\text { Grange } \\
\text { Grange } \\
\text { Grange } \\
\text { Grange } \\
\text { Grange } \\
\text { Grange } \\
\text { Grange } \\
\text { Grange } \\
\text { Grange } \\
\text { Grange } \\
\text { Grange } \\
\ldots \ldots . . . \\
\text { Grange } \\
\text { Grange } \\
\text { Grange } \\
\text { Grange } \\
\text { Grange }\end{array}$ \\
\hline
\end{tabular}


The Grange as an institution is the lengthened shadow of one man, Oliver H. Kelley, of Washington, D. C. At the close of the Civil War, Mr. Kelley was sent by the Commissioner of Agriculture on a long tour through the unhappy Southern States, to study and report on the destruction and reconstruction of Southern agriculture. The human side of the study made the deepest appeal to his imagination. It was a question of the farmer rather than farming that seemed to him to need first attention. The rancor of sectionalism, the bitterness of defeat, the helplessness of

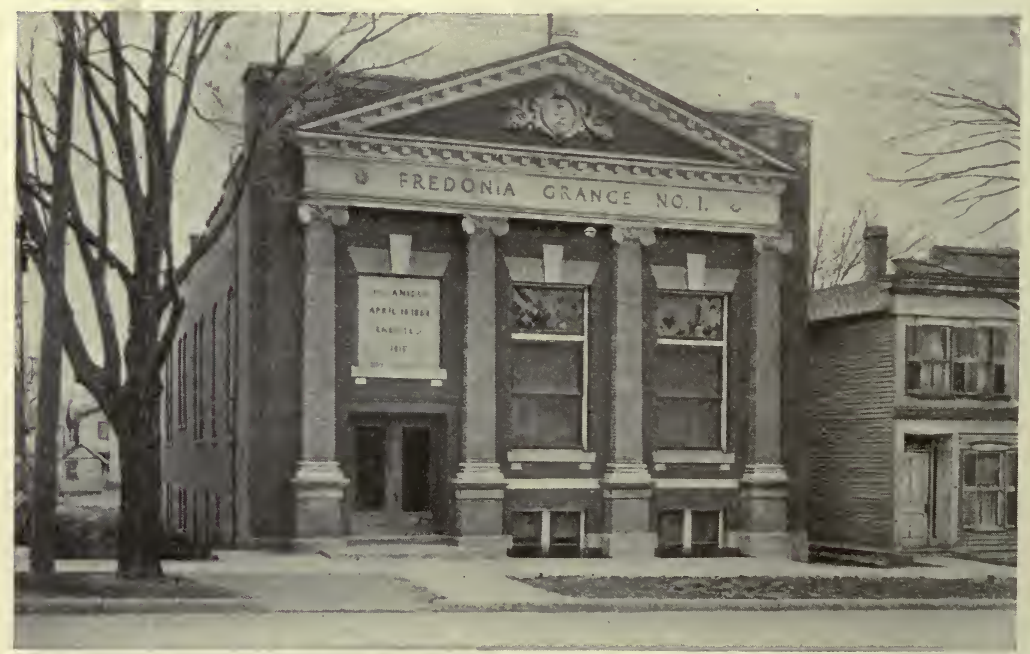

FIG. 51.-Home of the first local grange organized in the United States, Fredonia, N. Y.

the situation all rankled in the breast of the southern farmer. Mr. Kelley, being a loyal Mason, conceived the idea of a secret society with a beautiful and symbolic ritual as a means of restoring a fraternal feeling among the farmers north and south. It was his niece, Miss Caroline A. Hall, of Boston, who gave him the idea of having the new secret order include women as well as men. After some two years of study and consultation with intimate friends, Mr. Kelley in 1868 organized his new order, the Patrons of Husbandry. It was organized at the top first, namely, the national Grange, as the central unit was called. The order was to have three subdivisions, namely, State Granges, County Granges (or "Pomonas") and Subordinate Granges. It required the heroic faith and work of Mr. Kelley about two years to make any head- 
way with the new order. The first subordinate Grange was established at Fredonia, New York, in 1868, by Mr. Kelley himself (Fig. 51). Subordinate Granges were next started in Minnesota, Illinois, Indiana, Ohio and Tennessee. From Grange No. 1 comes S. J. Lowell, present master of the National Grange (Fig. 52).

It is well to pause here and enquire what were the real purposes of the Grange when it was organized. Since politics and religion were ruled out as subjects for discussion, these may be omitted from consideration. Rereading this early Grange history in the light of the present it is evident that the original purposes were not sharply defined in any one's mind, and were not set down in hard-and-fast rules. It is also evident that while Mr. Kelley was a practical man, yet he was actuated by lofty and idealistic views of economic, mental, moral, and spiritual blessings for the farmers. Apparently the spiritual blessings rather than the material were uppermost in his mind, and being a practical man, doubtless his views were not the same from year to year or in Fia. 52.-S. J. Lowell, a farmer of Fredonia, State after State which he visited. New York. Member of Grange No. 1; Time and place changed them. It

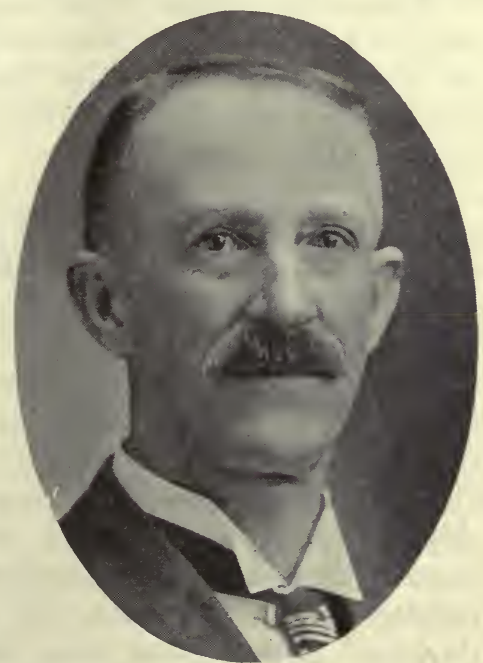
Ex-Master State Grange; Master of the is only fair to let Mr. Kelley speak for himself here, so the following quotation is introduced from his early writings:

"September 4, 1867: I have traveled some in our glorious country-for it still exists as God made it, notwithstanding the political troubles. I have noticed particularly those engaged in cultivating the soil who comprise the bulk of the population, and among these are noble minds, rough diamonds, that only need the polishing wheel of education to show their real value. Agricultural papers and works of art are doing much good among those who will read and think. Agricultural fairs have accomplished much; but these come but once a year, and while being advertised, create an interest; but as soon as they are over the interest is gone. Now what I design is this: An Order that will create an interest and keep it up. ... Among the objects in view may be mentioned a cordial and social fraternity of the farmers all over the country. Encourage them to read and think; to plant fruits and flowers; beautify their homes; elevate them; make them progressive. It will increase the subscriptions to the agricultural papers." 
In another letter he shows the policy toward young people.

"Bring up the boys and girls, and as fast as they prove by good hehavior and ability that they are worthy of advancement, give them a higher degree. It will stimulate them to be temperate, studious, and good. They will feel they are respected. Every organization will be provided with a library, and from that they can have books to impregnate their minds with sound sense ... I hope we can inaugurate an Order that will elevate our occupation as farmers, so that it will be a work of credit, not only to be a member of it, but also make it an honor to be a cultivator of the soil."

Somewhat similar views are expressed by other prominent members of the order. For instance, L. McKinstry, charter member of Fredonia Grange (No. 1) and its first Lecturer, in his address of welcome to O. H. Kelley (25th Anniversary of Fredonia Grange, 1893) said:

"But in my estimation, Brother Kelley, the Order you founded has had a higher value than in the line of material interests. It has served to stimulate and improve the social side of farm life. The social, parliamentary and literary education that has been gained in the Grange has brightened the life of many a family that would have otherwise led a lonely existence."

The rapid growth of the Grange, after the first three years of hard pulling, was beyond the fondest expectations of its best friends. The years 1873,1874 , and 1875 are the banner years in Grange history - the climax coming in 1875 , reaching a membership of one and a half million. For instance, in the year 1868, ten dispensations had been issued; in 1869, thirty-six; in 1870, one hundred and thirty-four. In February and March 1874, four thousand dispensations were issued. Granges were springing up all over the country, like mushrooms in the night. Not only among farmers, but also in villages and cities, Granges were being formed the members claiming to be "interested in agricultural pursuits." Three thousand organizers were in the field in 1874. During these three banner years the moneys received at the Secretary's office amounted to $\$ 350,000$. This made the Order financially strong. Miss Hall compiled a song book for the Order for which she was given $\$ 1,000$ by the National Grange. The Grange showed tremendous strength at this time in the States of Kansas, Missouri, Iowa, Illinois, Indiana, Kentucky, Ohio. There is clearly a connection here between the growth of the Grange and the economic depression sweeping the country at this time. It is true that the panic of 1873 was both industrial and agricultural. But the agricultural depression was more deep-seated and more enduring than the financial and industrial crisis. The West, after the Civil War, had been too rapidly settled. Aided by a huge government sub- 
sidy, the Union Pacific Railroad had been completed across a thousand miles of desert to the Pacific coast; the Northern Pacific, aided by a land grant the size of a small kingdom, had pushed on over the trackless prairies, across the Missouri river in Dakota. This wholesale bribery of railroads to build where they were not needed was matched by giving to each new settler who was bold enough to pioneer a farm of virgin soil as rich as the world has ever known. So the roads brought in settlers and the settlers brought in new roads. Then came the spectacle of overproduction of food, or, more correctly stated, more food was produced than existing marketing machinery could distribute widely, and the settlers began to sell food below the cost of production. Cheap food, cheap land, but dear money was the settler's lot. Much capital was needed to open up the new country. Interest rates were high. Mortgages were hard to pay off. Cheap food from the west was a blow to eastern agriculture also. The whole experiment in promoted development collapsed. The railroads went bankrupt. The farmers had their mortgages foreclosed. Many of them left the country. In 1872 corn reached the low price of twenty-seven cents a bushel on the Chicago Board of Trade. This meant ten cent corn on the farm. Wheat in 1874 reached the low point of seventy-eight cents in Chicago, a point not reached again till ten years later. Many farmers saw in the Grange a chance to bring about economic reforms, not realizing the fundamental nature of their distress. It was at this time that Secretary Kelley reported to the National Grange as follows:

"The educational and social features of our Order offer inducements to some to join, but the majority desire pecuniary benefits-advantages in purchase of machinery and sales of produce. To bring all the Granges into direct communication and to devise a system of coöperation, devolves upon the National Grange. But until its membership is much increased, we must wait patiently the appearance of our new Moses, who is to present the coveted plan."

A Decline.-Following 1875 came a rapid decline of the Grange. It had reached and passed the first peak of its power. At a stormy meeting of the National Grange at Charleston a measure was passed for the distribution of the surplus revenue among the subordinate Granges. Thus this large fund was dissipated, an insignificant amount going to each local Grange. When the Grange had manifested its strength, politicians and others, seeking only the loaves and fishes, hastened to join. Too many non-farmers had joined. Two Granges were organized in New York City, one the "Manhattan" on Broadway, with a membership of 45 wholesale dealers, sewing machine manufacturers, etc., represent- 
ing many millions of capital; the other was the "Knickerbocker." Boston has a similar Grange, which after much trouble was expelled from the National. Members of these city Granges were criticized as being interested in the farmer "as the hawk is interested in the sparrow." In 1876 four thousand Granges were reported delinquent. Salaries were at once reduced-the Master's from $\$ 2,000$ to $\$ 1,200$, and the Secretary's from $\$ 2,500$ to $\$ 2,000$. In 1879 the Master's salary was dropped entirely, and the secretary reduced to $\$ 600$.

Renewed Growth.-And now there began a new period of rapid growth. Some writers had reported the Grange as "dead." But it suddenly found new life, especially in the North and the East-particularly New England-and later in the Northwest. At the session of the National Grange in 1885, held at Boston, delegates were present from all the States and territories but eight! Such were the vicissitudes of ten years! Granges, dormant for many years, were resuscitated. New Granges were organized. During the whole life of the Grange it has thus evinced an almost incredible power to grow weak and become dormant and then suddenly to rise again into full might and activity. Evidently it contains the germs of life. It is now proper to pause and enquire into the economic aspects of Grange endeavor and also into its substantial achievements.

Economic Program of the Grange.-What are commonly called the "Granger laws" had no connection with the Grange. The so-called Granger legislation was railway legislation enacted by the separate States in the days before we had any federal Interstate Commerce Commission or federal regulation of the railroads. The States in the corn belt accordingly undertook to regulate the rates and services of these roads, and the roads in turn resisted all such regulation. The movement began in Illinois, in the Constitution of 1870 and the railway regulation Act of 1871. Other States now followed. The farmers back of this movement were considered radicals, and came to be commonly called "grangers," the term not indicating any connection with any Grange. These laws constituted "granger legislation," but not Grange legislation. There are at least three bits of evidence for this statement. The date of the laws. The Illinois constitution of 1870 -the pattern for all the rest-was adopted in 1870, after a few years of agitation, and the Grange at that time had not a foothold in the State. The State Grange of Illinois was organized in March, 1872. By 1874 seven States had enacted "Granger laws." (2) The per- 
sonnel of the movement. In Illinois the real organ of agitation was the "State Farmers' Association," composed of local "Farmers' Clubs." Its President, W. C. Flagg, testified in 1873 before the Windom Committee that he was not a member of the Grange and that his organization was an open, political one, not like the Grange, a secret non-political one. (3) Grange principles. The official declaration of purposes of the Grange, adopted in 1874 at St. Louis, states that the Grange is not hostile to railroads. In 1875 a resolution from Texas favoring railroad legislation was suppressed. Congressman D. W. Aiken of South Carolina, long a member of the Grange National Executive Committee, said in an address, "There existed in Illinois and Wisconsin and other sections of the Northwest agricultural clubs whose province seemed to be to wage war against transportation companies. Anathemas were hurled upon the Grange for making this attack; whereas every Patron of Husbandry knows that the Grange as such was not a participant in the fight from beginning to end."

However, whoever the farmers were that started the railroad reform legislation, the Grange did quite early become drawn into various economic movements. Mr. Kelley thought he was starting a social and educational movement. Hard times in the West, hard times in the East, low prices of farm products, soon caused the original purpose of the Grange to be overshadowed by the coöperative, anti-middleman feature. It was this feature which caused the tremendous growth of the Grange from 1870 to 1875, and almost threatened to transform the farmers into a race of merchants and traders.4 As soon as the more radical Granges of the West got control of the National Grange a movement was started to make of it a gigantic coöperative scheme, with three national purchasing agents, one at New York, one at Chicago, and one at New Orleans. This scheme was dropped as impracticable. Then came a period of the buying of patent rights to manufacture various machines, such as harvesters, mowers, reapers, etc. The Executive Committee expressed the theory of it in these words: "To secure rights to manufacture leading implements . . . is preeminently a duty of the National Grange, and a measure of the

4 An amusing incident occurred in connection with a General Business Purchasing Agent appointed by the Minnesota State Grange. The Secretary of the Minnesota State Grange wrote a letter to Mr. Kelley in Washington, informing him officially that the first purchasing order had reached St. Paul, the order being for the purchase of a jackass. Mr. Kelley wrote on this letter the following memorandum: "This purchasing business commenced with buying jackasses; the prospects are that many will be sold." 
greatest importance, directly, because the profits of manufacture will thus be controlled by the Order, as well as the profits of transfer or dealing; indirectly, by securing facilities that will favor the introduction of manufacturing establishments in districts at present far removed from them, and where their products are in demand." The theory of having the farmers' machinery manufactured at his door was an alluring one. And to divert the "profits" of the manufacturer into the pockets of the farmer was then, and it is now, the subject of many a naive scheme to "do something for the farmer."

Interest in Coöperation.- It was into coöperative enterprises of buying and selling, however, that the Grange was most actively drawn at this period. The craze for coöperation has indeed been compared to the craze for gold in 1849. The National Grange adopted the policy of promoting coöperation after the model of the English Rochdale system. An envoy was sent to England to study the question and confer with British coöperators. A large plan was conceived, whereby the Grange was to raise a capital fund of $\$ 125,000$ for building shipping depots, and a Grange Company, called the "Anglo-American Coöperative Company" was to carry on trade directly with England. Three English commissioners visited America and investigated the plan, and decided to erect their own warehouses at four seaboard cities. They were to furnish clothing and other manufactured goods at ten per cent discount, and were to buy farm produce at market price from the Grange, provided the Grange would concentrate its purchases through them. But a volume of business large enough to justify the venture could not be guaranteed, and the project was dropped. In the various States village coöperative stores were now quite extensively started, although the Rochdale plan was not very faithfully adhered to, particularly that feature of the English plan which distributes surplus earnings on the basis of patronage and not on the basis of capital. It is somewhat difficult to state the net gain derived by Grange members from all their many ventures, for substantially all of them were short-lived. In Iowa a purchasing agent bought plows and reapers for the local Granges, effecting a savings thereby in one year of fifty thousand dollars, according to Grange figures. If this lowered the prices of implement dealers who were taking too wide a margin, it was a permanent benefit to the Grange. If, however, it served to put out of business entirely many local dealers, thus making repairs difficult to secure, it was a loss rather than a gain in the end. At this distance, it is not easy 
to know all the facts. In New York a State buying agency was established and later abandoned; then district agencies were tried, making certain savings to the buyers, these, however, were also given up after a few years, and purchases were made through regular dealers. If the cold-blooded test of dividends be applied to these experiments, they were all failures. If, on the other hand, they be looked on as mere laboratories or experiment stations in marketing, and in part also as a potential club over the head of the over-mercenary middlemen, then these experiments were worth while. They may be considered in the light of "potential competition" which put a brake on high prices. In 1876 the Patrons were reported to own five steamboat or packet lines, twenty-two warehouses, and thirty-two grain elevators in the Chicago territory - principally in Iowa. In some cases State Granges financed these enterprises, having funds with which to experiment.

Effect of Low Prices.-The economic crisis through which the country passed in 1893 and 1894, and the agricultural depression extending well up into 1897 very naturally caused many farmers to turn to the Grange, as they had done in the 70's as a possible solution for their economic ills. Corn in Chicago, for instance, in 1895 touched the low point of 25 cents a bushel, and in 1896 the final bottom of $221 / 2$ cents! This meant 10 cent corn on the farmsa price much below cost of production. Wheat in Chicago reached $523 / 4$ cents in 1894 and $533 / 4$ cents in 1895 , which meant 40 cent wheat on the farms, a price below cost of production. No wonder the State Granges of California, Oregon, Illinois, Washington, Missouri, Virginia, and Pennsylvania sent a speaker to Washington to present a memorial to Congress setting forth the evils of the existing protective tariff system and asking for protection to agriculture in the form of export bounties. ${ }^{5}$ No "help" was given.

Achievements of the Grange.-The Grange has always taken part in working for agrarian legislation which it wanted and fighting legislation which it did not want. It has unquestionably opposed with success much pending legislation potentially harmful to farmers. The creation of the present Department of Agriculture is probably due more to the Grange than to any other influence. The rural free delivery of mail is largely also a Grange achievement. The Grange also has to its credit a long list of constructive and important acts concerning education, parcel post, the correct labeling of foods and drugs, etc.

${ }^{5} 54$ Cong. 2 Sess. Senate Doc. 157. 
Aaron Jones, Worthy Master of the National Grange, speaking before the National Grange meeting in Portland, Oregon, in 1904, summed up Grange achievements in these words:

"A generation has passed, crowded with greater advancement than any similar period in the world's history, since our organization was founded to meet conditions essential to public welfare. It was consecrated to develop the best type of social conditions, to foster and promote good citizenship, to develop agriculture, to secure equity in the business relations of the agricultural classes with the industrial and commercial interests of our country . . . The Grange removed the isolation of the farm homes, inculcated and promoted education, fostered and secured better schools for our children, raised the standard of intelligence among the farming population, developed the latent talent of its members, making them logical thinkers and writers and fluent .speakers, understanding the relation of agriculture to the varied and complex social, industrial and commercial interests of our country and the world. These glorious results were attained by steadfast adherence to the principles of our Order and methods suggested by the founders of our Fraternity."

The greatest significance of the Grange, as well as its most lasting achievements, have been in the social and educational influences which it has mobilized. Farmers and their wives and daughters have here met together, and together have enjoyed their music, their literature, their recreations, their beautiful and dignified ritual, and their serious deliberations. This wider neighborhood contact has been wholesome and pure and good. It has made for a certain culture and refinement not so easily attainable by the rural dweller as by the urbanite. It has tended to socialize the community and to foster community leadership by the farmer, for the farmer, and of the farmer.

3. Local Farmers' Organizations.-For many decades farmers have maintained with conspicuous success local and State-wide organizations along economic and educational lines, with the emphasis on the educational side. Thus we have the various State Agricultural Societies, the State Horticultural Societies, the Pomological Societies, and so on. Most of these societies meet annually and publish a volume of proceedings. The discussions have dealt almost entirely with the production side of the problem, rather than with the marketing side. Live-stock associations form another large groups of a similar nature. A mere list of the names of these would fill many pages. ${ }^{6}$

In more recent years these local farmers' organizations have more and more gone into marketing questions. Thus we have an

${ }^{6}$ The 1917 Yearbook, United States Department of Agriculture, pp. 595603, contains a list of 7 National Live-stock Associations, 19 National Poultry Associations, and 314 State Associations of live stock and poultry. 
increasing number of farmers' organizations that are purely coöperative marketing associations. Some typical examples of this have already been described in the chapter on Coöperation. Others lay stress on the general protection coming from being banded together. As an example of this may be cited the Farmers' Grain Elevator movement. As the movement stands at the present writing (the year 1919), it may be graphically represented as follows:

\section{Farmers' Grain Elevators in the United States. \\ 400,000 farmers own stock in grain elevators 4,000 country elevators owned by farmers \\ 12 State Associations of Farmer Grain Dealers? \\ 1 National Council representing these 12 Associations \\ 1 Journal as the official organ of this Council. 8}

Among the accomplishments claimed by the above organization of farmers are the following: sulphured oats permitted in interstate commerce; federal grain grades; federal supervision of grain inspection; patronage dividends exempt from income tax. On the program of things to do are the following: handle freight and traffic matters, particularly increase in freight rates on grain, or regulations pertaining to loss and damage claims, or bill of lading matters; car shortage problems; in short, protect the interest of farmers in production, transportation, and marketing of grain.

4. Political Organizations of Farmers.-In agriculture as in labor the idea has often gained temporary sway in local areas that a class party was needed. This has occurred in spite of the fact that the trend of our political evolution has been against either class or sectional divisions of our voters. A class party was started in 1915 among the wheat farmers of North Dakota, under the name of "Nonpartisan League."

The Farmers' Nonpartisan Political League, as this party came to be called, came into full control of the North Dakota State government in 1919, in all three branches-legislative, executive, and judicial. It had chosen a governor in 1916, and secured complete control of the executive and judicial branches of the State government. The League vote for governor in 1916 was 87,665; in 1918, 54,917. This movement began both as a union (on the labor union principle), charging a membership of six dollars a year, and as a political party, nominating candidates and adopting

7 The 12 States are: Texas, Oklahoma, Kansas, Nebraská, South Dakota, North Dakota, Minnesota, Iowa, Illinois, Indiana, Ohio, and Michigan.

8 This Journal is the American Coöperative Journal, Chicago. 
a platform. The background of the movement is both economic and political.

Economic Background.-The movement began in North Dakota in 1915, as a culmination of ten or fifteen years of agitation on the wheat marketing question. By the year 1915 North Dakota ranked second only to Kansas as a wheat producing State. But unlike Kansas, the Dakota wheat was not milled within the State; it was shipped chiefly to two Minnesota points-to Duluth for export, or to Minneapolis for milling. Hence the weighing, inspecting, grading, and docking, were all done by interests entirely outside the control of the North Dakota farmer or the North Dakota government. And to the North Dakota farmer, price fixing on his wheat seemed to be done autocratically and arbitrarily by the Minneapolis and Duluth Grain Exchanges. In such cases, the farmer always feels a sense of voiceless helplessness, a sense of indignation and resentment, and a sense of rebellion. It is now a matter of economic history that the weighing, inspection and grading of grain by the State of Minnesota had for many years been done in a fair and efficient manner; that the old arbitrary margin of 8 or 10 cents a bushel on the farmer's grain, fixed and taken by the big line elevator companies, had given place, thanks to the hundreds of farmers' elevators, to a narrow competitive margin; and that the price of wheat was fixed on a world-wide market outside of and beyond all the Grain Exchanges of the United States. But the North Dakota settlers, pioneering, depending on one crop, had come to feel that they were the victims of injustice in wheat marketing. All their discontent was focussed on this one point. Leaders, selfish and otherwise, had created the belief that the simple remedy for the injustice was in a terminal elevator or number of terminal elevators, owned and operated by the State. The voters amended the State Constitution-a fouryears process - to enable the Legislature to provide the terminal elevator. The Legislature refused to pass a terminal elevator law. This was the crowning "injustice," the farmers felt, for their years of hope and effort, and the whole farming population of the State was plunged into a state of anger. It counted for naught that the business members of the legislature, after an impartial survey and discovery of several terminal elevators for sale at half price, had decided that the venture was too risky for experimentation with public funds. At this juncture a group of organizers of the Socialist party left that party and began a most vigorous organization of a farmers' Socialist party under the name of the 
Farmers' Nonpartisan Political League - or Nonpartisan League, as it was called for short.

Political Background.-Financial, industrial, and railroad interests had long had control of the State government, the farmer members of the State Legislature being unable to cope with such forces. The feeling had taken root that even the State governors were nominated from time to time by a small group of friends in a secret meeting in a St. Paul hotel.

Hence the canvassers for the new party found the farmer's mind prepared for insurrection, both political and economic. And since the canvassers themselves were receiving a liberal commission on each membership sold, they developed some skill in salesmanship. Membership dues were raised to $\$ 9$ a year, and later to $\$ 16$ for two years. Soon 40,000 farmers in North Dakota were enrolled. This was enough to control both nominations and elections of candidates. The North Dakota Legislature in 1919 enacted into law the complete League program with a $\$ 17,000,000$ bond issue back of it, the major part of which program was as follows: (1) State-owned flour mills and terminal elevators, financed by $\$ 5,000,000$ of State credit; (2) State loans to home builders, land purchasers, and others, financed by $\$ 10,000,000$ of State credit; (3) a state-owned and operated bank, financed by $\$ 2,000,000$ of State credit; (4) control of education transferred to board of five persons, three of whom to be appointed by the Governor; (5) a State printing bill, having to do chiefly with the country press, and providing that one paper only in each county receive official public printing; (6) an Industrial Commission of three members - the Governor, Attorney General, and Commissioner of Agriculture and Labor-to have charge of the State Bank, the State Elevators, the State Flour Mills, and all other State business enterprises.

The League spread into fifteen States during its first four years. In 1919 it had three members of Congress from North Dakota. It also maintained a complete propaganda machinery, consisting of three daily papers, some forty or fifty weeklies, and an able corps of paid speakers. With its income of several millions of dollars it was able to carry on an organized campaign such as few other political parties were ever able to do. Its wealth and its success drew to it the usual army of camp followers seeking only the loaves and fishes. Its decline began in 1920 .

Farmers' Parties in the Past.-(1) The National Farmers' League, in the year 1891, was active in twenty-eight States. This 
was an era of great activity, economic and political, among farmers' organizations. The League above named came out, finally, as a distinctly political party. In this form it speedily disappeared from sight. (2) The Populist Party. The Farmers' Alliance of the Middle West and South at about this same time attained to great numbers and strength, working for economic reforms, particularly coöperative stores. However, by the year 1892, it had entered politics under the name of "People's Party." The Populist Party, as it was generally called, elected many State and a few Congressional candidates for office. Some of its reforms were abandoned

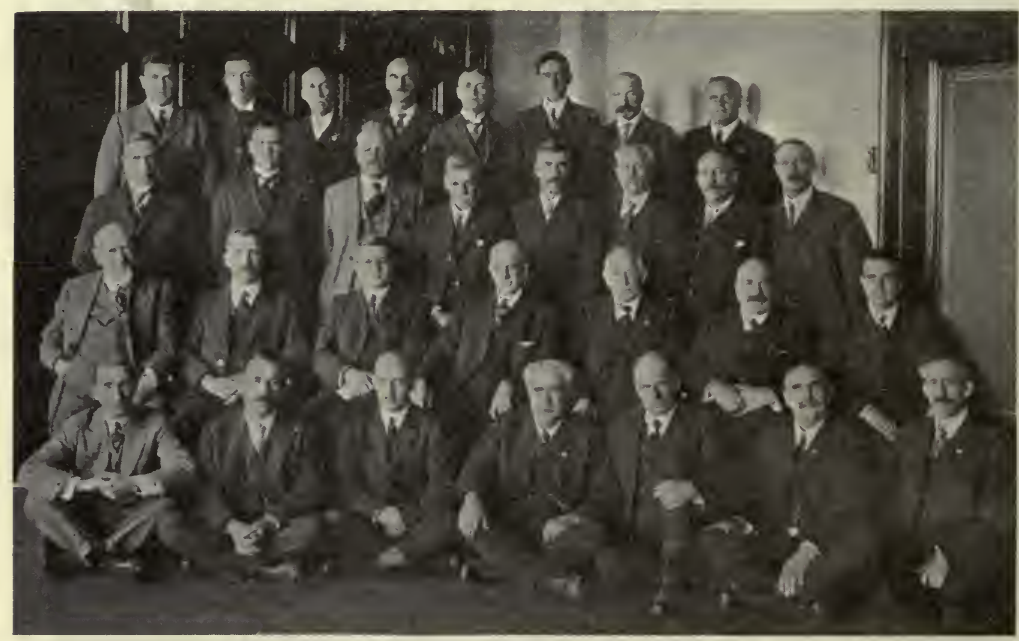

Frg. 53. - The Canadian Council of Agriculture, composed of four delegates from each of the following organizations: United Farmers of Alberta, Saskatchewan Grain Growers' Association, Manitoba Grain Growers' Association, Saskatchewan Coöperative Elevator'Co., United Grain Growers, United Farmers of Ontario, United Farmers' Coöperative Company of Ontario, Grain Growers' Guide.

as either impracticable or ahead of the times; others were adopted by the dominant parties. Hence the Populist party disappeared as suddenly as it had risen.

Canadian Council of Agriculture.-The careful reader of this chapter, who is familiar with our economic and political history, has already compared agricultural organizations with labor organizations in the United States, as to aims and methods. The two outstanding labor organizations since the Civil War have been the Knights of Labor and the American Federation of Labor. The Knights of Labor entered politics in order to secure the reforms they wanted. That is, they aimed to nominate and elect candi- 
dates to public office. The Knights of Labor disappeared entirely as a labor organization. The American Federation of Labor for nearly forty years has gained steadily in strength and power, and has at the same time kept out of politics. This Federation seeks to secure legislation by asking for it, not by nominating and electing candidates to public office. The Federation speaks for two million or more organized dues-paying laboring men, and hence its voice is heard by the national and State lawmakers. This statement concerning the American Federation of Labor may help to make clearer the aim and methods of the Canadian Council of Agriculture.

The Canadian Council of Agriculture is a Parliament-of the farmers, by the farmers, and for thefarmers (Fig. 53). It holds two regular sessions a year at Winnipeg, where it maintains permanent offices in charge of a paid secretary (Fig. 54). The Council is composed of four representatives from each important provincewide farmers' organization. In the year 1919 the membership was 36 , representing four educational and propaganda organizations, three coöperative commercial organizations, one farmers' newspaper, and one association of women, as follows: (1) United Farmers of Alberta, (2) Saskatchewan Grain Growers' Association,

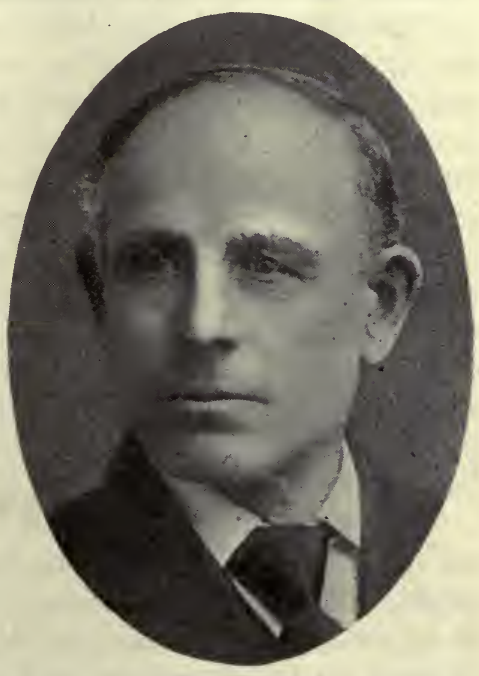

FIG. 54.-Roderick McKenzie, one of the organizers of the United Grain Growers, the Grain Growers Guide and the Canadian Council of Agriculture. First Secretary of the Canadian Council of Agriculture. (3) Manitoba Grain Growers' Association, (4) United Farmers of Ontario, (5) Saskatchewan Coöperative Elevator Company, (6) United Grain Growers, (7) United Farmers' Coöperative Company of Ontario, (8) Grain Growers' Guide, (9) Canadian Farm Women's Interprovincial Association. The Council began, in 1909, solely as the representative body of the educational organizations. But it lacked funds with which to finance any important activities or services. Accordingly, in the year 1916, the great coöperative trading companies of the grain growers were admitted to membership, and a per capita fee of 25 cents charged. These trading companies, of course, included almost the identical farmers who 
composed the educational associations. At this time the Council took on new strength and vigor, and issued its first "Farmers' Platform." This platform, endorsed by the constituent organizations, was an expression of the farmers' views upon economic, political and social questions. It was a scheme of reforms for benefiting not merely farmers but wage earners, artisans, professional men and tradespeople. This platform calls for tariff reform and a complete abandonment of the protective policy; taxes to be imposed on unimproved land value, on incomes and on inheritances; nationalization of railways, telegraph and express companies; natural resources to be developed by the government through a leasing system; the initiative, referendum, and recall; publicity of campaign contributions; abolition of the patronage system; each Province to have autonomy in liquor legislation (to the end that federal laws might not impede local prohibition); woman suffrage in any Province to confer automatically woman suffrage in federal elections. Although the farmers' movement in Canada began in a struggle to improve conditions in the grain trade, this platform contains no mention of the grain trade. This is conclusive evidence of the farmers' success in solving the grain trade problem, themselves, through coöperation, In 1918 a new platform was drawn up, embodying these same principles excepting those which had been enacted into law by the Parliament at Ottawa.

The aims of the Canadian Council of Agriculture are five, as set forth in its Constitution, namely, (1) to encourage the farm population of the Dominion of Canada to organize for the study of educational, economic, social, and political problems having a bearing on the happiness and material prosperity of the people. (2) To constitute in itself a medium through which the various organizations in membership may act collectively where their common interests are concerned. (3) To establish a bureau for the collecting and disseminating of statistics and other information bearing on rural welfare. (4) To provide unity of action on matters of common interest to the organizations in membership and to formulate demands for legislation and present the same to the Parliament of Canada. (5) To investigate methods of taxation for providing national revenue and disseminate information thus secured through farmers' organizations.

The achievements of the Council have been substantial. Many of its planks have been enacted into legislation. But more important is the fact that it has been the farmer's voice. It does not take a psychologist to recognize the truth that when the farmer 
is silent in the face of real or imagined wrongs, he becomes gradually more bitter and rancorous in his heart, ready to follow any demagogue or radical leader who can recite to him the story of his wrongs, until, finally, like a giant blindfolded, he strikes out wildly and madly at he knows not what. And monopoly, or the semblance of monopoly in high places, whether economic or political, is to the farmer an intolerable tyranny. The Canadian Council of Agriculture has furnished farmer leadership for the rank and file of the farmers themselves. Under this leadership, the farmer feels that he counts in the state, that he is significant, that he has a voice that not only is heard but is heeded. A member of the Council summed up its achievements in these words: "There can be no doubt that the Council has become an important factor in moulding the public life of Canada. And we confidently look forward to its exercising an ever increasing influence in all that makes for the well-being of the people."

Problems to Face.-Farmers' organizations have done enough experimenting thus far to bring out in sharp outline some very definite problems. Assuming that we are to have more rather than fewer farmers' organizations in the future, an early consideration of the problems and a policy towards them are necessary for the farmers and for all others interested in a broad way in a permanent and prosperous agriculture. This chapter is therefore concluded with a brief statement of a few of these problems.

(1) How Secure Political Reforms? - Shall the farmers imitate the Knights of Labor, and enter directly into political action as a class? Or shall farmers imitate the American Federation of Labor, leaving the nomination and election of candidates to existing parties, but standing for a definite program of legislation? In American political evolution class parties have been considered inimical to the general welfare, and have, thus far, accomplished but little.

(2) How Secure Economic Reforms?-In the labor world, the farmer may study various efforts at economic reform, such as "direct action," the strike, syndicalism, socialism, limitation of output, and the collective bargain.

Already in several cases farmers' organizations have used the strike with success. ${ }^{9}$ Syndicalism is roughly paralleled in those cases where the farmers have secured the collective ownership and operation of certain enterprises. Collective action (coöpera-

9 This is notably true in the so-called "milk war" in the Chicago District in 1915, and in the New York District in 1916 and in 1919. 
tion) is now very common in the marketing of farm products; it is not common in the field of production of farm products.

Limitation of Output.-There is no close parallel here between farmers' unions and labor unions. Limitation of output has been practiced in a few cases by a few unions; limitation of output by farmers really means a shifting of output. Thus the southern planters in the season of 1919 made a gigantic campaign to limit the cotton acreage. This limitation of output of cotton was misunderstood and even condemned by many. However, while it meant less cotton, it meant more corn, more hogs, more hay-all of which products the South consumed in great quantities. "Limitation of output" in this sense of the word is not only wise, but necessary, if the farmers are ever, collectively, to remove some of the "anarchy" now existing in the coördination of supply to demand.

Collective Bargaining.-Collective bargaining is now a common method of adjusting wages, hours, and conditions in several of the larger labor unions of the country. The United Mine Workers of America have repeatedly demonstrated the wisdom and value of this orderly and democratic way of industrial functioning. The farmer is just now beginning to use this method. But since he is not selling his labor for "wages" but his crop for a "price," he has already come into collision with the law against "price fixing." Hence collective bargaining by farmers is not making much head against the present legal status of this method of adjusting price. However, if there is one place above all others where the farmer feels he is the silent victim of a system of tyranny, it is exactly here in the field of price making. It is inevitable, therefore, that the courts and the legislators will adjust the law to fit economic evolution. Collective bargaining is now in successful use by farmers in many different places. A conspicuous example is that of the Dairymen's League and the large milk distributors of New York City. A few steps have been taken towards this goal by the big meat packers and the farmers in the various live-stock associations. However, the federal and State anti-trust laws are such as to cause hindrance and delay in actually carrying on collective bargaining by farmers.

(3) How Secure Leadership?-In one sense the farmers seem to be victims of the vicious circle-unable to produce real farmer leadership without organizations and unable to produce farmers' organizations without leadership. While the farmer is blest with a large amount of able, unselfish leadership from the ranks of 
those not farmers, yet it is doubtless true that he would be better off if he had more leadership from the rank and file of the farmers. An ideal "Council of Agriculture of the United States" would produce exactly this kind of leadership.

\section{QUESTIONS ON THE TEXT}

1. Describe and comment on the meeting of the bankers' committee on agriculture in Washington in 1919.

2. In what sense is it true that the farmers are not mobilized?

3. What are the two general methods of farmers' organizations securing benefits?

4. Which method has the Grange used, and with what success?

5. Show to what extent labor and capital are organized. Compare agriculture.

6. Cite the ease of mobilization by the Credit 'Men's organization.

7. Show the difficulty of classifying farmers' organizations.

8. According to two farm paper investigations, what organizations are rendering effective service to their communities?

9. Give examples of farmers' organizations coming under each of the following three classes: Federation; national; local.

10. Discuss in detail the Farmers' National Headquarters; the National Board of Farm Organizations; the American Federation of Farm Bureaus.

11. What national organization of farmers is over fifty years old?

12. Discuss the following points concerning the Grange: present status; origin and history; second rise to power; economic program; achievements of the Grange; relation to the so-called "granger laws."

13. Discuss scope and methods of local farmers' organizations.

14. Discuss in detail the Nonpartisan Political League.

15. What is the experience of farmers' parties of the past?

16. Discuss in detail the Canadian Council of Agriculture, and compare with Knights of Labor and American Federation of Iabor.

17. What problems of organization now face the farmers?

18. How ought farmers secure political reforms? Economic reforms?

19. Show the merits and defects of the following economic devices in organized agriculture: strikes; syndicalism; limitation of output; collective bargaining.

20. How shall farmers secure farmer leadership?

\section{QUESTIONS SUGGESTED BY THE TEXT}

1. Prepare a short history of each of the five national farmers' organizations.

2. Do we need an agrarian party?

3. Discuss the achievements of the agrarian party in Germany.

4. Would an agrarian party in this country be classed as radical or conservative?

5. How should a federation of all agricultural interests be effected?

6. Discuss the 1919 movement in the South to limit the cotton acreage.

\section{REFERENCES}

1. Atkeson, T. C.: "History of the Grange."

2. BUCK, S. J.: "The Grange Movement."

3. Butterfield, Kenyon: "Chapters in Rural Progress," Chicago, 1907, pp. $136-162$.

4. Commons, John R., et. al: "Documentary History of American Industrial Society," Vol. 10 , Nos. $1,2,3,4,5,6$. 
5. Coulter, John LeE: "Organization Among the Farmers of the United States." Yale Review, New Haven, November, 1909.

6. Darrow, J. Wallace: "History of the Grange." Chatham.

7. Drayton, C. O.: "Farmers must be Coöperators." Equity Textbook. Equity Union Publishing Co., Greenville, Illinois, 1914.

8. "Grain Growers' Textbook." Published by Equity Coöperative Exchange, Fargo, North Dakota, 1911.

9. "Grain Growers' Textbook, No. 2." Published by Equity Coöperative Exchange, St. Paul, 1916.

10. "Industrial Commission Report," Vol. 10, p. ecclxi.

11. Lansdon, W. C., Coöperation: "History, Necessity, Methods." A Textbook for Kansas Coöperators. Farmers' Union Library, Vol. 1, No. 1, Salina, Kansas, March, 1915.

12. Martin, E. W.: "History of the Grange Movement, or the Farmers' War Against Monopoly."

13. Michell, H.: "The Grange in Canada." Bulletin of the Department of History and Political and Economic Science in Queen's University, Kingston, Ontario, Canada, No. 13, October, 1914.

14. Pierson, Charles W.: "Rise and Fall of the Grange Movement; The Outcome." Popular Science Monthly, December, 1887, 199-208; 368-373.

15. "Proceedings of the Annual Sessions of the Farmers" National Congress of the United States." Published by the Secretary, 204 Second St., S. E., Washington.

16. "Proceedings of National Farmers' Association." Published by the Secretary, Waukesha, Wisconsin.

17. McVey, Frank L.: "The Populist Movement." Economic Studies, Vol. 1, No. 3, 1896.

18. Boyle, James E.: "The Agrarian Movement in the Northwest." American Economic Review, Vol. 8, September, 1918, pp. 505-521.

19. Gaston, Herbert: "The Nonpartisan League."

20. "National Milk Producers' Federation." American Economic Review, Vol. 7, No. 4, Dec., 1917. By-Laws of -See Marketing and Farm Credits (Chicago, 1916), 430-432.

21. "American Society of Equity." Grain Growers' Guide, April 11, 1917.

22. DREw, - "The Present Farmers' Movement." Political Science Quarterly, Vol. 6, 282-310, 1891.

23. Moorhouse, Hopkins: "Deep Furrows" (Coöperation among grain farmers of Canada).

24. Peffer, Senator: "The Farmers' Defensive Movement," Forum, Vol. 8, 463-473, 1889.

25. WALKER, - : "The Farmers' Movement." Annals, Vol. 4, 790$798,1894$.

26. Bailey, L. H. (Editor): "Cyclopedia American Agriculture," Vol. 4.

Ch. 7, 276-354.

27. Herron, L. S.: “An American Farmers' Movement." The Farmers' Union. Grain Growers' Guide, Feb. 19, 1919, 7.

28. For Farmers' Organizations in Other Lands, see International Review of Agricultural Economics, Rome.

29. Pearson, Raymond A.: "Agricultural Organizations in European Countries," Department of Agriculture, Albany, Bulletin 66, Dec., 1914.

\section{APPENDIX}

Principal Farmers' National Organizations, Giving Name and Address of Official

1. American Society of Equity, The Equity News, Milwaukee, Wis.

2. Equity Union, Equity Union Exchange, Greenville, Ill.

3. Farmers' Educational and Coöperative Union of America. No national 
organ. The following are state or local organs: Farmers' Union, Salina, Kans.; Pacific Farmers' Union, Spokane, Wash.; Colorado Union Farmer, Denver, Col.; Farmers' Union Messenger, Ft. Worth, Texas; Nebraska Union Farmer, Omaha, Neb.; Iowa Union Farmer, Columbus Junction, Iowa; Union Helper, Mt. Vernon, Ill.; James River Clarion, Lynchburg, Va.

4. Gleaners, Gleaner and Business Farmer, Detroit, Mich.

5. Patrons of Husbandry, National Grange Monthly, Springfield, Mass.

6. National Milk Producers' Federation (no organ).

\section{Federaiion of Farmers}

7. American Federation of Farm Bureaus (no organ).

\section{Political Organizations}

8. Nonpartisan League, Nonpartisan Leader, St. Paul, Minn.

The Farmer in Business. - "The farmer's interest in the great staple crops of cereals, cotton, wool, sugar beets, sugar cane, hay, beef and pork ceases when he sells the crop. Because orange and apple growers, some truck growers and milk and dairy producers have developed somewhat in marketing enterprises, all consumerdom has undertaken to say, and, worse than that, to really think that the farmer can market his products to consumers.

"Mr. Hamilton talks and thinks about buying food direct from the producers. He would have considerable trouble in buying sugar of the sugar beet grower; or flour of the wheat grower, or pork of the hog raiser. He tried a few years ago to help start a "farmers" " market in his city, and along with several hundred other business men is now unable to understand why it has "degenerated" into a "huckster's" market. That mental hiatus has functioned again.

"The facts are that the farmer who is really farming, working out a wellconsidered plan for farm operation which accounts for every day and every acre; work for his men, rain or shine; and work for his stock and his machinery which will make each individual item self-sustaining, has no time, no surplus energy, no talent and no training for selling. He does not wish to subject himself to the disagreeable features of peddling, or selling over the counter. His life habits are directed to production and sale in bulk. Mr. Hamilton would not think of turning his sales over to the foreman of his machine shop, but he would do worse when he expects the successful farmer to enter the selling game. And if a group of farmers unite and hire a salesman, and provide facilities for distribution, it is an open question if they can-or will-market and distribute their products at any economy over the present competitive distribution system."- "What Mr. Hamilton Doesn't Know," by T. C. Atkeson, Washington Representative of the National Grange. The Nation's Business, October, 1919, p. 26. 


\section{CHAPTER XX}

\section{STATE AID}

THE preceding chapter discussed certain attempts at self-help by organized farmers, and pointed out both the failures and successes of these efforts. State aid is that form of aid, direct or indirect, which is given the farmer by the government. There are two sources of state aid, that coming from the State government and its local divisions, and that from the Federal government. The real aim of all state aid is to make the farmer independent of state aid, able to take care of himself, able to walk alone without leaning on his government. State aid takes many and various forms: some, direct financial aid; some merely regulatory, such as the pure food laws; some, purely educational. Only the more prominent forms of state aid can be discussed here.

Direct State Aid.-This is a form of state aid which has been discredited in many times and places, and yet which just as constantly reappears in one form or another as though it were something new. Space is lacking to give a detailed history of each State's experiences in this field. The record of one State must serve as typical for the other States. Hence the State of Kansas is selected, being the geographic center of the country. Kansas experimented repeatedly with subsidies for the promotion of certain crops, and for the development of industries for the further utilization of crops. The following cases illustrate this practice:

Silk.-To encourage the planting of mulberry trees and the growing of silk-worms the State of Kansas enacted a law in $1887 . .^{1}$ Ten years later the attempt was abandoned as a failure.

Sugar Beets.-To encourage the growing of sugar beets in Kansas, a law was passed in 1887 providing for a bounty of two cents a pound for all beet sugar made in the State from beets grown in the State. ${ }^{2}$ This gave the industry quite a spurt. In 1891 the bounty claimed and paid was over $\$ 50,000$. In 1891 the rate of the bounty was cut to $\frac{3}{4}$ of a cent a pound. This "infant industry" was not yet able to walk alone. In a few years the bounty was entirely removed. A further decline in the industry followed, and in 1897 the last piece of beet sugar machinery was sold and sent into Nebraska where the business was still on its

${ }^{1}$ Laws of 1887, chapter 231.

${ }^{2}$ Laws of 1887, chapter 231. 
feet. However, in 1901, interest in the sugar beet was again aroused, and so the State Legislature provided a bounty of one dollar a ton on all sugar beets grown in the State. The hope of home sugar factories was abandoned. A limit of $\$ 5,000$ in any one year was set to the beet bounty. Sugar bounties paid on beet sugar made in Kansas were as follows:

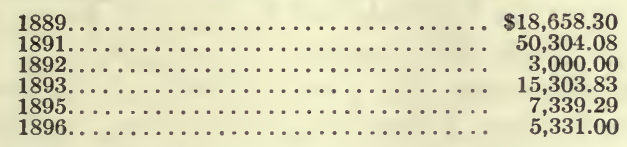

Kansas laws were frequently enacted at the request of local districts, to permit them to grant direct aid to agriculture. The following are typical cases:

The city of Burlingame, Osage County, was authorized to vote $\$ 25,000$ in bonds to aid in establishing a woolen mill in that city. ${ }^{3}$

Smoky Hill Township, McPherson County, was authorized to aid in erecting a flour mill with a subsidy of $\$ 6,000{ }^{4}$

All counties of over 30,000 population were authorized to subsidize the construction of starch works up to $\$ 41,000$ each county. ${ }^{5}$

Kentucky Township, Jefferson County, was authorized to grant a subsidy to a flour mill to the amount of $\$ 10,000 .^{6}$

Haskell County was authorized to grant a subsidy of $\$ 1$ an acre for breaking sod in that county, the limit to be $\$ 10,000 .^{7}$

Cimarron Township, Gray County, was authorized to subsidize the building of a flour mill. ${ }^{8}$

This same legislature authorized ten flour mills and three other private enterprises.

The legislature of 1893 authorized two townships to vote $\$ 5,000$ each in aid of flour mills. The 1895 legislature authorized one township to grant a $\$ 3,000$ subsidy in aid of a flour mill. The State Auditor's bond register for 1900 shows the following grants: Gray County, $\$ 15,000$ for a beet sugar mill and $\$ 8,000$ for a flour mill and $\$ 2,000$ for a cheese factory; Hamilton County, $\$ 4,000$ for a flour mill; West Plains township in Meade County, $\$ 15,000$ for a beet sugar mill.

Not only did these subsidized industries all fail, but in many cases the County or District voting the bonds defaulted in the

${ }^{3}$ Laws of 1870 , chapter 36.

${ }^{4}$ Laws of 1872 , chapter 85.

${ }^{5}$ Laws of 1873 , chapter 33.

- Laws of 1873 , chapter 48.

7 Laws of 1889, chapter 154.

${ }^{8}$ Laws of 1891 , chapter 44. 
payment of interest or principal of these bonds. The enterprises were so unsound that private capital refused to have anything to do with them. It is usually such experiments that clamor loudest for public funds. The later history of these Kansas subsidies is reflected in the adjustments and settlements found necessary. Thus the Cimarron township, Gray County, mentioned above. In 1897 the State of Kansas held in her permanent school fund $\$ 15,000$ of the flour mill bonds, due in 1902 . In the statute pertaining to this case are these words:" "Whereas, the said city of Cimarron has a bonded indebtedness of $\$ 55,000$ and a floating indebtedness of about $\$ 10,000$, and is in default of interest due on bonds more than $\$ 15,000$, making a total indebtedness of $\$ 80,000$, and the property of all kinds in said city has an aggregate assessed valuation of only $\$ 31,351$, and said city is insolvent and unable to pay but a small per cent of its indebtedness ... therefore ... the mayor and council of said city desire to scale indebtedness of said city down to a sum upon which they can pay interest and ultimately pay the principal." And permission was granted to scale down the debt. The city of Anthony, Harper County, went through a similar experience twice, so hard was it to learn the lesson that credit is a two-edged sword, to be used with care. ${ }^{10}$ In 1896 the commissioners of Lane County formally declared the county insolvent, and issued instructions to the county treasurer to refrain from further payments of interest on the bonded indebtedness.

Kansas, in common with other States, fully demonstrated the inherent and fundamental unsoundness of using public credit in direct aid to agriculture. It was a mere delusion to the farmer and a curse to the community experimenting with it.

General State Aid.- State aid to agriculture has taken such a multiplicity of forms that it is impossible to make even a catalog of it in one single chapter. In general, it may be said that education, since the famous Morrill Act of 1862, represents the largest of all single investments of State funds in agricultural matters. This educational outlay has vastly expanded, covering teaching, research, and extension work by State agricultural colleges and Experiment Stations. Agricultural education has also been extended into city high schools in many sections, and also into county agricultural high schools, and into congressional district

${ }^{9}$ Laws of 1897 , chapter 178.

${ }^{10}$ Laws of 1897, chapter 178; also Commercial and Financial Chronicle, New York, February 20, 1897. 
agricultural schools in some sections. This teaching for many years aimed to help the farmer produce more and better crops. In late years a new viewpoint has been gained, and education goes beyond the "making of two blades of grass grow where only one grew before": much attention is given to the marketing of crops; to financing and warehousing and transportation problems; to home economics, including the economic, civic, sanitary, esthetic mental, moral, and physical well-being of the family. The socalled "extension" work has shown the most rapid expansion of any form of education. It is a form of propaganda whereby experts and specialists go out from educational centers and meet the people that need their services.

State Department of Agriculture and the Police Power.-State aid to agriculture very early took the form of exercising the police power in protecting animals from disease and plants from insect pests. The destructive power of the foot-and-mouth disease of cattle, of cholera among hogs, of glanders among horses, and of other diseases among other animals taught the need of quarantine regulations and of State administrative boards such as live-stock sanitary commissions, State veterinary boards, and so on. Similar protective and regulative measures were administered in the realms of fruits, vegetables, and general farm crops. Anti-weed laws, pure food laws, pure drug laws, pure paint laws, and similar statutes have greatly increased in number in recent years. Pure seed laws in still more recent years have appeared, as have likewise laws concerning commercial fertilizers, commercial feeding stuffs, and laws on cold storage warehouses. The administration of such regulations has been left, in most States, to a State Department or Commissioner of Agriculture.

Farmers' Institutes.- In some cases under the State Agricultural Department, in others under the guidance of the College of Agriculture, so-called Farmers' Institutes are now held in most States. These consist of a group of meetings in which speakers from outside the community, as well as local talent discuss important agricultural topics. They are a valuable open forum for the discussion of vital topics.

Federal Government Aid.-Federal aid to agriculture comes mainly through two channels, namely, the United States Department of Agriculture, and financial aid given to State institutions for teaching, research, and extension.

The Department of Agriculture.-The history of the Department of Agriculture may be briefly stated in connection with the 
three historical dates, 1839, 1862, and 1889. (1) In the year 1839 Congress made the first law recognizing the need to agriculture of any attention from the Federal government. An appropriation of $\$ 1,000$ was voted for the "collection of agricultural statistics and for other agricultural purposes." This money was expended by the Commissioner of Patents, for he was the only individual in the Government manifesting any interest in the subject of agriculture. Hence the whole agricultural "department," such as it was, remained in the Patent Office till the year 1862.

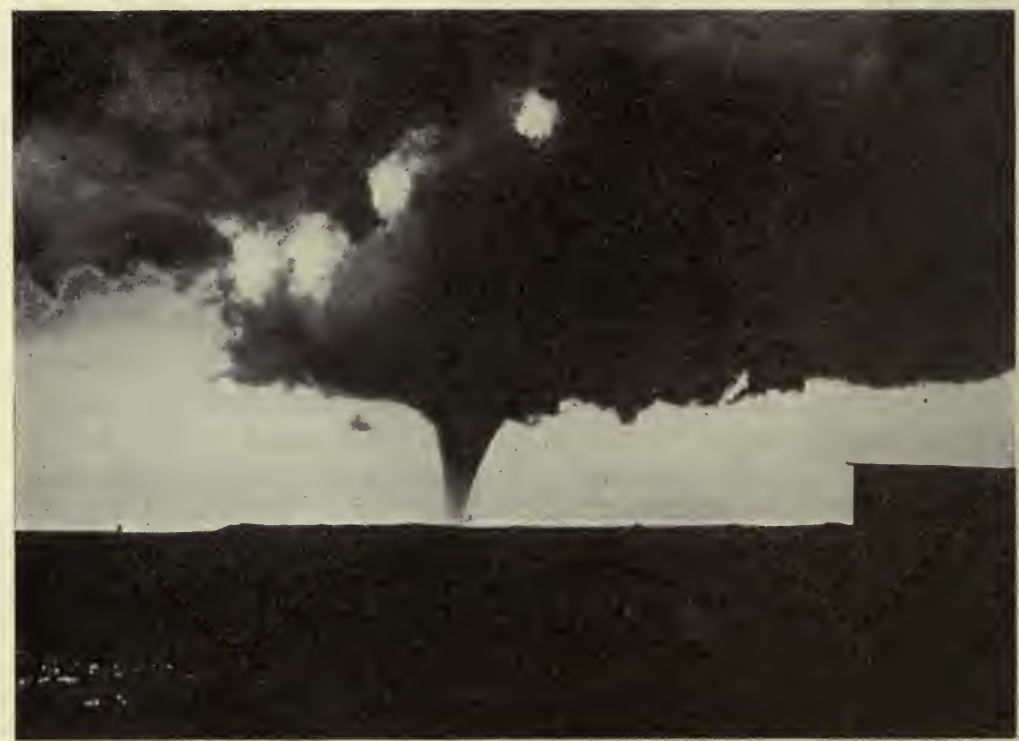

Frg. 55.-Tornado near Isabel, S. D., June 25, 1914. (U. S. D. A.)

The organic act of 1862 gave the country its present Department of Agriculture, although it was not till later under a Secretary with a cabinet position. The organic act provided for a "Commissioner of Agriculture" to preside over the new department. His duties were "to acquire and to diffuse among the people of the United States useful information on subjects connected with agriculture in the most general and comprehensive sense of that word, and to procure, propagate, and distribute among the people new and valuable seeds and plants." He was also directed to make practical experiments in agriculture. With this substantial beginning, the department rapidly expanded, its work branching out into the fields of plant and animal diseases, insect pests, farm crops, live 
The Bureau of Plant Industry deals chiefly with combating plant diseases of all kinds - a work of very great economic importance (Fig. 57). It also deals with crop acclimatization and fiberplant investigations, sugar plant studies, cereal investigations, seed testing, foreign seed and plant introduction, and with "free seed distribution." The last-named function is one which the farmers are asking to have discontinued.

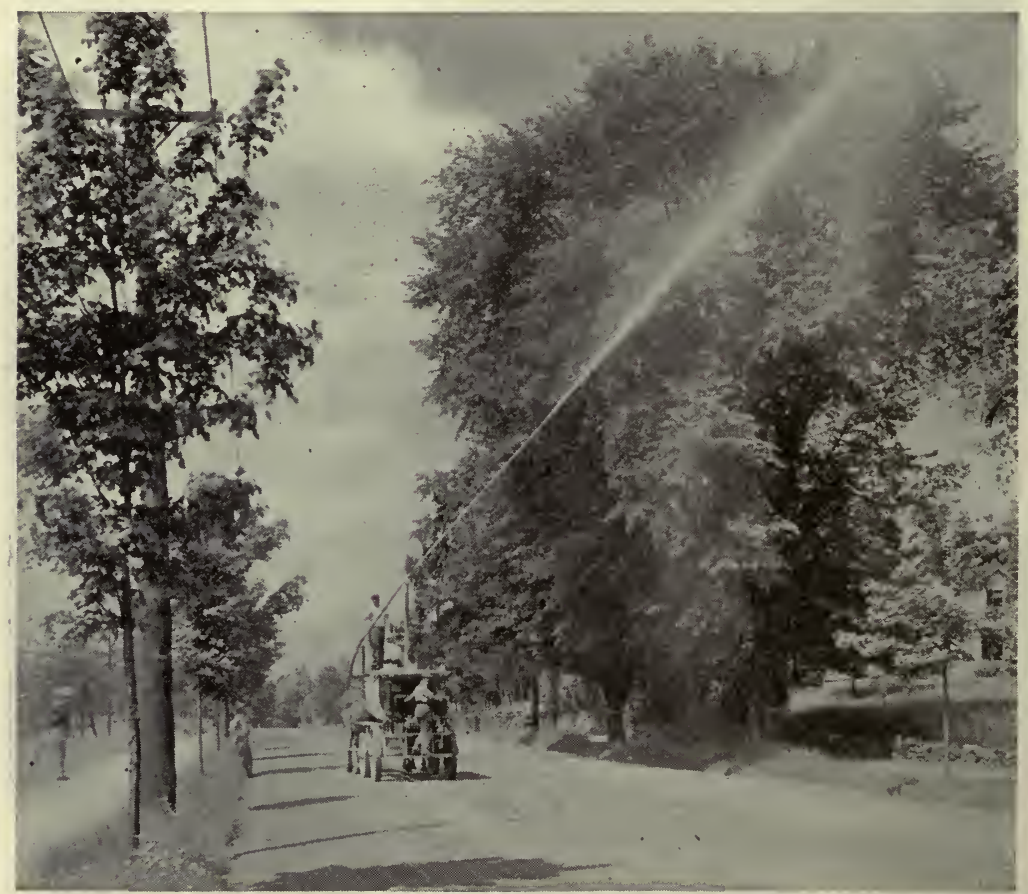

FIG. 57.-Testing out a new spray.

The Forest Service has charge of the utilization, protection (Fig. 58) and development of the National Forests, now comprising hundreds of millions of acres. The work also covers investigations into methods of preserving timber, testing of woods, and educa. tional work in matters of forestry.

The Bureau of Chemistry devotes about half its energy to enforcement of the Food and Drug Act (usually called the "pure food law"). Chemical investigations are made for other departments of the government. Its work also touches the bureaus of plant industry and of soils (Fig. 59). 
The Bureau of Soils conducts chemical and physical investigations of soils, seeks new sources of natural fertilizers, particularly potash; and makes soil surveys in the different States.

The Bureau of Entomology is chiefly engaged in combating insect pests, and coöperates in many ways with the Bureau of Plant Industry. Campaigns are waged against the gipsy and brown-tail moth, the boll-weevil, Hessian fly. and against various insect carriers of plant diseases.

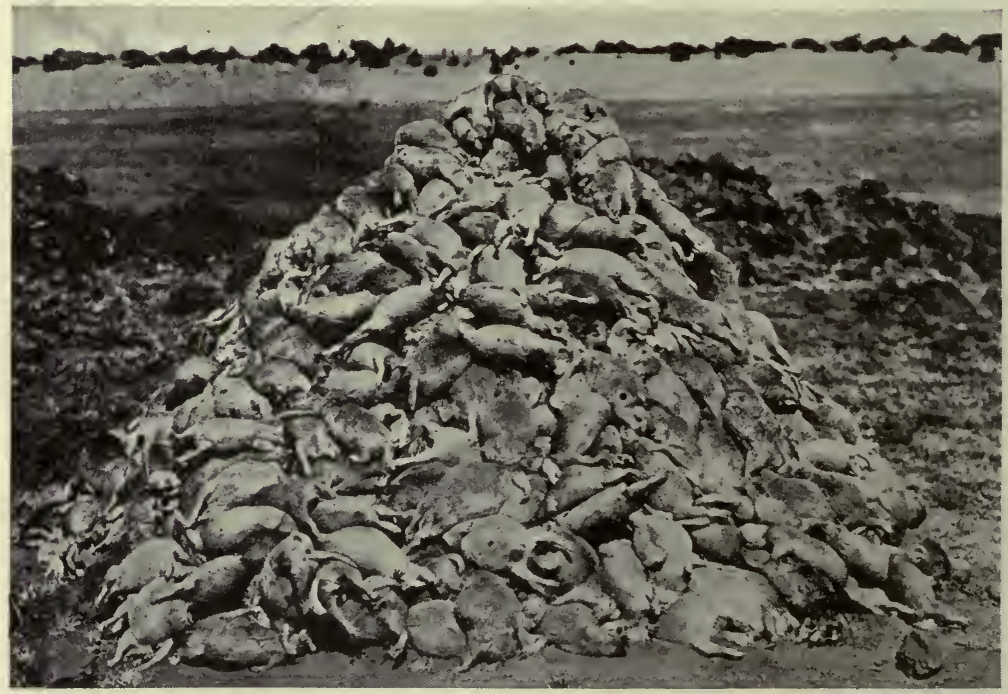

FIG. 60.-Results of poisoning operation by assistants of the Biological Survey in Arizona. On 320 acres 1641 prairie dogs were collected after one night's operation. Total cost of the extermination, including labor, $\$ 9.79$. (U.S. D. A.)

The Bureau of Biological Survey has charge of the enforcement of the Lacey Game Act, and the administration of the seventy Federal bird reserves and five large-game preserves. Protection is given to wild ducks, and other migratory birds, and to big game. It also experiments with destruction of animal pests (Fig. 60).

The States Relation Service is the bureau in charge of the supervision and control of federal funds expended through the State Agricultural Colleges for the purposes of Research and Extension. Under the four acts mentioned below (1862, 1887, 1906, 1914) this bureau has a very important and far-reaching service to perform, owing to the centralizing of so much power over State education in a few hands at Washington (Fig. 61). 
The Office of Home Economics began with food questions, but soon widened its scope to include household management and equipment, and family welfare.

The Bureau of Public Roads and Rural Engineering was created primarily to carry on investigations in regard to systems of road management, road construction and maintenance, road materials, farm irrigation, drainage, domestic water supply, construction of farm buildings, and miscellaneous rural engineering problems. The "Good Roads" movement throughout the United States received much aid and backing from this bureau (Figs. 62 and 63).

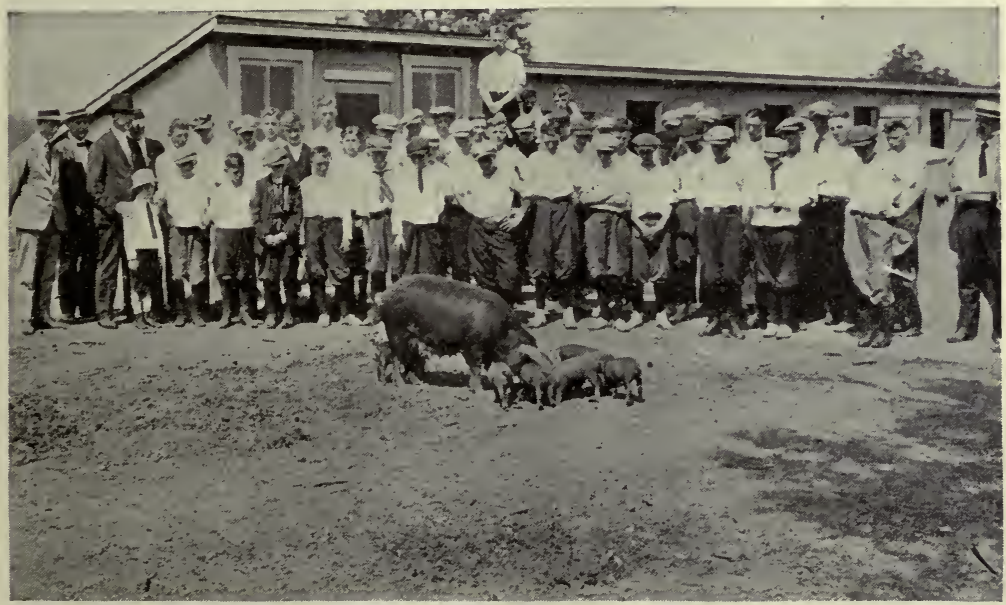

Fig. 61.-Pig demonstration at a boys' short course. Maryland College of Agriculture.

The Bureau of Markets deals with the problems of agricultural distribution, transportation, warehousing, grading, packing, coöperative marketing, rural credits, and coöperative purchasing (Fig. 64). It has charge of the Cotton Futures Act, the Grain Standards Act, the Warehouse Act.

The Office of Farm Management covers the field of general agricultural economics (except marketing), including studies of cost of production, farm organization, farm finance, insurance, taxation, farm labor, drift to cities, housing, agricultural history and geography, land utilization and settlement, land tenure, farm life studies, and coöperation.

The Bureau of Crop Estimates collects and publishes periodically crop and live-stock estimates. The grain trade has now come to place great reliance on the crop estimates gathered by this 
bureau through its nation-wide corps of volunteer crop reporters. The "Monthly Crop Reporter" issued by this bureau is also a source of valuable market information (Fig. 65).

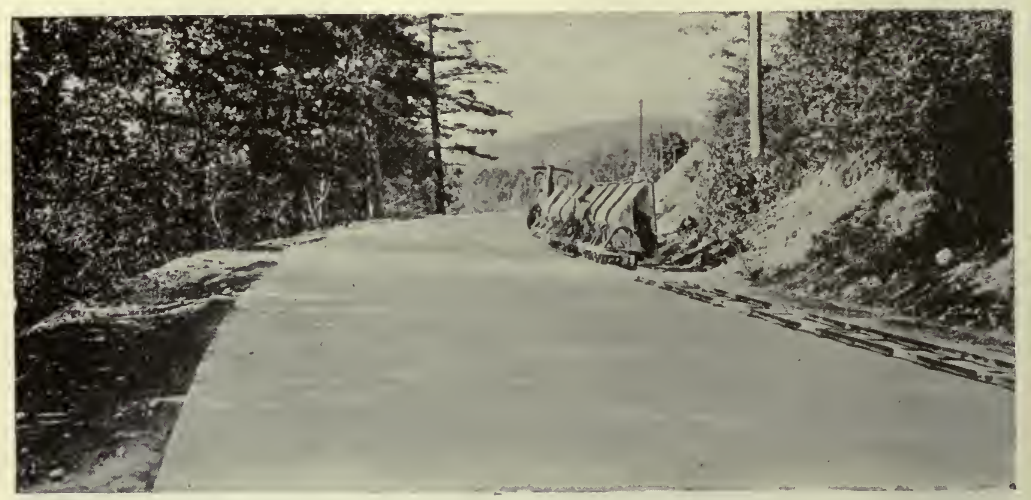

FIg. 62.-Road construction. (U. S. D. A.)

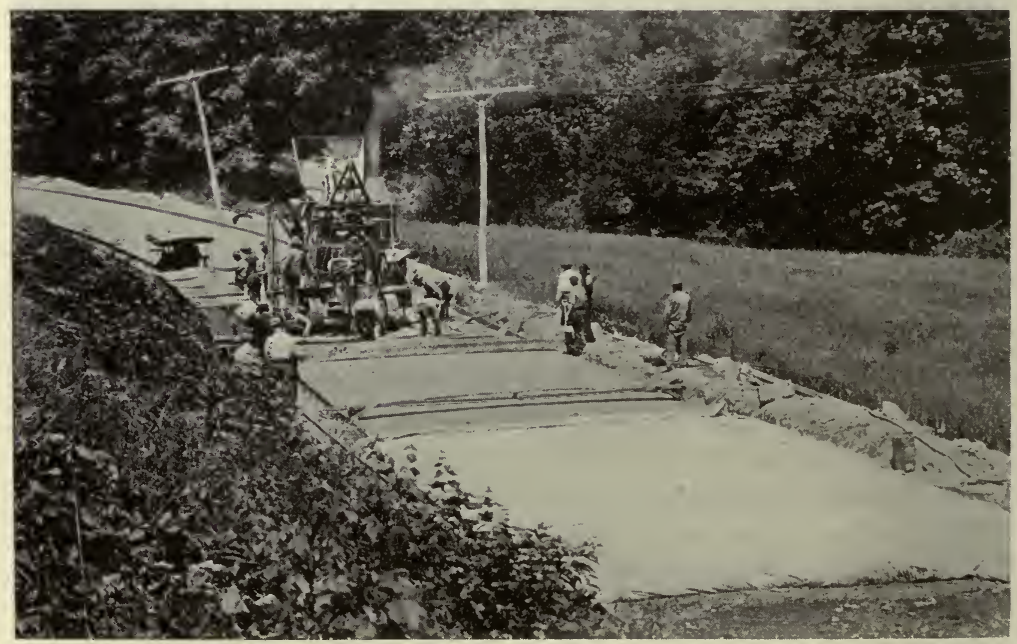

FrG. 63.-Road construction. General view of plant in operation. Note method used in covering concrete, also small number of men used. (U. S. D. A.)

Five federal laws dealing in a broad way with agricultural education mark the nation's increasing recognition of the basic importance of a prosperous agriculture. These five acts are in brief, as follows: 
(1) Morrill Act, I862.-This is the law which established in the United States the so-called "Land Grant Colleges," or State Colleges of Agriculture. Thirty thousand acres of land for each Senator and each Representative in Congress was set aside as a permanent fund for the endowment and maintenance of at least one agricultural college in each State.

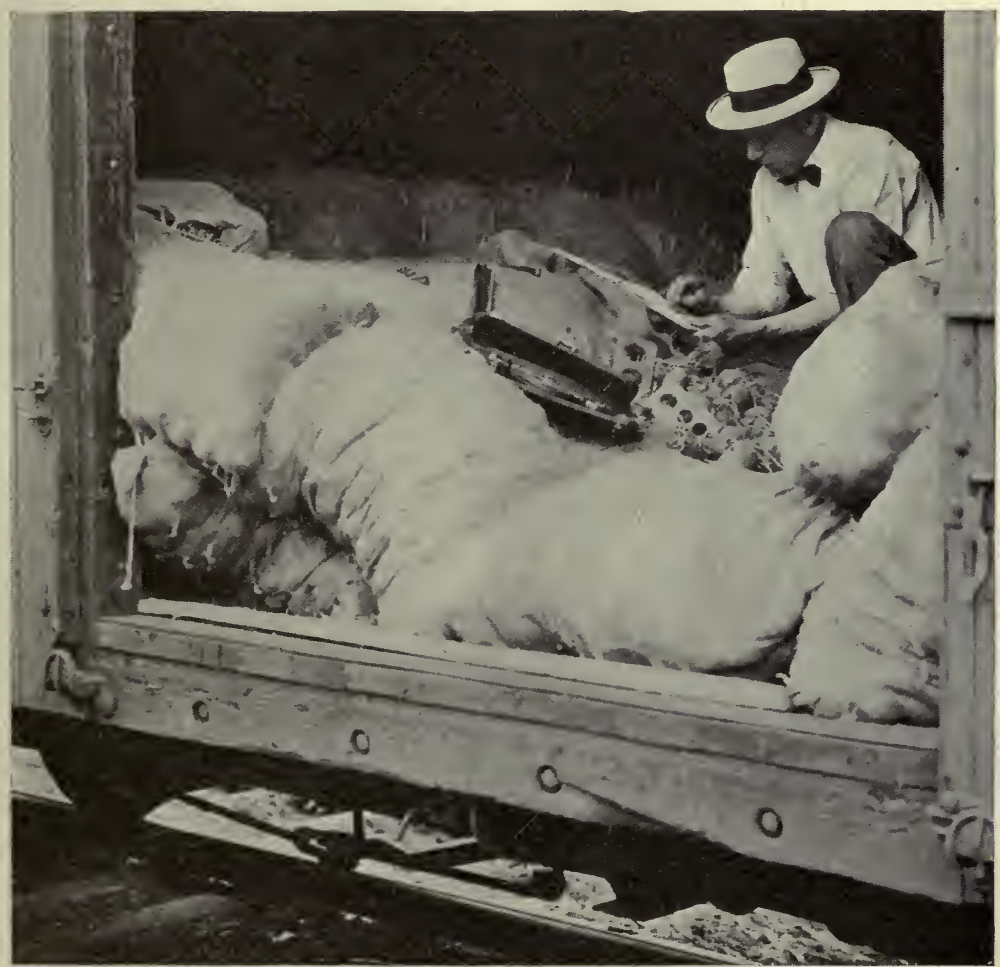

FIG. 64.-Government inspector examining potatoes rejected by buyer.

(2) Hatch Act, I887.- This law established federal Experiment Stations in connection with the Agricultural Colleges created by the 1862 law.

(3) Adams Act, I906.-This act makes an increase in the federal aid granted to Experiment Stations, under the Hatch Act.

(4) Smith-Lever Act, I9I4. ${ }^{1}$ - This act provides in detail a comprehensive scheme for federal supervision and control of

${ }^{1}$ For funds available to each State under this Act, see Appendix 1 of next chapter. 
moneys expended by the agricultural colleges under the Hatch and Adams Acts, and under this Act, in order that the Federal Government may be in constant touch with these institutions. This act organizes on a vast scale the extension work of the colleges. The work is on a coöperative basis, both as to financial support and as to control, each particular project being mutually agreed upon by the college and the Secretary of Agriculture and approved in advance. The college thus becomes the organizing

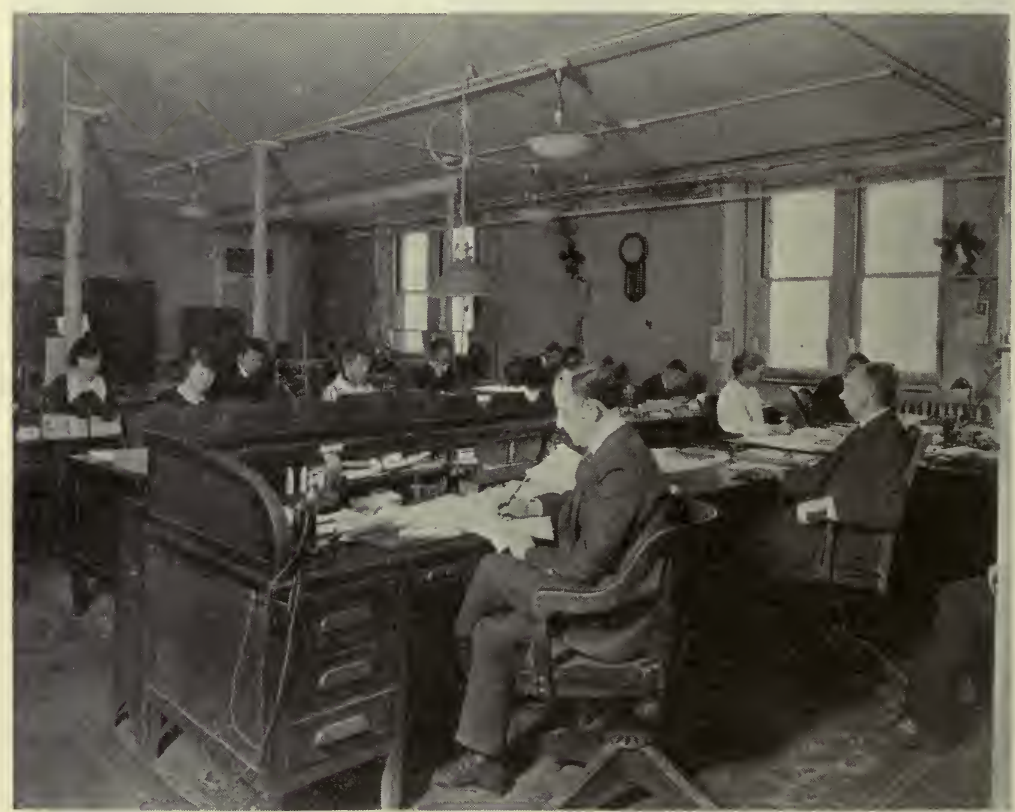

FIG. 65.-County section, division of crop reports, Bureau of Crop Estimates, expert tabulators and computers, who work up returns from 3000 county reporters who report crop and live-stock conditions in their respective counties. This constitutes one source of information upon which the government crop reports are based.

center for the extension work, which now has four principal forms, namely, (a) county agricultural agents; (b) boys' and girls' clubs; (c) extension specialists, who coöperate with the county agents in influencing the rural population directly; $(d)$ home economics, which is work for the farm women and the farm home.

(5) Vocational Education Act of I9I7.- This act appropriates money for the support of vocational education of secondary grade in agriculture, home economics, and industry. The act provides a scheme of coöperation between the Federal Government and the 
States. Under this act the Federal Government does not propose to undertake the organization and immediate direction of vocational training in the States, but does agree to make from year to year substantial financial contribution to its support. It undertakes to pay over to the States annually certain sums of money and to coöperate in fostering and promoting vocational education and the training of vocational teachers. The grants of Federal money are conditional and the acceptance of these grants imposes

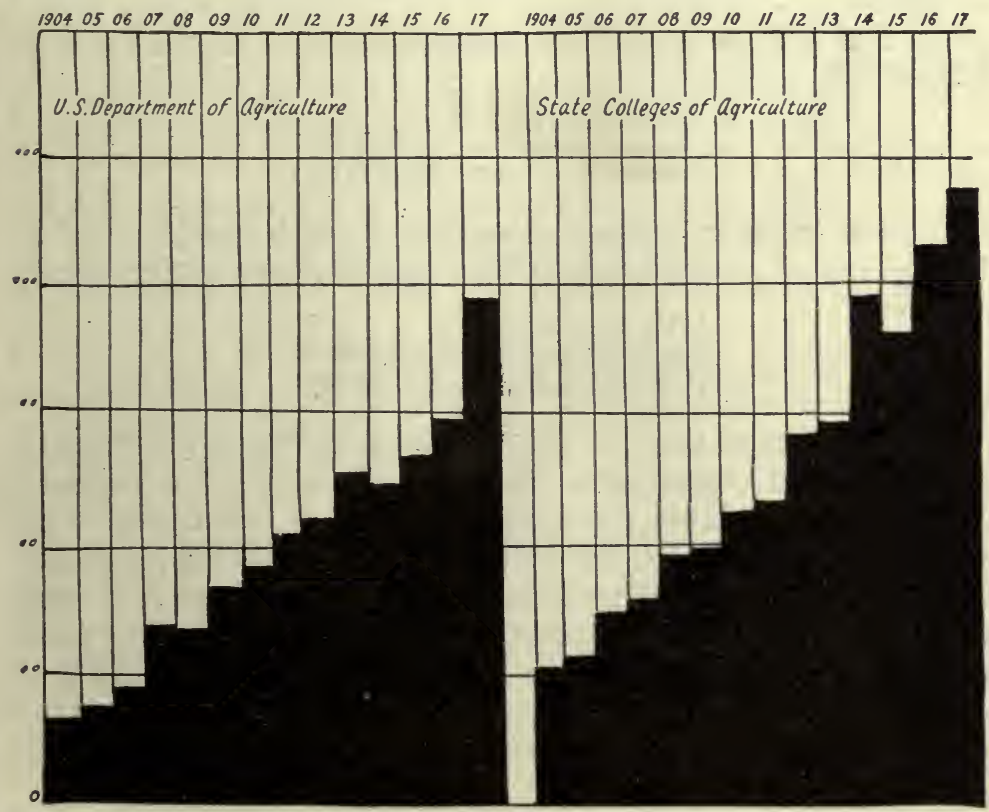

Fra. 66.-Federal Government appropriations to the United States Department of Agriculture and to the state agricultural colleges, for the fourteen years, 1904-1917.

on the States specific obligations to expend the money paid over to them in accordance with the provisions of the act. The State must show the kinds of vocational education for which it is proposed that the appropriations shall be used, and the kinds of schools and the equipment of the schools in which the instruction is to be given. The State must set up courses of study, methods of instruction, and qualifications of teachers who are to give such instruction.

Every dollar of Federal funds must be matched by a dollar of State or local funds, or both. 
The administration of these funds represents a chain of three links as follows: Local School-State Board-Federal Board for Vocational Education.

This form of administration leaves initiative with the local school and the State Board.

Money is appropriated for three kinds of education, namely, agriculture, home economics, trades and industries.

The Federal appropriation for agriculture under this act is as follows:

(a) For salaries of teachers, supervisors, and directors of agricultural subjects:

\title{
$1917-18-\$ 548,000$
}

Increases annually to $1925-26$

$1925-26$, and after- $\$ 3,027,000$

(b) For training teachers, a portion of which shall be used for the training of teachers, supervisors, and directors of agriculture:

\author{
$1917-18-\$ 546,000$ \\ Increases annually to $1920-21$ \\ $1920-21$, and after- $\$ 1,090,000$
}

Other Forms of Aid.- In addition to the federal aid through the Department of Agriculture and through the five acts named above, there are other forms of aid, more or less direct, which should be mentioned. They are the Federal-aid Road Act, which means more good roads for the farmers; the Farm Loan Act, which means to the borrowing farmer a system of cheap money based on first mortgages on the farmer's land; the International Institute of Agriculture at Rome, furnishing basic information on agricultural questions, a share of the expense of which is borne by the United States.

Success of State Aid.-State aid of a purely educational nature has proved an unmixed blessing to the farmer. State aid in the form of a direct cash bounty or subsidy has failed to achieve success. State aid in organizing farmers into groups for collective action, particularly marketing associations, has been attended by both success and failure. The danger in state aid of this kind is that it may be overdone, especially when in charge of an enthusiast, since farmers are quite easily led to form organizations. This is particularly true when little or no capital is involved. However, more and more experience is being gained in this field by the state agencies interested, and after the experimenting is done, doubtless much sound state aid can be given to farmers in the 
way of forming needed organizations, or preventing the formation of unnecessary organizations.

To repeat what has already been said, state aid must not be a substitute for self-help. It must be a mere temporary way of helping the farmer help himself, of tiding him over a difficulty till he can take care of himself.

\section{QUESTIONS ON THE TEXT}

1. Show the multiplicity of forms which state aid to agriculture takes.

2. Define direct state aid.

3. Give an account in detail of the Kansas experience in aiding the following: silk; beet sugar; woolen mills; flour mills; starch; sod breaking; cheese factories. Show final outcome of this policy of direct aid.

4. Show in general the extent and growth of state aid in education.

5. Show functions of State Departments of Agriculture under the police power.

6. Explain administration and functions of Farmers' Institutes.

7. Give a history of the United States Department of Agriculture, with special reference to the dates, 1839, 1862, 1889.

8. Name each Bureau or Division of the Department of Agriculture and show its main functions.

9. Explain scope and meaning of these five federal acts: Morrill Act; Hatch Act; Adams Act; Smith-Lever Act; Vocational Education Act.

10. Show how federal aid to agriculture is extended through other acts referring to good roads and rural credits.

11. What has heen the success of state aid?

12. Show correct interrelation of state aid and self-help.

\section{QUESTIONS SUGGESTED BY THE TEXT.}

1. To what extent should the administration of agricultural education be centralized at Washington? To what extent should extension work be controlled by (1) County, (2) the State, and (3) the Federal Government?

2. To what extent should both support and control of agricultural education be left to each State?

\section{REFERENCES}

1. Atreson, T. C.: "Semi-centennial History of the Patrons of Husbandry." New York, 1916.

2. BAILeY, Liberty Hyde: "The State and the Farmer." Presidential address before the Association of American Agricultural Colleges and Experiment Stations at Lansing, Michigan, May 28, 1907. Privately printed, Ithaca, New York, 1907.

3. Boyle, James E.: "The Financial History of Kansas." Bulletin of the University of Wisconsin, No. 247, Madison, 1908.

4. CAFFEY, Francis G.: "A Brief Statutory History of the United States Department of Agriculture." Cases and Comment, Rochester, New York, February, 1916; March, 1916.

5. Davis, BenJamin Marshall: "Agricultural Education in the United States." Chicago, 1912.

6. "Farmers' Institutes-A Historical Sketch of." Yearbook of Agriculture, Washington, 1903, pp. 149-159.

7. "Federal Board for Vocational Education," Washington. First Annual Report, 1917. Later reports annually. 
8. "Industrial Commission Report," Vol. 10, pp. ccclxviii-ccelxxx; Vol. 19 , pp. $193-200$.

9. International Institute of Agriculture, Rome. The following three monthly bulletins, published by the Institute contain information on the subject of this chapter. 1. "International Crop Report and Agricultural Statistics." 2. "International Review of the Science and Practice of Agriculture." 3. "International Review of Agricultural Economics."

10. "The Experiment Station Record," published monthly by the Department of Agriculture, Washington. This is the best publication dealing with the activities of the various experiment stations. It also contains abstracts of articles dealing with agriculture published in all countries.

11. "The Land Grant of 1862 and the Land Grant Colleges," Bulletin No. 13, Bureau of Education, Washington, 1918.

12. Yearbook Department of Agriculture: 1897- "Work of the U. S. Department of Agriculture for Farmers;" 59-279. 1899- "Agricultural Education in the U. S.," 157-190; 1899--"Agricultural Experiment Stations in the U. S.," 513-548; 1903- "Farmers' Institutes" (historical sketch), 149-159; 1911 - "Some Results of Farmers' Coöperative Demonstration Work," 285294; 1918- "Following the Produce Markets," 277-289.

13. Donaldson, T.: "The Public Domain" (Washington, 1884).

\section{APPENDIX}

List of Publications Issued by the Department of Agriculture, Washington, D. C.

1. Farmers Bulletins-for free distribution.

2. Departmental Bulletins-technical.

3. Circulars-miscellaneous subjects.

4. Serials: (a) Journal of Agricultural Research; (b) Experiment Station Record; $(c)$ The Monthly Crop Reporter; $(d)$ The Weekly News Letter-for Department employees and crop reporters; (e) Monthly Weather Review; $(f)$ National Weather and Crop Bulletin; $(g)$ Snow and Ice Bulletin.

5. Yearbook of Agriculture.

6. Market News Service of the Bureau of Markets: (a) Reports on Foreign Markets for Agricultural Products; $(b)$ The Market Reporter; $(c)$ Market Bulletins (in season) dealing with fruits and vegetables; (d) Cold Storage Holdings; (e) Live-stock and stock-yards reports. 


\section{CHAPTER XXI \\ THE COUNTY AGENT}

The County Agent Movement.-The most significant movement in agriculture in America in the present generation is the County Agent movement. It is a movement which is closest to the farmer. It is a movement that has back of it, in most cases, a Farm Bureau composed of dues-paying farmers. The County Agent lives in the county among the farmers he serves. His work is therefore responsive to local needs and conditions, although done in coöperation with distant State and federal agencies. It is the movement which most effectively creates agricultural leadership, and is in turn directed by that leadership. And community leadership of the farmer, by the farmer, and for the farmer is the most vital need of the rural community.

Definition.-A County Agent is a person of agricultural education and experience employed in a county to promote the general welfare of agriculture in that county. For over fifty years the agricultural colleges of the country have been teaching and have been conducting experiments. Enough scientific information has thus been accumulated to revolutionize ágriculture and readjust rural home life and rural community life. But the teaching force and the printed bulletins proved wholly inadequate to carry to the people themselves this knowledge. The natural step, therefore, was to create an agency to make available to the farmers themselves the accumulated information and experience of the Federal Department of Agriculture, the State Departments of Agriculture, the State Colleges of Agriculture, the great private experimental farms, and the practices of the best farmers themselves. Accordingly the Federal Department of Agriculture, as a first step, under the leadership of Dr. Seaman A. Knapp, established throughout the South Demonstration Agents, to carry to the individual farmer suggestions, help, and advice. These itinerant teachers succeeded in having many farmers modify their farm management in the direction of diversification of crops, home gardens, deep plowing, use of fertilizers, better seed selection, and better relationships with bankers and merchants. What the individual farmers accomplished under this leadership, they did on their own farms, under their own conditions. It is a noteworthy fact that farmers are 
not impressed with what they see done on "demonstration farms," operated with public money and not on a self-sustaining basis. But they are impressed by what they do themselves. Hence the $\checkmark$ success of the Demonstration Agent in the South-he brought about a high degree of self-help. The County Agent movement was the second phase of this demonstration work, and soon spread to all parts of the country. Now there is one County Agent in nearly every one of the three thousand counties of the United States. The Smith-Lever Act of 1914 strengthened the basis of the work from both the financial and the administrative standpoint. It is to be hoped, of course, that as the movement strikes its roots into the soil, the central control from Washington may become less bureaucratic and the local control may become more dominant and develop more initiative.

Functions.-The function of the County Agent is to influence farmers by any and all wise means within his power, both as individual farmers and as groups of farmers. Primarily his aim is to increase the farmer's net income. He is also to serve as a protector of the farmer's interests in all legitimate ways. ${ }^{1}$ In a broader and more social way, he is to elevate and dignify country life and make it more worth while (Fig. 67).

Farm Bureau Defined.-A definition of a Farm Bureau formulated by the States Relation Service, although a lengthy one, is yet a comprehensive statement of the functions of such a bureau. ${ }^{2}$ It runs as follows:

"A County Farm Bureau is an association of people interested in rural affairs, which has for its objects the development in a county of the most profitable and permanent system of agriculture, the establishment of community ideals, and the furtherance of the well-being, prosperity, and happiness of the rural people, through coöperation with local, State and national agencies in the development and execution of a program of extension work in agriculture and home economics."

1 A County Agent in Clay County, Minnesota was approached by a creamery promoter, and offered four hundred dollars for his support in foisting a creamery on a non-dairy community. The County Agent advised the farmers not to organize the creamery, and. his advice was followed.

A County Agent in Lee County, Illinois, was asked by a farmer concerning the merits of a patent oats-smut treatment being sold by a solicitor. The County Agent advised that the "patent treatment" cost five times as much as, and required twice the work of the simple formaldehyde treatment, with no better results.

Fake schemes are becoming difficult to work among farmers, now that the County Agent has the agricultural forces mobilized for protection against frauds and fakes.

${ }^{2}$ Circular 13, Office of Extension Work, North and West, States Relation Service, January, 1919. 
The Farm Bureau, as defined in this manner, is the usual form of organization through which the County Agent functions. The Farm Bureau is composed of the representative farmers of the county, and contains, under favorable conditions, from 50 to 100 per cent of the farmers of the county in its membership. Membership dues are paid annually, ranging from one dollar to ten dollars per member. It is to be hoped that this local support will steadily increase in volume. The Farm Bureau adopts a definite community program and appoints necessary committees to effectuate the plans. The Farm Bureau is, therefore, a local institution, organized by

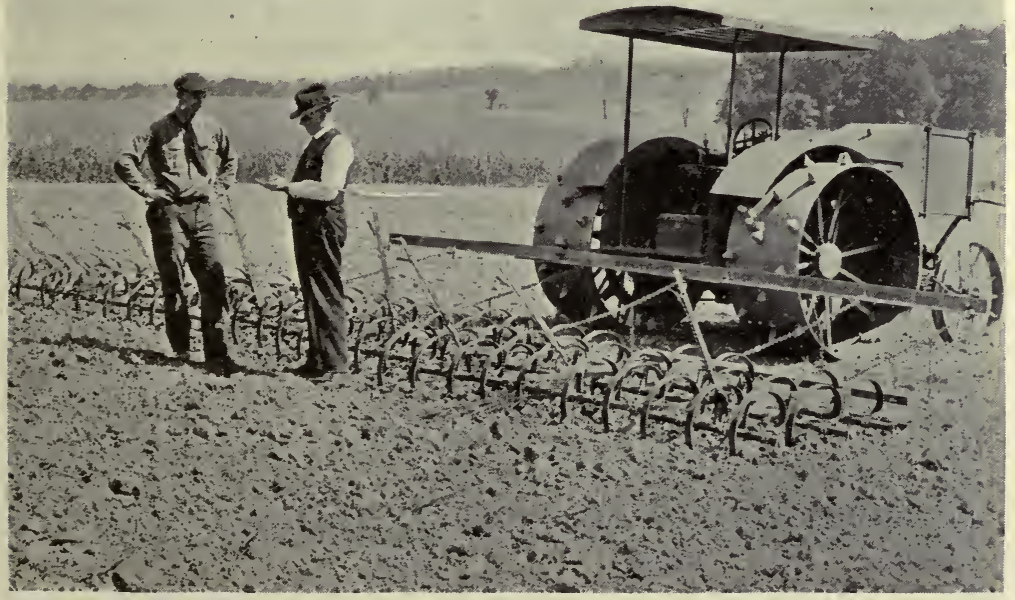

FIG. 67.-County agent and a farmer in conference in the field. Shows tractor attached to spring-tooth harrows in the background, Montgomery County, Md. (U. S. D. A.)

the people of the county. The Farm Bureau plan enables the community to carry out a wider program of community-effort than did the organized demonstration work in the South. The Board of Directors of the Farm Bureau chooses and appoints the County Agent and fixes his salary. The County Agent thus chosen must be approved by the State College of Agriculture (i.e., State Director of County Agents), if the Farm Bureau wishes to receive a share of the State and federal moneys for this form of extension work.

A wide-spread popular error concerning the County Agent was that his job was to give advice to the farmer. And since the County Agent is frequently more youthful than the farmer, this view of his functions was discouraging. The State Director of 
Farm Bureaus for New York State stated the functions of the Farm Bureaus to be, in the order of their importance, as follows:

1. The federation of all the existing agricultural forces and organizations in the county to a common purpose (i.e., schools, local granges, clubs, societies, etc.).

2. Agricultural leadership in its broad sense.

3. Organization of associations for better methods of production (e.g., cow testing, seed improvement, etc.).

4. Organization of marketing associations for both buying and selling.

5. The study of local economic needs of the county, that correct farm management practices may be demonstrated and introduced. important.

6. The giving of personal advice to farmers. This is last and least

7. General - "All these functions should be exercised with the point of view of increasing the financial profitableness of farming within the county by increasing the net income of farmers, and of making country life and work increasingly worth while in the larger sense." 3

These functions of the Farm Bureau are, strictly speaking, the functions of the County Agent, since he is the agent of the Bureau.

Finances.-The County Agent work is financed through three sources-federal, State and local. The local money comes in the form of dues from members of the Farm Bureau and from a tax on the property in the county. The State usually raises a fund for this work by a tax. The Federal Government, through its taxing powers, collects funds which are apportioned to the States on a basis of the rural population of the State. The Smith-Lever Act made the flat appropriation of $\$ 10,000$ per annum to each State. After the fiscal year 1915-1916 the grant under this act increases annually up to the year 1923, the maximum for that year and each year thereafter being a total of $\$ 4,580,000$. All grants above the first $\$ 10,000$ must be duplicated by the State, in order to entitle the State to receive the federal grant. The table in the appendix to this chapter shows the significance of these financial terms.

The cost of the County Agent to any individual farmer is but a small amount-a few dollars at most. Compared with what a laborer pays in annual dues to his union, the average farmer is contributing lightly to his Farm Bureau.

Growth of the Farm Bureau.-The very rapid spread of the Farm Bureau through the North and the West is shown by the following figures:

Dec. $1,1916 \ldots \ldots 287$ Farm Bureaus...... 98,654 members
Dec. 1, 1917....384 Farm Bureaus..... 161,391 members
June 30, 1918....791 Farm Bureaus....290,000 members

${ }^{3}$ Burritt, M. C., The County Farm Bureau Movement in New York State. Circular 93, Department of Agriculture, Albany, New York, 1914, p. 12. 
On the last date named above 29 of the 33 northern and western States were organized on the Farm Bureau Plan.

Home Bureaus.-The extension work in home economics has taken on such importance that it has gained recognition as being coördinate with the Farm Bureau. The situation is met by expanding the Farm Bureau to include home demonstration work, the representatives of the home economics work being added to the executive committee of the bureau. These representatives are influential farm women of the country, qualified for the work by their education, experience, and personality.

Boys' and Girls' Club Work.-A prominent place is now universally given to the work of boys' clubs and girls' clubs. A county representative of this club work, qualified by capacity for leadership, now has a place in the organization of the Farm Bureau in many States. In other words, the Farm Bureau program is easily expanded beyond the purely agricultural phases of the subject, so as to include home demonstration and boys' and girls' club work.

Some Difficulties Ahead.-The County Agent movement, in striving for "better farming"- that is, a greater production-will have the hearty coöperation of the various interests of the countymercantile, banking, transportation, etc. The same is true of work for better roads, better schools, better rural life conditions. However, in the field of buying and selling, the County Agent is likely to come into direct competition with certain interests already more or less well established. The pressure is so great on the County Agent to "do something" for the farmer in the field now occupied by the over-berated "middleman," that many County Agents are driven to their wits' end. Coöperative buying and selling enterprises form a legitimate and desirable field for farm activity, and in many instances have achieved conspicuous success. However, the death-rate of these enterprises is so high that the County Agent should proceed with caution in starting new ones. He ought to be reasonably assured in advance of the real need of the new undertaking, that the enterprise will have a large enough volume of business to make it worth while, that ample capital will be forthcoming to finance it in a purely business-like way, and that an able and honest manager is in sight to conduct the business through all the severe trials ahead of it (Fig. 68).

Pressure is also brought to bear on the County Agent to give marketing advice which is, in fact, the forecasting of prices. Since 
no one has yet been able to forecast price, the County Agent will be wise not to attempt it.

The County Agent is also under pressure to do actual marketing work for his clients - to sell their goods for them or to buy their supplies. This is a prostitution of his functions, for he is there to teach self-help, not to do the farmers' work for him. The end of such a course is disaster.

The agent will give all possible market information within his power, and direct the farmer to the various trade papers, to the federal and State market reports, and other sources of

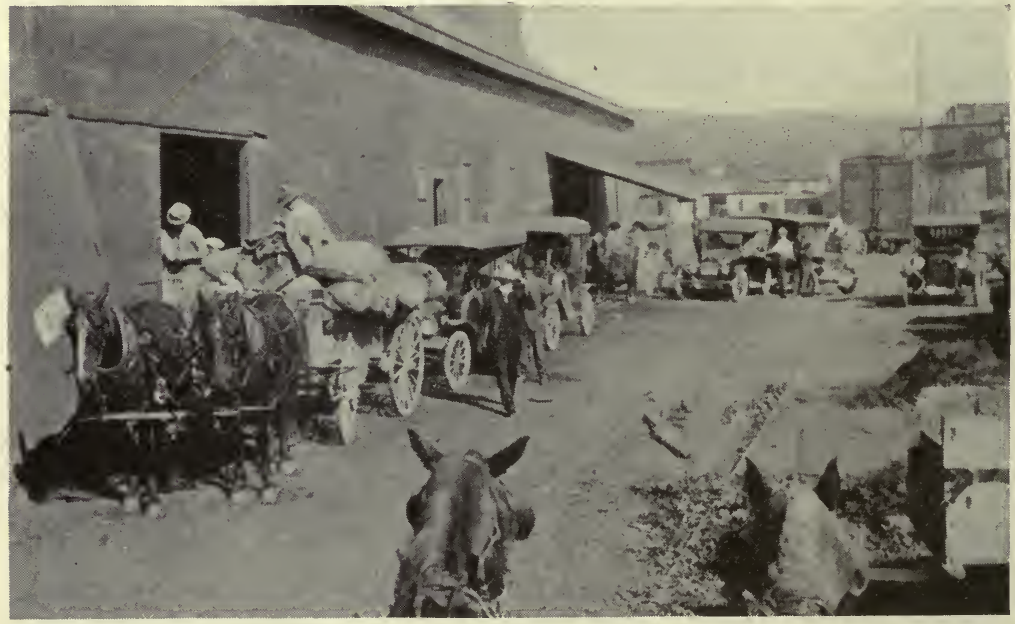

Frg. 68.-Marketing wool. Coöperative wool associations are formed by the County Agent. (U. S. D. A.)

information, and then he will let the farmer decide for himself how and when he shall use this information. In most cases of this kind, the daily market reports issued free by the United States Bureau of Markets will meet the farmer's need of up-to-date market news service.

The Middleman Question.-One neglected phase of "coöperation" may well receive the attention of the County Agent. In many cases farmers organize and bunch their buying or selling power, and hire one of their own number as manager. It would be equally coöperative, in many such cases, if these bunched buying or selling orders were turned over to some established dealer whose services and charges were deemed fair and satisfactory.

So much fiction has been written about the farmers' 35-cent 
dollar that rather extravagant hopes have been created in the breasts of farmers for reducing the "toll of the middleman." For the middleman, like the farmer, is working under competitive conditions, where easy and big gains are rare indeed, and where losses and failures are frequent. Hence, as stated above, the County Agent ought to proceed with caution in making farmers "their own middlemen."

\section{QUESTIONS ON THE TEXT}

1. Why is the County Agent movement the most significant movement in American Agriculture in this generation?

2. Define County Agent: Show the need of.

3. Trace the origin and growth of this movement.

4. What are the functions of a County Agent?

5. Give examples of farmers' interests being protected by County Agent.

6. Define Farm Bureau.

7. Show the advantage of the Farm Bureau plan over the original demonstration work plan.

8. How are County Agents chosen? How supported?

9. According to Mr. Burritt what are the functions of a Farm Bureau, in the order of their importance?

10. Explain the Home Bureau movement.

11. Discuss the Boys' and Girls' Club work.

12. What are some of the difficulties ahead of the County Agents?

\section{QUESTIONS SUGGESTED BY THE TEXT}

1. What should be the annual membership dues in a Farm Bureau? State reasons for and against $\$ 1$ dues; same for $\$ 10$ dues.

2. What is the ideal method of financing the County Agent movement?

3. In what manner can a County Agent secure a greater degree of coöperation between the agricultural and the other interests of his county?

\section{REFERENCES}

1. BurritT, M. C.: "A Community Farm Expert at Work and What He Has Done-The Organization, Methods of Work and the Results Obtained by the Farm Bureau at Binghamton, Broome County, New York, in Eighteen Months of Work-All lnterests Working Together-Great Value to the Community-Lessons to be Learned from this Successful Example." Tribune Farmer, New York, October 17, 1912.

2. BurRitT, M. C.: "The Farm Bureau Movement in New York State." Circular 93, State Department of Agriculture, Albany, 1914.

3. Crocheron, B. H.: "The County Farm Adviser." Circular 133, University of California, College of Agriculture, Berkeley, July, 1915.

4. "Farm Bureaus and County Agricultural Agents." Bulletin Massachusetts Agricultural College, Amherst, October, 1914.

5. Simons, L. R.: "Organization of a County for Extension Work-The Farm Bureau Plan." Circular 13, States Relation Service, Department of Agriculture, Washington, January, 1919.

6. Bulletin 60, Department of Agriculture, Albany, June, 1914. BuRriTT, M. C.: "The County Farm Bureau Movement in New York State." pp. 1594-1604. Robertson, F. E.: "A Brief Outline of the Jefferson County Farm Bureau Work," pp. 1604-1611. 


\section{APPENDIX}

Amounts of Federal Funds Available to the Several States Under the SmithLever Act.

\begin{tabular}{|c|c|c|c|c|}
\hline St & $\begin{array}{l}\text { Per cent that } \\
\text { rural } \\
\text { population of } \\
\text { state bears to } \\
\text { total rural } \\
\text { population* }\end{array}$ & $\begin{array}{c}\text { Maximum } \\
\text { amount each } \\
\text { state is entitled } \\
\text { to receive }\end{array}$ & \begin{tabular}{|c|}
$1917-18,1918-$ \\
$19,1919-20^{*}$ \\
$1920-21$ \\
$1921-22$ \\
For the above \\
fiscal years, \\
add each year \\
the amount \\
given below to \\
the total for \\
the immedi- \\
ately preceding \\
year
\end{tabular} & $\begin{array}{c}\text { For fiscal year } \\
1922-23 \\
\text { and thereafter }\end{array}$ \\
\hline 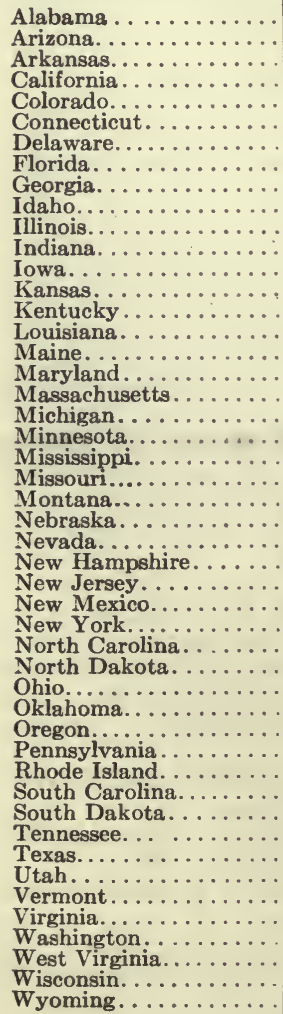 & $\begin{array}{l}3.58 \\
.29 \\
2.78 \\
1.84 \\
.80 \\
.232 \\
.13 \\
1.08 \\
4.19 \\
.52 \\
4.38 \\
3.16 \\
3.13 \\
2.43 \\
3.51 \\
2.35 \\
.731 \\
1.29 \\
.49 \\
3.00 \\
2.48 \\
3.22 \\
3.84 \\
.491 \\
1.79 \\
.14 \\
.36 \\
1.28 \\
.57 \\
3.90 \\
3.82 \\
1.04 \\
4.26 \\
2.71 \\
.741 \\
6.15 \\
.04 \\
2.61 \\
1.03 \\
3.53 \\
5.99 \\
.41 \\
.38 \\
3.21 \\
1.09 \\
2.01 \\
2.69 \\
.21 \\
\\
\end{array}$ & $\begin{array}{r}\$ 49,404 \\
13,147 \\
40,580 \\
30,236 \\
18,789 \\
12,563 \\
12,347 \\
21,898 \\
56,151 \\
15,702 \\
58,184 \\
44,729 \\
44,456 \\
36.686 \\
48,660 \\
35,839 \\
18,047 \\
24,203 \\
15.374 \\
43,005 \\
37,315 \\
45,438 \\
52,232 \\
15,412 \\
29,668 \\
11,529 \\
13,909 \\
24,043 \\
16,259 \\
52,979 \\
52,081 \\
21,431 \\
56,855 \\
39,802 \\
18,144 \\
77,637 \\
10,402 \\
38,768 \\
21,308 \\
48,870 \\
75,945 \\
14,468 \\
14,170 \\
45,323 \\
21,958 \\
32,130 \\
39,634 \\
12,290\end{array}$ & $\begin{array}{r}\$ 17,911 \\
1,431 \\
13,900 \\
9,198 \\
3,995 \\
1,165 \\
1,067 \\
5,408 \\
20,978 \\
2,592 \\
21,902 \\
15,786 \\
15,662 \\
12,130 \\
17,573 \\
11,745 \\
3,657 \\
6,456 \\
2,443 \\
15,002 \\
12,416 \\
16,108 \\
19,196 \\
2,460 \\
8,940 \\
695 \\
1,777 \\
6,383 \\
2,843 \\
19,536 \\
19,127 \\
5,196 \\
21,297 \\
13,547 \\
3,701 \\
30,744 \\
183 \\
13,076 \\
5,140 \\
17,668 \\
29,975 \\
2,031 \\
1,896 \\
16,056 \\
5,436 \\
10,059 \\
13,470 \\
1,041\end{array}$ & $\begin{array}{r}\$ 156,870 \\
21,730 \\
123,980 \\
85,424 \\
42,759 \\
19,554 \\
18,749 \\
54,345 \\
182,020 \\
31,254 \\
189,596 \\
139,442 \\
138,428 \\
109,466 \\
154,103 \\
106,309 \\
39,, 991 \\
62,936 \\
30,029 \\
133,016 \\
111,811 \\
142,086 \\
167,411 \\
30,172 \\
83,308 \\
15,699 \\
24,572 \\
62,341 \\
33,329 \\
170,195 \\
166,846 \\
52,607 \\
184,640 \\
121,081 \\
40,352 \\
262,101 \\
11,497 \\
117,223 \\
52,148 \\
154,873 \\
255,795 \\
26,655 \\
25,543 \\
141,659 \\
54,571 \\
92,484 \\
120,454 \\
18,541\end{array}$ \\
\hline & 99.988 & $\$ 1,580,000$ & $\$ 500,000$ & $\$ 4,580,000$ \\
\hline
\end{tabular}

* Figures after 1920 subject to returns of Fourteenth Census on rural population. 


\section{CHAPTER XXII}

\section{THE GRAIN TRADE}

International Nature of the Question. - The grain trade of the United States is not a national matter; it is an international matter. This is true for two reasons. The grain crop of foreign countries affects the prices received by the American farmer. Likewise, the crop of the United States affects the price received for grain by the foreign grower. For instance, the year 1915 was known as the bumper wheat crop year in the United States, the yield jumping to the unheard of figure of over one billion bushels. It was a season of prosperity for the American wheat grower. But the international aspect of this question is apparent when we turn to our competing neighbor in the South-Argentina. Our Daily Consular and Trade Reports of September 6, 1916, tell the following brief and significant story:

"Investigation of Grain Markets in Argentina."-"The Argentine Government recently appointed a commission to make an investigation of grain markets, with a view to protecting the interests of domestic growers and shippers. The report of this commission, as quoted in a recent number of the Revista Financiera y Comercial, showed that the present low price of wheat in Argentina is due chiefly to the extraordinarily large world production of wheat in the 1915-16 crop year. North America alone is able to supply nearly all the wheat needed in Europe, and the difference in freight does not permit Argentina to compete advantageously in this trade. The present wheat supply of Argentina is estimated at 1,500,000 tons, which is gradually being marketed."

This quotation illustrates the situation. A brief study of statistics makes the question yet clearer. Note, for instance, the world wheat crop-when it is harvested, where it is harvested, the quantity of it, the shortage in some sections and the surplus in others, and the consequent exportation and importation movements. Since both acreage and yield fluctuate widely from year to year, a table of facts of the above kind must represent only general average conditions. However, such a table is interesting and is worth while. Consequently such a table is herewith presented, for the convenience of the reader.

Wheat, as the following table shows, is being harvested some place every month of the year.

Among all agricultural crops of the United States; corn is first in value, as is suggested by the popular expression "Corn is King." 
World's Wheat Harvest; Where and When Harvested; Quantity (In Bushels)

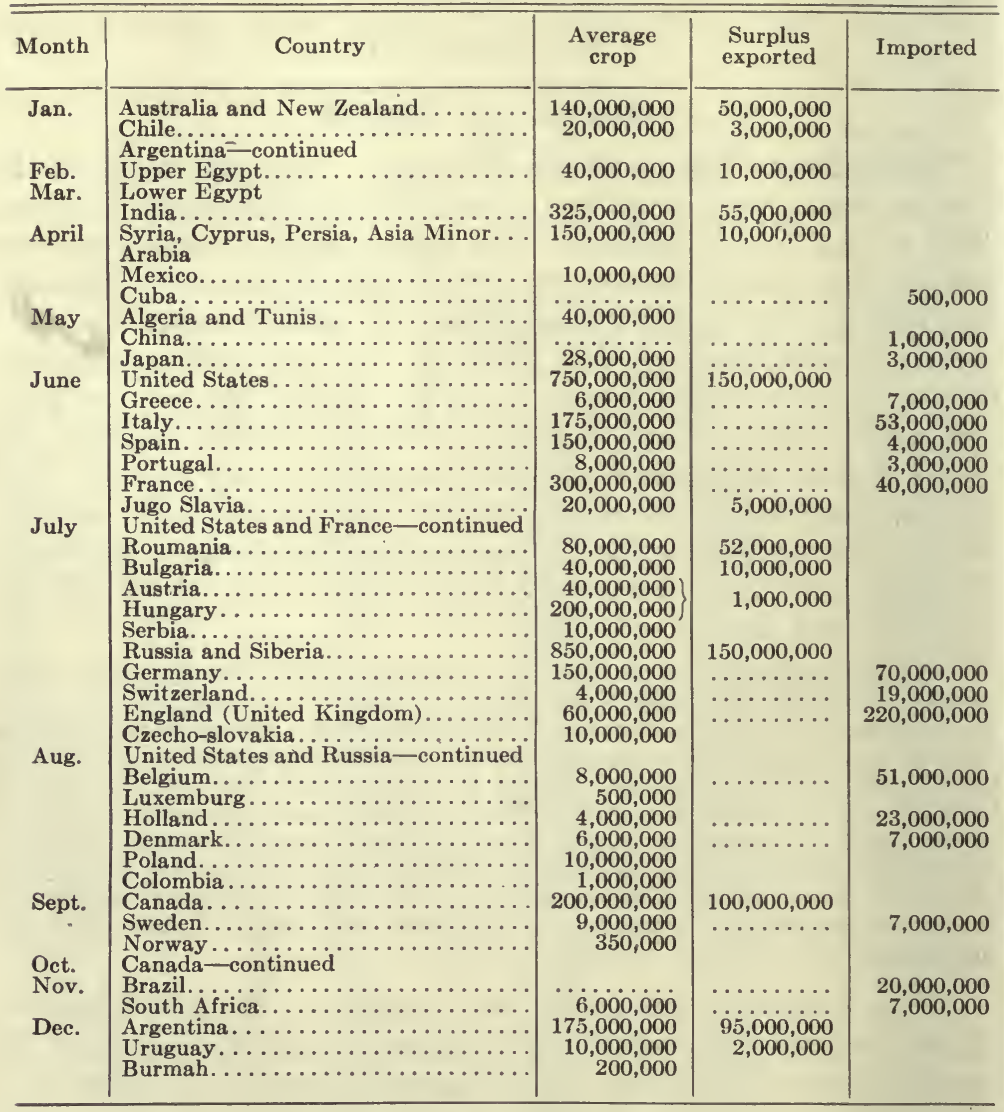

It is usual to rank cotton as second in value, considered from the standpoint of the farm value of the crop; on this basis hay is third and wheat is fourth; oats are fifth.

The brief table presented below shows the farm values for ten years of the five leading farm crops.

Corn from the marketing standpoint lacks the importance of wheat, since it does not figure largely in our exports, and since it is so largely consumed on the farm. Wheat of necessity must largely leave the farmers' hands. And although many writers and speakers have been announcing yearly, since 1870, that we are approaching a wheat famine, that we have at last arrived at 
Farm Values of Five Leading Crops, Ten Years

(From United States Yearbook of Agriculture).

\begin{tabular}{c|c|r|r|r|r}
\hline \hline & \multicolumn{1}{c|}{ Corn } & \multicolumn{1}{c|}{ Cotton } & \multicolumn{1}{|c|}{ Hay } & \multicolumn{1}{|c}{ Wheat } & \multicolumn{1}{c}{ Oats } \\
\hline 1918 & $\$ 3,528,000,000$ & $\$ 1,616,000,000$ & $\$ 1,524,000,000$ & $\$ 1,875,000,000$ & $\$ 1,092,000,000$ \\
1917 & $3,920,000,000$ & $1,566,000,000$ & $1,424,000,000$ & $1,278,000,000$ & $1,061,000,000$ \\
1916 & $2,281,000,000$ & $1,122,000,000$ & $1,023,000,000$ & $1,020,000,000$ & $656,000,000$ \\
1915 & $1,723,000,000$ & $631,000,000$ & $914,000,000$ & $942,000,000$ & $560,000,000$ \\
1914 & $1,722,000,000$ & $549,000,000$ & $779,000,000$ & $879,000,000$ & $499,000,000$ \\
1913 & $1,692,000,000$ & $863,000,000$ & $797,000,000$ & $610,000,000$ & $440,000,000$ \\
1912 & $1,520,000,000$ & $817,000,000$ & $857,000,000$ & $555,000,000$ & $452,000,000$ \\
1911 & $1,565,000,000$ & $688,000,000$ & $785,000,000$ & $543,000,000$ & $415,000,000$ \\
1910 & $1,385,000,000$ & $820,000,000$ & $842,000,000$ & $561,000,000$ & $408,000,000$ \\
1909 & $1,477,000,000$ & $698,000,000$ & $722,000,000$ & $669,000,000$ & $405,000,000$ \\
\hline Totals & $\$ 20,813,000,000$ & $\$ 9,370,000,000$ & $\$ 9,667,000,000$ & $\$ 8,932,000,000$ & $\$ 5,988,000,000$ \\
\hline
\end{tabular}

the point when "production and consumption look each other in the face," that we can no longer export, yet, in the face of all of these dire predictions, the exports of wheat during the last ten years greatly exceed the amount of wheat exports during any other ten years in our history. When such distinguished scholars as Liebig and Sir William Crookes err greatly in their attempts to forecast future wheat conditions, who would dare attempt to say what the next ten years may bring forth? ${ }^{1}$

Competitive Nature of Grain Trade.-The United States Department of Labor has for many years made a study of food prices, in order to know what the consumer's dollar is able to purchase. A study was made by this Department into "Wheat and Flour Prices from Farmer to Consumer." 2 The investigator was impressed with the highly competitive nature of the business in this field. He expressed his findings in these words:

"In a survey of the distribution of wheat and flour, three things are noticeable: The intensely competitive character of the business, the excess in the equipment for distribution, and the desire for independence of the people engaged in production and distribution. If one farmer will not sell his wheat at the price offered, another farmer will ... Beginning with production, there are more seeding and harvesting machines in the hands of farmers than would be needed if there were coöperation in production and each machine kept in operation the entire harvest season. There are more elevators in the wheat area than are needed, each operating most of the time on less than full capacity. In some sections there is useless duplication of railway trackage. More grain jobbers and commission men are in the field than can find continuous business. It is asserted that the mills of the United. States could grind all the wheat raised in the United States in 144 days ( 24 hours per day)."

${ }^{1}$ Crookes, Sir William, The Wheat Problem. New York and Iondon, 1900. Same (3d Edition), 1917. Conrad, Dr. J. Liebig's Ansicht von der Bodenerschöpfung und ihre geschichtliche, statistische und national ökono mische Begründung. Kritisch gepruift. Jena, 1864.

${ }^{2}$ Bulletin 130, United States Department of Lahor; Bureail of Labor Statistics, Washington, August 15, 1913, p. 14. 
Competition.- It is true that the whole grain trade (as well as the wheat trade) is one of fierce competition and narrow margins. It is a trade of many "middlemen," each taking a small margin, rather than a few, powerful, dominating middlemen taking a big toll. Competing farmers deal with competing country elevators. And country elevators ship to competing mills or to competing terminal markets. A partial list of the various grain exchanges, given below, indicates the real nature of this competition for the farmers' grain.

Chicago Board of Trade

Minneapolis Chamber of Commerce

Duluth Board of Trade

Omaha Grain Exchange

Kansas City Board of Trade

St. Louis Merchants' Exchange

Milwaukee Chamber of Commerce

Toledo Produce Exchange

Buffalo Corn Exchange

Philadelphia Commercial Exchange

New York Produce Exchange

New Orleans Board of Trade

Cleveland Grain and Hay Exchange

Cincinnati Chamber of Commerce

Baltimore Chamber of Commerce

Boston Chamber of Commerce

Indianapolis Board of Trade

Little Rock Board of Trade

St. Joseph (Missouri) Grain Exchange

Atchison Board of Trade

Ft. Worth Grain and Cotton Exchange
Louisville Board of Trade

Memphis Merchants' Exchange

Houston Grain and Hay Exchange

Topeka Board of Trade

Wichita Board of Trade

Salina (Kansas) Board of Trade

Hutchinson (Kansas) Board of Trade

Oklahoma City Board of Trade

Enid (Oklahoma) Board of Trade

Denver Grain Exchange

Sioux City Grain Exchange

Superior (Nebraska) Board of Trade

Cairo Board of Trade

Peoria Board of Trade

Wichita Merchants' Exchange

Seattle Board of Trade

Lincoln Grain Exchange

Des Moines Board of Trade

Tacoma Grain Exchange

Los Angeles Grain Exchange

No one market and no one class of dealers dominate the grain trade, although Chicago is our largest grain market, and the millers and terminal elevator interests are the largest buyers. Where, for instance, will the corn be sold that is in a country elevator in central Iowa? The elevator manager receives his daily price cards or market letters from the nearby terminal markets, namely, Chicago, Kansas City, Omaha, and Minneapolis. He also receives market quotations from the important interior markets, such as Cedar Rapids, Des Moines, Sioux City. He has the opportunity to consign his grain to the large terminals, and receive what the market will give when the grain arrives; or he may ship to any one of several buyers who send him "To arrive" bids, that is, a definite bid as to price and as to time of shipment. His grain may go to a nearby Iowa cattle feeder. Or a Kansas City house, specializing in corn, may buy the corn to ship to Maple Hill or Peabody, 
Kansas, important stock feeding centers. Or a private wire house in Chicago (that is, a large grain concern having its own leased telegraph lines) may want to buy the corn for a customer operating a feed mill in Montpelier, Vermont. Or a Sioux City grain broker may bid for it for a South Dakota customer. Or a broker at Fort Worth or a Terminal Elevator in Kansas City may bid on it for the purpose of shipping to Galveston to complete a cargo. Or a member of the Denver Grain Exchange may have a telegram from a customer in Petaluma, California (a dealer in poultry feeds); asking for corn, and this Denver dealer orders the Iowa corn shipped to the California customer. This is a fair picture of what actually happens, in the course of time, in the corn belt. The actual flow of grain fluctuates greatly from year to year, depending largely on local crop yields. One thing is constant, however, namely, the competition for the farmer's grain, competition among the various markets, and competition among the different industries that use grain. Thus; one manufacturer of corn products in Chicago uses annually 30,000,000 bushels of corn, and there are several manufacturers of corn products on this market. The manufacturers of rolled oats in its various forms use an increasing amount of oats for human food. So also with the various wheat products breakfast foods. The mills, the industries, the exporters, are all after a supply of grain, and are willing to bid the price which will keep their plants busy and their orders filled. And the extent of their orders depends in turn upon the volume the consumer is willing to take and pay for. It is apparent to everyone studying the grain market that the underlying forces of demand and supply are ever present, and finally determine the flow of the grain. The quickness and the sensitiveness with which prices constantly respond to the ever-changing pressure of supply and demand explain the price fluctuations. And our country has learned, as Argentina and other foreign countries have learned, that a big supply in our country must depress prices in competing countries.

Present Organization of the Grain Trade.-The present organization of the grain trade is a product of slow evolution - a growth, many critics say, from old abuses toward highest standards of commercial honor. The farmer hauls his grain to the country elevator (Fig. 69), and this local elevator is an institution of one of three classes: (1) Farmers' Elevators. In all the grain growing States the farmers have formed corporations at the local shipping points to own and operate grain elevators. These are generally called "coöperative elevators," although as yet fewer than half 
of them can qualify as purely coöperative corporations. Elevators of this kind are rapidly increasing in numbers. (2) Independent Elevators. Many local grain dealers-usually individuals-own and operate grain elevators, depending for their patronage on their standing and reputation in the community. (3) Line Elevators. At the terminal markets are certain large corporations engaged in one or more branches of the grain trade, and corporations of this kind often own and operate a large number of country elevators, or "line elevators" as they are familiarly called. Line elevator companies in the United States operate all the way from ten to

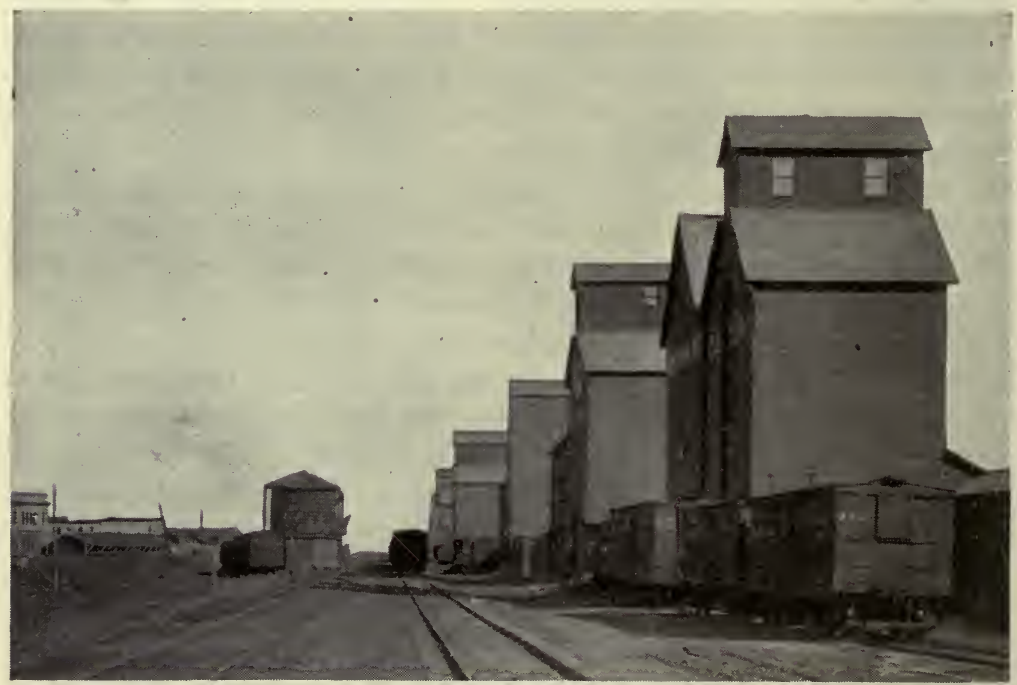

FIG. 69.-Country grain elevator in North Dakota.

six hundred country houses apiece. Elevators of this kind are rapidly decreasing in numbers, being bought out in part by farmers' companies and in part by flour milling corporations.

When the grain is once delivered at the local elevator at once there emerge the problems of inspecting and grading, financing and storing, and of transportation. Since ninety-five per cent of the farmers part with their grain at the country elevator and receive their pay in cash, it is unavoidably necessary for the manager to grade this grain. The price he receives at the terminal or other market will be governed by the grade there. Uniformity of grain grades has been established by the United States Grain Standards Act of August 11, 1916. Wheat, for instance, is divided 
into classes and sub-classes, and these again into grades. The grade depends on the color and condition, the test weight per measured bushel, the moisture content, on certain inseparable materials, and other factors. In addition to naming the grade, the local manager must determine the dockage, that is, the amount of foreign matter and broken kernels, which he screens out of the sample by putting the grain over a sieve. If 100 pounds of grain contains 10 pounds of screenings or dockage, it is customary to pay for the 90 pounds of grain out of each 100 delivered by the farmer. More will be said later concerning the dockage problem.

The local elevator manager may dispose of his grain in a number of ways, but the two most usual practices are to consign and to sell to arrive. If he thinks the market is working upward, he consigns to one or more commission houses with which he has established commercial relations. The financing of the grain in such a case is usually done in this manner. The commission house makes an advance to the country shipper when the grain starts to move, enabling the country manager to pay cash for the farmers' grain. This loan is repaid as the grain is sold at the terminal. The country shipper then forwards by mail draft with bill of lading to his consignee, who usually honors the draft several days before the arrival of the car, charging an interest rate for the money advanced as fixed by the Grain Exchange at that market. This banking function of the commission merchant is very important in the markets of Duluth, Minneapolis, and Chicago. The commission merchant in turn borrows from this city bank, using bills of lading as security. To indicate the importance of this kind of financing, it may be mentioned that one Chicago commission house had at one time over $\$ 800,000$ of borrowed money advanced to the country on consigned grain, none of which grain was yet unloaded at the terminal, and another house had out $\$ 2,000,000$.

If the market does not seem to be a rising one, or if a temporary car shortage impends, or if certain other conditions prevail, the local manager may sell his grain "to arrive." In the Minneapolis district this term usually means to arrive at Minneapolis within 20 days after acceptance of the bid. In the Chicago district the term "to arrive" refers to time of shipment, and hence the bids sent out from Chicago always specify time of shipment as three days, ten days, thirty days, ninety days, and so on. The local shipper, when he accepts the to-arrive bid, has his grain sold at a 
definite price. He then has no further interest in price fluctuations; so far as this grain is concerned.

The country shipper may sell grain "on track" terminal market, by shipping the grain to the terminal and selling it from a sample displayed on the table on the trading floor of the Grain Exchange. The country shipper may ship his grain to the terminal and there have it stored in a public elevator. In this case it is mixed with other grain of the same grade-but this process of mixing really began when the grain from different farms was mixed in the local elevator.

Storage and Hedging Problems of Country Elevator.-Grain, particularly wheat, is commonly hurried to the elevators soon after thrashing. The farmer has the privilege of storing his grain in the local elevator, if he so elects, taking therefore warehouse receipts commonly in the form of "storage tickets." The local elevator, holding from 25,000 to 35,000 bushels (on the average) soon fills up with grain, a part of which is "stored grain." It is thus often necessary to ship out stored grain. In such a case it is a common practice for the manager to protect himself against loss by hedging such shipments of stored grain in the future market. He hedges by buying for future delivery as much as he has received, shipped and sold on the cash market. He is now insured. Then when the time comes that the farmer owning the "stored grain" (not in the elevator) orders it sold, the future is sold out and the transaction is closed. Any loss on the cash grain is offset by a gain on the future; any gain on the cash grain is offset by a loss on the future.

The country shipper, particularly in the Minneapolis district, also hedges his day-to-day purchases of grain. If he buys 5,000 bushels to-day, he orders a future sold in the pit against it. In a few weeks the cash grain reaches the terminal and is sold. And now the future is bought back. Let us assume that the cash grain sells at a loss of ten cents a bushel, owing to a decline in the market. Future prices usually move with cash prices. Manifestly the future he has sold at one price may now be bought in at a profit of approximately ten cents a bushel, so that he has been insured against loss by price fluctuations. The converse is true, namely, that should cash prices sharply advance, futures would also advance, ordinarily, so that he would realize no speculative gain by market changes. Hedging is insurance against loss through price fluctuations. The owner of hedged grain has no further interests in price changes. 
The hedging of grain by country shippers is common in the North, but is not common in the Kansas City district. The chief reasons for this lack of hedging in Kansas and that section are as follows: (1) More grain is financed locally and less by commission merchants-the commission merchant requiring hedging and the local money lenders not; (2) More local mills and industries, buyers of grain, are situated near the local elevator, so that the time of the grain en route is less and the risk of loss consequently less; (3) Considerable grain is sold to arrive, and this is hedged by the terminal buyer.

Mixing.-As the grain flows from the country elevator to the terminal market following the harvest season-and one-half the wheat goes to market within four months-it is necessary to provide storage for it. Terminal elevators are the principal buyers and storers at this time. These elevators are both "public" and private, the "public" warehouses being houses owned by private corporations which store grain for the public at a regular storage fee. Private warehouses are those which store their own grain only. Much grain which is wet or otherwise out of condition finds its way to market. A class of private elevators known as Hospital Elevators either buy this grain or condition it for their customers at certain rates of compensation. Public elevators are not permitted to mix grains of different grades, whereas private houses mix their own grain to suit themselves and their customers. Some private houses derive considerable income from buying low-grade grain and mixing it with high-grade grain in such a way as to raise the grade of much poor grain. Since the price is reflected back to the country when low-grade grain is bought for mixing purposes, the farmers do not suffer from this terminal practice.

The Terminal Elevators at all times have strong competition from other buyers, such as flour and feed millers, exporters, and the industries using grain.

The Grain Exchange.-At the larger terminal markets the various buyers and sellers of grain and the receivers and shippers of consigned grain have associated themselves together and formed grain exchanges (Fig. 70). These exchanges are commonly incorporated, the corporation furnishing a place to trade, rules for trading, and market information of every available kind, but the corporation itself doing no trading. A strict code of ethics is imposed on the members in their dealings.with one another and with the outside public. A breach of the rules is punished by suspension or expulsion. Applicants for membership to 
the exchanges are scrutinized carefully. Few farmers' companies thus far have sought membership, partly owing to the high cost of membership and partly owing to the present efficient selling service rendered by the commission merchants. The Minneapolis Chamber of Commerce has three farmer companies as members. The Chicago Board of Trade has two farmers' companies among its membership. The applicant for membership must show good character and sound financial standing.

A visitor who sees for the first time the trading floor of one of the great grain exchanges is most impressed with the visible facilities for receiving and disseminating market information-

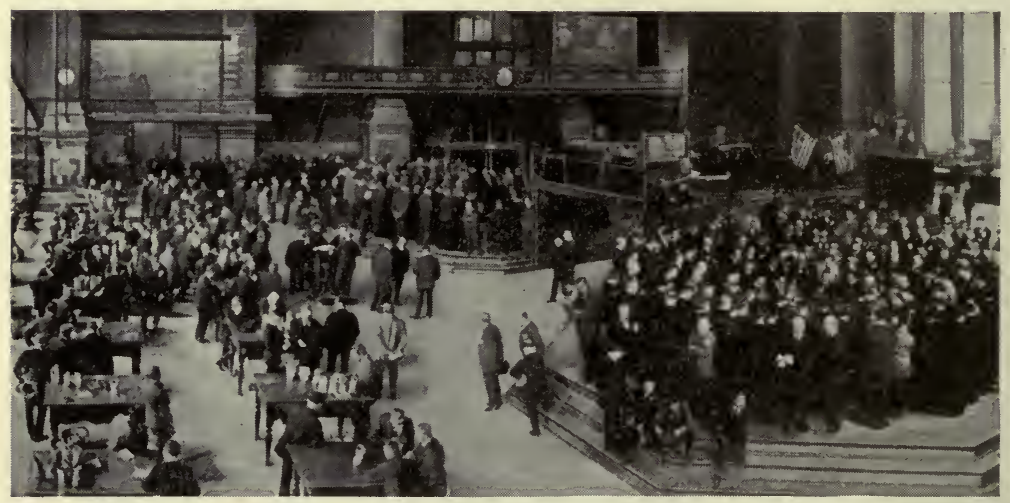

FIG. 70. -The exchange floor of the Chicago Board of Trade, the principal grain exchange of the United States. Cash grain department to left; pits on right. There are four pits wheat, corn, oats and provisions. Samples are from the Illinois State Grain Inspection Department. This picture was taken during the World War, and shows the members pausing at the noon hour for a minute of silent prayer. (Photo by Moulton.)

the scores of telegraph and telephone instruments-the weather maps and charts - the blackboards with statistics as to price quotations in all large markets, visible supply, exports, receipts and shipments, in and out inspections, grain afloat, and so on. The traders are certainly trading with their eyes open, so far as the latest and fullest market information is concerned. All exchanges have strict rules against spreading rumors and false reports about crops conditions or other market factors. The Chicago Board of Trade has a standing committee on Market Reports, and this Committee employs an expert-a grain dealer of long experienceto devote his entire time to supervision and censorship over crop reports, market reports and market quotations issued from that market. 
The Farmer and the Terminal Market.-As stated above, 95 per cent of the grain reaching the terminal has already passed out of the possession of the farmer. An increasing number of farmers, however, are now availing themselves of the machinery of the terminal markets, including that of the grain exchange itself. For instance, some farmers ship their grain to the terminal elevator and have it cleaned, and the dockage eliminated, before selling. The screenings are then sold at their market value for manufacture into stock feeds. A few farmers use the futures market for disposing of their crop. Thus in the fall of 1919 many Iowa and Illinois farmers found their corn crop assured, both as to quantity and quality, and the December contract price, during August, a satisfactory price. There was also at this time a tremendous campaign inaugurated by the Federal government against the high cost of living, and hence, partly in consequence of this campaign, a strong probability of a fall in corn prices. Hence many of these farmers sold their corn for December delivery, these future contracts assuring them of fair profits on their crops. Their judgment proved correct, for there was a decline in corn prices before the delivery month arrived. This service costs the farmer only one-fourth of a cent a bushel.

Past Organization of the Grain Trade.-The grain trade, in common with other commercial institutions of America within the last thirty years, has responded to the demands for a higher.code of business ethics. In all probability the practices in the grain trade were no better or no worse than the practices generally prevailing in manufacturing, transportation, or other branches of industry. The abuses in the grain trade of yesterday are so fresh in men's minds that many clever writers and speakers find it easy to stir up the farmer's wrath and hot indignation on this subject. The past organization of the grain trade, with its evils laid bare, is best traced under three topics, namely, (1) evolution of the organized grain exchanges; (2) evolution of the terminal elevatorrailway monopoly; (3) evolution of the farmers' elevator.

(1) Evolution of the Organized Grain Exchange.-Prior to our Civil War grain was handled very largely by independent dealers with no fixed customs in the different markets. Some markets, for instance, handled wheat by the measured bushel, others by the weighed bushel (sixty pounds). Each important market, like Buffalo and Baltimore, had its own grades. Lack of transportation facilities made it difficult to move grain to the seaboard from the inland. Water routes were of course long the sole means of 
transporting crops long distances. In the larger .commercial centers "Boards of Trade," as they were called, sprang up, to promote uniformity in the usages of merchants and to improve and dignify commerce in general. Few of these local boards, however, survived and became grain exchanges. The first and most important one to do so was the Chicago Board of Trade of 1848. It was ten years before this board of trade became a grain exchange in the modern sense of the term. The Chicago Board of Trade at once took up the fundamental market problems of weighing, inspecting, and grading the grain. The practice of the Chicago grain exchange of selling wheat by weight instead of the measured bushel was forced on the Buffalo and the New York markets. A system of weighing was developed which proved satisfactory to both buyers and sellers of grain. It is worthy of note that while inspection and grading have been taken over by the State as proper functions of State government (under Federal supervision), yet the weighing of grain on the Chicago market is still done exclusively by the Board of Trade. In the Kansas City and Minneapolis markets, however, weighing as well as inspection is now a State function.

Cash, to Arrive, and Futures: Corners.-Three forms of trading in grain developed before the Civil War on all the grain exchanges, namely, cash grain, to arrive grain, and future trading. Cash grain or spot grain means the grain itself or a sample of the grain is on hand when the trade is made. Dealers on the various exchanges, however, found it unsatisfactory to depend upon the supply of cash grain to meet their requirements. Hence contracts were made for grain to be shipped at certain times or within certain definite periods, and this form of dealing came to be called "to-arrive" business. As a natural outgrowth of "to-arrive" trading came future trading. "To-arrive" contracts were naturally made with parties having grain stored along the canal or railway. Before the Civil War, particularly on the Chicago market, traders began to make contracts to deliver wheat in a definite future month at a definite price, which wheat they did not yet own, but expected to buy and deliver. In other words, they sold short. In this way future trading started. The careful students of this subject are convinced that future trading began in this natural way, as an outgrowth of to-arrive trading, and in this manner served the interests of the cash grain business. The speculators, however, saw the possibilities in this new field, and proceeded to prostitute this wholesome form of trading till its abuses well-nigh 
outweighed ‘its uses. During the Civil War the Quartermaster's Department of the Army bought grain on contracts for future delivery, particularly on the Chicago Board of Trade. This gave a new impetus to future trading. Following the War, there came a period of tremendous speculation in railroads, in lands, and in general commodities. The same wave of speculation hit the organized grain exchanges, and future trading became the football of speculators. Ordinary hedging transactions became completely overshadowed by purely speculative trading. Cornering the market became almost a monthly occurrence, for every month in the year was delivery month instead of four months as now. Not till five years after the Civil War did the Chicago Board of Trade begin to make rules covering future trading and aiming to curb its abuses. This was the beginning of a fifty-year fight against the two serious abuses of speculation, namely, manipulation of the market and corners. The Chicago Board of Trade (and the other exchanges where future trading is carried on) found it frankly a matter of intelligent self-interest to preserve the benefits of future trading and eliminate its abuses. Rules were gradually added, increasing the number of grades deliverable on contract, so that corners became more difficult. Obviously if one grade only is deliverable on a future contract, cornering is a comparatively simple matter. At the present time 21 grades of wheat are deliverable on future contracts in Chicago. In case the delivery cannot be made, settlement can be made at a fair market price, not at a "fictitious" price due to the corner. Again, if the grain in the regular warehouses is held by the would-be cornerers, deliveries can be made on track during the last few days of the delivery month. Again, it may be added that the Supreme Court of the United States has declared cornering the market a crime. Hence the exchanges now stand ready to apply the remedy of expulsion to any member guilty of attempting a corner. As a matter of history, nearly every attempt to corner the grain market was a failure. Only in those few cases where actual market shortage was on the side of the cornerer did he realize a profit. For the natural consequence of accumulating a long line of grain in order to corner the market is to boost the price of the grain bought; and the second phase of the corner-unloading the long linehas the natural effect of lowering the price more than the buying had raised it. As one trader expressed it, "It is easy to corner the market, but it is hard to bury the corpse." And this is the reason why most attempted corners failed. In the public memory 
there stand out three so-called corners, namely, the Hutchinson corner of 1888, the Leiter corner of 1898 , and the Pattern corner of 1909. The Hutchinson corner was a genuine corner, his buying coinciding with actual market shortage; the Leiter corner was a failure, bankrupting Leiter and leading to his permanent suspension from the Chicago Board of Trade; the Pattern corner was not a corner, but an example of grain merchandising in accordance with a correct market forecast. For when Mr. Pattern quit the market, after his "May wheat deal," the prices continued to go up and stay up till the new crop came in.

Cornering the market, under the present rules of the organized exchanges, is now looked upon as a danger so slight as to be negligible. There have been no intentional corners in recent years.

Manipulation of the market means causing prices to rise or fall by means of some deception usually in the form of spreading rumors and false market reports. The rules of the organized exchanges in recent years have been made extremely severe in this matter, any member being subject to discipline’and expulsion for circulating any false reports. In the language of the trade, "The crop killer has been killed off."

Corners and manipulations were extremely common in the grain trade before exchanges were organized, and for the first years of the organized exchanges. But the total effect of the organized exchanges has been very greatly to curtail these evils in the grain trade. Corners and manipulations are still familiar, however, in commodities not dealt in on the organized exchanges.

A Wide Market.-For the purpose of carrying on legitimate hedging transactions a "wide" market is needed, that is, a market with enough buyers and sellers in it to absorb instantly and without shock large trades. In the language of the trade, it is a market "easy to get in and out of." To make a market wide enough for hedging every day in the year some speculators are needed. They buy till the regular consumptive buyers are ready to purchase their contracts; or they sell short, till the holders of either cash grain or long contracts are ready to sell to them, or till fresh speculators step in and close the trade. A trader on the "long" side of the market (a buyer) can close his trade in three ways: wait till delivery month and receive the grain; wait till delivery month and receive a "delivery notice" (i.e., a notice that the grain is in store for him, ana a warehouse receipt ready), which notice he immediately passes on to some other trader in fulfillment of a contract, this delivery notice passing on from hand to hand 
much like a piece of paper money; or the buyer may sell as much as he has bought and settle by offsetting one trade against the other, merely paying or receiving the balance due. ${ }^{3}$

Scalpers.-As a matter of fact most speculative trades are closed out before the delivery month comes around. There is a small class of speculators who buy and sell in the pit during the day on a very small fluctuation in price, but who aim to have all their trades closed out by the time the market closes. They are called "pit scalpers."

"Phantom Grain" Question.-The speculators and the scalpers produce a large volume of future trading, which some writers call mere dealing in "wind" or in "phantom" grain; and this "phantom grain," these same writers claim, depresses the price of actual grain. When such a claim as this is examined it is seen to be preposterous. For of all places, the organized exchange is the one center where accurate market information is collected and disseminated, and this information fully covers the visible supply of grain, the arrivals on all big markets, the amount afloat and in elevators, the conditions of growing crops, and every other known factor of significance as to supply or demand. No speculator is fooled by any "phantom" supply of grain, or he would be too childish a person to survive long as a speculator. Again, since the amount of "phantom" grain bought exactly equals the amount sold, it may be looked on as a case of demand (tending to raise price) just as much as it is a case of supply (tending to lower price).

${ }^{3}$ The use of delivery notices where one notice for 5,000 bushels, for instance, may settle contracts for many thousands of bushels, is very much similar to the use of money, checks, etc., in settling contracts to pay money. The analogy is very striking. The following story illustrates how a piece of paper "money" (i.e., credit money - a promise to pay money) does the work of real money (gold).

"Mr. Brown, a Kansas gentleman, is the proprietor of a boarding-house. Around his table at a recent dinner sat his wife, Mrs. Brown; the village milliner, Mrs. Andrews; Mr. Black, the baker; Mr. Jordan, a carpenter; and Mr. Hadley, a flour, feed, and lumber merchant. Mr. Brown took a ten dollar bill from his pocket and handed it to Mrs. Brown, with the remark that there was ten dollars towards the twenty he had promised her. Mrs. Brown handed the bill to Mrs. Andrews, the milliner, saying, 'that pays for my new bonnet.' Mrs. Andrews, in turn, passed it on to Mr. Jordan, remarking that it would pay for the carpentry work he had done for her. Mr. Jordan handed it to Mr. Hadley, requesting his receipted bill for flour, feed, and lumber. Mr. Hadley gave the.bill back to Mr. Brown saying, 'That pays ten dollars on my board.' Mr. Brown again passed it to Mrs. Brown, remarking that he had now paid her the twenty dollars he had promised her. She, in turn, paid it to Mr. Black to settle her bread and pastry account. Mr. Black handed it to Mr. Hadley, asking credit for the amount on his flour bill, Mr. Hadley again returning it to Mr. Brown, with the remark that it settled for his month's board; whereupon Brown put it back into his pocket, observing that he had not supposed a greenback would go so far."

The greenback may be presented to the United States Treasury and exchanged for real money-gold.

The above story is quoted from "Among the Humorists and After-dinner Speakers"; Collier \& Son, New York, 1909, p. 251. 
Speculation and Price Fluctuations.-The fact is that this speculation is a factor tending to put on brakes when the market starts to bulge or break. It stabilizes. It lessens the fluctuationsmakes them many and frequent and small, rather than few and large. Prices of wheat, for instance, fluctuated much more on the American market during the 60 years 1790-1850 (when there were no organized grain exchanges) than they did during the 50 years of organized grain exchanges (1865-1915). And, as stated in the chapter on speculation, grains subject to future trading show smaller price fluctuations than grains not subject to future trading (Figs. 71 and 72).

Cost of Future Trading.-Future trading has been defined as of two interrelated and interdependent kinds, hedging and speculation. All persons familiar with the grain trade admit the benefits of hedging, but many critics say that speculation is of such large volume as to overshadow completely the hedging transactions, and that this large volume of speculative trading imposes a toll on the public far outweighing the benefits of hedging. It is very probable that half the future trading in grain in the United States is done on the Chicago Board of Trade, this trading representing every State in the Union and a few foreign countries. It is the opinion of the writer that the volume of future trading in any one normal year in Chicago amounts to ten billion bushels of wheat and ten billion bushels of corn and oats together, a grand total of twenty billion bushels. The normal crop in these grains is five billion bushels, that is each bushel of cash grain is bought and sold four times in the pit. What is the "toll" on this amount of future trading? Future trading may be classified as of three kinds, so far as costs are concerned, namely, (1) members trading for themselves; no commission is charged on this; (2) members trading for other members; the rate on this is the "half rate," namely, \$6.25 for 5,000 bushels bought or sold or both bought and sold (the so-called "round turn"); (3) members trading for non-members, on which the rate is $\$ 12.50$ for 5,000 bushels round turn. Since about one-fourth of the future trading is for non-members and one-fourth for other members, it follows that the total commissions collected on a year's future trading in wheat, corn and oats in Chicago amount to approximately one-third of a cent a bushel "toll" on the year's crop, not a very heavy price for the insurance afforded by the hedging, which is an integral part of future trading.

Bucket-Shop Fight.-The account of the evolution of the organized grain exchange is not complete until the story of the bucket- 


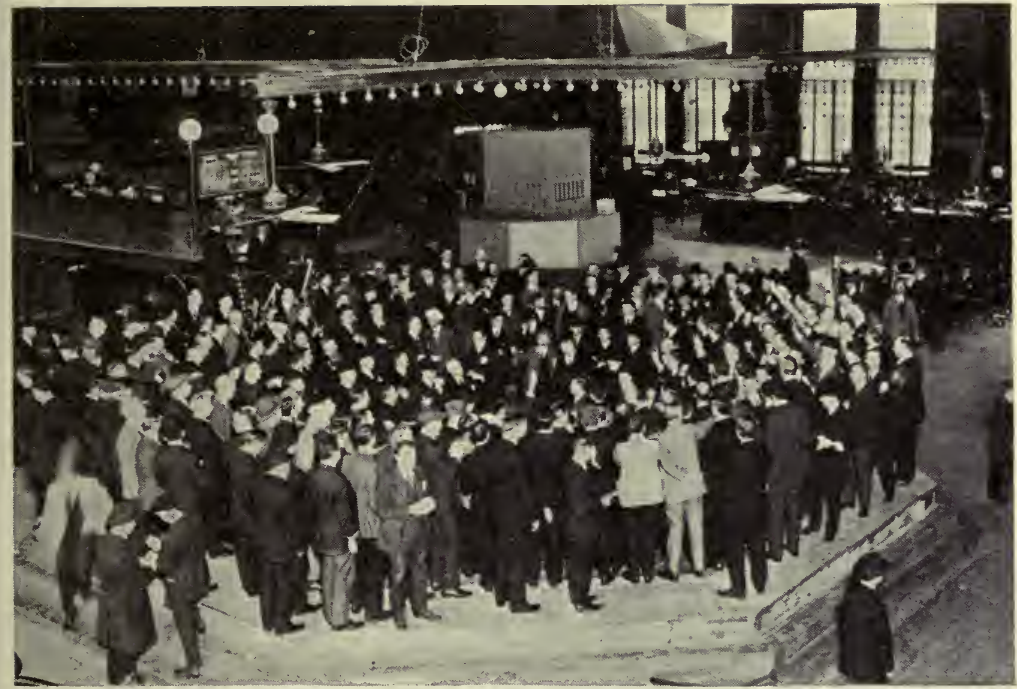

Fra. 71. Wheat pit, Chicago Board of Trade, where future trading is carried on.



FIG. 72. - The wheat pit during an exciting moment of trade. This is a flashlight taken during an actual period of trading, and almost every character of the trader's sign manual is shown. 
shop fight is told, although it can be told but briefly and inadequately here. A bucket shop is a counterfeit of a branch office of a member of the genuine exchange, and like most counterfeits, is a good imitation. It contains a blackboard for posting the continuous quotations as they come in over the wire. In this respect it resembles the branch office of any large "Private Wire house," that is, house operating leased wires and maintaining branch offices. Some of the largest dealers in both cash and futures on the organized exchanges are private wire houses. However, private wire houses are members of the regular exchanges, and all orders coming to them are executed on the open market on the trading floor of the exchange- that is, become binding contracts whose terms must be and are fulfilled. The private wire house usually requires a customer to deposit a so-called "margin" of ten per cent to protect the trade against an adverse turn in the market. Thus, if the trade happens to be for 5,000 bushels of corn at one dollar a bushel, the margin would be $\$ 500$. The bucket shop operator requires a very small margin, probably one cent a bushel or one-half cent a bushel, so that five dollars could margin a trade of 1,000 bushels. The operator of the bucket shop is not a member of the Exchange. He does not execute his orders on any exchange, and hence these "orders" are mere bets, and have no significance in registering supply and demand influences or in affording hedging facilities. The operator of the bucket shop takes the other side of the trade himself, that is, in trade language, he "buckets the trade." 4 The customer has a very slender chance indeed of winning. His margin is so small that upon a very slight fluctuation of the market his margin is gone and his trade is closed. And since the operator has it within his power to post false quotations, it is obvious that only enough customers are permitted to win to serve as bait for new victims. Bucket-shop gambling spread rapidly over the United States. Chicago, being the center for füture trading for the whole United States and for the world, naturally became the leader in the long struggle against the powerful, deeply intrenched bucket-shop interests. In the early 80's the evil became so prominent as to engage a very large share of the attention of the meetings of the Directors of the Board of Trade. In the year 1890 the Board decided to stop the giving out of all quotations on futures, and such an embargo was actually

4 This practice formerly occurred at intervals on the exchanges. It is now strictly forbidden. One exchange expelled one of its ex-presidents for bucketing trades. The exchanges have now practically eliminated this practice. 
put into effect. But, by hook or crook, the bucket shops were ingenious enough to get the quotations-mostly by theft. President Baker of the Board was re-elected to office in 1891 on the issue of embargoing quotations. He denounced the Western Union Telegraph Company as a secret enemy of the Board of Trade. In 1892 a return to open quotations was made, the embargo having proven ineffective. The bucket-shop fight now defined itself as a question of the control of quotations. President Warren of the Board of Trade called a convention of all leading grain exchanges to discuss ways and means of fighting bucket shops, and particularly the adoption of a national anti-bucket-shop law. Finally, after spending many tens of thousands of dollars on the fight, the Chicago Board of Trade evolved a successful plan. A telegraph company (the Cleveland Telegraph Company). was formed in 1900 to collect the quotations on the floor and to assume control of all wires and instruments on the floor. The Western Union Telegraph Company, now enjoying great revenue from the sale of quotations, was ordered off the floor. Quotations from this time on were furnished to the Western Union, or other companies, only upon the signing of a contract not to furnish them to bucket shops, and giving the Board itself the right to decide to what applicants such quotations should be furnished, and from whom they should be cut off. From this time on the Federal Department of Justice and various State legal departments joined in with the attorney of the Chicago Board of Trade, and a nation-wide campaign was relentlessly pushed. In 1905 came the Christie decision of the United States Supreme Court, giving the Board of Trade a property right in its quotations, and hence full control over them. By the year 1915 existing bucket shops had all been closed. Since that date an occasional one shows its head under some disguise, but the special agent of the Chicago Board of Trade or of the New York Stock Exchange, or the two working together, soon eliminate it.

Much of the condemnation of grain exchanges as "gambling places" come from the old bucket shops-bastard exchangeswhich were 100 per cent gambling places. These counterfeits have hurt the standing of the genuine exchanges. The fact remains, however, that the Board of Trade of Chicago and the other great organized grain exchanges, as they are now developed, are efficient pieces of market machinery, operating at a low margin of cost per bushel, under democratic rules of self-government, and managed by boards of directors responsive to the welfare and interests of the general public. 
(2) Evolution of Terminal Elevator-Railroad Monopoly.Following the Civil War, the competing railroads in the grain States found it necessary to erect terminal storage in order to secure their share of the grain business. Later these terminal elevators or warehouses were also built by large grain firms on the terminal markets. These firms, in many cases, then built a series or "line" of country elevators along particular railroads. There soon developed a form of combination between railroad and terminal elevator whereby rebates or other privileges were given to the terminal elevator companies, so that one firm would have a monopoly of the grain business along a certain railroad. Terminal elevator companies were at first mere custodians of grain. But this practice failed to yield enough income, so these companies became grain merchants in competition with their customers hiring storage in their bins. This gave them vast advantages, particularly in the mixing of grain and the manipulation of grades. Several scandals arose out of the sale of fraudulent warehouse receipts. When the terminal elevator companies had well-nigh completed their railroad monopoly of the country grain trade and had entered the terminal market as grain dealers, and the future market as heavy grain speculators, they were in a fair way to drive out all competitors. Seats on the grain exchanges fell in value. Grain commission firms were fast quitting the business as a losing game. When things reached this stage, reforms began to be worked out from within. The Chicago Board of Trade, for instance, sent a group to the capital of Illinois to lobby for a bill for a State warehouse act, prohibiting a public warehouse owner to be a dealer in giain and a custodian of grain in the same warehouse at the same time. Consequently any mixing of grain in Illinois had to be done in private warehouses, following the passage of this Act in 1871. The railroad rebate evil continued, however, for many years, even after the passage of the Interstate Commerce Act of 1887. It remained for one member of the Milwaukee Chamber of Commerce, trying to operate a terminal elevator in that market in the face of the railway-elevator combine, to bring the concrete situation to the attention of President Roosevelt. The significance of this act in securing remedial legislation in the form of the Hepburn Act is thus told by the editor of the Price Current Grain Reporter: ${ }^{5}$

"Of the many things that stand to his credit as a statesman, for one at least Theodore Roosevelt will be held in grateful remembrance by the American

${ }^{5}$ Osman, E. G., Price Current Grain Reporter, Jan. 15, 1919,.p. 7. 
grain trade. Conceived in the brain of the late F. P. Bacon and forced through a reluctant Congress in defiance of the opposition of the leaders of his own party by the inflexible determination of President Roosevelt to do the right thing in this, the Hepburn Act made the railroads for the first time, what they had been in name only before, 'common carriers,' compelled by law to treat all men as equals. Those only who know to what depths of meanness the railways had descended in the treatment of individuals before the Hepburn Act became law, and how they fought to retain their power to continue such practices, can realize how great is the debt of the grain trade to these two men. And yet so short is the public memory, or so great is public ignorance, most of the things for which railway reform agitators to-day are still clamoring will be found embodied in the Hepburn Act and its subsequent amendments bearing the signature of Theodore Roosevelt.

"The greatest evil of railroad management in the past was removed without revolution, although the influence of the Hepburn Act upon the conduct of the grain trade was revolutionary. It gave new life to competition in the grain trade of individuals and localities and rescued the trade from a state of monopoly that was rapidly becoming supreme throughout the surplus grain States. In other lines of trade and industry the same tendency towards concentration of trade in a few hands was in like manner checked in so far as equality of transportation service can ever stop that tendency."

In recent years railroads are forbidden to operate terminal elevators. Consequently their terminal elevators are either sold or leased to grain firms.

Terminal warehouses are now of two general kinds, public and private. In public houses, the grain of the public is stored for fixed storage charges, and grains of different grades are kept in separate bins. The owner of the warehouse is a custodian only and cannot use the house for storing his own grain. Private warehouses are used by owners for storing their own grain, which they are at liberty to mix in any manner they see fit. Grain sold for future delivery must be stored in the regular public warehouses, and receipts of these warehouses are used in making such deliveries. Private houses often contain machinery for drying wet grain, a serious problem in some years (as corn in 1917), and also machinery for cleaning and conditioning out-of-condition grain and grain not fit for storage or milling. These "hospital" elevators thus make a market for low-grade grain. Some buy the grain outright; some perform the service for the general public at fixed charges.

Under the presidency of Hiram N. Sager, the Chicago Board of Trade made a working agreement with the terminal elevator interests (Fig. 73). The terminal market machinery, so far as terminal storage is concerned, has finally been evolved so that the benefits of it accrue to the grain trade in general, including the country elevator and the farmer who raises the grain.

(3) Evolution of Farmers' Elevators.-Under the impetus of the Grange movement a few farmers' grain elevators were started 
during the early 70's. But the indications are that these all went out of existence. After this there grew up two kinds of country elevators, namely, the "independent" house, owned by some local business man, and the "line" house, belonging to some grain firm operating a number or line of country elevators. Most large terminal elevator companies owned a line of country houses; so did the larger mills. These elevators in each grain State were loosely federated in a State Grain Dealers' Association, to check irresponsible grain dealers, to fight "scoop shovelers," and for

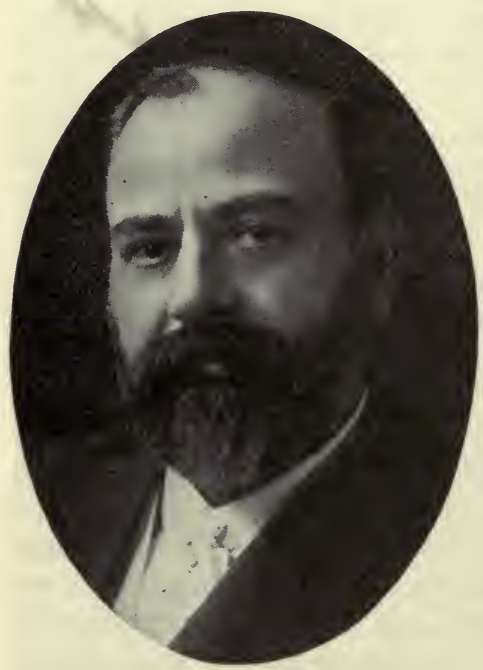

FIG. 73.-Hiram N. Sager, Ex-President of the Chicago Board of Trade. A type of the American grain merchant.

general protective purposes. To prevent price wars and destructive competition the " regular" elevators (as they came to be called) developed a price fixing scheme. A small committee, when terminal price changes warranted, would send out to the country, to each house, a new price schedule. This prevented any price war. But more important yet, it guaranteed a very liberal margin of profit to the terminal dealers, at the expense of the farmers. The State of Nebraska, for instance, was divided into 13 districts, on the basis of freight rates, and prices were fixed accordingly for each district. In Iowa the price fixing was administered through the Secretary of the Iowa Grain Dealers' Association, with headquarters at Des Moines. In Illinois, in a similar manner, the secretary of the Grain Dealers' Association safeguarded the interests of the "regulars." This system of graft at the expense of the farmer finally reached the breaking point. So far as our historical records go, the revolt of the farmers began at Rockwell, Iowa, in 1889, when the first successful farmers' elevator was erected. This little corporation inserted in its by-laws that very much discussed provision, namely, the "penalty clause." This meant that the member of the company delivering his grain to the competitor must pay a penalty to his own company of so much a bushel. Whether legal or illegal, it worked. And the "regular" house, after securing much farmer grain by raising its price, found that 
this increment in price was turned back to the farmers' company. Obviously, the more competition of this kind, the stronger would grow the farmer company. The fight was then shifted to the terminal market, and every effort was made to prevent the commission merchants or other dealers from handling grain from these farmers' houses. 'The fight now reached a critical stage, and the farmers' elevator movement was on the verge of being quickly put to death. Two commission firms on the Chicago Board of Trade at this time (1903-1904) came to the rescue of the farmers' movement. ${ }^{6}$ They sent speakers and organizers into Iowa and soon organized a large number of farmers' elevators. They received and sold the farmers' grain. The fight was won. The opposition collapsed. The farmers' elevator movement soon spread to twelve States, and in each State so-called Farmers' Grain Dealers' Associations were formed, with their own federation and their own official organ, the American Coöperative Journal.

The immediate effect of the farmers' elevator movement was to lower the spread in prices between the terminal and the local markets. Here the farmer had won his greatest victory, had overcome the greatest evil in the grain trade. He had won his fight partly by his own organization, partly by the help of members of the Chicago Board of Trade. Now a large per cent of the grain received on all markets comes direct from farmers' elevators.

The Fight in Canada. - It is worthy of note that a similar fight was had in Canada, and that there the farmers won a very signal victory, and succeeded in forming the largest coöperative company on the American continent, with a business exceeding in volume one hundred million dollars a year.

Farmers' Elevators Copy “Regulars."-The farmers' elevator movement having become a successful commercial venture is now copying many of the practices of the "regulars." The farmers have secured seats on the grain exchanges-two in Winnipeg, three in Minneapolis, and two in Chicago. The Canadian companies are already operating "line elevators." They own their own terminal elevators, including hospital elevators. They have their private wire from Winnipeg to Calgary (one thousand miles). In the United States many farmers' companies now operate lines of elevators. One farmers' company owns a terminal elevator.

Big Dividends.-One great weakness of the farmers' elevator is its undue fondness for big dividends, many of these houses

${ }^{6}$ These firms were Eschenburg \& Dalton, and Lowell Hoit \& Company. 
paying a dividend of one hundred per cent or more, year after year. The non-member who sells to the house, of course, does not participate in the dividend, although he helps create it.

Dockage Question.-The present problem of dockage is a pressing one. The farmers' elevator now usually follows one of four practices: (1) Runs the grain through a cleaner, and ships the clean grain to market. The "screenings" (dockage) accumulate until a carload is on hand, which is then shipped to the terminal and sold to the mills making stock feeds. In this way the farmer receives full market price for his screenings. (2) the grain is shipped, dirt and all, to the terminal, and is sold there on its merits, a certain per cent being deducted (or "docked") on account of the foreign matter contained. The freight has been paid on this matter, and yet nothing is received for it, in this case. The grain may be sent to a terminal elevator, ordered cleaned, the screenings sold on the market, and the clean grain sold on the market. (4) The farmer may have a cleaning mill on his farm, clean his own grain, and keep the screenings at home for poultry and stock feed. If he has a feed mill for grinding the screenings, he will not thus scatter foul seeds about his farm.

It is only within very recent years of high prices that screenings have taken on value and importance in grain marketing. A fifth suggestion may well be added concerning the heavy dockage in all spring wheat regions, namely, that if the farmers had a crop rotation and raised a few cultivated crops, they would thus eliminate the weeds, and then there would be no dockage problem. For after all, dockage is a weed problem, and the fundamental solution is to quit raising weeds.

\section{QUESTIONS ON THE TEXT}

1. Show that the grain trade of the United States is an "international matter." Cite Argentina's experience.

2. Name chief exporting countries (wheat), average amount exported; chief importing countries, and average amount imported.

3. Rank in order of money value the leading crops of the United States.

4. Show relative importance on the markets of wheat and corn.

5. Show the competitive nature of the grain trade. What markets, for instance, bid for Iowa corn?

6. Locate the more important grain exchanges of the United States.

7. Discuss present organization of the grain trade under the following topics: country elevator (three kinds); grading and dockage; selling the local grain; financing the local elevator; mixing; storage and hedging problem of country elevator; hedging in North and South compared; public and private terminal elevators; hospital elevators; grain exchange (organization, membership, market news service).

8. Show relation of farmer to the terminal market and how he may improve this relationship. 
9. Discuss in detail the past organization of the grain trade under the three following topics: (1) Evolution of organized exchanges (weighing, inspection, grading, cash grain, to-arrive grain, future trading, short selling, speculation and manipulation, corners and rules on-Hutchinson, Leiter, and Pattern corners-hedging speculation and the wide market question, delivery notices, pit scalpers, "phantom" grain questions, effect of speculation on price, cost of future trading, volume of future trading, the bucket-shop fight, present condition of exchanges). (2) Evolution of terminal elevators (early terminal storage, relation to railroads, early evils of system, early regulation, Hepburn Act and its effects, present situation as regards railroads and terminal elevators). (3) Evolution of farmers' elevators (first and second beginnings, "regular" houses, price fixing, Rockwell Iowa in 1889, "penalty clause," struggle of farmers to help themselves, aid from Chicago Board of Trade members, outcome, present commercial methods of farmers' elevators, problem of dockage and its fundamental solution).

\section{QUESTIONS SUGGESTED BY THE TEXT}

1. Compare the statements of Liebig and Sir William Crookes as to soil exhaustion, and criticise the position taken by each. What error, if any, did each make?

2. Compare the costs of marketing grain, through the organized exchanges, with the costs of marketing hay (without organized exchanges).

3. Can speculation in grain be limited to those who are members of the grain trade?

4. Is the cost of hedging-insurance too much?

5. Secure a copy of the annual report and of the rules of any leading grain exchange, and study them carefully. Are these rules fair to both farmers and consumers? Are the membership requirements too high?

6. Is the grain exchange an "open market"? Is it a competitive market?

\section{REFERENCES}

1. See Annual Reports issued by Secretaries of the following grain exchanges:

Chicago Board of Trade

Minneapolis Chamber of Commerce

Winnipeg Grain Exchange

Duluth Board of Trade

Omaha Grain Exchange

Kansas City Board of Trade
St. Louis Merchants' Exchange

Milwaukee Chamber of Commerce

Toledo Produce Exchange

Baltimore Chamber of Commerce

New York Produce Exchange

2. On Weighing, Inspection, Grading, see following Reports:

Annual Reports, State Weighmasters' Department, St. Paul, Minnesota. Annual Reports, State Grain Inspection Department, St. Paul, Minnesota.

Annual Reports, Illinois Railroad and Warehouse Commission, Springfield, Illinois.

Annual Reports, Missouri State Grain Inspector, Kansas City, Missouri.

Bulletins on Federal Grain Supervision, issued by United States Bureau of Markets, Washington, D. C.

3. Government Publications:

(1) Prices of wheat to producers in Kansas, etc., 63 Cong. 3 Sess. House Doc. 1271.

(2) Report of State Grain Commissioners. Bismarck, North Dakota, Public Document No. 26 (1910). 
(3) Report of the Board of Grain Commissioners to Governor John Burke, Bismarck, North Dakota. Public Document, No. 37 (1908).

(4) Report on Terminal Grain Elevators made to the Fourteenth Legislative Assembly of the State of North Dakota by the Board of Control of State Institutions (1915). Also "Further Report" of same Board, in Journal of the House, Fourteenth Legislative Assembly of North Dakota, February 18, 1915, pp. 77-107.

(5) Journal of the House, Thirty-eighth session, State Legislature of Minnesota, April 17, 1913. Report of the Special House Grain Investigating Committee, pp. 2-12.

(6) Journal of the Senate, Thirty-eighth session, State Legislature of Minnesota, April 22, 1913. Report of the Work's Grain Investigating Committee, pp. 49-79.

(7) Report of the Grain Markets Commission of the Province of Saskatchewan, 1914, Regina.

(8) Grain Inspection in Canada, By R. Magill, chief commissioner Board of Grain Commissioners of Canada. Issued by the Department of Trade and Commerce, Ottawa, Canada.

(9) The Canada Grain Act of 1912 with Amendments, Ottawa. This law may be termed the "Federal Inspection of Grain" as employed in Canada.

(10) Report of the Royal Commission on the Grain Trade of Canada, 1906. Ottawa, Canada.

(11) Report of the Elevator Commission of the Province of Saskatchewan, 1910. Regina.

(12) Progress Report from the Royal Commission on the Marketing, Transportation and Storage of Grain, Presented to the Parliament of Victoria, Australia, 1913. Melbourne.

(13) United States Industrial Commission Report, Nineteen volumes, 1898. Washington, Volume 10, Volume 19.

(14) Wheat and Flour Prices from Farmer to Consumer. Bulletin, United States Bureau of Labor Statistics, No. 130. Washington.

(15) Bucknell, Frank W., Wheat Production and Farm Life in Argentina. Bulletin No. 27, Bureau of Statistics, United States Department of Agriculture. Washington, 1904.

(16) La Follette, R. M., Speech on the Railroad and Elevator Monopoly. Congressional Record XL, Part 10, p. 9093.

(17) Testimony taken by Interstate Commerce Commission October 15November 23, 1906, in Matter of Relations of Common Carriers to the Grain Trade. 59 Cong. 2 Sess. Senate Doc. No. 278. Washington, 1907.

4. Non-official publications:

(1) The Siege of Ottawa. Being the story of the 800 farmers from Ontario, etc., who demanded more equitable legislation, etc. Published by Grain Growers' Guide, Winnipeg.

(2) American Produce Exchanges. Annals of the American Academy, September, 1911, Philadelphia.

(3) Speculation on the Stock and Produce Exchanges of the United States.

By H. C. Emery. Published by Columbia University, New York City, 1896.

(4) The Stock Exchange from Within, by W. C. Van Antwerp. Published by Doubleday, Page \& Co., Garden City, N. Y., 1913. Pages 415-446 contain the full report of Governor Hughes' Committee on Speculation in Securities and Commodities.

(5) Wheat Fields and Markets of the World, by Rollin E. Smith. Modern Miller Publishing Co., Chicago, 1908. This book contains very full accounts of the following exchanges and terminal elevators dealing in grain: Chicago, Minneapolis, Duluth, Kansas City, St. Louis, Winnipeg. Also the grain markets of the following places are discussed: Liverpool, London, Antwerp, Paris, Berlin, Buda Pesth. 
(6) Grain Exchange Facts. Two special numbers of the American Coöperative Journal, Chicago, August and September, 1915.

(7) Weld, L. D. H. The Marketing of Farm Products. New York, Macmillan, 1916. 1915.

(8) Huebner, Grover. Agricultural Commerce. New York, Appleton,

(9) Piper, C. B. Principles of the Grain Trade of Western Canada. Empire Elevator Company, Winnipeg, 1915.

(10) Usher, A. P. The History of the Grain Trade in France, 1400-1700. Cambridge, Massachusetts, 1913.

(11) Refsell, V. N. The Farmers' Elevator Movement. Journal of Political Economy (Chicago), Vol. 22, pp. 872-895; 969-992.

(12) The Saskatchewan Coöperative Elevator News. Regina (current files), June, 1916.

(13) Schelle, Gustave. Turgot et le pacte de famine. Institut de France, Acad. d. sci. Mor. et polit. Seances et travaux. n. s. V, 74, pp. 189-217. Paris, 1910.

(14) Perlmann, Louis. Die bewegung der weizenpreise und ihre ursachen. München und Leipzig, 1914.

(15) Kirkland, John. Three centuries of prices of wheat, flour, and bread. War prices and their causes, London, 1917.

(16) Boyle, James E. Speculation and the Chicago Board of Trade, New York, Macmillan, 1920.

(17) Taylor, Charles H. (Editor). History of the Board of Trade of the City of Chicago. 3 Volumes. Chicago, Robert O. Law Company, 1917.

(18) Grain Grading in Minnesota. Grain Growers' Guide, June 6, 1917.

(19) Wheat Marketing Through Pacific Northwest Non-profit, Coöperative marketing Associations (Washington, Oregon, and Idaho Wheat Growers' Associations). Pamphlet (16 pages) issued by Organization Committee of Wheat Growers' Associations of Pacific Northwest, Empire Building. Spokane, Wash., n. d. (January, 1920?).

\section{APPENDIX}

Relation of Future Trading to the Financing of the Grain Trade.-From an article in the National Hay and Grain Reporter of May 20, 1911, by David R. Forgan, President National City Bank, Chicago, Illinois.

"Warehouse receipts for grain, or anything else that finally becomes human food, are, in my opinion, the best possible collateral for bank loans. I have seen the time more than once when high-class stocks and bonds, and even Government bonds, could not readily be sold, but I have never seen the time, nor do I ever expect to see it, when anything that has to be eaten could not be sold. The warehouse receipts, therefore, above alluded to, constitute a collateral which is always available for the payment of debts.

"Furthermore, if the grain or provisions represented by warehouse receipts are already sold for future delivery, that fact adds a great element of strength to the loan, because there is a third party obligated to take the grain at a certain time for a given price. When I lived in Minneapolis I had the only unpleasant experience I have ever had in connection with the elevator business. A terminal elevator concern filled its elevators with wheat, and thinking that the market was likely to go up they did not hedge it by selling for future delivery. In other words they speculated on their wheat. The market had a large and a sudden drop, with the result that the elevator concern failed, and the bank with which I was connected made a loss. The present method, therefore, of carriers of grain or provisions selling them for future delivery is a highly satisfactory one to the banks whose money is loaned to the carriers. The sale for future delivery is the link in the chain that makes such loans the best."

An Argentina Need.- "There is no gambling in grain in Argentina, so frequently denounced in our Congress and by the public in this country. The grain business in Argentina is in the hands of a trust, which pays its own price as a rule for the products of the soil, exacting an enormous toll not only on the grain, but even on the bags which are furnished for transporting the grain.

"What the Argentine producer would like to have is a great Chicago or Minneapolis market where he could know just what the world thinks concern- 
ing grain prices. What he has are a few enormously wealthy exporters setting their own price upon his product.

"Argentina will never be a great agricultural country until she emerges from the chrysalis of monopoly which surrounds her grain trade. If the American farmer desires to test the efficacy of our own system of marketing and handling grain, and of our own methods of establishing prices for grain, let him proceed to study the Argentina system.

"I returned with a most wholesome respect for the American farmer, and I realize as never before, that the stability of this country depends upon the prosperity of the man who produces its wealth just as much or perhaps more than the man who consumes the products of the soil. But I also came back with a more intelligent regard for the great economic system which prevals in this country, which enables us to market grain at a minimum of profit between the man who produces it and the man who consumes it."-Prckell, $J$. Ralph, Agricultural Argentina, pp. 58-59. 


\section{CHAPTER XXIII}

\section{LIVE-STOCK AND MEAT INDUSTRY}

Introductory.-By reason of the large capital invested, the number of persons employed, and the value of the output, the meat packing industry of the United States ranks high among the great and fundamental industries of the country. Since American cotton, wheat and meat play such an important role in clothing and feeding the world, the meat and live-stock situation is one not merely of national but also of international concern.

The shifting of live-stock production to the open lands of the West and the concomitant growth of large centralized packing houses are the two outstanding features of the meat question in the United States. Five great packing house companies have risen above all competitors to a prominent position. Since the meat packing industry is one not protected by patents or monopoly, privileges or exclusive franchises of any kind, but represents the free play of competitive forces in American industrial evolution, the rise of five packing companies to a position of such vast and far-reaching power presents in concrete form certain unsolved economic and legal questions of public policy. Our eighteenth century legal philosophy of competition among small units does not square with our present-day economic facts of large scale business - of efficient competition eliminating the weaker competitor.

This chapter aims to present in larger outline the basic factors involved, since the issue presented to the country by the meat packing industry is one of public concern and one which needs constructive rather than destructive criticism.

The Live-stock Situation.- The live-stock question and themeat packing question are, from the public standpoint, merely two aspects of the one problem of furnishing to the public a continuing supply of animal food at fair prices. The welfare of the live-stock producers and the welfare of the packers are of public concern merely as they influence the permanent and practical problem of producing meat and distributing the same to the consumers, the meat to be of the quality and quantity desired, at the time desired, and at a fair price for each service rendered. 
Meat a Dear Food.-Meat is among the most expensive foods of mankind. As population increases, and cheap lands disappear, the live-stock increase fails to keep pace with the population increase. The live-stock industry, or at least the cattle and sheep industry, is characteristic of sparsely settled countries - empty countries with plenty of ranges for grazing purposes. In the past, at any rate, cattle and sheep raising has been a matter of extensive rather than of intensive farming.

Westward Movement of Live-stock Industry.-The development of manufacturing in the East and the consequent growth of large cities there have made it impossible for the farms of that section to supply their population with food. The grazing lands demanded for the raising of cattle and sheep are found in the West. The center of the production of corn and hay has moved to the more fertile lands of the Mississippi Valley. The fat cattle and hogs are fed in this section-over a thousand miles from the great cities of the seaboard. To reduce transportation costs, the dressed meats rather than the live animals are shipped east for consumption, and thus it is that the slaughtering business has moved westward with the live-stock industry. The dressed beef, for instance, weighs 55 per cent of the live beef, the remaining forty-five per cent of the animal going into byproducts or waste.

Shifts.-Taking the twenty-year period, 1880-1900, as representative, we find shifts occurring as follows in various branches of the live-stock industry: (1) Practically the only sections of the country showing an increase in the number of cattle on farms were those west of the Mississippi. Here the number rose $\mathbf{7 5}$ per cent. The States east of the Mississippi, on the other hand, showed an actual decrease in the number of cattle of over a million and a quarter head. In 1880,47 per cent of the cattle were west of the Mississippi; in 1900, the number was 62 per cent. The East of necessity furnishes whole milk to its city population, which necessitates a large number of dairy cattle, and a large slaughter of calves and of culls from dairy herds. In the year 1900, 72 per cent of the steers one year of age and over were west of the Mississippi, and 85 per cent of the cows two years of age and over not used for dairy purposes. In short, the beef industry had moved west of the Mississippi. (2) Much the greater part of the increase in the number of swine from 1880 to 1900 was in States west of the Mississippi. These western States had 39 per cent of the swine in 1880 and 50 per cent in 1900 . (3) There has been a very marked 
decrease in the number of sheep in the section east of the Mississippi, the shrink amounting to about 8,000,000 head in 20 years. In 1880, 51 per cent of the sheep were west of the Mississippi; in 1900, 68 per cent were found there. The west showed an increase of five and a half million head of sheep in these twenty years.

Live-stock Countries.-Live-stock production follows the open country, not only in the United States, but also in other countries. Thus it is that the five other surplus meat countries, besides the United States, are Argentina, Australia, Canada, New Zealand, and Uruguay. Denmark, by reason of her bacon export is a factor of importance, but Denmark is unimportant as a beef or mutton producing country, and hence is no exception to the above rule.

Decrease in Number of Live Stock. - In the United States it was a matter of much comment, prior to the World War, that livestock population was not increasing at so fast a rate as the human population. While maintaining large exports of pork products, we also became in certain months a large importer of meat.

Using the figures published by the United States Department of Agriculture in its Report on the Meat Situation in the United States, we have the following facts regarding live-stock production: On the basis of the number of animals per 100 people, the returns for 70 years are as follows:

$\begin{array}{lcl} & \text { I. CATTLE } & \\ 1840-88 \text { animals } & 1870-62 & 1900-89 \text { June 1. } \\ 1850-77 & 1880-72 & 1910-71 \text { April 15. } \\ 1860-81 & 1890-82 & 1914-57 \text { January 1.* } \\ & \text { II. SHEEP } & \\ 1840-113 \text { animals } & 1870-74 & 1900-81 \text { June 1. } \\ 1850-94 & 1880-70 & 1910-57 \text { April 15. } \\ 1860-71 & 1890-57 & 1914-50 \text { January 1.* } \\ & \text { III. HoGs } \\ 1840-154 \text { animals } & 1870-65 & 1900-83 \text { June 1. } \\ 1850-131 & 1880-95 & 1910-63 \text { April 15. } \\ 1860-107 & 1890-91 & 1914-60 \text { January } 1 . *\end{array}$

* Figures for January 1, 1914, omit crop of calves, lambs, and pigs, and hence are not comparable with figures for 1910 or 1900 . In this connection mention must be made of the tremendous increase in livestock production from 1914 to 1918 , under war conditions, showing the possibilities in this field of agriculture.

In the United States, and in the rest of the world, meat is becoming a relatively scarce article of diet. However, this may be merely a temporary reaction from our glutting the markets thirty years ago.

Outlook for the Future of Live Stock.-With the passing of cheap lands and of the great open ranges of the West, the question of our future live-stock supply becomes a serious one. Will we maintain our live-stock production? And if so, how? The packers, 
the railroads, the bankers, the Federal and State governments and many other interests are now coöperating with the farmers for the purrose of increasing the number and improving the breed of live stock. The factors making for and the factors making against an increase may be considered in turn.

(1) For an Increase. - The breeding of cattle and sheep on the ranges represents one phase of extensive agriculture. But intensive agriculture is gradually encroaching on this area. This means that the breeding of live stock will need to shift to the more intensive form of agriculture, in most cases, if any increase is to be expected. The problem of an increase is therefore, a two-fold one, namely, an increase in live stock in the so-called range country of the West, and an increase in livestock in the farming sections of the rest of the country. The Federal Department of Agriculture made an optimistic report in the year 1916 on the subject "Livestock Production in the Eleven Far Western Range States." In these eleven States (Arizona, California, Colorado, Idaho, Monana, Nevada, New Mexico, Oregon, Utah, Washington and Wyoming) the investigators for the Government found a decline of 13 per 'cent in the number of live stock between the years 1910 and 1914. This decline was attributed to the settlement of public lands and the consequent reduction of the range. However, in spite of this actual decline, the prediction was made that this decrease would in the future give way to an actual increase. The belief in an increase was based on the probability that the number of live stock on farms would be greater in the future; that the stock ranges in the national forests would continue to improve; that the carrying capacity of the range on the public domain would be increased by legal regulations; and that, finally, better and more scientific use would be made of forage. The Government's optimistic prediction is based on the calculation that the carrying capacity of the forest reserves can be increased by 15 per cent, and of the public domain by 30 per cent. Some consideration is also given to the use of better sires, and to more scientific feeding methods. The chief conclusions reached by this federal investigation are, to sum up, that hereafter there should be a slow increase in the output of beef and mutton in the range States of the West, but that this increase is likely to be accompanied by an increase in the cost of production. However, the problem of live stock increase cannot be solved by the eleven range States alone. As one of our leading publicists, Easton G. Osman, states it, "The future of meat depends on intensive agriculture rather than exten- 
sive grazing." 1 The limiting factor in producing live stock under conditions of intensive agriculture is of course the cost of the feed. This comparatively simple problem is further complicated by the farm management problems of crop rotation systems and the maintenance of soil fertility by the use of manure. Doubtless in many cases where the original range has been put under the plow and alfalfa or other forms of tame hay substituted for the wild hay, there has followed an actual increase in the amount of livestock feed produced. It is also true that much original range has been plowed with disastrous results. Aside from hay and corn, the principal feeds now used in fattening (or "finishing") cattle for the market, there is a rapidly swelling list of feeding stuffs coming onto the market. The Department of Agriculture, in reporting on the "Meat Situation in the United States," issues one report on the subject, "Utilization and Efficiency of Available American Feed Stuffs." In this report consideration was given to the following feeding stuffs: straw, corn stover, cottonseed meal and cake, linseed meal and cake, soy bean cake, peanut cake, sesame cake, copra (cocoanut by-products), palm-nut meal, winter wheat and winter oats as grazing crops, spineless cactus, sugar .cane, feterita, sudan grass, teosinte, velvet bean, kudzu vine, sweet clover, cassava, beggar weed, rape, roots (mangels, beets, turnips), silage, canning factory refuse, beet pulp, sugar cane, and molasses. Corn and corn products and alfalfa and alfalfa products are, of course, the important feed stuffs in the region contiguous to the great packing centers. It is obvious that an intensive agriculture can furnish more and better live stock than can extensive agriculture. But the comparative costs cannot be calculated in advance. The tendency is for cities to increase in population faster than rural districts, and for manufacturing to assume greater and greater importance. And the by-products of many lines of manufacture furnish feed for live stock, such for instance, as the by-products of the various oil-bearing seeds. It is impossible to predict the future development of commercial manufactured feed stuffs, or even the changes in method of preparing and feeding silage.

(2) Against an Increase.-There are at least three factors which make against any substantial increase in the number of live stock in the United States - disease, substitution of vegetable oils for animal fats and oils, and the increase in tenańcy. Disease is an important factor repressing meat production. The packers

${ }^{1}$ Editorial, Price Current Grain-Reporter, Chicago: July 31, 1918, p. 7. 
have aided other interests in a campaign against tuberculosis, which is rampant in dairy sections. West of the Missouri River contagious abortion is a more serious menace to cattle production. In the South the so-called Texas tick is a serious handicap. Hog cholera, the deadliest foe of swine, is only partially under control by vaccination(?) Sheep on higher altitudes are comparatively healthy, while at lower altitudes internal parasites and other ailments play havoc with flocks. Lack of care in winter is also a cause of many severe losses.

On the demand side of the market we are confronted with the fact that the people are eating less meat and more meat substitutes. Vegetable fats and oils are very rapidly establishing themselves in the dietary of the people. The nations which do consume less meat and more meat substitutes fail to show any loss in physical stamina thereby. The average annual meat consumption, per capita, of the meat eating countries of the world is 93.3 pounds of beef, mutton and pork. In the United States the meat consumption decreased from 181.5 pounds in 1900 to 170.6 pounds in 1909 . Only two countries exceed this-Australia, 263 pounds (in 1902) and New Zealand 212 pounds (in 1902). In 1906 the consumption of meat in the United Kingdom amounted to 125 pounds per. capita; in France, in 1904, to 77 pounds; in Germany in 1913, to 100 pounds. $^{2}$ The most serious factor of all making against an increase in live stock is the long-continued and steady increase in tenancy in the United States. Renters do not raise live stock, especially the short-term renters, which is the class known in this country. The tenant is not interested in live stock from the standpoint of maintaining the fertility of the soil, for it is not his soil. He is concerned chiefly with a "cash crop." He is not therefore concerned with a rotation system in which live stock forms a part.

Summing up the arguments for and against the probable increase in the number of live stock in the United States, it seems that the arguments against an increase outweigh the arguments for an increase.

Foreign Competition.-Foreign competition is taking the form both of producing live stock and of packing meat for the market. So far as South America is concerned, this competition is largely by transplanted American men and American capital. Thus in 1912 Murdo McKenzie of Texas and Denver, America's most prominent cattleman, went to Brazil to develop the cattle resources

${ }^{2}$ Meat Situation in the United States. Report 109, United States Department of Agriculture, pp. 16, 17. Washington, 1916. 
of that country. ${ }^{3}$ The live stock census of 1913 gave Brazil $30,705,000$ head of cattle, 10,653,000 sheep, and 18,399,000 hogs. The Brazilian government is offering substantial encouragement to breeders of cattle in order to improve the strain. Argentina has long been famous as a country which imports very expensive pure bred sires from England, and which has made much progress in breeding pure-bred cattle. Australia, New Zealand, and South Africa are also important market factors in producing live stock and exporting surplus meat.

It was not until 1901, when the exports of beef from the United States began to decline materially, that exports of Argentine beef began to assume commercial importance. Since that date the increase has been steady and rapid. The export of foreign mutton was left to Australia and New Zealand, which already dominated that field, and the beef industry, rather than pork, received Argentina's attention. During the years 1908 to 1914, however, there was an increase in Argentina's hog crop and a decrease in the cattle and sheep crop.

The large American packers have established meat packing plants in foreign countries as follows. ${ }^{4}$

Armour and Company.

Armour \& Company of Australasia (Australia and New Zealand).

Armour \& Company of Uruguay.

Compania Armour do Brazil.

Frigorifico Armour de la Plata (Argentina).

Cudahy Packing Company.

Cudahy \& Company, Limited, Australia.

Swift \& Company.

Australian Meat Export Company, Limited, Australia.

Compania Swift do Brazil.

Compania Swift de la Plata (Argentina).

Compania Swift de Montevideo (Uruguay).

Compania Paraguaga de Frigorifico (Paraguay).

Wilson \& Company, Inc.

Frigorifico Wilson de la Argentina (Argentina).

Armour \& Morris.

Sociedad Anonima La Blanca (Argentina).

The United States for many years enjoyed first place as an exporter of beef. First place has now passed to Argentina, with the United States second and Australia third. Argentina forged

${ }^{3}$ Murdo McKenzie, in the course of an address at the arnual meeting of the cattlemen at the Kansas State Agricultural College, spoke of the possibility of extending the live stock trade in South America, particularly in Brazil. Tuberculosis he named as the big evil in cattle. His company, he said, had bought 750,000 acres of land at 29 cents an acre and another large tract at 89 cents an acre, land equal to any land in Kansas.-Wallaces Farmer, June 22, $191 \%, p .4$.

${ }^{4}$ Summary of the Report of the Federal Trade Commission on the Meat Packing Industry, p. 12. Washington, 1918. 
steadily ahead and permanently passed the United States in exports of beef in 1909. The lead was held through the World War, although both Australia and the United States made incredibly large increase in exports to meet the needs of the Allies. The

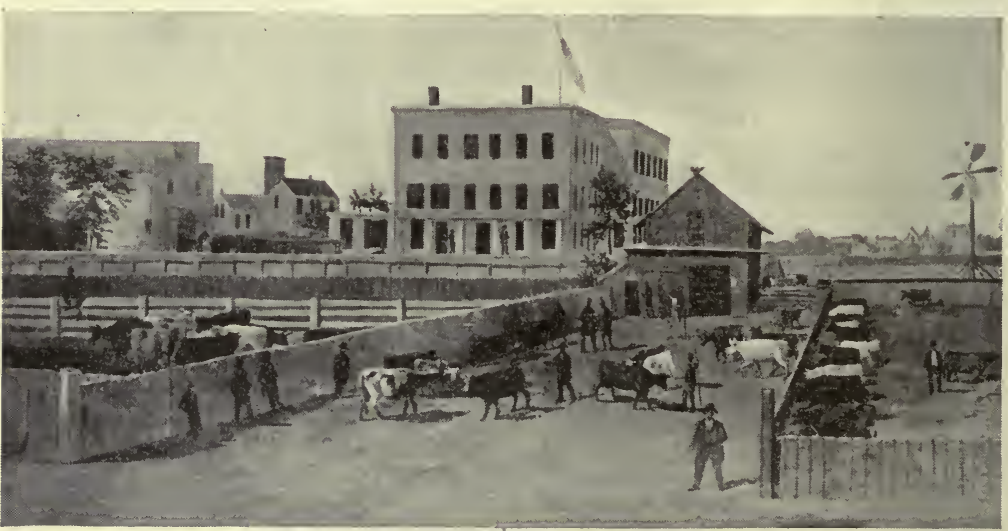

FIG. 74.-The Chicago stock yard in 1861.

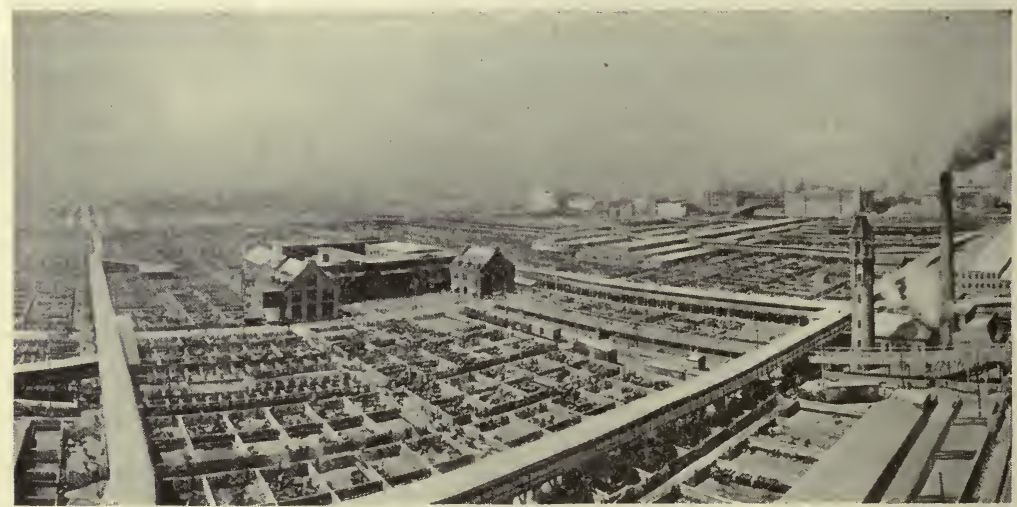

FrG. 75.-The Chicago stock yards fifty years later.

average yearly exports of beef from these three countries together increased from $925,000,000$ pounds in $1895-1904$ to $1,344,000,000$ pounds in 1905-1914, and to 1,909,000,000 pounds in 1915-1917. This huge feat was performed by the combined efforts of producers and packers.

The Meat Packing Industry.-The meat packing industry is one of the best examples of large-scale production in the United 
States (Figs. 74 and 75). One of the severest indictments brought against the competitive regime by the Socialists is the wastes of competition. The meat packing business, as now conducted by the five large-scale packing concerns is a business which has gone a long way towards eliminating the wastes incident to competition. And in arriving at the point of "large-scale production," the meat packing industry has challenged certain economic and legal doctrines of the country.

A Large-Scale Business.-While there are many small slaughtering establishments throughout the United States and an increasing number of municipal abattoirs, yet the high position of size

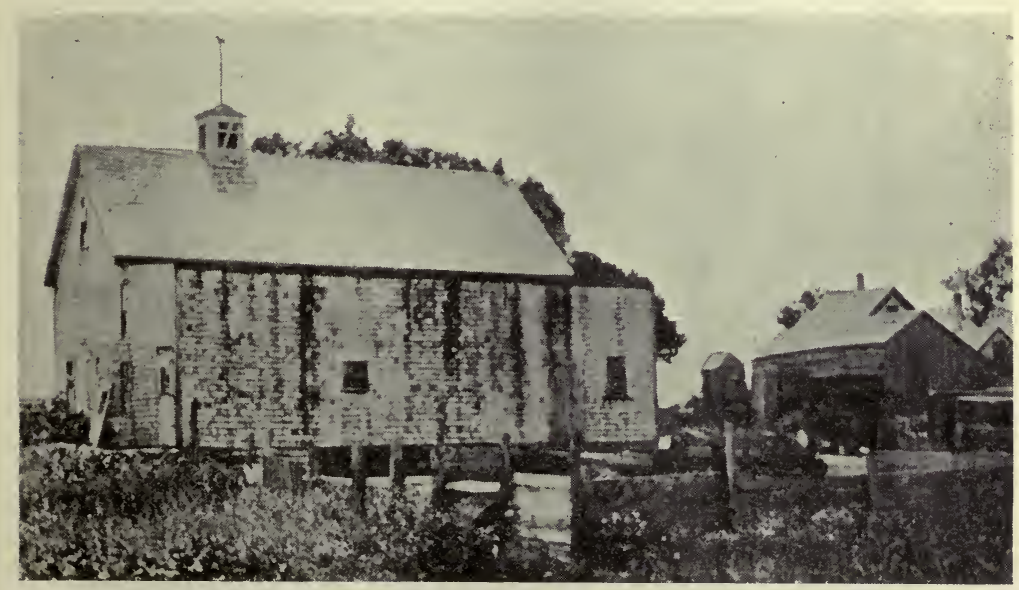

FIG. 76.-Evolution of the packing industry. The first plant of a big Chicago packer.

attained by five of the largest packers makes the packing industry in reality a large-scale business (Figs. 76 and 77). It is estimated that five companies now kill 70 per cent of the live stock slaughtered by all packers and butchers engaged in interstate commerce, which amounts to forty per cent of the total meat supply of the country. The largest single packer handles 15 per cent of the total meat supply of the country. According to the federal government's figures, there is only one packer, outside the five large ones, who slaughters as much as one per cent of the interstate total of cattle, and only nine who slaughter as much as one per cent of the interstate total of hogs. In other words, the 30 per cent of -the live stock slaughtered by "small-scale business" concerns is slaughtered by a large number of relatively very small concerns. Of course there is a vast volume of cattle and hogs slaughtered by local butchers 


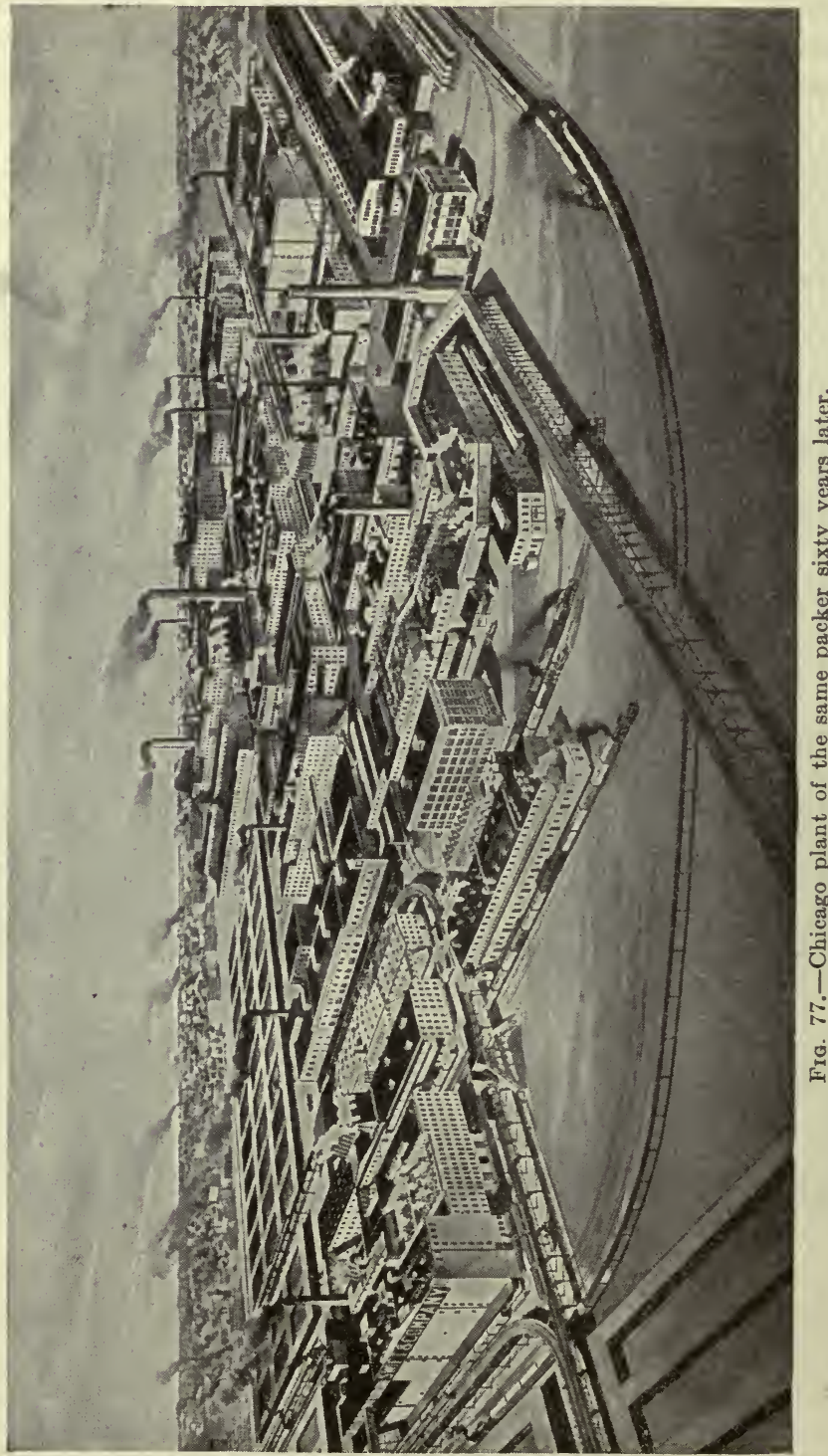


for their city trade which does not figure in the above calculations, not entering into interstate commerce. The five large companies own and operate packing houses at the following points: Chicago, Kansas City, South Omaha, St. Joseph, St. Louis and East St. Louis, South St. Paul, Fort Worth, New York, Sioux City, Los Angeles, Denver, Oklahoma City, Portland (Oregon), Cleveland, Andalusia (Alabama), Moultrie (Georgia), Harrisburg, Milwaukee, Albert Lea, Wichita. The advantages of large-scale production in meat packing are evidenced in five ways, namely, division of labor, utilization of by-products, better transportation and market distribution, better inspection and grading, and the number of "side lines" economically carried. The final economic test of the big packers is: Do they function economically in getting the live stock of the West to the cities of the East?

(1) Division of Labor.-Slaughtering on the farm or at the butcher shop is commonly done by two men. In this way two men can butcher two animals in ten hours. But in the big packing house the work is done by a "gang" consisting of about 150 men, who in ten hours handle more than a thousand cattle. In other words, by increasing the size of the gang seventy-five fold the packers increase the output five hundred fold. For instance, in a large Chicago packing plant a gang of 157 men, by the minute division of labor in use there, were able to handle in a typical working day of ten hours 1050 cattle. The work was divided as follows: 1 general foreman; 1 foreman over yard gang; 1 driver up; 2 penners; 2 knockers; 2 shacklers; 1 hanger off for shackler; 1 squeezing blood from beds; 1 switcher onto heading beds and putting up heads; 1 throwing down heads; 1 pritcher up; 1 dropper; 1 pritcher up helper; 1 sticker; 3 headers; 1 ripper; 4 leg breakers; 3 feet skinners; 1 gullet raiser; 7 floormen; 1 breast sawyer; 1 aitch sawyer; $2 \frac{1}{2}$ caul pullers; 2 putting in hooks to hoists for fell cutter; 1 floor squeezer; 1 washing crutches and bellies; 4 fell cutters; 1 cutting out bladders; 2 rumpers; 1 rump helper and drop hide feller; 2 backers; 4 splitters; 1 back and rump hand; 1 washing hind shanks; 1 ripping tails and cutting out; 1 . pulling tails; $2 \frac{1}{2}$ gutters; 2 throwing down guts and paunches; 3 tail sawyers; 2 hanging off from splitter; 3 beating out fells; 1 helper sawing tails and ripping open; 2 neck splitters; 1 tallow lot man; 1 trucking feet; 1 trucking up hocks; 1 hanging up hooks; 2. clearing out; 3 dropping hides; washing gang as follows: 1 foreman; 1 trimmer; 1 wiper; 1 putting in neck and kidney cloths; 1 scribe sawyer; 1 hoseman; 1 washing shanks; 1 switchman; 3 washing ribs and necks 
inside; 1 squeezing beef; 1 pumping kidneys; 3 long brush washers; 1 washing rags; 2 wiping hinds; 2 ladder men (knife); 2 bruise trimmers; 1 cutting off cords and shanks; 1 tying veins; 2 trimming skirts and necks; 1 pumping necks; Weighing beef and helpers as follows: 1 scaler; 1 grader; 1 pushing on scale or tagger; 1 pulling off scale; 1 elevator man; Refrigerating and car loading as follows: 14 beef coolers; 5 trimmers; 7 carriers and loaders; 11 laborers.

Such division of labor means that highly skilled workers are put on specialized jobs, and cheaper and less skilled labor is employed on the simpler jobs. In this way the utmost economy of time and effort is secured.

(2) Utilization of By-products. - It is literally true that no part of the animal entering the large packing house is wasted. The blood that falls on the floor passes down a chute and goes into fertilizer. During the World War blood was also made into albumen which was in turn used in the manufacture of airplanes. Hair, hide, bones, all are utilized. Liver, sweetbread, brains, tongue, heart, tail-all find their way into human foodstuffs. Buttons, knife handles, glue, gelatin, soap, curled hair, brewers' isinglass, sandpaper, music strings, combs, artificial teeth, pipe stems - these and many other commercial articles are by-products of the packing house. One of the large Chicago packers makes the statement that his company sells the dressed meat from a steer for less than the live animal cost on the hoof. Thus, as a typical example, a 1,000-pound steer was bought by this packer in September, 1918, for $\$ 160.00$, and from it 565 pounds of dressed beef were obtained. This beef was sold at wholesale for $\$ 141.25$. The hide sold for $\$ 15.75-$ a total for the beef and hide of $\$ 157$ or three dollars less than the cost of the live animal. The cost of slaughtering, dressing, and distributing was $\$ 5.79$ more, or a total deficit of $\$ 8.79$. The by-products of this steer in addition to the hide, however, amounted to $\$ 9.77$, leaving a profit of 98 cents on the animal. The by-product business is one feature of the largescale production, and means, in the case of the packers, the fruits of much experimentation, the development of private laboratories, and the work of scientists. This is particularly true of the chemical and medical preparations developed in the packing houses, such as pancreatin, thyroids, supra-renal, pineal substance, thromboplastin, and so on. Practically all these by-products are entirely wasted in the small packing houses.

(3) Transportation and Distribution.-The large packers own their own refrigerator cars and have volume enough of business 
to send out full loads under ice to distant markets. They own , heir own branch houses which sell direct to retail stores. Market gluts can thus be avoided by shipping promptly to points of greatest scarcity. Car routes reach towns which are not handled from branch houses.

(4) Inspection and Grading.-The large packing houses make government inspection feasible (Figs. 78 and 79). The government stamp on meat has come to be looked upon as a guarantee of the health of the animal. The large-scale business also permits

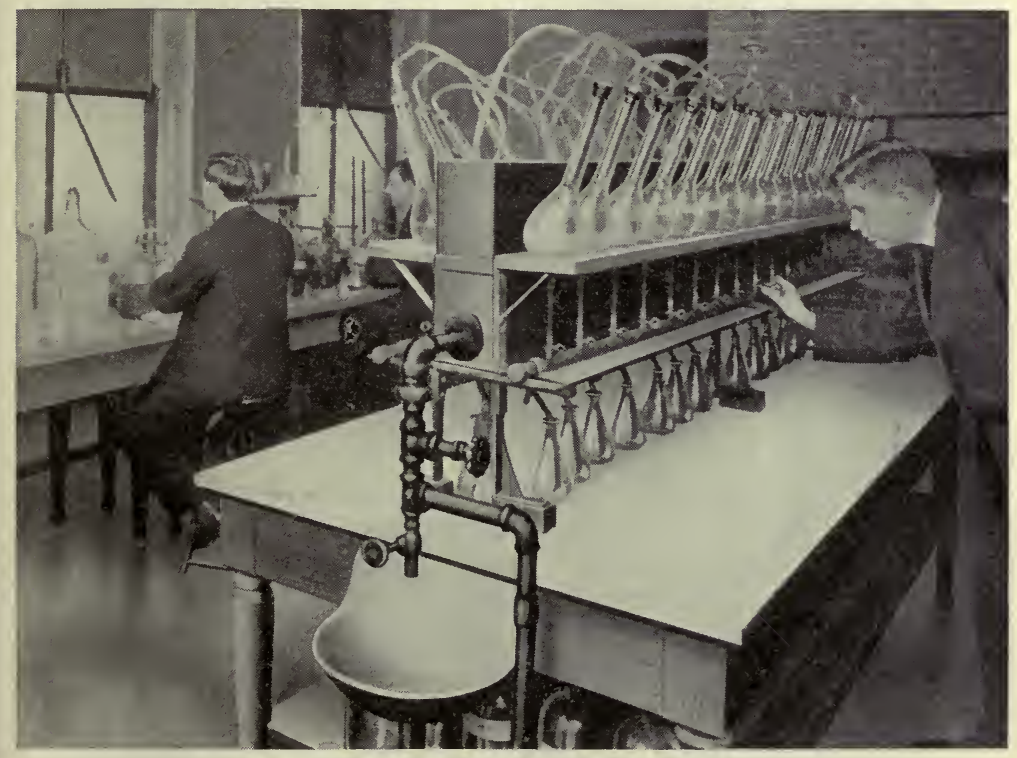

FIG. 78.-Private chemical laboratory of a big packing house.

the packer to furnish any consuming market the quality as well as the quantity of meat desired, and at any time desired.

(5) Side Lines.-The facilities for conducting the meat packing business and for distributing it by fast refrigerator car service, through branch houses in all population centers, also enable the packers to handle many side lines with economy of time and money, with mimimum of overhead expense.

Legal and Economic Questions.-The forefathers who drew up the Maryland Constitution of 1776 inserted these words:

"That monopolies are odious, contrary to the spirit of a free government, and the principles of commerce, and ought not to be suffered." 
Forty-one days before the writing of these words by the Maryland fathers, the Continental Congress had adopted the Declaration of Independence, marking the severance of the new Republic from the Old King. Autocratic political power was the thing abhorred by the people of the New World. In the century and a

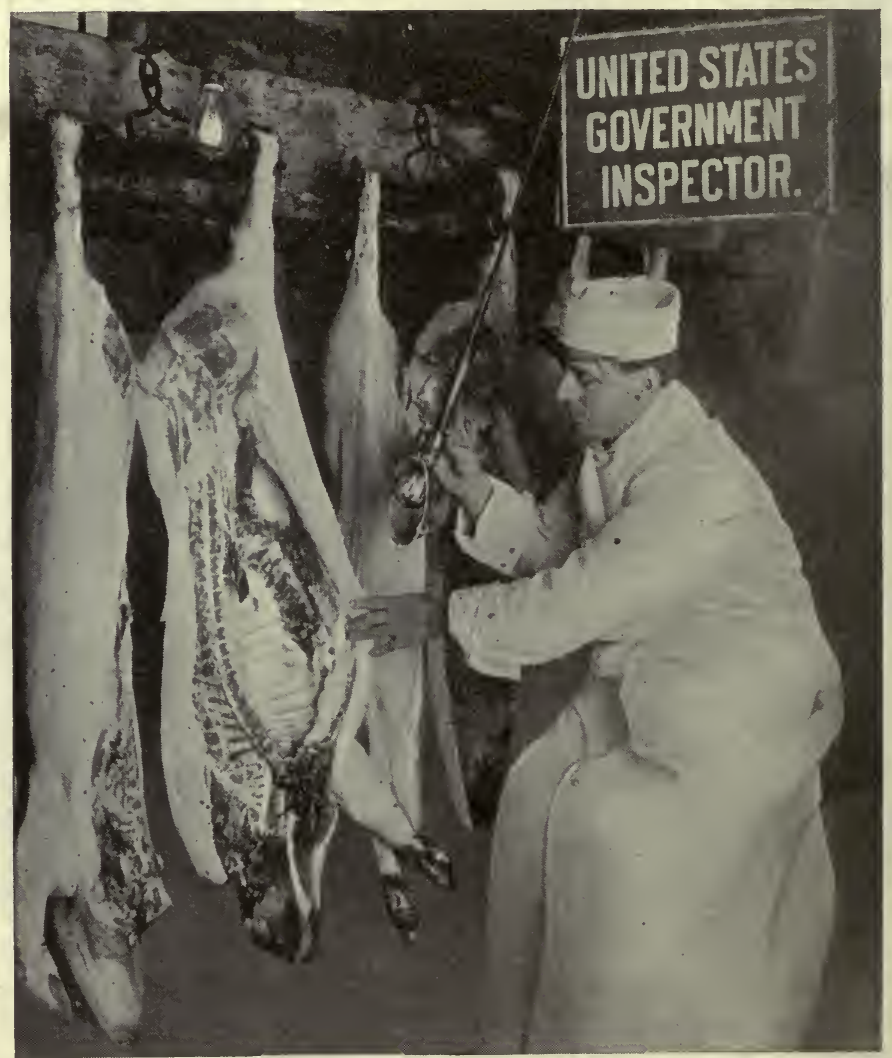

Frg. 79.-Government inspection of meat in a large packing house.

half which has elapsed since that struggle began autocratic political power has nearly vanished from the whole world. The same instinct of abhorrence towards autocratic political power which then existed now continues as an instinct against autocratic economic power. And so, in the last third of a century, we have seen the power of the federal courts invoked against the great consolidated business units operating in sugar, steel, oil, tobacco, harvesting 
machinery, and meat packing. Whether this instinct is now wise or unwise, whether well founded or ill founded, is not a profitable question to debate. The existence of such an instinct must be taken for granted. The existence of this instinct explains the persistent demand on the part of the people that the government "do something" with this great economic problem. Granting that the mere bigness of these various large-scale industrial corporations gives them power, does it also give them autocratic power? And do they use this big power so that society benefits thereby or so that society suffers thereby? These are some of the politico-economic questions underlying this phase of our nation's development.

The meat packing industry has been subject to many investigations, State and Federal. Out of this vast mass of material of lawsuits, hearings, investigations, injunctions, regulations, and so on, two investigations only will be reviewed here, since they bring out the fundamental issues which must be faced and settled.

The Garfield Report.-The Report of the Commissioner of Corporations in 1905, known as the Garfield Report, was made in response to a Resolution passed by the House of Representatives March 7, 1904. The Resolution stated the object of the investigation as follows:

"Resolved, that the Secretary of Commerce and Labor be, and he is hereby, requested to investigate the cause of the low prices of beef cattle in the United States since July first, nineteen hundred and three, and the unusually large margins between the prices of beef cattle and the selling prices of fresh beef, and whether the said conditions have resulted in whole or in part from any contract, combination, in the form of a trust or otherwise, or conspiracy, in restraint of commerce among the several States and Territories or with foreign countries; also whether the said prices have been controlled in whole or in part by any corporation, joint stock company, or corporate combination engaged in commerce among the several States or with foreign nations; and if so, to investigate the organizations, companies, and corporate combinations, and to make early report of his findings according to law."

Accordingly the report on "The Beef Industry" was the first report issued by the new Bureau of Corporations in the movement against the "Trusts" initiated by President Roosevelt. The chief findings of this Report are as follows.

(1) "Big Six" and Their Capitalization.-By far the most important concerns in the beef business were the following companies, frequently designated in the trade as the "Big Six"

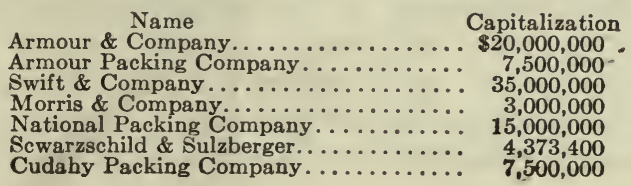


"It appears," says the Report, "reasonably clear that the capitalization of none of these companies is excessive as compared with its actual investments." In other words, there was found no watered stock.

(2) Extent of Control.- "The six concerns described are almost the only extensive shippers of dressed beef; that is, they are almost the only concerns which slaughter cattle in the great western markets and transport the product elsewhere for consumption. At the same time these companies do a smaller proportion of the beef business of the country than is ordinarily supposed, and comparatively narrow limits are placed upon the control which they could, even if they acted in harmony, exercise over the prices of cattle and of beef."

The Bureau estimated that in 1903 there were slaughtered in the United States 12,500,000 head of cattle, of which these six companies slaughtered 5,521,697 or 45 per cent. On the other hand, these concerns slaughtered 98 per cent of the cattle killed in the eight leading western packing centers-Chicago, Kansas City, South Omaha, East St. Louis, South St. Joseph, Fort Worth, Sioux City, and South St. Paul. The proportion of beef consumption which was furnished by these packers varied greatly with different cities and sections. The area east of Pittsburg differed greatly from the area west of Pittsburg. In New York these packers furnished about 75 per cent of the beef consumed; in Boston, 85 per cent; in Philadelphia, 60 per cent; in Providence, 95 per cent; in Baltimore, 50 per cent; Buffalo and cities west (such as Cleveland, Cincinnati, and Indianapolis) only from 10 to $331 / 3$ per cent. In the dairy sections the dairy industry was found to furnish a large number of surplus cattle for slaughter.

(3) Potential Competition.-On this subject the Report says: "Should the western packers try to obtain a much higher percentage of profit than they do at present, existing local slaughter houses at all consuming points would tend to expand their business materially, and new concerns would spring into existence. The possibility of a rapid increase in competition of local slaughterers was illustrated during the packing house strike of the summer of 1904 , when the shortage in the beef furnished by the western packers was to a very considerable extent made up by increased killing on the part of small concerns. .. . The business is not controlled by patents, secret processes, or monopoly of raw material, and the amount of capital necessary to provide even a 
system of several plants, with transportation lines and marketing facilities, is not so large as seriously to hinder new competition in case a very high margin of profit should be maintained by the present concerns."

Little fresh beef is sold to dwellers in the country. In fact a large proportion of the packers' beef is consumed in a few large cities. The packers might by predatory competition and price cutting in one locality, drive out a competitor, and recoup in other localities. But, says the Report, such a practice was unlikely, for the cutting of price in any of the large cities would mean a general reduction in that entire local market.

(4) The Price Question.- "During the year from July 1902, to June 1903, these packers slaughtered at the selected plants $2,017,864$ cattle. The average live weight of these cattle was 1,092 pounds, and the actual average cost $\$ 4.45$ per hundredweight, the cost per head being $\$ 48.58$. The cost of operation and administration at the packing plants averaged $\$ 1.90$ per head, making the total cost $\$ 50.48$. The weight of the beef derived from these cattle was equal to 55.68 per cent of the live weight, or 609 pounds per head. The average net selling price of the beef was $\$ 6.47$ per hundredweight, or $\$ 39.32$ per head. The net value of by-products from the cattle was $\$ 11.96$ per head, making the total proceeds $\$ 51.28$ per head. This showed an average profit of 80 cents per head, or 13.1 cents per hundredweight of dressed beef." This is a profit of about $1 / 8$ of a cent a pound on the beef sold.

"For the year from July 1903 to June, 1904, the computation covered 2,013,658 cattle. The average live weight was 1,115 pounds, and the average cost at $\$ 4.15$ per hundredweight was $\$ 46.23$ per head, the total cost, including killing, etc., being $\$ 48.19$. The average selling price of the beef was $\$ 6.25$, or $\$ 39.26$ per head, the average dressed weight being 629 pounds. The net value of by-products was $\$ 9.75$ per head, or more than $\$ 2$ per head less than in the preceding year. The total proceeds of the beef and the by-products were $\$ 49.01$, leaving a profit of 82 cents per head, equal to 13.5 cents per hundredweight of dressed beef."

(5) The Profits.-This Report states the profits of two of the large packers, based on the total volume of the year's business, the figures for Swift \& Company being 1.9 per cent, and for Cudahy \& Company 1.8 per cent.

The 1912 Case.-A lawsuit was carried through the courts in 1912 , with a regular jury trial, to decide the question of "monopoly control." It was found by the jury that no monopoly existed. 
It happened that 1905 was the low-water mark in the value of cattle, and from that date on, up to the end of the World War, there was an upward trend in the price of beef cattle. The price, however, was a very fluctuating one, so that the live-stock producers continued to feel dissatisfaction and distrust towards the packers. High prices of beef caused the consumers to feel that "something was wrong somewhere." Accordingly the President in 1917 addressed a letter to the Federal Trade Commission, dealing with the production and distribution of the nation's food supply, and containing these words:

"Unjustifiable fluctuations in prices are not merely demoralizing; they inevitably deter adequate production. It has been alleged before Committees of Congress, and elsewhere, that the course of trade in important food products is not free, but is restricted and controlled by artificial and illegal means. It is of the highest public concern to ascertain the truth or falsity of these allegations. No business can be transacted effectively in an atmosphere of suspicion. If the allegations are well-grounded, it is necessary that the nature and extent of the evils and abuses be accurately determined, so that proper remedies, legislative or administrative, may be applied. If they are not true, it is equally essential that the public be informed, so that unrest and dissatisfaction may be allayed .... Therefore I direct the Commission, within the scope of its powers, to investigate and report the facts relating to the production, ownership, manufacture, storage, and distribution of foodstuffs and the products or by-products arising from or in connection with their preparation and manufacture; to ascertain the facts bearing on alleged violations of the anti-trust acts, and particularly upon the question whether there are manipulations, controls, trusts, combinations, conspiracies, or restraints of trade out of harmony with the law or the public interest."

Federal Trade Commission Report, I9I8.-The Trade Commission, after a year's investigation, stated that the packing industry was dominated by five concerns, namely, Armour \& Company, Swift \& Company, Morris \& Company, Wilson \& Company, Inc., and the Cudahy Packing Company. The Commission examined witnesses, held public hearings, and examined minutely the letters and memoranda in the files of the packers. Unlike the Garfield Report, this Report does not endeavor to explain the margin between price paid for live cattle and price received for dressed beef. This Report is concerned chiefly with the magnitude of the operations of the packers and with the question of a "combination" among the so-called "Big Five."

(1) Magnitude of Business.-The five packers, together with their subsidiaries and affiliated concerns, were found to be extensively engaged in purveying other foodstuffs than meat, and to be engaged in various related and non-related side lines and businesses. In addition to packing houses, these packers also had extensive holdings in stockyards, private refrigerator cars, cold storage 
plants, branch-house system of distribution, banks and real estate. As parent companies, or through affiliated or subsidiary companies. these packers manufactured or handled, among other things, the following products (arranged alphabetically):

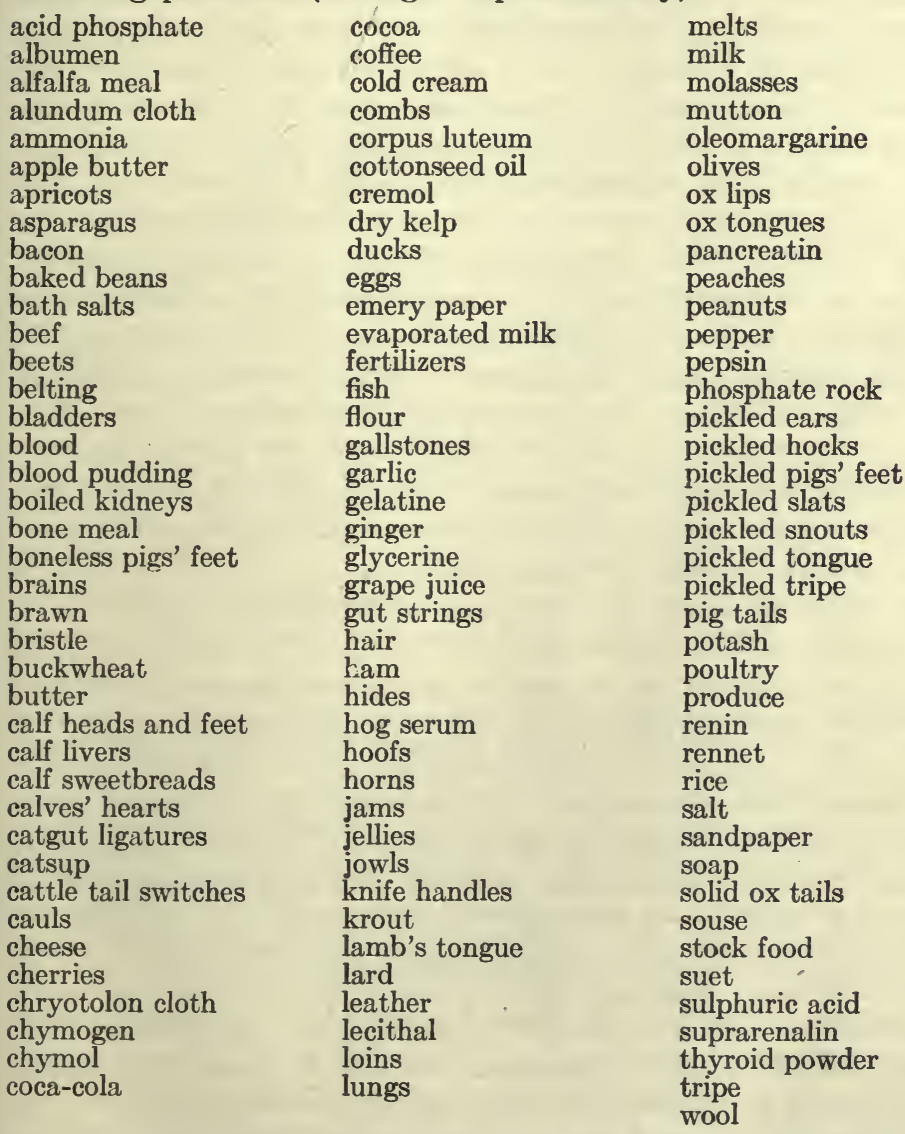

In developing these extensive by-products, side lines, and other lines these five packers made large use of the industrial principle of "integration of services" (that is, elimination of the middleman; direct production and marketing).

The five companies had the following capitalization in 1917:

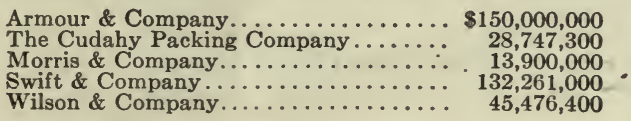


"The most satisfactory single index of the proportion of the meat industry controlled by the Big Five," says the Report, "is the fact that they kill, in round figures, 70 per cent of the live stock slaughtered by all packers and butchers engaged in interstate commerce." No exact figures could be given for the per cent of all slaughtering done by these packers, since there are thousands of butchers who kill for the local village or city trade, in addition to the slaughtering done on the farms by hundreds of thousands of farmers.

(2) Combination Among Packers. - The Commission found that in the purchase of live stock, there was a remarkable uniformity from year to year in the percentages purchased by each of the big packers, and concluded that this was circumstantial evidence of a combination. However, since the same uniformity exists among the small packers in the purchase of their requirements, and in many other industries, this evidence of combination is not convincing. No evidence was found that there was any "combination" among the big packers in fixing prices paid for live stock or fixing prices received for dressed meats, or that large profits were made on the volume of business done.

The conclusions reached by the Commission as to the autocratic powers of the packers were stated in these words:

"The great power of the five packers in the meat, by-product, and food industries, the history of their growth, the ramifications of their control and influence, their interrelations, and the corporate machinery through which they work, are matters that command public attention. A fair consideration of the course the five packers have followed and the position they have already reached must lead to the conclusion that they threaten the freedom of the market of the country's food industries and of the by-product industries linked therewith. They constitute a force operating with increasing power in the direction of monopoly of an important part of the country's necessities. An approaching packer domination of all important foods in this country seems a certainty unless fundamental action is taken to prevent it."

Remedies.-The Trade Commission considered various remedies for the situation which they found to exist, such as government ownership of the packing houses, private ownership and operation under federal license, and so on. The final "remedy" proposed by the Commission was a simple one, containing these four provisions:

(1) Government ownership of all cars used in transporting meat animals.

(2) Government ownership of the stockyards.

(3) Government ownership of all privately owned refrigerator cars.

(4) Government ownership of the branch houses of the packers, and of their cold' storage plants and warehouses. 
The Reply of the Packers.-When the above Report of the Federal Trade Commission was published, the packers involved replied that the proposed "remedy" would not result in better prices to producers, or lower prices to consumers, or prove in any way beneficial to the public. The packers very vigorously denied that they "dominated" the live stock market or were able to override the forces of supply and demand. Fluctuations in the prices of live stock and of meats they attributed solely to the two factors of supply of live stock and consumers' demand for meat.

The Real Evil and the Remedy.-The many investigations of the packers have generally been weak either in diagnosis or in therapeutics, or both. The mere bigness of the packers has challenged attention. Their prominent position-financial, industrial and otherwise--has created a state of mind among many producers and consumers that in these packers was vested autocratic industrial power. A popular feeling has been created that these big packers have not merely great power, but irresponsible power. This feeling is more than a mere belief, or mere conviction; it is a state of mind. This is the diagnosis of the situation. And it suggests the remedy. The principle of the cure is simple enough, namely, to preserve the economies of the large-scale business system developed by the packers and at the same time establish what may be termed a "responsible government" of the packers. This latter phrase needs some further elucidation.

A quotation was given above from the old Maryland Constitution, to illustrate the instinct of our people against autocratic, irresponsible power, both political and economic. Our forefathers established, or attempted to establish, a political government which would reflect and respond to the will of the people governed. The modern industrial clash between large aggregations of capital (popularly and wrongly called "Trusts") and the mass of the people themselves is due to this ancient instinct of abhorrence of irresponsible power. The almost childlike faith in competition as the "life of trade" reflects this same instinct. Hence came our Sherman Anti-Trust law, saying, in substance, "Thou shalt compete." And yet some of the most progressive nations have found it wise to pass laws, as concerns certain fields of commerce, saying, in substance, "Thou shalt not compete." 5

${ }^{5}$ The paradox of the Sherman law is apparent. It says, thou shalt compete. In competition (which is industrial warfare) the strong survive, the weak perish. By obeying this law too well, the powerful finally eliminate the weak, and competition ceases. Not to compete is, under the Sherman law, a crime. To compete too well is likewise a crime. 
Responsible Government for the Packers.-The principle of "responsible government" is as sound in economics as it is in politics. The small-scale business maintains the personal contact of owner and public to such a degree that the question never arises as to its "responsibility." The question to be solved is, how give those concerned in the meat business, as producers of live stock or consumers of meat, a "voice" in this business? For there must be a voice representing these interests if the business is to be in fact responsible. The simplest and most logical solution would be to let the producers' organizations and the organized consumers send duly elected representatives to meet in a conference or "parliament" with representatives of the packers. The consumers are not organized, as yet, to any extent, and such a proposal would have only a theoretical interest for them, for the immediate present. Producers of live stock are already fairly well organized in specialized associations. However, the live stock associations would do well to ally themselves, for such a conference as outlined, with the strongest farmers' organization in America, namely, the American Federation of Farm Bureaus. Or at any rate, a section of the American Federation, representing the packing house territory, would be very much interested in such a fundamental question as the issues between packers and live stock growers.

Such a conference would be in the nature of a collective bargain parliament. The producers would have to accept the economic law of supply and demand as fundamental in governing prices of live stock, rather than the cost-of-production theory. ${ }^{6}$ The producêrs' ancient grievance is price fluctuations from day to day. Doubtless a collective bargain could be made, stabilizing live stock prices over certain periods, such as is now done in the milk business with monthly milk prices. Only it would likely be impossible to stabilize live stock prices over periods exceeding one week in length. At any rate, the producer would feel that in such a conference he had a voice, and that he had a part in the directing, under economic laws, of the production and marketing of live stock. He would feel his own strength, his own power. He would perceive then, for the first time, that the packers' power, like his own, was not autocratic-except temporarily and locally and within very narrow limits. His instinct for "representative government" would be satisfied. Of course representative government does not make all men happy or cure all ills or level all inequalities or

${ }^{6}$ See Appendix to chapter XV for further discussion of this point. 
destroy the power of the strong leader, but it does satisfy that inexorable and eternal demand for a responsible government. The cherished belief in the "consent of the governed" must be honored.

A "solution" of the packing house problem that would substitute a bureaucratic government ownership for the initiative and enterprise of private ownership would be too costly a remedy to deserve serious consideration. It would inevitably result in poorer service at greater cost. The solution proposed above, however, would go far towards preserving all the good in the present system and eliminating its evils. Government control by licensing, by commissions or other administrative bodies would likely prove in the future, as it has in the past, wherever tried, too narrowly bureaucratic or too political. Such a "remedy" would be worse than the disease.

"Dissolution" of the Big Five Packers.-Under pressure of public opinion, the large packers began negotiations with the Federal Department of Justice, which led, in December, 1919, to a compromise solution, for the time, of the major points in dispute. A voluntary agreement was reached, the same to be made the subject of a "consent decree," which had for its main purpose the divorce of the packers from many side lines and subsidiary businesses. Under this agreement the packers were allowed two years to sell their stockyard holdings, their market newspaper interests, their cold-storage warehouses not used in the meat business, to quit the retail meat business, to drop various side lines, including groceries, fish, vegetables, fruits, molasses, honey, jams, jellies, preserves, ices, sauces, relishes, coffee, tea, chocolate, cocoa, milk, flour, sugar, rice, bread, crackers, biscuits; spaghetti, vermicelli, macaroni, cigars, china, furniture, etc. They were allowed two years to dispose of all branch houses, route cars, and automobile trucks not used in their own meat and dairy products business. Eggs, butter, poultry and cheese remain äs side lines. The Attorney General of the United States announced this voluntary agreement to be a "victory" for the government, since, under it, "the price of meat is within the control of the people themselves." The public has already seen more than one "trust "dissolved by the government, and hence will wait for time to show whether this "dissolution" will lower the cost or improve the quality of meat on the consumer's table.

Miscellaneous Problems.-(1) Coöperative Packing Houses. Coöperative meat packing houses have been tried in the Middle 
West, particularly Wisconsin, Iowa, Minnesota, and North Dakota. The record of these attempts is not an encouraging one. The death-rate has been very high among them. Apparently they are too small to conduct a large-scale business-which meat packing is, par excellence; they can buy live stock and kill it and prepare good meat; they are weak in marketing their product, because they can not furnish at any and all times the quality and the quantity of meat the buyer wants. This is because their supply of live stock is not constant and regular in quantity, quality, or time.

(2) Municipal Abattoirs.-Largely as a sanitary measure, American cities are beginning to erect and operate municipal abattoirs, and as experience accumulates, and as public health becomes more the concern of every taxpayer, there is certain to come an increase in the number of these slaughter houses. The unspeakable filth which surrounds many (probably most) small butchers' private slaughter houses, near the-villages and cities, is certainly a condition to challenge the attention of public health officers. In time the municipal abattoir will doubtless be a very important economic factor in the fresh meat business. The position of the large packers in the cured meats, however, seems to be safe from any local competition of this kind.

\section{QUESTIONS ON THE TEXT}

1. How does the packing industry rank in importance among American industries?

2. Show that this industry is of more than national importance.

3. Describe the course of live stock production in the United States. Significance of movement.

4. What economic and legal questions are involved in the study of meat packing?

5. Discuss the live stock situation under these topies: meat as food; geographical shift; change in number of live stock; future outlook for an increase and for a decrease; summarize.

6. State outlook for foreign competition.

7. Discuss the meat packing industry of the United States under following topies: large-scale business; division of labor; by-products; distribution; inspection.

8. Show American attitude toward monopoly, political or economic.

9. Give the findings of the Garfield Report.

10. Quote the President's letter of 1917 directing an investigation by the Federal Trade Commission.

11. Give findings of the Federal Trade Commission.

12. What remedies did the Trade Commission propose?

13. Give reply of the packers.

14. What is the real evil? The fitting remedy?

15. Discuss advisability of government ownership of the meat packing industry.

16. Give status of coöperative packing house movement.

17. Give situation as regards municipal abattoirs. 


\section{QUESTIONS SUGGESTED BY THE TEXT}

1. Debate: Resolved, that we should adopt the policy of government ownership and operation of the packing houses.

2. Give an account of the coöperative packing houses at La Crosse, Wisconsin; Madison, Wisconsin; Fairbault, Minnesota; Fargo, North Dakota.

3 . What is the social value of competition in large-scale industries?

4. Should the large packing houses be ordered to compete or to coöperate?

5. What method or system would best render the power of the Packers "responsible"?

\section{REFERENCES}

1. "The Beef Industry." Report of the Commissioner of Corporations, March 3, 1905. Washington, 1905.

2. "Report of the Federal Trade Commission on the Meat Packing Industry." Two Parts. Washington, 1918 and 1919. Summary and Part I, 1919; Part II, Evidence of Combination Among Packers, 1918.

3. Meat Situation in the United States. Five Parts:

I. "Statistics of Live Stock, Meat Production and Consumption, Prices and International Trade for Many Countries." By Geonge K. Holmes. (Report 109.)

II. "Live Stock Production in the Eleven Far Western Range States." By Will C. BarNes, and James T. Jardine. (Report 110.)

III. "Methods and Costs of Growing Beef Cattle in the Corn Belt States." By J. S. Cotton, Morton O. Cooper, W. F. Ward, and S. H. Ray. (Report 111.)

IV. "Utilization and Efficiency of Available American Feed Stuffs." By W. F. WARD and S. H. RAY. (Report 112.)

V. "Methods and Costs of Marketing Live Stock and Meats." By LouIS D. IIAll, F. M. Simpson and S. W. Doty. (Report 113.) Office of the Secretary, Department of Agriculture, Washington, 1916.

4. "Proceedings of the Conference Relative to the Marketing of Live Stock: Distribution of Meats and Related Matters." Held by the Direction of David Franklin Houston, Secretary of Agriculture. Conducted by the Office of Markets and Rural Organization, Charles J. Brand, Chief. Held at Chicago, November 15-16, 1915. 64 Cong., 1 Sess. House Doc. No. 855.

5. "Report of the United States Industrial Commission." 19 volumes. Vol. 6, pp. 225-267. Washington, 1898-1902.

6. "Swift and Company's Analysis and Criticism of Part II of the Report of the Federal Trade Commission on the Meat Packing Industry of November 25, 1918." Swift and Company, Chicago, April 5, 1919.

7. "Testimony of J. Ogden Armour on Behalf of Armour and Company, January 21, 1919, Before the Committee on Interstate and Foreign Commerce in the Matter of the Investigation of the Packing Industry." H. R. 13324. Washington, 1919.

8. DE RICQLeS, A. E.: "Statement Prepared by, on Live Stock Marketing Questions for the Use of Dwight B. Heard, President of the American National Live Stock Association, and the Market Committee of the American National Live Stock Association, and the Federal Trade Commission," n.d.

9. - : "Address on Live Stock Marketing, Before the Third Annual Conference on Marketing and Farm Credits," Chicago, 1916.

10. WELD, L. D. H.: "A Big Vital American Industry. The Story of Swift \& Company." The Bankers' Magazine, January, 1919. Vol. XCVIII. New York, 1919.

11. 1919, Ithaca, New York.

12. Armour, J. Ogden: "The Packers, the Private Car Lines and the People." Philadelphia, 1906. 


\section{Scientific American, November 7, 1857. Article on the First Refrig-} erator Car.

14. Leffingwell, Albert: "American Meat" (on order).

15. ANDEs, Louis E.: "Animal Fats and Oils."

16. Wilder, F. W.: "Wilder's Modern Packing House."

17. "Douglas's Encyclopedia of the Meat Packing Industry."

18. Nimmo, Joseph: "Report in Regard to the Range and Ranch Cattle Business of the United States." Annual report on the internal commerce of the U. S., 1885, pp. 95-294, with five maps. U. S. Treasury Department, Bureau of Statistics. Reprinted without the maps. House Exec. Document, No. 267, 48 Cong. 2 Session.

19. "Testimony taken by the Select Committee of the United States Senate on the Transportation and Sale of Meat Products." Washington, 1889.

20. "The Sheep and Wool Industry in the United States." Special Bulletin, Chamber of Commerce of the United States, Washington, April 26, 1918.

\section{APPENDIX}

Stabilizing Supplies and Prices.-A report of the Conference held in Chicago, March 10th and 11th, 1919, between representatives of the Kansas Live Stock Association, The Corn Belt Meat Producers Association, Missouri Live Stock Breeders Association, Illinois Live Stock Association, Illinois Agricultural Association, The Buyers and Sellers Association of Texas, and representatives of seventeen packing companies.

Proposed Agreement for the "Conference Committee" of the Live Stock Industry.At a conference held in Chicago on March 10 and 11, 1919, the representatives of the Kansas Live Stock Association, Corn Belt Meat Producers' Association, Missouri Live Stock Assoriation, Illinois Live Stock Association, and The Buyers' and Sellers' Association of Texas met with the five large packers and eleven other packers.

It is the sense of those participating in the conference that it would be to the mutual benefit of the live-stock industry, the packers, and the consumer, that steps should be taken to bring about a closer coöperation between the various interests concerned.

Realizing that the live-stock industry is on the threshold of an era of reconstruction, and with the prospect of removal of such control as has been exercised by the Food Administration during the war period, we are impressed with the importance of reaching a better understanding of the problems affecting the whole industry, and of effecting, if possible, more economic methods of production and distribution to the end that our businesses may be placed on a sounder basis, and in order that the finished product be furnished the consumer at a minimum price compatible with cost of production.

It is suggested that these ends may be obtained through the formation of a central committee composed of producers and representatives of the packing industry, the Bureau of Markets, and the National Live Stock Exchange, which should meet in Chicago once a month, or of tener, if necessary, for the purpose of taking such measures as may tend toward the stabilization of live stock receipts at various markets, and for the further purpose of studying one another's problems, of adjusting grievances, and of inaugurating such systems as will be helpful to the producer, the packer, and the consumer. The greatest possible publicity should be given to all of the proceedings. It is understood that if this proposal becomes effective it shall not be construed as in any way restraining the activities of the parties hereto in working for or against the passage of pending or future federal legislation for the regulation of the packing and allied industries. Its purpose is wholly constructive, looking to a better understanding and fuller coöperation between all interests involved.

It is obviously to the best interests of all concerned that receipts of live stock at all markets should be stabilized and distributed as evenly as possible in order that a five-day market may be established for all classes of live stock, and to this end it shall be distinctly the function of the committee to make effective such measures as may be possible for the accomplishment of this object.

It is contemplated that the producer shall obtain and furnish the committee all important information concerning the supply of meat animals in the various sections of the country. Shall advise the committee regarding feed conditions, and the amount of live stock which shall be ready for market during the various seasons, and in other ways be a source from which valuable information, including cost of production, may be-placed at the disposal of the committee.

It is contemplated that the packers shall prepare and submit to the committee information relative to the amount of finished product on hand, the foreign and home demands for meat products, together with the cost of live animals and the expense of slaughter, packing, and distribution of the finished products. The packers shall recommend any plans which tend to reduce their expense of operation, such as the equalization of receipts, etc. 
It is contemplated that the committee shall carefully investigate the annual earnings of the packing industry, including all the subsidiary companies; it shall be the privilege of the committee to employ a committee of public accountants of recognized standing to audit the yearly statements of the packers. Any statements or figures furnished to the committee by the packers, or by the producers, from time to time, may also be subject to verification by public accountants. Whenever duplication and unnecessary overhead expense are disclosed, it shall be the duty of the committee to recommend the elimination of the same.

It is contemplated that whenever certain methods and systems used by the producers may be shown to be wasteful or detrimental to the industry, it shall be the duty of the committee to recommend the elimination of the same.

It is contemplated that in regulating the receipts of livestock during abnormal times it will be essential that the committee shall have the support of the Railroad Administration or the Interstate Commerce Commission to the end that the regulation of transportation as recommended by this committee may control the receipts at market centers.

We feel that the membership of this central committee should be composed of the following representatives: One from the Bureau of Markets of the United States Department of Agriculture; two from the National Livestock Exchange, ten packers, and ten producers, representing the cattle, hog, and sheep industries, with alternates-a total of twenty-three. This central committee shall have authority to add one representative of the stockyards and one of the railroads, if it sees fit.

It is understood that the producers here present will take steps as soon as possible to notify all livestock producing organizations of the action here taken, and to call a general meeting of three delegates from each state, to be selected by the State Associations, and three delegates at large from each of the National Livestock Associations and the Southern Livestock Association, and it shall be the province of this meeting to select the ten producer representatives that are to serve on the central committee.

It is contemplated that the produccrs will exercise the utmost care and diligence in selecting their representatives, who will be men of unquestioned standing and ability, and that the packers shall name as their representatives the principals of the institutions represented.

It is understood that this committee, when appointed, shall formulate the rules and regulations governing its operation, and that a producer shall be selected as its chairman. The headquarters of the committee we feel should be in Chicago.

The permanent committee shall create the sub-committees at various markets and shall formulate the rules and regulations governing their operations. The purpose of these local committees is the immediate adjustment of any grievances, such as dilatory handling of excessive variations in the purchase price paid for the same grade of live stock on the same day.

We suggest that the financing of this organization be divided equally between the packing industry and the live stock associations, and that the methods of raising the necessary funds be left to the central committee.

\section{Parties Who Participated in the Conference Were:}

Geo. T. Donaldson, President Kansas Live Stock Association, Greensburg, Kan.

J. H. Mercer, Secretary Kansas Live Stock Association, Topeka, Kan.

Pet Nation, Kansas Live Stock Association, Hutchinson, Kan.

John Edwards, Kansas Live Stock Association, Eureka, Kan.

Dan Casement, Kansas Live Stock Association, Manhattan, Kan.

Arnold Berns, Kansas Live Stock Association, Peabody, Kan.

C. L. Daughters, Kansas Live Stock Association, Manhattan, Kan.

J. G. Imboden, President Illinois Live Stock Association, Decatur, Illinois.

Carl Marshall, Illinois Live Stock Association, Ipava, Illinois.

E. F. Keefer, Illinois Live Stock Association, Chicago, Illinois.

C. D. Yancey, President Missouri Live Stock Association, Liberty, Mo.

S. P. Houston, Vice-President Missouri Live Stock Association, Malta Bend, Mo.

S. T. Simpson, Secretary Missouri Live Stock Association, Columbia, Mo.

A. W. Nelson, Missouri Live Stock Association, Bunceton, Mo.

A. Sykes, President Corn Belt Meat Producers' Association, Ida Grove, Iowa.

Henry C. Wallace, Secretary Corn Belt Meat Producers' Association, Des Moines.

E. L. Burke, Omaha, Nebraska.

T. F. Moody, Buyers' and Sellers' Association of Texas, Canadian, 'Texas.

Peter Fleming, Prairie Farmer, Chicago.

Thos. E. Wilson, Wilson \& Company, Chicago.

V. D. Skipworth, Wilson \& Company, Chicago.

R. F. Eagle, Wilson \& Company, Chicago.

Arthur Meeker, Ammour \& Company, Chicago.

J. Ogden Armour, Armour \& Company, Chicago.

R. D. McManus, Armour \& Company, Chicago.

Edward F. Swift, Swift \& Company, Chicago.

G. F. Swift, Swift \& Company, Chicago.

T. H. Ingwersen, Swift \& Company, Chicago.

W. B. Traynor, Swift \& Company, Chicago.

L. D. H. Weld, Swift \& Company, Chicago.

Edward Morris, Morris \& Company, Chicago.

D. R. Buckham, Morris \& Company, Chicago.

E. A. Cudahy, Cudahy \& Company, Chicago. 


\section{Parties Who Participated in the Conference Were-(Continued):}

J. G. Connie, Dold Packing Company, Buffalo.

E. C. Merritt, Indianapolis Packing Company, Indianapolis.

J. R. Kingan, Kingan Packing Company, Indianapolis.

James Craig, Parker Webb, Detroit.

L. D. Nash, Cleveland Provisions Company, Cleveland.

F. J. Sullivan, Sullivan Packing Company, Detroit.

A. I. Eberhardt, Hornell Packing Company, Austin, Texas.

W. R. Miller, Miller \& Hart, Chicago.

G. Bishoff, Independent Packing Company, St. Louis.

Chas. I. Hammond, Hammond-Standish Packing Company, Detroit.

C. H. Nuckles, Nuckles Packing Company, Pueblo, Colorado.

W. G. Eckart, Pueblo, Colorado.

Harold Swift, Swift \& Company, Chicago.

Stabilizing Supplies and Prices. (A Producers' Committee of Fifteen, Chosen at Kansas City, April 12, 1919.) - "It is the sense of those participating in the conference that it would be to the mutual benefit of the live-stock industry, the packers and the consumers, that steps should be taken to bring about a closer coöperation between the various interests concerned.

"Realizing that the live-stock industry is on the threshold of an era of reconstruction, and with the prospect of removal of such control as has been exercised by the Food Administration during the war period, we are impressed with the importance of reaching a better understanding of the problems affecting the whole industry, and of effecting, if possible, more economic methods of production and distribution, to the end that our businesises may be placed on a sounder basis, and in order that the finished product be furnished the consumer at a minimum price compatible with cost of production.

"It is recommended that these ends may be promoted through the formation of a committee of live-stock producers which shall meet from time to time as may be found necessary, and counsel with similar committees representing the packers and other interests. Said producers' committee shall be selected at a national meeting composed of delegates from the several states (said delegates to be selected at state meetings attended by representatives of the various producers' organizations), and the members to represent the range cattle industry, the cattle-feeding industry, the hog industry and the sheep industry, the proportion of representation and the number constituting the committee to be decided by the national convention. Said convention shall be planned and called by the committee of fifteen which it is now proposed to create.

"Pending said national convention and the appointment of said committee, a live-stock producers' committee shall now be formed. as follows:

"The committee shall consist of fifteen members, of whom four shall represent the range interests, eight the feeding states, two the hog industry and one the sheep industry. Those representing the range interests shall be selected, two by the American National Live Stock Association, one by the Cattle Raisers' Association of Texas, and one by the Southern Cattlemen's Association. Those representing the feeding interests shall be selected one each by the associations of the states of Kansas, Missouri, Illinois, Iowa, Nebraska and Indiana, and two by the associations of the states in territory east of Indiana. The two representatives of the hog industry shall be named by joint action of the various national swine associations, and the one representing the sheep industry shall be named by the National Wool Growers' Association. The committee thus created shall have full authority to meet with the committees representing the packers and other interests and to do whatever may seem to it to be necessary to promote the interests of the producers, by taking such measures as may tend toward the stabilization of the live-stock industry and for the further purpose of studying one another's problems, of adjusting grievances, and of inaugurating such systems as will be helpful to the producer, the packer and the consumer. The various associations are requested before May 10 th to select their representatives on this committee of fifteen, and the committee shall meet at Chicago on May 15th, at which time it shall organize, elect its own chairman and secretary, and provide for such sub-committees as it may deem necessary to carry out the purposes for which it is created.

"To effect the proposed organization, a committee of six, in addition to himself as chairman, shall be chosen at this time by the chairman of this meeting, to put this plan into effect without delay, to notify the various state producers' associations, and to invite the packers and other interests to coöperate with the producers' committee thus created in promoting the meat industry of the nation."

Notw. - The Producers' Committee of Fifteen failed to function, and the committee was dissolved in November, 1919. Its work was turned over to the American Federation of Farm Bureaus. The action of the committee in dissolving itself did not have the universal approval of the stockmen whom it was supposed to represent. 


\section{CHAPTER XXIV}

\section{TAXATION PROBLEMS: SINGLE TAX; PROTECTIVE TARIFF}

\section{SINGLE TAX}

THE writings of Henry George have popularized the single tax in our own land and in many other lands. The fervor of his eloquence, the beauty and grace of his literary style, and the pure sincerity of his motives have given his work a strong appeal. He has succeeded, as few writers have, in yoking together economics and ethics.

Definition.-A single tax means a tax on land value. By land value is meant the rental value of the land, what it is worth annually for use, its economic rent. The word land, as used by the single taxers, includes minerals, water, oils, and every other thing of value created by nature and forming a part of the earth; and, conversely, the word land excludes all buildings, structures, and creations of man upon or in the land. To illustrate. If the single tax were applied as a substitute for all other forms of taxes, as its name implies it should be, there would cease to be any tax on incomes, or inheritances, on personal property, on imports, on business, on consumption, and so on. In the city, all buildings and their contents would be exempt from taxation-the land value alone being taxed. In the country, there would be no tax on houses, barns, other buildings, live stock, tools, grain, or any kind of personal property - the land value alone being taxed.

Incidence of the Tax.-The tax burden would be the same total amount, whether the money were secured from the single tax as advocated or from the multiple taxes now in use. But it would fall on different persons - on the owners of land values. The farmer, thinking of the millions of acres of farm lands as against the relatively few acres of city land, wonders whether the single tax would not shift the tax burden in large part from the city to the country. Obviously not. For the bulk of the land value is in the cities. Thus the land values in New York City alone are worth more than the total farm land values of one-half the States in the Union. The tax burden, therefore, under the single tax, would somewhat raise taxes in cities and lower taxes on farms, should the single tax be applied at once over the whole nation. However, if the single tax were applied in a State having no-great metro- 
politan districts, there would be little change in the burden as between city and country.

Argument for the Single Tax.-For a person who is not a single taxer to state the arguments for the single tax fairly is not an easy task. However, the effort will be made here. Condensed within very narrow limits the argument runs substantially as follows:

The private appropriation of ground rent is a privilege - in fact it is our worst form of special privilege to-day. No man created the earth or gave it value. The Almighty created the land, and society gives it value. Man cannot create new land. The supply is strictly limited. The use of the land is absolutely necessary for the existence of man. Society does not permit any one to mark off a certain area of the ocean, for instance, and require all users thereof to pay a toll for it. Were this permitted, especially useful parts of it, such as the entrances to harbors, would have a barrier thrown across them and their use permitted by the "owners" only to those who would pay a rent for them. The sea belongs to those who use it. Neither does society now permit private individuals to appropriate the use of socialized strips of land, such as streets and highways, and exact toll (rent) from the users thereof. So an individual who uses the land, like an individual who ventures to sea in his fishing schooner, is entitled to a wage on his labor and to interest on his capital, but not to a rent on the land which he did nothing to create. The rent of the land-the economic rent (the market value of its use)-is due to society, and hence should be appropriated by society. Society should collect this economic rent and call it a tax. For the individual to collect wages and interest is wise and just; for him to collect economic rent is a special privilege and is uneconomic and unjust. In other words, if he farms the land and receives a fair wage for his labor and a fair interest return on every cent he has invested in machinery, improvements, drainage, fertilizers, etc., he has received all the income he is entitled to. He who goes beyond this is reaping where he has not sown, and is to that extent a social parasite.

Speculation in farm lands would be stopped, and these vast non-productive funds now so employed (to the curse of society) would be diverted into industrial channels, in investments in mills and factories, in workshops and tools, in various productive enterprises calling for the employment of labor and capital (to the enrichment of society). For obviously a man having money to invest would not put it into land and expect to reap a reward by the rise in value of land (as many now do), because this increase, 
this "unearned increment" as they term it, would be taken by society that creates it. Neither could he buy a farm and expect to sublet it at a profit, while he retired and lives in ease and luxury off his tenants, because the economic rent would go to the state, not to him. Of course, the farmer who had put improvements on his farm of great value could and would retire, if he pleased, and "rent" this farm, but the land value rent or tax would go to the state, while his "rent" would be merely the interest on his outlay for improvements, equipment, tile, stock, etc. Speculative funds diverted from land speculation into productive capital would actually raise wages and bring general prosperity, say the single taxers, and, indeed, abolish poverty from the earth.

More fundamental yet, is the argument advanced by Henry George in his work "Progress and Poverty," his chief contention being that our boasted increase in population is accompanied with an iron law of wages, interest, and rent, namely, wages must fall; interest must fall; rent must increase. In short, progress means poverty-poverty for the many, wealth for the few who appropriate ground rent. His logic is very simple. As population increases, there are more mouths to feed. More food is needed. It must come from the land. The supply of land is fixed. It cannot be increased. As this demand on the land steadily grows greater and greater and more food must bewrung from the soil,food prices must rise; land values must rise; rents must rise. The landlords will be able to receive a larger and larger share of the products, leaving less and less for labor and capital. To make the illustration concrete. Here is a ten-acre field of wheat - and the country is new and sparsely settled. This field must furnish bread for the man and his wife and two children. A generation later (and our population has doubled); this field must now feed eight people. The relative scarcity of this food makes it dearer than it was before. This is equivalent to saying that the value of the land is morethat its economic rent has increased. These eight people must be fed from this land, and the owner of the land can and does demand a higher rent for the use of his land-because population has increased, not because he has improved the land. Let this ten acre field stand for the whole United States. 'The area of the continental United States is, in round numbers three and a half million square miles. It was this size one hundred years ago, and will be this size a hundred years hence. But the population to occupy this area was but $4,000,000$ in 1790 . This population was nearly doubled by 1810 , reaching $71 / 4$ millions. Thirty years later 
it was again doubled (standing at 17 millions in 1840). Thirty years later it was again doubled (standing at $381 / 2$ millions in 1870). Thirty years later it was again doubled (standing at 76 millions in 1900). So the process of doubling goes on every thirty years. The food supply must be doubled every thirty years. And the vacant lands are long since all occupied. Is Henry George right in his basic argument that an increase in food supply can be had only at increased cost? Must each added bushel of wheat be a dearer bushel than the preceding? If so, rents must rise. Land values must increase with increase in population. The owner of the land (the "appropriator of ground rent") will be the beneficiary.

The Question at Issue.-An iron law of rent of this kind is based on the theory of "diminishing returns" in agriculture, for agriculture as a whole. The individual farmer, in any case, doubtless has some land on the basis of increasing returns (where, for instance, increasing his investment of labor or capital or both by 10 per cent will increase his returns 15 per cent); some on the basis of stationary returns (where, for instance, increasing his investment of labor or capital or both by 10 per cent will increase his yield by 10 per cent); and some on the basis of diminishing returns (where, for instance, increasing his investment of labor or capital or both by 10 per cent will increase his yield by 5 per cent).

The food supply can be increased. It can be increased by using more labor-farming more intensively; by using better machinery; by using better tillage methods; by using better seed selection; by using pure bred live stock; by proper animal nutrition; by more scientific crop rotation; by introducing new legumes and farm crops; and in many other ways. The question at issue is: Does each added bushel of crop cost more than the preceding bushel? In other words, has agriculture reached the state of diminishing returns in the United States? Very clearly, a general answer cannot be given. Rents have fallen in some sections, and risen in others. Some farms are operated on the basis of diminishing returns; some on the basis of increasing returns. The various surveys that have been made and are now being made clearly illustrate this truth. If all farmers were operating on the basis of the few best farmers, the increase in food supply would be so enormous as to cause a slump in prices of foodstuffs, and a consequent fall in rents of land.

If the Single Tax Were Applied.-The single taxers would apply their single tax to both city and farm land, but base their chief arguments on the city land. For it is in city lands that ground 
rents are conspicuously high. Our discussion in this book, however, is concerned almost entirely with farm lands. While the large claims of the single taxers as to the efficacy of the single tax are doubtless far from being one hundred per cent true, yet they are in part true so far as urban conditions are concerned. Here land has only site value. But this view has little validity as applied to farm lands. The site of the land is secondary; its fertility is primary. And its fertility, if maintained and increased, is due in large part to the brains of the owner. If the single tax were applied to farm lands, it would have the immediate effect of increasing the taxes on those lands that are unimproved but yet have use value; on small farms with costly buildings and improvements the taxes would be lessened; on the average farm with average buildings the improvements exempted would just about offset the increase in the land tax-or in other words, there would be little change in the size of the tax. In fact, the Minnesota State Tax Commission, after giving very careful and sympathetic consideration to the whole single tax question-both in theory and in practice-reached the conclusion (in their 1912 Report) that, "To the average owner and occupant of a home or a farm the change (to a single tax) would probably not mean much one way or the other." 1

\section{PROTECTIVE TARIFF}

Introductory Statement.-The United States ranks among the "protective tariff" countries of the world. With the exception of about thirty years of our history (the period from 1830 to the Civil War, 1860) we have been frankly for high "protection." A protective tariff takes two forms: (1) it may be so high as to prohibit entirely the importation of the foreign competing article; (2) it may impose a duty, not prohibitive, on imports, causing the imported article to sell so high in America as not to compete on even terms with the American made article. The American manufacturer, in such a case, is able to charge more for his wares, evidently, than if competition were unrestricted, and the ultimate consumer is the one who pays the tax. The first strictly high protective tariff act was the Act of 1816 . The duties were raised in the next act-that of 1824. Four years later came a substantial increase, with the so-called "Bill of Abominations" of 1828. Since this led to the near-secession of South Carolina from the Union, and the Nullification (of the tariff) controversy, rates were lowered in the next acts. Tariff and Slavery, Nullification and Secession, then

${ }_{1}^{1}$ Third Biennial Report, Minnesota State Tax Commission, 1912, p. 177. 
kept Congress occupied for thirty years, till the Civil War settled the slavery issue. The subsequent tariff acts, namely, 1883, 1890, $1894,1897,1909$, and 1913 were all highly protective to the manufacturing industry. After the abolition of slavery in the South, and the growth of modern industrialism in that section under free labor, the South, too, came to favor a protective tariff on such products as were manufactured there. But prior to the Civil War, the tariff was referred to, quite generally, as a sectional issue, the North being the section benefited.

Theory and Practice.-Most great doctrines, like the doctrine of a protective tariff, should be tested by both theory and practice. The controversy in this country over the theory of protection is apparently as far from abatement now as it was at its inception a hundred and thirty years ago. It is more profitable, therefore, first to examine very briefly the workings of a protective tariff, as related to agriculture, before giving attention to the theory of the subject.

In New England.- New England is the one section of the country in which the cycle of protection is most nearly complete, and it will therefore be used to illustrate the workings of our protective system. Since the first "protective tariffs" were designed solely to protect manufacturing, and since manufacturing, prior to the Civil War, was confined almost wholly to the North, it seems fair to turn to this section to study the fruits of the protective system.

The first tariff act ever enacted by this government (July 4, 1789) bore this preamble:

"Sec. 1. Whereas it is necessary for the support of government, for the discharge of the debts of the United States, and the encouragement and protection of manufactures, that duties be laid on goods, wares and merchandise imported: Be it enacted ..."

Condition of the Country in 1789.-Documents of that day bespoke a period of prosperity for agriculture, for labor, and for manufactures. The abundance of free land made it possible for any man of ordinary ability to own a good home and a good farm. The second profound influence of free land was to keep wages high. One of the early fathers had written many years before this time, "Our children's children will hardly see this great continent filled with people, soe that our servants will still desire freedom to plant for themselves, and not stay but for verie great wages." A royal official wrote in 1723, "North America containing a vast tract of land, every one is able to procure a piece of land at an inconsiderable rate, and therefore is fond to set up for himself rather than work for hire. This makes labor continue very dear, a common 
laborer usually earning three shillings by the day ..." Albert Gallatin, when ex-Secretary of the Treasury, reported that as early as 1810 , there were north of the Potomac fifty mills for spinning cotton in operation, and twenty-five more went into operation the ensuing year. The date mentioned by Gallatin is interesting, since the protective policy was not applied to cotton manufactures till 1816. And finally we may fall back on the most noted report of the period, Hamilton's Report on Manufactures (1791), in order to determine the condition of prosperity already reached by manufactures, under the natural protection of 3,000 miles of sea between them and the competition of the mother country, and only slow sailing vessels for transportation. Hamilton wrote as follows:

"To all the arguments which are brought to evince the impracticability of success in manufacturing establishments in the United States, it might have been a sufficient answer to have referred to the experience of what has already been done; it is certain that several important branches have grown up and flourished with a rapidity which surprises, affording an encouraging assurance of success in future attempts. Of these it may not be improper to enumerate the most considerable:

1. Of Skins.- Tanned and tawed leather, dressed skins, shoes, boots, and slippers, harness and saddlery of all kinds, portmanteaus and trunks, leather breeches, gloves, muffs, and tippets, parchment and glue.

2. Of Iron.-Bar and sheet iron, steel, nail rods and nails, implements of husbandry, stoves, pots, and other household utensils, the steel and iron work of carriages and for shipbuilding, anchors, scalebeams, and weights, and various tools of artificers, arms of different kinds, though the manufacture of these last has of late diminished for want of demand.

3. Of Wood. - Ships, cabinet wares and turnery, wool and cotton cards, and other machinery for manufactures and husbandry, mathematical instruments, cooper wares of every kind.

4. Of Flax and Hemp.-Cables, sail-cloth, cordage, twine and packthread.

5. Bricks, and coarse tiles and potter's wares.

6. Ardent spirits and malt liquors.

7. Writing and printing paper, sheathing and wrapping paper, pasteboards, fuller's or press papers, paper hangings.

8. Hats of fur and wool, and of mixtures of both, women's stuff and silk shoes.

9. Refined sugars.

10. Oils and animals and seeds, soaps, spermaceti and tallow candles.

11. Copper and brass wares (particularly utensils for distillers, sugar refiners and brewers), andirons and other articles for household use, philosophical apparatus.

12. Tin wares for most purposes of ordinary use.

13. Carriages of all kinds.

14. Snuff, chewing and smoking tobacco.

15. Starch and hair powder.

16. Lampblack and other painters' colors.

17. Gunpowder.

Also vast amount of household manufacture (coarse cloth, coating, serges, flannels, linsey-woolseys, hosiery, coarse fustians, jeans and muslins, checked and striped cotton and linen goods, bed ticks, coverlets, tow linens, shirtings, sheeting, towels, table linen). Also flour, pitch, tar, turpentine, etc." 
Hamilton's Report is generally quoted by the friends of protection as the mighty bulwark of their faith. It is an able summary of the arguments both for and against protection, Hamilton's own conclusions being for protection. He takes for granted that manufactures are needed (to furnish a home market, and for other reasons); he assumes that protection is needed in order to have manufactures because foreign governments were using bounties, etc., and because of (1) the scarcity of labor, (2) the dearness of labor, and (3) the want of capital. He does, however, refer to the many towns "of size," as indicating a growing supply of labor; his list of successful manufactures has just been given above, indicating that without government aid manufacturing was thriving. Looking into the future workings of protection, he emphasized these two points, namely,

(1) Utilization of women and child labor;
(2) Utilization of immigrants.

"But there are," says Hamilton, "circumstances which have been already noticed with another view, that materially diminish everywhere the effect of scarcity of hands. These circumstances are: the great use which can be made of women and children ... lastly, the attraction of foreign immigrants ... It is a natural inference from the experience we have already had, that as soon as the United States shall present the countenance of a serious prosecution of manufactures, as soon as foreign artists shall be made sensible that the state of things here affords a moral certainty of employment and encouragement, competent numbers of European workmen will transplant themselves effectually to insure the success of our design."

Hamilton's forecast of the future was correct, for these two things happened-women and child labor was utilized, and immigrants did flock to the factories. The statistics gathered after nearly a hundred years of protection to manufactures tell the story. The platform adopted by one of the major political parties in 1912 reaffirmed its belief in the protective tariff policy, crediting this policy with protecting our workmen against (1) local competition, (2) foreign. But the statistics, quoted below, do not reveal this American workman in these protected factories (unless the word American workman means women and children); neither do they reveal absence of competition by the foreign laborer (but rather the success of the "foreigner" in driving the "American workman" out of the factory). 
Number and Per Cent of Americans and Foreign Born, Males and Females, in 46 Representative Cotton Mills in Maine, New Hampshire, Massachusetts and Rhode Island. ${ }^{2}$

(After 100 years of Protection.)

\begin{tabular}{|c|c|c|c|c|c|}
\hline \multirow{2}{*}{ Race } & \multicolumn{2}{|c|}{16 and over } & \multicolumn{2}{|c|}{ Under 16} & \multirow{2}{*}{ Total, all ages } \\
\hline & Males & Females & Males & Females & \\
\hline 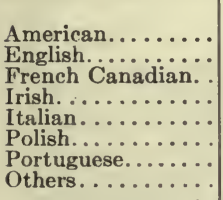 & $\begin{array}{c}\text { No. Per cent } \\
286-4.5 \\
604-9.5 \\
2610-40.9 \\
334-5.2 \\
303-4.8 \\
920-14.4 \\
322-5.0 \\
1001-15.7\end{array}$ & $\begin{array}{c}\text { No. Per cent } \\
1134-8.2 \\
1350-9.7 \\
5633-40.5 \\
2288-16.5 \\
249-1.8 \\
1759-12.6 \\
680-4.9 \\
803-5.8\end{array}$ & $\begin{array}{c}\text { No. Per cent } \\
76-9.7 \\
87-11.2 \\
410-52.6 \\
50-6.4 \\
36-4.6 \\
26-3.3 \\
34-4.4 \\
61-7.8\end{array}$ & $\begin{array}{c}\text { No. Per cent } \\
73-8.5 \\
73-8.5 \\
499-58.1 \\
63-7.3 \\
35-4.1 \\
38-4.4 \\
41-4.8 \\
37-4.3\end{array}$ & $\begin{array}{l}\text { No. Per cent } \\
1569-7.2 \\
2114-9.6 \\
9152-41.8 \\
2735-12.5 \\
623-2.8 \\
2743-12.5 \\
1077-4.9 \\
1902-8.7\end{array}$ \\
\hline 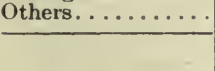 & $6380-100$ & $13896-100$ & $780-100$ & $859-100$ & 21915-100 \\
\hline
\end{tabular}

NotE.-Seven out of each hundred "workmen" are Americans. Two-thirds of these "workmen" are women or girls. This illustrates how literally Hamilton's prophesy was fulfilled.

New England Agriculture.-Early protection to manufacturing gave this occupation a form of preferential treatment which enabled it to draw the boys and girls from the farms. The "home market," consisting of the numerous manufacturing towns which cover New England, did not prove sufficient stimulus to keep agriculture from sagging. A hundred years of this history, and manufacturing had apparently reached its zenith, agriculture its nadir. New England became famous throughout the country as the land of "abandoned farms."

A chance news item in the Rural New Yorker stated the matter vividly in these words:

"Farming conditions in New England are at a critical point. New England imports 85 per cent of her food supplies for man and beast. She can and should produce 85 per cent or more thereof. The seriousness of the situation is attested by the recent formation of a league of manufacturers in Massachusetts to promote agriculture in order that New England's industrial supremacy may not be further endangered by enforced removal to centers of larger food production and lower food costs. J. S. B." ${ }^{3}$

The Eastern States Agricultural and Industrial League (as the league referred to above is termed) is backed by large capital, and is now making a strenuous effort to rehabilitate agriculture in New England. In a prospectus of theirs, describing the objects of the new league, they present the following melancholy figures showing the low estate of rural life in New England.

${ }^{2}$ Report on Condition of Women and Child Wage Earners in the United States, 19 vols. 61 Cong. 2 Sess. Sen. Doc. 645, Vol. 1, p. 99.

${ }^{3}$ Rural New Yorker, March 29, 1919, p. 572, New York City. 
"New England Industrial Supremacy Imperilled by Agricultural Decline. -From 1860 to 1910 there was a startling decline in New England agriculture, clearly indicated by the following facts:

Farm land under cultivation decreased 5,103,073 acres, or 42 per cent.

Cattle decreased from 56 to 20 per 100 population.

Sheep decreased from 60 to 4 per 100 population.

Population of 828 rural towns decreased 32 per cent.

Total population increased 110 per cent.

Wage earners increased during this same period from 390,806 to $1,191,290$, or 359 per cent.

New England must to-day import over 75 per cent of the food consumed.

As long as the food production in New England becomes less in comparison with the consumption, the differential must increase and ultimately reach a point where it will become increasingly difficult for New England to maintain its industries.

A successful farming community is one of the strongest factors in maintaining social stability. The farmer is not only a producer of the primary source of wealth, but is also a property owner and a small employer of labor and naturally stands for stability."

In order to secure an increasing element of "stability" of society, and in order to overcome the industrial handicap of dear food, the League is promoting agriculture, functioning through these various agencies: The Eastern States Agricultural and Industrial Exposition (to improve herds, crops, fruits, and farm practice); Market Bureau; Farm Finance Bureau; Boys' and Girls' Bureau; Publicity Bureau; New England Farm and Food Foundation. The last named agency "seeks to combine from ten to fifteen thousand manufacturing, mercantile and banking institutions with the progressive farmers of New England, in a joint effort to make effective such agencies as will enable the farmers to introduce modern methods for the purpose of greater, better and more economic production, and to effect a more efficient system of distribution, as well as establish adequate credit facilities."

It is not claimed that the protective tariff caused this decline in New England agriculture, but only that it contributed largely to this end by disturbing, artificially, the balance that first existed among agriculture, manufacturing, and commerce in New England. The law created an artificial status. It has now reached its logical fruition. Many a shrewd Yankee farmer is still raising wheat for his New England cousins - only he now is raising this wheat in Kansas and Nebraska, where one day's work will produce much more wheat than in New England, transportation costs included.

Webster's great tariff speech of 1824 set forth the true situation as concerned New England, a region then enjoying a prosperous agriculture and a prosperous commerce. He said:

"With me it is a fundamental axiom, it is interwoven with all my opinions, that the great interests of the country are united and inseparable; that agri- 
culture, commerce, and manufactures will prosper together, or languish together, and that all legislation is dangerous which proposes to benefit one of these without looking to consequences which may fall on the others."

When Congress singled out one of these three interests and pensioned it, so to speak, and bestowed on it special favor, special privileges, this favored industry, naturally forged ahead of the other two in the race. Congress did not "look to the consequences" which would "fall on the others." Both commerce and agriculture in New England steadily fell further and further behind in the competitive rate. Hence the lopsided growth of the present day, and the belated effort to take out of manufacturing large sums of money and put them back into agriculture. This is not done now as a charity to agriculture, but to obviate the "industrial handicap of dear food" and to establish islands of "stability" in the turbulent industrial sea of foreign wage earners who now compose the typical New England community.

Gallatin's Memorial.-Albert Gallatin, writing his Memorial on the Tariff in 1831, paid attention to the various theories of protection promulgated by Hamilton. Speaking of the "home market" for agricultural products, he said that flour prices rose and fell with foreign demand, and not with the growth of domestic manufactures; that the "foreign market," therefore, deserved consideration. Foreign commerce is, he declared, exactly like domestic commerce in principle; unrestricted intercourse between sections is needed.

Prosperity and high wages he connected in no way with the tariff. Prosperity he attributed to our vast natural resources. On labor he said, "After two centuries of free commerce with Great Britain and fifty years of similar intercourse with the rest of the world, the price of labor continues without alteration to be higher in the United States than in England or any other country."

Walker's Report.-Robert J. Walker, Secretary of the Treasury, made one of the few notable contributions to the tariff discussion, in his Report for December 3, 1845. He foretold with uncanny accuracy the labor difficulties of the factories, particularly the lowwage issue which formed a very unpleasant feature of the New England factory system till the first decade of the twentieth century.

Secretary Walker reported to Congress in part as follows:

Labor and Capital.-Capital's power over wages.- "When the number of manufactures is not great, the power of the system to regulate the wages of labor is inconsiderable; but as the profit of capital invested in manufactures is augmented by the protective tariff, there is a corresponding increase of power, until the control of such capital over the wages of labor becomes irre- 
sistible. As this power is exercised from time to time, we find it resisted by combinations among the working classes, by turning out for higher wages, or for shorter time; by trades-union; and in some countries, unfortunately, by violence and bloodshed. But the government, by protective duties, arrays itself on the side of the manufacturing system, and by thus augmenting its wealth and power, soon terminates in its favor the struggle between man and money-between capital and labor. When the tariff of 1842 was enacted; the maximum duty was 20 per cent. By that act the average of duties on the protected article was more than doubled. But the wages of labor did not increase in a corresponding ratio, or in any ratio whatever. On the contrary, whilst wages in some cases have diminished, the prices of many articles used by the working classes have greatly appreciated.

Profits.-A protective tariff is a question regarding the enhancement of the profit of capital. That is the object, and not to augment the wages of labor, which would reduce those profits. It is a question of percentages, and is to decide whether money vested in our manufactures shall, by special legislation, yield a profit of 10,20 or 30 per cent, or whether it shall remain satisfied with a dividend equal to that accruing from the same capital invested in agriculture, commerce, or navigation.

"No prejudice is felt by the Secretary of the Treasury against manufacturers. His opposition is to the protective system, and not to classes or individuals. He doubts not that the manufacturers are sincerely persuaded that the system which is a source of so much profit to them is beneficial also to the country. He entertains a contrary opinion, and claims for the opponents of the system a settled conviction of its injurious effects.

Free Trade Principle.- Soil, climate, and other causes vary very much, in different countries, the pursuits which are most profitable in each; and the prosperity of all of them will be best promoted by leaving them unrestricted by legislation, to exchange with each other those fabrics and products which they severally raise most cheaply. This is clearly illustrated by the perfect free trade which exists among all the States of the Union, and by the acknowledged fact that any one of these States would be injured by imposing duties upon the products of the others. It is generally conceded that reciprocal trade among nations would best advance the interests of all."

Secretary Walker also discussed the "home market" argument -the favorite argument used by the manufacturers to convince farmers that prosperity was being "passed around," and to secure the support of farmers for a taxing system which took money from the pocket of the farmer and transferred it to the pocket of the manufacturer. We have, reasoned Walker, a surplus of agricultural products; therefore we must have a foreign market; the real question is then, not the home market, but how. best develop a foreign market? Walker's answer was free trade.

Hamilton's Errors.-As the first Secretary of the Treasury, Hamilton, a young man of thirty-two, was confronted with gigantic national problems of credit, of money and banking, and of revenues, and with few precedents to guide him. The wonderful genius he displayed in successfully and rapidly solving his major problems has given him a rank in history as the second greatest man produced by the Revolution. He had never seen Europe, but he was greatly influenced in his decisions of policy by European practices. 
Thus, in his two great reports, his Report on the Coinage, and his. Report on Manufacturers, both made in 1791, he seems to have decided the two issues involved (Bimetallism, Protection) on the basis of what was actually the practice of the moment in Europe, rather than on the basis of his own logic. For instance, there is no better statement of Gresham's Law anywhere than in his report on the Coinage, for he clearly shows the impossibility of maintaining a double standard of value. But his conclusions are in favor of bimetallism, largely, it would seem, because no European country had yet adopted the single standard, and F.ngland was several years off from the status. It took a great many years for the country to correct this error. And so with his tariff policy. He was faced with the actual condition of protection in various forms in use by foreign governments. His words on this point are:

"But the greatest obstacle of all to the successful prosecution of a new branch of industry, in a country in which it was before unknown, consists, as far as the instances apply, in the bounties, premiums, and other aids which are granted in a variety of cases by the nations in which the establishments to be imitated are previously introduced. It is well known that nations grant bounties on the exportation of particular commodities to enable their own workmen to undersell and supplant all competitors in the countries to which those commodities are sent. Hence the undertakers of a new manufacture have to contend not only with the natural disadvantages of a new undertaking, but with the gratuities and remunerations which other governments bestow. To be enabled to contend with success it is evident that the interference and aid of their own governments are indispensable."

The Corn Laws of England furnish the outstanding example of government "protection" to one interest, in this case, the growers of wheat. Since the whole evil system of Corn Laws has long since been swept into England's large rubbish heap entitled "Reforms," even the champions of protection in England would not defend this unhappy venture in "protection." In becoming" the first gold-standard country and the first free-trade country, England, Hamilton's chief example, showed that the great Secretary's two errors came from confusing the practice of the moment with the established policies of the future.

Present Theory of Protection of Agriculture and Labor."Wages are high because of the tariff," is now a familiar saying, on the part of some very respectable politicians, about election time in the United States. This is a strange confusing of cause and effect. First, a tariff was asked because wages were high. Natural resources then (and now) were the chief cause of high wages. A protective tariff does not keep out foreign labor; indeed, in the factories enjoying the most protection are found the most 
foreign-born laborers. This competition lowers wages. In no instance is it apparent that tariff on manufactured goods does or can raise wages. A prohibitive tariff on labor (immigration) would do this, but such a form of protection has never been advocated by factory owners. The farmer was likewise told that a tariff of ten cents a bushel on corn (the rate some time in effect) protected him to that extent. Since we were exporting corn, not importing it, it is obvious that such a tariff could have no effect on price. In other words, had the tariff been ten dollars a bushel instead of ten cents a bushel, the price of corn in America would have remained the same, uninfluenced, one way or the other, by it. As a matter of fact, while the tariff on corn was ten cents a bushel, many farmers in Kansas and Nebraska, owing to larger production one season, sold their corn at nine cents a bushel. The United States has been an exporter (not an importer) of wheat from 1776 to date. Yet a tariff of twenty-five cents a bushel was in effect for many years, not to raise the price of wheat (which was fixed in the world's markets buying the surplus), but to give color to the idea that the farmer also, like the manufacturer, was enjoying "protection." So the protective tariff on the farmers' crops has served its real purpose, namely, to keep the farmer satisfied with the protective system while contributing cheerfully to its costs, and reaping none of its benefits.

\section{QUESTIONS ON THE TEXT}

1. Define Single Tax. Illustrate its meaning.

2. Under the single tax, what change would there be in the incidence of taxation? Refer particularly to question of city and farm lands.

3. State the arguments for the single tax referring to privilege; to Henry George's "Progress and Poverty."

4. Does the "iron law of rent" establish the claims of the single taxe-s? Reasons for and against.

5. What is the future outlook for a continued rise in rent?

6. If the singie tax were applied, how would it affect the farmer?

7. State also conclusions of Minnesota Tax Commission.

8. Define Protective Tariff. Illustrate its meaning.

9. What has been the tariff policy of the United States during the past 100 years?

10. In what sense does New England illustrate the workings of our protective system?

11. What was the economic condition of the country in 1789? Illustrate.

12. Quote Hamilton as to the prosperity of manufacturing.

13. Discuss Hamilton's Report on Manufactures; need of protection; women and child labor; immigrant labor.

14. Show the accuracy of Hamilton's forecast of the future.

15. Compare New England agriculture and manufacturing. Cite article in Rural New-Yorker.

16 Describe the need, purpose and method of the Eastern States Agricultural and Industrial League. 
17. Cite statistics on rural conditions in New England.

18. Show the need of "cheap food" and "stability" of society, from the standpoint of the manufacturer.

19. To what extent, if any, is the tariff responsible for the present condition of New England agriculture?

20. Cite Webster's 1824 speech on this point.

21. Cite Albert Gallatin's arguments on the "home market" theory; on high wages.

22. Cite the arguments of Secretary Walker on the factory labor problem; relation of protection to high wages; profits; free trade; home markets.

23. Cite and explain Hamilton's two errors.

24. Cite modern theories of protection to labor and agriculture. Criticize.

25. What is the relation of the farmer to the protective tariff?

\section{QUESTIONS SUGGESTED BY THE TEXT}

1. Resolved, that our protective tariff policy has added to the prosperity of American agriculture.

2. Debate. Resolved, that the Single Tax, as proposed by Henry George, should be put into operation for all national, state and local purposes.

3. Assuming that free trade is desirable as among all the so-called white races, should or should not the principle be extended to include all races of the earth?

4. Show the fallacy implied in the words "cheap labor" in the following sentences: We cannot compete with the cheap labor of Europe. We cannot compete with the cheap labor of the Orient.

5. Show by citing reliable data that in American factories paying the highest wages, the labor cost of the product is less than in similar plants paying lower wages.

\section{REFERENCES}

1. George, Henry: "Progress and Poverty."

2. - " "The Land Question."

3. Fillebrown, C. B.: "The A B C of Taxation." Boston, 1912.

4. —: "A Single Tax Hand Book." Boston, 1913.

5. Shearman, Thomas G.: "National Taxation."

6. "The American Economic League, Publications of." Cincinnati. (A league to promote the Single Tax idea.)

7. HYDER, JosepH: "The Case for Land Nationalization; with a special introduction by Alfred Russell Wallace." London, 1913.

8. Whittaker, Sir Thomas P.: "The Ownership, Tenure and Taxation of Land. Some Facts, Fallacies and Proposals Relating Thereto." London, 1914.

9. Miller, Joseph Dana: "The Single Tax Five-Year Book." New York, 1919.

10. Tadssig, F. W. (Editor): "State Papers and Speeches on the Tariff." Published by Harvard University, 1892.

11. - "Tariff History of the United States." 6 edition, New York and London, 1914.

12. - "How not to Revise the Tariff." American Economic Review, I, pp. 20-37, March, 1911.

13. Commons, John R.: "Tariff and Protection to American Labor." Annals of American Academy of Political and Social Science, September, 1908 , pp. 51-56.

14. Bigelow, Poultney: "In Darkest Connecticut." The Independent, October 19, 1911.

15. Tarbell, Ida M.: "The Tariff in Our Times." New York, 1911.

16. "Reciprocity and Commercial Treaties." United States Tariff Commission, Washington, 1919. 
17. "Periodical. The Single Tax Review." 150 Nassau St., New York City, $\$ 2.50$ a year.

18. Wrisht C. W.: "Wool Growing and the Tariff." Harvard Economic Studies, Vol. 5, 1910.

19. Rhodes, James Ford: "History of the United States." Vol. 3, 27-60.

20. Domeratzky —-: "European Tariff Policies after the World War." The Americas, Aug., Sept., Oct., Nov., 1919.

21. "Single Tax in Canada-for Unimproved Lands." Grain Growers' Guide, January 7, 1920, 6.

22. Brown, HARry G.: "International Trade and Exchange," (especially chapters 4, 5, 6 of Part II), New York, 1914.

\section{APPENDIX}

Speech of Daniel Webster.-(House of Representatives, April 6, 1814.) "I am not anxious to accelerate the approach of the period when the great mass of American labor shall not find its employment in the field; when the young men of the country shall be obliged to shut their eyes upon external nature, upon the heavens and the earth, and immerse themselves in close and unwholesome workshops, when they shall be obliged to shut their ears to the bleatings of their own flocks, upon their own hills, and to the voices of the lark that cheers them at the plough, that they may open them in dust, and smoke, and steam, to the perpetual whirl of spools and spindles, and the grating of rasps and saws ...

"It is the true policy of the Government to suffer the different pursuits of society to take their own course, and not to give excessive bounties of encouragements to one over another. This, also, is the true spirit of the Constitution. It has not, in my opinion conferred on the Government the power of changing the occupations of the people of different states and sections, and of enforcing them into other employments."

Question by Representative Livingston.-(Testimony of Le Grand Powers, Chief of the Division of Agriculture, United States Census, Washington, May 4, 1899, before the Industrial Commission.) If the farmers' products meet the competition of the world in foreign markets, and the manufacturers' products meet the same competition in foreign markets of the world, if the Government undertakes to help one in any way ought it not to help the other, both being situated in certain cases alike?

Answer.-Certainly.

Question.-Has it done it?

Answer.-I do not know why it has not, because the tariff cuts absolutely no figure. We have to-day, to catch certain of the voters, a nominal tariff on certain agricultural products brought here from other countries. That tariff may affect prices a little on the border, just a trifle, but in the markets of the United States, on all the farms of the United States, the prices are not affected a hair's breadth.

Question (Bounty on Exports).-You do not think that would remedy it?

Answer.-No; you would have out of such a bounty no benefit at all to the farmer. It would be the same as in Germany in the matter of the sugar bounty. The English farmer, as the result of the German bounty, is able to feed his hogs raw German sugar as one of the cheapest articles he can give them; and he does that at the expense of the German taxpayer. The system of bounties in Germany has simply raised the price of sugar to the consumers in Germany, and thus lessens the amount that is consumed in Germany. If Germany would take away all bounties on sugar the common people could and would consume more sugar, and they would thus make a market for as much sugar of their own in twenty years as they have built up by their export duties.-Industrial Commission Report. Vol. X, pp. 176, $17 \%$. 


\section{CHAPTER XXV \\ FOREIGN COMPETITION}

THE question of foreign competition in agriculture is one which looms on the immediate horizon of the future. Then somewhat more remote than this question, but none the less real, is that fundamental question of soil exhaustion and the future food supply. The first of these questions, foreign competition, will be briefly considered in this chapter.

A Leaf from England's Notebook.-We can view with great equanimity economic revolutions in other countries. Our detachment and perspective enable us to see and interpret, in a disinterested fashion, important transitions in agriculture which are forced on our neighbors. But may not the same revolutions and transitions happen to us? Since the logical outcome of foreign competition is change in our own agriculture, in certain particulars, it is extremely interesting and suggestive to observe the experience of England when foreign competition forced her to pass through a period of agricultural revolution during the twenty-five years following our own Civil War.

The opening up of the new lands of the United States, Canada, Argentina, Australia, and elsewhere proved a disaster, for the moment, to the English growers of wheat and live stock. Changes were made which may correctly be termed an economic revolution in English agriculture. Wheat was produced as the "pioneer crop" on the virgin soils of the new countries in such volume and at so low a cost of production that the English farmer simply could not compete. Ocean steamships furnished cheap and rapid transportation. The invention of cheap refrigeration opened up the British markets to the almost limitless supplies of beef and mutton from distant lands. At the same time occurred a steady fall in the price of wool, owing to the cheap supplies from the British colonies. And on top of all these disturbances came a succession of unfavorable seasons. These and other causes, all working together, shook the very foundations of British agriculture. The old order was changing; a new order was coming in.

The farmers who clung to the old order were ruined by the 
change. The farmers who saw the signs of the time and took advantage of them were made prosperous by the transition. The immediate effect of cheap bread and meat from abroad was to benefit the cities and the laboring classes in the industries in the cities. The prosperity of the working classes brought a demand from them for foods in addition to bread and meats, particularly articles of food which before had been looked on as luxuries. These food articles included milk, cream, butter, vegetables, fruit, jams, preserves, poultry, eggs, etc. Thus the prosperity of the cities was in part passed on to the farmers. Certain high-grade meats produced in England and Scotland were in greater demand. There followed as a natural consequence of agricultural revolution a great expansion in the growing of pure-bred live stock; particularly dairy cattle. There came also a growth in raising pure-bred beef cattle, partly to supply the home demand for prime beef, and partly for export purposes to countries like Argentina, where fancy prices were paid for pure-bred sires.

British farmers of the more progressive type recognized the changes in the world about them, and hastened to take advantage of them. Among the successful activities of the progressive farmers may be named the following: sale of fresh milk, fruit industry (including dried fruit, jam, preserved fruits, cider), flowers, bulbs, market gardening (including broccoli, cabbage, celery, peas, rhubarb), eggs and poultry. Marketing and transportation problems also received considerable attention, in order that a proper and wide distribution of these crops could be secured.

The non-progressive farmers, feeling the pinch of the transition, filled the newspapers with letters about the "depression in agriculture," and wanted the government to "do something" for the farmer. Many of them asked for a protective tariff against this "foreign competition." In short, the issue was the old familiar one of Self-help versus State-aid. But self-help prevailed as the policy to be pursued. And now the British farmer himself is glad to buy his wheat from abroad, paying for it with crops that yield him a higher net return. In other words, he can get a bushel of wheat from the prairies of western Canada with less labor than he can produce a bushel of wheat on his British soil. Consequently wheat-growing in England has been reduced to those areas having distinct advantages in producing this cereal. 
Conditions Facing the United States.-In the production of the staple "bread-and-meat" crops-wheat, corn, hogs, beef cattle -we face the competition of the newer and fast-developing countries of all the world. While there are many areas of this kind of much significance, yet the following three are of the most immediate and outstanding importance, namely, Canada, Argentina, Russia. These bread-and-meat products compete in the markets of the world. Rapid transportation has largely neutralized the effects of distance. Prices respond according to these world-wide conditions, in which the United States is clearly not an isolated unit, but an integral part. The following diagram illustrates this truth for the wheat crop. As we affect prices in these other regions, so must they affect prices in our country. Hence it is easily conceivable that in the course of agricultural evolution or revolution we may at no distant date see the American consumers eating bread and meat from foreign lands. Would this be a good thing or a bad thing for the country? In the case of the English transition, the farmer, on the whole, seems to be better off after the change than before the change. The economic principle of the so-called "comparative costs" should govern in any situation of this kind. This principle may be illustrated in this way. If the Canadian farmer can raise better and cheaper wheat than the American farmer, while the American farmer, in his turn, can raise better and cheaper corn than his Canadian cousin, then the American farmer had better buy his wheat from Canada-paying for it with corn, rather than keep on raising wheat for himself. Each produces what he can produce best and cheapest. And under a free interchange of products, each gets the maximum return at the least cost. This illustrates how a cheap agricultural product, imported from a foreign country, may not injure the American farmer. The consumers who are not farmers-and they constitute two-thirds of our population-are of course interested in any source of cheaper food supply which promises to be permanent.

Our Foreign Trade; Its Changes; Its Significance.-A glance at a table of our exports and imports during a period of three decades prior to the World War shows strikingly the change in our foreign trade in agricultural products. We are ceasing to export foodstuffs. We are beginning to import foodstuffs. -The tremendous increase in the volume of our exports is due to the growth of 


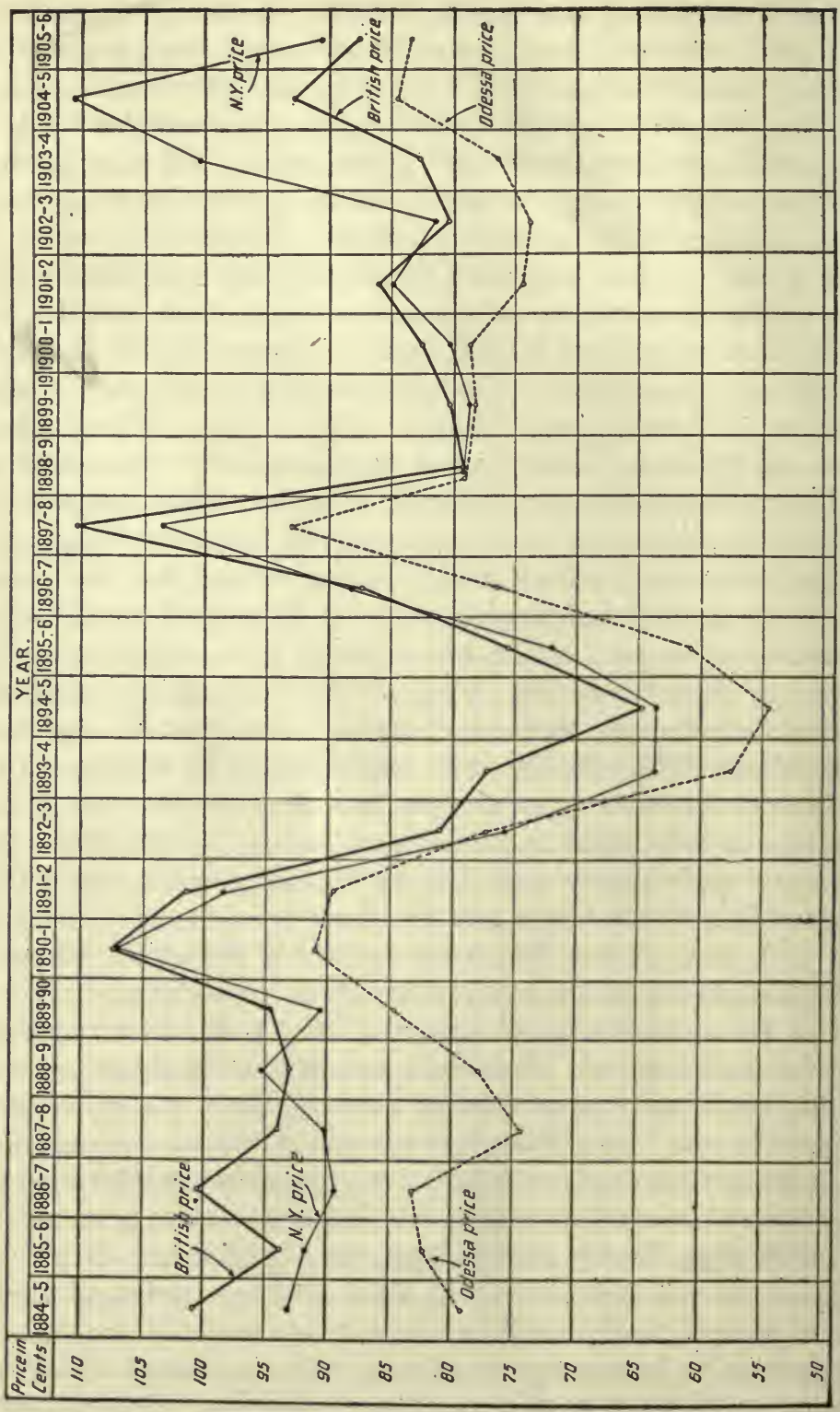

엉 
manufactures in this country. The following brief table tells the story:

Exports of Foodstuffs and Manufactures from the United States, and Percentage Which Each Group Forms of the Total; Changes in the Thirty-four Years Before the World War.

\begin{tabular}{|c|c|c|c|c|}
\hline \multirow{2}{*}{ Fiscal year } & \multicolumn{2}{|c|}{ Foodstuffs } & \multicolumn{2}{|c|}{ Manufactures } \\
\hline & Value & Per cent & Value & Per cent \\
\hline 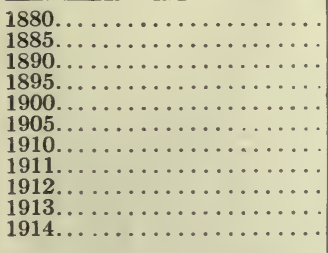 & $\begin{array}{r}\$ 459,461,673 \\
325,127,668 \\
356,829,763 \\
318,176,639 \\
545,473,695 \\
401,249,778 \\
369,087,974 \\
385,418,436 \\
418,737,763 \\
502,111,639 \\
430,713,457\end{array}$ & $\begin{array}{l}55.77 \\
44.74 \\
42.21 \\
40.11 \\
39.80 \\
26.90 \\
21.59 \\
19.13 \\
19.29 \\
20.72 \\
18.49\end{array}$ & $\begin{array}{r}\$ 121,818,298 \\
150,256,178 \\
178,982,042 \\
205,057,865 \\
484,846,275 \\
611,425,574 \\
766,981,245 \\
907,519,841 \\
1,020,417,687 \\
1,185,104,309 \\
1,102,132,210\end{array}$ & $\begin{array}{l}14.78 \\
20.67 \\
21.18 \\
25.84 \\
35.37 \\
40.98 \\
44.85 \\
45.07 \\
47.02 \\
48.80 \\
47.17\end{array}$ \\
\hline
\end{tabular}

The products of the factory greatly exceed the products of the farm in our exports. For many years the United States enjoyed the world's primacy as an exporter of cotton, breadstuffs, and meats. We have now reached the point where imports of packing house products normally exceed our exports. Likewise the imports of live animals exceed the exports of live animals. In breadstuffs our exports of flour have fallen to two-thirds their former level, but the export of wheat is maintained in peace times at about the same level, namely, about 100,000,000 bushels. In cotton we still have about two-thirds of the world's export trade, namely, about 8,000;000 bales.

The situation may be summarized as follows:

We are exporting bread and meat, but less than formerly.

We are importing foodstuffs, and more than formerly.

We are exporting manufactured goods, more and more. We have become, in fact, an urban people.

So much for our status; what are the future prospects of Russia, Canada, and Argentina? Some facts are submitted as to their resources, which indicate in some measure their future promises.

Our Competitors: Argentina.-As a typical example of our increasing competition from foreign countries, it is interesting to note the situation in Argentina. Few Americans, as yet, realize the significance of Argentina's actual and potential competition. Argentina has the same climate as the United States, occupying approximately the same position south of the equator as that of 
the United States north of the equator. Its area is two-fifths that of the United States, but its population (eight and one-half million) is only one-twelfth that of the United States. Less than one-fourth of its productive land is under cultivation. Hence we see the

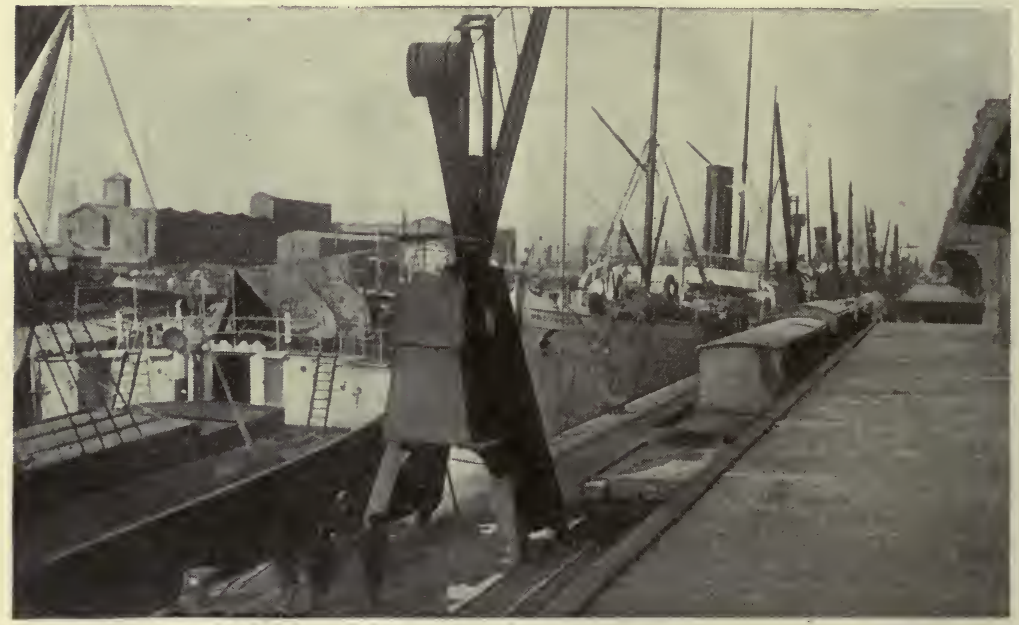

Frg. 81.-Ocean transportation, port of Buenos Aires.

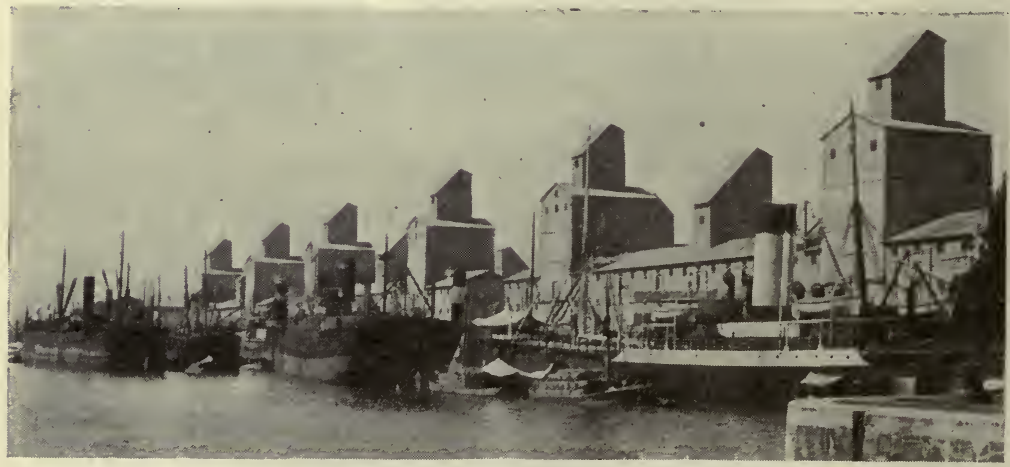

FIG. 82.-Modern grain elevators at Buenos Aires.

room for expansion both in population and production. In 1891 Argentina exported only 17,500,000 bushels of grain; in 1913 the exports arnounted to $397,000,000$ bushels, an increase of over two thousand per cent. The average yield per acre of corn in Argentina for the three years 1911, 1912, 1913 was $27 \frac{1}{2} 2$ bushels, against 
27 bushels in the United States. The percentage of the wheat crop of the United States exported was 17.5 per cent, while Argentina exported 60.6 per cent. Of the oats produced in the United States, only 1.1 per cent was available for export, while Argentina had an average surplus of 82.4 per cent of the crop. In the pro-

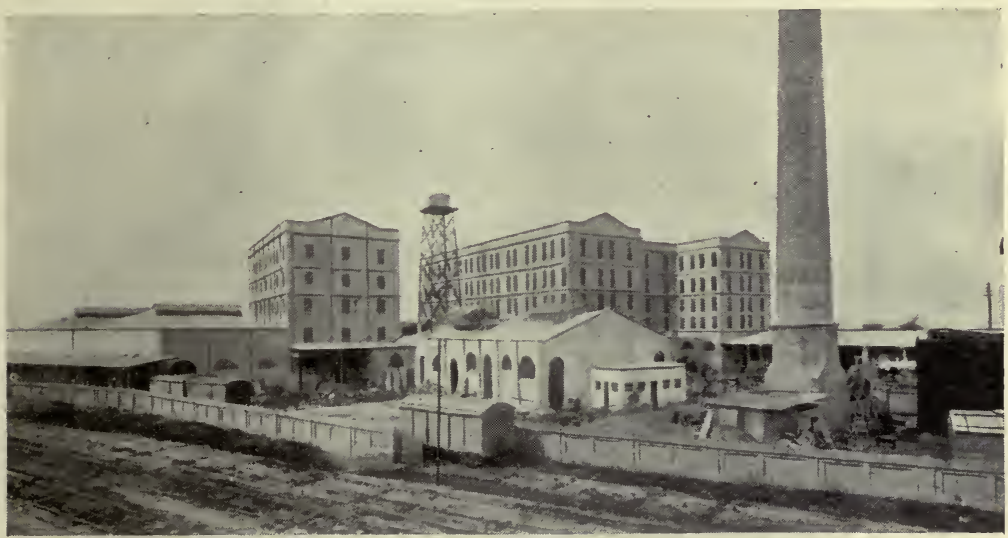

Fia. 83.-Mill of Minnetic y Cia, of Cordoba, located at Rosario.

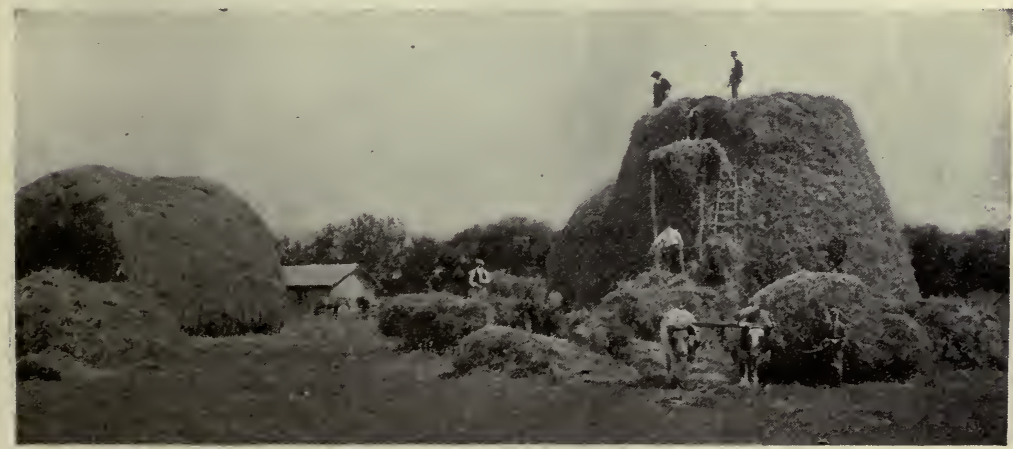

FIG. 84.-Alfalfa grows luxuriantly in Argentina.

duction of flaxseed Argentina exceeds the United States by over $10,000,000$ bushels, although an average of only - four onehundredths of 1 per cent is exported from the United States, while 81.8 per cent of the Argentina crop is available for export. The average yields per acre of flaxseed are the same in both countries, namely, $71 / 2$ bushels (Figs. 81 to 87 ).

The meat industry of Argentina shows greater strength even 
than the grain industry. "The growth of the meat trade in the Argentine Republic," says the United States Department of Agriculture, "has been little short of remarkable and its importance in the world's commerce is greatest in beef products." Argentina's

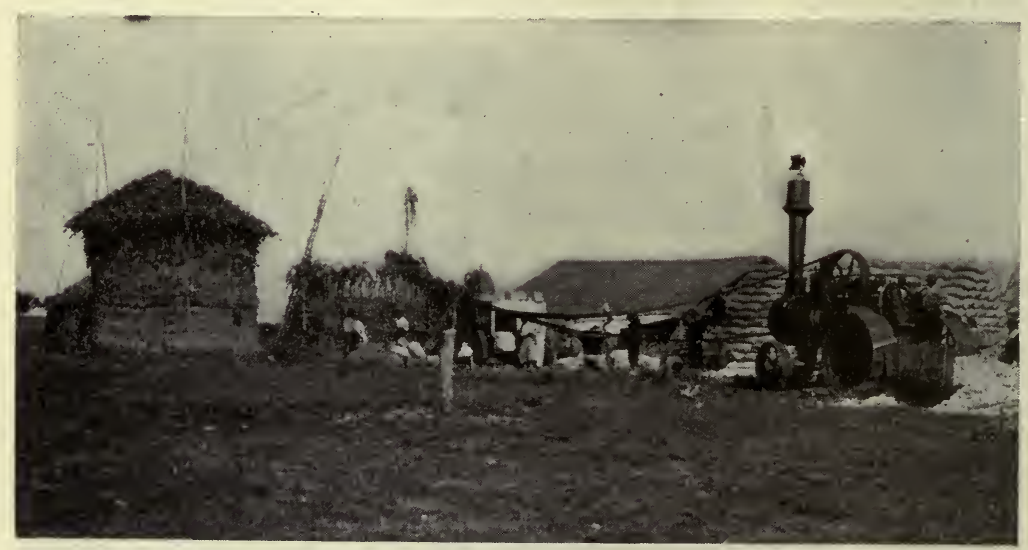

Fia. 85.-A modern method of shelling corn in Argentina.

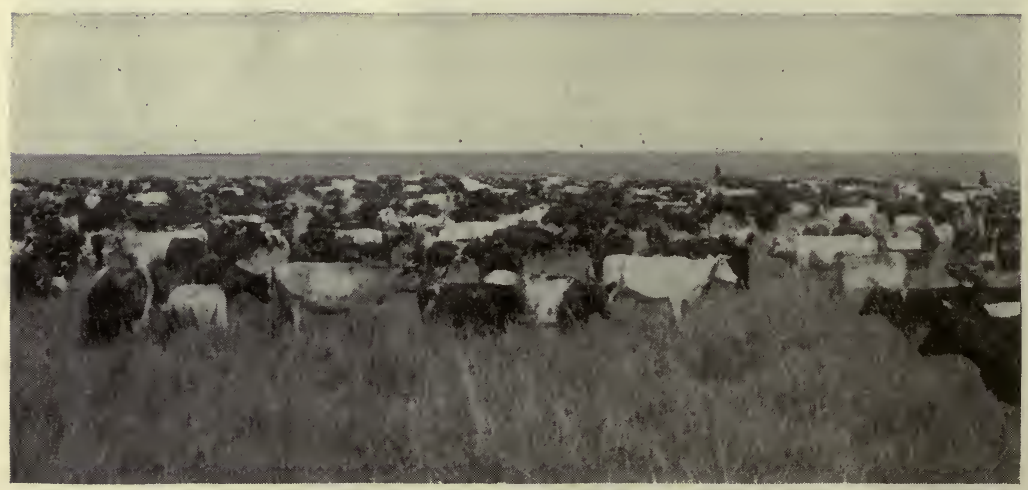

Fig. 86.-Magnificent herd of cattle in the Tampa Central, Argentina.

exports of frozen beef began in 1884; of chilled beef in 1901. The chilled beef trade has shown a rapid growth, reaching 2,989,805 quarters in 1913. This amount considerably exceeds the $351,748,333$ pounds of fresh beef exported by the United States in 1901, the year the Argentina chilled beef trade began and which year marked the beginning of the decline in the United States of exports of fresh beef. 


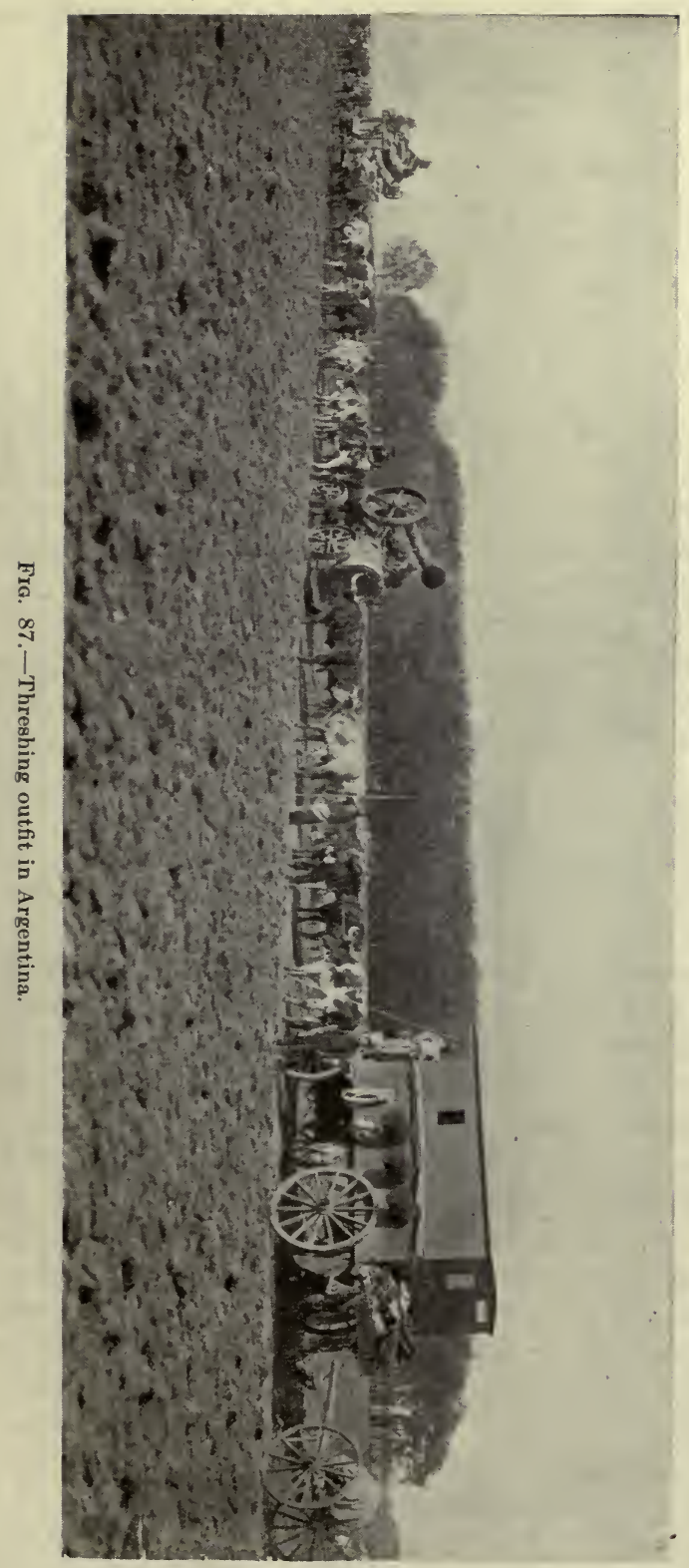


The following table shows in detail the growth of Argentina's beef trade.

Exports of Beef from Argentina

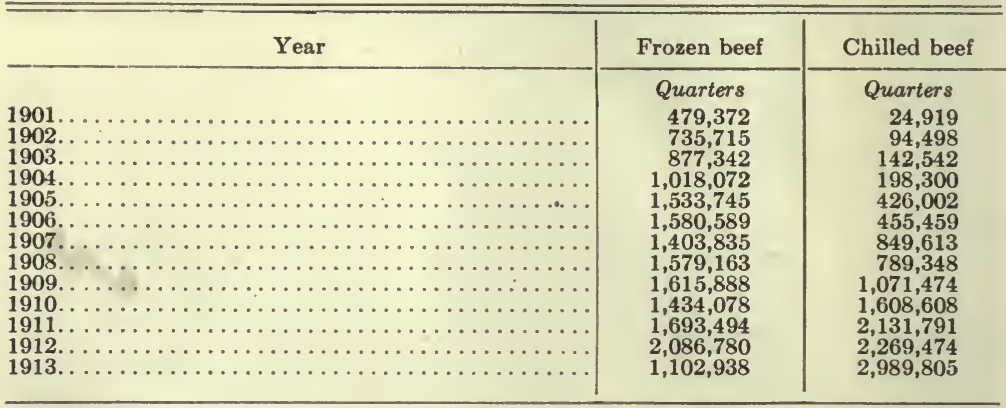

In contrast with this table, the following table shows the steady decline in United States beef exports.

Exports of Fresh Beef from the United States

\begin{tabular}{|c|c|c|c|}
\hline Year & $\begin{array}{l}\text { Quantity, } \\
\text { pounds }\end{array}$ & Year & $\begin{array}{l}\text { Quantity, } \\
\text { pounds }\end{array}$ \\
\hline 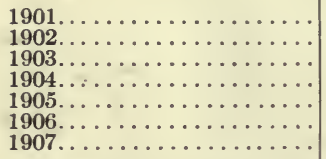 & $\begin{array}{l}351,748,333 \\
301,824,473 \\
254,795,963 \\
299,579,671 \\
236,486,568 \\
268,054,227 \\
281,651,502\end{array}$ & 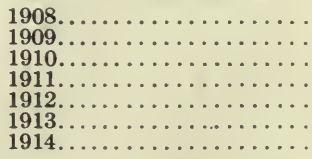 & $\begin{array}{r}201,154,105 \\
122,952,671 \\
75,729,666 \\
42,510,731 \\
15,264,320 \\
7,362,388 \\
6,394,404\end{array}$ \\
\hline
\end{tabular}

Argentine chilled beef normally sells on the English market within $11 / 2$ to 2 cents a pound of the price of English beef, and Argentine frozen beef from $13 / 4$ to $2 \frac{1}{2}$ cents a pound lower than Argentine chilled. The destination of nearly all of Argentina's beef is England, although the United States is beginning to import Argentine meat. In the twelve months prior to the World War the United States imported $153,882,670$ pounds of meat from Argentina. Cattle growing in Argentine has proved to be a much more certain enterprise than grain growing, hence the apparent tendency to convert grain lands into alfalfa pastures. Cattle breeding methods in Argentina are on a high plane, surpassing those of the United States. In the United States it is the exception to find a splendid herd of beef cattle handed down from father to son, but in Argentina it is so common as to be almost the rule. In fact, many establishments have been in the hands of the same family for nearly a century. Furthermore, the custom is universal of buying the best individual cattle and the best blood regardless 
of price. An Argentine breeder in 1913 paid $\$ 34,400$ for a Shorthorn bull, the highest price up to that time ever paid for a bull of any breed. Although the Argentine herds have been brought to a high standard, their owners are constantly in the market for breeding animals to bring in fresh blood or to improve the quality of the herds. This trade has heretofore gone almost entirely to Great Britain, and it has been one of the most profitable outlets which British breeders have had. The Commerce Reports of May 15, 1916, contains this significant statement; "The importation of fine cattle and sheep from England into Argentina is continuing in spite of the war. A shipment of shorthorn cattle from Liverpool for Buenos Aires is announced in La Razon for April 14, and another shipment is expected in May." The business and social relations between British and Argentine breeders are close. British judges nearly always officiate at the leading Argentine shows, and there is no recollection thus far of a single instance of a North American breeder having been asked to judge at an Argentine show. Some authorities look for a positive and beneficial effect on the United States beef cattle industry in Argentina's probable demand for breeding animals from the United States.

United States and Canada.-The total area of Canada is one and one-fourth times as large as the United States, but the population (1911 census, $7,206,643)$ is only one-thirteenth as large. As an exporter of wheat, oats, and flaxseed Canada has now become one of the strongest countries in the world. Omitting the Yukon and the Northwest territories, the nine organized provinces of Canada contain a total land area of $977,585,513$ acres, of which $109,948,988$ acres, or 11.25 per cent, is now occupied as farm land. The estimate of possible farm land in these nine provinces is $358,162,190$ acres, or 36 per cent of the total area. In other words, less than one-third the available land in these provinces is under cultivation.

The following table shows Canada's producing power in the years 1914 and 1915.

Yield and Value of Field Crops in Canada, 1914, 1915. Pre-War Basis.

\begin{tabular}{|c|c|c|c|}
\hline & Wheat & Oats & Barley \\
\hline $\begin{array}{l}1915 \text { yield. } \ldots \ldots \ldots \ldots \ldots \\
1914 \text { yield. } \ldots \ldots \ldots \ldots \ldots \\
1915 \text { yield per acre...... } \\
1914 \text { yield per acre. } \ldots \ldots \ldots \\
1915 \text { value of crop. } \ldots \ldots \ldots\end{array}$ & $\begin{array}{r}376,303,000.00 \text { bu. } \\
161,280,000.00 \text { bu. } \\
28.98 \text { bu. } \\
15.67 \text { bu. } \\
\$ 312,569,400.00\end{array}$ & $\begin{array}{r}520,103,000.00 \text { bu. } \\
313,078,000.00 \text { bu. } \\
45.76 \text { bu. } \\
31.12 \text { bu. } \\
\$ 176,894,700.00\end{array}$ & $\begin{array}{r}03,331,300.00 \mathrm{bu} . \\
36,201,000.00 \mathrm{bu} . \\
35.33 \mathrm{bu} . \\
24.21 \mathrm{bu} . \\
\$ 26,704,700.00\end{array}$ \\
\hline
\end{tabular}


Yield and Vaiue of Field Crops in Canada, 1914, 1915. Pre-War Basis-Cont'd

\begin{tabular}{|c|c|c|}
\hline & Flaxseed & Corn \\
\hline 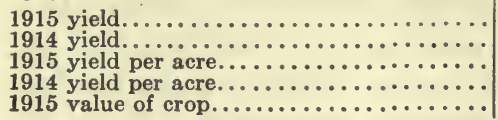 & $\begin{array}{r}10,628,000.00 \text { bu. } \\
7,175,200.00 \text { bu. } \\
13.18 \text { bu. } \\
6.62 \text { bu. } \\
\$ 15,965,000.00\end{array}$ & $\begin{array}{r}14,368,000.00 \mathrm{bu} . \\
13,924,000.00 \mathrm{bu} . \\
56.72 \mathrm{bu} . \\
54.39 \mathrm{bu} . \\
\$ 10,243,000.00\end{array}$ \\
\hline
\end{tabular}

Russia.-Russia is generally referred to as the "Great Unknown" in the grain trade. A vast country, sparsely settled, a

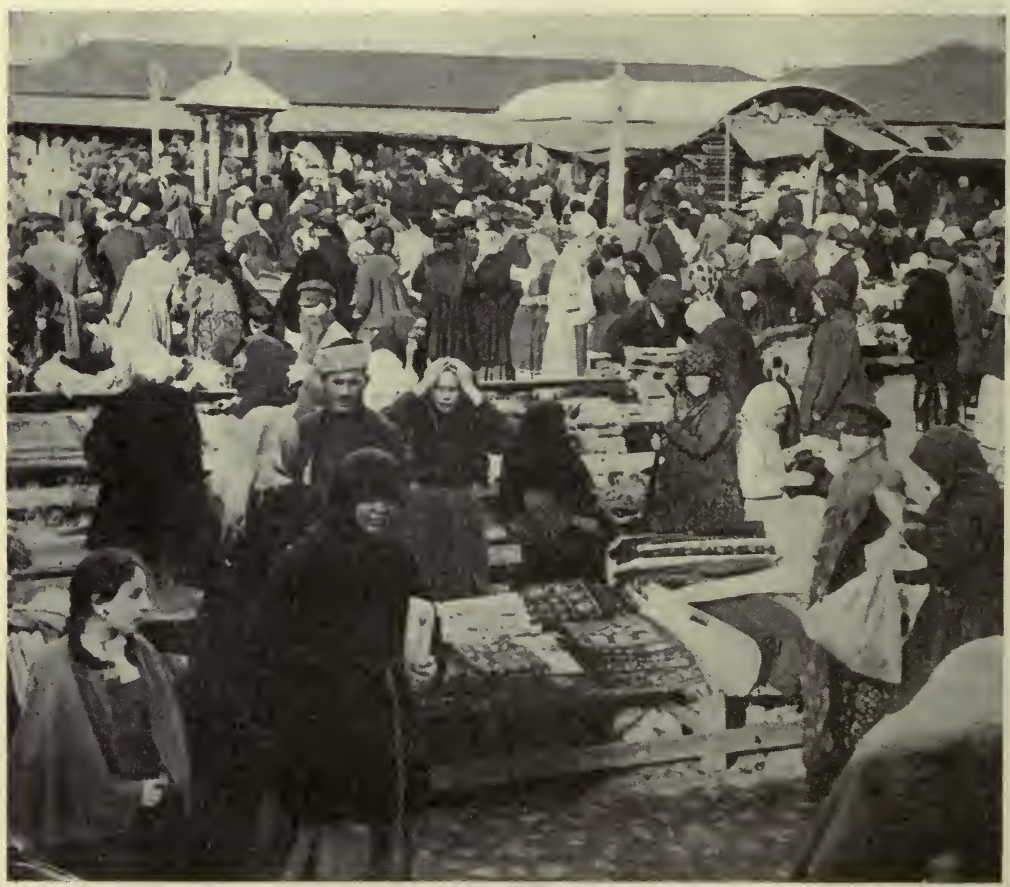

FIG. 88.-Direct marketing scene at a Russian fair.

fertile soil, and primitive conditions in soil cultivation and crop marketing, her real and potential crop surplus for export is a disturbing factor in the world's markets. Only one-third of European Russia's productive land is under cultivation as yet! And it is very poorly tilled! And only one-twentieth of Asiatic Russia's productive land is now under cultivation. It is impossible to forecast the possibilities of increase in agricultural production for such a country as this (Figs. 88 and 89). Education, scientific agriculture, modern storage and transportation facilities, stabilized 
government, all these influences must contribute to increasing very greatly Russia's annual crop yields.

The thoughtful student who aspires to be a real agricultural statesman must consider world conditions in agriculture. Three of our chief competitors in the world's agricultural commerce have been named. Our real and potential competitors are many, and can best be shown by means of a brief statistical table, showing

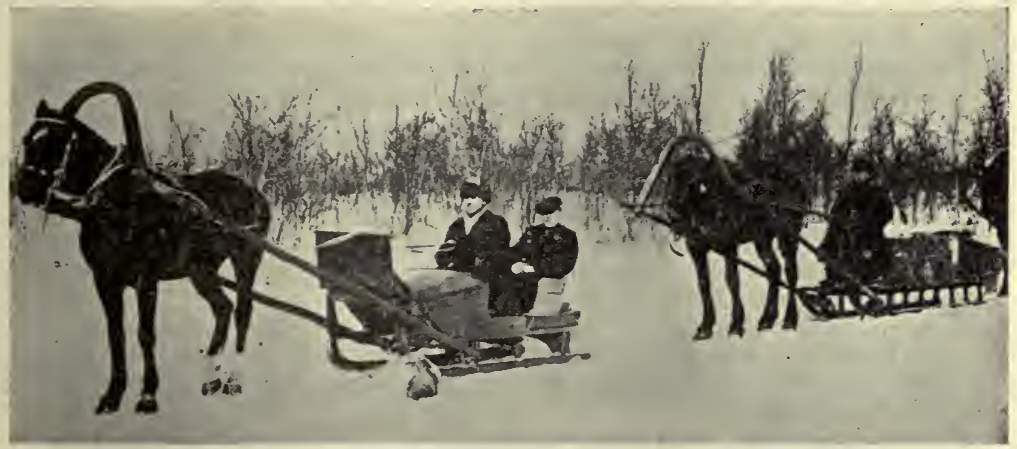

FIG. 89.-Transportation in Russia.

for each such country its total area, its productive land, and the present $\mathrm{a}_{2}$ ea of its cultivated land. Such a table is presented below:

Total Area and Agricultural Land in Various Countries.

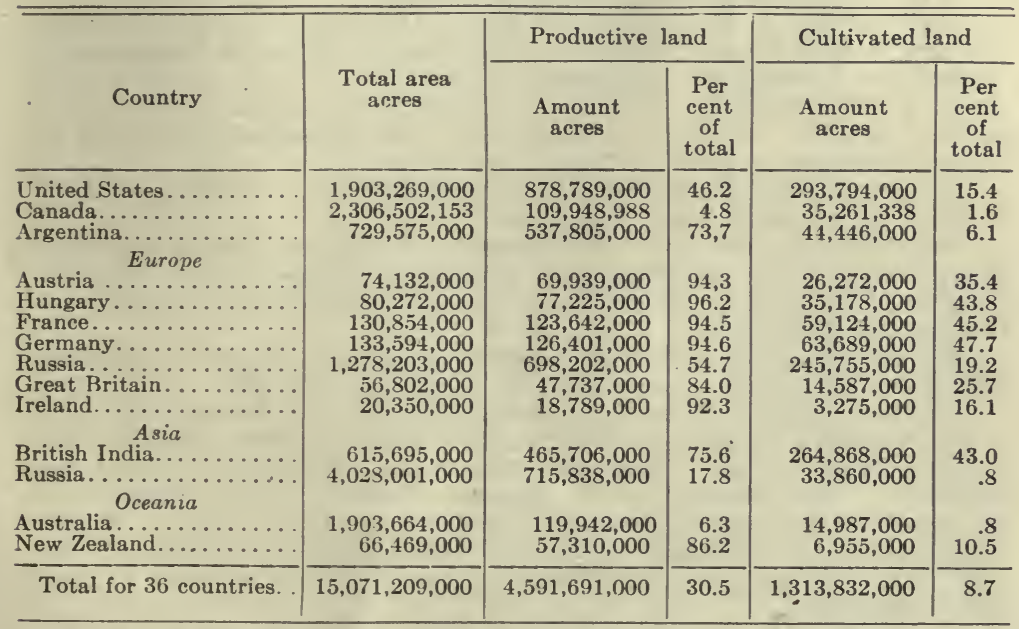

Nots.-By comparing the productive land (30.5) with the cultivated land (8.7) we find that but 28.5 per cent of the usable land is now cultivated. 


\section{QUESTIONS ON THE TEXT}

1. Describe in full the transition in English agriculture in the period following 1870. Same for Denmark (p. 423).

2. What suggestions, if any, for the United States, in the problems presented and methods used in this period in England?

3. Show what competitive conditions now face the United States.

4. Explain the principle of "comparative costs."

5. Show the changes in our foreign trade since 1880 , and state their significance.

6. Discuss Argentina as a competitor: area; climate; population; crops; live stock; exports.

7. In a similar way discuss Canada.

8. In a similar way discuss Russia.

9. The productive land of the world is what per cent of the total land acreage? The cultivated land constitutes what per cent of the productive land?

\section{QUESTIONS SUGGESTED BY THE TEXT}

1. Prepare a chart or graph showing the world's cotton production, also cotton production of United States, Fgypt, and India.

2. Prepare a table showing wheat acreage and yields for a series of years in the United States, Argentina, Canada, Russia, Australia, India, the Balkan States, France.

3. What should be the policy of our government in using a protective tariff on imports of foreign agricultural products, such as corn from Argentina, hay from Canada, beans from Manchuria, citrus fruit from Spain and Italy, etc.?

4. Debate. Resolved, that each country should devote itself to the production of those commodities in which it has special advantages, and there should be free interchange of all products.

\section{REFERENCES}

1. Finch, V. C., And Baker, O. E.: "Geography of the World's Agriculture, United States Department of Agriculture." Contribution from the Otfice of Farm Management, Washington, 1917.

2. Rubinow, I. M.: "Russian Wheat and Wheat Flour in European Markets." Bulletin 66, Bureau of Statistics, United States Department of Agriculture, Washington, June, 1908.

3. Davis, MACK H.: "Flour and Wheat Trade in European Countries and the Levant." Bureau of Manufactures, Department of Commerce and Labor, Washington, 1909.

4. "Imports and Exports of Agricultural Products." Published annually in Yearbook of Agriculture, Washington.

5. McKenna, Royal T.: "Annual and Average Production of and International Trade in Important Agricultural Products by Countries." Circular 31, Bureau of Statistics, United States Department of Agriculture, Washington, July, 1912.

6. "United States Industrial Commission Report," 19 vols., Washington, 1898-1902, Vol. 10, p. cccxxxix, p. 176; Vol. 19, pp. 187-193.

7. Pratr, E. A.: "The Transition in Agriculture." London, 1909.

8. Yearbook Department of Agriculture: 1903-Holmes, GEo. K.: "The Nation's Farm Surplus." 1913-Melvin, A. D.: "The South American Meat Industry." 1914-Melvin, A .D., Rommes, Geo. M.: "New Production in the Argentina and its Effects upon the Industry in the United States." 381-391. 1914-Joss, E. C.: "Meat Production in Australia and New Zealand," 421439. 1915-Duval, Laures: "Production and Handling of Grain in Argentina." 281-299.

9. "Industrial Commission Report." Vol. 10, cccxxxix-cccliv.

10. Day, Clive: "History of Commerce" (New edition), 1914. 
11. Evans, C. H.: "Domestic Exports from United States to all Countries," 1789-1882, 1884.

the United States," 1915 .

13. "Report of the Empire Cotton Growing Committee," London, 1920.

14. Smith, Rollin E.: "Argentina and the Grain Trade, Price Current Grain Reporter," Chicago, May 7, 1919.

15. Pickell, J. RAlPH: "Agricultural Argentina," Chicago, n.d.

16. "American Dairy Competition-Argentina and Canada-a Serious Question." The Market Reporter (U. S. Bureau of Markets), Vol. 1, No. 7, Feb. 14, 1920, p. 1.

\section{APPENDIX}

Foreign Trade of the United States in Agricultural Products, 1852-1918. (Compiled from Reports of Foreign Commerce and Navigation of the United States. All Values are Gold.).

\begin{tabular}{|c|c|c|c|c|}
\hline \multirow{3}{*}{ Year ending June 30} & \multicolumn{2}{|c|}{ Agricultural exports 1} & \multirow{2}{*}{\multicolumn{2}{|c|}{ Agricultural imports 1}} \\
\hline & \multicolumn{2}{|c|}{ Domestic } & & \\
\hline & Total & $\begin{array}{c}\text { Percentage } \\
\text { of all } \\
\text { exports }\end{array}$ & Total & $\begin{array}{l}\text { Percentage } \\
\text { of all } \\
\text { imports }\end{array}$ \\
\hline $\begin{array}{l}\text { Average: } \\
1852-1856 \ldots \ldots \ldots \ldots \ldots \\
\quad 1857-1861 \ldots \ldots \ldots \ldots \ldots \\
1862-1866 \ldots \ldots \ldots \ldots \ldots \\
1867-1871 \ldots \ldots \ldots \ldots \ldots \\
1872-1876 \ldots \ldots \ldots \ldots \ldots \\
1877-1881 \ldots \ldots \ldots \ldots \ldots\end{array}$ & $\begin{array}{r}\$ 164,895,146 \\
215,708,845 \\
148,865,540 \\
250,713,058 \\
396,666,397 \\
591,350,518\end{array}$ & $\begin{array}{l}80.9 \\
81.1 \\
75.7 \\
76.9 \\
78.5 \\
80.4\end{array}$ & $\begin{array}{l}\$ 77,847,158 \\
121,018,143 \\
122,221,547 \\
179,774,000 \\
263,155,573 \\
266,383,702\end{array}$ & $\begin{array}{l}29.1 \\
38.2 \\
43.0 \\
42.3 \\
46.5 \\
50.4\end{array}$ \\
\hline $\begin{array}{l}1882-1886 \ldots \ldots \ldots \ldots \ldots \\
1887-1891 \ldots \ldots \ldots \ldots \\
1892-1896 \ldots \ldots \ldots \ldots \\
1897-1901 \ldots \ldots \ldots \ldots \\
1902-1906 \ldots \ldots \ldots \ldots \ldots \\
1907-1911 \ldots \ldots \ldots \ldots\end{array}$ & $\begin{array}{l}557,472,922 \\
573,286,616 \\
638,748,318 \\
827,566,147 \\
879,541,247 \\
975,398,554\end{array}$ & $\begin{array}{l}76.3 \\
74.7 \\
73.0 \\
65.9 \\
59.5 \\
53.9\end{array}$ & $\begin{array}{l}311,707,564 \\
366,950,109 \\
398,332,043 \\
376,549,697 \\
487,881,038 \\
634,570,734\end{array}$ & $\begin{array}{l}46.8 \\
43.3 \\
51.6 \\
50.2 \\
46.3 \\
45.2\end{array}$ \\
\hline $\begin{array}{l}1901 \ldots \ldots \ldots \ldots \ldots \ldots \ldots \ldots \ldots \ldots \\
1902 \ldots \ldots \ldots \ldots \ldots \ldots \ldots \ldots \ldots \ldots \ldots \ldots \\
1903 \ldots \ldots \ldots \ldots \ldots \ldots \ldots \ldots \ldots\end{array}$ & $\begin{array}{l}951,628,331 \\
857,113,533 \\
878,480,557 \\
859,160,264 \\
826,904,777\end{array}$ & $\begin{array}{l}65.2 \\
63.2 \\
63.1 \\
59.5 \\
55.4\end{array}$ & $\begin{array}{l}391,931,051 \\
413,744,557 \\
456,199,325 \\
461,434,851 \\
553,851,214\end{array}$ & $\begin{array}{l}47.6 \\
45.8 \\
44.5 \\
46.6 \\
49.6\end{array}$ \\
\hline $\begin{array}{l}1906 \ldots \ldots \ldots \ldots \ldots \ldots \ldots \ldots \ldots \ldots \\
1907 \ldots \ldots \ldots \ldots \ldots \ldots \ldots \ldots \\
1908 \ldots \ldots \ldots \ldots \ldots \ldots \\
1909 \ldots \ldots \ldots \ldots \ldots \ldots \ldots\end{array}$ & $\begin{array}{r}976,047,104 \\
1,054,405,416 \\
1,017,396,404 \\
903,238,122 \\
871,158,425\end{array}$ & $\begin{array}{l}56.8 \\
56.9 \\
55.5 \\
55.1 \\
50.9\end{array}$ & $\begin{array}{l}554,175,242 \\
626,836,808 \\
539,690,121 \\
638,612,692 \\
687,509,115\end{array}$ & $\begin{array}{l}45.2 \\
43.7 \\
45.2 \\
48.7 \\
44.2\end{array}$ \\
\hline 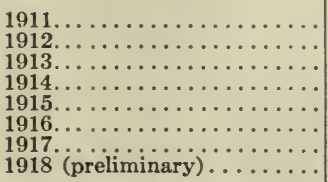 & $\begin{array}{l}1,030,794,402 \\
1,050,627,131 \\
1,123,651,985 \\
1,113,973,635 \\
1,475,937,607 \\
1,518,071,450 \\
1,968,253,288 \\
2,281,338,876\end{array}$ & $\begin{array}{l}51.2 \\
48.4 \\
46.3 \\
47.8 \\
54.3 \\
35.5 \\
31.6 \\
39.0\end{array}$ & $\begin{array}{r}680,204,932 \\
783,457,471 \\
815,300,510 \\
924,247,116 \\
910,786,289 \\
1,189,704,830 \\
1,404,972,108 \\
1,614,219,764\end{array}$ & $\begin{array}{l}44.5 \\
47.4 \\
45.0 \\
48.8 \\
54.4 \\
54.1 \\
52.8 \\
54.8\end{array}$ \\
\hline
\end{tabular}

1 Not including forest products.

The Transition in Agriculture in Denmark.-How it was Met.-(Without the use of a protective tariff.) The following extract is from a pamphlet, "A Short Outline of Danish Agriculture through the Last Generation," presented to British journalists on their visit to Denmark in August 1919, by the Union of Danish Agriculture. Copenhagen, 1919. 
“The time from about $188^{\circ}$ until the outbrcak of war in 1914 has for Danish agriculture been a period of extraordinary and prosperous development.

"Before 1880 Danish agriculture was mainly producer and seller of corn; but when America's surplus production of corn in the eighties reached Europe the corn prices fell rapidly and the corn producing agriculture had to work under very difficult conditions, particularly in Denmark where the chief part of the soil, especially in Jutland but also in parts of the islands, is of so poor a quality that it only yields comparatively small crops. Instead of entering into a - from the outset hopeless - competition against the transatlantic import of corn a happy fate led Danish agriculture in the quite opposite direction, and taking advantage first of the supplies of cheap corn and later of oil cakes as raw material a production of refined produces (products) of domestic animals was taken up-especially butter and bacon-which gradually became the specialty of Danish agriculture. This production spelt a thorough revolution of Danish agricultural economy and opened possibilities as well for rural enterprises to which the soil was better adapted than to corn growing as for the extensive outparceling of land to the small freeholds that have become a social blessing to the whole country...

"When the farmers after 1880 at a continually increasing rate took up the production of butter, bacon, and eggs, as the chief articles of export, this production was from the very start adjusted so as to suit British consumers; and the English market was held mainly in view from the very beginning also at the numerous new-established coöperative factories. Every effort was made to produce the particular quality of butter and bacon required by the great English army of consumers, and simultaneously every endeavor was made to ensure a fixed quality common for the whole country all the year round and to ensure equal shipments both summer and winter. The efforts were duly appreciated in England, and the Danish agricultural products gained in the course of time a firm and secure footing on the British Market." 


\section{CHAPTER XXVI}

\section{FOOD SUPPLY PROBLEM}

During the past two hundred years the United States has supplied foreign countries so lavishly with foodstuffs that the problem of a future food supply at home was scarcely thought of. But now that the tide is turning, now that we are importing some corn and some meat, it is an opportune time to pause and take an inventory of conditions as they are, and to endeavor to form an estimate of conditions as they soon will be.

Food Problem.-The food supply problem is a dual problem(1) How much food is produced? (Fig. 90.) (2) How many people are there to eat this food? We know that population is increasing. We know that the food supply is increasing also. But the present and the prospective ratio between the increase in population and the increase in food supply is the vital question that concerns us. Some of the most important literature of the world has been devoted to a discussion of one or more aspects of this problem. T. R. Malthus, the British clergyman, Liebig, the German agricultural chemist, and Sir Wm. Crookes, the British scientist, to name but three great thinkers, have all made notable contributions to the world's knowledge of this problem. The most widely known of these three is doubtless Malthus. Since he treats of the problem from the population standpoint, his doctrine will first receive attention.

The Malthusian Theory of Population.-Like a good many Englishmen of the "upper classes" of that day, Malthus was interested in "Plans of improving the poor." By battling with his critics for some 27 years (from 1798 to 1825) he finally worked out his conclusions that the trouble with the poor was their poverty; that their poverty was due to low wages; that low wages were due to the oversupply of labor, namely, to the oversupply of poor people, and that consequently the one effective remedy was to produce fewer laborers. This limitation of the supply of labor would raise wages, leave more food for each laborer, and not greatly inconvenience the "upper classes." "We must show the poor," said Malthus, "that the withholding of the supplies of labor is the only possible way of really raising its price, and that they themselves being the possessors of this commodity have alone 
power to do this." The proposed systems of "equality" of his day Malthus rejected as mere palterings with a serious problem.

The general effect of years of cheapness and abundance of food, says Malthus, is to dispose a great many persons to marry. Countries are populous according to the quantity of human food which

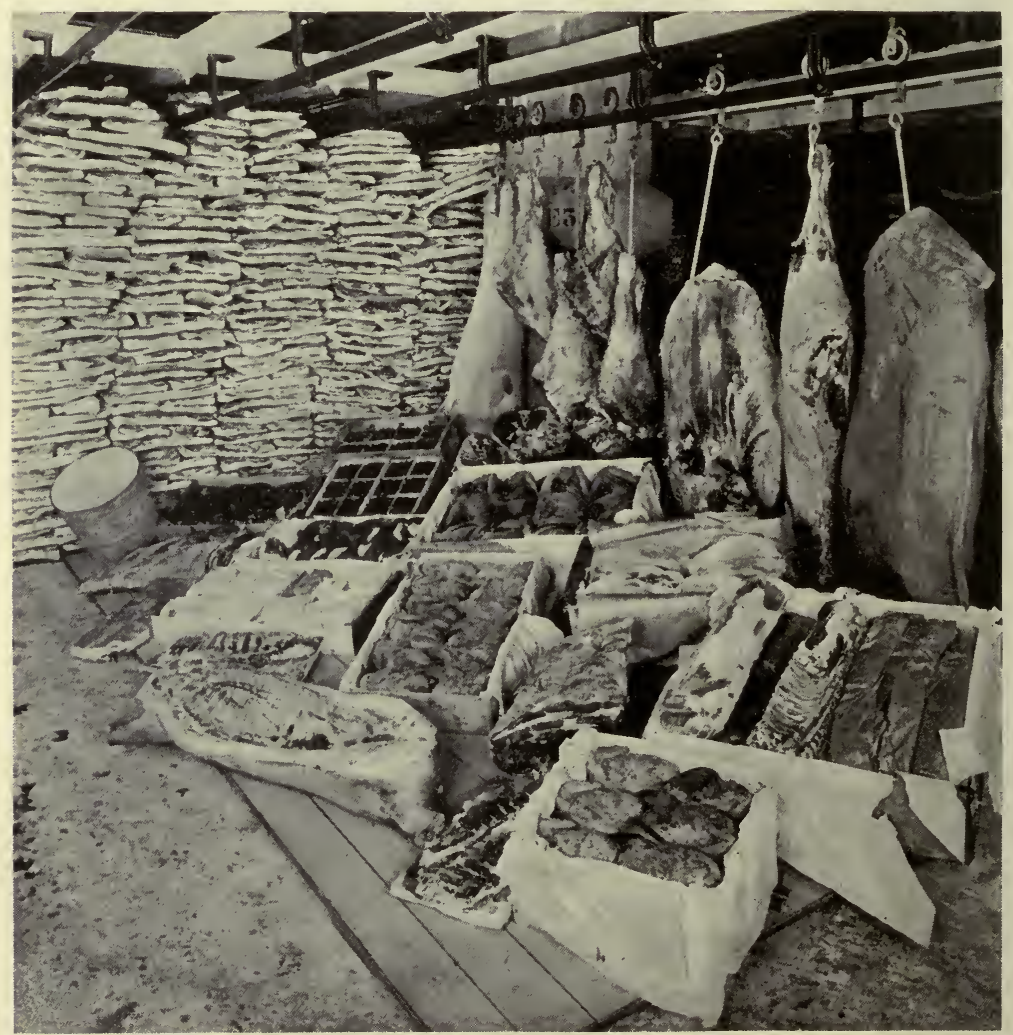

FIG. 90.-Fresh and cured meats in a cold storage warehouse in Chicago.

they produce or can acquire; and happy according to the liberality with which food is divided, the quantity which a day's labor will produce. Corn countries are more populous than pasture countries, and rice countries more populous than corn countries. This happiness depends on the proportion which the population and the food bear to each other.

But population, says Malthus, tends to increase beyond the means of subsistence. Population is limited by the food supply. 
Population when unchecked goes on doubling itself every twentyfive years-that is, it increases in a geometrical ratio. The food supply, under circumstances the most favorable to human industry could not possibly be made to increase, says Malthus, faster than in an arithmetical ratio. That is, population increases as the numbers $1,2,4,8,16$, and so on, while the food supply increases as the numbers $1,2,3,4,5$. Thus at the end of 100 years the population would tend to be more than 3 times the food supply. The Malthusian theory, of population consists of two parts-the first part, just stated, of the geometric increases of population when unchecked; the second part, of the "checks on population." The ultimate check is want of food. But the immediate checks are two, namely, (1) preventive - that is, voluntary restraint; (2) positive - that is, vice and misery in every form which causes a shortening of human life. Vice and misery include unwholesome labor, exposure, poverty, disease, war, plague, famine. Delay of marriage, from prudential considerations, said Malthus, is the nost powerful check in modern Europe in keeping down the population to the level of subsistence. A lower birth-rate would lead to a lower death-rate, said Malthus, that is, to fewer and better children. The apparent paradox that better wages would lead to earlier marriage and more children and lower wages, Malthus met by laying stress on a more general system of education and a higher standard of living for the workers.

He stated that the population of the United States had doubled every 25 years during the first 150 years, and he estimated a similar rate of increase for the future as long as abundance of cheap food lasted. This table compares his prediction with the facts.

Population of the United States.

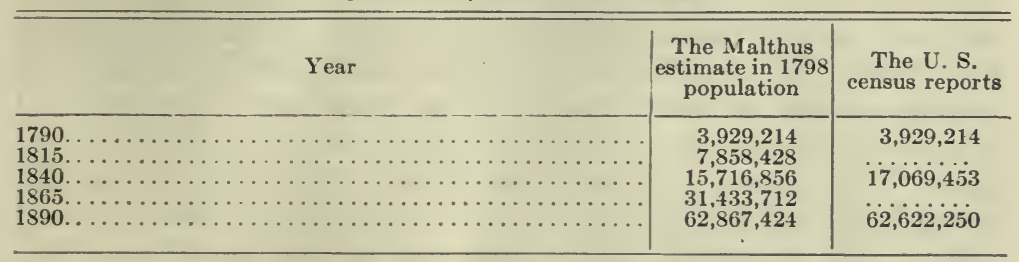

The actual population of the United States in 1890 , by the federal census, was $62,622,250$, or less than one-half of one per cent under the estimate made by Malthus some ninety years before. Following the year 1890, however, for the first time the "geometrical increase" failed to occur. On the basis of doubling every 
25 years, the population would have reached $125,734,848$ in 1915 . The actual population in 1915 was about 100,000,000. Evidently the Malthusian "check" on population had begun to operate.

The Malthusian theory of population is undoubtedly correct. The grimmer aspects of his theory are not so conspicuous to-day, since famine, pestilence, war, vice and misery do not take such heavy tolls as they once did in overpopulated countries. The prudential checks, the "higher standards of living," are lowering the birth-rate in many countries. The unknown factors now in the problem of ascertaining the present and prospective ratio of population to food supply include the following: declining birthrate; knowledge of birth control; declining death-rate; new knowledge concerning human and animal nutrition; possibilities of scientific agriculture. But somewhere in the background is the ultimate limit of population - the food supply. It would doubtless be a very simple biological feat to double the population of China or Japan in 25 years, but, as Malthus says, it is doubtful if the food produce of China and Japan could be doubled in any number of years.

Soil Exhaustion Question.-The last paragraph referred to China and Japan - the oldest agricultural districts in the world. The records show that agriculture has been conducted in the same fields here for at least four thousand years. The fact that this soil is not yet exhausted has given a sense of false security to those who live nearer the virgin soils of a new country. These countries serve as a warning, if anything, of the dire calamity of soil exhaustion. In Professor F. H. King's very excellent book on "Farmers of Forty Centuries" 1 he shows that the farmers of Japan and China maintain their soil fertility only by applying to the soil animal and vegetable waste matter of every possible kind. Not only are canal bottoms dredged for the fertile canal mud, but the straw from the grain, the leaves from the trees are all used in making a compost to be applied to the tiny fields. The urine of animals is saved, yes, even every bit of the human excrement itself. For this reason the great cities do not have sewer systems, all the night-soil being removed daily by farmers as food for their plants. This means for the average Oriental farmer a life of unremitting toil, and little hope of ever rising far above the danger line of starvation. "If," says Dr. King, "the agricultural lands of the United States are ever called upon to feed even 1,200 millions of

${ }^{1}$ King, F. H. Farmers of Forty Centuries. Madison, Wisconsin, 1911. Published by Mrs. F. H. King. 
people, a number proportionately less than one-half that being fedin Japan to-day, very different practices from those we are now following will have been adopted." But, he says, first must come the conviction of the need of plant feeding and better soil management.

Soil Exhaustion and Wheat.-Since wheat is the source of the "daily bread" of a large portion of civilized mankind, the wheat supply question affords a concrete problem in soil exhaustion. The matter can best be brought to the thoughtful reader's attention by citing a few passages from the Presidential address made to the British association at Bristol in $\mathbf{1 8 9 8}$ by Sir William Crookes, O.M., F.R.S. The importance of the man and the importance of the occasion combined to given the address great weight. Quoting passages from the third edition of this address (published in 1917), we find the opinions of Sir William expressed in these words:

"My chief subject is of interest to the whole world-to every race-to every human being. It is of urgent importance to-day, and it is a life-anddeath question, for generations to come. I mean the question of Food supply. Many of my statements you may think of the alarmist order; certainly they are depressing, but they are founded on stubborn facts. They show that England and all civilized nations stand in deadly peril of not having enough to eat. As mouths multiply, food resources dwindle. Land is a limited quantity, and the land that will grow wheat is absolutely dependent on difficult and capricious natural phenomena. I am constrained to show that our wheat producing soil is totally unequal to the strain put upon it ... Wheat is the most sustaining food grain of the great Caucasian race, which includes the peoples of Europe, United States, British America, the white inhabitants of South Africa, Australasia, parts of South America, and the white population of the European colonies. Of late years the individual consumption of wheat has almost universally increased. In Scandinavia it has risen 100 per cent in twenty-five years; in Austria-Hungary, 80 per cent; in France 70 per cent; while in Belgium it has increased 50 per cent. Only in Russia and Italy, and possibly Turkey, has the consumption of wheat declined. In 1871 the bread eaters of the world numbered $371,000,000$. In 1881 the number rose to $416,000,000$; in 1891 to $472,000,000$, and at the present time (1898) they number $516,500,000 \ldots$

"It is now recognized that all crops require what is called a 'dominant' manure. Some need nitrogen, some potash, others phosphates. Wheat preeminently demands nitrogen, fixed in the form of ammonia or nitric acid . . ."

Nitrates Question.-Sir William referred to experiments at Rothamsted in the use of nitrate of soda in improving the yield of wheat. A field was planted with wheat 13 consecutive years without manure, yielding an average of 11.9 bushels to the acre. For the next 13 years it was seeded with wheat, and dressed with 560 pounds of nitrate of soda per acre, other mineral constituents also being present. The average yield for these years was 36.4 bushels per acre -an increase of 24.5 bushels. In other words, each 22.86 pounds of nitrate of soda produced an increase of one bushel of wheat. 
"Let us remember," said Sir William, "that the plant creates nothing; that there is nothing in bread which is not absorbed from the soil, and unless the abstracted nitrogen is returned to the soil its fertility must ultimately be exhausted."

What is Soil Fertility?-From 65 to 95 per cent of the soil, by weight, is made up of finely disintegrated rock. The black color is given to the soil by the humus, that is, the decayed vegetable and animal matter-the so-called organic matter-of all kinds. This matter usually ranges from 2 to 5 per cent. The soil also contains a certain amount of water and of air. These elements, taken altogether, constitute the plant food. Much of this plant food is not fit for use by the plants until it has been acted on by an additional element in the soil, namely, the soil bacteria. Presence of plant food and soil bacteria constitute fertility. The human body, for instance, contains iron; but the unhappy person who lacks iron in his tissues cannot supply the need by swallowing "raw" iron. He will probably eat foods like celery, lettuce, carrots, etc., containing iron in a digestible form. Thus also, with wheat for instance, which cannot feed on raw nitrogen. Assume then, that a soil has enough water, enough sunshine, enough warm temperature to insure plant growth, enough lime to prevent acidity, what are the chief plant foods which are subtracted from the soil by continuous cropping? The three chief plant foods mined from the soil by cropping are nitrogen, phosphorus and potash. According to forty-nine analyses of soils in different parts of America, the average acre of soil contained the following plant food:

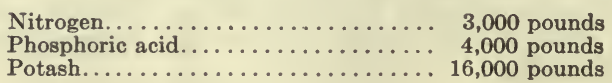

Taking the average wheat crop of the United States as 13.8 bushels per acre (as it was for the period 1899 to 1908), this wheat and this straw removed each year from the soil about 14.5 pounds of nitrogen, 10.6 pounds of phosphoric acid, and 14 pounds of potash per acre.

Similar calculations may be made for other crops, some taking more, some less plant food from the soil. Continuous cropping, without rotation and without putting anything back into the soil, gives warning of soil depletion in the form of diminished yields. And yet how little attention the average farmer in the newer parts of the country gives to this warning. And herein lies one of the chief evils of the American short-term tenancy system, for the 
tenant has no compunction in "mining" the fertility of his landlord's land.

Liebig.-The German agricultural chemist, Liebig, called the attention of the world to the historical and economic significance of soil exhaustion. Existing methods of farming he called soilrobbery, and claimed such methods would in time render the soil completely and forever barren. The phosphorus and potash of the soil, says Liebig, may be called the "capital" with which the farmer carried on his agriculture. With every harvest some of this "capital" is drawn off; the bigger the harvest, the bigger the drain on this "capital." A part of this "capital" is fed to his stock and comes back in manure; a part is sold as grain, live stock, wool, milk, cheese, wood, etc., in the cities, and only a little of this ever gets back to the land. The soil, therefore, annually gets a little poorer by this drain. Finally this "capital" is used up. It is absolutely necessary to return to the soil as much as was taken from it.

Liebig painted a gloomy picture by describing the past and faded agricultural glories of Mesopotamia, Persia, Egypt, Greece, Italy, Sicily, and Spain. Liebig's various critics, particularly Conrad, claimed that the agricultural decline of these countries was due to other causes than soil exhaustion, such as deforestation, lack of irrigation, bad government, government price fixing, etc. ${ }^{2}$ Liebig claims that the soil determines the history of nations. Conrad claims that the form of government-the political and social regulations-have more influence on agriculture than on trade and industry; have more influence than climate or the method of treating the soil; so that agriculture reaches its greatest perfection not in those countries most favored by nature, but where the governments are best.

When one considers the millions of tons of commercial fertilizers now being used every year in our Eastern States and the scores of pages of State laws to "regulate" this traffic, the reality of the problem of soil exhaustion becomes apparent, whatever the merits of the Liebig-Conrad controversy. For soil fertility is like a bank account-there is a limit to the amount that may be drawn out.

${ }^{2}$ Conrad, J. Liebig's Ansicht von der Bodenerschöpfung und ihre geschichtliche, statistische und nationalökonomische Begründung Kritish geprüft. Jena, 1864. Concerning Spain we read, "Das Aergste war aber unbedingt, dass dem Bauer selbst der Preis bestimmt wurde, zu welchem er sein Korn verkaufen durfte, und dies geschah bereits seit der Regierung Alphons X und wurde erst im vorigen Jahrhundert aufgehoben," p. 81. "Cette loi decourageait le fermier et ajoutait encore a son apathie naturelle." Weiss II, 96. 
Soil Destruction Question.-Far more serious than soil exhaustion is soil destruction. The three chief ways in which soil destruction is brought about are over-cultivation, over-grazing and deforestation. These lead to erosion by wind and water. Deforestation has come about in various ways, such as destruction of the forest by farmers for the purpose of securing farms, careless lumbering methods, and forest fires. Steep hillsides, deforested by farmers or logging companies, often have their soil all swept away by the washing of the rain. When President Roosevelt launched his campaign for conservation he issued to Congress - really to the country at large - an illustrated message showing whole valleys in China, once populous with teeming cities, now a dreadful desert, due to the complete destruction of the soil. Torrential rains, at certain seasons, wash down the hillsides, causing bowlders to fill the valleys. In the United States there are doubtless millions of acres suffering to a lesser or greater degree from the damages of deforestation. When the soil is gone and the bare rock exposed, this land is doubtless rendered barren forever.

The Soil and the Man on the Soil.-A study of the literature dealing with soil exhaustion and soil improvement, and an observation of the methods used by successful farmers lead to the conclusion that the fundamental question is not the soil, but the man on the soil. Some farms show a steady decline in fertility, until a different person takes charge. Under new management a "wornout" farm becomes again productive. And what is more significant, under such management such a farm often proves to be a case of "increasing returns" on the investment.

For the purposes of illustrating in a concrete manner the significance of the human factor in the "soil-exhaustion" problem, two examples will be given from "run-down" New York farms which were rehabilitated by able management. The first example is that known as the M. J. English farm in Broome County, southern New York. The second is known as the T. E. Martin farm, in Monroe County, northwestern New York. The information concerning these farms is taken from two bulletins published by the United States Department of Agriculture. ${ }^{3}$

${ }^{3}$ Burritt, M. C., and Barron, John H., An Example of Successful Farm Management in Southern New York. Bulletin No. 32, United States Department of Agriculture. Burritt, M. C., A Successful New York Farm. Farmers' Bulletin 454, United States Department of Agriculture. 
The M. J. English Farm.-The English farm is in the typical hill region of southern New York, and was in a condition of "diminishing returns" when this owner took possession. English bought this 162 -acre farm in 1897 , for $\$ 16,000$, one-half in cash, one-half on mortgage. He had had no previous farm experience. The farm was in very poor condition. English's program, laid down at the outset, included (1) improvement of the dairy herd, (2) diversification, (3) crop rotation to improve the soil. The "scientific management" of this farm, which resulted finally in building up the worn-out soil and in increasing the owner's net income, consisted largely in the following steps:

Crop rotation was introduced, plus the application of lime and commercial fertilizer, plus some drainage. The rotation included clover. The soil was put in good tilth by proper cultivation. Part of this farm-about 72 acres-is hill land, and was worth less than $\$ 20$ an acre when bought by English. His systematic treatment of this piece for five years made it worth at least $\$ 100$ an acre at an expense of less than $\$ 30$ an acre. Speaking of this hill land, the author of the bulletin says, "An income of $\$ 30.76$ per acre for each of the five years is not a bad record for abandoned land."

The T. E. Martin Farm.-The Martin farm is another New York farm which illustrates the relationship between scientific management and increasing returns in agriculture. This farm is in the northwestern part of New York State, and was in very poor condition when bought by young Martin, a farmer. There was a mortgage, poor fences, poor drainage, and more or less run-out land. The farm, 57 acres, was bought in 1892 for $\$ 5,000$. It was necessary to give a mortgage of $\$ 3,000$ upon the place at the time. To make this debt more burdensome, there followed a period of low prices from 1892 to 1900 . Potatoes sold as low as 8 cents a bushel, wheat 48 cents a bushel, rye 32 cents a bushel, eggs 10 cents a dozen, butter 13 cents a pound, and lard 6 cents a pound. These figures are all taken from the owner's books.

The scientific management of this farm included these steps:

(1) Rotation, so that the fertility of the soil was not only maintained but increased. Wheat, clover, and timothy, corn, potatoes, buckwheat-these crops represented the usual rotation scheme. In time the farm was cleared of stumps and fences, and the whole thrown into three large fields where a three-year rotation was regularly and systematically followed.

(2) Drainage. Much of the soil was sour and even boggy. Over ten miles of drain-tile were laid during 18 years at a cost of 28 
$\$ 2500$. In other words, the drainage system represented a cost of $\$ 44$ an acre.

(3) Fertilizers. Nitrogen, phosphoric acid and potash were supplied to the land in the form of commercial fertilizer. The quantity of commercial fertilizer used was reduced each year as the improvement of the farm fertility made its use less necessary.

Some results of the scientific methods used are shown in the wheat yields, which were as follows:

\begin{tabular}{|c|c|c|c|}
\hline Year & $\begin{array}{l}\text { Yield per } \\
\text { acre }\end{array}$ & Year & $\begin{array}{l}\text { Yield per } \\
\text { acre }\end{array}$ \\
\hline 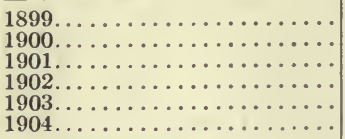 & $\begin{array}{l}8.1 \text { bu. } \\
18.8 \\
18.0 \\
34.0 \\
40.0 \\
19.0\end{array}$ & 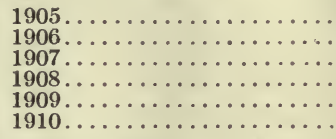 & $\begin{array}{l}24.7 \mathrm{bu} . \\
22.7 \\
24.3 \\
18.3 \\
45.0 \\
34.0\end{array}$ \\
\hline 6-year average. & 23.0 & 6 -year average. . & 28.2 \\
\hline
\end{tabular}

The potato yield showed an even more striking gain for the later years. The average potato yield for the first 9-year period was 132 bushels per acre; for the next 9-year period, 282 bushels per acre.

The Farm Income.-The increase in the farm income is as impressive as the increase in crop yields. The average annual receipts, for the first nine years, were $\$ 1094.40$; the average income for the next nine years was $\$ 2786.33$, an increase of 155 per cent. And while the income increased 155 per cent, the expenses increased but 102 per cent, thus exhibiting a striking case of increasing returns in agriculture. The author of the bulletin states, on this point:

"The profitableness of this farm may be measured in another way. The owner began with a debt of $\$ 3,000$ and several hundred dollars on the equipment. All indebtedness had been paid. In addition, a tile drainage system costing $\$ 2500$ has been put into operation on the farm. The farm, shop, and house equipments have been increased to the maximum of efficiency. These and other improvements have doubled the value of the farm and have left a considerable cash balance in the bank. All this must be credited to 18 years of good farming which may be called fairly successful financial management."

Conclusions.-If one-half the farmers would employ the successful methods now used by the few best farmers, there would be no soil exhaustion problem for many years to come. If all farmers were to use the skill and science now used by a few farmers, there would be no soil exhaustion problem for many generations. 


\section{QUESTIONS ON THE TEXT}

1. Show that the food supply problem is a dual problem.

2. State the Malthusian ideas concerning poverty and poor relief. State the Malthusian theory of population (increases and checks).

3. What, according to Malthus, is the most powerful check on population in Europe?

4. Give Malthus's statement concerning United States population.

5. Criticize this statement of Malthus.

6 . Is or is not the Malthusian theory of population correct?

7. What are the unknown factors to-day in population increases?

8. How many years have the fields of Japan and China been cultivated?

9. How is soil fertility maintained in these older regions?

10. State briefly the impending danger of a world wheat shortage, as announced by Sir William Crookes.

11. What is meant by soil fertility?

12. What are the three chief plant foods subtracted from the soil by cropping?

13. The average acre of soil in America contains how many pounds of each of these three?

14. An average wheat crop removes how many pounds of each of these three per acre?

15. State briefly the claims made by Liebig as to the meaning and danger of soil exhaustion.

16. How did the crities, especially Conrad, answer Liebig?

17. Where, according to Conrad, does agriculture reach its greatest perfection?

18. Summarize the conclusions on the soil exhaustion question.

19. What is meant by the Soil Destruction question? How are soils destroyed?

20. How serious is the question of soil destruction in the United States?

21. Which is the more fundamental problem, the soil or the man on the soil? Why?

22. Give an account of the English farm, showing how increasing returns were secured.

23. Give an account of the Martin farm, showing how the soil fertility problem was solved. Account for the increasing returns on this farm.

24. Summarize final conclusions as to soil exhaustion problem.

\section{QUESTIONS SUGGESTED BY THE TEXT}

1. Give the "Trench System" of restoring soil fertility as practised at Allahabad, India.

2. Describe the methods in use in Japan, Korea, and China for maintaining soil fertility.

3. Give the principal sources of commercial nitrogen; phosphorus; potash.

4. What is the outlook for the future supply of these three forms of plant food?

5. Cite examples that have come to your notice of "worn-out" land being restored to fertile condition by scientific farming.

6. Cite examples of fertile lands that have been reduced to "waste lands" by bad methods of treatment.

\section{REFERENCES}

1. Malthus, Rev. T. R.: "An Essay on the Principle of Population," 7 th edition. London, 1872.

2. King, F. H.: "Physies of Agriculture."

3. ㄴ. "The Soil."

4. : "Farmers of Forty Centuries." Madison, Wisconsin, 1911.

5. Roberts, I. P.: "The Fertility of the Land." 1898.

6. Lipman, J. G.: "Bacteriology in Relation to Country Life." 1908. 

1913

7. Warren, G. F.: "Elements of Agriculture." 13th edition, New York,

8. Crookes, Sir William: "The Wheat Problem-Based on Remarks Made in the Presidential Address to the British Association at Bristol in 1898." Revised. New York, 1900. Same, 3d Edition, with additional chapter. London and New York, 1917.

9. Liebig, Justus: "Die Organische Chemie in ihrer Anwendung auf Agrikultur, Chemie, und Physiologie," 1840. 1862.

10. ㄴ. "Die Chemische Prozess der Ernährung der Vegetabilien."

11. — - "Die Naturgesetze des Feldbaus, 1862.

12. —-: "Agricultural Chemistry."

13. Conrad, J. Liebig's: "Ansicht von der Bodenerschöptung und ihre Geschichtliche, Statistische und Nationalökonomische Begründung Kritisch Geprüft." Jena, 1864.

14. Lyon, Fippin and Buckman: "Soils, Their Properties and Management." New York, 1915.

15. PARKer: "Field Management and Crop Rotation." St. Paul. 1915.

16. Russell and Hastings: "Agricultural Bacteriology." Madison,

17. Stoddart, C. W.: "Chemistry of Agriculture." Philadelphia, 1915.

18. "Rothamsted Memoirs."

19. Bulletins: 1. "The Maintenance of Soil Fertility." A Quarter Century's Work with Manure and Fertilizers. Ohio Agricultural Experiment Station, Wooster, April, 1919, Bulletin 336. 2. "Commercial Fertilizers." United States Department of Agriculture Farmers' Bulletin 222. 3. "Lime and Clover." United States Department of Agriculture, Farmers Bulletin 237. 4. "Leguminous Crops for Green-manuring." United States Department of Agriculture, Farmers' Bulletin 278. 5. "Renovation of Worn-Out Soils." United States Department of Agriculture. Farmers' Bulletin 245. 6. "Bulletins and Pamphlets issued (free) by Soil Improvement Committee of the National Fertilizer Association, Postal Telegraph Bulletin," Chicago, Ill. 7. "Bulletins of International Harvester Company of Chicago" (Agricultural Extension Department). A large number of bulletins pertaining to soils. 20. Yearbook-Department of Agriculture: 1912-CAMERON, FranK K.: "Possible Source of Potash in the U. S.," 523-537. 1913-Davis, R. O. E.: "Economic Waste from Soil Erosion." 207-220. 1916-Dana, SAmuel T.: "Farm, Forests and Erosinn." 107-135. 1917-STine, O. C.: "The World's Supply of Wheat," 461-481.

21. Spain-"Problem of Provisioning and the Policy with Regard to the Food Supply." International Review of Agricultural Economics, July, 1918, 585-603.

22. Hopkins, Cyril G.: "Effect of Soil Depletion and Soil Enrichment on Loan Values of Farms." Address delivered at Ninth Annual meeting of Life Insurance Presidents, New York, Dec. 10, 1915. (Betterment of Life Insurance Series.) 


\section{INDEX}

Abattoirs, municipal, 388

Acre considered standard unit, 251

Act, Adams (1906), 323

Hatch (1887), 323

Hepburn, 356

Morrill (1862), 323

Smith-Lever (1914), 323

Federal funds available under, 336

vocational education of 1917,324

Adams, A. B., on Perishable Farm Product Risks, 147

Adams, H. B., History of Coöperation in the United States, 173

Agricultural advertising to create demand, 246

colleges, State, Federal appropriations, 325

conditions, Congressional investigation of (1898), 27

facing the United States, 411

in England and United States similar, 97

in Great Britain and Ireland, 34

of Canada, similar to that of United States, 13

depression, causes and remedies, 26,27

education, five Federal laws dealing with, 322

employment agencies, private, 104

exports, value of, 5

industry, unorganized, 12, 13

labor, chapter on, 96

seasonal nature of, 98

transportation and distribution problem, 106

unorganized movement, 104

land, area of, in various countries, 421

of United States, 7

machinery, improved, benefits of, 116

and the trust question, chapter on, 115

industry more "capitalistic," 115

press and scientific farming, 282 chapter on, 279
Agricultural, press of United States, list of, 283

publications on, 283

prices and law of supply and demand, 225

and valorization, chapter on, 225

higher in spring than in fall, 225

publications on, 243

problems and the mail order

house, 156

production, statistics, 23

products, decline in price of, 41

foreign trade of United States in, 423

increasing consumption of, 49

progress, per cent of increase, 1870-1910, 6

Publishers' Association, 282

transportation, 188

unrest, 61

publications on, 204

wages, reports on, 113

Agriculture, anarchy of, chapter on, 15

evidenced by overproduction, 21

and labor, present theory of protection of, 405

Canadian Council of, 306

capital invested in, 5

capitalistic, 175

census reports (U. S.), 14

chart showing rank as an industry, 2

commissioner of, in Louisiana, 135

coöperation in, 158

Department of, United States, history of, 315

direct aid to, in Kansas, 313

effects of pests and diseases on, 19

English, economic revolution in, 409,410

failure to coördinate supply and demand in field of, 15

Federal Government aid to, 315

flourishes where government is best, 431 
Agriculture, foreign competition in, chapter on, 409

general State aid, 314

in Denmark, transition in, 423

industrial concentration, economic differences between, 10

revolution in, 115

International Institute of (Rome), 74-76, 113

leaf from England's notebook on, 409

manufacturing, commerce, chapter on, 1

New England, 401, 402

New York Agricultural Society discussion on, 53

persons engaged in, proportion of, shows a decline, 3

place of, in modern industrial society, 14

primacy of, lost due to economic evolution of our country, 1 profitable, meaning of, 30 publications on, cited, 112, 113 rank of, among our industries, 1 statistics on, 1-3

transition in, 28

unorganized industry, 15

value of product, 5

Yearbook, Department of, articles on farming, 14

Aid, Federal, other forms of, 326

State, success of, 326

Alfalfa in Argentina, 415

Almonds, California, distribution, 147

American Federation of Labor, 305

Society of Equity, 311

Americans employed in cotton mills, 401

Anderson, B. M., Grain Speculation, 276

Animal industry, bureau of, 317

Animals, maladies affecting, 1915 report on, by Secretary of Agriculture, 23

Arable land in United States, 14

Argentina grain producer's need, 363

Armour, J.O., The Packers, 224, 389

Atkeson, T. C., History of the Grange, 309

on marketing, 311

Australia, a country of large holdings, 38

"Back to the land" movement, chapter on, 31

Bailey, L. H., Testimony, 27
"Banker-Farmer," the, 159

Banks, joint stock land, 182

Bargaining, collective, 153, 231, 241, 308

Barley, cost of producing, per acre, 260

price ranges, 278

Barron, John H., 432

Beans, loaded improperly, 193

Beef exports from the United States, 418

industry, report on, 379

trade, Argentina's, 418

Benjamin, E. W., cited, 155

"Big Business," 228

Big farm versus small farm, question of, 31

"Big Six," 379

extent of control by, 380

Binders, improvements in, 120

quality and price of, 120

Biological survey, bureau of, 320

Black, J. D., cited, 77

Bonanza farming, 43-45

Bonds, United States, fluctuations in, 278

Books (see Literature)

Brand, C. J., of the Bureau of Markets, 21

Bucket shop fight, 352, 354, 355

Budge, Wm., quoted, 44

Bureau of Corporations, report on lumber industry, 10, 11

Burritt, M. C., on county farm bureau, 332,335

on successful farming, 432

Butter, cold storage record, 216 statistics on, 144

Wisconsin, marketing of, 145

Caffey, F. G., History of U. S. Department of Agriculture, 327

California Fruit Growers' Exchange, report of, $41-43$

Camp, Wm. R., and the Credit Union, 171

Canada, agricultural condition similar to that of United States, 13

Canadian Council of Agriculture, 305-307

achievements of, 306 aims of, 306

Cance, A. C., Immigrant Rural Communities, 109, 110, 112

Capitalism and agriculture, 55

Capitalistic agriculture, 175

Carver, T. H., cited, 76

Cash renters, 64 
Cattle, cost of producing, does not determine selling price, 244 herd of, in Argentina, 416

Chantland, W. T., Valorization of Coffee, 244

Cheese, a staple food, 50 ।

Chemistry, bureau of, 318

China and Japan oldest agricultural districts, 428

Chinese and Japanese farmers, 254

City, drift to the, 106

labor for farms, 109

population, increase in, 108

versus country, 91

Class organization, 285

Classes, two social, 264

Closer settlement legislation of Australia, 39

Cold storage, chapter on, 214

effect of, on prices, 221

extent and use of, 217

government regulation of, 222

in Russia, 218, 219

influence of, on health, 219 inventions, 214

pork, fresh, in, 220

publications on, 224

record of butter, 216 of eggs, 215

suggested improvements, 223 warehouses, 217

direct refrigeration system of, 220

public, view in, 218

Collective bargaining, 153, 308

as price fixing, 241

by almond growers, 232

by walnut growers, 231

Commerce, history of, 14

Competition question, the, 49

Competitors, our (Argentina), 413419

Conclusions on farming, 92

Conference, Winnipeg retailers', 150

Conrad, 431

Consumer's dollar, division of, 144

Consumption-overproduction problem, 42

Control, concentration of, in banking, railroading and manufacturing, 12

in lumber industry, 10

in other industries, 11

Coöperation among farmers, publications on, 173

and production, 169

economic significance of, 171
Coöperation, effect of, 36

essentials in, 172

farmers', largest example among, 165-168

in agriculture, chapter on, 158

in broader sense, 158

in buying, 170

in Kentucky, example of, 162, 163

in narrow sense, 160

in selling, 169

interest of granges in, 298

of railroads with farmers, 159

purpose of, 161

some causes of failure of, 164

successful, an example of, 162

Coöperative credit, 170

in America, beginning of, 177

elevator, farmers', 164

hail insurance, 208-210

insurance, 170

movement, success of, 168,169

packing houses, 387

Corn, extreme prices of, 247

cost of producing, per acre, 259

method of shelling in Argentina, 416

Cornering the markets, 263

Corners in grain, 348

Corporation farming, 66, 78

Corporations, Garfield report on, 379

Cost accounting, other, 252

problems in, 255-257

signs of progress, 255

of production and farm accounting, books on, 258, 259

chapter on, 250

importance of, 257

of corn, barley, oats and wheat, 259-261

Costs of crop production, 251

Cotton and wheat, crop fluctuations, 16

dealings in, risky for producer, middleman, speculator or spinner, 19

exchanges, report of Bureau of

Corporations on, 19

production and farm value of, 8

Coulter, J. L., on farm laborers, 111, 112

Ooöperation Among Farmers, 173

Organization Among Farmers, 310 .

Country elevator, storage and hedging problems, 344 
Country life, 94

newspapers, weekly, 282

real-estate transaction, a typical, 25,26

County agent and the farmer, 331 and marketing, 334

and the middleman, 334

chapter on, 329

definition of, 329

difficulties ahead of, 333

financing of, 332

functions of, 330

movement, 329

agents and club work, 333

Credit, cheap, significance of, 182, 138

coöperative, 170

beginning of in America, 177

farm, chapter on, 174

land, 180

long and short time, 177

new view of, 174

union, the, 178

North Carolina, 178

unions, criticism of, 179

North. Carolina, financial statement of, 187

Crerar, President T. A., of the United Grain Growers, 168

Crookes, W., Wheat Problems, 339, 435

Crop estimates, bureau of, 321, 324

prices, 20

yields, 20

and prices, relation between, 20

Crops and live stock, table of increase or decrease, 1870-1910, 17

costs of producing, 250

farm, factors of uncertainty, 17 values of five leading, 339

field, annual hours of labor per acre, 261

cost per acre, 253

grain, items of cost for, 253,254

miscellaneous factors of production cost, 254

Cucumbers, loaded improperly, 193

Cyclopedia of Agriculture, 155

Dairy products, 132

Danish migration to United States, high per cent of, 52

agricultural transition, 423

coöperation, 36

"peasant proprietors," 36

Debt, 174
Desjardins, Alphonse, founder of American rural credit, 177

Dillon, John, of New York, 136

Diseases, farm crop, 18

Dockage a weed problem, 360

question in relation to grain, 360

Domeratzky, European Tariff Policies After the World War, 408

Drayton, C. O., Farmers Must Be Coöperators, 310

Drift to the city, 106

Dye, F., quoted, 45

Economic reforms, how to secure, 307 significance of coöperation, 171

Economics, elementary, materials for the study of, 30

Education and health, 91

Eggs, cold storage record of, 215 from farmer to consumer, 145 shipping by parcel post, 141

Elevators, evolution of terminal, 356 evolution of farmers', 357-359

Ely, R. T., cited, 74

Emery on stock and produce exchanges, 20

cited, 266,277

English, M. J., farm, 433

Entomology, bureau of, 320

Equity Union, 311

Eschenburg and Dalton, 359

Essentials in coöperation, 172

Evolution of terminal elevator-railroad monopoly, 356,357

Exchanges, organized, services of speculation on, 272

speculation on the organized, 270

Express and parcel post compared, 197

business, 195

rural motor, 199

Family-size farm, 46, 47

Farm accounting, 255

cost of production and, 250

example from England, 261

big, versus small farm, question of, 31

bonanza, of West and Northwest, 43

bureau, the county, 105

defined, 330

growth of the, 332

movement, books on, 335

Bureaus, Ameriçan Federation of, 289

contributions, 90

credit, chapter on, 174 
Farm crop insects and diseases, 18 crops, factors of uncertainty, 17 employment, irregular, 105 expenses, 88

family size, 46,47

house conveniences, 91

household labor on the decline, 103

income, 89, 434

Journal, 281

labor exchange, national, 105

Federal government and, 105

immigration and, 109

problems in England, 96

question, several aspects of, 96

supply of, 194

wage in England, 96

wages of, on the increase 100

laborer, life of, 110

land, future ownership of, 13

of United States and Canada, 419

rise in selling price of, 27

large, views of, 48

lease tenure, 62

machinery, American, in Siberia, 124

annual depreciation on, 252

labor-saving, 108

purchase of, 117

management, office of, 321

mortgages increasing, 69

organizations, federation of, 287

owners, age of, 64

paper, best type of, 279

point of view of, 279

the specialized, 282

two policies in editing, 284

worst type of, 280

papers, other types of, 281

prices, trend of, chart, 226

problem in the United States,

40

produce, perishable, shipping by

parcel post, 142

product receipts, 88

products, cost of production and price, 233

marketing of, 145

standardizing and advertising of, 43

property, value of, for years

1850-1910, 3

tenancy, declaration on, 81

in Canada, per cent, 81
Farm tenancy, in Missouri, 65

in Wisconsin, 65

Wallace, H., on, 81

wages, statistics, 101

work, by women, decline since

1871,101

in Germany, 38

of foreign birth, 102

Farms, average size of in United States, 51

operated by tenants increase faster than those operated by owners, 4

per cent mortgaged, 79

size of, 67 operated by tenants, 80

small, in France, 33

two rehabilitated, 433

Farmer, American, other occupations of, 107

and railroad, the, 191

and the terminal market, 347

direct State aid for, 312

economic condition of, chapter on, 83

German, living conditions of, 37 customs of, 36

in business, 311

other attractions for, 92

prosperous Icelandic, in North

Dakota, 93

State aid for the, 312

Farmers and the I. W. W., 100

better business for, 7

Chinese and Japanese, 254, 428

coöperation among, largest example of, 165-168

number and supply of, 104

of Alabama, 44

of forty centuries, 428

political organizations of, 301 economic background of, 302

shifting of, 81

Farmers' capital, 88

coöperative insurance companies, 205

trucks, 200

economic income too low, 92

Educational and Coöperative

Union of America, 311

elevator movement, immediate effect of, 359

weakness of, 359

elevators copy "regulars," 359 in Canada, 359

grain elevators in United States, 301 
Farmers' income, 83, 95

compared with city incomes, 90

Federal government report on, 83,84

other estimates, 87

"survey" method of determining, 87

institutes, 315

labor income calculated, 89

living, what the farm contributes to, 95

middleman, the, 152

mutual insurance companies, 205

national headquarters, 287-289 organizations, 311

organizations, benefits from, 285 chapter on, 285

difficulty of classifying, 286 local, 300

national, 290

political background of, 303

problems to face, 307

publications on, 309,310

parties in the past, 303

Farming, bonanza, 43-45

effects of, 44

conclusions on, 92

conditions in foreign countries,

publications on, 52

by corporations, 66

does it pay? 83

example of successful, 84-86

financial profitableness of, 332

future of, 52

in China and Japan, 428

industry in New Zealand, 40

methods, successful, 434

practices, best, popularized, 86

publications on, 52

report of Roosevelt Country

Life Commission on, 7-10

versus land speculation, chapter on, 24

Federal Farm Loan Act, 180-182

Land Banks, the twelve, 186

Money Trust Investigation, 11

Reserve System and agriculture, 183

Trade Commission, report on packing industry, 382

Fertilizer, saving of, in Germany, 38

Field crops in Canada, 419

Filley, H. C., cited, 154

Fire patrol, 319
Flour and wheat prices from farmer to consumer, 143

Food problem, 425

supply problem, chapter on, 425 publications on, 435

supplies, government control of in Germany during World War, 244-246

Foods, seasonal production of, 214

Foodstuffs and manufactures, value of, 413

Foreign competition in agriculture, chapter on, 409

publications on, 422,423

trade, its changes, its significance, 411

Forest service, 318

Forestry and landscape gardening, 194

Forgan, David R., Grain Financing, 363

France cited regarding small farms, 33

Frear, D. W., on marketing small fruits and vegetables, 147

Free trade in land, 69 principle, 404

Fruits, citrus, statistics, 146

Gallatin's memorial, 403

Galpin, C. J., cited, 74

Gambling, 275

Webster's definition of, 266

Gaston, H., Nonpartisan League, 310

George, Henry, on Progress and Poverty, 30

German farmer, customs of, 36

Gleaners, 311

Goldenweiser, E. A., The Farmer's Income, 95

Government regulation of cold storage, 222

Grain, cash, 348

crops, distribution of cost per acre, 253-254

statistics of movement of, 23

elevator manager, 343

problems, 342

elevators, Buenos Aires, 414

exchange, Chicago Board of Trade, 346

evolution of the organized, 347

exchanges, trading on, 349,350

futures, 348

market, manipulation of the, 350 a wide, 350

markets in Argentina, 337

mixing in elevators, 345

price fluctuations of, 271 
Grain, "to arrive," 348

trade and Russia, 420

chapter on, 337

competition in, 340

competitive nature of, 339

international nature of, 337

past organization of the, 347

present organization of, 341

publications on, 361-363

relation of future trading to financing, 363

Grains, cost of growing, 252

Grange, the, 291

achievements of, 299

as an institution, 292

decline of the, 295

economic program of, 296

first local, 292

history of, 309

interest of, in coöperation, 298

low prices and the, 299

purpose of, 293

rapid growth of, 294

renewed growth of, 296

States, 291

Gray, C. E., Keeping of Butter, 224

Greeley, M. F., quoted, 45, 115

Green bug, 18

Haggard, H. Rider, on the poor and the land, 74

Hall, Caroline A., and the Grange, 292

Hamilton's errors, 404

Hammond, Harry, quoted, 44

Harvester Company, case against, 125 case for the, 122-125

trust, 118

case for or against, 122

earnings, 122

exclusive contract, 119

history of, 118

investment and capitalization, 119

prices, at home and abroad, 121

repairs procured from, 121

Hasbach, W., English Agricultural Laborer, 113

Health, influence of cold storage on, 219

Hedrick, W. O., cited, 156

Herrick, M. T., How to Finance the Farmer, 179, 185

Herron, L. H., The Farmers' Union, 310

Hibbard, B. H., cited, 76, 156

Hill, James J., For Pure-bred Sires, 159

Hoagland, H. E., quoted, 109

Hoard, W. D., editor, 281
Hockaday, R. W., on marketing, 21

Holland cited on peasant proprietorship, 35

Home bureaus, 333 economics, office of, 321

Hopkins, C. G., Soil Depletion and Soil Enrichment, 436

Howard, J. R., President of American Farm Bureau Federation, 290

Hudson Bay Company as speculators, 277

Huebner, Grover, cited, 154

Hughes, H. J., on the hired man, 105 on editorial policy, 284

Hunt, Dean T. F., quoted, 175

Hyder, J., Land Nationalization, 407

Immigration and farm labor, 109

Income from unpaid labor, 89

Increment, measured, 30

Independent Harvester Company126-128

Industrial evolution of the United States, 14

Insects, farm crop pests, 18

Insurance, chapter on, 205 coöperative, 170

farmers' mutual hail, statistics, 212

hail, present tendency, 211

mutual hail, 208-210

North Dakota State hail, 207, 208

publications on, 213

Saskatchewan State hail, 206

International Institute of Agriculture, Rome, publications on agricultural economics, 52, 74, 113, $173,185,204,328$

Interurban electric lines, 197

Italian, cotton tenant in Mississippi delta, 110

I. W. W., 61,100

Jackson, T. C., on farm accounting, 261

Jam production in England, 50

Jefferson's views, 31

Jenkins, W. C., Truth About Cold Storage, 224

Jessness and Kerr, Coöperative Purchasing and Marketing, 173

Johnson, O. R., on big or little farms, 52

Kelley, O.H., founder of the Grange, 292

Kennedy, Joseph, quoted, 93

King, F. H., Physics of Agriculture, 435 
Kirkland, J., Wheat, Flour and Bread War Prices, 363

Knapp, Bradford, quoted, 86 Seaman A., 329

Knights of Labor, 304

Labor population, floating, crime a by-product of, 99

Laing, on Continental peasant proprietor, 32

on Norway farmers, 32

Lake transportation, 197

Land certification, 71

commercial value versus market value, 28

Land credit, 180

free trade in, 69

overcapitalized, 24

bad thing for farmers, 29

ownership, tenure, and taxation of, 30

question, report of Commission on Industrial Relations on, 59, 60 tenure, chapter on, 53 interpretation of tendencies of, 54

title system of recording, 71

trading problem, 72

value, relation of tenancy to, 82

Leadership for the farmer, 308

Legal and economic questions on monopolies, 377,378

Leiserson, W. M., on farm labor, 112 Liebig, J., 431

on agriculture and organic chemistry, 435

on wheat conditions, 339

Liebig-Conrad controversy, 431

Life insurance companies, 183

Limitation of output, 308

Lipman, J. G., Bacteriology in Relation to Country Life, 435

Literature on agricultural labor, 112-114 machinery and the trust question, 129

press, 283

prices, 243

agriculture, 23,52

issued by United States Department of Agriculture, 328

manufacturing, commerce, 14

coöperation among farmers, 173 cost of production and farm accounting, 258

economic condition of the farmer, 95
Literature, farm bureau movement, 335

farmers' organizations, 309, 310 farming, 52 and land speculation, 30

food supply, 435,436

foreign agricultural competition, 422,423

grain exchanges, 361-363

insurance, 213

land tenure, 74-78

live-stock and meat industry, 389,390

marketing and the middleman, 154-156

farm products, 154-156

milk marketing, 155,156

rural credit, 185

speculation, 276,277

State aid, 327, 328

taxation problems, 407, 408

transportation, 204

Liverance, W. B., quoted, 157

Livermore, K. C., of Cornell, 88

Live stock and crops, table of increase or decrease, 1870-1910, 17 and meat industry, 365 publications on , 389,390

competition, foreign, 371

countries, 367

decrease in number of, 367

factors making against an increase of, 369

for an increase of, 368

fluctuation, 16

foreign competition in, 370

future of, 367

in Australia, 371

in: South Africa, 371

in South America, 371

industry, westward movement of, 366

production, 365

shifts in, 366

situation, 365

supplies and prices, stabilizing, 390-392

Lloyd, O. G., on farm ownership, 64

Long and short time credit, 177

Losses in soil fertility, 254

Lowell, Hoit \& Company, Grain, 359

Lowell, S. J., of State and National Grange, 293

Lubin, David, of the International Institute of Agriculture, Rome, 204 Lumber industry, Report of the Bureau of Corporations on, 10, 11 Luxuries, definition of, 41 
Machinery, labor-saving, 108

Macklin, T. H., cited, 156

Magill, R., on wheat prices, 232

Mail order house and agricultural problems, 156

Maladies of farm animals, 23

Malthus, T. R., Principle of Population, 435

Market, cornering the, 273

director, State, functions of a, 134

Marketing activities, State, 131 and the middleman, chapter on, 130

costs, 152

direct, 152 money, 151

in Idaho, 132

law of California, 132

officials, national association of, 140

parcel post, 140

peach crop, 21

problems in Texas, 139 of Washington, 139

publications on, 154-156

scene at Russian fair, 420

seasonal, 21

State field agents in, 139

work in New York, 136 in North Carolina, 137

Markets, Bureau of, 140, 321

in Ohio, 138

in Pennsylvania, 138

cornering the, 263

department of, in Michigan, 136 Martin, T. E., Farm, 433

Mathis, Mrs. G. H., Farmer Leader, 158

McKenzie, M., on transportation of live stock, 189

Live-stock Trade in South America, 371

McKenzie, R., of Winnipeg, 305

McNiel, John, Farm, 67

Mead, Elwood, cited, 77, 78

Meat a dear food, 366

inspection, 317

margins of profit, 143

packers, largest, 373

packing industry, 372 plants, 371

Meats fresh and cured, 426

Michell, H., The Grangein Canada,310

Middleman, cost of, 142

elimination of, 153,157

marketing and the, chapter on, 130

problem, probable solution of, 149

services of the, 148
Middleman, speculative, function performed by, 269

Milk, ideal food, 50

marketing, books on, 155, 156

Mill, John Stuart, on peasant proprietors, 34

Misused terms-hoarding, 262

Mitchell, W. C., History of Prices During the War, 244

Morgan, J. P. \& Co., Bankers, 12

Morman, J. B., Principles of Rural Credit, 185

Mortgage and tenancy problems, 55

Mortgages, farm, increasing, 69

Mowers, improvements in, 120

Mowing machines, American, in Italy, 124

Myrick, H., How to 'Coöperate, 155

National Agricultural Organization Society, 171

Farmers League, 303

Nitrates question, 429

Nonpartisan League, 302, 303

Norway has best social and economic conditions, 32

Nourse, E. G., cited, 14, 155

Nystrom on economics of retailing, $149,150,155$

Oats, cost of producing, per acre, 260 extreme prices of, 248,249

Ocean transportation, 201 and the World War, 202

Organization, strong, example of, 286

Osman on Hepburn Act, 356

Output, limitation of, 308

Overcapitalized land, 24

a bad thing for farmers, 29

Owner farming, view of, 57

Packer, first plant of a large, 373 large, first plant of, 373

plant of, sixty years later, 374

Packers and price question, 381

Big Five, dissolution of the, 387 combination among, 384

Federal Trade Commission report on (1918), 382

magnitude of business, 382

potential competition, 380

profits of, 381

real evil of, and the remedy, 385 reply of, to Federal Trade Commission Report, 385

responsible government for the, 386

side lines of, 377 
Packers, transportation and distribution by, 376

Packing house, by-products, utilization of, 376

Government inspection in, 378

situation, evils of, remedies for, 384

houses, coöperative, 387

inspection and grading in, 377

Palmer, D. B., on educating the consumer, 149

Parcel post and express compared, 196 marketing, 140 shipping eggs by, 141

perishable farm produce by, 142

Parker, Field Management and Crop Rotation, 436

Peaches, California, collective marketing of, 146

Pearson, R. A., Agricultural Organizations in Europe, 310

Peasant proprietor in Holland, 35 proprietors, 34

in Denmark, 36

proprietorship in Norway cited, 32

on the Continent, 32

Peffer, Senator, Report of, on Agricultural Depression, 26, 27

Perishability, risks from, 147

Pests and diseases, effects on agriculture, 19

"Phantom grain" question, 351

Pickell, J. R., Agricultural Argentina, 363,423

Pierson, C. W., Rise and Fall of the Grange movement. 310

Pit scalpers, 351

Plant industry, bureau of, 318

Plunkett, Sir Horace, on rural life problems, 7

Political reforms, how to secure, 307

Poole, R. R., quoted, 44

Pope, J. E., cited, 226

Population, city, increase over country, 51

Malthusian theory of, 425

Populist Party, 304

Pork, fresh, in cold storage, 220

Porter, W. R., on farm labor, 106

Potato marketing, 132 production, fluctuations, 16

Potatoes, government inspection of, 323

improperly packed, 194

marketing of, discussions on, 145
Powell, G. H., on citrus fruit selling, 42

consumer's dollar, 146

Powers, LeGrand, on decline in price of agricultural products, 41, quoted, 45, 106, 108, 408

Pratt, E. A., on small holders, 28, 36, 74

Press, Agricultural, and Scientific

Faiming, 282

Price and value, 239

equilibrium, 229

fair, 229

conclusions on, 240

fixing, 229

collective bargaining of, 241

in practice, 230

fluctuation, risks in, 147

fluctuations, 246-249, 271

theory, 227

Price, T., on the good and wise corporation, 67

Prices, effect of cold storage on, 221 extreme, of wheat, corn and oats, 246-249

just, 228,229

Problem of land trading, as Vermont sees it, 72

Production, cost of, importance of, 257

Prom, Brynjolf, quoted, 44

Prosperity, farmer's, variable factors in, 20

Protection, Hamilton on, 399, 400

of agriculture, theory of, 405

Protective policy in 1816, 399 tariff, 397

and conditions in 1789, 398

policy, introductory statement, 397, 398

theory and practice, 398

workings in New England, 398

Publications (see Literature)

Public roads, bureau of, 321

Quaintance, H. W., Influence of Farm

Machinery on Production and

Labor, 108, 129

Question, soil exhaustion, 428

Railroad forestry management, 194 marketing service, 193

Railroads, 188

and agricultural education, 192

and the farmer, 191

discontent against, 189-191

evils of, 188

securing new settlers, 192

Railway finance, 191 
Raisins, California, distribution, 147 Real estate exchanges, 73

Reaper, first successful (1831), 116 model of 1847,121 model of 1858,121 modern self-binder and, 122

References (see Literature)

Refrigeration in Moscow, 219

Refsell, V. N., Farmers' Elevator Movement, 363

Rent contract of tenants, 61

Report of Bureau of Corporations on Lumber Industry, 14

Industrial Commission, 14

Resources, natural, exploitation and conservation of, 7

Retailing,Nystromoneconomics of, 150 system, an ideal, 150

Rhodes, J. F., Taxation Problems, 408

Road construction, 322

Roads, good, 198

valuable to farmer, 201

Roberts, I. P., Fertility of Land, 435

Rogers, T., Agricultural Prices in England, 244

Roosevelt Country Life Commission, Report on Farming, 7-10

Roosevelt, President, Reforms in Grain Trade, 356

Rubinow, I. M., Russian Wheat and Flour, 422

Rural credit in Europe, studied by United States, 176

credits, publications on, 185, 186 districts of England, low wages in, 97

motor express, 199

population, decrease of, for decade 1900-1910, 114

of Middle West, loss in, shown, 107

Russell and Hastings, Agricultural Bacteriology, 436

Sager, Hiram, American Grain Merchant, 357,358

Saskatchewan Coöperative Elevator Company, 168

Scholtz, W. C., of Idaho, 132

Seasonal production of foods, 214

Sedgwick, Prof. Wm. T., quoted on cold storage, 221

Service, selling is a, 149

Shade, Charles, quoted, 84

Share croppers, 64 renters, 64

Silk culture, 312

Simons, A. M., on capitalism and agriculture, 55
Single tax, 393

applied to city and farm land, 396, 397

argument for, 394-396

definition of, 393

incidence of, 393

question at issue, 396

Size of farms, 67

Slaughtering, division of labor of, 375

Small holdings, an objection to, 36

Smith, C. L., Dakota Farmer, 25

Social or individual viewpoint considered, 45

Soil and the man, 432

destruction question, 432

exhaustion and wheat, 429

cause of decline of nations, 431

fertility, 430

losses in, 254

Soils, bureau of, 320

Speculation and price fluctuations, 352

and public interest, $273-275$

chapter on, 262

definitions of, 265

its evils, 273

its services, 268

publications on, 276, 277

two kinds of, 267

Speculator, food, three functions of, 270

second function of the, 269

Speculators and "the Charter of New

England-1620," 277

Spillman, W. J., quoted, 46, 56

Stabilizing prices, 392

Standardizing and advertising of products, 43

State aid for the farmer, chapter on, 312

in sugar beet culture, 312

publications on, 327,328

department of agriculture and

the police power, 315

market director, functions of, 134

State marketing activities, 131

States relation service, 320

Stelzle, Charles, quoted, 53

Stockyard, Chicago (1861), 372

fifty years later, 372

Strawberry marketing, 162

Taft, President, on rural credit, 176

Tarbell, I. M., Tariff in Our Times, 407

Tariff, Gallatin's memorial on, 403

labor and capital, 403

Le Grand Powers on, 408

protective, and profits, 104 
Tariff, protective, effect on farmer's crop prices, 406

Walker on, 403

Tax, single, 393

Taxation problems, chapter on, 393

Daniel Webster on, 408

publications on, 407, 408

Taylor, H. C., cited, 156

on price-fixing, 231

Telephone, farmers' coöperative, 170

Tenancy and mortgage problems, 55

farm, Federal government report on, 62,63

publications on, 76-78

farming on increase in United States, 55

relation of, to land value, 82 statistics, 55

Tenant class a menace, discussion on, 60,61

farmer, rent contracts of, 61

farming in the cotton belt, 64 report on evils of, 57-59 view of, 56

Tendency of large farmers to absorb small farmer, 67

Terminal warehouses, 357

Thomson, E. H., Farm Bookkeeping, 259

Threshing outfit in Argentina, 417

Tobacco consumption, 50

distribution statistics, 146

production, fluctuations, 16

Tornado, view of, 316

Torrens system of recording titles, 71

Tousley, E. M., on coöperation, 127

Trade acceptance, 184

Trading, cash and future, 263 cost of future, 352

Transportation, chapter on, 188 farmers' coöperative truck, 200 Great Lake, 197

in Russia, by wagon, 199

motor truck, 200

ocean, 201

publications on, 204

river and canal, 197

Tucker, G. M., American Agricultural Periodicals, 283

United Grain Growers, 165-168

United States a beef exporter, 371 studies rural credit in Europe, 176

"Weekly News Letter to Crop Correspondents," 30

Valgren, V. N., Farmers' Mutual Fire Insurance Company, 213

Valorization, agricultural prices and, 225
Valorization, effects of, 236

in Brazil, 233-239

Value and price, 239 relation of, to cost of production and demand, 240

Vogt, P. L., on farmer's income, 87 von Engelken, F. T. H., quoted, 36 von Tungeln, eited, 95

Vrooman, Carl, on farm problems, 21

Walker's Report, on the tariff, 403

Wallace, Henry, on farm tenancy, 81 editor, 281

Warren, G. F., "Survey," 88 on price-fixing, 229, 243, 244

Washington, George, A Successful Farmer, 94

Weather Bureau, 317

Webster, Daniel, on the tariff, 402 , 408

Weinstock, Harris, of California, 133

Weld, L.D. H., live-stock and marketing questions, 145, 154, 389

Wheat conditions, future, forcasts on, 339

and cotton, crop fluctuations, 16 and flour prices from farmer to consumer, 143

average annual prices, 412 crop-producer to consumer, 143

extreme prices of, 246, 247

harvest, where and when every month, 338

pit, views of, 353

price of, 232

soil exhaustion and, 429

spring, cost of producing, per acre, 261

winter, cost of producing, per acre, 260

yields, results of scientific methods, 434

Whittaker, Sir Thomas, on ownership, tenure and taxation of land, 30,407

Wilcox, E. V., Department of Agriculture Plan for Handling Farm Labor Problem, 112

Wiley, H. W., on tobacco statistics, 50

Wilson, Henry D., of Louisiana, 135

Wilson, President, on self-help, 285

Wilson-Wallace Report, 34

Woman's land army, 103

Women and war work, 103

Wright, C. D., Industrial Evolution of the United States, 14

Young, A., on English farming, 94

Travels in France, 33 

RETURN TO the circulation desk of any University of California Library or to the NORTHERN REGIONAL LIBRARY FACILITY Bldg. 400, Richmond Field Station University of California Richmond, CA 94804-4698

ALL BOOKS MAY BE RECALLED AFTER 7 DAYS - 2-month loans may be renewed by calling (510) 642-6753

- 1-year loans may be recharged by bringing books to NRLF

- Renewals and recharges may be made 4 days prior to due date.

DUE AS STAMPED BELOW

DEC2 21999

ULO 0 2 2002 


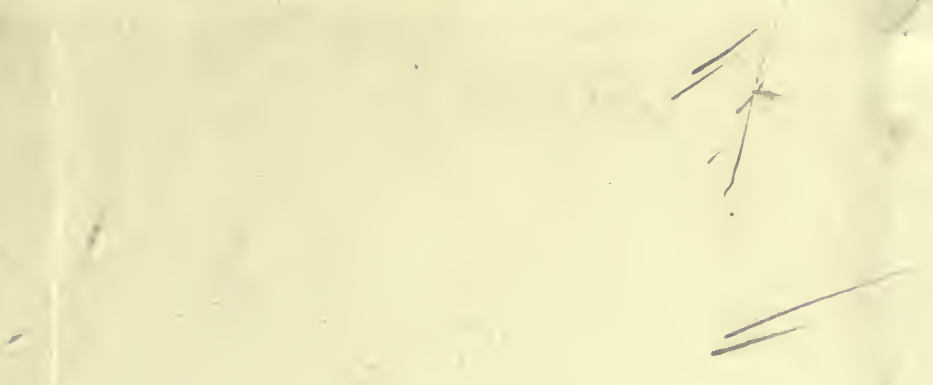


